Universidad Politécnica de Madrid

Escuela Técnica Superior de Arquitectura de Madrid

\title{
ARQUEOLOGÍA DEL FUTURO
}

Tesis Doctoral

Autor: Carmelo Rodríguez Cedillo, arquitecto

Director: José Alfonso Ballesteros Raga, doctor arquitecto 
Departamento de Proyectos Arquitectónicos

Escuela Técnica Superior de Arquitectura de Madrid

\section{ARQUEOLOGÍA DEL FUTURO}

Tesis Doctoral

Autor: Carmelo Rodríguez Cedillo, arquitecto

Director: José Alfonso Ballesteros Raga, doctor arquitecto 
Tribunal nombrado por el Mgfco. Y Excmo. Sr. Rector de la Universidad Politécnica de Madrid, el día

Presidente D.

Vocal D.

Vocal D.

Vocal D.

Secretario D.

Realizado el acto de defensa y lectura de Tesis el día

en la Escuela Técnica Superior de Arquitectura de Madrid

Calificación:

EL PRESIDENTE

LOS VOCALES

EL SECRETARIO 


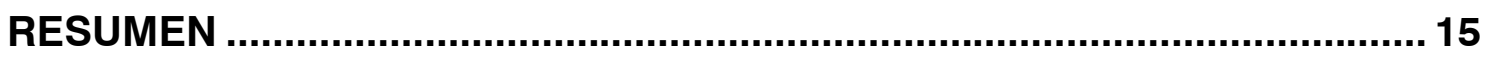

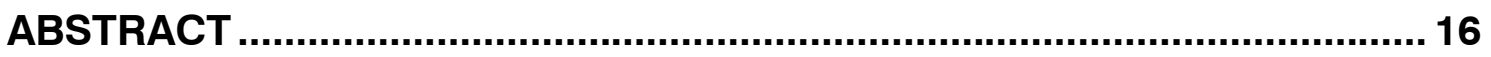

O/ARQUEOLOGÍA DEL FUTURO: INTRODUCCIÓN / METODOLOGÍA /

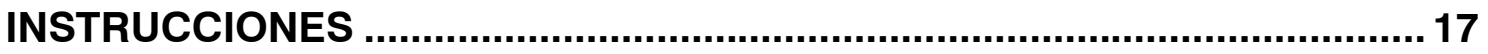

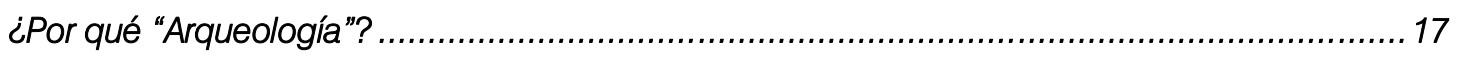

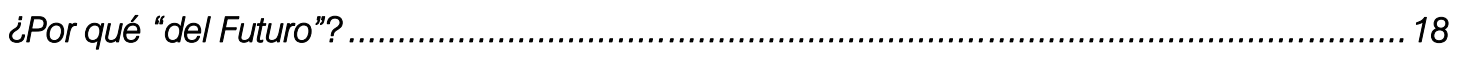

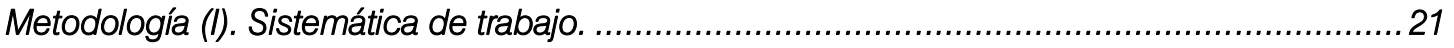

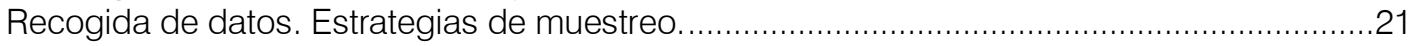

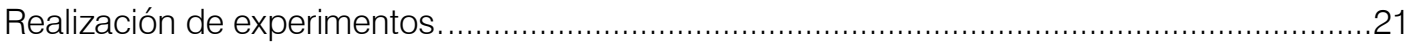

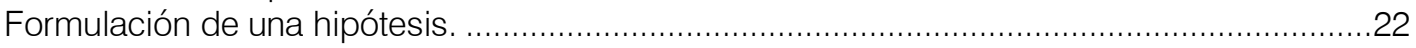

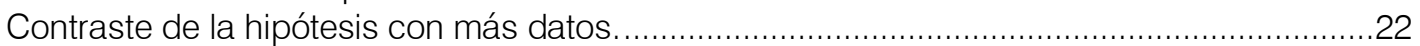

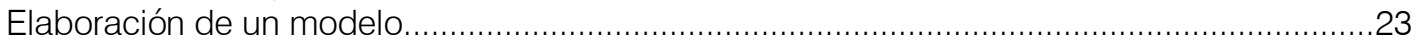

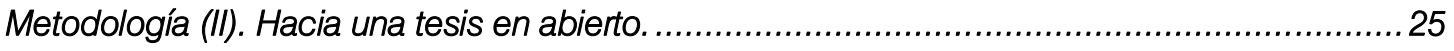

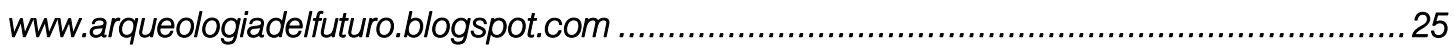

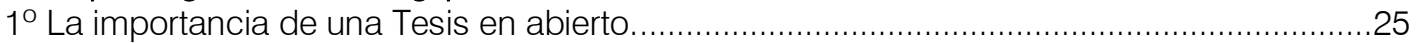

$2^{\circ}$ La Tesis como labor pedagógica. Sobre la difusión de las investigaciones académicas...25

$3^{\circ}$ La Tesis como lugar de debate, como conector de experiencias similares. ......................26

$4^{\circ} \mathrm{La}$ Tesis como herramienta para cambiar protocolos obsoletos......................................26

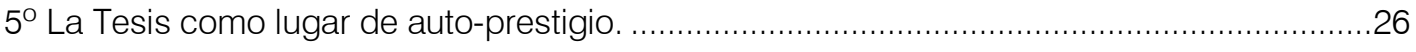

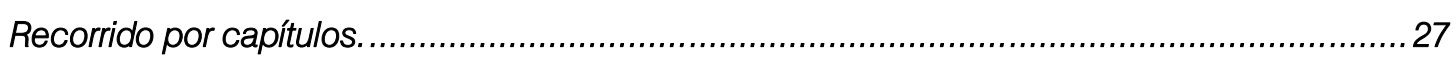

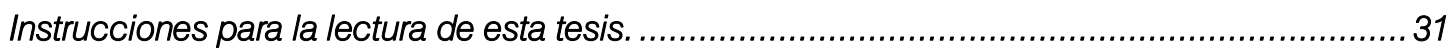

Capítulo 1. SOBRE EL PASADO DEL FUTURO........................................... 33

Nociones históricas. Construcción del contexto temporal....................................................33

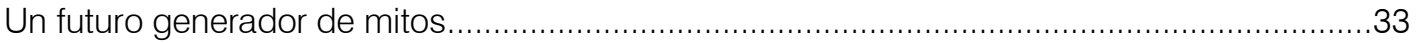

La redefinición de la Utopía como motor de futuro...............................................................3

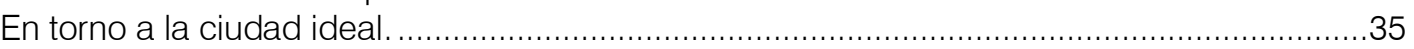

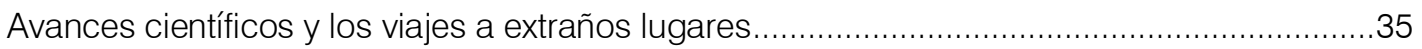

El viaje en el tiempo, la obsesión por el año 2000. Hacia una nueva sociedad. ......................36

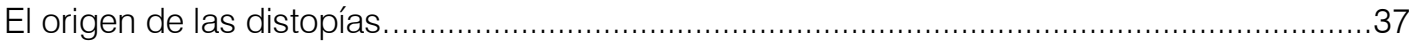

El problema de los recursos. La utopía frente a la religión....................................................38

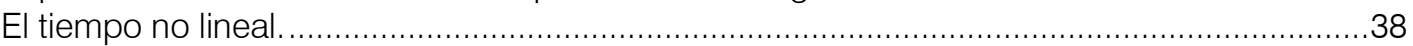

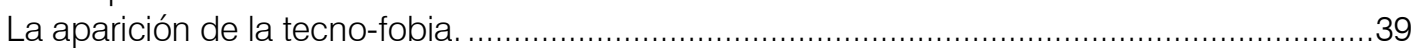

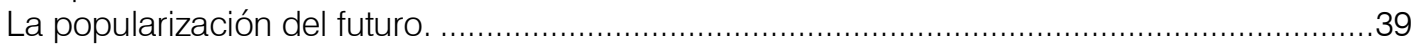

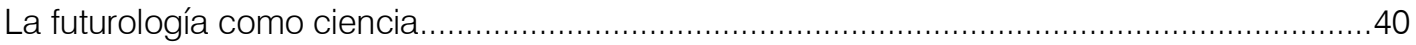

Contexto para una arqueología del futuro arquitectónica...................................................... 41

Capítulo 2. PREDICCIONES ARQUITECTÓNICAS......................................... 43

La aparición de la etiqueta "Futuro" en la difusión arquitectónica........................................... 43

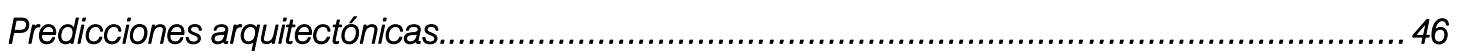

1963 “¿Dónde viviremos mañana?” (Michel Ragon) ........................................................ 49

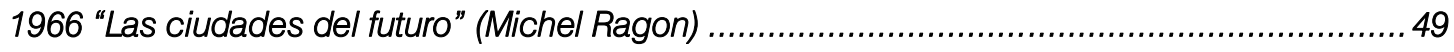

1965-73 “Cosmorama” (AD The Architectural Design) ........................................................ 51 
Sección de la revista "AD The Architectural Design" activa desde julio de 1965 hasta

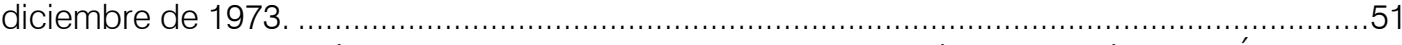

Cambio de escala. Utópico VS Experimental. Colectivo VS Autónomo. Estética VS Ética. .....52

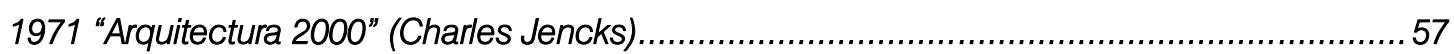

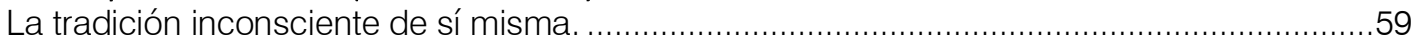

El catálogo y el "Do it yourself" como alternativas de futuro. ................................................59

La tradición consciente de sí misma...............................................................................5

La mega-estructura y los sistemas de control como alternativas de futuro............................59

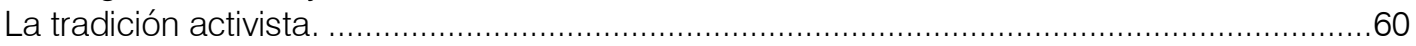

La flexibilidad, la participación y los intercambios de información como alternativas de futuro.

Perversiones naturales, los robots y el control ambiental como alternativas de futuro. ...........60

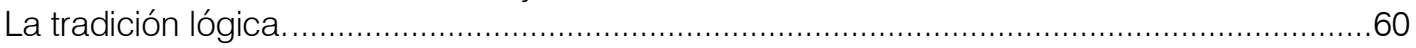

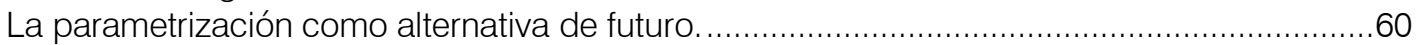

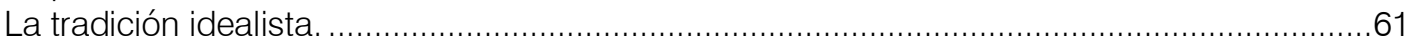

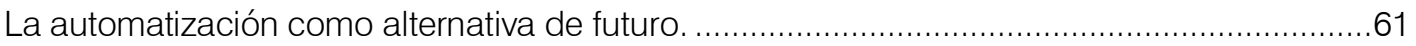

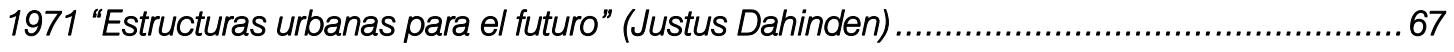

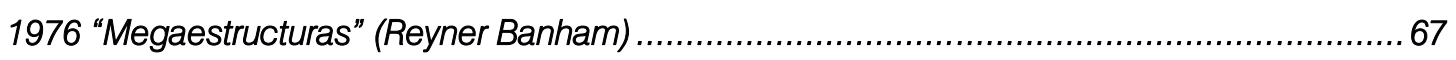

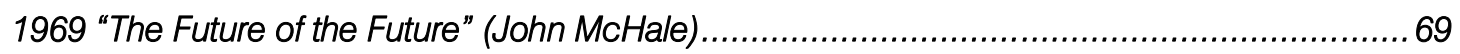

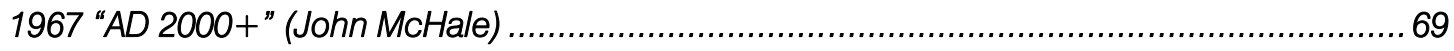

1967 "Architecture: action and plan" (Peter Cook)........................................................ 73

1970 "Experimental Architecture" (Peter Cook) ................................................................ 73

Capítulo 3. ALTERNATIVAS PARA UNA ARQUITECTURA DEL FUTURO. . 77

Predicciones de Futuro convertidas en estrategias de diseño arquitectónico........................... 77

Alternativa de futuro \#1 Cambio de Escala....................................................................... 79

Alternativa de futuro \#2 Perversiones Naturales. ............................................................ 83

Alternativa de futuro \#3 Hacia una arquitectura virtual. ............................................................ 87

Alternativa de futuro \#4 La Movilidad como opción de futuro.............................................. 89

Capítulo 4. CAMBIO DE ESCALA. ................................................................ 93

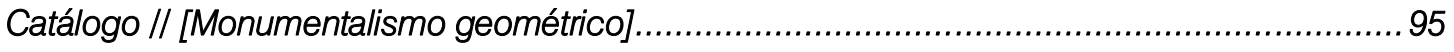

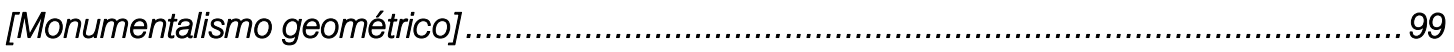

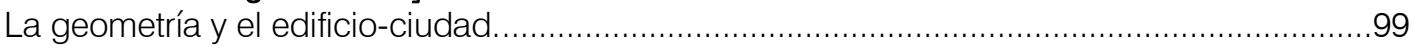

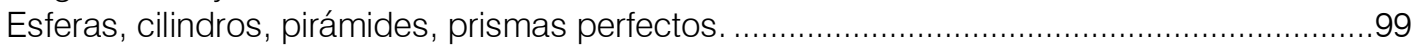

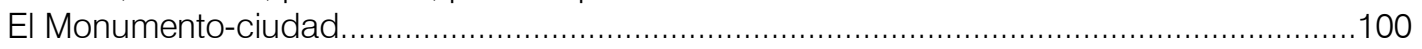

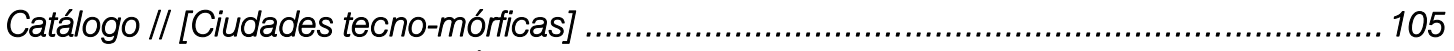

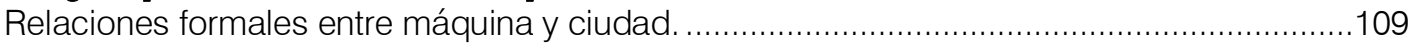

Máquinas urbanas. La máquina superpuesta a la ciudad existente ...................................111

Iconografía maquinista. De la tubería y el motor a los circuitos eléctricos.............................114

De la ciudad-máquina al edificio-máquina como monumento .............................................117

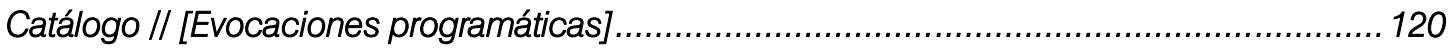

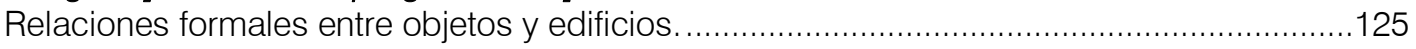

El potencial semántico de los objetos. Objetos superpuestos a un contexto. ......................128

La búsqueda del potencial arquitectónico de los objetos. Edificios diseñados a partir de objetos. 
El potencial publicitario de los objetos. Edificios-anuncio..................................................133

El potencial identitario de los objetos. Identidades reflejadas en edificios...........................135

El potencial obsesivo de los objetos. Arquitectura de las obsesiones. ..............................137

El espacio público como monumento. La nostalgia del cambio de escala ..........................138

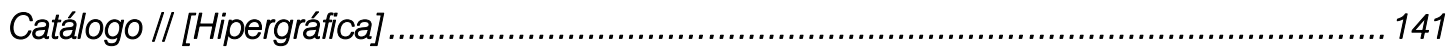

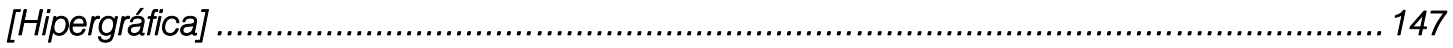

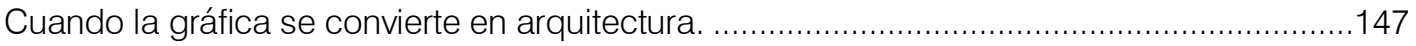

La supergráfica como revestimiento. Distorsiones espaciales, técnicas de camuflaje y

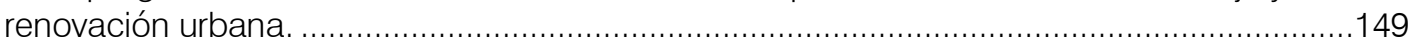

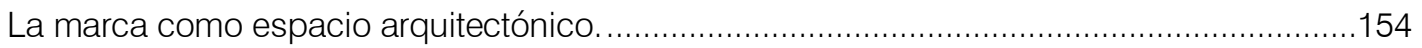

El edificio-cartel. Carteles publicitarios convertidos en arquitectura. .....................................155

La ciudad alfabética. Hipergráfica = hipermensajes......................................................159

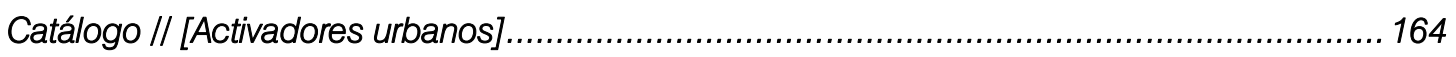

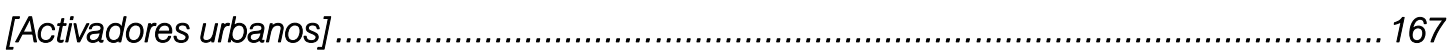

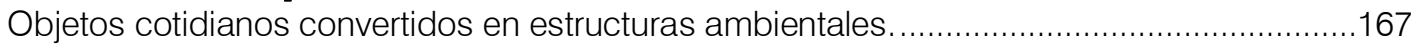

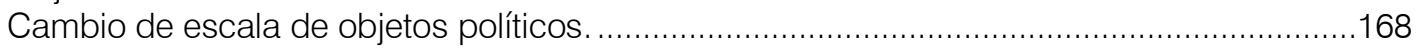

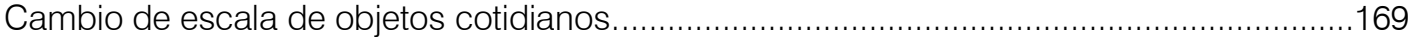

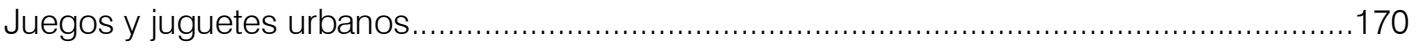

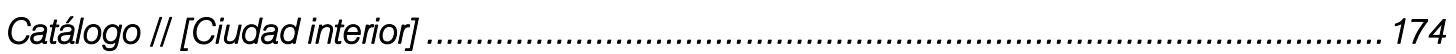

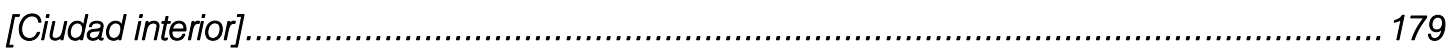

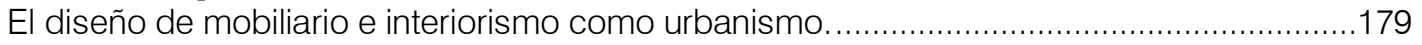

De las habitaciones dentro de habitaciones al Super-mobiliario......................................180

Urbanismo de interiores. Edi-muebles, mobiliario diseñado como edificios........................182

Distorsiones domésticas. Interpretaciones pop del diseño de interiores...............................186

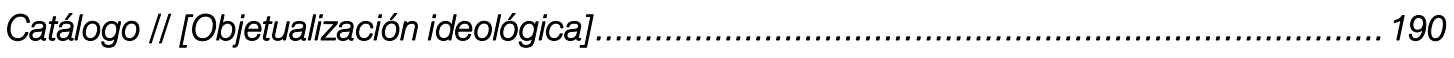

[Objetualización de la ideología]................................................................................ 193

Transformación de ideologías arquitectónicas en iconos objetualizados.............................193

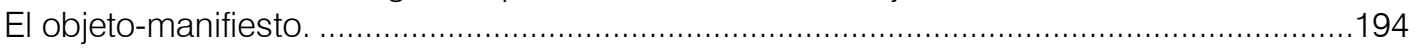

Capítulo 5. PERVERSIONES NATURALES. ............................................... 201

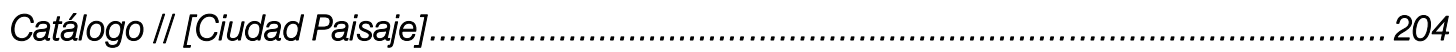

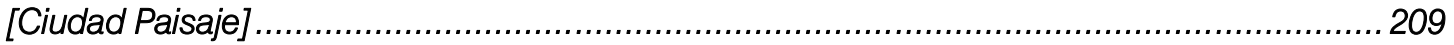

La Ciudad convertida en paisaje como alternativa a la megaestructura. ............................209

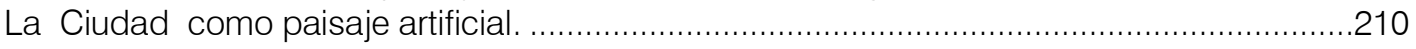

De las analogías biológicas organizativas a la ciudad-árbol............................................211

La naturaleza como soporte. De la Ciudad-Roca a la Ciudad-Montaña. .............................213

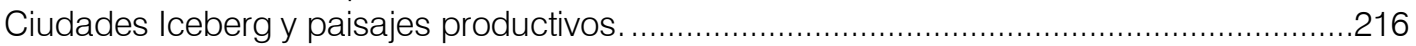

Excavando en el terreno para una desaparición de la arquitectura. La Ciudad-Río, la Ciudad-

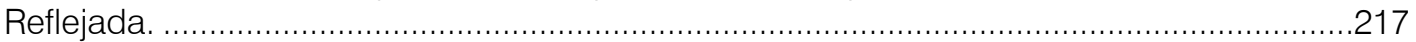

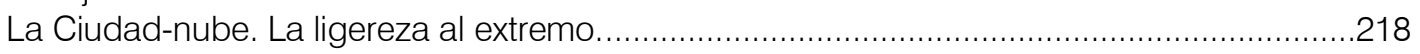

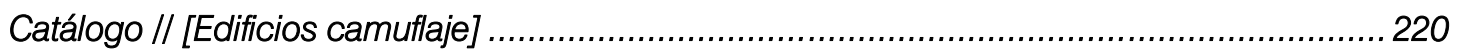

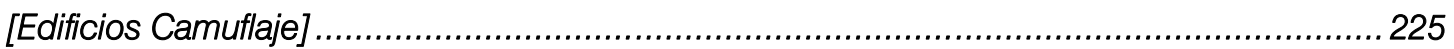

Tácticas de camuflaje para edificios proyectados como naturalezas artificiales. .................225

Cambio de escala. De la montaña a la rocalla. El objeto arquitectónico como unidad

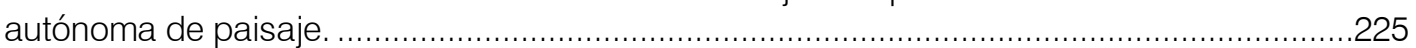

Edificios-árbol y edificios-bosque. De la metáfora a la reproducción. .................................229

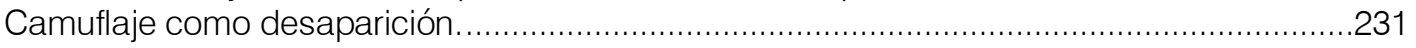

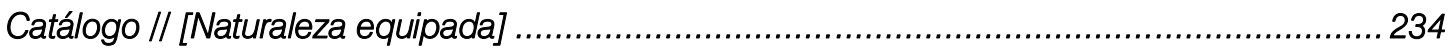




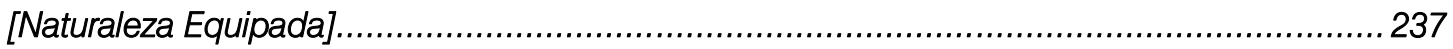

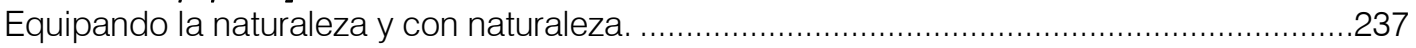

Naturaleza equipada. La emulación como camuflaje.....................................................237

Redes invisibles de energía e información. Otra vez la desaparición de la arquitectura........240

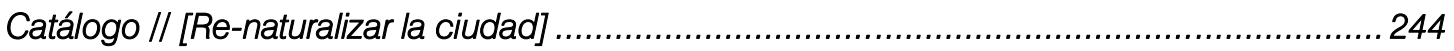

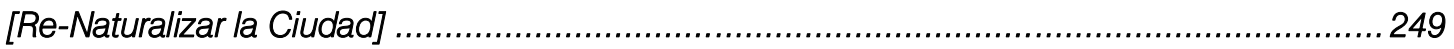

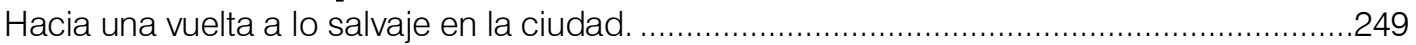

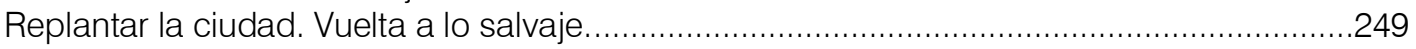

La naturaleza como equipamiento. La naturaleza utilizada como kit.................................253

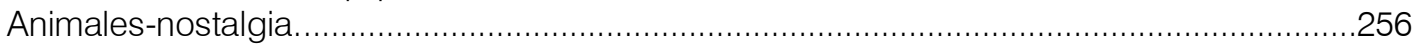

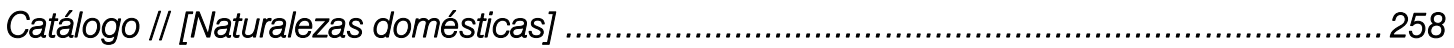

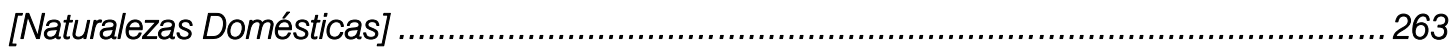

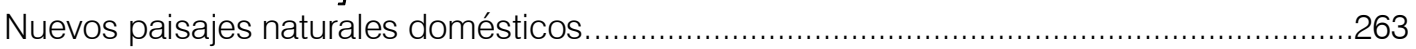

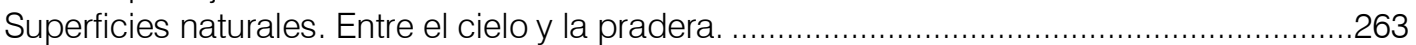

Objetos salvajes para equipar los nuevos paisajes domésticos..........................................26

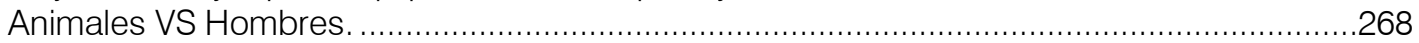

Capítulo 6. HACIA UNA ARQUITECTURA VIRTUAL.................................... 271

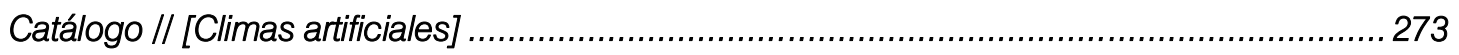

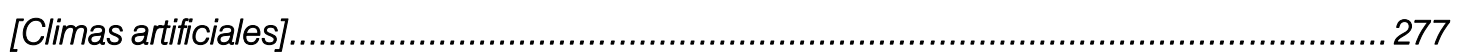

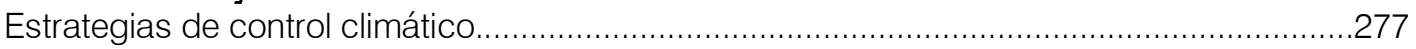

De la búsqueda de un clima global a la desaparición de la arquitectura ...........................278

Oasis urbanos, o cómo sobrevivir en un mundo contaminado...........................................28

Climas personales, el traje de astronauta como arquitectura .............................................28

Catálogo // [Distorsionadores autónomos de la percepción] ................................................ 289

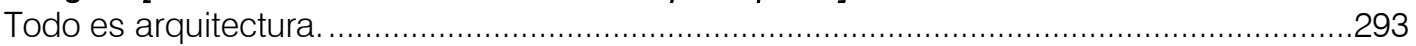

Las fuentes del espacio. El cerebro como simulador espacial. .........................................294

Gafas, cascos y otros dispositivos distorsionadores. Intensificación de la experiencia

arquitectónica. La sala de meditación como nuevo equipamiento doméstico.......................296

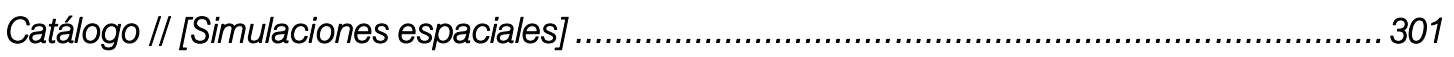

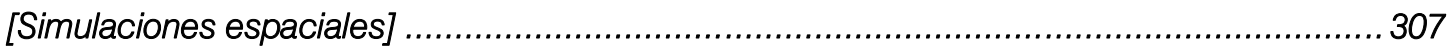

Experimentos en torno a la generación de ambientes temporales.....................................307

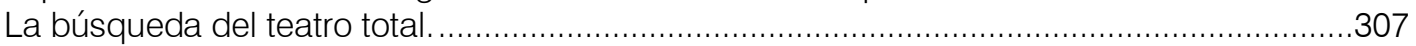

Generación de programas arquitectónicos a partir de ambientes. La discoteca como "Palacio

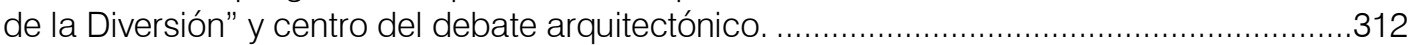

Experimentaciones ambientales sensoriales. Del espacio artístico al arquitectónico.............316

Capítulo7. LA MOVILIDAD COMO OPCIÓN DE FUTURO........................... 323

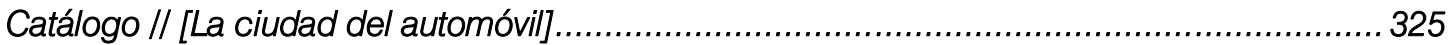

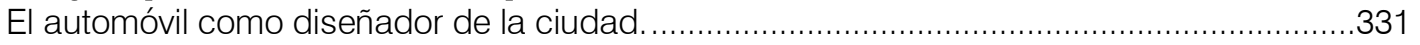

Arquitectos diseñando automóviles y automóviles diseñando ciudades..............................331

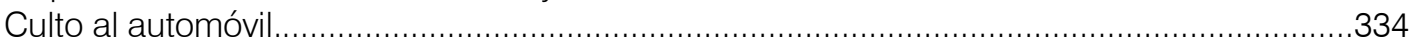

El automóvil como vivienda móvil. El auge del caravaning ...............................................336

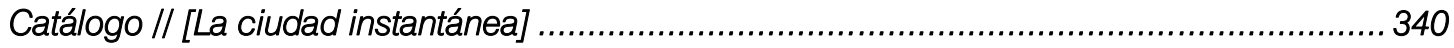

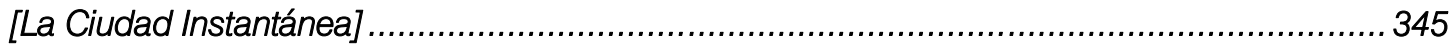

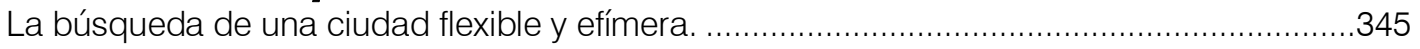

De la ciudad de emergencia a la de vacaciones como "prototipos"'" posibles. ......................345

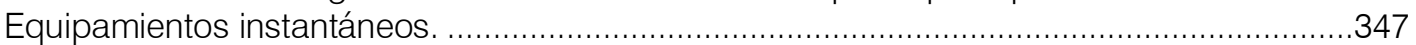

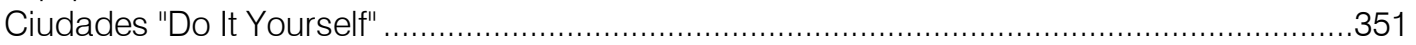


Planos y catálogos como recursos de emancipación arquitectónica...................................353

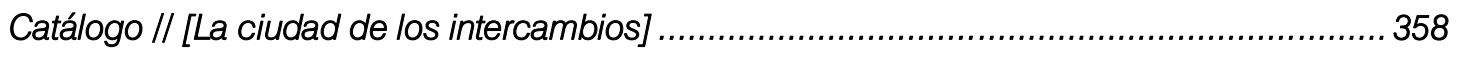

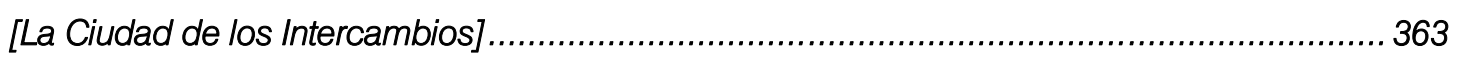

Intercambios de energía e información en los ambientes urbanos......................................363

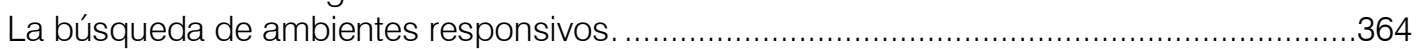

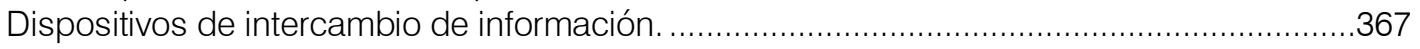

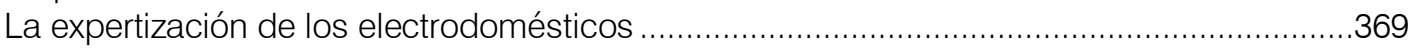

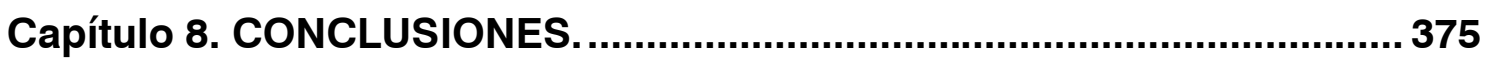

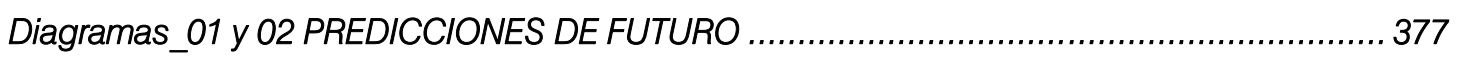

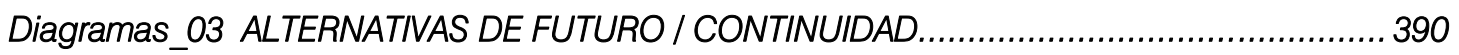

Diagramas_04 ESTRATEGIAS DE FUTURO / DE LA CIUDAD AL MOBILIARIO......................... 394

Diagramas_05 CASO APLICADO / DE LOS SISTEMAS DE CIUDAD A LAS VIVIENDAS

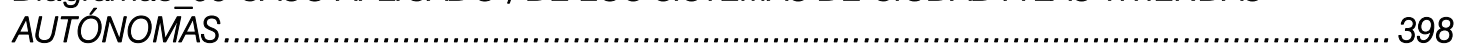

De la ciudad como generadora de ideología arquitectónica al poder del objeto. Un cambio de

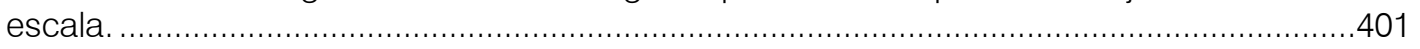

Diagramas_06 ESTRATEGIAS DE FUTURO / TRANSFERENCIAS ...................................... 402

Transferencias formales y escalares entre estrategias proyectuales. ...................................... 405

Diagramas_07_08 DETONANTES / MÁXIMA PRODUCCIÓN / DESMOTIVADORES................... 406

Detonantes, puntos de máxima producción y desmotivadores. Sobre la importancia de la

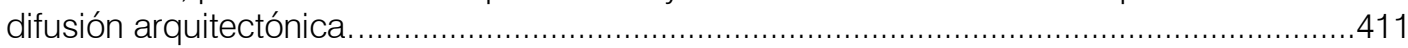

Diagramas_09 CAMBIO DE ESCALA / Monumentalismo Geométrico / Ciudades Tecnomórficas /

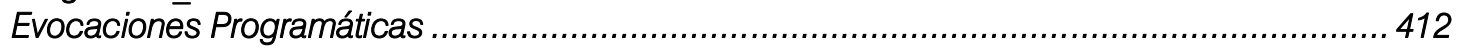

Diagramas_10 CAMBIO DE ESCALA / Hipergráfica / Activadores Urbanos / Ciudad Interior..... 412

Diagramas_11 PERVERSIONES NATURALES / Ciudad Paisaje / Edificio Camuflaje.................. 412

Diagramas_12 PERVERSIONES NATURALES / Naturaleza Equipada / Ciudad Re-Naturalizada /

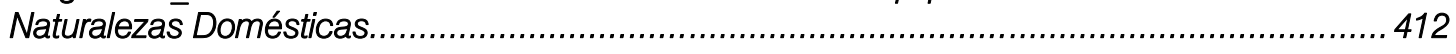

Diagramas_13 HACIA UNA ARQUITECTURA VIRTUAL / Climas Artificiales / Distorsionadores

Autónomos de la Percepción / Simulaciones Espaciales.

Diagramas_14 LA MOVILIDAD COMO OPCIÓN DE FUTURO / La Ciudad del Automóvil / La

Ciudad Instantánea / La Ciudad de los Intercambios....................................................... 412

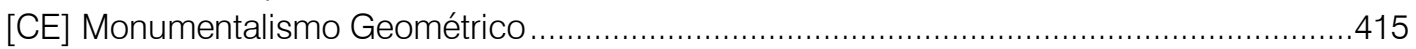

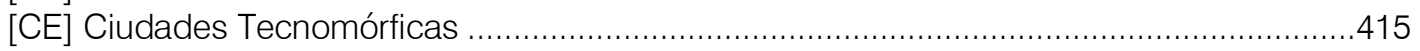

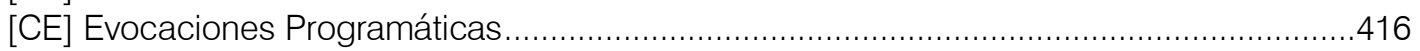

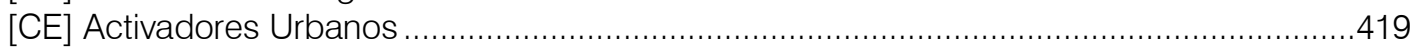

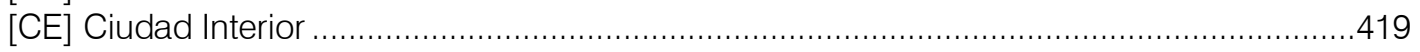

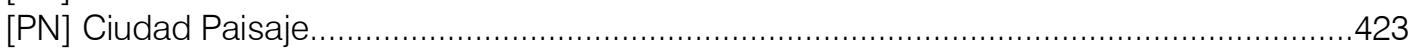

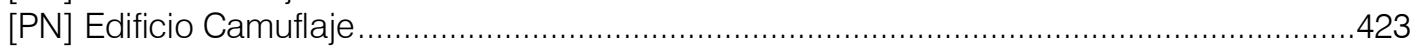

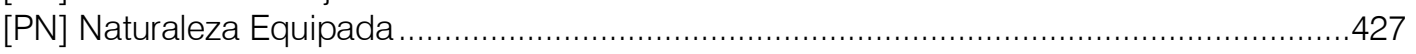

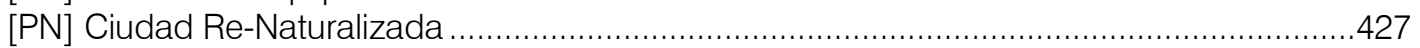

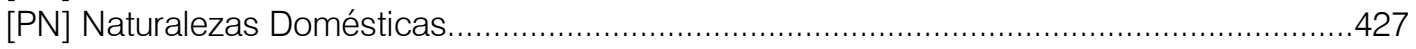

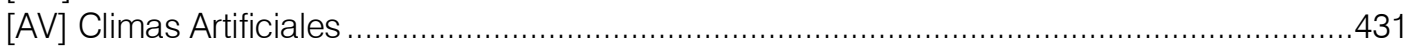

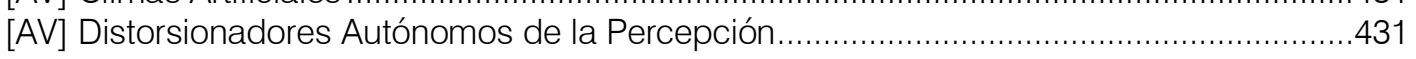

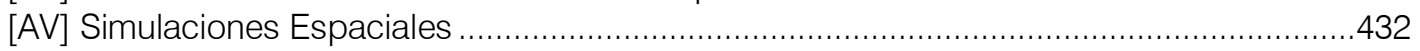

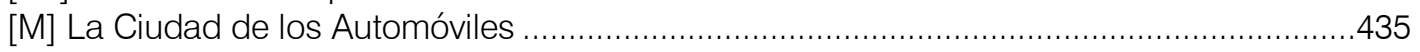

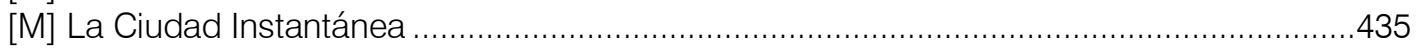

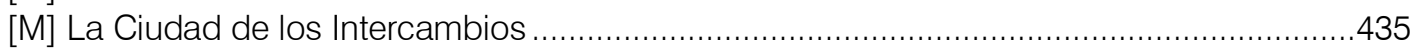

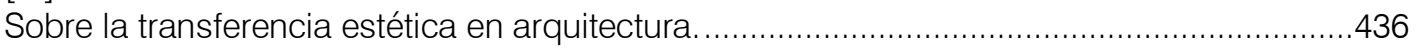


Capítulo 9. BIBLIOGRAFÍA.

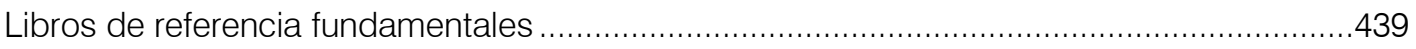

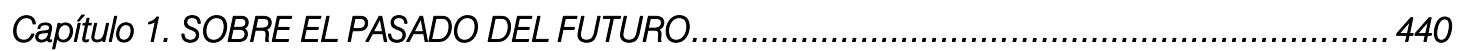

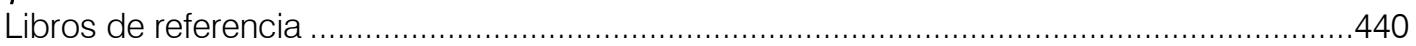

Libros sobre futurología, utopía, ciudades utópicas y Ciencia Ficción .................................440

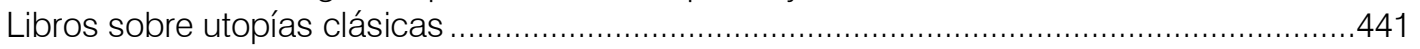

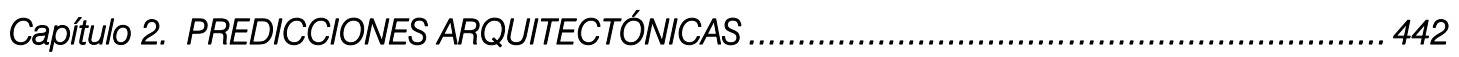

Capítulo 3. ALTERNATIVAS PARA UNA ARQUITECTURA DEL FUTURO …..............................442

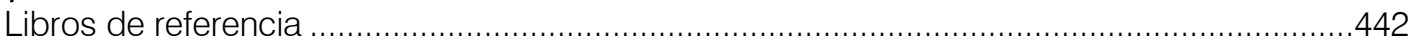

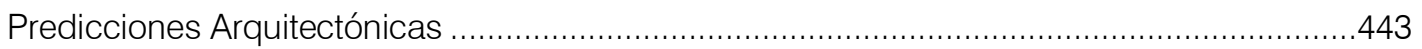

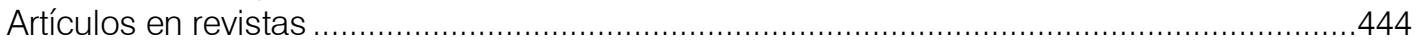

Artículos en AD The Architectural Design (ordenados cronológicamente) ............................444

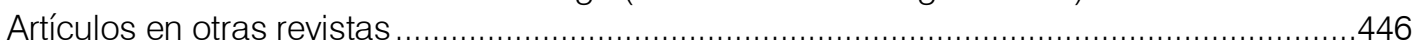

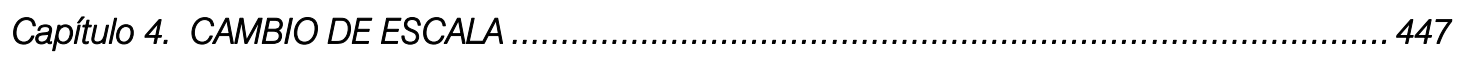

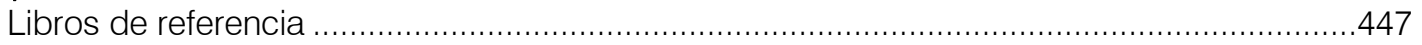

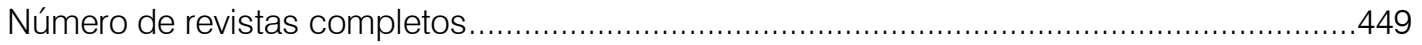

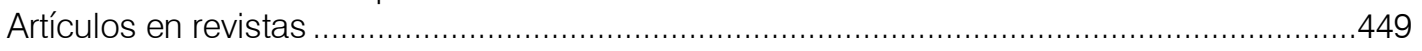

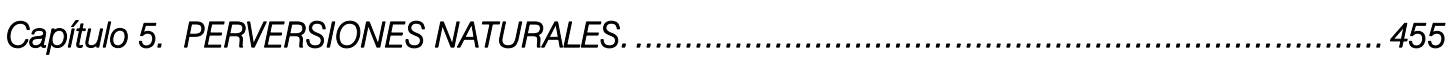

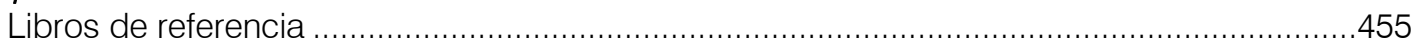

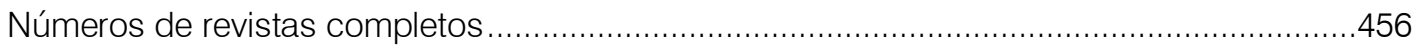

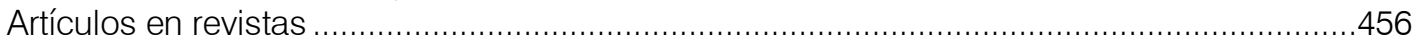

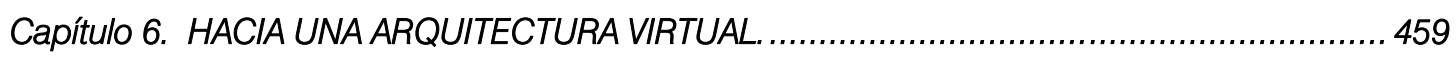

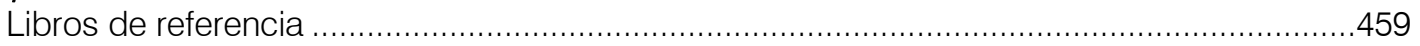

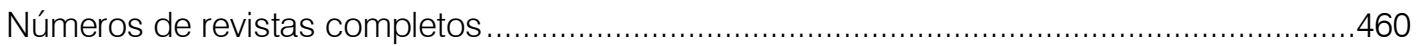

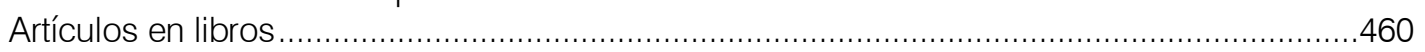

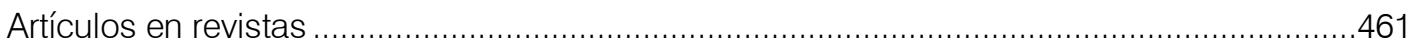

Capítulo 7. LA MOVILIDAD COMO OPCIÓN DE FUTURO..................................................464

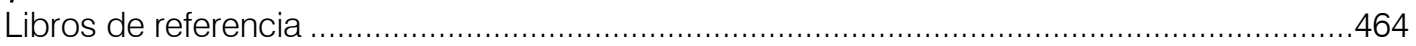

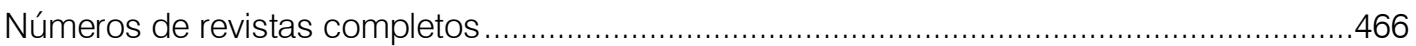

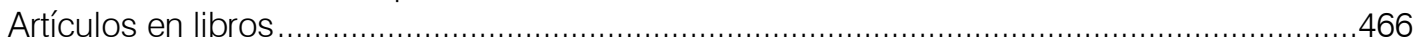

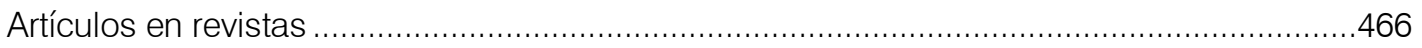




\section{RESUMEN}

"Un día necesitaremos arqueólogos para que nos ayuden a adivinar los argumentos originales hasta de las películas clásicas"1 (Gibson, 2004)

A través de la historia aparecen muchas y variadas manifestaciones de cambio, necesarias para afrontar el futuro ${ }^{2}$ de la humanidad; también de la arquitectura. Estas manifestaciones, alternativas, teorías y proyectos, a menudo denostados por la crítica o dejados de lado por las teorías históricas de carácter generalista, destacan por su capacidad de convertirse en herramientas críticas frente al orden establecido, promoviendo así nuevos imaginarios colectivos. En el contexto temporal que transcurre desde finales de la década de los años cincuenta hasta mediados de los setenta, esa "búsqueda del futuro" no sólo se encuentra totalmente aceptada y popularizada, sino que llega a convertirse en un acto necesario, legitimado por la incorporación de la futurología como ciencia de estudio fundamental. Este contexto resulta el marco idóneo para la aparición de una serie de predicciones arquitectónicas encaminadas a dibujar nuevos caminos posibles para el futuro de la arquitectura, o lo que es lo mismo, para una arquitectura del futuro: "Où vivrons-nous demain ?" (1963) y "Les cités de l'avenir" (1966) del historiador francés Michel Ragon, el número "AD 2000+" (1967) de la revista Architectural Design y "The Future of the Future" (1969) del artista inglés John McHale, "Architecture: action and plan" (1967) y "Experimental Architecture" (1970) de Peter Cook, "Megastructure. Urban futures of the recent past" del crítico inglés Reyner Banham, "Architecture 2000" (1971) del norteamericano Charles Jencks, "Stadstrukturen für morgen" (1971) del suizo Justus Dahinden, "Arthropods: new design futures" (1972) del editor norteamericano Jim Burns y la sección "Cosmorama" (1965-1973) de la revista inglesa Architectural Design, pueden considerarse como las más destacadas. A pesar de lo heterogéneo de sus autores y enfoques, todas ellas gravitan en torno a cuatro alternativas para una redefinición del futuro de la arquitectura:

- La incorporación de la arquitectura al heterogéneo espectro formal derivado de la explosión de las artes visuales y la exuberancia y proliferación de los objetos de consumo a través de un CAMBIO DE ESCALA.

- La generación de nuevas relaciones que experimenten en torno a los límites entre natural y artificial, o PERVERSIONES NATURALES.

- La apertura de un nuevo camino, HACIA UNA ARQUITECTURA VIRTUAL, que experimente con una construcción de ambientes auspiciada por los avances tecnológicos derivados del control perceptivo.

- LA MOVILIDAD COMO OPCIÓN DE FUTURO, una respuesta a la aparición de una nueva sociedad en continuo cambio, abogando por estructuras más flexibles en todos los campos del ámbito arquitectónico, de lo urbano a lo doméstico.

1 GIBSON, William. Mundo espejo. Minotauro. Barcelona, 2004.

2 Futuro, ra. 1. adj. Que está por venir. U. t. c. s. m. 4. m. Gram. Tiempo que sirve para denotar una acción, un proceso o un estado de cosas posteriores al momento en que se habla. 


\section{ABSTRACT}

"One day we'll need archaeologists even to help us guess original plots of movie classics" 3 (Gibson, 2004)

Throughout history, many and varied signs of change have appeared as a need to face the future 4 of humanity, and of architecture too. Those signs, alternatives, theories and projects, that were often neglected by the critics or left aside by historical theories of general-interest, have an outstanding capacity to become critical tools with regards to the established order, and to promote new collective imagery. Within the timeframe that lasts between late fifties and midseventies, that "quest for the future" is not only accepted and made popular, but it even becomes an act of necessity that is legitimized by the incorporation of futurology as a key scientific field of study. This timeframe provides the most suitable context for the appearance of a series of architectonical predictions that are aimed to define new potential paths for the future architecture to follow, in other words, an architecture of the future: "Où vivrons-nous demain?" (1963) y "Les cités de l'avenir" (1966) from French historian Michel Ragon, issue number "AD 2000+" (1967) of Architectural Design magazine and "The Future of the Future" (1969) from English artist John McHale, "Architecture: action and plan" (1967) and "Experimental Architecture" (1970) from Peter Cook, "Megastructure. Urban futures of the recent past" from English critic Reyner Banham, "Architecture 2000" (1971) from North-American Charles Jencks, "Stadstrukturen für morgen" (1971) from Swiss Justus Dahinden, "Arthropods: new design futures" (1972) from North-American editor Jim Burns and the section "Cosmorama" (1965-73) from English magazine Architectural Design, can be considered as the most prominent architectonical predictions of that time. Despite the heterogeneity of authors and approaches, all of them are built around four alternatives that are aimed to re-define the future of architecture:

- The incorporation of architecture to the heterogeneous formal spectrum of visual arts and the exuberance and the proliferation of objects of massive consumerism through an operation of CHANGE IN SCALE.

- The production of new relationships aimed to experiment around the limits between natural and artificial, in other words, NATURAL PERVERSIONS.

- A new road TOWARDS VIRTUAL ARCHITECTURE, to enable experiences with ambiance construction that are favored by technological advances derived from the control of perception.

- MOVILITY AS AN OPTION FOR THE FUTURE, a response to the appearance of a new ever changing society, a bet on more flexible structures in all areas of architecture, from urban to domestic scale.

3 GIBSON, William. Mundo espejo. Minotauro. Barcelona. 2004.

4 Futuro, ra. 1. adj. Que está por venir. U. t. c. s. m. 4. m. Gram. Tiempo que sirve para denotar una acción, un proceso o un estado de cosas posteriores al momento en que se habla. 


\title{
O/ARQUEOLOGÍA DEL FUTURO: INTRODUCCIÓN / METODOLOGÍA / INSTRUCCIONES
}

\section{¿Por qué "Arqueología”?}

La arqueología aparece como ciencia a mediados del siglo XIX ligada a las teorías evolucionistas de Charles Darwin ${ }^{5}$, generando el concepto de Prehistoria ${ }^{6}$ y destrozando el mito cristiano del origen del mundo, fijado en el año 4000 A.C. aproximadamente con la creación de Adán y Eva por parte de Dios. En su manera de operar, la arqueología se presenta como una disciplina histórica, ya que se ocupa del pasado del hombre, a la vez que científica. El registro que sirve de fuente principal para la elaboración de la historia hace declaraciones, ofrece opiniones, emite juicios. Sin embargo, la arqueología se nutre de una serie de objetos que no dicen nada en sí mismos directamente, no expresan de forma directa qué debemos pensar sobre ellos, por lo cual requiere de estudios sistemáticos para la elaboración de futuros modelos operacionales a partir de los mismos. Así es como se ha articulado toda la metodología de esta tesis, dando la mayor importancia a los proyectos arquitectónicos, más allá de las opiniones coetáneas o futuras vertidas sobre ellos, y utilizando la taxonomía como método comparativo, a través de catálogos de elementos presupuestos como iguales. El trabajo de campo corresponde a los lugares en los que se han encontrado esos proyectos, las predicciones arquitectónicas como punto de partida y una serie de publicaciones periódicas de las que se extrajeron los proyectos citados en las mismas.

\begin{abstract}
"Los arqueólogos encuentran de vez en cuando, en sus excavaciones en el desierto del Sahara o en cualquier gruta que, en tiempos, se hallara a las orillas del mar, algún fragmento de residuo animal y, según examen y estudio riguroso, llegan a saber que era un trozo de diente de un ser que vivió en el período paleolítico superior, cualquier especie de Homo desconocido. El fragmento pasa a manos de otros expertos que intentan reconstruir en su integridad el animal, el hombre o el objeto (en otros casos) a base de su relieve estructural, matérico, etc...
\end{abstract}

...Haremos una reconstrucción teórica de un objeto imaginario basándonos en fragmentos de residuos de uso desconocido y de incierto origen...... No sabemos que resultará de ello, ni a qué mundo podrá corresponder...

...Y así, con calma, y sin acordarnos de Rafael, habremos reconstruido algo que antes no existía; algo que nadie viera antes; algo que nosotros mismos desconocíamos; algo que arrojaremos de inmediato a la papelera porque no valdrá nada. Perseverando si acaba por lograrse. " (Bruno Munari, 1970 (1999), pp.8-9)

\footnotetext{
5 Charles Darwin [1809-1882] en El Origen de las Especies. 1859. establece el concepto de evolución como mejor explicación del origen y desarrollo de todas las plantas y animales.

6 El término "Prehistoria" adquirió un uso general tras la publicación del libro de John Lubbock, Prehistoric Times. 1865.

7 MUNARI, Bruno. Reconstrucciones Teóricas de Objetos imaginarios. En: Fisuras de la Cultura Contemporánea, n7, Abril 1999. pp. 8-12.
} 


\section{¿Por qué "del Futuro"?}

Cualquier manifestación que opere más allá de los mecanismos sociales, culturales o tecnológicos de su presente es susceptible de adquirir el carácter prospectivo que le confiere la etiqueta "Futuro". Si bien es cierto que cualquier época ha sido productora de este tipo de alternativas, desde distintos enfoques culturales tan dispares como el bienestar social, la fantasía, la utopía, las distopías o el radicalismo como más tarde veremos, es a partir del siglo XX cuando éstas se popularizan, convirtiéndose en parte del imaginario colectivo, a través de Exposiciones Universales, juegos ${ }^{8}$ o películas de ciencia ficción. Desde finales de los años cincuenta hasta mediados de los setenta se contextualiza el período de tiempo en el que tienen una mayor influencia en el campo de la arquitectura, apareciendo así como contexto temporal objeto de estudio de esta tesis.

Cabe destacar la importancia del estudio de dichas manifestaciones, herramientas, estrategias o proyectos de futuro a partir de sus grados de vigencia en la actualidad, ya sea por su influencia en el pensamiento arquitectónico contemporáneo, claramente reflejado en estudios como el de las publicaciones independientes de aquella época ${ }^{9}$, convertido en la exposición itinerante "Clip Stamp Fold. The radical architecture of Little magazines. 196X to 197X" dirigido por Beatriz Colomina, la redefinición de la estética contemporánea a partir de planteamientos "vintage" 10 derivados de la década de los sesenta o setenta ${ }^{11} \mathrm{e}$ incluso como reinterpretación a modo de catálogo de primigenias estrategias ecológicas como en la reciente exposición "EcoRedux" comisariada por Lidia Kallipoliti².

Para reforzar la importancia que tienen muchos de esos proyectos en la actualidad, más allá de la nostalgia que impregna nuestra aún latente posmodernidad, se hace referencia a dos textos de Dominique Rouillard y Frédéric Maigayrou en los que se subscribe ese carácter "inspirador" de estas manifestaciones arquitectónicas en las nuevas generaciones de arquitectos:

"El período comprendido entre 1950 y 1970 acelera el fin de la modernidad y lo reemplaza discretamente por la situación contemporánea. Nunca más que durante estas dos décadas, el futuro de la arquitectura ha comprendido hasta ese punto el

8 Con motivo de su 20 Aniversario, en 1966 la Kaiser Aluminium Chemical Corporation comisionó un juego para predecir "posibles futuros" para los próximos 20 años (es decir para 1986). El juego "Future" permite desarrollar futuros probables para 1986 a partir de rangos de predicciones hechas por dos expertos asociados a redes de pensamiento y la industria aeroespacial norteamericana. El juego es por lo tanto un modelo de simulación para predecir, o mejor dicho generar una serie de posibles mundos.

9 Exposición "Clip/Stamp/Fold. The Radical Architecture of Little Magazines 196X-197X" 13 de Marzo al 17 de Mayo de 2009 en la sede de Disseny HUB (Barcelona).

10 Es interesante comprobar la influencia del contexto objeto de estudio en la actualidad a través de la gran cantidad de remakes de exposiciones contextualizadas en proyectos o autores incluidos en la tesis.

11 HARDINGHAM, Samantha (editora invitada). AD The Architectural Design Profile, The 1970s is Here and Now. Willey. Londres, 2005.

El número completo ya especula sobre una posible vuelta a los años 70 desde la perspectiva de la revista como gran influencia de muchas de los posicionamientos estéticos de la arquitectura actual en múltiples hibridaciones en torno a la cultura de masa, la tecnología o el medio ambiente.

12 KALLIPOLITI, Lidia (editora). AD The Architectural Design Profile. EcoRedux: Design Remedies for an Ailing Planet. Willey. Londres, 2011. 
proyecto arquitectónico como un deseo de realidad"13 (Dominique Rouillard, 2004, pp.11-12)

"Podremos, en fin, asir el recurso que representa para la arquitectura actual, habiendo desplegado de nuevo todos los valores de la arquitectura; la relación con el cuerpo, con la medida, el entorno y, claro está, con el objeto, con habitarlo. Las premisas de una arquitectura siempre fáctica, siempre en acto, que se nutre de una intervención y de una relación permanente con el contexto, parecen ser efectivamente en la actualidad un recurso vigorosamente reivindicado por la generación emergente." ${ }^{" 14}$ (Frédéric Maigayrou, 2001, p.2)

Otro de los aspectos importantes que justifican la "revisión" de esas estrategias arquitectónicas pertenecientes al contexto temporal antes enunciado, es el "olvido" y "desprecio" generalizado al que este período arquitectónico ha sido sometido en las "grandes" historias de la arquitectura moderna, ya sean las de Benévolo, Tafuri o Frampton, convertidas desde los años ochenta hasta nuestros días en catálogos de "referencia" en Escuelas de Arquitectura de medio mundo.

"Sin embargo, esto no es más que un intento de dar sentido al fenómeno del consumo de masas. No es casual entonces que una gran celebración de la falta de forma se lleve a cabo bajo la bandera de una utopía tecnológica. Las metáforas irritantes e irónicas de Archigram, del grupo Archizoom, o de la arquitectura concebida como una explosión de fragmentos de John Johansen, hundan sus raíces en el mito tecnológico." ${ }^{15}$ (Manfredo Tafuri, 1974, p.54)

"Con Banham representando los ademanes narcisistas de Visnú en su burbuja hinchable y solipsista, equipada con un aparato de alta fidelidad y presumiblemente otras comodidades (como homenaje, probablemente, al espíritu inculto de la letra irónica de Fuller para la canción Road Home to a Dome), todos ellos proponían valores espaciales que estaban muy por debajo del Existenz minimum de antes de la guerra a quienes supuestamente despreciaban."16 (Kenneth Frampton, 1980, p.286)

13 "1950-1970: la période accélere la fin de la modernité, et lui substitue discrétement la situation contemporaine. Jamais autant que durant ces deux décennies, le futur de l'architecture n'aura à ce point saisi le projet d'architecture comme une volonté de réalité."

ROUILLARD, Dominique. Superarchitecture. Le Futur de l'architecture 1950-1970. Éditions de la Villette. Paris, 2004. pp. 1112.

14 MIGAYROU, Frédéric. Radicalismos europeos. En: Arquitectura Radical. Arquitectura radical: Centro Andaluz de Arte Contemporáneo, Sevilla, enero-marzo de 2003. Junta de Andalucía. Sevilla, 2003. p.2.

15 "Yet this is but an attempt to give meaning to the phenomenon of mass consumption. It is not by chance then that a great many such celebration of the formlessness take place under the banner of a technological utopia. The irritating and ironic metaphors of Archigram or of the Archizoom group, or of architecture conceived as an explosion of fragments by John Johansen, sink their roots deep into the technological myth."

TAFURI, Manfredo. L'architecture dans le Boudoir. The language of criticism and the criticism of language. En: OPPOSITIONS, n³, mayo 1974. p.54.

16 FRAMPTON, Kenneth. Historia crítica de la arquitectura moderna. Gustavo Gili. Barcelona, 1998. p.286. Traducción: Jorge Sainz. Ed. original: Modern Architecture. A critical History. Thames \& Hudson. Nueva York, 1980. 
Por lo tanto, los olvidos de Benévolo y las críticas aparentemente tecnófobas de Frampton y Tafuri en la década de los ochenta, contrastan con los esfuerzos por sacar a la luz "Ios archivos ocultos" de esa época por parte de investigaciones como la de Colomina:

"La idea del proyecto Clip / Stamp / Fold es recuperar este momento exuberante, período sobre el que hay algún tipo de amnesia. Incluso los protagonistas, editores y arquitectos involucrados en la producción de estas revistas, parecen haber olvidado lo increíble, denso y explosivo que fue ese momento." ${ }^{.17}$ (Beatriz Colomina, 2010, p.8)

De esta manera, Arqueología del Futuro supone un estudio de prácticas, sistemáticas y estrategias arquitectónicas del pasado que siguen teniendo "repercusión" en nuestros días, en los que ha vuelto al debate arquitectónico la esperpéntica pregunta "¿Qué es arquitectura?". Para nada el fin de esta investigación es la búsqueda de ese reduccionista ¿Qué? sino de los heterogéneos ¿Cómo?, que sufrieron una fértil revolución y evolución en ese período comprendido entre finales de los años cincuenta y mediados de los setenta, auspiciados bajo la etiqueta "futuro". Una multiplicidad de "maneras" de desarrollarse como arquitecto más allá de la visión de una arquitectura entendida como disciplina autónoma y auto-referencial. Unas opciones de futuro materializadas en proyectos arquitectónicos concretos, difundidas a través de una serie de variadas predicciones arquitectónicas.

"The future of the past is in the future.

The future of the present is in the past.

The future of the future is in the present."18 (John McHale, (1967) 1969, prólogo)

"Tiempo presente y tiempo pasado.

Tal vez ambos estén en el futuro,

Y el futuro contenido en el pasado"19 (T.S Elliot, 1936)

\footnotetext{
17 "The idea of the Clip/Stamp/Fold project is to recover this exuberant moment about which there is some kind of amnesia. Even the protagonists, the editors and architects involved in the production of these magazines, seem to have forgotten how amazing, dense and explosive that moment was"

COLOMINA, Beatriz; BUCKLEY, Craig (editores). Clip, Stamp, Fold: The Radical Architecture of Little Magazines 196X 197X. Actar. Barcelona, 2010. p.8.

18 MCHALE, John. The Future of the Future. George Braziller. Nueva York, 1969. prólogo.

19 Cita del poema "Burnt Norton" (1936) de T.S. Elliot en el prólogo del libro "Arquitectura 2000, predicciones y métodos" de Jencks.
} 


\section{Metodología (I). Sistemática de trabajo.}

Arqueología del Futuro es fundamentalmente una taxonomía de proyectos arquitectónicos, dividida en dos partes: una primera investigación general y un caso aplicado, que acota una de las áreas generales objeto de estudio. En esta investigación se ha trabajado a través de las cinco fases principales de cualquier investigación arqueológica ${ }^{20}$ : recogida de datos y estrategias de muestreo, realización de experimentos, formulación de hipótesis, contraste de la hipótesis con más datos y por último, elaboración de un modelo.

\section{Recogida de datos. Estrategias de muestreo.}

La primera recogida de datos se realizó casualmente en sentido inverso al orden de la tesis. Esa búsqueda primigenia de proyectos iba encaminada a viviendas móviles y transportables como alternativa de futuro, sin un contexto temporal preconcebido. Derivada de ésta fase inicial de búsqueda, el ya citado contexto desde finales de los años cincuenta a los primeros setenta se consolidó como especialmente fértil en relación al objeto de estudio de la investigación. Esa búsqueda desencadenó un estudio más amplio, debido a que en muchas ocasiones esos proyectos de vivienda iban etiquetados con ese calificativo "del futuro". El interés por otros proyectos "de futuro" determinó como fundamentales las publicaciones que se han denominado como "predicciones arquitectónicas".

El trabajo con la bibliografía resulta fundamental en un trabajo taxonómico de proyectos arquitectónicos, por lo que se ha primado el uso de la información visual asociado a los proyectos mucho más que la documentación escrita sobre ellos.

\section{Realización de experimentos.}

Los primeros proyectos encontrados en esas predicciones arquitectónicas se clasificaron y catalogaron en una búsqueda de parámetros comunes, que poco a poco iban respondiendo a las cuatro alternativas de futuro antes citadas: cambio de escala, perversiones naturales, hacia una arquitectura virtual y la movilidad como opción de futuro ${ }^{21}$. El caso aplicado de la tesis, relacionado con viviendas móviles y transportables se convertiría de esta manera en una de las sub-clasificaciones derivadas de las estrategias de movilidad.

El uso de catálogos visuales se ha revelado como herramienta fundamental de esta investigación.

\footnotetext{
20 Algunas veces se ha confundido en esta investigación la palabra "arqueología" con una simple metáfora y no como metodología posible.

21 Es obvio que las categorías comenzaron de manera difusa y se fueron delimitando al encontrar más proyectos que iban respondiendo a unos parámetros comunes.
} 


\section{Formulación de una hipótesis.}

El análisis, datación, representación y segregación de los proyectos, posibilitó un primer estado de los objetos a partir del cual las alternativas de futuro se concretaron como estrategias arquitectónicas más específicas, de ahí que los catálogos se fueran diferenciando en operaciones particulares, derivadas de una misma alternativa de futuro. Uno de los objetivos principales de la tesis ha sido tratar de exponer todos esos catálogos de proyectos de futuro a partir de estrategias arquitectónicas comunes, más allá de los simplificados clichés de "cápsulas" o "megaestructuras".

\section{Contraste de la hipótesis con más datos.}

La necesidad de acumular proyectos que permitieran esclarecer las evidencias mostradas por la primera recogida de datos, hizo necesario ampliar el campo de búsqueda a una serie de publicaciones periódicas relacionadas con el contexto de trabajo. Muchas de esas publicaciones y números concretos de las mismas, estaban referenciados en las bibliografías de las predicciones, otras simplemente publicaban proyectos ya catalogados y se buscaron como posibles contenedoras de otros similares. De esta manera se realizó una revisión de los números de varias publicaciones comprendidos desde 1960 a 1975, en las bibliotecas de la ETSAM y el COAM fundamentalmente.

- La francesa L'Architecture d'Aujourd'hui ampliamente referenciada por Michel Ragon y Justus Dahiden. Por referencias en la misma también se consultaron algunos números de la también francesa Techniques et Architecture.

- La inglesa Architectural Design, referenciada por Charles Jencks, John McHale y sobre todo por Peter Cook.

- La japonesa The Japan Architect, con varios números relacionados con megaestructuras referenciados por Justus Dahinden.

- Las italianas Domus y Casabella, que a pesar de no ser referenciadas, publicaron muchos proyectos relacionados, revelando así una importancia vital para el esclarecimiento de varias de las estrategias relacionadas con alternativas de futuro concretas.

- La norteamericana Progressive Architecture, de la que Jim Burns fue editor durante varios años.

- Se consultaron números concretos de otras publicaciones como las españolas Arquitectura y Nueva Forma, la suiza Bauwelt, la alemana Bauen und Wohnen o los Cuadernos SummaVisión argentinos ${ }^{22}$.

Esa consulta ampliada ayudó a construir una herramienta específica relacionada con las fuentes bibliográficas que se ha utilizado para obtener conclusiones en el caso aplicado y que permitió establecer un conjunto de proyectos que respondían a las categorías estudiadas, lo suficientemente extenso como para poder elaborar un modelo operacional. En 
toda la investigación se han catalogado más de 1500 proyectos, 1143 en la primera parte y 391 en el caso aplicado.

Cambio de escala (389 proyectos catalogados)

Perversiones naturales (329 proyectos catalogados)

Hacia una arquitectura virtual (173 proyectos catalogados)

La movilidad como opción de futuro (252 proyectos catalogados)

Caso aplicado Viviendas Móviles / Transportables / Transformables (391 proyectos catalogados)

\section{Elaboración de un modelo}

Tanto en la parte general de la investigación como en el caso aplicado se ha generado un modelo operacional de comportamiento de los proyectos a través de los catálogos comparados y su relación con las fuentes bibliográficas. Así es como la tesis presenta una serie de lecturas múltiples. Cada una de las alternativas de futuro y sus estrategias asociadas pueden leerse de manera autónoma, de manera conjunta con su catálogo o atlas visual asociado, o en relación al conjunto de todas ellas en el contexto temporal referenciado. De esta segunda lectura imbricada se han realizado una serie de diagramas o árboles genealógicos que explicitan una serie de evidencias temporales delimitadas a modo de conclusiones. En el caso aplicado se ha intentado dar un paso más en relación al uso de la metodología taxonómica arqueológica, generando un modelo totalmente operativo en relación a los parámetros y estrategias bajo los cuales se han catalogado las viviendas estudiadas. De la misma manera el trabajo bibliográfico ha sido también más riguroso, lo que ha permitido detectar una serie de comportamientos o tendencias temporales en relación al objeto de estudio. Se ha procurado en todo momento que esos modelos, tanto los derivados de la primera parte de la investigación, como los relacionados con el caso aplicado se comporten como sistemas abiertos, pudiéndose trabajar con ellos en un futuro bajo dos sistemáticas totalmente divergentes:

- Trabajando con las hipótesis de partida y los modelos operativos, intentando refutar o refrendar el modelo con la incorporación a la investigación de nuevos proyectos encontrados.

- No asumiendo las hipótesis ni los modelos de trabajo pero pudiendo trabajar desde distintas perspectivas con todos o algunos de los proyectos aquí referenciados. 
"Todavía hoy es necesario ser precavidos ante la seducción natural de lo nuevo; a fin de cuentas, cuando se conocen los "principios" esenciales de la función oblicua, se advierte que una propuesta como ésta existió ya en el pasado, en épocas muy alejadas en el tiempo, muy distintas en lo moral y económico, y que dieron lugar a formulaciones concretas de las que la arqueología nos ofrece un testimonio irrecusable. Desde la Turquía del VII milenio a.C, hasta los pueblos actuales del sur de Argelia, ha existido un pasado de la función oblicua. Este pasado ha tenido, o conserva hoy, su verdad, su realidad sociológica. Es en este sentido, a la función oblicua le está permitido descubrir, imaginar en el pasado, esta arqueología del futuro; del mismo modo que en el presente es posible detectar el germen, ya sea en las ideas o los actos, de una futurología. Es decir, de una ciencia basada en el descubrimiento del futuro de la humanidad, en tanto que futuro no impuesto ni padecido por sus dos partes -los habitantes y los inventores creadores-, sino integrando la imaginación de los unos con el uso de los otros. DEBEMOS LEER EL

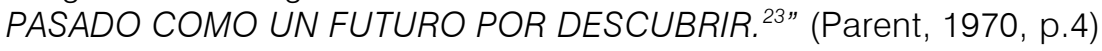




\section{Metodología (II). Hacia una tesis en abierto. www.arqueologiadelfuturo.blogspot.com}

En paralelo a esta investigación académica, en verano de 2008 aparece el blog www.arqueologiadelfuturo.blogspot.com como lugar de recopilación de contenidos de la tesis en abierto. A pesar de poder parecer un acto irrelevante para una investigación académica a prestigiar ante un tribunal académico, el hecho de que esta tesis haya tenido ese blog asociado a la misma ha supuesto el mayor hallazgo metodológico e incluso el carácter más innovador de esta investigación. Se ha creído conveniente sintetizar en cinco puntos fundamentales la relevancia del formato blog asociado a una investigación puramente académica:

\section{La importancia de una Tesis en abierto.}

La búsqueda de información sigue siendo aún en nuestros días una herramienta al servicio del poder. "Quién tiene la información posee el control". Existe una misma visión en el mundo doctoral y académico en el que esta tesis se ha desarrollado, con una gran dificultad para saber sobre qué temas están investigando otros doctorandos y sobre todo al acceso de la información que se maneja en tesis paralelas. Muchas veces se están estudiando los mismos períodos y los mismos proyectos, realizando las labores de reformateado de la información de manera casi simultánea. ¿Por qué no crear una base de datos de proyectos, de bibliografía, de documentación gráfica, de artículos, común a toda la comunidad de investigadores?

La información debe ser compartida desde su proceso y no sólo cuando ya se ha reformateado y condensado en una investigación personal como es una tesis doctoral. Muchas veces esa información sin elaborar es más productiva que dentro de un marco ya totalmente encorsetado. En ese sentido, el blog ha sido el contenedor de los pequeños hallazgos proyectuales que se han ido encontrando durante el proceso de investigación.

\section{La Tesis como labor pedagógica. Sobre la difusión de las investigaciones académicas.}

Una de las labores fundamentales de una investigación académica se presupone que debe ser la de la difusión en lugares de prestigio. El fin de una tesis parece ser la de ser almacenada en un cajón de la universidad o alimentar el poco visitado portal de la UPM. La labor de difusión se reduce a grupos elitistas en el que el objetivo más optimista será el de acabar como una publicación al uso.

El blog ha servido como lugar de difusión de Arqueología del Futuro, no como resultado final sino como proceso. Desde julio de 2008 a diciembre de 2014, el blog ha recibido casi 350,000 visitas por parte de más de 200,000 usuarios, con un total de 750,000 páginas vistas, con una media de unas 100 visitas diarias y entre 3500 y 7000 visitas mensuales. De esta manera la tesis ha cumplido su labor de difusión, mucho antes de salir a la luz como producto final, como proceso de investigación. 


\section{La Tesis como lugar de debate, como conector de experiencias similares.}

La tesis entendida como un proceso, debería convertirse en lugar de debate, en un conector de experiencias de investigación paralelas. La mayoría de las veces, la ineficiencia de los denominados grupos de investigación de la ETSAM hace que muchos de los investigadores busquen otros formatos, otras maneras para poder formar sus grupos de investigación de manera informal. La publicación del proceso de la tesis mediante el blog ha permitido conectar esta tesis con un gran número de agentes interesados en investigaciones parecidas, generando un diálogo de ida y vuelta y una manera de compartir recursos bibliográficos, conceptuales o anímicos más allá de las aulas de la universidad. Ese grupo de trabajo virtual se ha compuesto con agentes muy diversos y con iniciativas que han hecho crecer la investigación de manera exponencial.

\section{4 a Tesis como herramienta para cambiar protocolos obsoletos.}

Las instituciones académicas todavía dependen demasiado de protocolos obsoletos de prestigio que se fundamentan en las relaciones personales y el boca a boca, fomentando una inercia negativa del "yo estuve allí". El mundo de la investigación académica sigue aún vinculado a la meritocracia derivada de los "papers" en congresos por los que hay que pagar por publicar, y a la figura de becarios precarios que no cobran dinero por sus servicios públicos, generando competencia desleal, reproduciendo en la institución pública un mal derivado de los estudios profesionales privados. En este sentido, la difusión a través del blog ha permitido que Arqueología del Futuro pudiera participar en publicaciones, conferencias y exposiciones ya no sólo sin pagar, sino al contrario, recibiendo retribuciones por muchas de esas experiencias académicas.

\section{5 ㅇ La Tesis como lugar de auto-prestigio.}

Cada día resultan más dudosas las estructuras destinadas a prestigiar a otros, llámense tribunales de tesis, concursos de miss España o certificados de seguridad en calderas. Las cada vez más democráticas redes posibilitan la aparición de lugares de auto-prestigio, sin tener que ser avalados por ningún agente o institución de prestigio. El blog ha sido el lugar de auto-prestigio de esta investigación. A partir del mismo, esta investigación ha podido participar en cursos, conferencias y publicaciones, eventos que de otra manera hubieran sido imposibles, al no estar vinculada de "otras maneras" a ninguna institución académica, en parte por tener que compaginar trabajo profesional con investigación académica. 


\section{Recorrido por capítulos.}

\section{Capítulo 1. SOBRE EL PASADO DEL FUTURO.}

La investigación comienza con una pequeña introducción sobre la producción histórica de visiones de futuro con el objetivo de proveer un contexto histórico mínimo al desarrollo de esta tesis. Se enuncian algunas de las estrategias generadoras de posibles futuros más relevantes, para llegar así al contexto de estudio, desde finales de la década de los cincuenta a mediados de la década de los setenta, en la que la palabra "futuro" no sólo se ha legitimado sino también popularizado, invadiendo así cualquier ámbito relacionado con la cultura.

\section{Capítulo 2. PREDICCIONES ARQUITECTÓNICAS.}

En ese contexto de popularización del futuro, la arquitectura utiliza las exposiciones universales y las ferias para reivindicar también su potencial para generar imágenes o ensoñaciones de lo que vendrá. Más allá de esos contextos populares, la propia disciplina se debate en cómo será la arquitectura del futuro a través de publicaciones a modo de predicciones arquitectónicas. De todas esas publicaciones destacan especialmente once volúmenes:

"Dónde viviremos maña" (1963) y "Las ciudades del Futuro" (1966) de Michel Ragon.

"Architecture: action and plan" (1967) y "Experimental Architecture" (1970) de Peter Cook.

"The Future of the future" (1969) y el número de febrero de 1967 de The Architectural Design " "AD 2000+" de John McHale.

"Arquitectura 2000. Predicciones y métodos" (1971) de Charles Jencks.

"Urban structures for the future" (1971) de Justus Dahinden.

"Arthropods: new design futures" (1972) de Jim Burns.

"Megaestructuras. Futuro urbano del pasado reciente" (1976) de Reyner Banham.

La sección "Cosmorama" (1965-1973) de la revista británica The Architectural Design.

\section{Capítulo 3. ALTERNATIVAS PARA UNA ARQUITECTURA DEL FUTURO.}

El análisis de esas predicciones permite diseccionar los proyectos de futuro que ellas presentan a partir de cuatro alternativas de futuro:

- La incorporación de la arquitectura al heterogéneo espectro formal derivado de la explosión de las artes visuales y la exuberancia y proliferación de los objetos de consumo a través de un CAMBIO DE ESCALA. 
- La generación de nuevas relaciones que experimenten en torno a los límites entre natural y artificial, o PERVERSIONES NATURALES.

- La apertura de un nuevo camino HACIA UNA ARQUITECTURA VIRTUAL que experimente con una construcción de ambientes, auspiciada por los avances tecnológicos derivados del control perceptivo.

- LA MOVILIDAD COMO OPCIÓN DE FUTURO, una respuesta a la aparición de una nueva sociedad en continuo cambio, abogando por estructuras más flexibles en todos los campos del ámbito arquitectónico, de lo urbano a lo doméstico.

\section{Capítulo 4. CAMBIO DE ESCALA.}

La búsqueda de una redefinición formal a partir del cambio de escala para una arquitectura del futuro gravita en torno a siete estrategias fundamentales:

- Monumentalismo geométrico, la fascinación por la formas geométricas convertidas en monumentos-ciudad.

- Ciudades tecno-mórficas, la aplicación de formas maquinistas para la generación de edificios-ciudad.

- Evocaciones programáticas, relaciones formales entre programas, identidades, objetos y edificios.

- Hiper-gráfica, sistemas gráficos convertidos en elementos arquitectónicos.

- Activadores urbanos, cómo objetos domésticos cambian de escala para convertirse en activadores del espacio público.

- Ciudad interior, el interiorismo y diseño de mobiliario pensados como urbanismo.

- Objetualización de la ideología, la transformación de ideologías arquitectónicas en objetos de consumo.

\section{Capítulo 5. PERVERSIONES NATURALES.}

Las experimentaciones en torno a los límites entre natural y artificial se articulan a partir de estas cinco estrategias fundamentales:

- Ciudad paisaje, la ciudad convertida en paisaje como alternativa a la megaestructura.

- Edificios camuflaje, tácticas de camuflaje para edificios proyectados como naturalezas artificiales.

- Naturaleza equipada, como equipar la naturaleza y con la naturaleza.

- Re-naturalizar la ciudad, una vuelta a lo salvaje en la ciudad.

- Naturalezas domésticas, nuevos paisajes naturales domésticos. 


\section{Capítulo 6. HACIA UNA ARQUITECTURA VIRTUAL.}

El concepto de "ambiente" genera una serie de proyectos alternativos que gravitan en torno a tres estrategias:

- Climas artificiales, el control climático como herramienta para una desaparición de la arquitectura.

- Distorsionadores autónomos de la percepción o "todo es arquitectura".

- Simulaciones espaciales, experimentos en torno a la generación de ambientes temporales.

\section{Capítulo7. LA MOVILIDAD COMO OPCIÓN DE FUTURO.}

La búsqueda constante de una movilidad total a todas las escalas arquitectónicas se fundamenta en tres modelos de ciudad claramente delimitadas:

- La ciudad del automóvil, en la que todos los equipamientos desean adoptar el rol de libertad destilado por el automóvil.

- La ciudad instantánea, una búsqueda de una ciudad efímera y flexible.

- La ciudad de los intercambios, una ciudad como mediadora entre los intercambios de energía e información de sus usuarios. 


\section{Instrucciones para la lectura de esta tesis.}

Al ser esta investigación una taxonomía visual de proyectos, ha sido necesario separar entre la parte escrita y los catálogos visuales y diagramas. Así es como cada una de las partes debe ser leída con su atlas visual correspondiente.

Al inicio de cada capítulo se adjunta el catálogo de imágenes o conjunto de diagramas asociado al texto, de manera que recomiendo tenerlo presente cuando se lea el texto.

Esta separación se ha realizado debido al gran número de proyectos y a la necesidad de imágenes para ilustrarlos. Todo ese material visual inserto en el texto dificultaría la lectura en demasía. 


\title{
Capítulo 1. SOBRE EL PASADO DEL FUTURO. Nociones históricas. Construcción del contexto temporal.
}

"Es porque no conocemos bien el presente ni sabemos estudiarlo, que nos esforzamos en estudiar el porvenir." 24 (Pascal, 1656, p.20)

A pesar de no ser ésta una investigación puramente histórica, por las razones citadas anteriormente, veo necesario hacer una pequeña introducción sobre la producción histórica de visiones de futuro con el objetivo de proveer un contexto histórico mínimo al desarrollo de esta tesis.

\begin{abstract}
"La noticia de una turba de gente sin trabajo que se aglomeraba ante el ministerio de Transportes, desalojaba el Big Ben con fuego de mortero y se disponía a destruir la $B B C$, alarmó tanto a algunos radioyentes el 16 de enero de 1926, que acudieron al teléfono a fin de cerciorarse. Unos doce años más tarde, un susto semejante se produjo en los Estados Unidos después de un informe radiofónico acerca del aterrizaje de los marcianos en la Tierra, cundiendo también un gran pánico. El hecho de que la causa de ambos pánicos fuera una fantasía profética, en el primer caso hecha por el padre Ronald Knox, en el segundo por H.G. Wells, fue una indicación de cómo las visiones del futuro reflejan tensiones emocionales colectivas en nuestro propio presente." ${ }^{25}$ (Armytage, 1968, prólogo)
\end{abstract}

\section{Un futuro generador de mitos.}

Desde los primeros hallazgos escritos, aparece un interés primigenio del hombre por intentar planear su futuro como vía de escape a esas tensiones sociales citadas por Armytage, ya sea desde la perspectiva de los profetas judíos que proclamaban la misión del país a través de la futura venida de Yaveh, cresmólogos griegos como Calcas y su predicción sobre cuánto duraría la guerra de Troya, los famosos augures romanos e incluso mediante personajes inventados como el mago Merlín, popularizado a partir del siglo XII por Geoffrey de Monmouth, cuyas profecías, esperanzas y creencias contribuyeron al auge del orgullo nacional sajón. Salvo raras excepciones, entre las que destacaría "La República" de Platón y la construcción de un tipo de comunidad ideal que supuso el monasterio de St. Gallen de los monjes benedictinos ${ }^{26}$, esas primeras visiones de futuro iban más encaminadas a la creación de seres extraordinarios, desencadenantes apocalípticos, leyendas fantásticas, mitos, pseudo-paraísos e incluso herramientas de control político, que a la generación de nuevos sistemas sociales, culturales o tecnológicos como alternativas de futuro.

\footnotetext{
24 PASCAL. Carta VIII dirigida a MIle. De Roannez. Diciembre 1656. p.20.
}

25 ARMYTAGE, W. H. G. Visión Histórica del Futuro. Edicions 62. Barcelona, 1971. Prólogo. Ed. original: Yesterday's Tomorrows: A Historical Survey of Future Societies. University of Toronto Press. Toronto, 1968.

26 Ambos ampliamente referenciados en:

FEUERSTEIN, Günther. Urban Fiction. Strolling through Ideal Cities from Antiquity to the Present Day. Edition Axel Menges. Sttugart/Londres, 2008. 


\section{La redefinición de la Utopía como motor de futuro.}

Será Tomás Moro con su famoso libro "Utopía"27 (1516) quién gestione el inicio del denominado programa utópico a través del personaje de Raphael Hythloday y su estancia durante cinco años en la isla de "Utopía", término que juega con la ambigüedad entre el nolugar y el lugar mejor, generando de esta manera un modelo de sociedad más avanzada, cuya característica más destacada y diferenciadora supone la abolición del dinero como forma de critica al sistema existente. Esta "Utopía" de Tomás Moro representa según Fredric Jameson una de las mejores definiciones del enclave utópico o programa utópico ${ }^{28}$, diferenciado del impulso utópico ${ }^{29}$, al regirse por una ley de cierre, en este caso una isla exótica apartada del mundo conocido y una sistemática que asume la categoría de totalidad, al producirse una secesión radical con el sistema preestablecido. Es a partir de aquí que se vislumbran nuevas manifestaciones utópicas, generalmente relacionadas con la idea de progreso y materializadas a través de viajes extraordinarios a lugares aún inexistentes ${ }^{30}$, para la construcción de nuevas realidades sociales paralelas a la existente.

De esta manera aparecen enclaves utópicos como "La città del sole"31 (1602) de Tommaso Campanella, que plantea una nueva organización basada en la generalización del espacio del monasterio, o la "Bensalem" ${ }^{22}$ (1626) de Francis Bacon, bajo la misma formalización de Moro de isla exótica aún por descubrir, en la que el hombre busca las causas y efectos de las fuerzas de la naturaleza así como la expansión de su propio poder. Ambos enclaves, representan junto a la "Christianopolis" (1619) de Andreae, una visión más contemporánea de un futuro fundamentado en el progreso científico, como claramente este último solicita para el barrio central de su nueva república:

"Todo lo que la Tierra contiene en sus entrañas está sujeto a las leyes e instrumentos de la ciencia... A menos que analices la materia por medio de experimentos, a menos que corrijas las deficiencias del conocimiento por medio de instrumentos más adecuados, no tienes ningún valor." "33 (Andreae, 1619)

27 MORO, Tomás. Utopía. Akal, Madrid, 1997. Ed. original: Utopia. A Fruitful and Pleasant Work of the Best State of a Public Weal and the New Isle called Utopia. Leyden, 1516.

28 JAMESON, Fredric. Arqueología del Futuro: El Deseo llamado Utopía y otras aproximaciones de Ciencia Ficción. Akal. Madrid, 2009. Traducción: Cristina Piña Aldao. Ed. original: Archaeologies of the Future: The Desire Called Utopia and Other Science Fictions. Verso Books, 2005.

29 En: BLOCH, Ernst. The Principle of Hope. MIT Press. Cambridge, 1986. Vol.1, vol.2 y vol.3.

El autor postula un impulso utópico que rige todo lo orientado al futuro en la vida y la cultura; y lo abarca todo, desde los juegos a los medicamentos patentados, desde los mitos al entretenimiento de masas, desde la iconografía a la tecnología.

30 Resulta muy interesante el cambio de viaje en el espacio a viaje en el tiempo característicos en la construcción del enclave utópico.

31 "La ciudad de/ sol", ideada por Tommaso Campanella está situada en la cima de una gran colina, ceñida por siete murallas enormes, dentro de las cuales estaba encerrado todo el conocimiento humano gestionado por una élite de sacerdotes.

32 BACON, Francis. Nueva Atlántida. Akal. Madrid, 2006. Traducción: Emilio García Estébanez. Ed. original: Nova Atlantis. Londres, 1626.

33 ANDREAE, J.V. Christianopolis. The Ideal of 17th Century. Cosimo INC. New York, 2007. Traducción: Felix Emil Held. Ed. original: Reipublicae Christianopolitanae descriptio. Argentorati. Estrasburgo, 1619. 


\section{En torno a la ciudad ideal.}

Anteriores y contemporáneas a estas manifestaciones, aparecen nuevas ciudades, en este caso con enclaves conocidos e incluso algunas parcialmente ejecutadas, diseñadas por arquitectos, militares y pintores en una búsqueda de "ciudad ideal" ligada a la geometría y el descubrimiento de la perspectiva. Todas ellas nacerán a partir de parámetros defensivos como "Palmanova"34 (1593) de Vicenzo Scamozzi o la "Arquitectura Militar"35 (1570) de Francesco de Marchi, pictóricos como "The City Ideal Space" (1480) de Piero della Francesca e incluso utilitarios como en la "The Standarized City" (1594), en la que Simon Stevin se pregunta por qué han de ser cada una de las viviendas de una ciudad diferentes, anticipando conceptos de la posterior revolución industrial como es el de la "estandarización"36.

\section{Avances científicos y los viajes a extraños lugares.}

A partir del siglo XVII, los avances científicos en el campo de la biología y la astronomía derivados del auge de las matemáticas, comienzan a fructificar a través de dos vertientes principales: las analogías animales como "metáfora" de un futuro perfeccionamiento de la especie humana, ya existente desde la antigüedad como herramienta para generar seres míticos o apocalípticos, y la exploración de nuevos lugares.

Las analogías animales aparecen en nuevas visiones del futuro como experimentos de antropología social a través de la metamorfosis de hombres y animales como en "Blazing World"37 (1666) de la duquesa de Newcastle, o nuevas razas como los severambi de "The Isle of Pines" (1667) de Henry Neville o los Houyhnhnms de "Gulliver's Travels" (1726) de Johnatan Swift, desembocando en la capacidad explicita del hombre para autogenerarse, como narra en "Frankenstein" (1818) Mary Shelley, inicio para muchos de la novela de ciencia ficción.

Por otro lado, la exploración de nuevos lugares presenta dos ejes iniciales de acción, la aceptación de la teoría heliocéntrica de Copérnico (1543) y la imaginación de la parte no vista de la Luna por parte de Kepler en "Somnium" (1630). A pesar de que relatos anteriores como "Historia Verdadera" (180 d.C) de Luciano ya habían especulado con tales iniciativas, ambos escritos hacen que el astro vecino comience a ser considerado como un posible

34 Incluida en su libro: SCAMOZZI, Vicenzo. L'idea della Architettura Universale. Venecia, 1615.

35 DE MARCHI, Franceso. Della Architettura Militare del Capitano Francesco de'Marchi, Bolognese, gentil' huomo romano (1599). Roma, 1810.

36 Cabe recordar que no es objeto de la tesis hacer un amplio recorrido histórico sobre ciudades ideales y utópicas para lo cual recomiendo otros dos textos de referencia:

NEUER BERLINER KUNSTVEREIN. Stadt und Utopie : Modelle idealer Gemeinschaften. Fröhlich \& Kaufmann. Berlín, 1982.

VERCELLONI, Virgilio. Atlante storico dell'idea europea della citta ideale. Jaca Book. Milán, 1994.

37 CAVENDISH, Margaret. Observation upon Experimental Philosophy to wich is added: The Discription of a New Blazing World. 1666.

La autora define nuevas especies de hombres- mono que actúan como científicos, hombres-oso como filósofos u hombres-rana políticos. 
"enclave utópico" sobre el que generar toda clase de nuevas sociedades. Así es como ocurre en el texto sobre el joven español Domingo González "The Man in the Moon" (1620) escrito por el obispo inglés John Godwin de Hereford. Por otro lado, destaca la aparición de "Mathematical Magick" (1648) del también obispo Wilkins, por el cual la magia se convierte en tecnología al posibilitar entre otras cosas la existencia de colonias humanas bajo el mar.

Ambos posicionamientos favorecen la aparición de infinidad de fantasías tecnológicas entre las que destacan las postuladas en "L'Autre Monde" (1657) por Savinien de Cyrano de Bergerac, donde el autor describe una gran cantidad de máquinas volantes, viviendas móviles e incluso libros que pueden escucharse, en lo que podría ser una acertada predicción de los actuales soportes de audio, así como en los anteriormente citados "Viajes de Gulliver", con ciudades voladoras como Laputa o sistemas de construcción de viviendas a partir de globos aerostáticos.

\section{El viaje en el tiempo, la obsesión por el año 2000. Hacia una nueva sociedad.}

Otro de los hitos en las visiones de futuro se relaciona con el cambio del viaje producido en términos espaciales a lugares fantásticos, por viajes temporales a lugares ya conocidos, convirtiéndose así ese salto temporal en el generador de dicho enclave utópico, como es el reflejo de la ciudad de París del año 2440 radiografiado por Louis Sébastien Mercier en "L'An 2440" (1770) o el inicio de una de las obsesiones futuristas sobre el año 2000 con la novela "L'An Deux Mille" (1790) de Restif de la Bretonne, en las que el autor predice cambios sociales como la igualdad de la mujer. De esta manera, el año 2000 se convierte en la fecha más relevante en la mayor parte de estudios futurológicos a partir de la primera mitad del siglo XX y en parte del título de una de las predicciones arquitectónicas más importantes, como es la enunciada por Charles Jencks "Architecture 2000":

"Aunque no se anticipe el fin del mundo ni el Apocalipsis que fue pronosticado para el año 1000, ni el derrumbamiento del edificio de la Iglesia para celebrar el hecho de que tal apocalipsis no tuvo lugar, hay todavía quién imagina que el año 2000 será algo fuera de lo corriente, sencillamente sólo por la especulación que ha engendrado. Desde, por lo menos 1790 que fue cuando se inició la cuenta atrás, ha existido siempre especulación." ${ }^{\text {38 }}$ (Jencks, 1971, p.12)

La sucesión por lo tanto de viajes de exploración a nuevos lugares, acrecentados por la figura de Julio Verne y sus novelas "Viaje al Centro de la Tierra" (1864), "De la Tierra a la Luna" (1865) o "Veinte Mil Leguas de Viaje Submarino" y las previsiones de cambio social en torno al segundo milenio, como ocurre en el exitoso libro "Looking Backward 2000-1887"39 (1888) de Edward Bellamy y su tecnificado ejército industrial que garantiza la felicidad social en el Boston del año 2000, generan el contexto necesario para la aparición de la primera teoría científica del futuro, con la obra "Fragment d'histoire future" (1896) de Gabriel Tarde, al desechar la idea de búsqueda de un suceso previo para apoyar el siguiente, rechazando el concepto de evolución por el de transformación:

38 JENCKS, Charles. Arquitectura 2000. Predicciones y métodos. Editorial Blume. Barcelona, 1975. p.12. Ed. original: Architecture 2000. Studio Vista. Londres, 1971.

39 "Looking Backward" fue imitada, refutada, continuada y denostada en más de sesenta libros posteriores, adoptada por una secta religiosa (los teosofistas), manifiesto de un partido político y germen que popularizó las visiones del futuro como práctica literaria habitual. 
"No me parece ni más concebible ni menos, que el futuro, que todavía no es, haya de influir en el presente, que lo que lo haga el pasado, que ya no es." ${ }^{40}$ (Tarde, 1896)

Paralelamente a esas manifestaciones, aparecen cientos de prototipos de nuevas comunidades asociadas a las nuevas tipologías industriales, como "Las salinas de Chaux" (1789) de Claude Nicolas Ledoux ${ }^{41}$, la fundación de nuevas religiones como en las "Ciudades Mormonas" (desde 1830) asentadas en el estado de Utah e ideadas por su mentor Joseph Smith, nuevos modelos económicos plasmados en los asentamientos de "New Lanark" (1815) y "New Harmony" (1825) diseñados por Robert Owen o los malogrados intentos de nuevos modelos sociales como los que promulgaba el "Falansterio" (1830) de Charles Fourier ${ }^{42}$ o el "Familisterio" (1859) de André Godin.

\section{El origen de las distopías.}

La aparición de un futuro temporal empieza a consolidar las ideas de "conservación" o "preservación", como ocurre en la relación de los recursos terrestres como factor importante para el desarrollo del ser humano. Ante tales suposiciones empiezan a generarse posturas divergentes, tanto positivas, como la de una capital tecnificada de los Estados Unidos del Mundo o "Centrópolis", dirigida mediante energía solar y geotérmica, narrada por Julio Verne en su publicación póstuma "Ayer y Mañana" (1910); como negativas, asociadas en primera instancia a la falta de alimento derivada de una excesiva demografía. La primera de estas utopías negativas es esbozada en 1761 por el ministro de la iglesia de North Street de Edimburgo, Robert Wallace ${ }^{43}$ y postulada definitivamente por Malthus en su "Ensayo sobre los principios de la población" (1798) en el que predice un futuro desastroso en el que el hombre se multiplica en proporción geométrica mientras el alimento lo hace de manera aritmética. Sin embargo, la publicación de la teoría evolucionista de selección natural en 1859 en "El Origen de las Especies" de Charles Darwin, a partir de las teorías de Malthus, impone una nueva doble perspectiva de aparición de distopías, o utopías negativas, frente a todo tipo de historias de humanos mejorados genéticamente. Resurge el eterno debate entre detractores e impulsores de la tecnología en pleno auge de la revolución industrial.

Así es cómo aparecen algunas manifestaciones tecnófobas del futuro basadas en un retorno medieval a comunidades de baja densidad gestionadas mediante talleres de artesanos como la imaginada por William Morris en "Nowhere"44 (1891), germen activo de la ciudad jardín ${ }^{45}$ o "Erewhon" (1872) de Samuel Butler, en la que su protagonista, Higgs, visita un país

40 DE TARDE, Gabriel. Fragmentos de Historia Futura. Abraxas. Barcelona, 2001. Traducción: Miguel Giménez Sales.

41 CHRIST, Yvan. Utopies et divagations de Claude Nicolas Ledoux. París, 1961.

42 CHOAY, Françoise. L'urbanisme, utopies et réalites. Editions du Seuil. París, 1961.

Pueden verse los distintos intentos fallidos de crear comunidades basadas en el Falansterio como aquella fundada en Condé-sur-Vesgre en 1833 por uno de sus discípulos, Mr.Baudet Dulary, y la cual Fourier considera una caricatura de sus ideas.

43 WALLACE, Robert. Various Prospects of Mankind, Nature and Providence. Edimburgo, 1761.

44 MORRIS, William. News from Nowhere or an epoch of rest, being some chapters from a Utopian Romance. 1891.

45 HOWARD, Ebenezer. Garden Cities of Tomorrow. Oxford, 1965. 
que ha abandonado el industrialismo por el temor a una rápida evolución desarrollada por las máquinas que haga peligrar la supremacía humana:

"...fragmentos de un gran número de nuestros inventos más avanzados; pero todos ellos parecían tener siglos, y por ser colocados donde estaban, no para instrucción, sino para satisfacer la curiosidad..., todos estaban estropeados y rotos." ${ }^{\text {"46 }}$ (Butler, 1872)

\section{El problema de los recursos. La utopía frente a la religión.}

Mientras el problema malthusiano de los recursos hizo crecer las distopías alimentarias, como "Meda: A Tale of the Future" (1888) de Kenneth Folingsby, en la que el problema de la disminución de alimento dio lugar a un nuevo tipo de humanos, o "Three Hundred Years Hence" (1881) de Hay, en el que se explora de nuevo la posibilidad de ciudades submarinas como forma de paliar la falta de alimento, estudios como "The Coal Question: An Inquiry concerning the Progress of the National and Probable Exhaustion of our Coal Mines" (1865) de W.S. Jevons, alertan del derrumbamiento del actual progreso por el agotamiento de las reservas de carbón, ampliando de esta manera el espectro de recursos naturales más allá de los alimentos básicos como origen de futuras visiones negativas. De manera parecida, sectores religiosos ven atacados sus intereses ante algunos progresos médicos e intentan acallar esas amenazas con visiones de futuro en las que incluso la muerte es controlada por el hombre, desapareciendo incluso de esta manera el amor, como sucede en "Inner House" (1888) de sir Walter Besant o generándose un aburrimiento tal, que posibilita la aparición de lugares destinados al suicidio colectivo como en "Caesar's Column" (1890) de Ignatius Donnelly, reforzando así las manifestaciones en contra del progreso y la tecnología enmascaradas en sociedades tecnocráticas como formas deshumanizadoras:

"La verdad es que en esa ciudad vasta y superpoblada, el hombre es una rémora, algo superfluo, y creo que muchos hombres y mujeres se mueren del aplastante sentimiento que les produce su propia insignificancia; en otras palabras, a partir del hábito de sentir que no son nada, se convierten en nada... La raza ha crecido en poder y soledad; me temo que ha perdido su atractivo." ${ }^{47}$ (Donnelly, 1890)

\section{El tiempo no lineal.}

Cabe destacar que la aparición por esta época, finales del siglo XIX, del concepto de tiempo no lineal, contribuye a la creación de teorías como la de F. W. H. Myers (1882) sobre la coexistencia de pasado, presente y futuro, o la de Bertrand Rusell en torno al "Complejo de compresencia" o momento en el que se aprehenden juntos pasado, presente y futuro. Dichas teorías son reinterpretadas en varios textos como apologías tecnológicas. A partir de la construcción de un objeto que permitía viajes temporales como en "La Máquina del Tiempo" (1895) de H. G. Wells o la victoria de la ciencia sobre la magia en el viaje de un

46 BUTLER, Samuel. Erewhon, o tras las montañas. Cátedra. Madrid, 2000. Traducción: Joaquín Martínez Lorente. Ed. original: Erewhon, or Over the Range. 1872.

47 DONNELLY, Ignatius. Caesar's Column. F.J. Schulte \& Co. Chicago, c1890. 
yanqui inventor desde la Norteamérica de 1879 a la Gran Bretaña del 528 en "A Conneticut Yankee At King Arthur's Court" (1889) de Mark Twain.

\title{
La aparición de la tecno-fobia.
}

Como réplica directa a la aparición de mecanicistas proféticos como Wells, aparecen una serie de visiones tecnófobas de corte medievalista. "Napoleon of Notting Hill" (1904) de G. K. Chesterton, reivindica para un futuro datado en 1984 una vuelta a los antiguos derechos, hábitos y ceremonias en los barrios de Londres, de los que habían sido despojados por el incipiente progreso, o más tarde "The Machine Stops" (1947) de E. M. Forster, dibuja una de las visiones más paradigmáticas de ciudad del futuro, poblada por humanos hacinados en pequeñas habitaciones y miles de botones con los que poder obtener comida, música e incluso comunicarse a distancia, en un mundo deshumanizado donde el hombre queda a voluntad de la máquina:

\begin{abstract}
"Creamos la máquina para hacer nuestra voluntad, pero ahora no podemos hacer que haga la nuestra. Nos ha privado del sentido del espacio y del tacto, ha embotado todas las relaciones humanas y ha rebajado el amor a un acto carnal, ha paralizado nuestros cuerpos y nuestras voluntades, y ahora nos obliga a adorarla." ${ }^{48}$ (Forster, 1947, pp.140-141)
\end{abstract}

A la par de estas visiones, arquitectos como C. R. Ashbbe o F.LL. Wright ${ }^{49}$ se encuentran diseñando ciudades extensivas como vuelta morrisiana al pasado, ya sean "Broadacre City" o "Taliesin" ${ }^{50}$. Nuevas fábulas sobre la pérdida de la libertad en un mundo futuro totalmente controlado por el "Gran Hermano" como en "Brave New World" (1932) de Aldous Huxley e incluso la creación de "Consejos Antropológicos" que promulgan su "debemos desandar nuestro camino o perecer" en "Seven Days in New Crete" (1949) de Robert Graves, vaticinan un futuro vislumbrado como retorno a un estado anterior de progreso humano.

\section{La popularización del futuro.}

A pesar de esa lucha entre detractores y propulsores del progreso maquinista, la idea de progreso tecnológico difundida a través de descubrimientos como la dinamo, generan nuevos manifiestos maquinistas como "Le Futurisme" (1912) de Marinetti así como el apoyo a nuevas figuras de poder denominadas bajo el término "Tecnocracia". Uno de esos adeptos tecnócratas, Hugo Gernsback, se convierte en uno de los principales propulsores de la difusión de estas historias fantásticas asociadas a la tecnología y el progreso a través de los magazines populares estadounidenses, publicando revistas como "Science wonder Stories"

48 FORSTER, E. M. The Machine Stops. En: Collected Short Stories. Penguin Books. Londres, 2002. pp. 140-141.

49 WRIGHT, Frank Lloyd. El Futuro de la Arquitectura. Editorial Poseidón. Barcelona, 1978. Ed. original: The Future of Architecture. Horizon Press. Nueva York, 1953.

50 Taliesin es el nombre de un druida de la corte del rey Arturo que cantaba las glorias de las Bellas Artes.

51 Dónde se emplea por primera vez el término Ciencia Ficción. 
Bradbury, "Utopia News", "Astounding Stories" (1930) o "Amazing Stories"53, con un amplio intercambio entre editores y lectores a través de secciones abiertas al público, así como mediante la creación de asociaciones como la "Sociedad Utópica" o la "Liga de la Ciencia Ficción" fundada en 1934 por el mismo Gernsback, que tuvieron bastante éxito también en Inglaterra antes de la II Guerra Mundial ${ }^{54}$. Resulta interesante la aparición en este período de nuevos términos tan vinculados a la ciencia ficción como la palabra "Robot" fantasía "R.U.R. Rossum's Universal Robots" (1921) escrita por Karel Capek.

\section{La futurología como ciencia.}

A pesar de la creación de foros de conjeturas organizados a principios del siglo XX por el Gobierno Británico como consecuencia del agotamiento de los recursos del carbón o la aparición en 1937 del Comité de Recursos Naturales de los EEUU, no es hasta después de la II Guerra Mundial que la predicción del futuro se convierte en una actividad científica legítima. A partir de estas fechas, científicos como Charles Darwin con "The Next Million Years" (1952), George Thomson con "The Foreseeable Future" (1955) o Dennis Gabor con "Inventing the Future" (1963) impulsaron la generación de nuevos métodos científicos para la predicción del futuro, creándose en paralelo todo tipo de grupos de investigación como la "Asociación Americana para el Progreso de la Ciencia" (1955). Todo ese furor por investigar el futuro termina desembocando en cientos de estudios, comisiones y congresos, destinados a evaluar el impacto humano sobre el futuro, desde el inventario de Buckminster Fuller de los Recursos Mundiales a la "Comisión sobre el año 2000" capitaneada por Daniel Bell, apareciendo así nuevas ciencias como la "Futurología" o la "Prospectiva", aceptadas por EEUU y Francia respectivamente como países pioneros ${ }^{56}$, términos como "Futuribles" 57 , "Invariantes" 58 "Corrientes"59 y cada vez más relatos sobre posibles descubrimientos tecnológicos como sucede en "Profiles of the Future" (1962) de A. C. Clarke.

De esta manera no sólo siguen popularizándose los magazines temáticos sobre ciencia ficción y progreso, sino que el debate llega también a publicaciones científicas como "New Scientist"60, que en 1964 realiza un sondeo entre 100 prestigiosos científicos acerca de sus predicciones futuras, magacines generalistas como el "Weekend Telegraph" que en su número del 3 de marzo de 1967, se pregunta "¿qué pasará en 1990?", e incluso "The New

52 MOSKOWITZ, Sam. Explorers of the Infinite. Shapers of Science Fiction. World Publishing Company. Nueva York, 1963.

53 Tendencia que se acrecentó después de la II Guerra Mundial con la aparición de "Fantasy and Science Fiction" (1949), "Worlds of IF" (1950), "Galaxy Science Fiction", que publicaron grandes obras maestras de la Ciencia Ficción como "Farenheit 451" de Ray Bradbury, "The Demolised Man" de Alfred Bester o "The Martian Shop" de Howard Fast.

54 Dónde el pionero fue Walter H. Gillins con sus “Tales of Wonder” (1937).

55 Derivado del término checo "Robota".

56 GRAS, Alain. Futurología. Martínez Roca. Barcelona, 1978. Ed. original: Clefs pour la futurologie. Editions Seghers. París, 1976.

57 Concepto tomado del teólogo español Molina y enunciado en: DE JOUVENEL, Bertrand: The Art of Conjecture. Basic Books. Londres, 1967

58 Invariantes o tendencias lentas dentro de un entorno de cambio.

59 "Corrientes" o "Trends" seguidas por una tecnología determinada. Ver: BECKWITH, B. The Next 500 Years. Scientific predictions of major social trends. Exposition Press. Nueva York, 1968.

60 Publicado como: CALDER, Nigel (editor). The World in 1984. 2 vols, 1965. 
York Times" que en el ejemplar del 9 de abril de 1967 divaga sobre los métodos, consecuencias y visiones del futuro. La popularidad alcanzada por esta vorágine prospectiva es tal, que incluso uno de los centros de ocio de masas gestionados por Walt Disney es denominado "EPCOT" o "Comunidad Prototípica Experimental del Mañana", y que tiene no sólo como temática el "Futuro" sino una pretensión de convertirse en banco de pruebas y estudios sobre el mismo:

"...nunca estará completa, nunca dejará de ser un esbozo del futuro y siempre se introducirán nuevos materiales, nuevos sistemas y nuevas ideas." ${ }^{61}$ (Walt Disney, 1967)

\section{Contexto para una arqueología del futuro arquitectónica.}

Es en este contexto, de popularización del futuro por un lado y de institucionalización de la futurología como ciencia por otro, en el que se desarrolla esta "Arqueología del Futuro", el prestigio adquirido por el apelativo "futuro" y cualquiera de sus manifestaciones hará que se disparen las propuestas arquitectónicas asociadas al mismo, ya sea desde el contexto de las Exposiciones Universales, las viviendas de exposición o la aparición de nuevos objetos de mobiliario o materiales, a partir de finales de los años treinta.

Sin embargo, será desde finales de los años cincuenta hasta principios de los setenta, cuando la palabra "futuro" aparece vinculada de manera sistemática tanto a proyectos arquitectónicos como publicaciones, convirtiéndose en cómplice protagonista de una serie de propuestas que no sólo reivindican una ruptura manifiesta con su pasado o una insatisfacción con su presente, sino que vislumbran nuevos caminos de desarrollo de la propia disciplina arquitectónica. De esta manera aparece una nueva dialéctica contradictoria en torno a la interacción entre las imágenes arquitectónicas del pasado, presente y futuro, objeto de esta investigación:

"Las imágenes positivas del futuro, concebidas en cada época presente, son codeterminantes para el futuro de esa época. Recíprocamente, el futuro proyectado ejerce ya su influencia sobre el presente a través de dichas imágenes, y por una interacción continua, también afecta la construcción de imágenes revisadas del futuro." ${ }^{62}$ (F.L. Polak, 1961, pp.114-115)

61 Palabras pronunciadas por Walt Disney para el artículo: LEWIN, David. Disney's Last and Greatest Dreams is Coming True. En: Daily Mail, 14 de febrero de 1967.

62 POLAK, Frederik Lodewijk. The Image of the Future. Elsevier Scientific Publishing Company. Amsterdam / Londres / Nueva York, 1973. pp.114-115. 


\title{
Capítulo 2. PREDICCIONES ARQUITECTÓNICAS. La aparición de la etiqueta "Futuro" en la difusión arquitectónica.
}

A partir de 1851, coincidiendo con la "Great Exhibition of the Works of Industry of all Nations" de Londres ${ }^{63}$, las exposiciones nacionales se internacionalizan, adquiriendo un carácter global y convirtiéndose de esta manera en exhibiciones del poder industrial, comercial y creativo de los países participantes, en instrumento de proyección política y de imagen del país organizador así como en facilitadoras de iconos urbanos, como la "Torre Eiffel" o de extraordinarios hallazgos constructivos como el del "Crystal Palace" (1851) de Paxton. En estas exposiciones se genera una hibridación entre la incorporación de nuevos productos como la luz eléctrica, los sistemas de industrialización o los nuevos sistemas de comunicación y los elementos históricos de las culturas locales que presuponen la dicotomía contemporánea entre local y global, y de la que por supuesto estas exposiciones no son un gran ejemplo, al "revisitar" las tradiciones locales la mayor parte de las veces a través del pastiche y el cartón piedra. Esta dicotomía vendrá siempre asociada a la idea de progreso, construyendo así paisajes divergentes que van desde el suntuoso "Palais du Electricite" de Edmond Coignet en la Exposición Universal de París (1900) como gran pastel de bodas conmemorativo de esa nueva "Electricidad" hasta la réplica "Cliff Dwellings" de la Exposición de St. Louis (1904), reconstrucción de las viviendas excavadas por los indios norteamericanos en los cañones del Midd-West, exterminados y convertidos en icono al mismo tiempo. Esta idea de progreso germinal, llega a su culmen en 1933 con la Exposición de Chicago "A Century of Progress Exposition", y con ella, una serie de experimentos en torno a lo que debería ser la "Arquitectura del Futuro", derivados de la tensiones sociales de la época generadas por el ascenso de regímenes totalitarios en países de la vieja Europa.

\begin{abstract}
"En la década de 1930, Estados Unidos había abandonado el clasicismo, ahora asociado con el fascismo en lugar de la democracia, en favor de una racionalización y modernidad para una nueva cultura de masas, que implicaba un progreso en el mundo libre. La arquitectura futurista fue el sello distintivo de la 'A Century of Progress, International Exposition' celebrada en Chicago en 1933." "64 (Jackson, 2008,
\end{abstract} p.59)

En esa Exposición de 1933, aparece la "House of Tomorrow" de George Fred Keck, visitada por más de 750,000 personas durante la feria y popularizada en medios de comunicación como la "America's First Glass House" al considerarla como la primera "Casa del Futuro" con relevancia internacional, a pesar de haber sido denominada como "Casa del Mañana" y todavía no explícitamente "del Futuro". Keck propone de esta manera una cubierta plana, diseño modular, industrialización, sistemas pasivos de climatización y mucha iluminación. Una industrialización y luminosidad auspiciadas por las industrias del aluminio y el vidrio concretamente, como alternativas de un futuro de la vivienda muy rentables para las empresas patrocinadoras. De esta manera, las etiquetas "progreso" y "mañana" anticipan la palabra "Futuro", que se convierte en gran protagonista de la "New York World's Fair" de 1939 en Nueva York, cuyo tema principal es "Building the World of Tomorrow" ("Construyendo el Mundo del Mañana"), y en la que varias propuestas se disputan el sobrenombre esta vez

63 FINDLING, J.E; PELLE,K.D. Historical Dictionary of World's fairs and Expositions 1851-1988. Greenwood Press. Nueva York, 1990.

64 "By the 1930s the United States had abandoned classicism, now associated with fascism rather than democracy, in favour of a streamlined, mass-appeal modernism that implied progress in the free world. Futuristic architecture was the hallmark of the A Century of Progress, International Exposition held in Chicago in 1933"

JACKSON, Anna. Expo. International Expositions 1851-2010. V\&A Publishing. Londres, 2008. p.59. 
de "Ciudad del Futuro", "Democracity" de Henry Dreyfuss y "Futurama" de Norman Bel Geddes y Albert Kahn, para la General Motors. Ambas fueron la segunda y primera exposición más visitadas de la feria, presentando un futuro urbano dominado por el automóvil en el que, además de la General Motors, otras marcas de automóviles o de componentes para ellos, como Chrysler, Ford o Firestone tenían pabellones propios en la feria dentro de la denominada "Transportation Zone". Desde entonces las viviendas y ciudades del futuro se suceden en las posteriores Exposiciones Universales, incluso a partir de ejemplos construidos y realmente habitados como el icónico "Habitat" de Montreal'67 diseñado por Moshe Safdie.

Entre los años 1955 y 1956, ya fuera del contexto de estas Exposiciones Universales aunque con un mismo carácter expositivo, tres prototipos de vivienda se disputan la denominación de "Casa del Futuro", no sólo desde los medios masivos que suponen las revistas populares norteamericanas de la época en las que se fraguan gran parte de los estereotipos denominados "de futuro" como "Popular Science", "Popular Mechanics" o "Mechanix Illustrated"65, o los periódicos nacionales de carácter sensacionalista, sino también desde el ámbito de difusión arquitectónica ${ }^{66}$. Estos tres prototipos de viviendas del futuro fueron la "House of the Future" (1956) de los británicos Alison y Peter Smithson para la "London Mail Ideal Home Exhibition" (1956), "Monsanto House" (1955-1957) de los norteamericanos Richard W. Hamilton y Marvin E. Goody para el parque temático "Tomorrowland" de Walt Disney, y "La Maison Plastique" (1956) de lonel Schein, arquitecto de origen rumano afincado en Francia, para la muestra "Arts Ménagers" (1956) de París.

A pesar de presentar tipos arquitectónicos muy diversos, una reinterpretación de la casapatio en el caso de la vivienda de los Smithson, un esquema orgánico-evolutivo en la de Schein y una propuesta de núcleo central derivada de la Wichita House de Fuller para la Monsanto House, los tres prototipos responden a un mismo carácter de "vivienda de exposición" y a dos paradigmas comerciales encubiertos a través de esa etiqueta "Futuro". Por un lado, un material en creciente desarrollo en ese momento como es el plástico, y un sistema de industrialización para la construcción en masa ante la creciente demanda de viviendas en sus países de origen, Gran Bretaña, Estados Unidos y Francia, después de la II Guerra Mundial, que no casualmente son también los productores de mayor número de

65 Monsanto House:

BEHRENDT, Ernst. Plastic house of the future may come in mass produced, no up-keep parts that you arrange to suit the whole family. En: Popular Science, abril 1956. pp. 144-147.

La Maison Plastique:

HAYES, Leon y Lester. The latest from Paris, an all-plastic house. En: Popular Mechanics, agosto 1956. pp. 88-90.

The House of the Future:

This is a house?. En: Mechanix Illustrated, septiembre 1956. pp.61-63.

66 Monsanto House:

Plastic 'House of Tomorrow' built by Monsanto Chemical Company at Anaheim, California. En: Architect \& Building News, 1957 octubre. 9. pp. 478-485.

La Maison Plastique:

Maison prefabriquee en matiere plastique. En: AA L'Architecture d'Aujourd'hui, n 58, febrero 1955. p. XXIII.

The House of the Future:

House of the Future at the Ideal Homes Exhibition. En: AD The Architectural Design, marzo 1956. pp. 101-102. 
proyectos de futuro hasta finales de los años cincuenta. La etiqueta "Casa del Futuro" o "Ciudad del Futuro" abandona con estos tres prototipos de vivienda el ámbito exclusivamente popular de Exposiciones Universales y medios masivos, para alcanzar también el ámbito exclusivamente intelectual de las revistas especializadas y del pensamiento arquitectónico.

A partir de este momento, el apelativo "Futuro" no aparece solamente vinculado a objetos arquitectónicos de exposición y en general asociados a empresas patrocinadoras sino que empieza a ser utilizado en numerosas ocasiones como etiqueta identificativa de proyectos diversos, con el fin de cualificar de esta manera sistemas constructivos, mobiliario doméstico67, materiales, posturas urbanas, nuevos instrumentos de experimentación arquitectónica e incluso textos y libros de arquitectura, que aparecen enunciados como predicciones de futuros posibles.

Uno de los primeros libros que empiezan a plantearse el futuro, ya no de las ciudades, sino de la propia arquitectura, es "The Future of Architecture" (1953) de Frank Lloyd Wright, que ya no busca una vivienda o ciudad del futuro concretas aunque publicite proyectos de comunidades futuras como "Broadacre City", sino de una nueva manera "orgánica" de hacer arquitectura, cercana a la naturaleza y donde forma y función son una misma cosa. De carácter panfletario, el texto de Wright, no intenta mostrar un panorama abierto de posibles futuros, posicionamiento que determinaremos más tarde como predicciones, sino que plantea incluso una futura debacle mundial si la arquitectura que él denomina como orgánica no prevaleciera sobre la Tierra, en este caso, el mundo presentado de una manera narcisista como los Estados Unidos de América:

"Si la arquitectura orgánica (intrínseca) no se salva, los habitantes de los Estados Unidos no viviremos nunca como una verdadera cultura." 68 (F.LL. Wright, 1953, p.276)

67 Por ejemplo la cocina del futuro de la General Motors y Frigidaire, 1956 Motorama Kitchen of Tomorrow. Ver:

SCOTT HOLLIDAY, Laura. Kitchen Technologies. En: Promises and Alibis, 1944-1966 Camera Obscura (2001) 16(2 47). pp. 79-131.

68 WRIGHT, Frank Lloyd. El Futuro de la Arquitectura. Editorial Poseidón. Barcelona, 1978. p.276. Ed. original: The Future of Architecture. Horizon Press. Nueva York, 1953. 


\section{Predicciones arquitectónicas.}

Ya en las décadas de los sesenta y setenta, claramente influenciados por el anteriormente citado auge de las nuevas ciencias incipientes relacionadas con el futuro como la "Prospectiva" o la "Futurología", varios arquitectos se embarcan en la labor de generar "predicciones" ${ }^{69}$ desde el ámbito puramente arquitectónico, desenmarañando una serie de opciones de futuro que servirán de base para el desarrollo de las líneas principales de trabajo de esta investigación. Cabe destacar que la procedencia de dichos autores corresponde con los contextos en los que el futuro había sido prestigiado, o lo que es lo mismo, los países que habían resultados ganadores de la II Guerra Mundial, Francia, Estados Unidos e Inglaterra. Los criterios de inclusión de las predicciones corresponden al contexto temporal objeto de estudio y a la priorización de proyectos arquitectónicos concretos como instrumentos ejemplares para una serie de alternativas propuestas.

Empezaré por citarlas todas bibliográficamente por orden cronológico y etiquetarlas a partir de sus nombres abreviados para hacer más legible el desarrollo del capítulo:

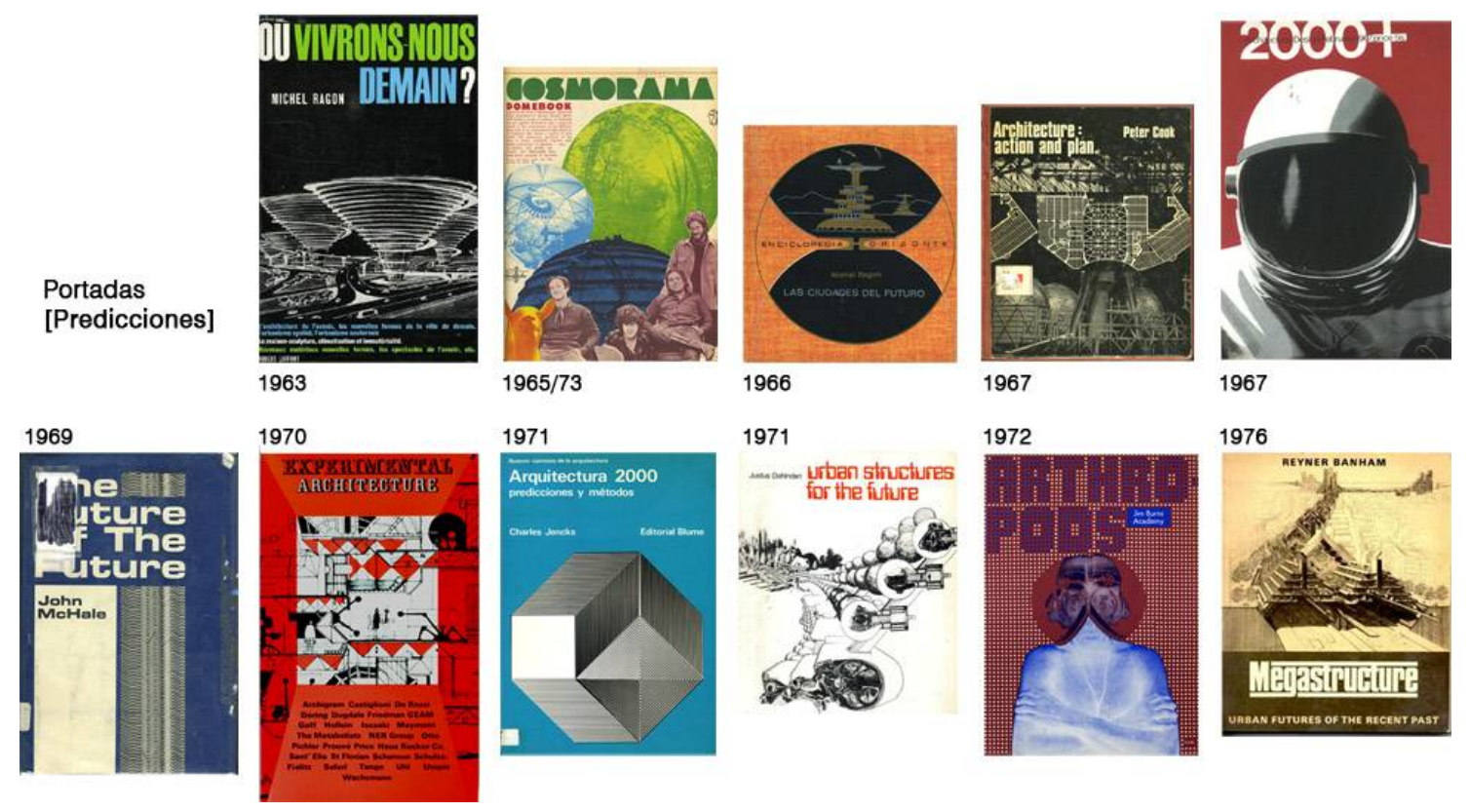

Imagen de las portadas de las Predicciones seleccionadas elaborada por el autor.

1963 "¿Dónde viviremos mañana?" (Michel Ragon)

RAGON, Michel. ¿Dónde viviremos mañana? Luis de Caralt. Barcelona, 1966. Ed. original: Où vivrons-nous demain? Robert Laffont. París, 1963.

1965-73 "Cosmorama" (AD The Architectural Design)

Sección de la revista "AD The Architectural Design" activa desde julio de 1965 hasta diciembre de 1973.

1966 "Las ciudades del futuro" (Michel Ragon)

69 El término predicción puede referirse tanto a la "acción y al efecto de predecir" como a "las palabras que manifiestan aquello que se predice"; en este sentido, predecir algo es "anunciar por revelación, ciencia o conjetura algo que ha de suceder". 
RAGON, Michel. Las ciudades del futuro. Plaza \& Janes. Barcelona, 1970. Ed. original: Les cités de l'avenir. Encyclopédie Planète. París, 1966.

1967 "Architecture: action and plan" (Peter Cook)

COOK, Peter. Architecture: action and plan. Studio Vista. Londres, 1967.

1967 "AD 2000+" (John McHale)

MCHALE, John (editor). 2000+, AD The Architectural Design, vol67, February 1967.

1969 "The Future of the Future" (John McHale)

MCHALE, John. The Future of the Future. George Braziller. Nueva York, 1969.

1970 "Experimental Architecture" (Peter Cook)

COOK, Peter. Experimental Architecture. Studio Vista. Londres, 1970.

1971 "Arquitectura 2000" (Charles Jencks)

JENCKS, Charles. Arquitectura 2000. Predicciones y métodos. Editorial Blume. Barcelona, 1975. Ed. original: Architecture 2000. Studio Vista. Londres, 1971.

1971 "Estructuras urbanas para el futuro" (Justus Dahinden)

DAHINDEN, Justus. Urban Structures for the Future. Pall Mall Press. London, 1972. Ed. original: Stadstrukturen für morgen. Verlag Gerd Hatje. Sttutgart, 1971. Ed. castellano: Estructuras Urbanas para el Futuro. Gustavo Gili, Barcelona, 1972.

1972 "Arthropods" (Jim Burns)

BURNS, Jim. Arthropods: new design futures. Academy. Londres, 1972.

1976 "Megaestructuras" (Reyner Banham)

BANHAM, Reyner. Megaestructuras. Futuro urbano del pasado reciente. Gustavo Gili, Barcelona, 1978. Ed. original: Megastructure. Urban futures of the recent past. Thames and Hudson. Londres, 1976.

De un primer vistazo, se puede advertir la influencia de la etiqueta "futuro" en los títulos de todas las publicaciones aunque desde perspectivas diversas. Los libros de Michel Ragon, "¿Dónde viviremos mañana?" (1963) y "Las ciudades del futuro" (1966) ${ }^{70}$, presentan títulos encaminados a la búsqueda de un futuro de las ciudades de manera genérica, en la que "habitar" se convierte en el centro del debate arquitectónico y la "ciudad" en su medio de expresión más perfecto. Tanto "Estructuras urbanas para el futuro"71 (1972) de Dahinden, como "Megaestructura. Futuro urbano del pasado reciente" (1976) de Banham, puntualizan la búsqueda de ese deseado futuro de las ciudades a partir de unas "estructuras" concretas derivadas del "urbanismo espacial" y las "megaestructuras", desde formatos y términos divergentes como luego veremos. La importancia del año 2000 también aparece como claro referente, tanto en "Arquitectura 2000" (1971) de Jencks como en "AD 2000+" (1967) de Mc

70 Completarían la lista de libros sobre futurología del autor:

RAGON, Michel. Les visionnaires de l'architecture. Robert Laffont. París, 1965.

RAGON, Michel. La Cité de l'an 2000. Casterman. París, 1965.

RAGON, Michel. Paris: hier, aujourd'hui demain., Hachette, coll. La nouvelle encyclopédie. París, 1965.

Estos títulos no se han incluido en la lista porque trabajan desde una perspectiva similar a los ya incluidos en el catálogo de predicciones.

71 En el que la palabra alemana "morgen" (mañana) es sustituida por "futuro" en sus traducciones inglesa y castellana. 
Hale, así como en otro título de Ragon referenciado en el anterior pié de página, derivado de la importancia simbólica de esa fecha en la tradición histórica prospectiva ${ }^{72}$. Aunque sin referencias explícitas al futuro en sus títulos, los dos libros de predicciones de Peter Cook parecen encaminados a la búsqueda del futuro de la arquitectura como disciplina a partir de dos preceptos diferentes: el planeamiento y la acción en el de 1967 y un carácter experimental de la misma sólo tres años después en "Experimental Architecture". "Arthropods" (1971) de Jim Burns se alinea con los textos de Cook en cuánto a un futuro de la arquitectura como disciplina de "diseño", con todas las connotaciones de apertura de la disciplina que ello conlleva. "The Future of the Future" (1969) de McHale, artista, sociólogo y miembro del Indepent Goup, es sin duda el más completo y abierto, el más riguroso y sin embargo carente de proyectos arquitectónicos concretos requeridos como material de base para una "Arqueología del Futuro", por lo cual resulta el menos fructífero para esta investigación, a pesar de su relevancia como preconizador de las ideas de ecología en relación a materiales y energía de manera conjunta a los diversos tratados de Buckminster Fuller sobre estos conceptos.

Antes de presentar las "Alternativas de Futuro" derivadas del estudio comparado de estas predicciones arquitectónicas se ha realizado una introducción de cada una de ellas debido a que muchas de ellas se encuentran descatalogadas y no suelen ser elementos pertenecientes al imaginario colectivo utilizado de manera recurrente en gran parte de las tesis o investigaciones de proyectos arquitectónicos. 

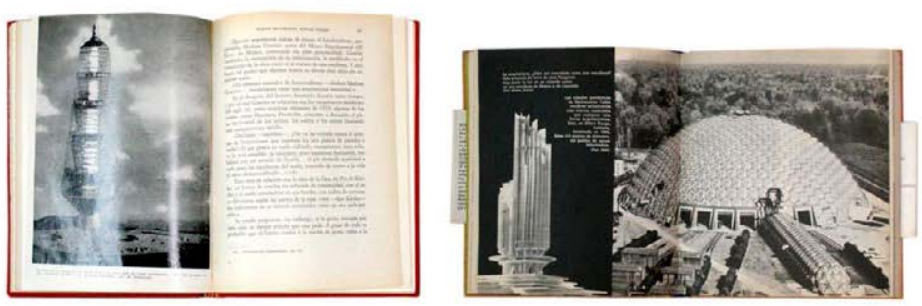

\section{3 “¿Dónde viviremos mañana?” (Michel Ragon) 1966 "Las ciudades del futuro" (Michel Ragon)}

Ambos textos de Michel Ragon, escritor, historiador y crítico de arte y arquitectura francés, toman como punto de partida las problemáticas urbanas de superpoblación en relación a la futura escasez de recursos y una movilidad, derivada de la recién estrenada "Sociedad del Ocio" a partir de la posguerra, enunciada como principal peligro para la existencia del hombre por futurólogos de referencia como Dennis Gabor:

"Nuestra civilización se enfrenta a tres grandes peligros. El primero es la destrucción por la guerra nuclear, el segundo la superpoblación y el tercero la Edad del Ocio. Si llega el primero la gente sabrá qué hacer... Si el mundo se ve amenazado por la superpoblación, la gente sabrá también qué hacer...Sólo la Edad del ocio encontrará al hombre psicológicamente no preparado." ${ }^{73}$ (Gabor, 1963, pp.11-12)

Sus dos libros resultan una crítica abierta al urbanismo derivado del movimiento moderno y Ios CIAM, así como un alegato a los nuevos conceptos de "arquitectura escultura" y sobre todo de "urbanismo espacial" o "arquitectura tridimensional". En 1965, Michel Ragon forma junto a Yona Friedman, Walter Jonas, Paul Maymont, Georges Patrix, Ionel Schein y Nicolas Schöffer el GIAP ${ }^{74}$, por lo que sus ideas de un nuevo futuro urbano serán canalizadoras de las propuestas arquitectónicas de sus colegas del Groupe International d'Architecture Prospective: las viviendas en materiales plásticos de Schein, la arquitectura móvil de Friedman y el GEAM" ${ }^{75}$, las ciudades subterráneas de Maymont y Utdjian o "La ville cybernétique" de Schöffer. He aquí el manifiesto que Ragon prepara para el evento de inauguración del grupo celebrado el 21 de Junio de 1965 en París:

"La explosión demográfica, la aceleración espectacular de los avances tecnológicos y científicos, el aumento constante de los niveles de vida, la socialización del tiempo, del espacio y del arte, la creciente importancia del ocio, el incremento de los factores del tiempo y la velocidad en las ideas de comunicación, han roto las estructuras tradicionales de la sociedad.

73 GABOR, Dennis. La Invención del Futuro. Credsa. Barcelona, 1967. Ed. original: Inventing the Future. Secker \& Warburg. Londres, 1963. pp.11-12.

74 GIAP Groupe International d'Architecture Prospective.

75 GEAM Groupe d'Étude d'Architecture Mobile. 
Nuestras ciudades, nuestras regiones, ya no pueden adaptarse a estas transformaciones.

Cada vez es más urgente organizarse hacia el futuro con el fin de evitar el sufrimiento.

El objetivo del GIAP es unir a técnicos, artistas, sociólogos y especialistas en diferentes disciplinas en busca de nuevas soluciones urbanas y arquitectónicas.

El GIAP pretende ser el nexo de unión entre investigadores de todos los países, incluso si sus tesis son a veces opuestas a los nuestras.

Por el momento, por lo tanto, el GIAP no tiene ninguna otra doctrina que la arquitectura prospectiva.

Frente a una arquitectura de carácter retrospectivo. Por una arquitectura prospectiva." ${ }^{" 76}$ (Ragon, 1978 (1965), p.341-342)

A pesar de la búsqueda a través de sus libros de una internacionalización de sus ideas, mediante conceptos asociados a la generación de nuevos climas en los que incluye trabajos de Fuller o Archigram, la formalización de su urbanismo espacial está especialmente enfocada a sus "colegas franceses", obcecados en buscar nuevos lugares colonizables por el hombre frente al peligro de la superpoblación. Así es como la mayoría de los casos resultan meras caricaturas de un futuro simplificado y totalitario, del cual ya advierte Charles Jencks en "Arquitectura 2000":

"Todo es aceptable en tanto sea ligeramente interesante, diferente de lo actual y exótico. Así es que los escritores de ciencia ficción tienden a fertilizar la tradición y muchos pronosticadores, tales como Michel Ragon, basan simplemente sus predicciones en lo que es diferente pero posible, tal como vivir en el subsuelo o bajo el agua. De este modo es fácil criticar esta tradición por su ingenuidad; pues es suponer que lo que es técnicamente posible será socialmente aceptable y se difundirá a través de una sociedad. ${ }^{\prime 77}$ (Jencks, 1971, p.97)

La obsolescencia del futuro urbano propuesto por Ragon es evidente a pesar de que comparte alguna de las alternativas de futuro que luego serán estudiadas en esta investigación. La formalización de sus textos y los proyectos asociados que visualizan las ideas vertidas en los mismos, lo sitúan más como un futuro histórico ${ }^{78}$, muy difícilmente instrumentalizado y re-convertido a estrategias operacionales que puedan ser re-utilizadas en nuestro presente.

76 RAGON, Michel. Prospective et Futurologie. En: Volumen 3 Historie mondiale de l'architecture et de l'urbanisme modernes. Casterman. París, 1978. pp. 341-342.

77 JENCKS, Charles. Arquitectura 2000, 1975 (1971). p.97.

78 Para la documentación de este período ver:

BUSBEA, Larry. Topologies: the urban utopia in France, 1960-1970. MIT Press. Cambridge, 2007. 

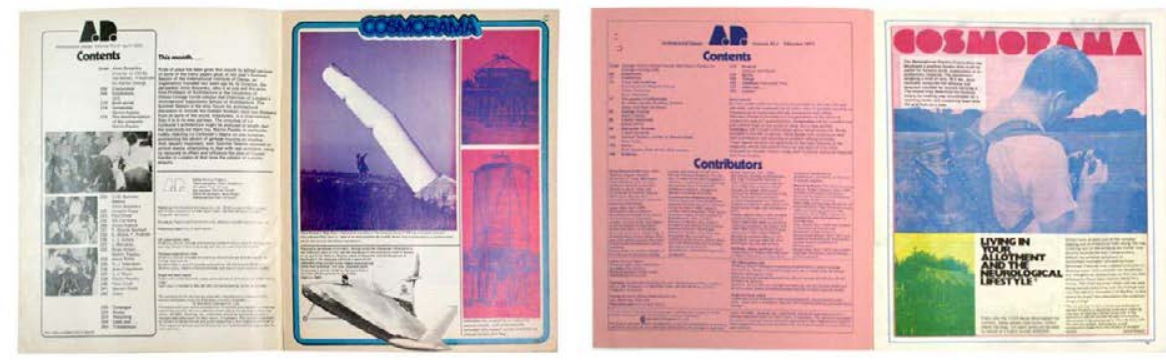

\title{
1965-73 "Cosmorama” (AD The Architectural Design) Sección de la revista "AD The Architectural Design" activa desde julio de 1965 hasta diciembre de 1973.
}

Cosmorama $^{79}$ nace en julio de 1965 como sección interna de la prestigiosa revista inglesa de arquitectura "The Architectural Design" sustituyendo a la anterior "UK and World News", de la mano de la directora de la revista en ese momento Monica Pidgeon y de su editor principal Robin Middleton ${ }^{80}$.

\begin{abstract}
"Este mes, el apartado de la revista UK and World News cesa. En su lugar introducimos Cosmorama, una crónica sobre edificios y eventos en todo el mundo que vis/umbran una nueva arquitectura." ${ }^{81}$ (Robin Middleton, 1965, p.316)
\end{abstract}

De julio de 1965 a diciembre de 1973 Cosmorama despliega más de quinientas páginas en las que mezcla proyectos de arquitectura, avances tecnológicos y alternativas de futuro, sirviendo de conexión entre la revista británica y un gran número de publicaciones arquitectónicas, artísticas, científicas y de actualidad por todo el mundo. Las diferencias entre Cosmorama y el resto de predicciones catalogadas son fundamentalmente dos: su carácter dinámico y evolutivo al formar parte de una revista mensual de gran tirada y su carácter como sección conformada a partir de diversos colaboradores, lo que posibilita que la heterogeneidad de sus enfoques sea mucho mayor que el carácter unilateral y personal del resto de publicaciones prospectivas. De esta manera, sus "predicciones" no sólo van variando a lo largo del tiempo sino que pertenecen a generaciones diferentes, entre las que se produce un debate interno que es el reflejo de las tensiones sociales visibles y de las distintas maneras de enfrentarse a ellas, suscitadas con el paso de la década de los sesenta a la de los setenta.

\footnotetext{
79 Cosmorama fue también el nombre de un espectáculo en el siglo XIX en Londres, en el 207-209 de Regent Street, en la que el público pudo ver las escenas de tierras lejanas y exóticas a través de dispositivos ópticos que magnificaban las imágenes.
}

80 Robin Middleton fue editor técnico de AD desde diciembre de 1964 a julio de 1972.

81 "This month the separate UK and World News features cease. Instead we introduce Cosmorama, a commentary on buildings or on events throughout the world that impinge upon architecture"

Cosmorama. En: AD The Architectural Design, julio 1965. p.316. 


\section{Cambio de escala. Utópico VS Experimental. Colectivo VS Autónomo. Estética VS Ética.}

Una de las características más relevantes de Cosmorama es el cambio de escala de los "objetos arquitectónicos" y "soluciones tecnológicas" que la sección publica en relación a la movilidad. A partir de secciones internas como "moving with the times", Cosmorama despliega un gran número de soluciones de transporte colectivo, "people movers" de Montreal'67, diseñado por WED, monorraíles ${ }^{83}$ y grandes transportadores utópicos como la "Strip City" ${ }^{84}$ de Hodgetts y Walker, derivados de operaciones urbanas a gran escala y muchas de las veces pertenecientes a "contextos tematizados" como son Exposiciones Universales o parques temáticos ${ }^{85}$ a los que se les da bastante cobertura en la sección. De la misma manera, a partir de finales de los setenta, tienen cabida en la sección todo tipo de sistemas autónomos asociados al automóvil, como los hoteles rodantes de George Holtt ${ }^{86}$, estableciendo una fuerte controversia entre sistemas autónomos y colectivos en pos de una "movilidad como opción de Futuro".

El mismo cambio de escala puede detectarse en la manera en que Cosmorama se posiciona en relación a las estructuras urbanas, al pasar de los clusters propuestos por el Team X y sus adeptos, las megaestructuras tecnológicas, como las construidas en Montreal'67 y Osaka' $70^{87}$ o las imaginadas por Archigram o los metabolistas japoneses, hasta todo tipo de

82 People Mover. En: AD The Architectural Design, noviembre 1967. p.453.

83 Free Speed travel. En: AD The Architectural Design, agosto 1965. p.370.

84 Strip City. En: AD The Architectural Design, abril 1970. p.178.

85 Disney World. En: AD The Architectural Design, abril 1967. p.153.

86 Hotel Auto Reisen. En: AD The Architectural Design, noviembre 1965. p.529.

Rotel. En: AD The Architectural Design, mayo 1966. p.215.

87 Montreal'67

AD The Architectural Design, Montreal'67, julio 1967.

Ontario Government Pavillion (Fairfield y Dubois). En: AD The Architectural Design, julio 1965. p.311.

Habitat'67 (M.Safdie). En: AD The Architectural Design, septiembre 1965. p.4.

USA Pavillion (R.B. Fuller), West German Pavillion (Frei Otto), West German Pavillion 3th prize (Rathe y Szabo). En: AD The Architectural Design, octubre 1965. p.435.

France Pavillion (Faugeron), African complex (Fiset), Netherlands Pavillion (Eijkelenboom y Middelhock), Czechoslovakia Pavillion (Repa y Cubr). En: AD The Architectural Design, noviembre 1965. p.527.

British Pavillion (Sir Basil Spence). En: AD The Architectural Design, diciembre 1965. p.580.

Soviet Pavillion (Mikhail Posokhin), Canadian National Railways Pavillion (Frank McDowell). En: AD The Architectural Design, marzo 1966. p.111.

Japanese Pavillion (Ashihara). En: AD The Architectural Design, mayo 1966. p.214.

Outdoor Play Spaces (Cornelia Hahn Oberlander). En: AD The Architectural Design, junio 1966. p.268.

Habitat'67 (M.Safdie). En: AD The Architectural Design, Aagosto 1966. p.374.

Cuba Pavillion (Garatti, Baroni y D’Acosta). En: AD The Architectural Design, octubre 1966. p.479. 
tecno-utopías y experimentos urbanos colectivos "Do It Yourself" ejemplificados en las famosas "Drop City ${ }^{88 " ~ o ~ " R e s u r r e c t i o n ~ C i t y " 89 . ~ A m b o s ~ c a m b i o s ~ d e ~ e s c a l a ~ e n ~ r e l a c i o ́ n ~ a ~ l a ~}$ movilidad y las infraestructuras urbanas se relacionan directamente con el trabajo del grupo Archigram $^{90}$, que varía su propuesta para una ciudad del futuro, del tecno-romanticismo megalómano de la "Walking City" (1964) o el control computerizado de viviendas intercambiables convertidas en meros objetos de consumo de la "Plug In City" (1964-66), al equipamiento cultural ligero e itinerante con el que equipar ciudades británicas que suponía la "Instant City" (1968). Esa transición de la ciudad infraestructural a la ciudad equipada y el cambio de escala que ello supone tiene también un interesante reflejo en los trabajos de aquellos años de alumnos de la Architectural Association ${ }^{91}$, en la que Peter Cook empieza a dar clase en 1964, algunos de los cuales serán objeto de estudio en el caso aplicado sobre movilidad de esta investigación.

El trabajo de The Architectural Design y Cosmorama también sirve como referente frente al dualismo "ética o estética" el subtítulo de su libro "El Nuevo Brutalismo"93 (1966) y por el cual define a ese nuevo

Gyrotron (Sean Kenny), Venezuela Pavillion (Carlos Raul Villanueva). En: AD The Architectural Design, noviembre 1966. p.533.

Osaka'70

AD The Architectural Design, Osaka'70, junio 1970

Japan Pavillion (Kawasaki). En: AD The Architectural Design, octubre 1966. p.476.

Festival Plaza (Arata Isozaki). En: AD The Architectural Design, septiembre 1967. p.375.

Amusement Park (Kiyoshi Awazu), Canadian Pavillion Competition (Rickson y Massey). En: AD The Architectural Design, octubre 1967. p.411.

Festival Plaza Structure (Kenzo Tange). En: AD The Architectural Design, mayo 1968. p.202.

Fuji Group Pavillion (Yutaka Murata), French Pavillion (Le Coteur y Sloan), Astrorama (Sanwa Group). En: AD The Architectural Design, junio 1968. p.251

Takara Beautillion, Toshiba IHI Pavillion (Kurokawa). En: AD The Architectural Design, septiembre 1968. p.397.

US Pavillion (Brody y Davis), USSR Pavillion, West German Pavillion (Schwanzer y Gutmann). En: AD The Architectural Design, octubre 1968. p.445.

Electrical Industries Pavillion (Kunio Maekawa), Japan Steel Pavillion (Sakakura), Suitoma Fairytale Pavillion (Otani), Mitsui Group Pavillion (Azuma), Japanese Government Exhibit, Ricoh Pavillion (Nikken Sekkei), Festival Plaza (Tange e Isozaki), Radio and Restaurant Tower (Kikutake), Osakagram (Archigram), Takara Beautillion, Toshiba IHI Pavillion (Kurokawa), Netherlands Pavillion, (Bakema). En: AD The Architectural Design, agosto 1969. pp.412-415.

88 Drop City. En: AD The Architectural Design, noviembre 1967. p.453.

89 Resurrection City. En: AD The Architectural Design, agosto 1968. p.351.

90 Architectural Design fue la primera revista británica de arquitectura en publicar el trabajo del grupo inglés: Archigram-Group: Chronological Account of their Work. En: AD The Architectural Design, noviembre 1965. pp. 559-572.

91 Una buena muestra de esos trabajos pueden verse en:

GOWAN, James (editor): Projects. Architectural Association. 1946-71, AA Cahiers series No.1. Architectural Association Press. Londres, 1972

92 Dualismo aún vigente y lema de la Biennale di Venezia del año 2000, titulada: "Less Aestethics, More Ethics" y cuyo director era Massimiliano Fuksas.

93 BANHAM, Reyner. El brutalismo en arquitectura: ¿ética o estética? Gustavo Gili, Barcelona, 1967. Ed.original: The New Brutalism: Ethic or Aesthetic? The Architectural Press. Londres, 1966. 
"brutalismo" como un movimiento puramente estético, a pesar de que ambos términos no fueran totalmente excluyentes ${ }^{94}$. Mientras Archigram y otros arquitectos afines despliegan su estética tangencialmente asociada a la sociedad de consumo y reforzada por la inclusión en la propia sección de objetos tecnológicos de "última moda", desde terminales robóticas de comunicación ${ }^{95}$ a prototipos de sistemas de geolocalización ${ }^{96}$, o sistemas de construcción industrializados, aparecen en Cosmorama y en otros nuevos apartados de la revista como "Ecotech" o "Recycling", una serie de proyectos considerados como "éticos" relacionados con la autoconstrucción, la economía de recursos, la eficiencia energética, es decir, con la construcción de una ecología a pequeña escala. Desde mercados de puertas y ventanas recicladas en Turquía durante los años 30 y $40^{97}$ a una vivienda ecológica con un tratamiento primario de la materia orgánica generada ${ }^{98}$. Si Archigram era en ese momento el representante de la estética de la sociedad de consumo, la ética sin duda provenía de catálogos de recursos generados por la contracultura norteamericana, entre los que destacaba el "Whole Earth Catalog", editado por Stewart Brand de 1968 a 1971, un compendio de herramientas dirigido a aquellos que quieran desafiar los estilos de vida convencionales. Este catálogo es referenciado varias veces en Cosmorama $^{99}$ con comentarios de algunos de los miembros de Archigram incluidos, que a su vez colaboraron en el último número del catálogo ${ }^{100}$, lo cual corrobora aún más esa controversia entre ética y estética generada en el ámbito arquitectónico durante ese contexto temporal. De igual manera la sección dará cobertura a otros catálogos relacionados como el "Domebook ONE ${ }^{101 " ~(1970), ~ c o n ~ s o l u c i o n e s ~ c o n s t r u c t i v a s ~ p a r a ~ l a ~ a u t o-c o n s t r u c c i o ́ n ~ d e ~ t o d o ~ t i p o ~ d e ~}$ cúpulas geodésicas o el "Inflatocookbook"102 (1970), elaborado por los también norteamericanos Ant Farm, a partir de instrucciones de montaje para la construcción de estructuras neumáticas. Así es como el catalogo se convierte en una clara alternativa de futuro, ya sea desde la perspectiva contracultural del "Do It Yourself", la generación de herramientas y recursos compartidos, la eficiencia de recursos, el reciclaje y la autosuficiencia, entre los que también destacan los trabajos del diseñador Victor Papanek ${ }^{103}$

94 Para profundizar en esta teoría entre la dicotomía entre "ética y estética" en Architectural Design ver: PARNELL, Steve. Ethics VS Aesthetics Architectural Design 1965-1972. En: FIELD. A Free Journal for Architecture, Vol 4, issue 1, Ecology, University of Sheffield, 2011. pp.40-52.

95 Communication Terminal Dummies. En: AD The Architectural Design, agosto 1970. p.423.

96 Westinghouse Electric Corporation position locator. En: AD The Architectural Design, febrero 1971. p.66.

97 OZKAN, Suha. Recycling Building Componentes, Ecotech. En: AD The Architectural Design, diciembre 1972. p.672.

98 The Ecological House, Recycling. En: AD The Architectural Design, mayo 1972. p.140.

99 - Whole Earth Catalog. En: AD The Architectural Design, mayo 1969. p.239.

Whole Earth Catalog. En: AD The Architectural Design, abril 1970. pp.169-170.

100 BRAND, Stewart. Archigram. En: The Last Whole Earth Catalog, junio 1971. p.89.

Anteriormente, el magazine Archigram\#08 había sido también referenciado en:

BRAND, Stewart. Archigram. En: Whole Earth Catalog, spring 1969. p.20.

101 EASTON, Robert; KAHN, Lloyd. Domebook, issue NN1. Pacific Domes. Califonia, 1970.

EASTON, Robert; KAHN, Lloyd. Domebook, issue No2. Pacific Domes. Califonia, 1971.

102 ANT FARM. Inflatocookbook, nº1, enero, Sausalito, 1971.

103 Ya sea como manifiesto como en:

PAPANEK, Victor. Design for the Real World. Thames \& Hudson. Londres, 1972.

O como catálogo de recursos en: 
o como sistema de recursos comerciales relacionados con la sociedad de consumo, ya sea a través de catálogos de venta o posibilidades dentro de un sistema constructivo determinado, como en el "Bac-pac man"104 (1970) de Archigram, un inventario de recursos para una vida nómada.
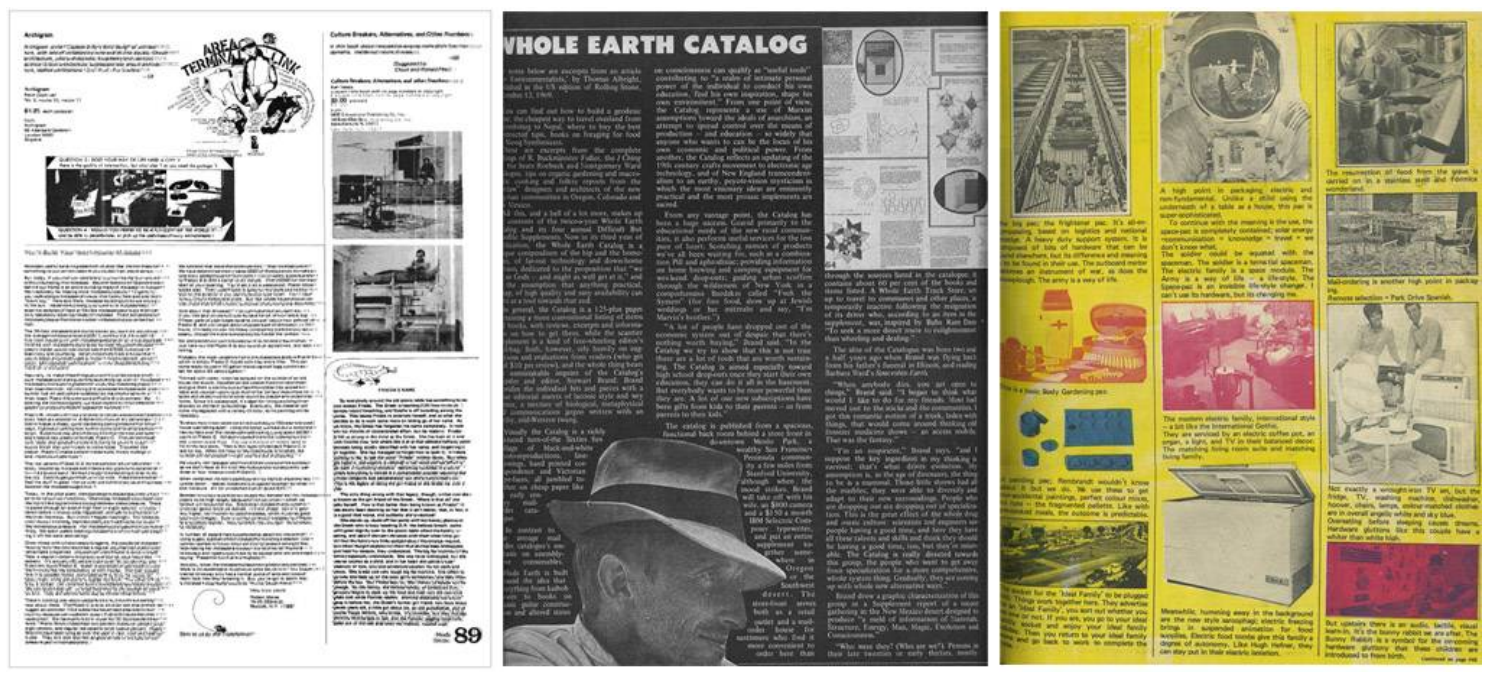

BRAND, Stewart. Archigram. En: The Last Whole Earth Catalog, June 1971. p.89. // Whole Earth Catalog. En: AD, Apr 1970, pp.169-170. // CHALK, Warren; BARNARD, Michael. Bac-pac man. En: AD, Sep 1970, pp.436-441.

La opción de uno u otro catálogo tiene también consecuencias materiales muy diferentes. Mientras el catálogo de productos se relaciona con sistemas industrializados en materiales plásticos o metálicos producidos en serie, el catálogo de recursos aprovecha el espectro de nuevos materiales "pobres" como la madera o el cartón, del que también Cosmorama se hace $e^{105}$ a partir de un número especial dentro de la sección, con proyectos experimentales como el stand de cartón de David G. Emmerich para el "Salon de l'emballage" de París de 1968 o los prototipos de viviendas construidas por métodos de plegado de Arthur Quarmby de finales de los años 50, así como estructuras neumáticas y otros sistemas DIY como el vaporizado, que dibujan nuevos campos de usos para los materiales plásticos más allá de esos sistemas industrializados antes citados, al adecuarlos a situaciones de emergencia o de bajos recursos.

PAPANEK, Victor; HENNESSEY, James. Nomadic Furniture. Phanteon Books. Nueva York, 1973.

PAPANEK, Victor; HENNESSEY, James. Nomadic Furniture 2. Phanteon Books. Nueva York, 1974.

104 CHALK, Warren; BARNARD, Michael. Bac-pac man. En: AD The Architectural Design, septiembre 1970. pp.436-441.

105 Paper House Review. En: AD The Architectural Design, octubre 1970. pp.449-504. 


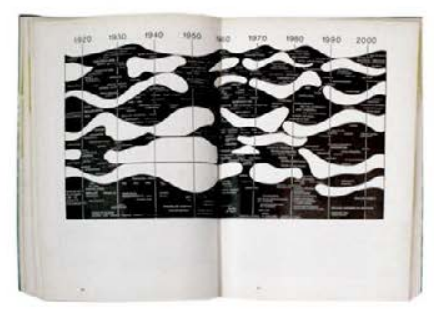

\section{1 “Arquitectura 2000” (Charles Jencks)}

"Es desde luego, inútil dar una serie de predicciones específicas para el futuro, separadas de su contexto e ideología. Esto es por lo que, en este libro sobre arquitectura, he sentido la necesidad de partir de principios muy amplios, tales como los métodos de previsión, las ideologías que suelen acompañarlos y su pertinencia para la política, la sociedad de consumo y la revolución, puesto que todas esas grandes fuerzas proporcionan el contexto de la predicción o pronóstico arquitectónico específico." ${ }^{" 106}$ (Jencks, 1971, prólogo)

Con la obsesión por el año 2000 como punto de partida107, "Arquitectura 2000" se presenta como uno de los referentes principales en lo que a futurología ${ }^{108}$ arquitectónica se refiere. Su relación con el futuro es pretenciosamente declarada e incluso en la primera parte del libro, Jencks referencia no sólo textos clásicos de futurología sino también una serie de métodos, estudios y técnicas relacionados directamente con esa "nueva" ciencia como la seccionabilidad ${ }^{109}$, la curva $S$ o de Verhulst ${ }^{110}$ o las tendencias inexorables, utilizadas fundamentalemente como herramientas en predicciones relacionadas con el progreso científico. Sin embargo, la idea de progreso evolutivo en la que están fundamentadas la mayor parte de sus prospectivas tecnológicas, defendida a su vez por futurólogos no profesionales como McHale y Fuller, no es del todo compartida por Jencks por las dudas que le causa la idea del tiempo reversible ${ }^{111}$, por lo que configura toda su predicción en torno a un análisis estructuralista de las principales tradiciones arquitectónicas ligadas a una serie de ideologías concretas, derivando en una futurología estilística, materializada en su

106 JENCKS, Charles. Arquitectura 2000. 1975 (1971). prólogo.

107 En la bibliografía de Jencks sobre este tema aparecen una serie de estudios predictivos en torno a ese año, en relación a I avance de nuevas tecnologías, publicados entre 1967 y 1969:

BELL, Daniel. Toward the Year 2000: Work in the Progress. Daedalus, Academy of Arts and Science. Boston, 1967.

KAHN, Herman; WIENER, Anthony. Year 2000. MacMillan and Co. Londres, 1967.

JUNGK, Robert; GALTUNG, Johan. Mankind 2000. Allen and Unwin. Londres, 1969.

108 La futurología es definida por Gaston Berger (uno de los fundadores de la disciplina), como la ciencia basada en el método científico que estudia el futuro para comprenderlo y poder influir en él.

109 Herramienta para seccionar partes relativas a un sistema aparentemente totalitario para ser estudiadas de manera independiente al mismo.

110 Referida al crecimiento de una fuerza con el paso del tiempo.

111 Derivada del libro: LEVI STRAUSS, Claude. The Scope of Antropology. 1967. 
célebre "The evolutionary tree"112 ("El árbol de la evolución"113). Mediante este gráfico, Jencks trata de relacionar la evolución arquitectónica a través de familias o especies generadas a partir de cuestiones de "estilo" inexorables. Uno de los argumentos esgrimidos por Jencks para definir esta cuestión estilística es la detección de una tendencia al neoclasicismo cada 25 años en Norteamérica ligado a la construcción de edificios públicos representativos.

"Si consideramos la cuestión de las relaciones internas dentro de un período tal, podemos ver que hay una tendencia natural de ciertos conceptos y tipos de arquitectura a agruparse y a formar un conjunto coherente." ${ }^{114}$ (Jencks, 1971, p.38)

Esta afirmación conduce a Jencks a reducir la arquitectura a seis bloques consistentes derivados de las subsiguientes tradiciones históricas: la inconsciente y consciente de sí mismas, la activista, la intuitiva, la lógica y la idealista. Todas ellas aparecen en su árbol evolutivo imbricadas a partir de manchas irregulares que vibran a través de las distintas tendencias. Resulta interesante la autocrítica de Jencks al carácter bidimensional del diagrama, que genera un mayor distanciamiento entre tradiciones y que simplifica lo que para él debería ser un sistema más complejo de relaciones ${ }^{115}$ entre los términos que rellenan las manchas y que definen las corrientes y nombres principales del panorama arquitectónico.

Un análisis sobre las tendencias fundamentales del diagrama, revela varios puntos interesantes como el auge que Jencks vaticina de una nueva escuela biomórfica descendiente de las tradiciones intuitiva y activista, derivada del desarrollo de la biología y la automatización, que realmente puede considerarse como una predicción cumplida debido al actual panorama de diseño paramétrico, auspiciado por las nuevas capacidades de herramientas informáticas, fundamentado en parámetros naturales a modo de restricciones abiertas.

El carácter predictivo del libro es por lo tanto más interesante en cuanto a su carácter abierto a través de las seis tradiciones antes mencionadas, del que resultan una serie de proyectos y alternativas de futuro, muchas de las cuales constituyen capítulos posteriores de esta tesis, muy concretas y fácilmente fragmentadas como estrategias proyectuales.

112 Publicado como anticipo de su libro en:

JENCKS, Charles. The Evolutionary Tree. En: AD The Architectural Design, octubre 1970. p.527.

113 Sistemática utilizada en otros diagramas posteriores como en:

JENCKS, Charles. The New Paradigm in Architecture, The Language of Post-Modern Architecture. Yale University Press. London, New Haven, 2002.

114 JENCKS, Charles. Arquitectura 2000. 1975 (1971). p.38.

115 Basado como el explica en las notas del capítulo 2 del libro, en las discusiones de George Kubler sobre objetos en forma de haces fibrosos en:

KUBLER, George. The Shape of Time. Yale university Press. New Haven, 1962. pp.81-82. 


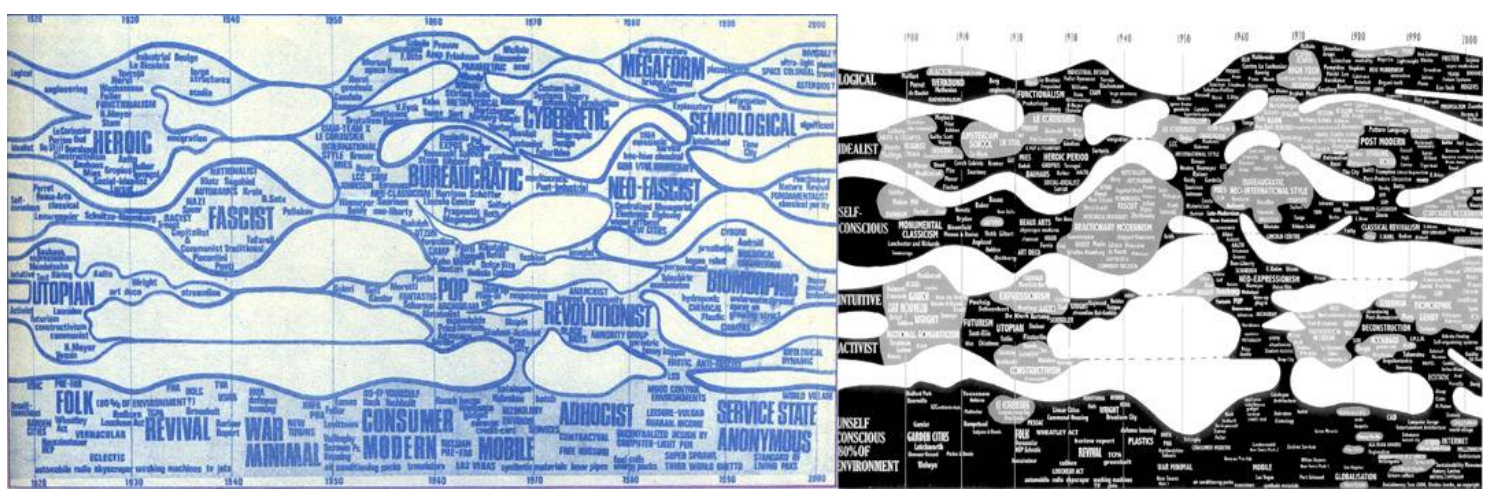

JENCKS, Charles. The evolutionary tree. En: AD The Architectural Design, octubre 1970. p.527.

JENCKS, Charles. Evolutionary Tree. En: Arquitectura 2000. Predicciones y métodos. 1975 (1971). pp.50-51.

\title{
La tradición inconsciente de sí misma. \\ El catálogo y el "Do it yourself" como alternativas de futuro.
}

\begin{abstract}
"Puesto que la tradición inconsciente de sí misma en arquitectura, es responsable de cerca de un $90 \%$ de nuestro total ambiente circundante, muchos arquitectos han estado tratando de adoptarla durante largo tiempo."116 (Jencks, 1971, p.53)
\end{abstract}

Esa adopción por los arquitectos de la cultura de masas presenta una serie de interesantes alternativas de futuro a partir del estudio de la relación de los usuarios con los objetos y en este caso con el "objeto arquitectónico". De esta manera aparecen dos estrategias proyectuales derivadas de sistemáticas comerciales como son el "Do it yourself" y el catálogo como claras alternativas de futuro, adoptadas por los arquitectos como herramientas para la generación de proyectos. Ambas estrategias están encaminadas a la adaptabilidad y personalización de las estructuras por parte del usuario, el catálogo a partir de la libertad de elección entre una amplia gama de opciones, como sucede en la casa de los Eames, y el "Do it yourself" como personalización a partir de piezas especiales que se adhieren a un conjunto no cerrado o piezas prefabricadas que se insertan de maneras distintas. Otra alternativa de futuro es situada por Jencks en la adopción de lenguajes y recursos publicitarios populares como los utilizados por escritores como Tom Wolfe o arquitectos como Robert Venturi.

\section{La tradición consciente de sí misma.}

La mega-estructura y los sistemas de control como alternativas de futuro.

Ampliamente relacionada con los sistemas burocráticos, la tradición consciente de sí misma genera sistemas de control a gran escala. Las alternativas de futuro que presenta esta tradición gravitan desde las mega-estructuras como opción habitacional hasta las grandes infraestructuras de transporte. Ligadas al utopismo clásico de organismos totalitarios, ambas opciones presentan un alto grado de obsolescencia debido a su dependencia en

116 JENCKS, Charles. Arquitectura 2000. 1975 (1971). p.53. 
sistemas de gobierno muy centralizados y a las consecuencias sociales que este tipo de estructuras pueden tener y desgraciadamente han tenido.

\author{
La tradición activista. \\ La flexibilidad, la participación y los intercambios de información como alternativas de \\ futuro.
}

Tradición caracterizada por sus fuertes críticas al sistema preestablecido o status quo. Ampliamente relacionada con el "Do It Yourself", pero no como sistema de mercado sino como estandarte de la autoconstrucción y la participación social, presentan alternativas de futuro relacionadas con la representatividad del usuario en el espacio público y los sistemas de intercambio de información como estrategias encaminadas a una democratización del espacio, ampliamente relacionadas con la generación y gestión de comunidades.

Amparados por la flexibilidad, la capacidad de cambio o los entornos sensibles, Jencks selecciona proyectos tan dispares como el "Fun Palace" (1963) de Cedric Price, "Le Dyodon" (1967) de J.P. Jungman o la "Drop City" de Colorado como alternativas sociales a partir de distintos modelos de gestión del espacio urbano.

\title{
La tradición intuitiva. \\ Perversiones naturales, los robots y el control ambiental como alternativas de futuro.
}

A partir de reinterpretaciones de la cultura popular, la tradición intuitiva busca en la sociedad y la cultura, entornos especialmente ajenos a la disciplina arquitectónica, referentes que puedan ser aplicados a la arquitectura. Jencks confiere a esta tradición una gran capacidad para imaginar posibles futuros debido a la pluralidad de referencias de las que están cargadas sus especulaciones. Entre ellos aparecen una serie de diversificadas alternativas de futuro, desde los sistemas de control ambiental como alternativa de elección personal, ejemplificada en toda la obra del grupo Archigram y sus relaciones abiertas entre Hardware y Software, las perversiones naturales de los derivados biomórficos y las nuevas relaciones hombre-máquina encaminadas a un futuro robótico y una tendencia hacia una arquitectura de servicios.

\section{La tradición lógica. \\ La parametrización como alternativa de futuro.}

Derivada de los procesos científicos y tecnológicos aplicados a la arquitectura de una manera sistemática, la tradición lógica configura una serie de alternativas de futuro ligadas a la escuela paramétrica y las colonias espaciales. A pesar de la dudas de Jencks por una sistematización de los parámetros de diseño derivada de los estudios de Christopher Alexander ${ }^{117}$, estas nuevas tecnologías derivadas de la automatización comienzan a posibilitar un mayor rigor en cuanto a la sistematización de dichos parámetros. 


\section{La tradición idealista. \\ La automatización como alternativa de futuro.}

La tradición más fuertemente dependiente del movimiento moderno, se encuentra muy capacitada para la generación de esquemas alternativos de futuro, más allá de soluciones singulares con finalidades fijas como pudiera suceder con la tradición intuitiva. De esta manera, su acercamiento a la cultura de masas se realiza a través del estudio de los sistemas de producción como la automatización, para generar posibles opciones de futuro afines a otras tradiciones mediante los recursos ya existentes. Un claro ejemplo es la antes citada "House of the Future" (1956) de los Smithson, en la que esa producción va encaminada hacia una arquitectura orgánica hecha al mismo coste que una arquitectura con una estética de producción en serie. 


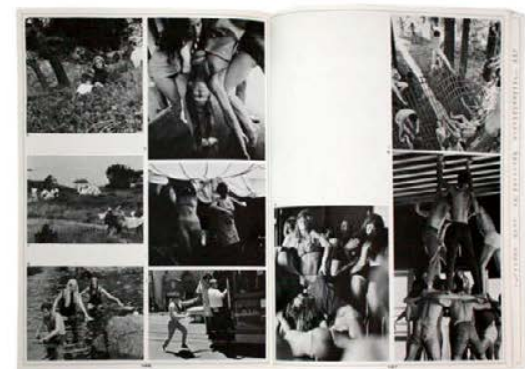

\section{2 “Arthropods” (Jim Burns)}

"What is your group doing? Arthropods.

Living pods, plug-in pods - what's your species?

New groups - New designs - New Environments.

Individual environments... for couples, families, communities... for fun, for living, for loving, for meditating, for eating, sleeping, working, creating, teaching, learning, making out...

A book is being prepared about all these kinds of environments by groups. What is your group doing? Get it in the book! Send model, photos, plans, copies, drawings, explanations and descriptions before February 1, 1971, to the author:

Jim Burns, 147 East 35 Street, New York, NY. 10016, USA"118 (Jim Burns, 1971, p.106)
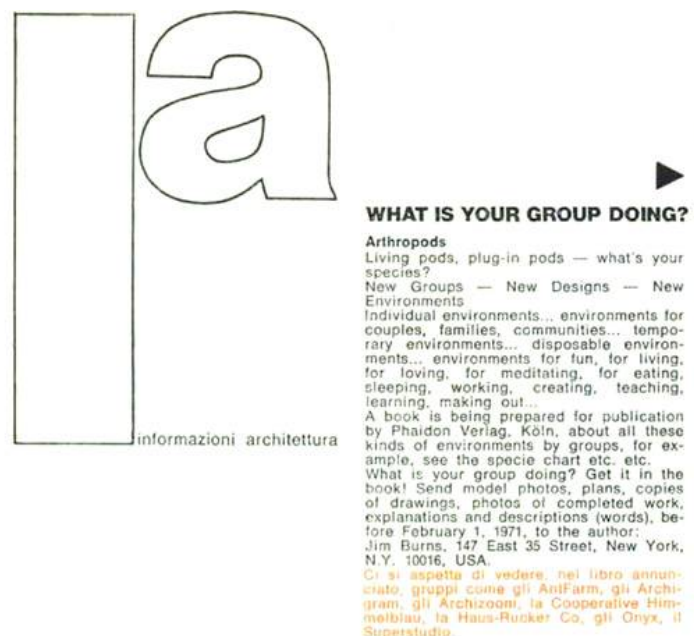

DESIGN: A FORUM AND A PLATFORM (ANCORA A LONDRA)
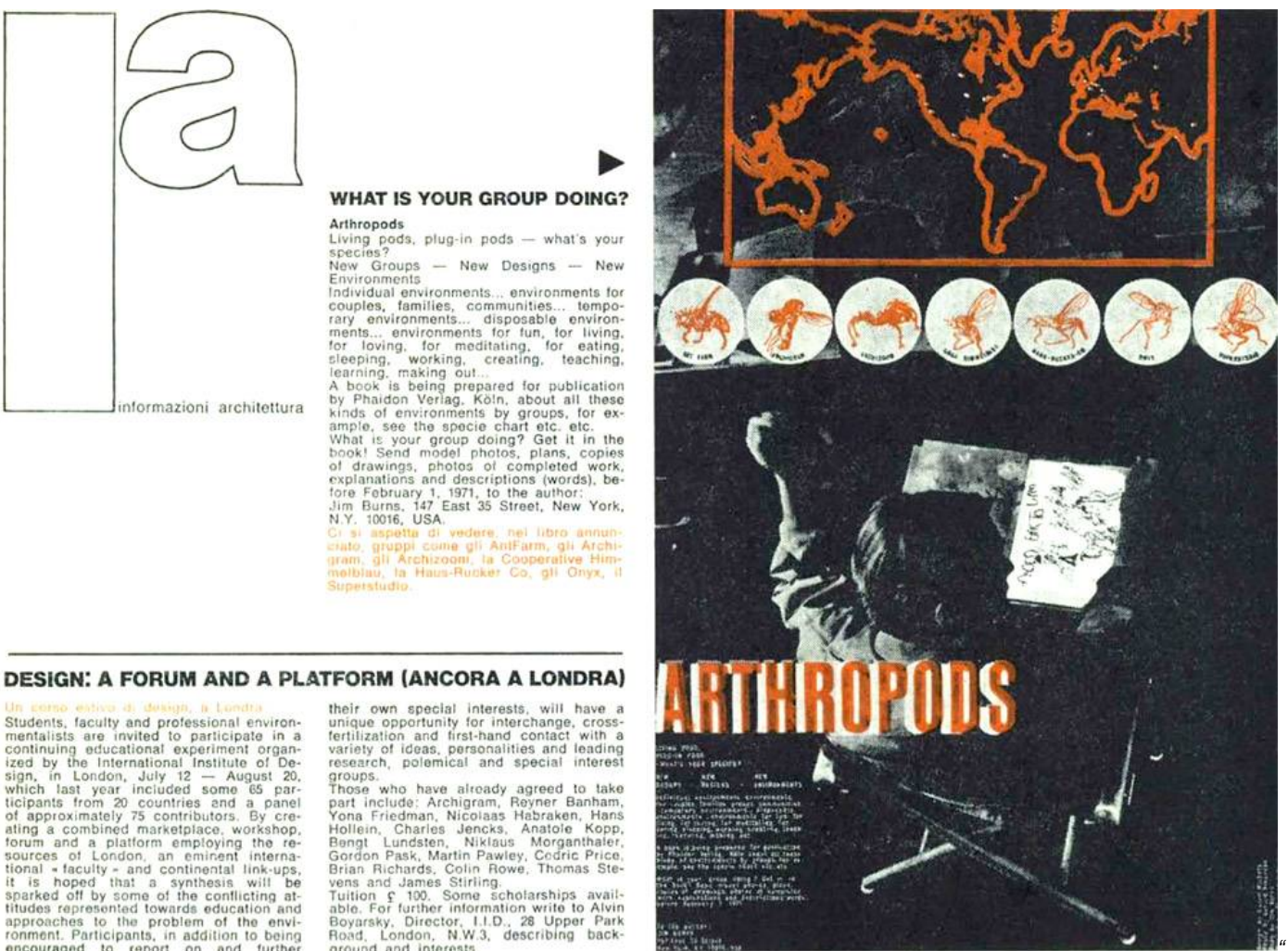

118 No se ha traducido la cita porque pierde todo su sentido:

BURNS, Jim. Arthropods. En: Domus, n496, marzo 1971. p.55. 
Así es como Jim Burns, editor de la revista "Progressive Architecture" de 1954 a 1969, hace un llamamiento a diversos grupos de arquitectos y diseñadores de varios países para la confección de un libro en busca de "diseños" de futuro que había denominado con el sobrenombre de "Arthropods", un juego de palabras entre la palabra "Arthropod" = artrópodo y "pod" = vaina / cápsula, que a juzgar por su llamamiento tenían que estar relacionados con la generación de ambientes o entornos "environments". "Arthropods" tiene por lo tanto dos interesantes puntos de partida a la hora de configurar nuevas alternativas de futuro, el primero, su carácter abierto y a priori interdisciplinar, al usar la palabra "diseño" y no "arquitectura", y el segundo, el proponer un futuro urbano a partir de la generación de ambientes y no de "estructuras", "megaestructuras" o simplemente "ciudades".

Para Burns, la metáfora del nombre, "Arthropods", tiene que ver tanto con el carácter grupal de las intervenciones, ya que entendía los grupos o colectivos de arquitectos como organismos formados por diversas patas según sus miembros, como con la importancia del proceso y la capacidad de adaptación de los mismos en relación a la generación de esos "ambientes" propuestos.

"Este libro es una revisión de una serie de aproximaciones en torno a los aspectos generales de cambio ambiental. Discute el trabajo, práctica y teoría de un número de individuos y grupos de varios países que tienen como base común un interés en la mejora del destino del hombre por medio de la generación de un ambiente cada vez más sensible, y de postular diversas estrategias en que se puede tener - en menor o de mayor escala - una influencia decisiva en las maneras en que van a vivir y la naturaleza de los lugares en los que ya viven." 119 (Jim Burns, 1972, p.7)

En la primera parte de su predicción, Burns define una serie de términos asociados a esos futuros propuestos por diversos grupos o arquitectos que analizan sus "actitudes" y sus "orientaciones":

- "Performance", "Invo/vement": el carácter performativo y la participación como generadores de vínculos entre diseñador y usuario.

- "Play", "Recreation", "Live-in": la generación de nuevos lugares y maneras de vivir, no desde presupuestos tipológicos sino mediante la experimentación directa de los ciudadanos a través de mecanismos de juego y esparcimiento.

- "Communications": la importancia de los intercambios de información mediante la experimentación con los nuevos formatos incipientes.

- "Interfacing": la incorporación de áreas y agentes aparentemente incompatibles en el proceso de diseño.

- "Monumentality": la transgresión y mezcla de distintas escalas para la generación de efectos ambientales.

\footnotetext{
119 "This book is an examination of a number of approaches to the general aspects of environmental change. It discusses the work, practical and theoretical, of a number of individuals and groups from a number of countries who have as common ground an interest in ameliorating man's lot in an increasingly sensitized atmosphere, and of postulating ways in which he can have -in smaller or larger scale- a deciding influence on the ways he will live and the nature of the places in which he lives."

BURNS, Jim. Arthropods: new design futures. 1972. p.7.
} 
- "Process Design / Object Design": la importancia de la experimentación en el proceso para la generación de objetos en constante re-interpretación.

- "Permanence / Disposability": la capacidad de las estructuras urbanas para ser diseñadas en relación a períodos de permanencia realistas, poniendo en duda siempre su inmutabilidad.

- "Graphics": Ia incorporación de efectos visuales a partir de dibujos, textos o símbolos para transmitir mensajes que influyan en el aspecto de edificios, interiores o ambientes temporales.

- "Mobility", "Movement", "Changeability": la generación de estructuras, soportes, ambientes, que tengan capacidad de respuesta ante distintas situaciones urbanas, con un carácter móvil y flexible, en relación tanto a su entorno externo como interno.

- "Transformation": la capacidad de los diseños, estructuras o actividades de transformar el entorno en que se insertan.

- "Man / Machine Media": establecer nuevas relaciones e intercambios entre hombre y máquina, natural y artificial, como nuevos paradigmas de nuestro tiempo.

- "Open System": elaborar sistemas abiertos, donde el usuario, a través de la participación, tenga capacidad de decisión y cambio.

En la segunda parte del libro, Burns cataloga por grupos o arquitectos, ONYX, Cedric Price, Haus Rucker-Co, Superstudio o EAT entre otros, esos posibles "Arthropods", como experimentos referenciales para nuevas alternativas de futuro dentro del ámbito arquitectónico:

"Éstos son los nuevos caminos para adentrarse en un acto de generación de entornos sensibles donde podamos vivir una vida positiva juntos. Quizá no mañana, sino en el futuro. Un futuro que siempre será futuro, por lo que pensando en lo que haremos cuando lleguemos a él fomentamos ese implacable pensamiento lineal. Esa implicación en el presente con el entorno es la situación en la que esos "Arthropods" aparecen llenos de posibilidades."120 (Jim Burns, 1972, p.165)

120 "These are new ways to get into the act of making responsive places where we can live positive lives together. Not tomorrow, either; the future is fine, but it is always the future, and always thinking about what we will do when we get there encourages relentless linear thinking. Environmental involvement in the changing present is the situation Arthropods find most laden with possibility."

BURNS, Jim. Arthropods: new design futures. 1972. p.165. 


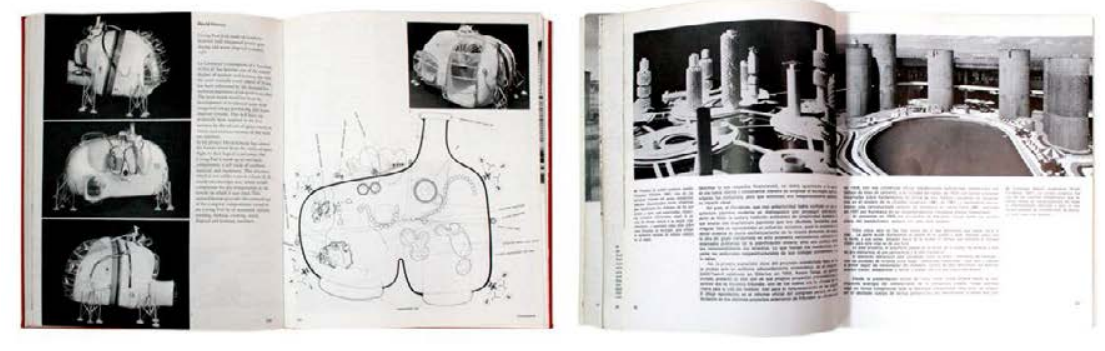

\title{
1971 "Estructuras urbanas para el futuro" (Justus Dahinden) 1976 "Megaestructuras" (Reyner Banham)
}

\begin{abstract}
"La Megaestructura es una gran estructura en la que tienen cabida todas las funciones de la ciudad o de parte de ella. La tecnología la ha hecho posible. En cierto modo es un rasgo artificial del paisaje. Es como la gran colina sobre la que se construyeron las ciudades italianas." ${ }^{21}$ (Maki, 1964, p.8)
\end{abstract}

Los posicionamientos ante un "futuro urbano" de Banham y Dahinden, aunque tangenciales, resultan bastante diversos en cuanto a la manera de ser presentados. Mientras Justus Dahinden escribe "Estructuras urbanas para el futuro" en 1971, cuando se encuentra inmerso en varios proyectos no construidos de este tipo de estructuras que a la vez publica junto a muchos otros ejemplos bajo el mismo título, Reyner Banham publica "Megaestructuras" en 1976 como compendio histórico-crítico, en un momento en el que este tipo de estructuras parecían haberse agotado definitivamente como alternativa de futuro. Banham presenta esas megaestructuras como "futuro urbano de un pasado reciente", tras su fracaso urbano en ejemplos como Cumbernauld o Thamesmead, convertido en icono de la mega-decadencia a través de los ojos de Kubrick en "La Naranja Mecánica", y el desapasionamiento de los arquitectos tras la sobre-estimulación megaestructural un tanto vacua de las Exposiciones Universales de Montreal'67 y Osaka'70.

"Más o menos hacia 1968 pareció advertirse que una ciudad, o una gran parte de una ciudad, proyectada por un hombre, o por un grupo lo suficientemente homogéneo como para producir un proyecto comprensible, resultaría en un ambiente lamentablemente tenue, inane y empobrecido, tanto visualmente como en términos culturales más amplios, menos precisos; Thamesmead es el caso extremo, pero el problema estaba manifiestamente presente en el Hábitat de Montreal. Sospecho que también se advirtió, aunque nunca se planteara claramente, que la solución lógica al problema consistía en conceder tanta libertad a las intenciones de autodeterminación y auto-alojamiento, que también tuvieran libertad para destruir la propia megaestructura. Tangencialmente, Peter Hall acertó; auto-destructoras era, además de importante, una palabra profética, y dado que ningún arquitecto que se considere digno de su profesión puede tolerar el hecho de ser testigo de la destrucción de sus

\footnotetext{
121 "The megastructure is a large frame in which all the functions of a city or part of a city are housed. It has been made possible by present day technology. In a sense, it is a manmade feature of the landscape. It is like the great hill on which Italian towns were built."
}

MAKI, Fumihiko. Investigations in Collective Form. Washington University Press. St. Louis, 1964. p.8. 
proyectos, especialmente si se trata de magnos proyectos a escala de la ciudad, la megaestructura demostró ser un concepto auto-supresor." ${ }^{122}$ (Banham, 1976, p.217)

Aunque la megaestructura como alternativa de futuro no será propiamente estudiada en esta investigación ${ }^{123}$, resultan interesantes dos planteamientos que van asociados a la definición de la misma, el cambio de escala y la monumentalidad que presentan como rasgos formales significativos y las transgresiones entre natural y artificial que sugieren en relación no sólo a su implantación sino a la generación de climas artificiales en el interior de las mismas.

El interés de "Estructuras Urbana para el Futuro" es su carácter estructuralista, al presentarse en forma de catálogo por tipologías concretas: Aglomerados celulares, "Clip-on" / "Plug-In", conceptos popularizados en el ámbito arquitectónico por el propio Banham ${ }^{124}$, Estructuras puente, Hiper-contenedores, Estructuras marinas, La Diagonal en el espacio, en relación a posicionamientos fundamentados en el aterrazamiento, o las Bio-estructuras. Sin duda alguna esta taxonomía en forma de catálogo es imprescindible para entender la segunda parte de este trabajo de investigación en torno a la movilidad en el ámbito de la vivienda en el contexto temporal objeto de estudio.

\begin{abstract}
"Mirando hacia el futuro.
A causa de la revolución científico-técnica que ha sido la marca distintiva de nuestra era moderna, el hombre tendrá que adoptar una perspectiva completamente nueva si es que quiere asumir su responsabilidad con el futuro. Este futuro aparece como un mundo artificial, urbanizado, que es a la vez causa y efecto del cambio social.

Hoy en día, aceptar nuestra responsabilidad con el futuro supone hablar de planeamiento total, lo cual es inconcebible sin una visión de lo que pueda llegar a ser futuro." ${ }^{125}$ (Justus Dahinden, 1971, p.7)

"Después de haber tratado los aspectos sociales y antropológicos de las aglomeraciones urbanas modernas en la primera parte de este estudio, ahora me propongo a concentrarme en las características arquitectónicas de las estructuras urbanas. La relación entre las estructuras urbanas y las formas sociales es recíproca, un cambio en uno de estos ámbitos, produce de forma automática una reacción en el otro." ${ }^{\text {26 }}$ (Justus Dahinden, 1971, p.19)
\end{abstract}

122 BANHAM, Reyner. Megaestructuras. 1978 (1976). p.217.

123 RICHTER, Markus; VAN DER LEY, Sabrina (editores). Megastructure reloaded. Visionary Architecture and Urban Design of the Sixties Reflected by Contemporary Artists. Hatje Cantz. Ostfildern, 2008.

124 BANHAM, Reyner: A Clip on Architcture. En: Design Quarterly, n63, Walker Art center. Minneapolis, 1965

125 "Looking into the Future.

Because of the scientific and technical revolution that has been the hallmark of our modern era, man will have to adopt a completely new outlook if he is to assume responsibility for the future. This future appears as an artificial, urbanized world that is both the cause and the outcome of social change. Today acceptance of responsibility for the future presupposes total planning, which is inconceivable without a vision of what the future may look like."

DAHINDEN, Justus. Urban Structures for the Future. 1972 (1971). p.7.

126 "Having dealt with the social and anthropological aspects of modern conurbations in the first part of this study, I now propose to concentrate on the architectonic features of urban structures.

The relationship between urban structures and social forms is reciprocal; a change in one of these spheres automatically produces a reaction in the other."

DAHINDEN, Justus. Urban Structures for the Future. 1972 (1971). p.19. 


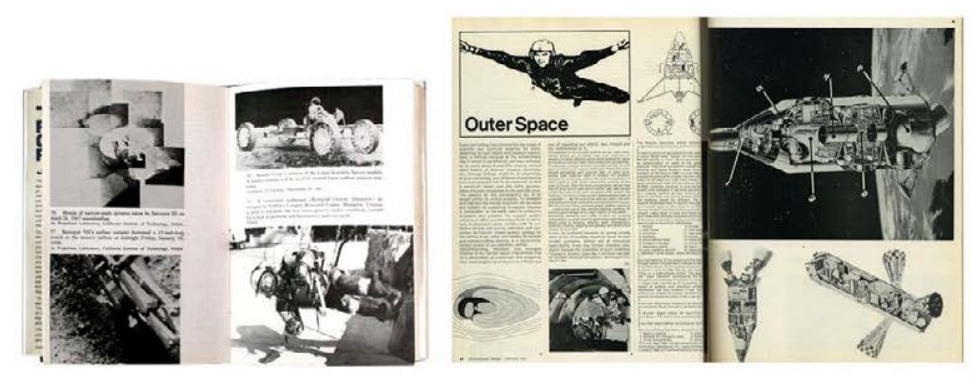

\section{9 "The Future of the Future" (John McHale) 1967 "AD 2000+" (John McHale)}

"The Future of the past is in the future.

The Future of the present is in the past.

The Future of the future is in the present"127 (McHale, 1969, p.1)

A pesar de no ser arquitecto, aunque ampliamente relacionado con la arquitectura a partir de su estrecha relación con Buckminster Fuller y la edición de "AD200+" como número especial en Architectural Design, la visión futura de McHale es la más completa y socialmente imbricada de todas, pero la menos proyectual, ya que no incorpora proyectos "inspiradores" sino referencias de tecnologías experimentales en fase de pruebas. Muy ligado a las teorías fullerianas de eficiencia energética global, McHale presenta un futuro basado en ecosistemas autosuficientes cerrados diseñados en torno a los conceptos de relación entre comunicación, ambiente y energía, también asociados a muchas de las ideas surgidas a partir del trabajo de Cedric Price. Fascinado por el concepto de cyborg acuñado por el científico Manfred Clynes ${ }^{128}$ y el desarrollo de las nuevas tecnologías de comunicación y control de masas, como explica Marshall McLuhan a partir de términos como "Aldea Global" 129 , McHale vaticina un nuevo estado de simbiosis entre el hombre y su entorno a través de una tecnología mediadora, o lo que es lo mismo, un sistema de nuevas relaciones entre lo artificial y lo natural.

"A nivel mundial, al igual que se produce en las relaciones simbióticas naturales del hombre con las plantas y los animales, sus relaciones con los sistemas cibernéticos han ido sutilmente cambiando hacia una interdependencia más estrecha, como si de un tejido orgánico que se asemeja a sus otros vínculos ecológicos se tratara. El punto alcanzado recientemente, cuando estos sistemas se combinan con otros como la teledetección o los sistemas de vigilancia y control de satélites en órbita, supone una extensión de esta simbiosis que incluye a la ecología planetaria."130 (McHale, 1969, p.123)

127 MCHALE, John. The Future of the Future. 1969. p.1.

128 MANFRED, Clynes. Foreword to Cyborg: Evolution of the Superman. Harper \& Row. Nueva York, 1965. p.8.

129 Ver: MCLUHAN, Marshall. Understanding Media: The Extensions of Man. Gingko Press. Berkeley, 1964.

130 "At the global level, as in man's natural symbiotic relations with plants and animals, his relationships to cybernetic systems has been subtly changing toward a more closely woven organic interdependency resembling his other ecological ties. The point reached recently when such systems were combined with remote sensing, monitoring and control capacities of the orbiting satellite marks the extension of this symbiosis to include the entire planetary ecology." 
El momento de cambio para McHale es aquel en el que el hombre se convierte en agente activo de su propio desarrollo y dominador de la tecnología como herramienta de evolución en el proceso natural genético, convertida en "extensiones del propio hombre", en un proceso que McHale determina como "Man Plus"131. Este proceso permite adquirir nuevas capacidades en ese proceso de simbiosis entre hombre-tecnología, natural-artificial. Estas extensiones suponen nuevos avances en apéndices robóticos, como los brazos industriales "Versatran" y "Unimate", los sistemas de movimiento "Hardiman" o "Walking Truck"132 o los exoesqueletos, todos ellos desarrollados a partir de las necesidades bélicas nacidas durante la II Guerra Mundial, hasta el uso de psicofármacos como el LSD o las nuevas estructuras criogénicas de generación de órganos artificiales construidos con materia orgánica derivados de los nuevos avances en el campo de la biónica, sobre los cuales McHale advierte los posibles riesgos éticos que plantean ${ }^{133}$.

"La fábrica automatizada no es sólo una serie de manos aumentadas, sino también de ojos adicionales, cerebro y otros sensores o capacidades de control."134 (McHale, 1969, p.99)

La alternativa de futuro sostenida con mayor convicción por McHale gravita en torno a la idea de aprovechamiento de la recién inaugurada movilidad humana, que le ha permitido abandonar el plano horizontal en el que desarrollaba su vida para colonizar nuevos espacios verticales, derivados de la carrera espacial y la investigación de los océanos, que él conceptualiza utilizando términos como "Outer Space" e "Inner Space".

"En su primera fase histórica, el hombre se expande horizontalmente por todos los rincones del planeta, en el presente, alcanza la movilidad vertical, hacia el espacio exterior y hasta el fondo de los océanos." ${ }^{335}$ (McHale, 1969, p.98)

MCHALE, John. The Future of the Future. 1969. p.123.

131 MCHALE, John. The Future of the Future. 1969. pp.98-122.

132 "Walking Truck" es un referente casi icónico al aparecer en varias predicciones y libros "futuristas" posteriores:

COOK, Peter. Experimental Architecture. 1970. p.152, f.98.

JENCKS, Charles. Arquitectura 2000. 1975 (1971). p.108, f.91.

Four-Footed Friend. En: AD The Architectural Design, junio 1969. p.293.

Creepy-Crawlies. En: AD The Architectural Design, abril 1970. p.198.

133 Ver:

BLOCK, Henry; GINSBERG, Herbert. The Psychology of Robots. En: Psychology Today, abril 1968. pp. 50-55.

134 "The automated factory is not only a series of augmented hands but also of extra eyes, brains, and other sensing and control capacities"

MCHALE, John. The Future of the Future. 1969. p.99.

135 "In his first historical phase, man spread out horizontally into every corner of the planet; in the present, he has become vertically mobile, out into space and down to the bottom of the oceans."

MCHALE, John. The Future of the Future. 1969. p.98. 
A pesar de presentar un planteamiento paralelo al de Ragon, en cuanto a la confianza en la exploración de esos nuevos lugares, McHale prioriza en su argumentación la tecnología desarrollada para alcanzar dichos fines, frente al ensimismamiento ingenuamente colonialista de Ragon. De esta manera, McHale plantea un futuro como optimización del entorno a partir de la oportunidad que estos sistemas tecnológicos representan en cuanto al nuevo marco de relaciones entre la persona y su entorno, para buscar maneras más eficaces de aprovechar los escasos recursos del planeta, que se basan en los conceptos de autosuficiencia y ecología cerrada propuestos por los sistemas habitacionales de cápsulas espaciales o submarinos. Estos habitáculos aparecen tanto en el final de "The Future of the Future" como en "AD2000+" y serán analizados en el caso aplicado de esta Tesis. 

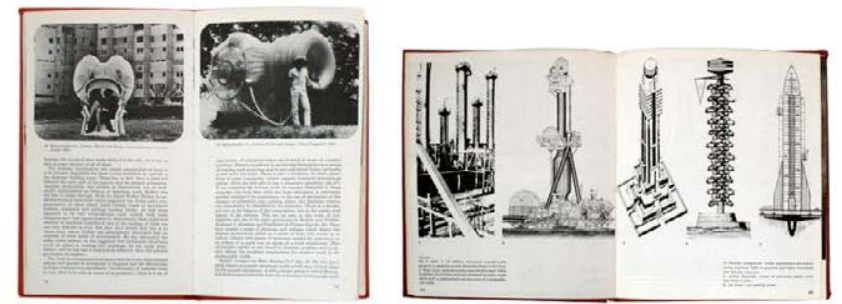

\section{7 "Architecture: action and plan" (Peter Cook) 1970 "Experimental Architecture" (Peter Cook)}

Ambos libros fueron adscritos por el propio Peter Cook al grupo "Annals of the RIBA Amateur Futurology Club", aunque no existe ningún anagrama, reseña o marca que lo corrobore en las primeras ediciones impresas de los mismos. Así es como estas dos publicaciones tienen vocación de presentarse como libros de futurología arquitectónica, a pesar de las críticas recibidas en medios especializados como la publicada en "New Sciencist" sobre "Experimental Architecture", que evidencia la gran brecha entre la futurología científica posibilista y las imágenes estáticas de futuro producidas en el ámbito arquitectónico.

"Las armas de los héroes que aparecen en el libro son mala futurología, con apoyo de malos gráficos y prosa sinuosa.

La introversión de este club amateur de futurología es tal que sus miembros parecen sólo recoger noticias de segunda mano sobre el mundo exterior, por lo que sus predicciones aparecen debilitadas por su escasa y obsoleta comprensión de computadoras, prótesis y bioingeniería." ${ }^{.136}$ (Colin Moorcraft, 1970, pp.611-612)

Sin embargo, tanto "Architecture: action and plan", como "Experimental Architecture", suponen dos predicciones arquitectónicas fundamentales no sólo para comprender la influencia del grupo Archigram en la futurología arquitectónica, sino por generar vínculos con otras experiencias afines de su presente y pasado. La diferencia radical con el resto de predicciones arquitectónicas aquí enunciadas es que su autor, Peter Cook, auto-determina sus propios trabajos en Archigram como "proyectos de futuro", además de analizar proyectos o modelos afines que refrendan sus propias perspectivas futuristas. También Dahinden presenta algunos de sus propios trabajos en "Estructuras Urbanas para el Futuro", pero de una manera secundaria y no como centro de interés de su predicción.

"Soy consciente de haber escrito a partir de dos posiciones a menudo en conflicto: como protagonista activo de una línea particular de experimentación y, al mismo tiempo como alguien que siente la responsabilidad de presentar una gama suficientemente amplia de posiciones de los valores subyacentes y nuevas relaciones emergentes. ${ }^{1137}$ (Peter Cook, 1970, p.7)

\footnotetext{
136 "The heroes weapons are bad futurology, supported by bad graphics and meandering prose. The introversion of the club is such that it members seem only to pick up news about the outside world at second hand, consequently their predictions are enfeebled by poor grasp of, for example, computers, prosthesis and bioengineering."
}

MOORCRAFT, Colin. Experimental Architecture. En: New Scientist, 31 de diciembre de 1970. pp.611-612. 
En "Architecture: action and plan", Cook plantea su futuro arquitectónico a partir de lo que considera las cuatro grandes revoluciones de la arquitectura moderna más allá del período heroico de los años veinte y treinta, integrando los proyectos de la primera época del estudio Archigram con experimentaciones afines anteriores a su contemporaneidad de 1967.

La primera revolución sugiere una nueva relación entre máquina y arquitectura, que aparece durante el movimiento moderno, para generar un acercamiento a partir de la estética de eficacia de la máquina. Así es como las "101 Fantasías" (1925-1933) de Tchernikov se emparentan con la "Walking City" (1964) en una nueva manera de entender esa estética maquinista.

La segunda revolución se relaciona con la idea de "planta libre" y como este prototipo primigenio del movimiento moderno convierte a los edificios en flexibles, en los que las libertades individuales tienen su reflejo espacial derivado de los procesos de acción humana que ocurren dentro de ellos.

La tercera revolución propone un cambio de expresión arquitectónica en concordancia al cambio social y material experimentado por la industrialización y los sistemas comerciales asociados al capitalismo avanzado. Cook propone una equiparación de la heterogeneidad formal y tipológica de la arquitectura con el sistema de objetos que nos rodea. En este sentido, a través del proyecto "Plug in City" (1964-66), Cook entiende también la vivienda y el resto de usos de una ciudad como objetos de consumo con períodos distintos de obsolescencia, lo que presupone una transferencia entre la arquitectura y el resto de objetos mediante estrategias evidentes de cambio de escala entre los mismos.

"La tercera fue una revolución tanto de contexto como expresión. La arquitectura nunca volvió a ser la misma." ${ }^{138}$ (Peter Cook, 1967, p.95)

"La revolución que tendrá lugar involucra la extensión de todos ellos, pero fundamentalmente, la explosión de la arquitectura en sí misma en algo mucho más equitativo con el resto de los artefactos que nos rodean." ${ }^{139}$ (Peter Cook, 1967, p.95)

Sin embargo, la última de esas revoluciones, aún no alcanzada por la arquitectura en ese momento según Cook, requiere de una planificación total en torno a la idea de convertir al usuario en constructor de su propio entorno a partir de un sistema de elementos entre los

137 "I am conscious of having written from two positions often in conflict: as an active protagonist of one particular line of experiment, and at the same time as one who feels a responsibility to present a broad enough range of positions for underlying values and relationships to emerge."

COOK, Peter. Experimental Architecture. 1970, p.7.

138 "The third was a revolution of context as much as of expression. Architecture was never again be the same."

COOK, Peter. Architecture: action and plan. 1967, p.95.

139 "The revolution which will happen next involves the extension of all these, but more fundamentally the explosion of architecture itself into something much more equitable with the rest of our artefacts."

COOK, Peter. Architecture: action and plan. 1967. p.95. 
que elegir, aplicando los sistemas de elección del catálogo utilizados por la sociedad de consumo de masas al campo de la vivienda u otras tipologías arquitectónicas. Este concepto se relaciona estrechamente con el proyecto que Cook estaba realizando justo en el momento de la publicación de "Architecture: action and plan", el sistema de viviendas "Control and Choice", propuesta de entorno responsivo incluido en la participación británica en la Bienal de París de 1967.

"La acción llega a formar parte de la planta. En última instancia, el usuario es tenido en cuenta. ¿Tiene el consumidor la opción de elegir entre diversas unidades prefabricadas de vivienda que impliquen entender que cada hombre puede convertirse en su propio arquitecto?" ${ }^{\text {"140 }}$ (Peter Cook, 1967, p.95)

Con la experimentación como modus operandi para proponer alternativas de futuro, Peter Cook presenta en "Experimental Architecture" una primera parte contextual a partir de las principales tradiciones históricas, sistema de búsqueda que le emparenta con el posterior libro de Jencks "Arquitectura 2000", y de la inexorable tendencia a la exploración derivada de la lógica de la producción, el valor del objeto y la oportunidad de la tecnología. Así es como Cook analiza distintos modelos, desde las estructuras espaciales de Wachsmann, la Dymaxion House de Fuller o las cápsulas de materiales plásticos de Lionel Schein. El planteamiento de Cook adopta también una postura geográfica bastante interesante, ya que realiza unos pequeños acercamientos a los diversos contextos internacionales que presuponen estrategias similares en función de agrupaciones o contextos geográficos determinados, en los que aparecen como exponentes: los austríacos Höllein, Walter Pichler, Raimund J. Abraham, St. Florian, Haus Rucker-Co, Zünd up o Coop Himmelblau, denominados como "The Austrian Phenomenon" ${ }^{141}$, que suponen para Cook la generación de jóvenes arquitectos más interesante del contexto internacional, los metabolistas japoneses, con Kenzo Tange, Kiyonori Kikutake y Kisho Kurokawa como grandes canalizadores, la heterodoxia norteamericana de Bruce Goff, Herbe Greene o Paolo Soleri, la hipersensibilidad italiana de Gino Valle, Gregotti y Giancarlo de Carlo frente al radicalismo de grupos como 9999 o UFO ${ }^{142}$, la tradición del gesto francesa con agentes como Paul Maymont o Friedman, la seriedad alemana de Wolfang Döring o Johannes Uhl y la continuidad británica de varios grupos de arquitectos, el propio Archigram entre ellos, de los conceptos de las nuevas estrategias arquitectónicas derivadas de los proyectos de Cedric Price.

La fascinación de Cook por sucesos tecnológicos como la carrera espacial, le llevan a generar especulaciones de posibles futuros que varían entre los conceptos del hardware y el software. Si "Architecture: action and plan" especula en torno a la generación de soportes comunes que puedan dar capacidad de elección al usuario, en "Experimental Architecture",

\footnotetext{
140 "The action becomes more part of the plan. Ultimately the user comes into his own. Does consumer choice of prefabricated living units and the like imply that every man might become his own architect?"

COOK, Peter. Architecture: action and plan. 1967. p.95.

141 Categorización que será utilizada tiempo después para etiquetar el movimiento austríaco durante la década de los sesenta y primeros setenta fundamentalmente:
}

PORSCH, Johannes; ARCHITEKTURSENTRUM WIEN (editores). The Austrian Phenomenon: Architecture Avantgarde Austria 1956-1973. Birkhäuser Boston INC. Boston, 2005.

142 Las sinergias entre Gran Bretaña e Italia van creciendo con intercambios entre la Architectural Association de Londres y el entorno más alternativo florentino. Ver:

HAGGART, Bruce. The Italian trip. En: AD The Architectural Design, abril 1972. pp.201-202. 
Cook defiende los sistemas que aportan autonomía al individuo, por lo que el automóvil se revela como paradigma de lo que Cook denomina como "Soft Network", destacando los proyectos de Archigram que a partir de 1967 devienen en sistemas de equipamientos móviles, ya sean individuales, como sus viviendas-traje "Suitaloon" (1967) o "Cushicle" (1966) o colectivos, desde el "Tuned Suburn" (1968) a la "Instant City" (1968) ), proyectos que generan una nueva actitud de cambio ya no desde la sustitución total de los modelos de ciudad anteriores, formalizada como ciudades utópicas que aparecen de la nada, sino desde un proceso generativo de cambio de las obsoletas estructuras urbanas.

\begin{abstract}
"Desde este enfoque no es necesario rediseñarlo todo. Aquí, el cambio fundamental viene de nuestra consideración sobre la evolución urbana y el soporte individual: un tema central para los arquitectos será que no es necesario reemplazar todo por algo nuevo. Y esto es un cambio fundamental en el corazón de la anterior arquitectura moderna." ${ }^{143}$ (Peter Cook, 1970, p.122)
\end{abstract}

Al final del libro, Cook vislumbra seis posibles futuros a partir de la reinterpretación de los artefactos de nuestro tiempo, la transferencia de tecnologías e información interdisciplinar, el confort, la personalización, la movilidad o la inexistencia de contextos perdurables y sobre todo, lo que él define como "The future of architecture lies the brain", "El Futuro de la arquitectura se encuentra en el cerebro", un capítulo en el que documenta varias experiencias de arquitectura virtual: simulaciones de entornos visuales como los "Hyperspaces" (1969) de Raimund Abraham y Gerald Sphiro en la Architectural League de Nueva York, la "Imaginary Architecture" (1969) exhibida por Friedrich St.Florian en el Moderna Museet de Estocolmo, generación de climas artificiales como el centro de vacaciones "Summerland" (1968) de Kinji Fumada, Minoru Murakami y Toshio Sato o equipamientos robotizados como aquel generado por los "RM robots" de Arata Isozaki para el "Theme Pavillion" de la Exposición Universal de Osaka'70.

\footnotetext{
143 "It's not necessary in this approach to redesign everything. Here a fundamental change is coming from our consideration of the evolving urban region, and of individual support: a central issue for architects is that it is not necessary to replace everything by something new. And this is a fundamental change of heart from the earlier modern architecture."
} 


\title{
Capítulo 3. ALTERNATIVAS PARA UNA ARQUITECTURA DEL FUTURO.
}

\author{
Predicciones de Futuro convertidas en estrategias de diseño \\ arquitectónico.
}

\begin{abstract}
"Creamos nuestros mitos literarios, leyendas y epopeyas del futuro, no para encontrar nuestra edad de oro, sino porque con la creación de estándares utópicos, hemos creado formas que posibilitan la acción en el presente. Toda forma de acción hace que el uso de ideales, como la ficción en la ciencia, los cielos en la religión, las utopías en la política o los auto-satisfechos actos artísticos ... pueda generar una serie de medios o modelos por los cuales determinemos la eficiencia de nuestras acciones en el presente". ${ }^{144}$ (Duncan (McHale)), 1961 (1969), pp.241-242)
\end{abstract}

Desde finales de la década de los cincuenta, la arquitectura se suma a esa necesidad y consiguiente popularización de generación de posibles futuros demandada por una sociedad que había ya incorporado de manera natural esas "ensoñaciones del futuro" desde el ámbito de la literatura, el cómic, el cine, la publicidad o cualquier tipo de expresión visual artística. Esa concepción de imágenes de futuro desde la arquitectura y su conversión en herramientas para la crítica y motor de cambio del presente supone el enfoque principal de todas las predicciones arquitectónicas aquí analizadas.

Con el movimiento moderno languideciendo ${ }^{145}$ y una serie de alternativas consideradas como continuistas ${ }^{146}$, fundamentadas en las propuestas urbanas del Team $X$ o los metabolistas y sus consecuentes megaestructuras, la capacidad de proyectar futuros desde el ámbito arquitectónico se convierte en una potente herramienta no sólo como manera de presentar una gran multiplicidad de propuestas de cambio urbano, sino de amplificar la influencia de la arquitectura y el interés de los arquitectos por una mayor diversidad de escalas, más allá del edificio o la ciudad, convertidas en objetos arquitectónicos protagonistas.

"La arquitectura experimental puede madurar e incorporarse a la credibilidad que ahora se le está dando a la búsqueda de Futuros." ${ }^{147}$ (Cook, 1970, p.29)

\footnotetext{
144 "We create our literary myths, legends and epics of the future, not so that we will find our golden age, but because in the creation of utopian standards, we have created forms which make present action possible. Every form of action makes use of ideals, as fiction in science, heavens in religion, utopias in politics or completely self-fulfilling acts in art... thus (creating) a means, model, a standard by which we determine the efficiency of present action."
}

DUNCAN, Hugh D. Language and Literature in Society. The Bedminster Press. Nueva Jersey, 1961. p.15. citado en: The Future of the Future. 1969. pp.241-242. 145 Incluso con fecha de muerte datada irónicamente por Charles Jencks coincidente con la demolición del emblemático
complejo de viviendas "Pruit-Igoe Housing" diseñadas por Minoru Yamasaki un 15 de Julio de 1972 a las tres y treinta y dos
de la tarde.

JENCKS, Charles. The Language of Post-Modern Architecture. Rizzoli. Nueva York, 1977. p.7.

146 BANHAM, Reyner. Megaestructuras. 1978 (1976). p.197.

147 "Experimental architecture may mature and merge with the credence that is now being given to the pursuit of Futures" 
"Yo he tratado de sugerir que el futuro de la arquitectura radica en la propia explosión de la arquitectura y también he intentado expresar una visión muy optimista que se reconoce en el trabajo que he elegido para ilustrar. ${ }^{.148}$ (Cook, 1970, p.152)

Esa "explosión de la arquitectura desde la propia arquitectura" promulgada por Peter Cook demanda también un cambio radical en la manera en que se gesta la misma. Ese futuro de la arquitectura no radica sólo en una cuestión estilística sino en una apertura del papel que el arquitecto jugará en esa "nueva sociedad", una reinterpretación de la arquitectura como proceso más allá de sus consecuencias finales como bien explicará Jim Burns:

"Un gran número de jóvenes arquitectos y urbanistas se han cansado, si es que no lo habían rechazado desde el principio, del concepto del arquitecto como maestro de obras, un benévolo dispensador de obras maestras para que la gente viva, ame y haga negocios en ellas." ${ }^{149}$ (Jim Burns, 1972, p.7)

La adopción de nuevas estrategias o la recuperación de otras sepultadas por el yugo del movimiento moderno generan un panorama de libertad formal y conceptual como nunca antes se había producido en el ámbito de la especulación arquitectónica derivada del proyecto. Es así como "Arqueología del Futuro" se convierte en una catalogación taxonómica de estrategias proyectuales derivadas de las cuatro alternativas del futuro de la arquitectura sobre las que gravitan las principales predicciones arquitectónicas: Cambio de Escala, Perversiones Naturales, Hacia una Arquitectura Virtual y la Movilidad como alternativas de futuro.

COOK, Peter. Experimental Architecture. 1970. p.29.

148 "If I have tried to suggest that the future of Architecture lies in the explosion of Architecture, I have also tried to express something very optimistic and this optimism is acknowledged in the work I have chosen to illustrate."

COOK, Peter. Experimental Architecture. 1970. p.152.

149 "A great number of young architects and planners have become weary of, if they have not rejected from the outset, the concept of the architect as "master builder", the benign (ideally) dispenser of masterworks for the people to live, love and do business in"

BURNS, Jim. Arthropods: new design futures. 1972. p.7. 


\section{Alternativa de futuro \#1 Cambio de Escala.}

El futuro de la arquitectura reivindica un proceso de Cambio de Escala radical como búsqueda de una equiparación formal de la misma con el resto de las artes visuales y su influencia en el sistema de objetos de consumo. La transgresión escalar es total y la amplificación y transferencias de escala hace que "el mundo sea una ciudad o un cojín"150, introduciendo así en el debate arquitectónico todo tipo de escalas hasta ahora relegadas a un plano secundario.

La primera de esas estrategias de cambio de escala supone un Monumentalismo Geométrico, derivado del continuismo de la megaestructura frente a los megaplanes de ordenación de los suburbios propuestos por el movimiento moderno. A pesar de las críticas $^{151}$ a su carácter autoritario y monótono y su pronta defunción materializada a modo de predicción tardía, el uso de una geometría radical asociada al gran tamaño de la megaestructura reincorpora a la arquitectura el uso de la súper-escala. Ésta es utilizada desde una perspectiva ingenieril, ligando arquitectura e infraestructura, entendiendo la ciudad como entidad autónoma ${ }^{152}$ a través de una acción planificadora total o mediante una instrumentalización de lo monumental como herramienta efectiva para la generación de complejidad y contradicción ${ }^{153}$ frente a la simplificada arquitectura moderna.

"Hoy en día la aceptación de una responsabilidad por el futuro presupone la planificación total, que es inconcebible sin una visión de lo que el futuro puede llegar a ser. ${ }^{1154}$ (Dahinden, 1971, p.7)

"Y así, si nuestras macro estructuras son para ser habitables, hay que adquirir un nuevo sentido del valor de la escala. De lo contrario, el gran tamaño de estas estructuras resultará intolerable."155 (Dahinden, 1971, p.15)

\footnotetext{
150 "The world is a village or a cushion" es el título de uno de los capítulos de la predicción "Experimental Architecture" de Peter Cook:
}

COOK, Peter. Experimental Architecture. 1970. pp.122-132.

151 JENCKS, Charles. Arquitectura 2000. 1975 (1971). pp.79-80.

152 Discurso utilizado por Peter Blake para comparar la "Plug-In City" de Archigram con las ciudades medievales de Urbino o Sant Gimminiano.

BANHAM, Reyner. Megaestructuras. 1978 (1976). p.17.

BLAKE , Peter. The secret scrapbook of an architectural scavenger. En: Architectural Forum, vol.121. n², agostoseptiembre 1964. p.114.

153 VENTURI, Robert. Complejidad y contradicción en la arquitectura. Gustavo Gili. Barcelona, 1974. Ed. original: Complexity and Contradiction in Architecture. The Museum of Modern Art. Nueva York, 1966.

154 "Today acceptance of responsibility for the future presupposes total planning, which is inconceivable without a vision of what the future may look like."

DAHINDEN, Justus. Urban Structures for the Future. 1972 (1971). p.7.

155 "And so, if our macrostructures are to be habitable, we must acquire a new sense of scale values. Otherwise the sheer size of these structures will prove intolerable"

DAHINDEN, Justus. Urban Structures for the Future. 1972 (1971). p.15. 
"Efectivamente, la idea de la arquitectura moderna está tan íntimamente conectada con los valores abstractos y comprobables del ingeniero que casi todo el mundo lo identifica con cosas tales como los puentes colgantes, las redes tensoras y las grandes megaestructuras geométricas." ${ }^{156}$ (Jencks, 1971, p.113)

"Creación de efectos ambientales de súper-escala para generar asombro ambiental, la creación de efectos ilusorios; trabajando con cuestiones de cambio de escala." ${ }^{157}$ (Jim Burns, 1972, p.36)

También relacionadas con la megaestructura y la súper-escala, aparecen las Ciudades Tecnomórficas, analogías directas entre arquitectura y máquina, ya no como relación simbólica sino como válvula de escape hacia la búsqueda de una mayor heterogeneidad formal, más allá de lo orgánico o lo abstracto. Varias predicciones presentan un paralelismo total entre proyectos arquitectónicos y todo tipo de lugares industriales ${ }^{158} \mathrm{como}$ estrategia de legitimación de los mismos. La nueva ciudad funciona como una máquina y se formaliza como ella, en superposición con la obsoleta ciudad existente.

"Esta primera revolución ya había comenzado a principios del siglo XX. Al principio solo era un sentimiento instintivo de que la belleza y la máquina de alguna manera tenían que reconocerse mutuamente y ser la mejor manera de convertirse en objetos y edificios. ${ }^{1159}$ (Cook, 1967, p.92)

De igual manera, el repertorio formal asociado a la máquina se diversifica, apareciendo nuevas iconografías maquinistas en las que tuberías, cables o pistones pasan a formar parte del imaginario arquitectónico en el mismo plano que los elementos históricamente considerados como intrínsecos a la arquitectura.

156 JENCKS, Charles. Arquitectura 2000. 1975 (1971). p.113.

157 "Creation of super-scale environmental effects for environmental awe, creating illusionary effects; commenting on matters of appropriate scale."

BURNS, Jim. Arthropods: new design futures. 1972. p.36.

158 Peter Cook pone en paralelo las torres de refinerías de petróleo con su propuesta para la "Entertainment Tower" de Montreal'67

COOK, Peter. Architecture: action and plan. 1967. pp.44-45.

Reyner Banham presenta como uno de los referentes más utilizados de las megaestructuras las refinerías de petróleo de Redondo Beach

BANHAM, Reyner. Megaestructuras. 1978 (1976). p.18.

Charles Jencks ilustra con una imagen de la plataforma petrolífera Red Sands Fort, situada en un estuario del Támesis su Arquitectura 2000:

JENCKS, Charles. Arquitectura 2000. 1975 (1971). p.61. f.41.

159 "This first revolution had already begun at the beginning of the twentieth century. It was at first an instinctive feeling that beauty and the machine had somehow to recognize each other if the best was to be made objects and buildings."

COOK, Peter . Architecture: action and plan. 1967. p.92. 
"Oponiéndose a la concepción clasicista del estilo internacional sobre la tecnología y la máquina como primorosos sólidos regulares y uniformes de aspecto anónimo, los megaestructuralistas más jóvenes entendieron claramente la tecnología como un disparatado y copioso lío de tuberías, cables eléctricos, riostras, pasarelas, erizadas antenas de radar, tanques de combustible suplementarios y plataformas de aterrizaje, todo ello distribuido sobre geometrías regulares estilo NASA." ${ }^{1160}$ (Banham, 1976, p.17)

Esa formalización maquinista se convierte en una cuestión estilística más al reivindicarse de manera autónoma, abandonando la escala ciudad para poder contaminar cualquier elemento arquitectónico a través del tecnomorfismo.

El proceso de reformulación de la forma arquitectónica tiene como aliado el amplio repertorio de objetos de consumo, sumiéndose en un proceso de transgresión y transferencia de escala a través de una gran variedad de Evocaciones Programáticas, relaciones formales con cambio de escala entre objetos de consumo, usos, identidades y todo tipo de elementos arquitectónicos.

"La revolución que tendrá lugar involucra la extensión de todos ellos, pero fundamentalmente, la explosión de la arquitectura en sí misma en algo mucho más equitativo con el resto de los artefactos que nos rodean." ${ }^{161}$ (Cook, 1967, p.95)

El potencial semántico de los objetos es exprimido al máximo por los arquitectos, no sólo en pos de esa adecuación formal de la arquitectura con otras artes ${ }^{162}$, sino para la obtención de una vinculación total entre identidad, comunicación y experimentación de la que la arquitectura había sido despojada por medio del proceso unificador del "estilo internacional".

"Hay algunos fenómenos, sin embargo, que son locales y no tienen nada que ver con el intercambio intelectual. Entre ellos se encuentran los estilos cheesecake de California, Hawaii y Florida, y los gestos étnicos construidos por bien intencionados diseñadores en pos de una identificación de lo local. Estas situaciones pueden ser divertidas e incluso emocionantes y, bajo ciertas circunstancias, formalmente experimentales." ${ }^{.163}$ (Cook, 1970, p.70)

160 BANHAM, Reyner. Megaestructuras. 1978 (1976). p.17.

161 "The revolution which will happen next involves the extension of all these, but more fundamentally the explosion of architecture itself into something much more equitable with the rest of our artefacts."

COOK, Peter. Architecture: action and plan. 1967. p.95.

162 Que Ragón explicará hasta la extenuación en sus predicciones con la doble vinculación "Arquitectura / Escultura" y "Escultura / Arquitectura":

RAGON, Michel. ¿Dónde viviremos mañana?. 1966 (1963). pp.113-118.

RAGON, Michel. ¿Dónde viviremos mañana?. 1966 (1963). pp.119-120.

163 "There are some phenomena, however, which remain local and have nothing to do with intellectual interchange. Among them are the cheesecake styles of California, Hawaii and Florida, and the ethnic gestures which are made by quite wellmeaning designers towards highly identifiable localities. These things can be amusing and even exciting and, under certain circumstances, formally experimental"

COOK, Peter. Experimental Architecture. 1970. p.70. 
Así es como cualquier objeto y su consecuencia formal son susceptibles de ser transformados en estrategia proyectual mediante el proceso de búsqueda de su potencial comunicador e identitario.

La arquitectura se llena de edificios-anuncio, viviendas que se parecen a sus usuarios y todo tipo de proyectos formalmente parecidos a los objetos que les proporcionan este nuevo lenguaje. Al mismo tiempo, dichos objetos son susceptibles de reproducir formalmente las arquitecturas que los contienen.

La Hipergráfica juega un papel destacado, no sólo al incorporarse al proceso arquitectónico, sino al convertirse en protagonista de la experiencia arquitectónica, transformando recursos gráficos en elementos arquitectónicos.

"Sin profundizar en la teoría de la semiología, puede decirse que una de sus contribuciones será la de esclarecer las relaciones entre la diversidad de recursos colectivos, la lengua y la selección y creaciones individuales de ésta, la palabra. El arquitecto irá aumentando el uso de signos de procedencias heterogéneas, incluidos los mismos letreros de establecimientos. ${ }^{1164}$ (Jencks, 1971, p.122)

Del mismo modo que la heterogeneidad de objetos se incorpora al repertorio formal arquitectónico, también lo hace la diversidad de mensajes, codificados a través de una infinita paleta de recursos gráficos transformados en revestimiento, camuflaje, estrategias urbanas de transformación, edificios-anuncio o marcas convertidas en elementos arquitectónicos, desembocando en una explosión del mensaje con consecuencias formales para el objeto arquitectónico.

"Efectos visuales con pintura, impresión, signos, símbolos y palabras para transmitir mensajes o cambiar la apariencia de edificios, espacios interiores y ambientes temporales." ${ }^{1165}$ (Jim Burns, 1972, p.36)

El cambio de escala también afecta a un futuro urbano, en el que objetos cotidianos aumentados de tamaño se convierten en Activadores Urbanos a través de arquitecturas representadas mediante acciones y juegos, secundados por la construcción de ambientes temporales de materiales de bajo coste.

Procesos análogos entienden que la vivienda del futuro puede diseñarse como si una ciudad a pequeña escala se tratara, una Ciudad Interior como lugar de experimentación total del cambio de escala que termina desembocando en una Objetualización Ideológica, que incorpora teorías arquitectónicas al ambiente doméstico reconvertidas en vulgares objetos de mobiliario.

164 JENCKS, Charles. Arquitectura 2000. 1975 (1971). p.122.

165 "Visual effects with paint, print, signs, symbols, and words to transmit messages or affect the appearance of buildings, interior spaces, and temporary environments"

BURNS, Jim. Arthropods: new design futures. 1972. p.36. 


\section{Alternativa de futuro \#2 Perversiones Naturales.}

La experimentación en relación a la disolución de los límites entre los términos abstractos "natural" y "artificial" supone la segunda de las alternativas de futuro, focalizada en las predicciones de Jencks y McHale como estrategia global y en las de Banham y Dahinden como estrategia efectiva para la incorporación de las mega-ciudades al paisaje.

"El siguiente paso parece inevitable: lo tecnológico y lo orgánico se examinarán juntos. La simbiosis será completa, la función natural ya no será sólo simbólica sino real."166 (Cook, 1970, p.23)

"Por una parte, los hombres están dispuestos a mirar la naturaleza, la cultura y la máquina como especies similares de una misma cosa puesto que ya no pueden por más tiempo, literalmente, hallar distinciones entre ellas."167 (Jencks, 1971, p.127)

"Lo visualmente borroso de la diferencia entre naturaleza y cultura en sus contornos ambientales tiene su paralelismo en la re-conceptualización de naturaleza y cultura efectuada por el incremento de conocimiento del hombre y su desarrollo". 168 (Jencks, 1971, p.128)

"Las construcciones basadas en lo biológico presuponen la eliminación de nuestra tecnología entendida de la manera actual y una apuesta por la química completa, física y biológica en total simbiosis con el hombre y su entorno." ${ }^{169}$ (Dahinden, 1971, p.40)

Dicha búsqueda de mímesis con el paisaje de la megaestructura y el edificio-ciudad enfatiza el término Ciudad-Paisaje, bajo el que las analogías biológicas organizativas dan paso a todo tipo de simulaciones de naturalezas artificiales a modo de ciudades-roca, ciudadesmontaña, ciudades-río o ciudades-nube. A ese proceso de simulación natural también se adhieren los Edificios-Camuflaje, reproduciendo geometrías naturales como bio-estructuras o simplemente intentando emular cualquiera de las propiedades naturales de su entorno, ya sea como simples metáforas o como procesos que intentan devolver el espacio ocupado por el edificio a su estado natural.

"Si la madera sintética y la piedra artificial pueden ser elaboradas de manera que se les dé la forma deseada y visualmente no se distinguen de sus contrapartidas

166 "The next step seems inevitable: the technological and the organic will be examined together. The symbiosis complete,
the natural function will not just be symbolic but actual"

COOK. Peter. Experimental Architecture. 1970. p.23.

167 JENCKS, Charles. Arquitectura 2000. 1975 (1971). p.127.

168 JENCKS, Charles. Arquitectura 2000. 1975 (1971). p.128.

169 "Biologically-based construction presupposes the elimination of our present-day makeshift technology and the complete chemical, physical and biological symbiosis of man with his environment"

DAHINDEN, Justus. Urban Structures for the Future. 1972 (1971). p.40. 
naturales, resulta pedante e infructuoso insistir en la posesión de un material real."170 (Jencks, 1971, p.128)

"Las construcciones de los ingenieros tendrán en el porvenir una semejanza cada vez mayor con las estructuras biológicas; más exactamente esas construcciones tenderán a semejar pequeños animales, insectos, por ejemplo, porque los esfuerzos debidos al peso son menos importantes que los debidos a otras fuerzas." ${ }^{171}$ (Ragon, 1963, p.75)

"Mediante la combinación de la ciencia de la materia viva (biología) con la ciencia de la arquitectura (estructuras), hemos sido capaces de establecer una ciencia de síntesis de estructuras vivas, que llamaremos bio-estructuras. Esta síntesis comprende todo tipo de estructuras urbanas: edificios, órganos y sistemas de control, que hasta ahora habían sido considerados como interdependientes. ${ }^{172}$ (Dahinden, 1971, p.66)

El cambio radical de escala de los escenarios de futuro posibilita la aparición de una serie de especulaciones en torno al concepto de Naturaleza Equipada, una naturaleza susceptible de ser amplificada con implantes tecnológicos ${ }^{173}$ al servicio del hombre, entendida como un kit, permitiendo a su vez iniciar un proceso de Re-Naturalización de la ciudad, que sin duda establece una vuelta a un estado salvaje anterior como alternativa de futuro, una nostalgia de "lo natural" identificado como "lo salvaje" al que el hombre sólo será capaz de volver con ayuda de la tecnología.

El ambiente doméstico tampoco escapa a esa seducción por "/o salvaje", aplicándose así el mismo concepto de paisaje a una vivienda que logre incorporar un amplio repertorio de Naturalezas Domésticas como reproducciones del futuro salvaje urbano bajo la influencia de lo doméstico.

\footnotetext{
170 JENCKS, Charles. Arquitectura 2000. 1975 (1971). p.128.

171 RAGON, Michel. ¿Dónde viviremos mañana?. 1966 (1963). p.75

172 "By combining the science of living matter (biology) with the science of architectonics (structures), we have been able to establish a synthetic science of living structures, which we call bio-structures. This synthesis embraces all urban structures buildings, organs and control systems- which are now regarded as interdependent."
}

DAHINDEN, Justus. Urban Structures for the Future. 1972 (1971). p.40.

173 La simbiosis total a partir del proceso de hibridación entre "natural" y "artificial" a nivel urbano o entre "hombre" y "máquina" a nivel conceptual será la alternativa de futuro más deseada por McHale y Jencks.

MCHALE, John. The Future of the Future. 1969. pp.98-122.

JENCKS, Charles. Arquitectura 2000. 1975 (1971). pp.127-134. 
"En los sustitutos futuros de la piel con pelo, la piel sin pelo y otros efectos antropomórficos proliferarán hasta que sea completamente posible para todo el mundo poseer un entorno que responda a una vista amable y un tacto agradable, como el anuncio del visón lo hace."174 (Jencks, 1971, p.107)

"Además, cuando la biología llegue a ser la mayor metáfora de los años 90, la tradición intuitiva explotará en un estallido de imágenes bio-mórficas acomodado al desarrollo individual y orgánico."175 (Jencks, 1971, p.107)

174 JENCKS, Charles. Arquitectura 2000. 1975 (1971). p.107.

175 JENCKS, Charles. Arquitectura 2000. 1975 (1971). p.107. 


\title{
Alternativa de futuro \#3 Hacia una arquitectura virtual.
}

La tercera alternativa de futuro propone un viaje Hacia una arquitectura virtual, construida a partir de la sobrestimulación de la percepción por un lado y el control higrotérmico por otro, como estrategias arquitectónicas fundamentales auspiciadas por la tecnología.

\begin{abstract}
"Visiones y estimulantes.
Si la televisión puede extendernos hacia un medio ambiente total y si en vez de una arquitectura cerrada, obtenemos una especie de ventana al mundo, tendremos que investigar las posibilidades de esa arquitectura de la visión. Por el momento parece que hay dos enfoques. El primero se refiere a la extensión de las técnicas ya existentes y la posible combinación de las mismas. Este enfoque exige claramente la generación de un entorno experimental en los que la electrónica, los sistemas mecánicos flexibles y las instalaciones de confort, sean utilizados de una manera tan intensa como sea posible. El otro enfoque parte de considerar la estimulación visual de la experiencia arquitectónica sin necesidad de llevar los aspectos más allá de sus propias capacidades actuales." ${ }^{176}$ (Cook, 1970, p.134)
\end{abstract}

La generación de Climas Artificiales supone trabajar mediante la experimentación de una gran diversidad de estrategias de control climático encaminadas a una búsqueda de un clima global confortable y homogéneo que desemboque en una desaparición de la arquitectura como consecuencia final. También una arquitectura despojada de sus condicionamientos ambientales externos ya sea desde el control exterior o interior, a través de la generación de climas unipersonales ejemplificados en el traje de astronauta.

"La temperatura constante y la protección proporcionadas por las cúpulas eliminarán los efectos nocivos del medio ambiente natural, aumentando así el valor habitacional de la esfera pública." ${ }^{1177}$ (Dahinden, 1971, p.31)

"Con las técnicas modernas, lo interior y lo exterior se están mezclando con las cualidades de día y noche, verano e invierno, norte y sur. En breve, grandes porciones de la población habitarán en una ciudad-campo con aire acondicionado, iluminada durante las veinticuatro horas del día, con toda clase de servicios y con vida activa durante un período continuo."178 (Jencks, 1971, p.127)

\footnotetext{
176 "Visions and Stimulants

If television can extend towards the total environment and if, instead of closed architecture, we have something of a window on the world. We must investigate the possibilities of a vision architecture. At the moment there seem to be two approaches The first is concerned with the extension of existing techniques and their combination. This approach clearly demands that the experimental environment should provide the electronics, flexible mechanics and the comfort facilities as intensely as possible, in the traditional way of taking the physical thing to its breaking point and then suggesting a series of optimum techniques which can be applied in more general circumstances. The other approach is to consider the visual stimulation of an experience without necessarily pushing the technical aspects any further that they need to go"
}

COOK, Peter. Experimental Architecture. 1970. p.134.

177 "The constant temperature and the protection from the elements provided by domes will eliminate the harmful effects of the natural environment and so enhance the habitational value of the public sphere."

DAHINDEN, Justus. Urban Structures for the Future. 1972 (1971). p.31.

178 JENCKS, Charles. Arquitectura 2000. 1975 (1971). p.127. 
Esa búsqueda de producción y reproducción de arquitectura desde el propio sujeto tiene como consecuencia primordial una gran experimentación en la construcción de Distorsionadores autónomos de la percepción, gafas, cascos y todo tipo de artefactos para una intensificación de la experiencia perceptiva, con el "todo es arquitectura" como lema para una nueva arquitectura.

"Así como los barcos y aviones han extendido la movilidad física del hombre, las artes y otros medios de comunicación han ampliado enormemente la exploración psíquica del espacio y el tiempo."179 (McHale, 1969, p.102)

"La expansión mental inducida por las drogas, una de las formas más antiguas de extender la experiencia humana, se ha convertido en un nuevo culto casi religioso."180 (McHale, 1969, p.103)

Las Simulaciones Espaciales suponen un gran campo de experimentación en torno a la generación de ambientes temporales, encontrando una gran multiplicidad de aliados en el entorno de las artes escénicas y visuales y nuevos "lugares" como son los "palacios de la diversión" y las discotecas, que se convierten así en centro del debate arquitectónico. La sobre-estimulación de la percepción viaja del espacio artístico al arquitectónico para incorporarse débilmente en el ambiente doméstico como parte de la "experiencia arquitectónica".

179 "Just as ships and airplanes have extended man's physical mobility, so the arts and other communication modes have enormously expanded his psychic exploration in space and time."

MCHALE, John. The Future of the Future. 1969. p.102.

180 "Drug induced mind expansion, one of the oldest forms of extending human experience, has become a new quasireligious cult."

MCHALE, John. The Future of the Future. 1969. p.103 


\section{Alternativa de futuro \#4 La Movilidad como opción de futuro.}

La Movilidad como opción de futuro se convierte en una de las grandes obsesiones del arquitecto del futuro. Un nuevo nomadismo derivado de una creciente sociedad del ocio impone una gran multiplicidad de imágenes de futuro en el que "las casas se desplazarán con los hombres"181, "las ciudades serán transportables"182 y "las estructuras se pondrán en movimiento"183. Una gran cantidad de los futuros vislumbrados en este período temporal se articulan en torno a "una movilidad total en relación a los artefactos que la posibilitan, por un lado mediante la transferencia de energía e información necesaria, y la movilidad física derivada del aumento de los medios de transporte por otro." ${ }^{184}$

La Ciudad del Automóvil supone el primero de los contextos de experimentación arquitectónica en torno a esa búsqueda de una movilidad total. Arquitectos que diseñan automóviles y automóviles que imponen su omnipresencia en el diseño de la ciudad. Una controvertida relación entre ciudad y automóvil y un auge del mismo en la esfera de la cultura arquitectónica traducido en el culto a la libertad e independencia ${ }^{185}$ que desde su aparición produce en el mercado. El automóvil encuentra en la búsqueda romántica de una vivienda-móvil definitiva un importante aliado, y en la caravana su complemento perfecto para llegar incluso a convertirse en una prolongación de la vivienda como si de una pieza más de mobiliario se tratara.

"La verdadera ventaja del coche eléctrico es que se convirtiera en un pedazo de superficie lo suficientemente pequeño como para ser entrelazado con las estructuras urbanas existentes. Además de esto, se puede hacer lo suficientemente seguro mediante control automático como para ser considerado no como otro tipo de coche, sino como un objeto más del mobiliario de la vivienda." ${ }^{186}$ (Cook, 1970, p.119)

Se inicia la búsqueda de una ciudad flexible, una exploración que va de la ciudad de emergencia a la de vacaciones como prototipos posibles para el diseño de La Ciudad Instantánea, una ciudad que responda a los cambiantes estilos de vida del ciudadano y en la que la arquitectura ya no sea estable y perdurable sino elástica y perecedera.

"Las instalaciones móviles están siendo discutidas en muchas áreas: instalaciones de emergencia en las que la movilidad puede ser una cuestión de vida o muerte, o instalaciones que pueden necesitar ser movidas por cuestiones económicas o simplemente por la extensión de un servicio. La movilidad puede ser necesaria

181 RAGON, Michel. ¿Dónde viviremos mañana?. 1966 (1963).p.185.

182 RAGON, Michel.¿Dónde viviremos mañana?. 1966 (1963). p.189.

183 RAGON, Michel.¿Dónde viviremos mañana?. 1966 (1963). p.183.

184 COOK, Peter. Experimental Architecture. 1970. pp.127-132.

185 COOK, Peter. Experimental Architecture. 1970. pp.117-126.

186 "The real advantage of the electric car is that it would be give a piece of moving surface small enough to be intertwined with existing urban structures. Besides this it can be made safe enough by control for it to be thought of not as another kind of car but as a mobile piece of furniture."

COOK, Peter. Experimental Architecture. 1970. p.119. 
cuando se trata de la única o la manera más rápida de infiltrarse en el mayor número de comunidades como sea posible."187 (Cook, 1970, pp.121-122)

"La superposición trabajo / vacaciones / fin de semana en nuestra vida también está acompañada por la adopción flexible de un estilo apropiado para los diferentes roles sociales que ahora el individuo ocupa.

En cuanto a la movilidad física, esta gran diversidad de estilos o roles del individuo requiere del uso diferencial de un mayor número de instalaciones físicas. "188 (McHale, 1969, p.284)

"Todos los sistemas, todos los edificios, deberían ser diseñados de modo que durasen exactamente el tiempo en que se conservan útiles, ni un segundo más." 189 (Jencks, 1971, p.94)

El arquitecto se convierte así en un gestor de posibilidades arquitectónicas entre las que el usuario pueda escoger, interpretar o modificar a su antojo en unas nuevas ciudad y vivienda influenciadas por la creciente cultura del "Hazlo-Tú-Mismo" y la emancipación arquitectónica. La arquitectura se reduce a una serie de equipamientos básicos e instrucciones de montaje, a una caja de herramientas que facilite la total personalización del espacio en relación al uso y a los deseos del usuario.

"O bien, en términos ambientales, la libertad consiste en la aptitud de modificar y seleccionar aquellas partes que tienen importancia para el problema particular que se trata. Para esa clase de libertad he escogido el término -adhocismo- porque indica la aptitud para unir partes preexistentes adhoc, para esa finalidad particular. Una de las grandes ventajas de esa aproximación es que personaliza las cosas producidas en serie gracias a la incorporación de las mismas a un conjunto construido por un individuo."190 (Jencks, 1971, p.58)

"Efectivamente, el hombre está retornando a su primigenio estado como bricoleur, auxiliado por la gran cantidad de productos de consumo con sus folletos de instrucciones y revistas relativas al modo de hacer las cosas." ${ }^{.191}$ (Jencks, 1971, p.58)

\footnotetext{
187 "Mobile facilities are now being discussed in so many areas: emergency facilities where mobility may be a matter of life or death, and facilities which may need to be moved for the general economy and spread of a service. Mobility may be necessary where this is the only or quickest way of infiltrating into as wide a range of communities as possible"

COOK, Peter. Experimental Architecture. 1970. pp.121-122.

188 "The overlapping of work / vacation / weekend living is also accompanied by the flexible adoption of appropriate styling for the many different social roles that the individual now occupies.

In terms of physical mobility, this greater diversity of styles requires differential use of an extended number of physical facilities"

MCHALE, John. The Future of the Future. 1969. p.284.

189 JENCKS, Charles. Arquitectura 2000. 1975 (1971). p.94

190 JENCKS, Charles. Arquitectura 2000. 1975 (1971). p.58

191 JENCKS, Charles. Arquitectura 2000. 1975 (1971). p.58
} 
"La influencia potencial evidente se encuentra en la evolución de los elementos de tuning: piezas que se pueden agregar a una estructura existente, temporales e intercambiables, quizá derivados de una herencia diferente. ${ }^{.192}$ (Cook, 1970, p.27)

La Ciudad de los Intercambios gestiona la transferencia de energía e información entre espacios y usuarios a través de la búsqueda de "ambientes responsivos".

"A nivel global, como en las relaciones simbióticas naturales del hombre con las plantas y los animales, su relación con los sistemas cibernéticos ha ido cambiando sutilmente hacia una interdependencia orgánica tan estrechamente tejida que se asemeja a sus otros vínculos ecológicos.

El punto alcanzado recientemente cuando tales sistemas se combinan con los sensores remotos, los sistemas de monitorización y control de las capacidades del satélite en órbita marca la extensión de esta simbiosis para incluir toda la ecología planetaria." ${ }^{193}$ (McHale, 1969, p.123)

La generación de arquitecturas que puedan responder a las distintas comunidades de intereses depende de la capacidad de los arquitectos en el diseño de los distintos dispositivos de comunicación que conecten al usuario con todos los ámbitos de su esfera pública.

"La respuesta de los arquitectos a ese problema será diseñar con gran flexibilidad sus estructuras, proponer una estructura flexible en sí misma o bien proporcionar una pluralidad de centros fijos que puedan responder a las distintas necesidades." ${ }^{194}$ (Jencks, 1971, p.90)

"Esta participación de las personas en el proceso de cambio de sus propios ambientes conduce a una evolución del papel del diseñador y urbanista como un guía, no un director, un participante experto y no un agente que impone sistemas ambientales cerrados." ${ }^{195}$ (Jim Burns, 1972, p.7)

\footnotetext{
192 "The obvious potential influence is in evolution of tuning elements: parts that can be added to an existing structure, temporary and exchangeable, perhaps derived from a different heritage"
}

COOK, Peter. Experimental Architecture. 1970. p.27

193 "At the global level, as in man's natural symbiotic relations with plants and animals, his relationship to cybernetic systems has been subtly changing toward a more closely woven organic interdependency resembling his other ecological ties. The point reached recently when such systems were combined with the remote sensing, monitoring, and control capacities of the orbiting satellite marks the extension of this symbiosis to include the entire planetary ecology"

MCHALE, John. The Future of the Future. 1969. p.284

194 JENCKS, Charles. Arquitectura 2000. 1975 (1971). p.90

195 "This involvement of people in the process of change in their own environments leads to the changing role of the designer and planner as a guide not a director, an "expert participant" not an imposer of closed environmental systems"

BURNS, Jim. Arthropods: new design futures. 1972. p.7. 
La interconexión y el intercambio es total, la vivienda se convierte en el principal lugar de relación del individuo con el mundo exterior a través de un proceso de expertización de los electrodomésticos.

"Una persona, sentada en su casa u oficina, o en movimiento, será capaz de comunicarse con cualquier otra persona en cualquier parte del mundo. A través de información escrita, datos informáticos o fax será capaz de establecer una transmisión instantánea a cualquier distancia." ${ }^{196}$ (McHale, 1969, p.146)

"Estos podrían ser denominados como gadgetecture: tiendas de campaña, paquetes, cosas que se pueden derribar o doblar hacia arriba o desempaquetar o combinar en objetos híbridos. En todo caso, tendrán necesariamente que involucrar la elección del usuario." ${ }^{.197}$ (Cook, 1970, p.127)

"Por supuesto que varios pronosticadores predicen que el robot doméstico pronto llegará a ser totalmente común en los hogares hacia el año 2000." ${ }^{198}$ (Jencks, 1971, p.112)

"Lo que en realidad se está estudiando aquí es el prototipo de una casa autónoma, que podría funcionar en cualquier parte de la tierra, sin líneas de servidores o servicios públicos de energía, con un mantenimiento mínimo y una vinculación de los bienes de consumo."1999 (McHale, 1969, p.182)

\footnotetext{
196 "A person sitting in his home or office, or in movement will be able to communicate with any other person anywhere in the world. Written information, computer data and facsimile will be capable of instant transmission from point to point over any distance"

MCHALE, John. The Future of the Future. 1969. p.146.

197 "These could be termed gadgetecture: they may be tents, they may be packages, they may be things you can knock down or fold up or unpack or combine into hybrids. At any rate, they will necessarily involve your choice."
}

COOK, Peter. Experimental Architecture. 1970. p.127.

198 JENCKS, Charles. Arquitectura 2000. 1975 (1971). p.112.

199 "What is actually being studied here is the prototype for an autonomous, self-servicing house that could function anywhere on earth, without server lines or power utilities, and with minimal maintenance and real estate linkage"

MCHALE, John. The Future of the Future. 1969. p.182. 


\section{Capítulo 4. CAMBIO DE ESCALA.}

Casi todas las predicciones arquitectónicas antes citadas inciden en una redefinición del sistema referencial formal utilizado en la disciplina arquitectónica para su adecuación al contexto social y cultural, que se consolida en occidente entre los años cincuenta y setenta del siglo XX, a partir de dos premisas fundamentales: la equiparación de la heterogeneidad formal de la arquitectura con un sistema de objetos de consumo en expansión exponencial y la hibridación de la arquitectura con otras disciplinas, creando escenarios para una evolución paralela de las mismas. La primera, enunciada por Peter Cook en "Architecture: action and plan" (1967) o Charles Jencks en "Arquitectura 2000" (1971) y defendida anteriormente por sistemas de trabajo como el Team X, y la segunda, bajo conceptos como "arquitectura-escultura" de Michel Ragon y en contra de la desconexión entre la arquitectura y otras artes aplicadas sufrida durante el movimiento moderno.

Dicha redefinición formal, iniciada a partir de finales de los años cincuenta, presenta diversas estrategias de cambios de escala a partir de una gran variedad de transferencias entre los diversos elementos arquitectónicos, entendidos como una simbiosis entre edificio / ciudad / mobiliario, y el sistema de objetos pertenecientes el ámbito artístico o relacionados con bienes de consumo, social y culturalmente aceptados y referenciados a contextos temporales determinados. La alternativa del cambio de escala opera de esta manera a partir de siete estrategias claramente delimitadas:

- [Monumentalismo geométrico] la fascinación por las formas geométricas convertidas en monumentos-ciudad.

- [Ciudades tecno-mórficas] la aplicación de formas maquinistas para la generación de edificios-ciudad.

- [Evocaciones programáticas] relaciones formales entre programas, identidades, objetos y edificios.

- [Hiper-gráfica] sistemas gráficos convertidos en elementos arquitectónicos.

- [Activadores urbanos] cómo objetos domésticos cambian de escala para convertirse en activadores del espacio público.

- [Ciudad interior] el interiorismo y diseño de mobiliario pensados como urbanismo.

-[Objetualización de la ideología] la transformación de ideologías arquitectónicas en objetos de consumo. 


\section{Catálogo // [Monumentalismo geométrico]}

Las imágenes están referenciadas por números en la zona superior de las columnas verticales [del 1 al 12] y letras en la zona izquierda de las filas horizontales [de la A a la E].

Todas las referencias están ordenadas cronológicamente.

Referencias de imágenes del [1B] a [12C]. Cada uno de los proyectos referenciados gráficamente en el catálogo presentan antes de su nombre un código con un número en relación a su columna vertical y una letra en relación a su fila horizontal.

\section{Ejemplo:}

[7E] "Cloud 9" (1962) de Buckminster Fuller. Buscar referencia en la columna 7 y la fila E del catálogo referenciado al principio del capítulo.

[Nota]: no todos los referentes gráfico del catálogo están referenciados en el texto por lo que se recomienda una lectura del mismo antes de comenzar la lectura.
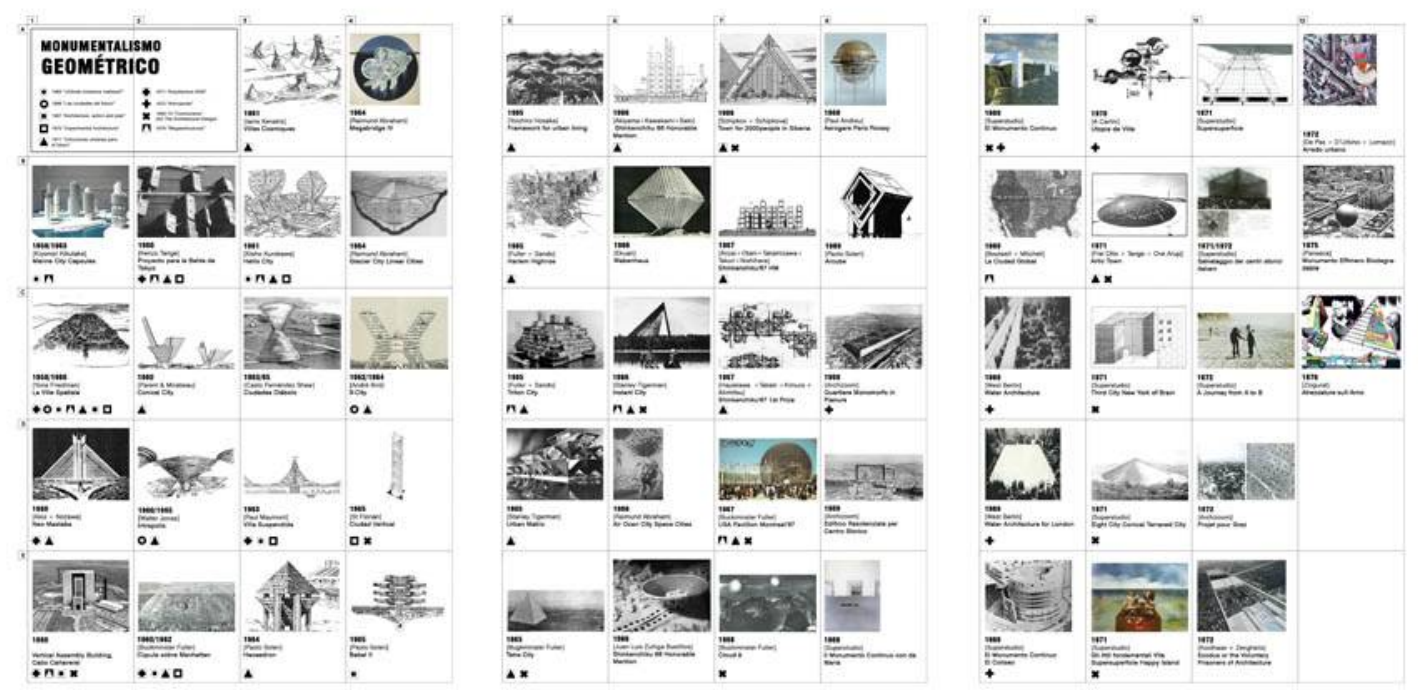


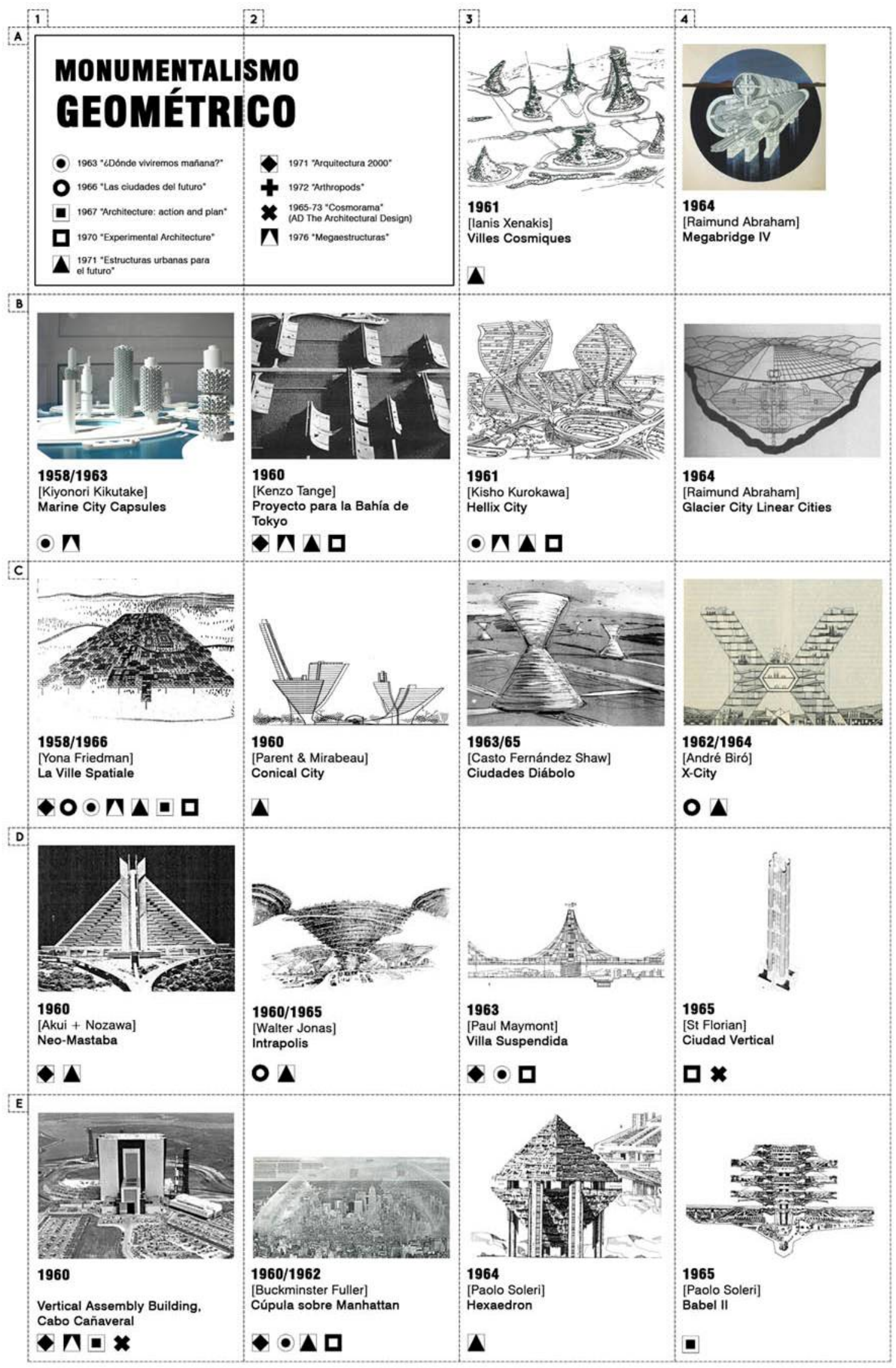




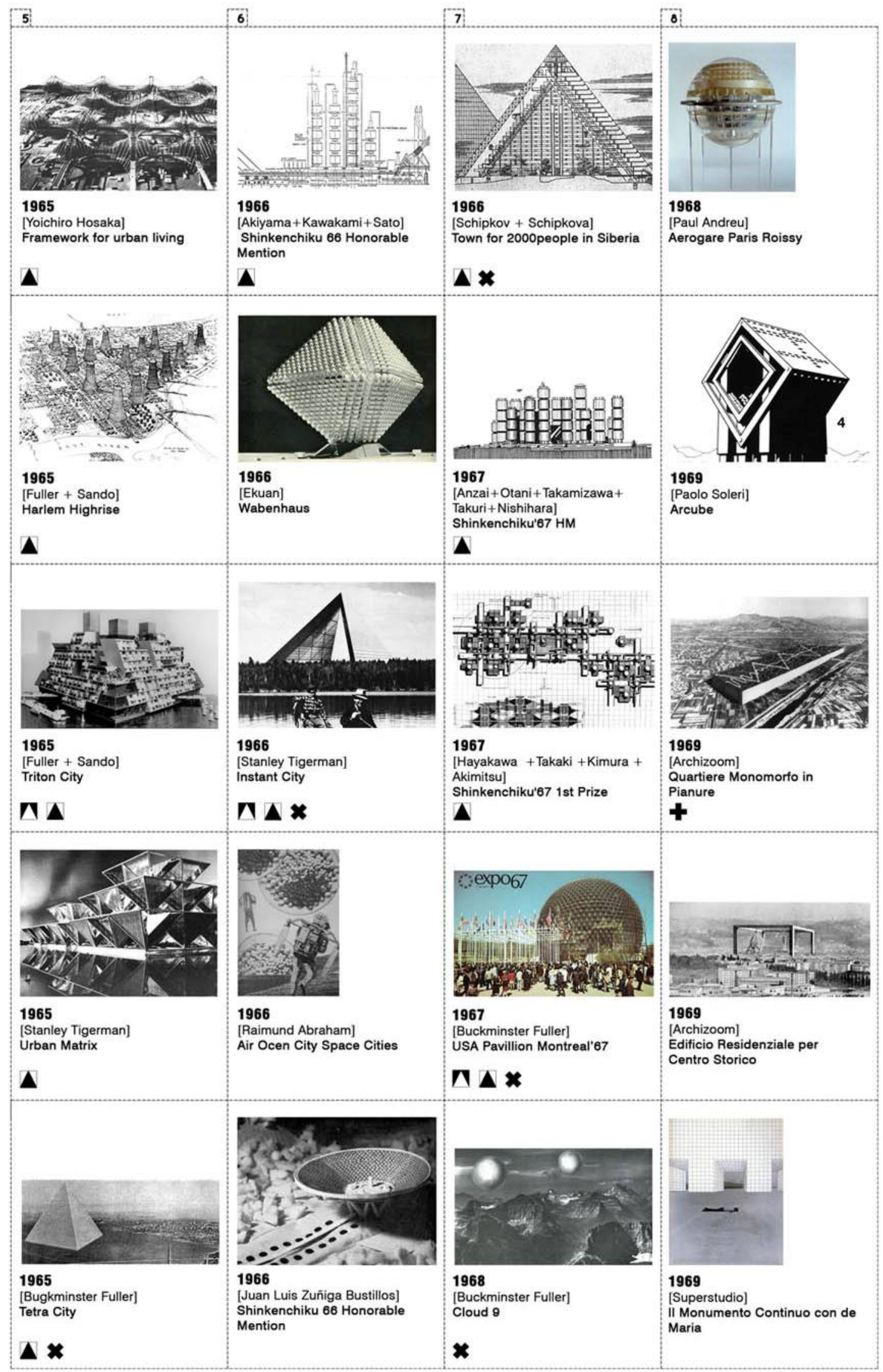




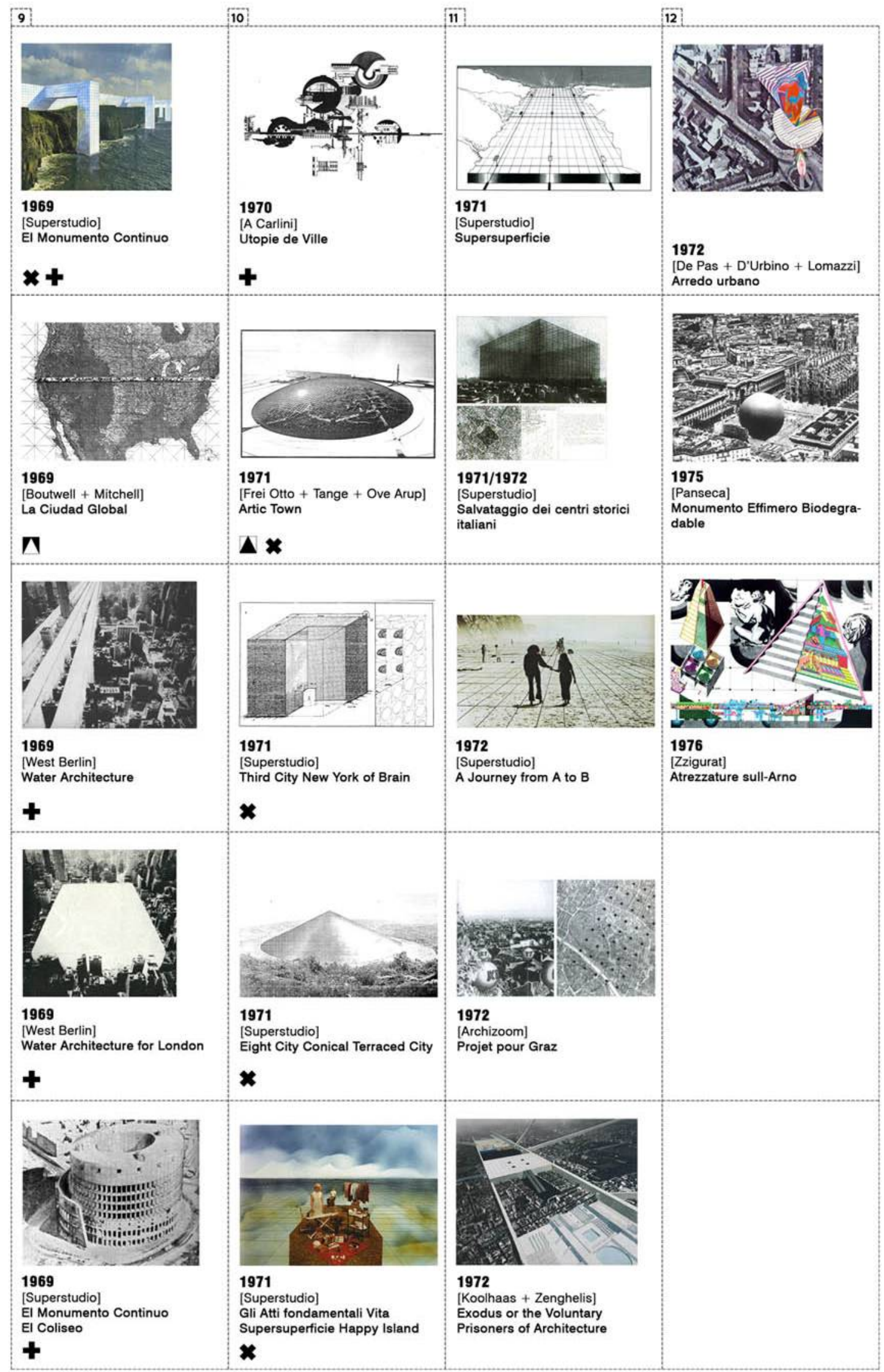




\section{[Monumentalismo geométrico] La geometría y el edificio-ciudad.}

El cambio de escala radical asociado a las megaestructuras, formalizadas como edificiosciudad, supone la proliferación de una gran variedad de proyectos concretos que redundan en ese monumentalismo geométrico, derivado de una confianza ciega en estructuras formales dependientes de geometrías puras euclidianas como son la esfera, el cilindro, la pirámide, los prismas regulares y las súper-superficies, como método proyectual para la búsqueda de ciudades "ideales" ejemplares.

\section{Esferas, cilindros, pirámides, prismas perfectos.}

La esfera ha sido históricamente relacionada con la perfección, la creación del mundo o las distintas representaciones del añorado cosmos a través de múltiples proyectos ideales. Algunos ejemplos paradigmáticos van desde la "Casa para un guardés" (1804) de Claude Nicolas Ledoux, el "Cenotafio de Newton" (1784) de Etienne Louis Boullée, la "Casa esférica" (1784) de Laurent Vaudoyer o el "Diseño para la Biblioteca Lenín" (1928) de J.L. Leonidov. Sin embargo no será hasta la popularización de la geometría geodésica por parte de Buckminster Fuller a finales de los años cuarenta ${ }^{200}$ y el auge de las construcciones neumáticas durante toda la década de los sesenta y principios de los setenta ${ }^{201}$, que esos proyectos son capaces de alcanzar el cambio de escala que la esfera como hipercontenedor universal perfecto requería. De esta manera la geometría esférica se convierte a partir del proyecto de Fuller "Dome over Manhattan" (1960-1962) [2E] en el protector climático perfecto dentro del cual es posible un nuevo tipo de ciudad más allá de las restricciones climáticas geográficas. La esfera adopta así no sólo un carácter efímero sino aéreo ${ }^{202}$, que transgrede la manera en que había sido representada en el pasado. Esas pesadas esferas monumentalizadas se transforman en ciudades aéreas como la "Cloud 9" (1962) [7E] de Buckminster Fuller o la "Air Ocean City" (1966) [6D] de la serie "Space Cities" de Raimund Abraham. A pesar del carácter teórico de muchas de esas propuestas, uno de los principales referentes será el "Pabellón de Estados Unidos" [7D] de la Exposición Universal de Montreal'67 diseñado por el propio Fuller, una cúpula geodésica de setenta y seis metros de diámetro y sesenta y uno de altura completando casi una esfera completa, que alberga un microclima en su interior, regulado por un sistema mecánico de aperturas y control de la iluminación, que contendrá incluso una de las paradas del monorraíl principal del recinto. La idea de un futuro asociado a la geometría geodésica convierte a la esfera en icono a partir de este edificio e incluso en uno de los modelos de futuro populares más paradigmático como es la comunidad EPCOT en Walt Disney ${ }^{203}$, en el que una de las

200 Derivada de sus experimentos con Kenneth Snelson en los workshops de la Black Mountain Collegue entre 1948 y 1949, la geometría de la cúpula geodéica fue patentada por el propio Fuller en 1954. U.S. patent 2,682,235.

201 Citaré dos volúmenes fundamentales para la comprensión de ese auge de las estructuras neumáticas:

DESSAUCE, Marc (editor). The Inflatable Moment. Pneumatic and Protest in '68. Princeton Architectural Press. Nueva York, 1999.

HERZOG, Thomas. Pneumatic Structures. A Handbook of Inflatable Architecture. Oxford University Press. New York, 1976

202 Dicha divergencia material y espiritual queda en evidencia en los proyectos de esferas presentado por Günther Feuerstein en su catálogo de arquitectura para el pabellón austríaco de la Biennale di Venezia de 1996.

FEUERSTEIN, Günther. Visionary Architecture in Austria in the Sixties and Seventies. Ritter Verlag, Klagenfurt. Viena, 1996. pp. 30-31. 
atracciones se incluye en el interior de una cúpula geodésica, esta vez totalmente opaca, de la que el propio Fuller fue incluso consultor. Con un desfase de casi quince años, la comunidad del futuro seguirá aún siendo formalizada como una esfera de grandes proporciones, a pesar de que la idea de ciudad interior y control ambiental fueran totalmente pervertidas en la misma. La esfera pierde a partir de mediados de los setenta su carácter utópico y su escala de edificio-ciudad para volver a un estado meramente monumental, como se verá reflejado en proyectos como el "Monumento Effimero Biodegradable" (1975) [12B] de Panseca, una esfera de treinta metros de diámetro que se va degradando hasta desaparecer en noventa días como icono representativo y efímero en una de las plazas más emblemáticas de Milán.

Otro volumen perfecto como el cilindro será la geometría utilizada por Kiyonori Kikutake para desarrollar los módulos de vivienda de su proyecto "Marine City" (1958-1960) [1B], uno de los primeros proyectos-manifiesto metabolistas. El cilindro presenta una clara asociación con el tubo, la tubería o el conducto, y por lo tanto con el movimiento de fluidos o personas, en esta idea de ciudad metabolista diseñada como un complejo organismo interconectado. El cilindro alberga así los sistemas encaminados al equipamiento y la flexibilidad habitacional a través de estrategias "Plug-in" derivadas del núcleo infraestructural ${ }^{204}$. La misma idea de soporte y comunicación relacionada con el cilindro es utilizada en ciudades lineales compactas como "Megabridge IV" (1964) [4A] de Raimund Abraham o "Vertical City" (1965) [4D] de Friedrich St. Florian, ya sea extendiéndose de manera horizontal por el territorio o como ciudad-hito vertical.

\begin{abstract}
"La formalidad del trabajo de los austríacos podría ser visto a menudo en términos de su geometría; en ella hay un uso constante de semi-círculos, tubos cilíndricos que tienden a reunirse en cruces complejos. Existe una tendencia a utilizar formaciones cilíndricas como medio de creación de grupos axiales o estructuras verticales, todos ellos formalizados como tubos. ${ }^{1205}$ (Peter Cook, 1970, pp.74-75)
\end{abstract}

\title{
El Monumento-ciudad.
}

Esa búsqueda, durante la década de los sesenta, de una ciudad ideal contemporánea se lleva a cabo a partir del desarrollo de una gran cantidad de proyectos de mega-ciudades fundamentadas en otros volúmenes geométricos como el tetraedro, la pirámide o el hiperboloide. La mayor parte de ellas se articula a partir de un perímetro de viviendas y un vacío interior de equipamientos públicos con clima propio controlado. Dicha tipología supone una variación del modelo fulleriano en el que la cúpula protectora es sustituida por una pared tapizante de viviendas con condiciones óptimas de soleamiento. Desde ejemplos metabolistas como "Wabenhaus" (1966) [6B] de Kenji Ekuan o "Tetra City" (1965) [5C] de Buckminster Fuller y Shoji Sadao, basados en la geometría del tetraedro, hasta "Intrapolis"

203 LANDAU, Royston. Mickey Mouse. The Great Dictator. The Disney game as a control system. En: AD The Architectural Design, Goes West, septiembre 1973. pp.591-595.

204 El cual desarrollaré en el caso aplicado de esta tesis. Su cambio de escala posibilita estructuras que actúan como facilitadores de viviendas entendidas como elementos temporales dentro de la propia ciudad.

205 "The formality of Austrian work is very often to be seen in terms of its geometry; there is a use of semi-circles, of cylindrical tubes which tend to meet at complex junctions. There is a tendency to use cylindrical formations as a means of creating axial groupings and to use cylindrical forms vertically as well as for the tubes."

COOK, Peter. Experimental Architecture. 1970. pp.74-74. 
(1960) [2D] de Walter Jonas, de desarrollo hiperbólico o "Neomastaba" (1960) [1D] diseñada por Akui y Nozawa como una pirámide de dimensiones descomunales. Todos estos proyectos son desautorizados por predicciones como la de Jencks ${ }^{206}$ como alternativas de futuro viables, debido a su carácter dependiente de sistemas de poder centralizados, los únicos que serían capaces de poder desarrollar intervenciones a esta escala monumental.

De manera casi simultánea, edificios como el "Vehicle Assembly Building" (1960-1966) [1E] de Cabo Cañaveral, el mayor espacio simple jamás construido por el hombre con un volumen de 424.752 metros cúbicos, alimenta entre los arquitectos el sueño de que los mega-edificios se convertirán en propuestas de futuro posibles. El "Vehicle Assembly Building" no sólo es referenciado en gran parte de las predicciones antes citadas ${ }^{207}$, sino que además representa el sueño de un "Monumento Contemporáneo" por su hiper-escala y carácter representativo-funcional de la conquista del espacio por parte del hombre. Este colosal edificio ilustrará también el manifiesto de Superstudio en torno a su idea del "Monumento Continuo" [9A], proyecto que desarrollan de 1969 a 1970, en el que exploran en torno a dicho manifiesto a través de imágenes utilizadas como objeto crítico arquitectónico.

"Para los que como nosotros estén convencidos de que la arquitectura es uno de los pocos medios para hacer visible en la tierra el orden cósmico, para poner orden entre las cosas y sobre todo para afirmar la capacidad humana de actuar según la razón, se puede considerar una utopía moderada sobre la hipótesis de un futuro próximo en el que toda la arquitectura sea producida por un único acto, a partir de un solo diseño, capaz de clarificar de una vez por toda los motivos que han llevado al hombre a levantar dólmenes, menhires, pirámides y a trazar ciudades cuadradas, circulares, estrelladas y a señalar con una línea blanca en el desierto.

La gran muralla china, el muro de Adriano, las autopistas; como los paralelos y los meridianos, son señales tangibles de nuestra comprensión de la tierra." ${ }^{1208}$ (Superstudio, 1969, p.44)

Superstudio parte de una radicalidad extrema a la hora de formalizar muchas de las ideas derivadas del monumentalismo geométrico; por una parte su aparente eficacia, que en el caso del "Monumento Continuo" se evidencia a través de una malla inexpresiva y homogénea que aparece como elemento primario constructor del todo; por otra, la

206 JENCKS. Charles. Arquitectura 2000. 1975 (1971). p.70.

207 Referencias textuales y visuales en las predicciones arquitectónicas del "Vehicle Assembly Building":

BANHAM, Reyner. Megaestructuras. 1978 (1976). p.7.

JENCKS. CHarles. Arquitectura 2000. 1975 (1971). pp.24-25.

COOK, Peter. Experimental Architecture, 1970. p.112.

COOK, Peter. Architecture: action and plan, 1967. p.61.

208 "Per chi come noi sia convinto che l'architettura è uno dei pochi mezzi per rendere visibile in terra l'ordine cosmic, per pore ordine tra le cose e sopratutto per affermare la capacità umana di agire secondo ragione, è "moderata utopia" ipotizzare un future prossimo in cui tutta la architettura sia prodotta da un unico atto, da un solo disegno capace di chiarire, una volta per tutte i motivi che hanno spinto l'uomo a innalzare dolmen, menhir, piramidi, e a tracciare città quadrate, circolari, stellar e infine a segnare (ultima ratio) una linea Bianca nel deserto.

La grande muraglia ciñese, il vallo d'Adriano, le autostrade, come i paralelli e i meridiani, sono i Segni tangibili della nostra comprensione della terra."

SUPERSTUDIO. Superstudio: discorsi per immagini. En: Domus, n481, diciembre 12/1969. p.44. 
radicalidad de un sistema que se extiende hasta el infinito en cualquier contexto imaginado. El "Monumento Continuo" representa el fracaso del cambio de escala de la mega-estructura, mientras la malla homogénea hace alusión a la idea de un estilo unificador promulgada por el movimiento moderno. La inclusión por parte del grupo florentino de imágenes de inútiles monumentos exclusivos en su "Discorsi per immaginni", imágenes que van desde la Meca hasta pirámides o acueductos, contrasta con el carácter versátil de su mega-edificio continuo, cuyo tejido principal es la vivienda, pero que podría albergar cualquier tipo de uso en su interior. El "Monumento Continuo" se reivindica mediante dos estrategias fundamentales; por una lado, mediante una sacralización del "hábitat" a través de la súperescala; por otro, a partir de esa citada capacidad para superponerse a cualquier tipo de situación paisajística por medio de su carácter homogéneo y monomorfo, desde ciudades existentes como Nueva York o Coke Town, a parajes naturales, como los desiertos de Arizona o las playas de Tropea. Desde esta perspectiva paisajística, el proyecto se emparenta con intervenciones "Land Art" de artistas como Christo, Robert Smithson o Walter de María, al cual dedican incluso una de sus imágenes del proyecto, "Il Monumento Continuo con De María" [8E], como homenaje.

Ese monomorfismo monumental destilado por el "Monumento Continuo" es utilizado de manera simultánea por otro grupo de arquitectos florentinos, Archizoom, en varios diseños publicados en el mismo número de la revista italiana Domus de $1969^{209}$. A través de varios proyectos, "Quartieri paralelli per Berlino", "Be/vedere" o "Quartiere Monomorfo in Pianure" [8C], los miembros de Archizoom expresan la misma monumentalidad que Superstudio como alternativa distópica de futuro que apresura lo que ellos denominan como "Utopia della quantitá", regida por el número y la amplitud de espacio democrático frente a aquella ilusionista y fantástica "Utopia della qualitá". La idea de superponer un edificio de viviendas gigante que enmarque a la catedral de Santa María dei Fiori de Florencia expresa de nuevo esa idea de des-monumentalización de los iconos históricos con nuevos monumentos habitables. De manera análoga opera el proyecto "Salvataggio di centri storici italiani"210 (1971-72) [11B] de Superstudio. Mediante el mismo, los florentinos construyen imágenes de salvación para distintos centros históricos italianos amenazados; motorizando Venecia a partir de la sustitución de los canales por calles de circulación rodada, presentando una Milán cubierta por una super-estructura que compense su mala climatología, equilibrando en Pisa que todos los otros monumentos se inclinen para corregir la desviación de su torre más famosa o inundando completamente Florencia para salvarla de futuras riadas como la acontecida en 1966.

De nuevo Superstudio realizarán en su ensayo distópico de 1971 "Twe/ve Ideal Cities"211, una caricatura del entusiasmo por la gran escala del edificio-ciudad de las décadas de los cincuenta y sesenta a través de doce ciudades ideales temáticas ${ }^{212}$. "2000-ton city" superpone una trama ortogonal perfecta a porciones de terreno virgen sometidos de esta

209 ARCHIZOOM. Archizoom: discorsi per immagini. En: Domus, n481, diciembre 12/1969. pp.46-47.

En el mismo número de Domus vuleve a aparecer publicado el "Monumento Continuo" de Superstudio como parte de la muestra Tringon'69 celebrada en Graz durante octubre de 1969.

SUPERSTUDIO. Lettera da Graz. Tringon'69. Una mostra sul tema: architettura e Libertá. En: Domus, n481, diciembre 12/1969. pp.49-54.

210 SUPERSTUDIO. Salvataggio di centri storici italiani. En: IN, n5, mayo-junio 1972.

211 SUPERSTUDIO. Twelve Cautionary Tales for Christmas. En: AD The Architectural Design, diciembre 1971. pp.737-742.

212 Una tematización de la ciudad que supone una de las alternativas de futuro propuesta por John McHale:

MCHALE, John. The Future of the Future. 1969. pp.291-293. 
manera a su geometría. "Temporal Cochlea City" se construye a través de un sistema cilíndrico enterrado que con su propio giro va solventando el crecimiento de la ciudad. "New York of Brains" [10C] aparece como un gran cubo contenedor de cerebros. "City of the Hemispheres" diseñada como un extenso cementerio generado a partir de una gran superficie reflectante camuflada en el paisaje. "Conical Terraced City" [10D] continua la tradición de la diagonal en el espacio y las viviendas aterrazadas de las megaestructuras. "City of the book", de diez kilómetros de longitud, emula las continuas ciudades lineales proyectadas a partir de la funcionalidad de la cadena de montaje.

"Superstudio evoca doce visiones de ciudades ideales, el supremo logro de veinte mil años de civilización, sangre, sudor y lágrimas; el refugio último del hombre en posesión de la verdad; libre de contradicción, ambigüedad e indecisión; totalmente y para siempre repleto de su propia PERFECCIÓN."1213 (Superstudio, 1971, p.737)

Ese ya denostado Monumentalismo Geométrico vuelve a ser hibridado con la escala megaestructural en proyectos utópico-festivos como "Arredo Urbano" [12A] de De Pas, D'Urbino y Lomazzi o "Atrezzature sull'Arno" [12C] de Zzigurat, ambas propuestas del concurso ADI/1973 convocado por la revista Casabella ${ }^{214}$. En el mismo participa también la propuesta de Rem Koolhaas, Elia y Zoe Zenghelis y Madelon Vriesendorp, "Exodus, or the voluntary prisoners of Architecture ${ }^{1215}$ [11E], proyecto-manifiesto en el que el monumentalismo geométrico también se utiliza como crítica directa a la gran divergencia entre el ensimismamiento utópico de finales de los cincuenta y primeros sesenta y la realidad urbana contemporánea.

213 "Superstudio evoke twelve visions of ideal cities, the supreme achievement of twenty thousand years of civilization, blood, sweat and tears; the final haven of Man in possession of Truth, free from contradiction, equivocation and indecision; totally and forever replete with his own PERFECTION"

SUPERSTUDIO. Twe/ve Cautionary Tales for Christmas. 1971. p.737.

214 Una buena reseña de los proyectos presentados al concurso puede verse en:

RAGGI, Franco. Proposte al Concorso ADI/Casabella. La Cittá come ambiente significante. En: Casabella, n³83, noviembre 1973. pp.17-35.

Ambas propuestas serán también referenciadas en la revista Domus:

Arredo Urbano. Temporaneo Alternativo Festoso. En: Domus, n523, junio 06/1973. p.1.

ZZIGURAT. Attrezzature Sull'Arno. En: Domus, n554, enero 01/1976. pp.6-9.

215 El proyecto será portada de la revista Casabella de junio de 1973. Ver:

Casabella, n³78, junio 1973. portada. 


\section{Catálogo // [Ciudades tecno-mórficas]}

Las imágenes están referenciadas por números en la zona superior de las columnas verticales [del 1 al 11] y letras en la zona izquierda de las filas horizontales [de la A a la E].

Todas las referencias están ordenadas cronológicamente.

Referencias de imágenes del [1B] a [11B]. Cada uno de los proyectos referenciados gráficamente en el catálogo presentan antes de su nombre un código con un número en relación a su columna vertical y una letra en relación a su fila horizontal.

\section{Ejemplo:}

[7E] "Cloud 9" (1962) de Buckminster Fuller. Buscar referencia en la columna 7 y la fila E del catálogo referenciado al principio del capítulo.

[Nota]: no todos los referentes gráfico del catálogo están referenciados en el texto por lo que se recomienda una lectura del mismo antes de comenzar la del propio texto.
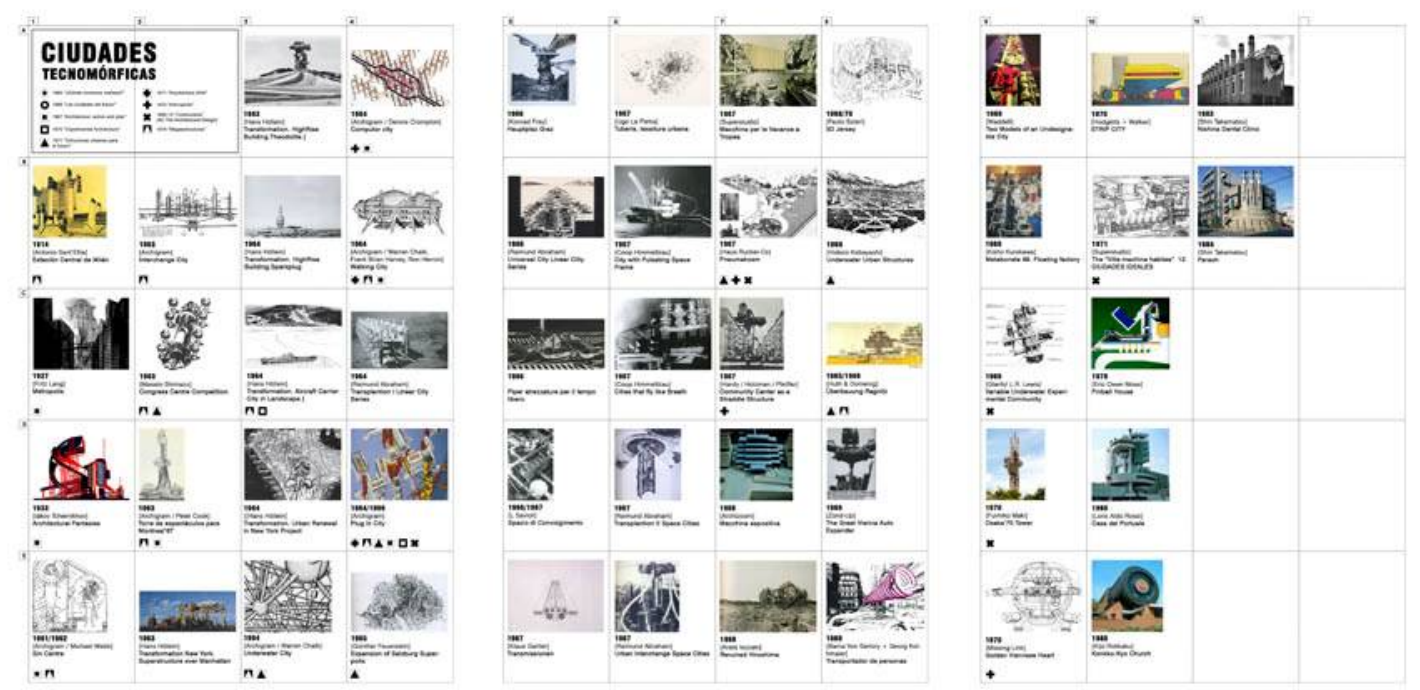


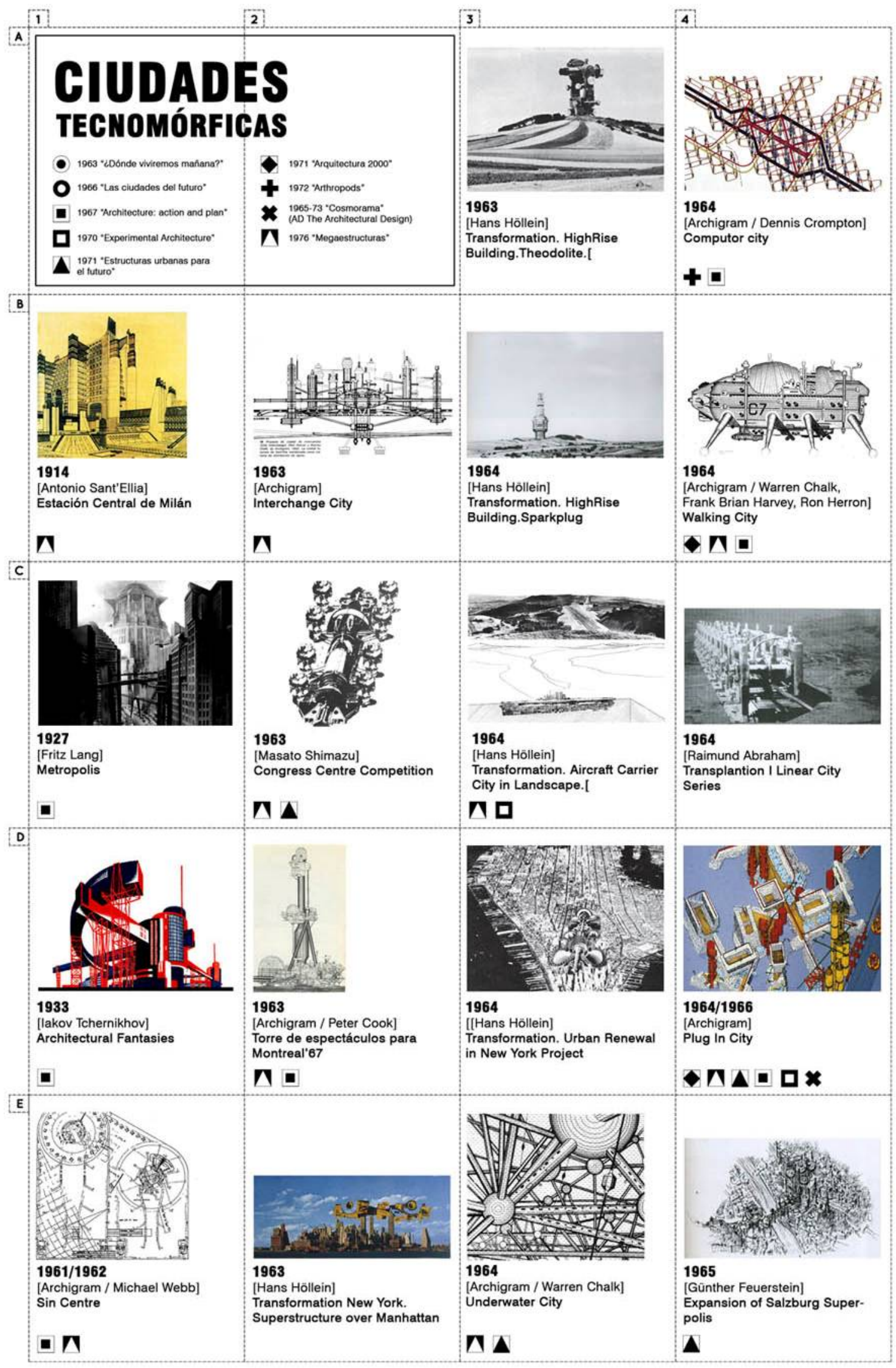




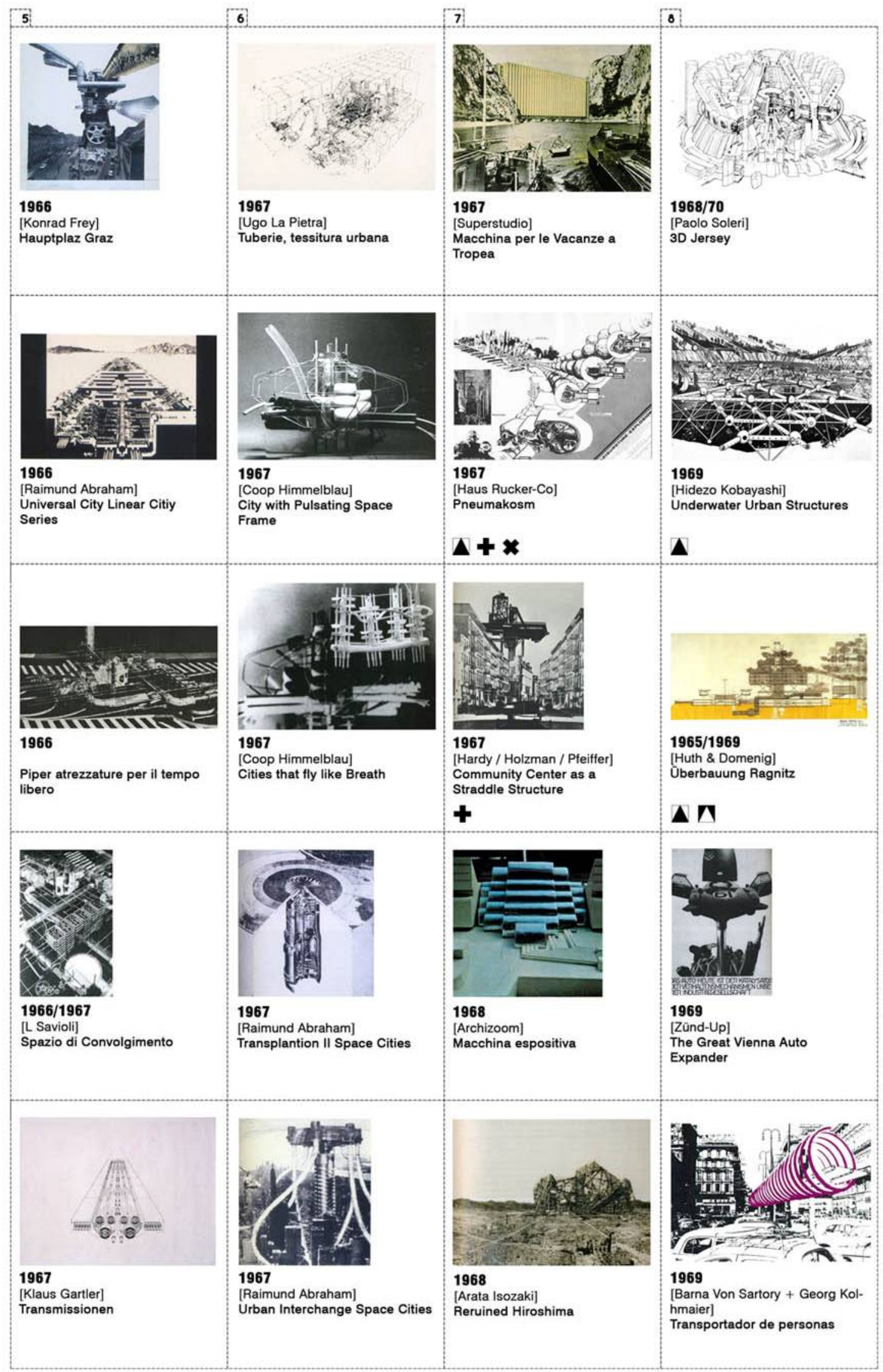




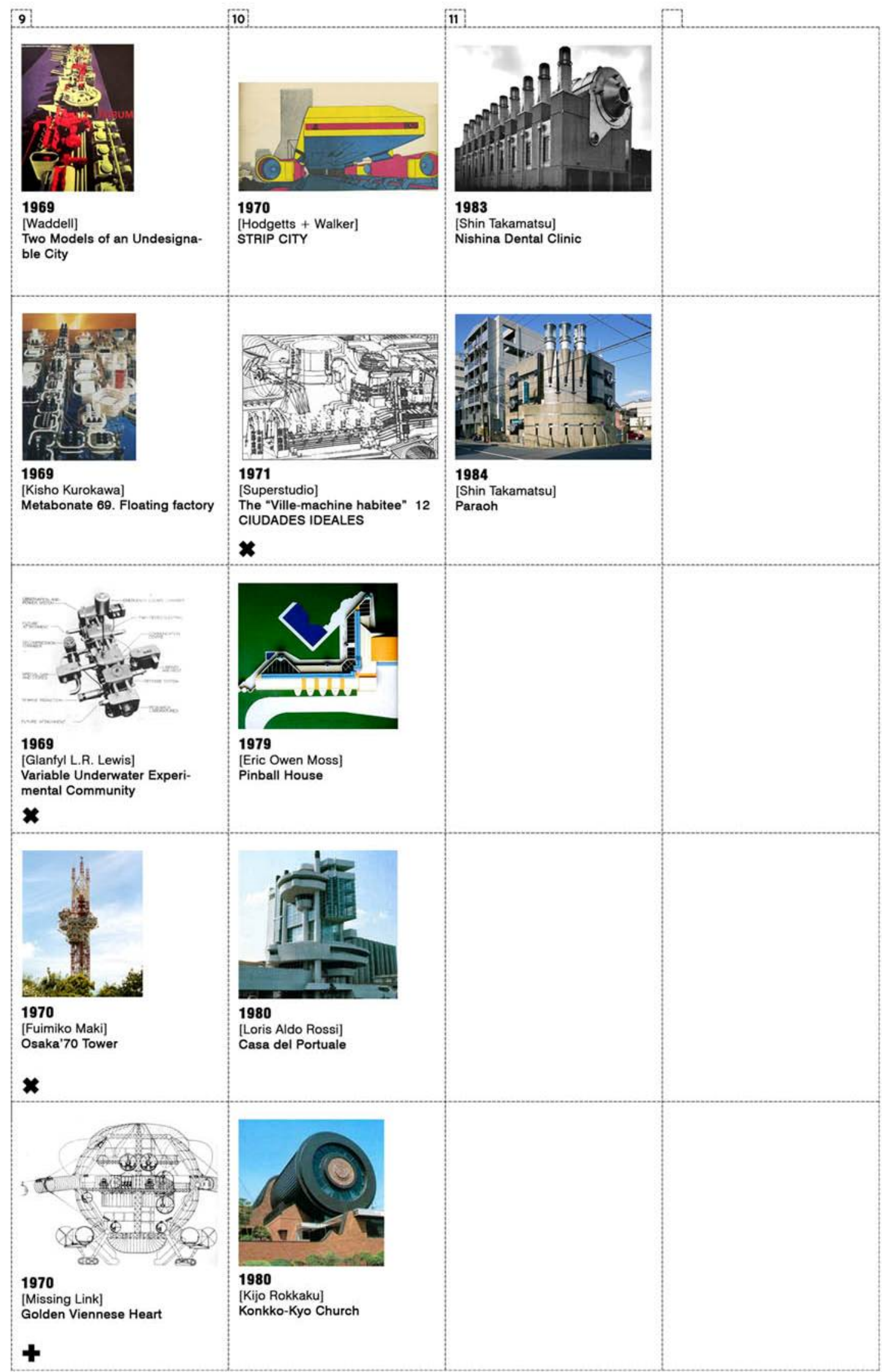




\section{[Ciudades tecno-mórficas]}

\section{Relaciones formales entre máquina y ciudad.}

La seducción de los arquitectos por la tecnología formalizada como máquina es sin duda uno de los grandes temas de debate arquitectónico suscitados a partir de la primera revolución industrial, y sobre todo después de la I Guerra Mundial y el acelerado progreso tecnológico surgido tras la misma. Desde el idilio de Le Corbusier con los automóviles, transatlánticos o silos en "Hacia una arquitectura"216 (1930), las "Architectural Fantasies" (1925-1933) de lakov Chernikhov y sus estudios de juntas de construcción y ritmos de movimiento de diversos motores, máquinas y arquitecturas como si de una misma cosa se tratara en "Construction of architectural and machine forms"217 (1931), hasta la "Citté Industrielle" (1917) de Tony Garnier o la monumentalización de la fábrica de turbinas AEG (1909) de Peter Behrens. Reyner Banham explica cómo esa adopción de la tecnología formalizada como máquina es convertida por el movimiento moderno en un estilo más, una arquitectura como símbolo del progreso más que como artífice del mismo:

"Los arquitectos del Estilo Internacional han producido una arquitectura de la era de la máquina sólo en el sentido de que esos monumentos fueron construidos en una era de la máquina."218 (Banham, 1960, p.329)

"En muchos aspectos, la arquitectura del Movimiento Moderno también puede ser vista como un género de edificios que eran el legado del siglo XIX más que como una precursora del primer siglo XX. Su arquitectura representa una visión idealizada y revolucionaria de la era de la máquina, aunque en realidad se basó principalmente en la apariencia en lugar de la tecnología para la creación de su imagen. A pesar de que hay muchos hermosos edificios que fueron construidos por arquitectos del Movimiento Moderno, se puede argumentar que un individuo capacitado puede producir objetos maravillosos en cualquier estilo, y que el Modernismo fue sólo eso, un estilo como el que exhiben muchos edificios de estilo neoclásico y neogótico que se erigían al mismo tiempo."1219 (Banham, 1960, p.327)

Una de las primeras idealizaciones de las seductoras cualidades de la tecnología de la máquina proviene de teóricos futuristas como Filippo Tomaso Marinetti y su "Manifiesto Futurista" de 1909 y el arquitecto Antonio Sant'Elia, que ya en 1914 escribe sobre la

216 LE CORBUSIER. Vers une architecture, L'Esprit Nouveau. París, 1930.

217 CHERNIKHOV, lakov. Construction of architectural and machine forms (1931). En: AD The Architectural Design Profile, Chernikhov: Fantasy and Construction, Volume 54, 9/10-1984. pp.41-88.

218 "The International Style architects have produced a Machine Age Architecture only in the sense that its monuments were built in a Machine Age"

BANHAM, Reyner. Theory and Design in the First Machine Age. Architectural Press. Londres, 1960. p.329.

219 "In many ways Modern Movement architecture can also be seen as a genre of buildings that were legacy of the nineteenth century rather than a precursor of the twenty first. Its architecture represented an idealized, revolutionary view of the machine age, though in reality it relied primarily on appearance rather than technology for the creation of its image. Though there are many beautiful buildings that were built by Modern Movement architects, it can be argued that gifted individual will produce wonderful objects in any style, and that Modernism was just that, a style like that exhibited by the many Neoclassical and neo-Gothic buildings that were also erected at the same time"

BANHAM, Reyner. Theory and Design in the First Machine Age. 1960, p.327. 
necesidad de diseñar edificios como máquinas, de la misma manera que él mismo había hecho con su "Cittá Futurista":

"Debemos inventar y reconstruir ex-novo nuestra ciudad moderna como un inmenso y tumultuoso astillero, activo, móvil y dinámico en todas sus partes, y el edificio moderno como una máquina gigantesca. ${ }^{1120}$ (Sant'Elia, 1914, p.87)

Ya en la década de los sesenta, esa capacidad de evocación formal de la tecnología es utilizada por Hans Höllein en su catálogo de ciudades compactas diseñadas junto a Walter Pichler, formalizadas a partir de cambios de escala de objetos mecánicos para la exposición "Architektur"221 (1963) y su artículo para BAU "Zukunft der Architektur"222 (1965), en el que plantea un futuro a partir del entendimiento de que arquitectura significa ciudad y cómo ésta debe ser un reflejo de los avances tecnológicos contemporáneos:

"La forma de los edificios cambiará. Los descubrimientos tecnológicos de nuestro siglo serán utilizados."223 (Höllein, 1965, p.11)

Höllein ilustra su artículo con ejemplos de ciudades tridimensionales con evidencias tecnomórficas, tanto de sus antecesores, las anteriormente citadas "Architectural Fantasies" [1D] de Chernikhov entre otras, como de contemporáneos suyos, como la "Walking City" (1964) [4B] de Ron Herron y Bryan Harvey de Archigram. También incluye fotografías de estaciones petrolíferas, convertidas en icono de lo que debería ser una ciudad por parte de muchos de los arquitectos asociados al tecno-morfismo 224 . En el artículo aparece por primera vez publicada una de las versiones de su serie de fotomontajes "Aircraft Carrier City in Landscape" [3C] (1963-1964), en el que la torre de control de un portaviones varado en medio del desierto se convierte en paradigma de las ciudades autónomas de estética maquinista ${ }^{225}$. Esos collages de Höllein en relación al portaaviones son también referenciadas en varias de las predicciones arquitectónicas antes citadas. El potencial de

220 "We must invent and rebuild ex novo our modern city like an immense and tumultuous shipyard, active, mobile and everywhere dynamic, and the modern building like a gigantic machine"

SANT'ELIA, Antonio. Nuove Tendenze Goup Messaggio in 1914. En: FRAMPTON, Kenneth. Historia crítica de la arquitectura moderna. Gustavo Gili. Barcelona, 1998 (1980). p.87.

221 "Höllein. Pichler. Architektur", exposición en la galería St.Stephan, del 8 al 12 de mayo de 1963.

222 HÖLLEIN, Hans. Zukunft der Architektur. En: Bau, Heft 1, 1965. pp. 8-11.

223 "The shape of buildings will change.

The technological achievements of our century will be utilized"

HÖLLEIN, Hans. Zukunft der Architektur. En: Bau, Heft 1, 1965. p.11.

224 La propuesta de torre diseñada por Peter Cook para la Exposición Universal de Montreal'67 supone sin duda alguna uno de los ejemplos más evidentes del paralelismo entre plataforma petrolífera y edificio.

225 Banham también explicará la influencia anterior del transatlántico en alguna de las más célebres megaestructuras construidas:

"En ambos casos, la silueta que aflora en la superficie es a todas luces la que inspiró a los megaestructuralistas. Aunque por las fechas sea imposible que estos collages influyeran sobre el proyecto del Cumbernauld Town Centre (no fueron expuestos hasta 1964, cuando Cumbernauld ya estaba en construcción), el proyectista, Geoffrey Copcutt, empleó reiteradamente la analogía del portaaviones para caracterizar las intenciones de su proyecto."

BANHAM, Reyner. Megaestructuras. 1978 (1976). p.21. 
esas imágenes es tal que los autores de las mismas exaltan esta capacidad a la vez semántica e ideológica que supone la estampa del portaaviones:

"La imagen del portaaviones posado sobre la colina es muy convincente. Sugiere que el portaaviones es una ciudad que contiene una estructura coherente, sugiere que lo último en tecnología podría posarse por sí mismo sobre la tierra, sugiere la ironía de un conglomerado ridículo de funciones humanas sobre un punto en una colina como una roca, sugiere que siempre habrá una paradoja entre los objetos hechos por el hombre y el resto, o puede ser visto como una mezcla de todos ellos."1226 (Peter Cook, 1970, pp.72-73)

El valor conceptual de esta superposición de Höllein, estrategia que vuelve a utilizar de manera recurrente, como ocurre con un teodolito en "Highrise Building Theodolite" (1963) [3A] o una bujía en "HighRise Building.Sparkplug" (1964) [3B], reside en dos características esenciales: por una parte, esa contextualización en un paisaje desértico convierte a la torre de control y a todo el portaaviones en una ciudad monumental habitada, por otra, la vuelta a un carácter simbólico de la máquina, que había ya seducido a infinidad de arquitectos con anterioridad. Años antes Le Corbusier diseñaba la "Unité d'habitation" como si de un paquebote se tratase. En el mismo contexto temporal que Höllein, el italiano Paolo Soleri utiliza la idea del portaaviones para asociarla a la búsqueda de compacidad en sus "Arcologías":

"Tres características esenciales no son comunes: estructural y funcionalmente, el transatlántico está diseñado para moverse por un fluido; el transatlántico es el continente de un conjunto transitorio de personas sin relación mutua; el transatlántico es un cuerpo hermético que sólo se relaciona con el exterior mediante informaciones sintéticas. Fuera de estas tres tiranías, el transatlántico, su concepto, puede desarrollarse y, manteniendo su flexibilidad organizativa, convertirse en una verdadera máquina para vivir en ella."227 (Paolo Soleri, 1969, p.14)

\section{Máquinas urbanas. La máquina superpuesta a la ciudad existente}

Otros proyectos de transformación, diseñados por el propio Höllein a través del cambio de escala de objetos maquinistas, se apoyan en la misma superposición de estos objetos a un contexto existente conocido, renovándolo mediante la inserción de una nueva estructura urbana tecnomórfica. De esta manera operan proyectos como "Transformation New York. Superstructure over Manhattan" (1963) [2E], con partes de una máquina Carterpillar uniendo varios edificios de Manhattan como si de una megaestructura parásita se tratase, y sobre todo "Urban Renewal in New York Project" (1964) [3D], en el que el interior de una máquina compleja ${ }^{228}$, se superpone a una vista aérea de Nueva York, muy parecida a la que Fuller

\footnotetext{
226 "The image of the aircraft carrier sitting upon the hill is very compelling. It suggests that either the aircraft carrier is a city within a coherent structure; or it suggest that the ultimate in technology could poise itself on the land; or it suggest the irony of a ridiculous conglomeration of human function sitting at a point on a hill, like a rock; or it suggest that there will always be a paradox between the involved man-made thing and the rest; or it can be seen as some mixture of all these"
}

COOK, Peter. Experimental Architecture, 1970. pp.72-73.

227 SOLERI, Paolo: Arcology. The City in the image of man. The MIT Press. Boston,1969. p.14.

228 Publicada anteriormente sin contexto en BAU: HÖLLEIN, Hans. Technik. En: Bau, Heft 2, 1965. p.54. 
había usado como contexto para su "Dome over Manhattan" unos años antes. Los proyectos de ciudades tecnomórficas presentan de esta manera una doble condición: poder constituirse por sí mismas en una ciudad compacta altamente especializada o superponerse al tejido existente convirtiéndose en "Máquinas Urbanas" al servicio de la ya obsoleta ciudad, concepto que aparece en "Estructuras Urbanas para el Futuro" (1972) de Justus Dahinden:

\begin{abstract}
"Debido a esta insistencia en la tecnología; el equipamiento técnico, que siempre ha jugado un papel secundario en el diseño de la arquitectura tradicional, se ha convertido en un elemento estructural en sí mismo. Como resultado de este nuevo desarrollo, los componentes y mecanismos son ahora una característica importante de las estructuras urbanas que están plenamente justificadas al hablar de máquinas urbanas." ${ }^{1229}$ (Justus Dahinden, 1971, p.22)
\end{abstract}

El poder de la máquina de ser capaz de renovar fácilmente cada uno de los componentes de un edificio o ciudad, es literalmente incorporado a la arquitectura bajo los términos anglosajones "Plug-in" y "Clip-on", conceptos acuñados en 1961 por Llewelyn Davies ${ }^{230}$, no sólo como capacidades dentro de una estructura ya prefijada, llámese megaestructura, sino como un nuevo sistema de relaciones entre lo nuevo y lo existente.

"El epítome de la arquitectura Clip-on en el momento (1961) fue el motor fuera de borda, cuyas consecuencias para la teoría del diseño nos intrigó a muchos en ese momento expresadas en los siguientes términos: con un motor Evinrude o Johnson Seahorse se puede convertir prácticamente cualquier objeto flotante en un buque navegable. Un pequeño paquete concentrado de maquinaria convierte una estructura indiferenciada en algo que tenga función y utilidad."231 (Banham, 1965, p.534)

Esa capacidad que Banham, suscribiendo las palabras de Llewelyn Davies, otorga a pequeños paquetes de tecnología, es aplicada literalmente por un gran número de arquitectos para sus propuestas de renovación urbana. En Austria, bajo la influencia de los proyectos de transposiciones tecnológicas de Höllein y su publicación sistemática en la revista $B A U^{232}$, empiezan a aparecer un gran número de estos proyectos urbanos. En 1965 ,

229 "Because of this insistence on technology, technical equipment, which has always played a subsidiary part in traditional architectural design, has become a structural element in its own right. As a result of this new development, components and mechanisms are now such an important feature of urban structures that we are fully justified in speaking of urban machines"

DAHINDEN, Justus. Urban Structures for the Future. 1972 (1971). p.22

230 Es interesante comprobar la influencia que Reyner Banham y Llewelyn Davies en la enseñanza de arquitectura en las décadas de los cincuenta y sesenta, que será explícitamente declarada por autores como Peter Cook, Chris Abel, Mark Fisher o Chris Dawson.

CRINSON, Mark; LUBBOCK, Jules. Architecture. Art or profession? Three Hundred Years of Architectural Education in Britain. Manchester University Press. Manchester, 1994. pp. 157-179.

231 "The epitome of the clip-on at the time (1961) was the outboard motor, whose consequences for the theory of design intrigued many of us at the time, in the following terms: given an Evinrude or a Johnson Seahorse, you can convert practically any floating object into a navigable vessel. A small concentrate package of machinery converts an un-differentiated structure into something having function and purpose"

BANHAM, Reyner. A clip-on Architecture. En: AD The Architectural Design, noviembre 1965. p.534.

232 La revista BAU dará total cobertura no sólo a los proyectos de ciudades tecnomórficas de Höllein sino a todas las propuestas contemporáneas de arquitectos afines a él, especialmente en dos números simultáneos de 1969.

Bau, Heft 2/3, Wien, 1969. 
Günther Feuerstein proyecta "Superpolis" [4E] como expansión de Salzburgo, un conjunto de evidente tecno-morfismo que fagocita a la ciudad histórica a la que contrapone su estética maquinista. "Superpolis" formará parte junto a otros ejemplos de ciudades visionarias de arquitectos austríacos, basadas todas ellas en estrategias derivadas del tecno-morfismo y la ciudad-escultura, de la exposición comisariada en Viena por el propio Feuerstein en 1967 denominada como "Urban Fictions", con gran proyección internacional a través de diversas publicaciones ${ }^{233}$. Otra de esas propuestas, el proyecto "Hauptplaz Graz" (1966) [5A] de Konrad Frey, imagina un sistema de comunicaciones para la ciudad de Graz mediante un fotomontaje en el que combina sistemas de poleas gigantes, imágenes del monorraíl como medio del futuro o salas de máquinas de turbinas, componiendo así un sistema de superposición que de nuevo sirve para equipar a la obsoleta ciudad. El también austríaco Raimund Abraham, simula un gran intercambiador de transportes sobre la ciudad de Nueva York, con la yuxtaposición de imágenes de sistemas de presión neumáticos, un cuerpo central basado en un pistón comercial y una serie de tubos comunicadores que van invadiendo la ciudad en su "Urban Interchange" (1967) [6E] de la serie "Space Cities". Para la misma ciudad, Abraham realiza una serie de suplantaciones a partir de su "Universal City" (1966) [5B], trama maquinista perteneciente a la serie de "Linear Cities", que invade una franja de Nueva York de largo variable y del mismo ancho que Central Park. Todas estas evocaciones, que aparecen simplemente como meras superposiciones, son evolucionadas por proyectos posteriores como "Pneumakosm" (1967) [7B] de Haus Rucker-Co, una superestructura de nuevo para la ciudad de la Gran Manzana ${ }^{234}$, formada por un sistema de viviendas con forma de bombilla, aprovechando el valor semántico de intercambiabilidad y fácil reposición de la misma, que emulan una gran máquina luminosa y que trabajan con el cambio de escala del "Plug-In" hacia estructuras más flexibles que las antes presentadas, aunque basadas en la misma reproducción tecno-mórfica.

La misma inserción en la ciudad existente le sirve al grupo Zünd-up ${ }^{235}$, para generar una mega-estructura sobre Viena, "The Great Vienna Auto-expander" [6D] que en 1969 se sitúa como proyecto crítico en torno al omnipotente modelo de ciudad dominada por el automóvil. A través del analogismo con una gigantesca máquina de "pinball", muy popular en las décadas de los sesenta y setenta y gran icono pop norteamericano, generan una estructura de ocio para un uso hedonista del automóvil en el centro de la ciudad histórica. Desde lavados aromáticos para el coche hasta simuladores de conducción tienen cabida en un proyecto distópico que aprovecha semánticamente el cambio de escala del popular juego para construir una mega-estructura autocrítica sobre el poder funcional y psicológico que el automóvil ejerce sobre la sociedad ${ }^{236}$ :

"Las agresiones urbanas habitan en la forma fatal del tráfico, un problema que será analizado y juzgado en nuestro Auto-Expander. El coche, hoy en día, es el catalizador de los mecanismos de comportamiento de nuestra sociedad industrializada." ${ }^{237}$ (Zünd-up, 1969 (2010), p.84)

Bau, Heft 4/5, Graz, 1969

233 Urban Fiction. An Architectural Exhibition in Vienna. En: Domus, n²449, abril 04/1967. pp.4-5.

234 La relación entre Austría y USA será muy estrecha ya que arquitectos como Raimund Abraham o Friedrich St.Florian fijarán allí su residencia, colaborando como profesores en varias universidades. Otros como Hans Höllein o algunos miembros de Haus-Rucker-Co pasarán grandes temporadas colaborando también con universidades o instituciones culturales mediante el sistema de becas artísticas norteamericano.

235 Grupo austríaco formado por Timo Huber, Bertram J. Mayer, Michael Pühringer y Herman Simböck.

236 El proyecto supone un ejercicio de curso propuesto por Karl Shwanzer a sus estudiantes de la Technische Hochschule de Viena, para la construcción de un garaje cercano a la Karlplatz. 
Dentro de este recorrido en torno al concepto de "máquinas urbanas", el proyecto "Re-ruined Hisroshima" [7E] presentado por Arata Isozaki en su instalación "Electric Labyrinth" en la XIV Triennale de Milán de 1968, también se presenta como una situación urbana distópica. En él aparecen unas mega-estructuras tecno-mórficas semiderruidas, superpuestas a las ruinas reales de una Hiroshima devastada por uno de los avances tecnológicos de la II Guerra Mundial como será la bomba atómica, tecnología también generadora de modelos de ciudad derivados del miedo a una respuesta similar hacia los Estados Unidos, ejemplificada en proyectos como la "Atomville" (1950) de Paul Laszlo, o la "Undergound City" (1969) de Oscar Newman ${ }^{238}$.

\section{Iconografía maquinista. De la tubería y el motor a los circuitos eléctricos.}

El imaginario maquinista se presenta como una gran fuente de referencias formales que pueden ser transferidas al objeto arquitectónico, de la misma manera que nutre a otras artes visuale $^{239}$. El motor, en cualquiera de sus variaciones, se convierte en uno de los principales objetos de esta seducción maquinista debido no sólo a su perfeccionamiento estético a partir del depurado industrial continuo, preconizado por Le Corbusier en su fascinación por la máquina, sino a su construcción a partir de elementos claramente diferenciados pero con un funcionamiento global solidario, durante mucho tiempo convertido en paradigma de lo que cualquier ciudad podría requerir para un óptimo funcionamiento. De esta manera, proyectos como el "Centro de Congresos en Viena" (1963) [2C], del japonés Masato Shimazu, o "Transplation I, Linear Cities" (1964) [4C] y "Transplation II, Space Cities" (1967) [6D] del austríaco Raimund Abraham, generan visiones futurísticas de maquinas reales con su escala aumentada, convertidas en ciudades compactas. Pistones convertidos en rascacielos interconectados o cilindros como núcleos de comunicación, reivindicando la posibilidad de un funcionamiento perfecto de la ciudad, de un tamaño concreto y controlable, de una compacidad que libere grandes cantidades de terreno. Es interesante comprobar las relaciones que se establecieron entre estos proyectos a través de las publicaciones periódicas arquitectónicas, que sirvieron de herramienta de difusión de estas ciudades tecnomórficas. Una conexión que se evidencia en paralelismos como la utilización que Raimund Abraham hace en su propuesta "Transplation I" de 1964, de un máquina antes publicada en un anuncio de ventanas del famoso número 102 de "L'Architecture d'aujourd'hui" de $1962^{240}$, titulado "Arquitectures Fantastiques", incluyendo gran parte de los ejemplos del famoso libro de Conrads y Sperlich.

Esta seducción por el funcionamiento formal de la máquina es también el punto de partida de experimentaciones docentes como las del arquitecto italiano Leonardo Savioli a mediados de los años sesenta en su curso de proyectos de la Universidad de Florencia.

237 PORSCH, Johannes; ARCHITEKTURSENTRUM WIEN (editores). The Austrian Phenomenon: Architecture Avantgarde Austria 1956-1973. Birkhäuser Boston INC. Boston, 2005. p.84.

238 Ambos proyectos están referenciados en:

SKY, Alison; STONE, Michelle. Unbuilt America: forgotten architecture in the United States from Thomas Jefferson to the space age : a book. McGraw-Hill. Chicago, 1976.

239 COOK, Peter. The Mechanistic Image. En: AD The Architectural Design, junio 1967. p.288.

240 AA L'Architecture d'Aujourd'Hui, n¹02, Architectures Fantastiques, junio-julio 1962. p.LXXXIV. 
Destacará de entre esas prácticas el ejercicio de diseño de espacios urbanos de participación, "Spazio di Coinvolgimento" [5D] de 1967. En palabras de su por entonces asistente, Adolfo Natalini, uno de los fundadores de Superstudio:

\begin{abstract}
"Durante el curso, se han identificado los diversos métodos de composición que la arquitectura puede tomar prestados de las artes visuales (Arte ambiental, Pop art y Op Art): el problema era utilizarlos de manera creativa, y no solamente irónica o desmitificadora. Distorsión, transposición de escala, combinación, montaje, descomposición, repetición e iteración, contaminación, son términos que utilizamos constantemente, y sobre todo, eran situaciones o estímulos nuevos que daban a la arte de proyectar la activación necesaria para pasar del material de estudio o la rutina profesional a las acciones creativas y activas... Introdujimos una nueva óptica y la mediación del mundo pasaba por la mediación de la máquina... el proceso Pop en arquitectura actúa de esta manera, aumentando el repertorio formal existente."241 (Adolfo Natalini, 1968, p.34)
\end{abstract}

Leonardo Savioli desarrolla sus teorías mega-estructuralistas a partir de implantaciones de elementos tecno-mórficos como tuberías, poleas o motores, por lo que no es casual que su ejercicio de curso de 1966 se denominara "Piper, atrezzature per il tempo libero" [5C], en clara alusión a la tubería como paradigma de comunicación universal, elemento que también fue exaltado por el propio Höllein en 1965, en sus anteriormente citados artículos "Technik" o "Zukunft der Architektur" en la revista Bau, con explícitos paralelismos entre autopistas y refinerías, lugar en el que la tubería adquiere su máximo carácter de expresión:

"El tráfico abandona la tierra, ya no hay sólo formas horizontales y verticales de comunicación tales como ferrocarriles, carreteras y remontes, sino una nueva tridimensionalidad en todas las direcciones para que la comunicación se desarrolle a través de rutas dinámicas, oblicuas, que penetran en los cuerpos urbanos a partir de líneas que fluyen, como escaleras mecánicas, pasillos, cintas transportadoras, todos ellos similares a las tuberías. Hoy en día podemos transportar casi cualquier cosa por medio de tuberías."242 (Höllein, 1965, p.10)

La relación entre movilidad y tubería se convierte en verdadero icono formal de múltiples visiones urbanas tecno-mórficas de finales de los años sesenta. En 1969, Barna Von Sartory y Georg Kolhmaier, con el fin de revalorizar las áreas periféricas de Graz, proponen un "Transportador tubular de personas"243 [8E], una gran tubería gigante que tecno-morfiza la ciudad antigua. Las analogías maquinistas tienen también como símbolo importante a los vehículos submarinos y el desarrollo de los hábitats en las profundidades marinas, con

241 NATALINI, Adolfo; SAVIOLI, Leonardo. Spazio di coinvolgimiento. En: Casabella, n³26, julio 1973. pp.17-35.

242 "Traffic leaves the ground, there are no longer only horizontal and vertical means of communication, such as railways, roads and lifts, but three-dimensionality in all directions so that communication along, dynamic, oblique routes penetrates these urban bodies in flowing lines, as escalators, passengers walkways, conveyor belts for transport, as pipelines (today we can transport almost anything in pipelines)"

HÖLLEIN, Hans. Zukunft der Architektur. En: Bau, Heft 1, 1965. p.10.

243 Proyecto expuesto en la exposición Trigon'69 en Graz, junto a proyectos como la mega-estructura también tecnomórfica "Ragnitz" (1966-69) de Huth y Domenig.

SUPERSTUDIO. Lettera da Graz. Tringon'69. Una mostra sul tema: architettura e Libertá. En: Domus, n481, diciembre 12/1969. pp.49-54 
arquitectos involucrados en esas investigaciones marinas como el francés Jacques Rougerie $^{244}$, futurólogos como McHale exaltando la exploración del mundo submarino como alternativa de futuro, así como una gran difusión de la experimentación subacuática en revistas arquitectónicas ${ }^{245}$. Aparecen así una gran cantidad de ejemplos de ciudades marinas surcadas por tuberías de manera casi caricaturesca, como la "Underwater City" (1964) [3E] diseñada por Warren Chalk miembro de los británicos Archigram, análoga marina de la terrestre "Interchange City" (1963) [2B] o las "Underwater Urban Structures" (1969) [8B] de Hidezo Kobayashi. La tubería alcanza su máxima expresión en la "Plug In City" (1964) [4D] de Peter Cook, Warren Chalk y Dennis Crompton, en la que una doble estructura diagonal de tuberías, funcionando como transportadoras de personas y mercancías, son la base de una ciudad que opera como una gran máquina en la que cada una de sus partes presenta unos rangos de obsolescencia determinados. Sin embargo, la exaltación de la tubería pronto se agota en su propio carácter banalmente formal, y en 1969 Theodore Waddell expone en el MOMA de Nueva York una maqueta realizada con tuberías, neones y componentes electrónicos como bujías o pistones denominada "Function without Form, two models of a Undesignable City" [9A], dos modelos de ciudades tecno-mórficas que critican la rigidez del planeamiento urbano pero que solamente son defendibles como objeto de exposición o como portada de la revista "Architectural Forum" en abril de 1969:

"El mensaje de la exposición era cómo el planeamiento convencional a gran escala en la planificación ofrece demasiado pronto un escenario concreto que pone en peligro la espontaneidad humana, estos modelos demuestran un lenguaje visual alternativo que puede acomodar a la evolución imprevisible." ${ }^{.246}$ (Waddell, 1969, p.57)

Ya agotados el motor y la tubería, afloran nuevos sistemas tecnológicos como referentes formales: las placas base de las incipientes computadoras o los circuitos electrónicos, en los que el transporte ya no es de fluidos por tubería, sino de electricidad o información, mediante cables y sistemas mucho menos voluminosos, un salto de la mecánica a la electrónica como alternativa tecno-mórfica de futuro. Propuestas como "City with Pulsating Space Frame" [6B] o "Cities That Beat Like a Heart, Cities That Fly Like Breath" (1967) [6C], diseñadas por Coop Himmelblau, simulan nuevas ciudades mucho menos corpóreas, más ligeras, fundamentadas en nodos y comunicadores mucho más parecidos al de esos incipientes circuitos eléctricos. Formalizaciones parecidas serán adoptadas por proyectos como "Floating Factory, Metabonate'69" (1969) [9B] de Kisho Kurokawa, o "Computor City" (1964) [4A] desarrollada por Dennis Crompton como complemento a la "Plug In City" de Archigram.

"El Proyecto Computor City es un estudio paralelo al de la Plug-in City. Sugiere un sistema de detección continua de las necesidades de la ciudad que utilizando el potencial electrónico de convocatoria, pueda responder a la escala del día a día, así

244 ROUGERIE, Jacques; VIGNES, Édith. Habiter la mer. Éditions Maritimes et d'Outre-Mer. París, 1978.

245 Incluso "Architectural Design" le dedica un número completo en 1969 a las experimentaciones en cuanto al mundo submarino se refiere con Jean Michel Cousteau como uno de los editores invitados:

COUSTEAU, Jean Michel; HUSSEIN, Faroq (editores invitados). AD The Architectural Design, Inner Space, april 1969.

246 "The message of the exhibition was that conventional large-scale planning is offer settled too earlier a stage and can threaten human spontaneity; these models demonstrate an alternative visual language which can accommodate unforeseeable developments"

WADDELL, Theodore. Undesignable. En: Design, n²48, agosto 1969. p.57. 
como a la escala de año a año dentro de la estructura de la ciudad."247 (Dennis Crompton, 1964 (1972), p.41)

Esa dicotomía entre mecánica y electrónica, hardware y software, tubería y circuito, llega a producirse simultáneamente en el trabajo de un mismo grupo o arquitecto, como en el caso de los británicos Archigram, asociado a esas estrategias de cambios de escala tecnomórficos.

\section{De la ciudad-máquina al edificio-máquina como monumento.}

En 1968, el colectivo florentino Superstudio, compuesto por Adolfo Natalini, Piero Frassinelli, Cristiano Toraldo di Francia y Roberto Magris, se posiciona de una manera clara y efusiva a favor del tecno-morfismo como estética necesaria para el futuro de la arquitectura:

"A partir de los procesos industriales, la arquitectura aprende métodos de composición (montaje, repetición, cambio de escala) y los demuestra. La máquina produciendo objetos da a luz una arquitectura a imagen de la máquina.

Así, en lugar de una arquitectura a imagen del hombre (más o menos Vitrubiana), encontramos la arquitectura tecno-mórfica.

Después de la ética de la máquina de la primera era industrial, (cuando la máquina representa sólo la relación trabajo-producción-dinero) la edad de los consumidores produce una estética de la máquina." 248 (Superstudio, 1968 (1971), p.304)

Entre 1966 y 1968, Supestudio desarrolla varios proyectos a partir de la construcción de máquinas urbanas que aportan funciones especializadas a la ciudad a partir de esa "estética de la máquina". Su "Macchina per le Vacanze a Tropea" (1967) [7A] se convierte en una super-estructura adosada a un gran acantilado que funciona como ciudad de vacaciones. Su exterior presenta una clara falta de escala así como una gran contradicción al presentarse como fachada totalmente cerrada al paisaje, lo que genera una imagen de una gran máquina superpuesta al entorno natural de un lago como si de un gran radiador se tratara. Una estrategia similar es usada en su "Macchina espositiva" (1968) [7D], un proyecto para la restauración de la fortaleza de Basso en Florencia, que se equipa como centro de exposiciones a partir de la superposición de una máquina macro-escalar que alberga aparcamientos, salas de exposiciones y conferencias. Este edificio-máquina inexpresivo de Superstudio adquiere un carácter monumental para competir con el monumento, la fortaleza,

\footnotetext{
247 "The Computer City Project is a parallel study to Plug-in City. It suggest a system of continual sensing of requirements throughout the city and, using the electronic summoning potential, makes the whole thing responsive on the day-to-day scale as well as on the year-to-year scale of the city structure."

COOK, Peter (editor). Archigram. Studio Vista. Londres, 1972. p.41.

248 "From industrial processes, architecture takes methods of composition (assembly, repetition, change of scale) and demonstrates them. The machine producing objects gives birth to an architecture in the image of the machine. Thus, in place of an architecture in the image of man (more or less Vitruvian), we find technomorphic architecture. After the machine ethics of the early industrial age, (when the machine represented only work-production-money) the consumer age produces machine aesthetics"
}

SUPERSTUDIO. Superstudio. En: Perspecta, The Yale Architectural Journal, Volúmenes 13-14, 1971. p.304. 
que lo alberga. La máquina se convierte en monumento en esta transición de la máquinaciudad al edificio-máquina, en una reivindicación de la máquina como referente estético y no como máxima aspiración funcional de la ciudad.

"La arquitectura tecnomórfica cambió el enfoque en el futuro al exorcizar las dudas y temores introducidas por la máquina en el aprendiz de brujo. La arquitectura era una máquina de funcionamiento simbólico. ${ }^{1249}$ (Superstudio, 1969, p.38)

249 "L'architettura tecnomorfa spostava l'attenzione sullipotesi e sul futuro, esorcizzando i dubbi e le paure introdotte dalla macchina negli apprendisti stregoni. L'architettura era una macchina a funzionamento simbolico."

SUPERSTUDIO. Superstudio. Progetti e Pensiero. En: Domus, nº479, octubre 10/1969. p.38. 


\section{Catálogo // [Evocaciones programáticas]}

Las imágenes están referenciadas por números en la zona superior de las columnas verticales [del 1 al 16] y letras en la zona izquierda de las filas horizontales [de la A a la E].

Todas las referencias están ordenadas cronológicamente.

Referencias de imágenes del [1B] a [16A]. Cada uno de los proyectos referenciados gráficamente en el catálogo presentan antes de su nombre un código con un número en relación a su columna vertical y una letra en relación a su fila horizontal.

Ejemplo:

[7E] "Cloud 9" (1962) de Buckminster Fuller. Buscar referencia en la columna 7 y la fila E del catálogo referenciado al principio del capítulo.

[Nota]: no todos los referentes gráfico del catálogo están referenciados en el texto por lo que se recomienda una lectura del mismo antes de comenzar la del propio texto.
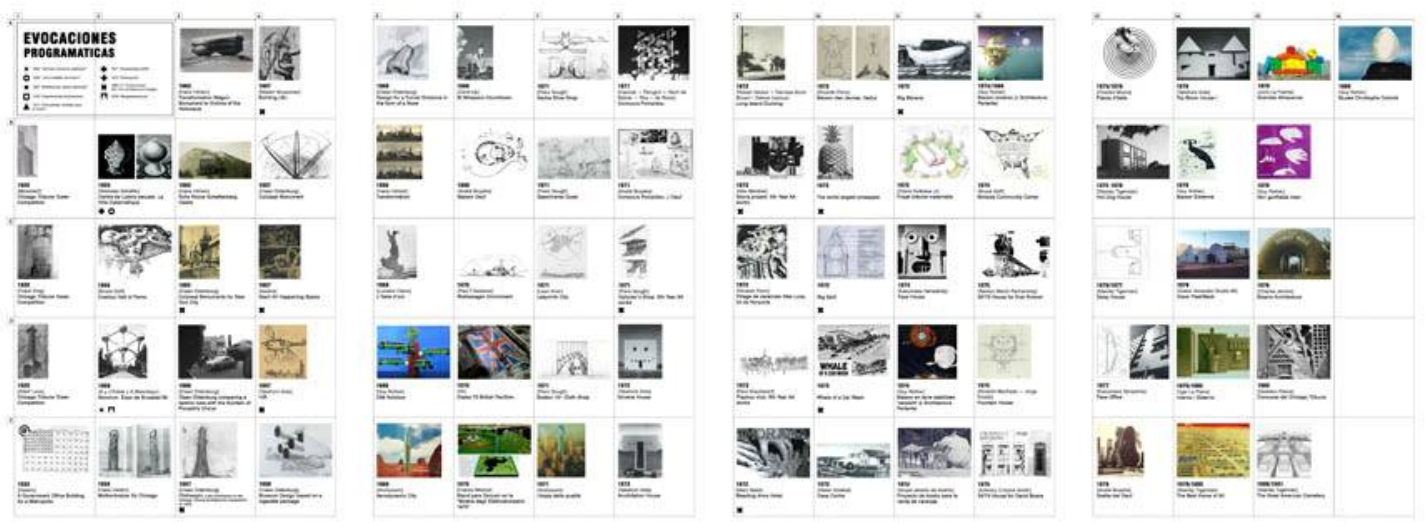


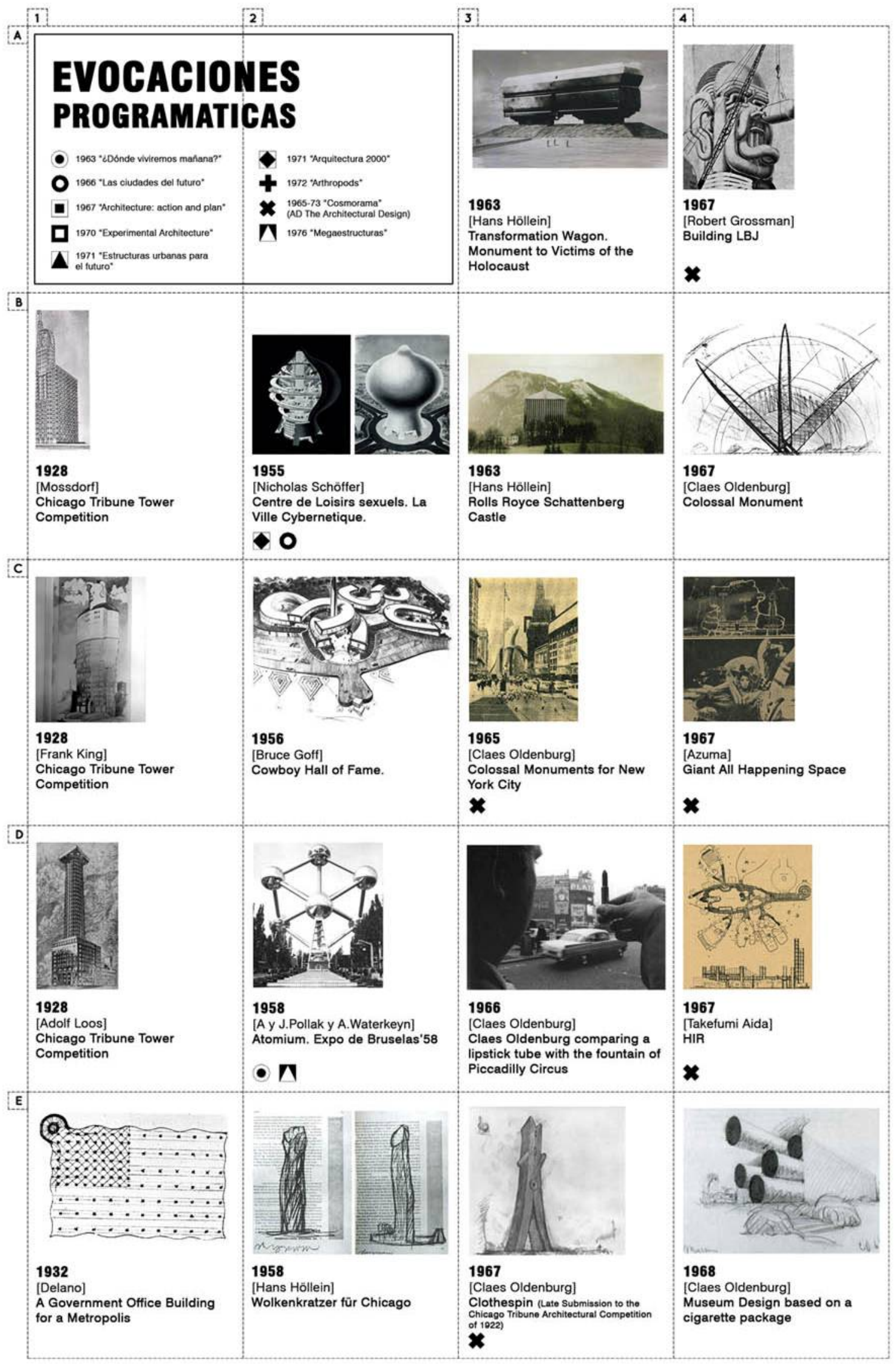




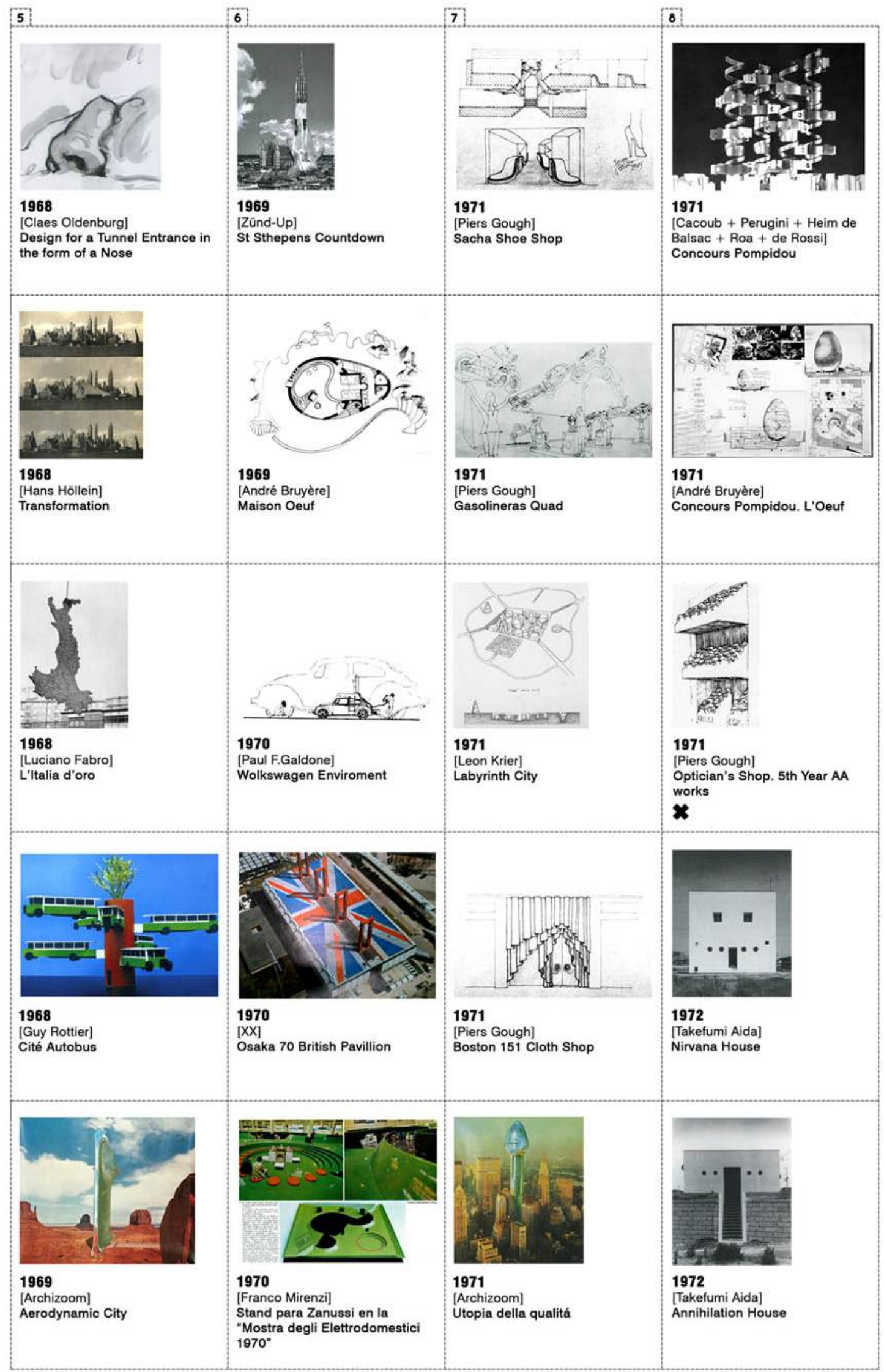




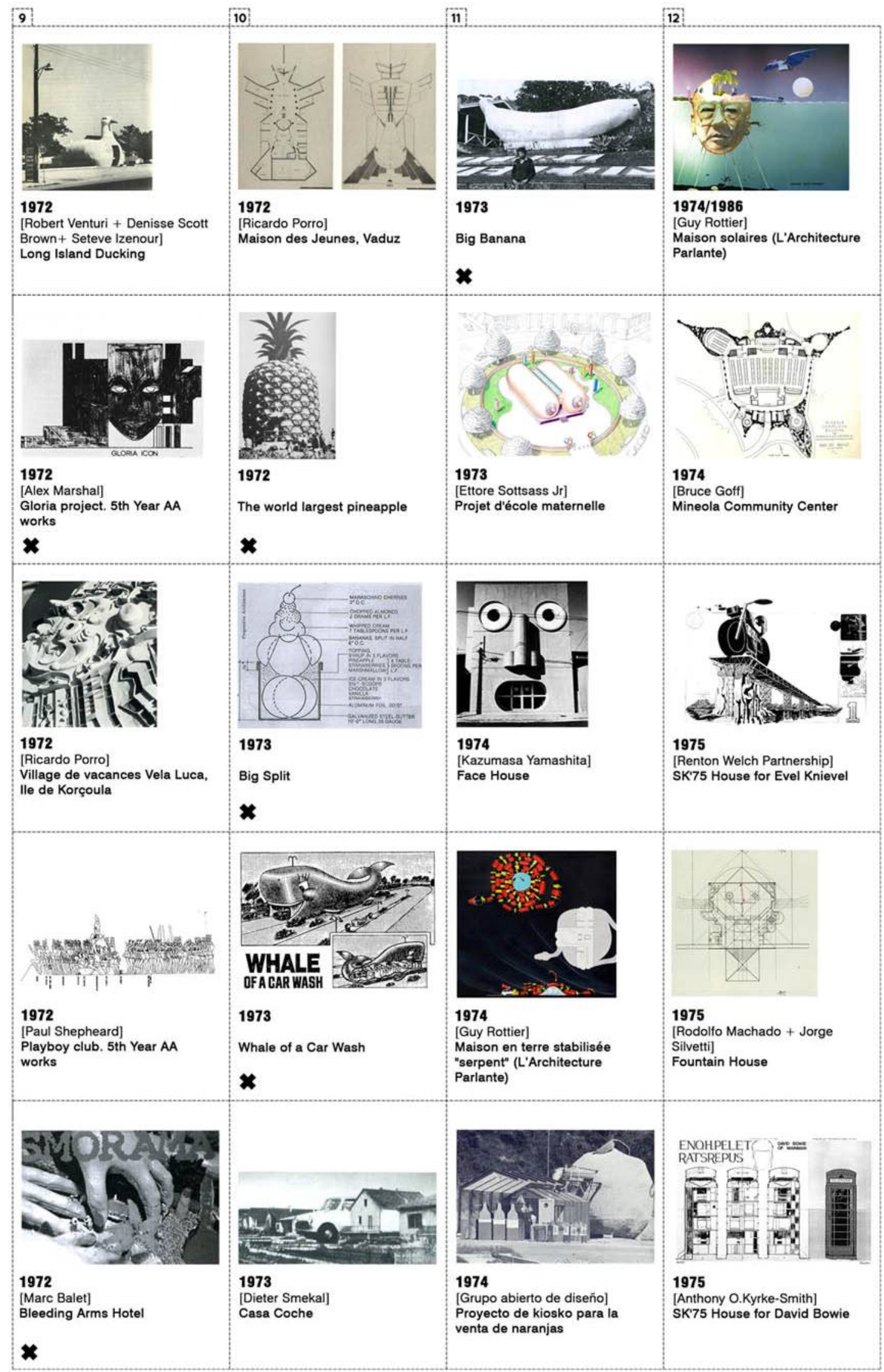




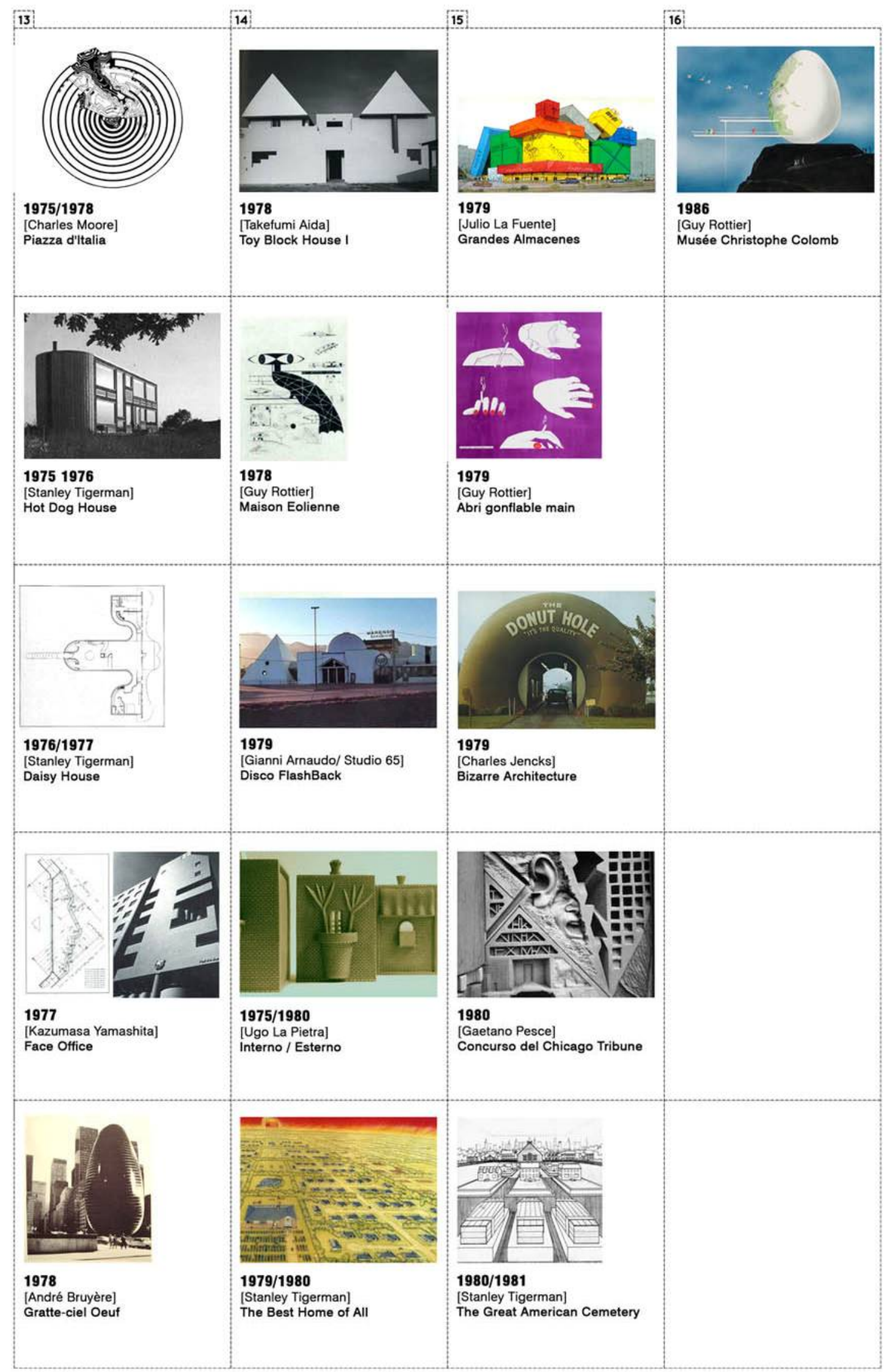




\section{[Evocaciones programáticas] Relaciones formales entre objetos y edificios.}

El uso del cambio de escala de objetos no arquitectónicos, reconocibles por parte del imaginario colectivo, como estrategia fundamental del proyecto arquitectónico, presenta claros referentes históricos, la mayor parte de la veces denostados por los "cánones arquitectónicos" predominantes en cada época, a pesar del entusiasmo con que suelen ser acogidos por parte de la cultura popular ${ }^{250}$. Algunos de estos antecesores son incluidos en la célebre exposición "Fantastic Architecture"251 (1960) de Conrads y Sperlich bajo la categoría denominada como "Pre-figured Architecture". Mediante ese calificativo, los autores vislumbran dos propiedades esenciales derivadas de ese cambio de escala de objetos para su re-conversión en arquitecturas; por una parte, lo apriorístico de la búsqueda de la forma como contraposición al célebre precepto "la forma sigue a la función" 252; por otra, la confrontación entre el espacio interior y exterior que en ellas se intuye, una divergencia sobre la que pocos años después Robert Venturi construirá su polémico manifiesto "Complejidad y contradicción en la arquitectura" (1966) .

"La improvisación dentro de ciertos límites formales, es sólo un paso a una arquitectura cuyo exterior es, en su forma total, completamente preconcebida. Esta actitud es ahora completamente anti-funcional, lo que no significa que las estructuras generadas no tengan un uso concreto. El encanto reside en la confrontación entre contenedor y contenido, por lo que el exterior ha sido liberado sin piedad de todas las contingencias habituales." ${ }^{253}$ (Conrads, Sperlich, 1960, p.17)

"El Pop Art ha demostrado que estos elementos vulgares a menudo son la principal fuente de variedad y vitalidad fortuita de nuestras ciudades y que no es su banalidad o vulgaridad como elementos lo que causa la banalidad o vulgaridad del panorama, sino sus conexiones contextuales de espacio y escala." ${ }^{254}$ (Venturi, 1966, p. 71)

Conrads y Sperlich ilustran esta arquitectura pre-figurada del cambio de escala a partir de tres ejemplos fundamentales. Por una parte encontramos dos proyectos derivados de la iconicidad del elefante ${ }^{255}$, "Triumphal Elephant $256 "$, diseñado por C.F. Ribart en 1758, un

250 Arropados por movimientos artísticos como el Pop Art desde mediados de la década de los cincuenta.

251 CONRADS, Ulrich; SPERLICH, Hans G. Fantastic Architecture. The Architectural Press. London, 1963. Ed. original: Fantastische Architektur, Verlag gerd Hatje, Stuttgart, 1960.

252 Precepto de diseño durante gran parte del siglo XX. La célebre frase se atribuye al arquitecto norteamericano Louis Sullivan: "form follows function".

253 "From improvisation within certain formal bounds it is only one step to an architecture whose exterior is, in its total shape, completely pre-conceived. The attitude is now utterly anti-functional, although this does not mean that the structures are of no use. Rather, the practical function and internal spatial relationships are not immediately apparent. The charm lies in a confrontation of contents and container, whereby the exterior covering has been ruthlessly freed of all the usual contingencies."

CONRADS, Ulrich; SPERLICH, Hans G. Fantastic Architecture. 1963 (1960). p.17.

254 VENTURI, Robert. Complejidad y contradicción en la arquitectura. Gustavo Gili. Barcelona, 1974 (1966), p.71.

255 Referenciaré aquí otros referentes históricos de proyectos o imágenes que trabajan con ese simbolismo del elefante:

"L'elefante di Chaillot" (1806) Vignet 
elefante-monumento habitado para los Campos Elíseos, situado en el lugar que ahora ocupa el Arco del Triunfo, y otro construido y convertido esta vez en monumento nacional de los Estados Unidos bajo el nombre de "Lucy the Elephant" (1882-1883) de J. V. Lafferty. Ambas arquitecturas zoomórficas ${ }^{257}$ pueden considerarse como simples "monumentos habitados" en los que su interior es anecdótico ya que aprovechan la enigmática e icónica figura de "El Elefante"258 para auto-determinarse como monumentos, sin evocar ninguna conexión semántica con el programa que albergan, simplemente irrelevante. Por otro lado, el tercer referente será la polémica y bien conocida propuesta de Adolf Loos para el concurso de una torre para el periódico Chicago Tribune de 1922, en la que el arquitecto austríaco plantea la idea de un rascacielos como si de una columna dórica ${ }^{259}$ habitada a escala gigante se tratase. Este proyecto se convierte en referencia esencial relacionada con el uso del cambio de escala como estrategia arquitectónica ${ }^{260}$. La frecuente alusión al proyecto se produce en algunos casos por la contradicción que supone en relación a la ideología arquitectónica del propio Loos, en otros, por convertirse en un futuro liberador arquitectónico para muchos arquitectos que lo homenajearán asiduamente desde su contemporaneidad. Hans Höllein en 1958 y $1970^{261}$. Claes Oldenburg en 1967 o Robert A. M. Stern ${ }^{262}$ en 1980 realizarán propuestas contemporáneas para el mismo concurso de una manera auto-referencial y simbólica a modo de pequeños homenajes, siguiendo así las proféticas palabras del propio Adolf Loos:

"Incisione d'architettura" (1598) Wendel Dietterlin
"L'elefante di piazza della Bastiglia" (1809) Jean-Antonie Alavoine
256 La iconicidad de este proyecto se acrecentará durante los años setenta por convertirse en portada de libros como:

CHRIST, Yvan. Paris des Utopies. Editions Baland. París, 1970.

257 Ambos proyectos serán también referenciados en el célebre artículo de Peter Blake "The Secret Scrapbook of An Architectural Scavenger" en el número de Architectural Forum de agosto y septiembre de 1964 bajo el lema "Animalism":

BLAKE, Peter. The Secret Scrapbook of An Architectural Scavenger. En: Architectural Forum, agosto-septiembre 1964, Vol.121. pp.81-114.

258 Sobre la iconografía del Elefante en la historia de la Arquitectura resultan interesantes estos dos artículos de Marco Dezzi Bardeschi, en una serie de artículos denominados como "Architettura Sacro Bosco" y derivados de sus estudios en el "centro studi architettura OUROBOROS" de Florencia y publicados en 1974 en la revista Casabella:

DEZZI BARDESCHI, Marco. Elefantica, ovvero il colosso abitato. En: Casabella, n³91, julio 1974. pp.12-14.

DEZZI BARDESCHI, Marco. Elefantica, dalla Bastiglia a Las Vegas. En: Casabella, n³94, octubre 1974. pp.14-16.

259 La columna dórica supone el icono principal entre los elementos arquitectónicos cambiados de escala. Algunos de estos referentes históricos como la columna dórica gigante que aperece como cama improvisada en el primer plano de "Architect's Dream" (1840) de Thoms Cole o la "Casa en forma de columna" de Françoise Barbier, referenciados en:

DEZZI BARDESCHI, Marco. Supercolossi e Supercomittenza. En: Casabella, n³83, noviembre 1973. pp.14-16.

260 Ya en el mismo concurso hay varios casos de otros "edificios-columna", un rascacielos con forma de indio y su tomahawk o incluso un referente antropomórfico diseñado por el caricaturista Frank King. Ver:

SOLOMONSON, Katherine. The Chicago Tribune Tower Competition: Skyscraper Design and Cultural Change in 1920s. Cambridge University Press. Nueva York, 2001.

261 La columna de Loos aparece en la portada de BAU en 1970 cuando aún Höllein era el director de la misma:

Bau, Heft 1, 1970, portada

262 TIGERMAN, Stanley (editor). Late entries to the Chicago Tribune Tower competition. Rizzoli. Nueva York, 1980. 
"La gran columna dórica será construida, si no en Chicago en cualquier otra ciudad, si no para el Chicago Tribune, para cualquier otro, si no por mí, por cualquier otro arquitecto. ${ }^{1263}$ (Loos, 1922 (1973), p.5)

La arquitectura construida a partir del cambio de escala de un objeto se ve entonces sometida a la prefiguración de su forma exterior, pero como contrapartida ésta se nutre de su capacidad semántica de evocación. En los ejemplos anteriores, la figura del elefante aparece como símbolo de animal adorado y exótico y la columna dórica como elemento de una arquitectura esencial. Ese carácter evocativo de los objetos reside en su capacidad de representación de una realidad ya aprendida por el imaginario colectivo a la que el mismo ha otorgado unos "valores" y "contravalores" determinados. Uno de los aspectos más importantes de esta capacidad semántica será el potencial de universalización de la misma, o lo que es lo mismo, la disposición del objeto a convertirse en icono referencial para un contexto determinado en el sistema de relación global-local. John $\mathrm{McHale}^{264}$ advierte sin embargo del alto grado de obsolescencia que presentan algunos objetos referenciales, especialmente aquellos convertidos en referentes desde la sociedad de consumo, para convertirse en iconos legibles en su célebre artículo doble ${ }^{265}$ "The expendable ikon":

"Culturalmente vivimos en un período de enorme expansión y exploración, donde la gama del espectro sensorial se ha extendido; el hombre puede ver más, oír más, viajar más rápido, vivir experiencias más que nunca. Sus extensiones ambientales, como el cine, la televisión o las revistas, traen a su conciencia un alcance sin precedentes de la experiencia visual.

Estos cambios acelerados en la condición humana requieren una serie de imágenes simbólicas del hombre a las que la altura de las exigencias de cambio constante les otorga una impresión fugaz y una alta tasa de obsolescencia. Una serie reemplazable, consumible de iconos. "266 (McHale, 1959, p.82)

Sin embargo, la advertencia de John McHale no va encaminada de ningún modo a la no utilización de esas imágenes referenciadas a objetos sino al conocimiento de las propiedades que los medios de comunicación les confieren y a la propia utilización de esos 263 "La grande colonna dorica sarà costruita se non a Chicago in qualche altra città se non per il Chicago Tribune per
qualcun altro, se non da me, da un altro architetto."

SARTOGO, Piero. Hai Capito?. En: Casabella, n³79, julio 1973. p.5.

264 John McHale será uno de los pioneros en introducir la heterogeneidad visual de los objetos de consumo en la cultura arquitectónica de los que él se nutría como parte del movimiento Pop británico a través de su militancia en el "Independent Group".

265 El artículo "The expendable ikon" aparece publicado en dos partes en Architectural Design:

MCHALE, John. The expendable ikon 1. En: AD The Architectural Design, febrero 1959. pp.82-83.

MCHALE, John. The expendable ikon 2. En: AD The Architectural Design, marzo 1959. pp.116-117.

266 "Culturally a period of enormous expansion and exploration; the whole range of the sensory spectrum has been extended -man can see more, hear more, travel faster-experience more than ever before. His environment extensions, movie, TV, picture magazine, bring to his awareness an unprecedented scope of visual experience.

Such accelerated changes in the human condition require an array of symbolic images of man which will match up to the requirements of constant change, fleeting impression and a high rate of obsolescence. A replaceable, expendable series of icons"

MCHALE, John. The expendable ikon 1. 1959. p.82. 
medios con fines arquitectónicos. Esta teoría será expresada en su conferencia "The Plastic Parthenon"267 en el ICA en 1961, en la que presupone una mayor importancia a las reproducciones del Partenón en los diversos medios de comunicación de masas, desde suvenires hasta imágenes en libros o televisión, que al propio edificio en sí. De esta manera, el objeto sujeto al cambio de escala lleva asociadas unas condiciones de "reproducibilidad" que el arquitecto debe aprovechar.

“¿Cuál es el estatus del original frente a sus múltiples reproducciones en facsímiles multicolor?"268 (McHale, 1967, p.5)

De esta manera, la reproducción de imágenes preconcebidas convertidas en proyectos arquitectónicos a cualquier escala presentan dos estrategias que dependen de esas "capacidades" del objeto: por un lado, el potencial comunicativo semántico del mismo; por otro, su capacidad para adaptarse a una función determinada.

\section{El potencial semántico de los objetos. Objetos superpuestos a un contexto.}

En 1958, bajo el marco de la Exposición Universal celebrada en Bruselas, se construye el "Atomium" [2D] como icono de la misma. Un edificio proyectado por los arquitectos A. y J. Pollak y el ingeniero A. Waterkeyn mediante la ampliación en $165 \times 10^{6}$ veces del modelo molecular de esferas y barras, que alberga un conjunto de restaurantes y miradores de apoyo a la exposición, supeditados a un sistema de comunicaciones diagonales entre ellos. Una vez más un edificio sin pretensiones concretas de uso se convierte en monumento a partir del cambio de escala de un objeto, en este caso el modelo nuclear atómico, símbolo de futuro del progreso científico, que convierte al "Atomium" de manera directa, en seña de identidad de la exposición y de manera indirecta, en referente arquitectónico para muchas megaestructuras posteriores, como evidenciará Reyner Banham:

"Sin embargo, más pertinente es el hecho de que sus creadores situaron casi toda la comunicación vertical dentro de los tubos de acero que constituían las barras de su composición tetraédrica, prototipo admitido de la situación de escaleras y escaleras mecánicas en los elementos diagonales de muchas estructuras posteriores, como las de la Plug-In City de Archigram." ${ }^{269}$ (Banham, 1976, p.40)

Este potencial comunicativo del cambio de escala de objetos referenciales será usado de manera muy diferente por Hans Höllein también en 1958, con dos propuestas tardías para el "Concurso del Chicago Tribune" [2E]; dos dibujos de un brazo con el puño cerrado y un pene como futuros rascacielos urbanos para Chicago. De esta manera se pregunta Höllein "¿Qué es arquitectura?":

267 MCHALE, John. The plastic Parthenon. En: Dot Zero 3, Spring 1967. pp.4-11.

268 "What is the status of the original with facsimile multicolor reproduction?"

MCHALE, John. The plastic Parthenon. 1967.p.5.

269 BANHAM, Reyner. Megaestructuras. 1978 (1976). p.40. 


\begin{abstract}
"La arquitectura no es necesariamente una membrana de protección ni un monumento, ya que un requisito básico es que está construida o excavada, o formada por cualquier otro medio de construcción. Una cueva no es arquitectura, ni tampoco lo es un árbol. Sin embargo, un perfil de acero, colocado en el medio del desierto, si lo es. La arquitectura es la creación de un espacio por los seres humanos para los seres humanos. "270 (Höllein, 1958 (1966), p.35)
\end{abstract}

Höllein no sólo plantea la artificialidad de una arquitectura entendida como acto imprescindiblemente humano sino que además anticipa una visión sobre cómo a través de una doble estrategia de contextualización y cambio de escala de objetos cotidianos, éstos pueden ser convertidos en arquitectura. Continuando con esta hipótesis, el arquitecto austríaco plantea, a principios de los años sesenta, cuál será la arquitectura del futuro, a través de dos artículos fundamentales para entender el cambio de escala como estrategia arquitectónica de futuro. Primero, a través de sus experimentos de ciudades-escultura junto a Walter Pichler expuestos en la exposición "Architektur"271 (1963), y dos años más tarde con su explícito "Zukunft der Architektur" (1965) o "El futuro de la arquitectura", en el que apuesta por la tridimensionalidad de unas futuras ciudades convertidas en icono a través de su célebre collage "Aircraft Carrier City in Landscape" (1963/64). Será a partir de 1963 cuando Hölllein comience a producir toda su serie "Transformations", así definida por el crítico de arte vienés Friedrich Achleitner:

\begin{abstract}
"Las transposiciones de Höllein son montajes que pueden ser en parte materializados en papel, pero también en la realidad actual. De este modo un vagón de tren, al ponerlo sobre una base y a través de un cambio de escala se convierte en un monumento, o un portaaviones situado en el desierto se transforma en una ciudad. Todo ello pertenece a la naturaleza del montaje en el que no sólo algo nuevo aparece en ese lugar a través de la creación de relaciones irreales, sino que también los propios objetos han sido cambiados, transformados." 272 (Achleitner, 1966, p.25)
\end{abstract}

Los rasgos comunes de todas esas transformaciones de objetos cotidianos en arquitecturas de Höllein serán tres: el evidente cambio de escala, la monumentalidad derivada de dicho cambio y el potencial semántico de los mismos. De esta manera no es casual que un vagón de tren se convierta, mediante un cambio de escala y su colocación en un pódium, en un monumento a las víctimas del Holocausto, evocando a los miles de judíos apiñados en largas filas de vagones conducidos hasta la muerte en "Transformation Wagon. Monument to

\footnotetext{
270 "Architektur ist notwendigerweise weder ein schützendes Gehäuse noch ein Monument, aber eine der Grundvoraussetzungen ist, daß sie gebaut ist oder herausgegraben, oder geformt mit irgendwelchen anderen Mitteln des Bauens. Eine Höhle ist nicht Architektur, noch ist es ein Baum. Jedoch ein Stahlprofil, in die Mitte der Wüste gerammt, ist es. Architektur ist das Schaffen von Raum von Menschen für Menschen"
}

HÖLLEIN, Hans: Fragmente zur Architektur. En: Protokolle '66. Wiener Jahresschrift für Literatur, bildende Kunst und Musik. Hrsg. Otto Breicha und Gerhard Fritsch, Jugend und Volk, Wien München, 1966. p.35.

271 HÖLLEIN, Hans; PICHLER, Walter. Architektur, work in progress: 8. Bis 12. Mai 1963, Galerie St. Stephan, Wien, 1963.

Ampliamente referenciada junto a otros proyectos similares en:

HÖLLEIN, Hans. Architektur. En: Bau, Heft 2/3, 1969.

272 "Höllein's transpositions are montages which can be partly realized on paper but partly also in actual reality. Thus a railroad car - by putting it on a base and through a change of scale - becomes a monument-. An air-craft carrier in the landscape becomes a city. It belongs to the nature of montage that not only something new comes into existence through the creation of unreal relations, but that also the objects themselves are changed, transformed. "

HÖLLEIN, Hans. Transformations by Hans Höllein, Architect. En: Arts \& Architecture, mayo 1966. pp.24-25. 
Victims of the Holocaust" (1963) [3A] o que un radiador de una conocida marca de automóviles sustituya al castillo Scattenberg, transformándose así en un importante centro turístico en "Rolls Royce Schattenberg Castle" (1963) [3B]. Ambos ejemplos abordan la conversión de objetos en monumentos, tema sobre el que el artista sueco Claes Oldenburg estaba trabajando simultáneamente a Höllein en Nueva York. Si ya en sus primeras esculturas Oldenburg reproduce objetos cotidianos, deliberadamente ordinarios, a un mayor tamaño del habitual a partir de materiales pobres, enfatizando sus colores y haciéndoles perder esa condición de producción en serie, es a partir de las transformaciones de Höllein, cuando Oldenburg descubre también el espacio urbano y la influencia de esos cambios de escala en el mismo. Así es como comienza a utilizar esos objetos banales, generalmente relacionados con la comida, el sexo o la sociedad de consumo, como monumentos que sustituyen a los ya existentes antropomórficos, zoomórficos o de geometrías simbólicas, esferas, tetraedros o pirámides, como manera de desacralizar el espacio público al superponer a la realidad existente esos objetos sin dignidad pública y carentes de importancia. Un peluche "Teddy Bear", un ventilador o un plátano ${ }^{273}$, se convierten en monumentos para la ciudad de Nueva York en su trabajo "Colossal Monuments for New York" (1965) [3C], algunos de los cuales fueron publicados por el propio Hans Höllein en 1966 en la revista $\mathrm{BAU}^{274}$.

Tanto "Transformations" de Höllein como "Proposals for Monuments and Buildings" de Oldenburg coinciden en la búsqueda del potencial arquitectónico de los objetos a partir de dos puntos de vista divergentes aunque complementarios. Por una parte, el objeto puede generar sensaciones visuales muy distintas en relación al contexto en el que se inserte, generando una búsqueda del potencial formal relacional del objeto. Por otra, la propia capacidad del objeto actuando de manera autónoma, pero supeditada a su tamaño, puede generar situaciones espaciales relacionadas con funciones arquitectónicas determinadas, a través de una búsqueda formal que implica tanto el interior como el exterior del objeto. En esa primera búsqueda contextual referencial del objeto, Oldenburg deja claras sus intenciones:

"Elijo el objeto que de algún modo es apropiado a la forma, las condiciones y las asociaciones del emplazamiento. El gigantesco perrito caliente tiene una forma parecida a los barcos que pasan subiendo y bajando por el Hudson. La tabla de planchar sobre el Lower East evoca la forma de la isla de Manhattan."275 (Oldenburg, 1969, p.15)

Esa doble búsqueda del potencial arquitectónico y semántico de un objeto asociado a un emplazamiento concreto, tendrá de nuevo a la ciudad de Nueva York como principal objeto de experimentación. Mientras Oldenburg busca espacios públicos emblemáticos para colocar sus objetos colosales ${ }^{276}$, Höllein trabaja generalmente con el skyline de la ciudad y

273 Icono pop reinterpretado en multitud de ocasiones por otros artistas como Warhol y su célebre portada del disco "The Velvet Underground \& Nico" en 1967.

274 OLDENBURG, Claes. Bau interview mit Claes Oldenburg. En: Bau, Heft 4, 1966. pp.83-87.

275 "The object is chosen because in some way it fits the shape, the conditions and the associations of the site. The giant frankfurter has a shape like the ships that pass it, going up and down the Hudson. The ironing board over the Lower East echoes the shape of Manhattan island."

OLDENBURG, Claes; CARROLL, Paul. Proposals for monuments and buildings, 1965-69. Big Table Pub. Co. Chicago, 1969. p.15.

276 Oldenburg hará propuestas para New york y otras ciudades emblemáticas como Londres, Wasinghton o Toronto, la mayor parte de las veces sustituyendo monumentos ya existentes por sus objetos gigantes. 
una escala más cercana a la del edificio-ciudad. De esta manera el frontal del Rolls Royce convierte lo que antes fue una alusión al castillo Schattenberg en el rascacielos más alto de la ciudad como sede de Wall Street, utilizando así ese simbolismo capitalista del emblema de la marca británica de automóviles convertida en edificio. La experimentación con el célebre perfil neoyorkino llega a su máxima expresión en el trabajo de Höllein de 1968, en el que superpone distintas partes del cuerpo humano sobre el mismo. Una oreja "Plug-In" como prótesis de un rascacielos, una nariz como super-topografía urbana o una boca a modo de embarcadero, en su serie "Transformations" [5B] para la exposición "Super-Design"277 celebrada en Viena. A partir de estas propuestas contextuales, aparecerán todo tipo de proyectos de superposición de objetos en contextos naturales o de relevancia urbana. El anterior dibujo de Höllein para un rascacielos en Chicago de forma fálica es utilizado por Archizoom años más tarde, contextualizado ahora en Nueva York, para expresar la "Utopia della qualitá" (1971) [7E], aquella que intenta cambiar la realidad a partir de la superposición mediante imágenes sensacionales, en este caso a través de un rascacielos fálico perfectamente reluciente y contorneado, sucesor de la anterior "Aerodynamic City" (1969) [5E]. El uso masivo del fotomontaje o collage como herramienta proyectual propositiva se complementa con otros experimentos como los realizados por Oldenburg mediante fotografías en las que sustituye directamente elementos de la ciudad por objetos que porta personalmente como en "Giant Lipstick" (1966) [3D], imagen en la que sustituye la fuente de Picadilly Circus $^{278}$ de Londres por un pintalabios, propuesta relacionada con la capacidad de cambio del espacio urbano por parte del usuario propuesta a través de las derivas situacionistas.

\section{La búsqueda del potencial arquitectónico de los objetos. Edificios diseñados a partir de objetos.}

La búsqueda del potencial puramente semántico del objeto se complementa con una serie de investigaciones en torno al potencial arquitectónico del mismo. Una vez testada su capacidad para convertirse en monumento, el objeto como arquitectura sólo puede convertirse en herramienta para una nueva arquitectura a través de un proceso de transformación del mismo a edificio, o lo que es lo mismo, a través de las distintas maneras de habitarlo. En este sentido se desarrollan las propuestas de Oldenburg, transformando una nariz en túnel de carretera en "Design for a Tunnel Entrance in the form of a nose" (1968) [5A], una pinza de la ropa en rascacielos en "Clothespin (Late Submission to the Chicago Tribune Architectural Competition of 1922)" (1967) [3E] o una cajetilla de cigarrillos en museo en "Museum Design based on a cigarette package" (1968) [4E]. En este último, el artista intenta construir una narrativa funcionalista al proyecto, fundamentando el movimiento de esos cigarros en el paquete como definición espacial de unas salas de exposiciones concretas en este museo ficticio ubicado en la ciudad de Los Ángeles.

En este contexto de búsqueda de justificación funcional del objeto fuera de su propia escala, Nicholas Schöffer diseña un "Centre de Loisirs Sexuels" (1955) [2B] en forma de gran seno super-escalado. Al igual que Claude-Nicolas Ledoux en 1803 diseñó su "Oikema" o casa de

277 "Superdesign", exposición celebrada en Viena, en la galería St.Stephan, del 10 de junio al 7 de julio de 1968. En ella se expondrán trabajos de Hans Höllein, Bruno Gironcoli, Walter Pichler, Roland Goeschl y Oswald Oberhuber.

278 Tanto los objetos como los lugares de trasposición serán en muchos casos comunes entre los heterogéneos autores de este tipo de propuestas. En relación a Picadilly Circus, en 1971 los británicos Simon Conolly y Mark Fisher situarán en la misma plaza un teléfono gigante convertido en puesto de información para una empresa telefónica londinense a modo de homenaje a la propuesta de Oldenburg. 
las pasiones desenfrenadas con una planta fálica ${ }^{279}$, también Schöffer busca una forma con connotaciones sexuales ${ }^{280}$ para formalizar ese nuevo programa para su "Ville Cybernétique ${ }^{\prime 281}$ que supone el centro de los placeres sexuales:

"Las líneas curvas dominarán en la concepción de la edificación, situada en medio del parque, recordando la forma de un seno turgente, emplazada sobre un dilatado zócalo."1282 (Ragon, 1966, p.200)

Así es cómo nuevas soluciones formales se transforman en nuevas funciones en posibles nuevas ciudades, convirtiéndose el cambio de escala de objetos en alternativa de futuro. Un futuro de nuevas formas referenciadas a nuevos usos que será sin embargo denostado por Charles Jencks en su referencia al proyecto de Schöffer:

"O tal vez sea porque no soportamos la carga de un falso futurismo en el que todo ha sucedido demasiado bien, una tradición que niega la magnificencia de la vida, que suprime el disentimiento y la complejidad, que trivializa el sexo y que ofrece utopías sin tener la más ligera sospecha de que son, en realidad, mucho peores que las condiciones que pretenden suplantar. "283 (Jencks, 1971, p.9)

Este tipo de relaciones semánticas en las que se trata de reducir un uso concreto a un objeto fuera de escala, cuyo significado está relacionado con el uso del edificio, se evidencia claramente en la propuesta de Bruce Goff para el concurso de 1956 "Cowboy Hall of Fame" [2C], en el que el arquitecto norteamericano resuelve un proyecto de "salón de la fama para cowboys" a partir de una reinterpretación del famoso juego de las herraduras y otro tipo de motivos relacionados con el salvaje oeste:

"En la medida en que el vaquero no había sido identificado en particular con ningún estilo edificatorio o arquitectura, me pareció apropiado utilizar motivos característicos del diseño de las cosas que se asocian con su vida cotidiana como elementos para construir una gramática adecuada con la que realizar esta arquitectura. Por lo tanto las formas, materiales, colores y texturas de sillas de montar, espuelas, costuras de cuero, las marcas del rancho, herraduras, todos de gran resistencia y con reminiscencias de la vida al aire libre, desempeñan un importante papel como fuente de inspiración para el diseño de lo que hubiera sido un homenaje sincero a la vida sana y honesta de los vaqueros. "284 (Bruce Goff, 1956 (1976), p.106)

279 Proyecto relacionado por Günther Feuerstein con otras propuestas eróticas de los años sesenta en su muestra para la Biennale di Venezia de 1996, "Visionäre Architektur in Österreich".

FEUERSTEIN, Günther. Visionary Architecture in Austria in the Sixties and Seventies. 1996. p.55.

280 También Ettore Sottsass Jr utilizará dos senos para diseñar su "Projet d'ecole maternelle" en 1973. A las propuestas fálicas de Archizoom o Hans Höllein se incorporarán proyectos posteriores despojados de esa búsqueda semántica como la "Daisy House" (1976/1977) diseñada por el norteamericano Stanley Tigerman.

281 Nicolas Schöffer recopiló toda su investigación en torno a la construcción de una Ciudad Cibernética en

SCHÖFFER, Nicolas. La Ville cybernétique. Volumen 91 de Bibliothèque Médiations. Denoël, Gonthier, 1972.

282 RAGON, Michel. Las ciudades del futuro. 1970 (1966). p.200.

283 JENCKS, Charles. Arquitectura 2000 . 1975 (1971). p.9. 
El hecho de incorporar motivos vaqueros ${ }^{285}$ en un edificio como homenaje a los vaqueros va en este caso más allá de la búsqueda de una forma que resuelva un programa ${ }^{286}$ y a la vez sirva de reclamo semántico. La palabra tributo y el programa de "salón de la fama" se inscriben perfectamente en la idea de monumento tratada con anterioridad, por lo que el proyecto demuestra una componente nostálgica en el cambio de escala. Construir una arquitectura a través de la estética de los vaqueros americanos resulta una estrategia similar a la generada por movimientos tan populares como la "Googie Architecture 287 " de finales de los años cuarenta y principios de los cincuenta en la costa oeste de los Estados Unidos. Influenciada por la cultura del automóvil y la era espacial, cuyos referentes populares eran series de televisión como los Jetson, este estilo arquitectónico incorpora recursos formales como geometrías paraboloides, luces de neón o formas redondeadas en edificios como moteles o restaurantes de carretera, a la manera que se presentan en los platillos volantes o estaciones espaciales imaginadas en las revistas populares de ciencia ficción y las series de televisión. La arquitectura se adapta formalmente a una estética determinada, cambiando de escala motivos "futuristas" sin ni siquiera tener que reproducir el objeto completo. Sin embargo, su período de obsolescencia es tan corto, que ya en los años sesenta estos edificios son considerados como nostalgia de una época, al cambiar radicalmente la estética espacial popularizada, gracias al desarrollo de la carrera espacial y a películas como "2001: A Space Odyssey" (1968) de Stanley Kubrick.

\title{
El potencial publicitario de los objetos. Edificios-anuncio.
}

Muchos de los ejemplos anteriores utilizan el recurso del cambio de escala a partir de su potencialidad proyectual pero quedan condicionados de esa manera por una forma que tampoco les confiere esa carga semántica o fácil identificación expresada anteriormente. El seno de Schöffer es demasiado abstracto para ser comprensible y las herraduras de Goff sólo son apreciables en un documento abstracto como es la planta. Esta controversia generada en torno al cambio de escala de un objeto utilizado como reclamo semántico publicitario por un edificio es el centro de la investigación llevada a cabo por Robert Venturi, Dennise Scott-Brown y Steve Izenour en su viaje de 1968 junto a estudiantes de la Universidad de Yale a Las Vegas. En "Aprendiendo de Las Vegas" (1972), compilación revisada de ese estudio, los arquitectos norteamericanos ensalzan esa capacidad

\begin{abstract}
284 "Inasmuch as the cowboy had never been identified with any particular style of building or architecture, it seemed appropriate to use characteristic design motifs of things he associated with in his daily life as elements from which a suitable grammar of architectural character could be realized. Hence forms, materials, colors and textures of saddles, spurs, leather stitching, ranch brands, horseshoes, all of robust ruggedness and with much feeling for great outdoors played their parts as inspiration for the design which would have been an honest tribute to the cowboys healthy and honest life"
\end{abstract}

SKY, Alison; STONE, Michelle. Unbuilt America: forgotten architecture in the United States from Thomas Jefferson to the space age : a book. 1976. p.106.

285 Este proyecto de Bruce Goff se ha reconstruido digitalmente, por lo que en el vídeo pueden apreciarse cómo todo el edificio se construye con cuero, tachuelas y demás referentes vaqueros:

"Bruce Goff, a creative mind", Museum of Art. Oklahoma. Del 9 de octubre de 2010 al 2 de enero de 2011.

286 El sistema del juego de las herraduras parece resolver bien en planta un programa de salas de exposiciones en torno a un núcleo central de instalaciones.

287 El origen del término "Googie Architecture" data del 1949, cuando el arquitecto John Lautner diseñó el café Googies en el "West Hollywood" con los rasgos característicos de este tipo de arquitectura. "Googie" era el apodo de Lillian K. Burto, la esposa del dueño original, Mortimer C. Burton.

HESS, Alan. Googie Redux: Ultramodern Roadside. Chronicle Books. Los Ángeles, 2004. pp.73-74. 
comunicativa de la arquitectura, perdida completamente durante el movimiento moderno, a partir de la utilización de la denominación "duck" o "edificio-pato":

"Cuando los sistemas arquitectónicos de espacio, estructura y programa quedan ahogados y distorsionados por una forma simbólica global. Llamaremos pato (duck) a esta clase de edificios -que se convierten en escultura-, en honor de (The Long Island Ducking), drive-in en forma de pato que ilustra Peter Blake en su libro God's Own Junkyard." ${ }^{288}$ (Venturi; Scott-Brown, 1972, p.114)

El edificio-pato se auto-legitima como edificio-anuncio y como recurso inagotable de futuro en proyectos necesitados de una capacidad comunicativa muy alta, en el contexto de edificios comerciales o representativos. A partir de "Aprendiendo de Las Vegas", estos ejemplos de edificio-pato derivados de la cultura popular serán referenciados con promiscuidad en revistas arquitectónicas. Ballenas convertidas en lavacoches ${ }^{289}$ [10D], plátanos gigantes ${ }^{290}[11 \mathrm{~A}]$, helados colosales ${ }^{291}$ [10C] O piñas monumentales ${ }^{292}$ [10B], construidos desde el anonimato, o aquellos construidos por arquitectos "de prestigio" de diversas latitudes, como el icono-depósito de naranjas "La Naranja Mecánica"293 [11E] diseñado en 1974 por los arquitectos y diseñadores catalanes del Grupo Abierto de Diseño, o los grandes almacenes [15A] proyectados en 1979 por el español Julio LaFuente como paquetes de regalos gigantes definidos como "exaltación alegre del consumismo"294.

En ese ámbito comercial-comunicativo, destacan los trabajos de Pier Goughs aún como estudiante en la Architectural Association, en los que sustituye elementos arquitectónicos concretos por objetos relacionados con los comercios en los que se insertan. El arquitecto británico utiliza cientos de cabezas de plástico con ojos iluminados para el escaparate de una óptica "Optician's Shop. 5th Year AA woks" (1971) [8C], unos zapatos convertidos en estanterías en "Sacha Shoe Shop" (1971) [7A] o la remodelación de la fachada de una tienda de ropa a partir de una simulación de telas plegadas construida mediante planchas de acero inoxidable onduladas en "Boston 151 Cloth Shop" (1971) [7D]. Estas estrategias también se aproximan a las antes citadas de la arquitectura "Googie" y la construcción de un "estilo". Otro proyecto de objetualización de interiores, el "Stand para Zanussi en la Mostra degli Elettrodomestici 1970" [6E] de Franco Mirenzi, aprovecha esa condición del cambio de escala para diseñar todo un stand de una feria como si de una gran bandeja de plástico se tratase, olvidando sin embargo la capacidad semántica del objeto que se queda en una

288 VENTURI, Robert; SCOTT-BROWN, Denisse; IZENOUR, Steven. Aprendiendo de Las Vegas. El simbolismo olvidado de la forma arquitectónica. Gustavo Gili. Barcelona, 1978 (1972). p.114.

El primer extracto de la investigación se publica en Architectural Forum con posteriores reproducciones casi simultáneas en revistas como la italiana Lotus o la alemana Werk:

VENTURI, Robert; SCOTT-BROWN, Denisse. A Significance for A\&P Lots, or Learning from Las Vegas. En: Architectural Forum, 128 n², marzo 1968. pp.37.43.

289 Car Wash. En: AD The Architectural Design, diciembre 1973. p.755.

290 Big Banana. En: AD The Architectural Design, mayo 1973. p.268.

291 Big Split. En: AD The Architectural Design, marzo 1973. p.136.

292 The world largest pineapple. En: AD The Architectural Design, septiembre 1972, p.537.

293 AGUAVIVES GARNICA, F; GOMÁ PRESAS, X; GRUPO ABIERTO DE DISEÑO. Proyecto de kiosko para la venta de naranjas. En: Cuadernos de Arquitectura y Urbanismo, no 103, julio-agosto 1974. p. 31

294 LAFUENTE, Julio. Progetto per un grande magazzino. En: Domus, n595, junio 06/1979. p.43. 
anécdota auto-referencial e incluso absurda, a pesar de resolver con solvencia el uso encomendado.

El auge del edificio-anuncio le convierte en protagonista del debate arquitectónico e incluso en pieza de arte a finales de la década de los setenta, en la que los proyectos construidos para la compañía de grandes almacenes "BEST Products" por arquitectos como Venturi, Rauch y Scott-Brown, SITE Architects con James Wines a la cabeza o Hardy, Holzman y Pfeiffer serán expuestos en el MOMA ${ }^{295}$ de Nueva York junto a nuevas propuestas para la marca diseñadas por Charles Moore, Stanley Tigerman, Allan Greenberg, Robert M. A. Stern, Michael Graves y Anthony Lumsden. La propuesta "The Best Home of All" [14E] de Stanley Tigerman, dibuja un nuevo prototipo de los almacenes Best a partir de un cambio de escala de la vivienda típica de los suburbios de cualquier ciudad norteamericana, convirtiéndose en crítica de un modelo y reclamo publicitario al mismo tiempo.

"El buzón BEST será igual que uno normal, sólo que cuatro veces más grande. La puerta del garaje se vería parcialmente abierta, al igual que en la realidad, y la puerta de entrada estaría también abierta de manera tentadora, revelando ese sueño americano hecho al fin realidad... con una estadounidense de 22 pies de altura maravillosamente bella como Mary Tyler Moore. Desde la autopista, el nuevo hogar de BEST tendrá argumentos contextuales de una vez por todas." ${ }^{296}$ (Tigerman, 1979, p.25)

\section{El potencial identitario de los objetos. Identidades reflejadas en edificios.}

En el ámbito de la vivienda, las estrategias de cambio de escala tienen en el famoso concurso "Shinkenchiku Residential Design Competition", convocado por la revista "The Japan Architect", un claro referente. El gran interés del mismo reside en su continuidad temporal, desde 1965 hasta nuestros días, y su temática relacionada con la vivienda, elegida por un arquitecto invitado que luego formaba parte de la dirección del jurado. En su etapa desde 1965 a 1975, los enunciados varían de escala de trabajo, desde una "Ciudad paralela a Tokio"297, como tema de 1966 propuesto por Kenzo Tange, hasta "Casa para una Superestrella" 298 en 1975 con Arata Isozaki como gran jurado. De esta manera, se intuye el cambio radical de la percepción no sólo de la escala desde la que se está repensando la vivienda, que va de una colectividad llevada al extremo en los grandes conjuntos metabolistas a la búsqueda de una vivienda unifamiliar para un cliente concreto $^{299}$, sino también de los 295 Exposición: "Building for Best Products", Museum of Modern Art, Nueva York, del 13 de Diciembre de 1979 al 10 de
Febrero de 1980, comisariada por Arthur Drexler bajo la proposición de Philip Johnson.

296 "The Best mailbox would be just like their very own, only four times as big. The garage door would be partially open, just like their own broken one, and the front door would be invitingly open as well, revealing an American-dream-come-true-atlast... A 22' tall beckoning fair one as American and as wonderfully wholesome as Mary Tyler Moore. From the highway, their Best new home would settle contextual arguments once and for all."

TIGERMAN Stanley. The Best Home of All. En: Buildings for Best Products. Museum of Modern Art. Nueva York, 1979. p.2225.

297 Winners in the Shinkenchiku residential Design Competition 1966. En: JA The Japan Architect, nº127, enero-febrero 1967. pp.27-65.

298 Winners in the Shinkenchiku residential Design Competition 1975. En: JA The Japan Architect, n²38, febrero 1976. pp.19-46. 
estándares bajo los que se realiza esta reformulación. Este cambio de actitud parte de estructuras que pueden responder a esta dicotomía entre público y privado de lo colectivo y se encamina hacia una vivienda que responde de manera representativa a la identidad totalmente determinada de una persona individual. En "Casa para una Super-estrella"1300, dos de los proyectos ganadores trabajan el tema de la identidad a partir de un proceso de objetualización, bajo la premisa de que la elección de una superestrella significa la de un objeto simbólico que le represente. De esta manera, Evel Knievel, piloto de acrobacias norteamericano, es simbolizado mediante una mega-motocicleta vivienda convertida en monumento, una casa-sección supeditada a la forma de una moto [12C]; por otro lado, David Bowie es sacralizado a partir de una vivienda como si de una cabina de teléfono Iondinense a gran escala se tratase, la misma en la que aparece metido Bowie en la trasera de su célebre disco de 1972 "Ziggy Stardust" [12E]. Ambas propuestas presentan los problemas de pre-figuración y fecha de caducidad del símbolo antes tratado. Mientras la motocicleta-vivienda se enclaustra en una forma que imposibilita ciertas aptitudes arquitectónicas y la convierte en una estatua habitada; la casa-cabina diseñada para Bowie depende de un objeto que ni siquiera guarda una relación unívoca con el cantante.

La búsqueda de identidad personal ${ }^{301}$ de la vivienda en comunión con la de sus ocupantes se vuelve más literal en las "Maisons solaires" (1974-1986) [12A] diseñadas por Guy Rottier. Dicha serie de viviendas se diseña a partir de las cabezas de sus amigos mediante un esqueleto común aparentemente geodésico y una cobertura exterior que simula los rasgos de cada uno de ellos. Kazumasa Yamashita utiliza un mayor grado de abstracción en su experimento de personalización para el diseño de "Face House" (1974) [11C], una vivienda cúbica que presenta una de sus fachadas de manera convencional-funcional y la otra como si de un rostro abstracto se tratase, a partir de la superposición de elementos arquitectónicos que simulan un rostro: la entrada será la boca, los ojos unas ventanas circulares y una chimenea la nariz. De manera análoga, Takefumi Aida busca la misma generación de rasgos antropomórficos ${ }^{302}$ a través de elementos arquitectónicos diseñando así una cara en estado de calma mediante unas ventanas circulares que alargan la sonrisa de la boca-puerta en la "Nirvana House" (1972) [8D] y una expresión de grito a través de una puerta alargada por una escalinata de fuerte pendiente en la "Annihilation House" (1972) [8E]. Esa búsqueda de transferencia de identidad personal a la arquitectura, ya sugerida por

299 La obsesión por la personalización y el carácter autónomo de la vivienda en particular y la disciplina arquitectónica en general Ilevará al Concurso Shinchenchiku a promover como lema "Una casa para Karl Friedrich Schinke/" en 1979.

Winners in the Shinkenchiku residential Design Competition 1979. A House for Karl Friedrich Schinkel. En: JA The Japan Architect, n²74, febrero 1980. pp.7-52.

300 El concurso servirá también para generar "Viviendas-Manifiesto" como la aplicación del proyecto "Suburban Sets", convirtiéndolo en una vivienda para la Reina de Inglaterra, "Sets fit for the Queen", con el que Ron Herron ganó el $2^{\circ}$ premio. Es interesante comprobar como el propio Herron había desarrollado ya en 1972 la ampliación de la vivienda de una Superestrella como Rod Stewart bajo preceptos similares.

COOK, Peter. Long steps short steps - Archigram projects 1973-1974. En: Casabella, n³98, febrero 1975. pp.20-31.

301 Esa identificación ha sido reinterpretada contemporáneamente en trabajos como el de Louis Hellman y sus ArchiTetes, ilustraciones de caras de arquitectos famosas dibujadas a partir de los elementos arquitectónicos más representativos de sus proyectos. Ver:

HELLMAN, Louis. Archi-Tetes: The ID in the Grid. Willey-Academy. Londres, 2000.

302 Dichos rasgos antropomórficos asociados a fachadas contemporáneas serán equiparados por Charles Jencks a ejemplos pasados como "Palazzo Facade via Gregoriana" (1592) diseñado por Federico Zuccaro en "The Language of PostModern Architecture" e incluso catalogados como "Face Houses" en el posterior "Bizarre Architecture".

JENCKS, Charles. The Language of Post-Modern Architecture. Rizzoli. Nueva York, 1977. p.16.

JENCKS, Charles. Bizarre Architecture. Rizzoli. Nueva York, 1979. pp.68-76. 
Höllein en su artículo "Allest ist Architektur" mediante la incorporación de una caricatura de Robert Grossman de un edificio construido con tuberías petrolíferas con la cara del presidente Lyndon Baines Johnson ${ }^{303}[4 \mathrm{~A}]$, deviene en continuos proyectos de casas metafóricas personalizadas para amigos artistas, médicos o filósofos, en un proceso narcisista y elitista, que muchos arquitectos desarrollarán a partir de mediados de los años setenta y que terminará dando el peligroso salto a la esfera de la vivienda pública colectiva.

\section{El potencial obsesivo de los objetos. Arquitectura de las obsesiones.}

Esta transferencia formal entre objetos y arquitecturas se irá convirtiendo poco a poco en un recurso puramente formal, en una dialéctica compositiva, perdiendo de esta manera el valor semántico para convertirse en mero juego proyectual. Líneas de investigación como la "Arquitectura Parlante"304 de Guy Rottier así lo atestiguan. El arquitecto francés opera mediante la búsqueda de asociaciones espaciales a objetos concretos, desde la utilización de serpientes enrolladas como cubrición de una casa enterrada en "Maison en terre stabilisée serpent" (1974) [11D], o la construcción de una vivienda en materiales plásticos aprovechando el espacio de una mano abierta a gran escala, en "Abri gonflable main" (1979) [15B], dónde incluye un objeto "pop" como el cigarrillo para utilizarlo a modo de chimenea dentro de este proyecto de refugio móvil. Se detecta además un alto valor de recurrencia en algunos de los objetos transferidos, de esta manera, el mismo espacio de la mano abierta será aprovechado por el británico Marc Balet en su proyecto de 1972 "Bleeding Arms Hotel"[9E]. Diversos antropomorfismos aparecerán también como recurso compositivo en planta, como la cabeza que articula la "Fountain House" (1975) [12D] de Silvetti y Machado o el cuerpo que distribuye la "Maison des Jeunes" (1972) [10A] de Ricardo Porro, e incluso en volumen, como en la "Ciudad de Vacaciones en Vela Luca" (1972) [9C] del mismo arquitecto cubano. En este último ejemplo, Porro evoca un edificio-hombre saliendo del agua en el que todas las funciones se reparten por el cuerpo a partir de una analogía con las funciones vitales; la administración se sitúa en la cabeza, el restaurante en el vientre y los espacios sociales en las manos. Antropomorfismos gigantes escultóricos también son también utilizados como recurso paisajístico en el "Playboy club. 5th Year AA woks ${ }^{305 " ~(1972) ~[9 D] ~ d e ~}$ Paul Shephard.

Más allá de los recursos antropomórficos, otros muchos objetos cotidianos se convierten en referentes formales recurrentes, desde el automóvil, uno de los iconos pop por excelencia, al huevo ${ }^{306}$, adorado por artistas surrealistas como Dalí, y sobre el cual el arquitecto francés

303 HÖLLEIN, Hans. Alles ist Architektur. En: Bau, Heft 1/2, 1968. p.5.

304 El término "Architecture Parlante" se le atribuye a Ledoux, para denominar aquellas arquitecturas que explicitan su propia función o identidad.

305 Además de las líneas de trabajo de arquitectos particulares, ya sea el francés Guy Rottier, el norteamericano Bruce Goff, el austríaco Hans Höllein o el cubano Ricardo Porro, es interesante comprobar como en escuelas como la Architectural Association también empezarán a proliferar los proyectos que trabajan la estrategia del cambio de escala desde una perspectiva de la evocación programática.

GOWAN, James (editor): Projects. Architectural Association. 1946-71, AA Cahiers series No.1. Architectural Association Press. Londres, 1972.

306 Ya en 1963, también Michel Ragon en su mirada obsesiva por la "nueva" arquitectura-escultura admite:

"Entre las formas naturales, el huevo es la que parece llamada a un mayor porvenir arquitectónico"

RAGON, Michel. ¿Dónde viviremos mañana?. 1966 (1963). p.90. 
André Bruyère escribe todo un tratado en $1978^{307}$. En él presenta estudios en planta para una casa-huevo en "Maison Oeuf" (1969) [6B], su propuesta para el famoso concurso del nuevo centro Georges Pompidou en París de 1971-1972 [8B] o un rascacielos para la ciudad de New York en 1978 [13E], todos ellos basados en diversos cambios de escala de la geometría del huevo. También Guy Rottier diseña un museo en homenaje a Cristóbal Colón en 1986 [16A] formalizado en un huevo geodésico de proporciones colosales.

Una obsesión similar llevará al japonés Takefumi Aida a diseñar toda una serie de viviendas, las "Toy Block Houses" [14A]. En la primera de ellas, construida en 1978, Aida utiliza las piezas de los juegos de construcción de niños pero de dimensiones mucho mayores. En sus viviendas sin embargo, esta transformación de las piezas es simplemente formal, ni programática ni estructural, pervirtiendo así las características esenciales del juego como son la versatilidad de las piezas para asociarse y las distintas configuraciones posibilistas derivadas de las mismas. De manera análoga, el automóvil también pierde sus capacidades como objeto-máquina cuando es usado como simple imagen más o menos reivindicativa dentro de la estrategia de cambio de escala. En el proyecto "Casa-Coche" (1973) [10E] Dieter Smekal pretende dotar a la vivienda del mismo carácter simbólico del automóvil convirtiendo en un coche a gran escala una de las viviendas de un suburbio anónimo, en un trabajo presentado en la muestra "Konfrontationen ${ }^{308 " ~ e n ~ l a ~ " G e s e l / s c h a f t ~ f u ̈ r ~ A r c h i t e k t u r " ~ d e ~}$ Viena. De una manera parecida, Paul F. Galdone, aún estudiante de Raimund J. Abraham en la Rhode Island School of Design, formaliza "Wolkswagen Environment" [6C] como un automóvil aumentado de escala construido como una vivienda móvil neumática dependiente de los sistemas de movilidad y electricidad del propio automóvil, aunque a pesar de ello, sin dejar de convertirse en un auto-homenaje un tanto absurdo.

\section{El espacio público como monumento. La nostalgia del cambio de escala.}

Si el cambio de escala sirve en la década de los sesenta como pretexto para una reivindicada apertura formal de la arquitectura y una re-definición del concepto de monumento en un intento de desacralización del espacio público, su uso parece sin embargo producir el efecto contrario, siendo cualquier tipo arquitectónico susceptible de convertirse en "monumento".

En este sentido, en la propuesta para la "Piazza Italia" (1975-78) [13A] de Nueva Orleans, ideada por Charles Moore, toda la plaza se diseña como un remake de monumentos históricos de Roma, conectados por una gran fuente topográfica generada a partir de la silueta del país, en un acto de sobre-estimulación semántica de una "romanidad clásica" impostada:

"Una segunda manifestación del post-modernismo ilusionista histórico puede verse en el diseño de edificios enteros a partir del estado de ánimo de un momento anterior de la historia. Así, la Piazza d'Italia de Charles Moore, encargada por un grupo de italoamericanos como elemento decorativo a la entrada de una anodina torre de oficinas, evoca los monumentos originales de Italia, como lo hacen las imágenes de la

307 BRUYÈRE, André. L'Oeuf / The Egg. Albin Michel. París, 1978.

308 Da Vienna. Ideas Exhibition. En: Domus, n537, agosto 08/1974. pp.20-21. 
arquitectura de ese país que hemos recibido de las películas de Hollywood." "309 (Robert A. M. Stern, 1977, p.131)

En este proyecto, el arquitecto norteamericano Charles Moore, no sólo cambia de escala unos monumentos a partir de las reproducciones que de ellos han quedado en el imaginario colectivo a través del cine norteamericano, sino que además los referencia de manera redundante al nombre de la plaza y al país en el que se encuentran. Esta monumentalización del espacio público es contradictoria por dos razones fundamentales, por un lado, porque la referencia histórica no sólo depende de la obsolescencia del propio valor semántico de esas arquitecturas, que por el texto de Stern se deduce que caducarán cuando se acaben las películas de romanos en el cine, metiéndose así de lleno en el concepto de "Moda Nostalgia", sino además, por convertir el espacio público en monumento a partir de la expresión de la fuente Italia, imagen que unifica el conjunto pero que no tiene ninguna relación histórica con los monumentos que se presentan, construidos cuando Italia no era ni siquiera Italia, una asociación simbólica que en el pasado había sido utilizada de manera análoga por artistas como Luciano Fabro en su obra "L'Italia d'oro" [5C] (1968-1971), una silueta en bronce de Italia colgada de una soga simbolizando las contradicciones identitarias de la Italia actual, en este caso la de 1970.

\footnotetext{
309 "A second manifestation of post-modernist historical illusionism can be seen in the infusion of the design of entire buildings with the mood of a previous moment in history. So it is that Charles Moore's Piazza d'Italia, commissioned by a group of Italian-Americans as an embellishment to the forecourt of an undistinguished office tower, as much evokes the genuine monuments of Italy, as it does the images of that's country's architecture we have received on celluloid from Hollywood."
}

STERN, Robert A.M. New Directions in American Architecture. Revised Edition. George Braziller. Nueva York, 1977. p.131. 


\section{Catálogo // [Hipergráfica]}

Las imágenes están referenciadas por números en la zona superior de las columnas verticales [del 1 al 20] y letras en la zona izquierda de las filas horizontales [de la A a la E].

Todas las referencias están ordenadas cronológicamente.

Referencias de imágenes del [1B] a [20E]. Cada uno de los proyectos referenciados gráficamente en el catálogo presentan antes de su nombre un código con un número en relación a su columna vertical y una letra en relación a su fila horizontal.

\section{Ejemplo:}

[7E] "Cloud 9" (1962) de Buckminster Fuller. Buscar referencia en la columna 7 y la fila E del catálogo referenciado al principio del capítulo.

[Nota]: no todos los referentes gráfico del catálogo están referenciados en el texto por lo que se recomienda una lectura del mismo antes de comenzar la del propio texto.

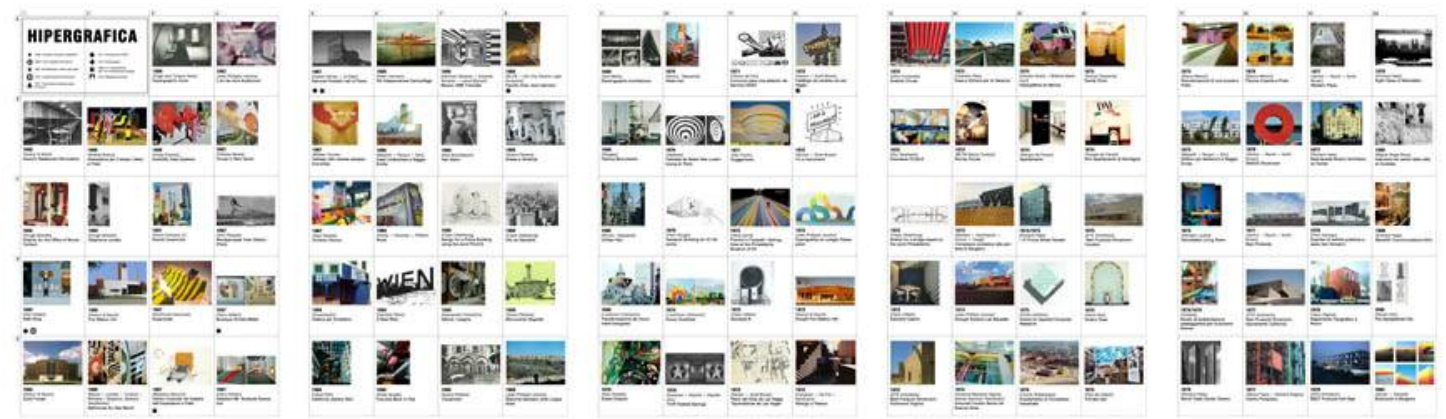




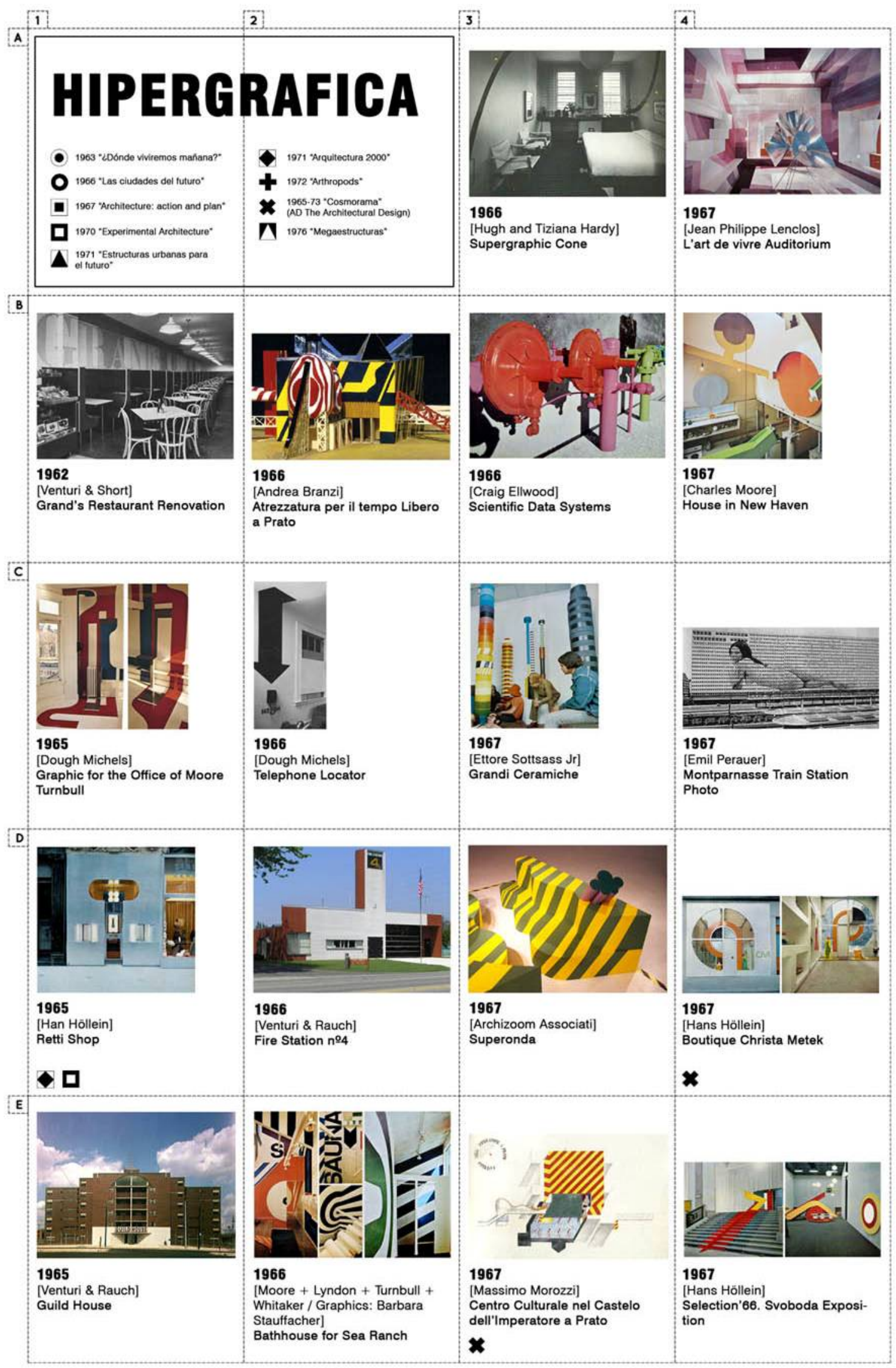




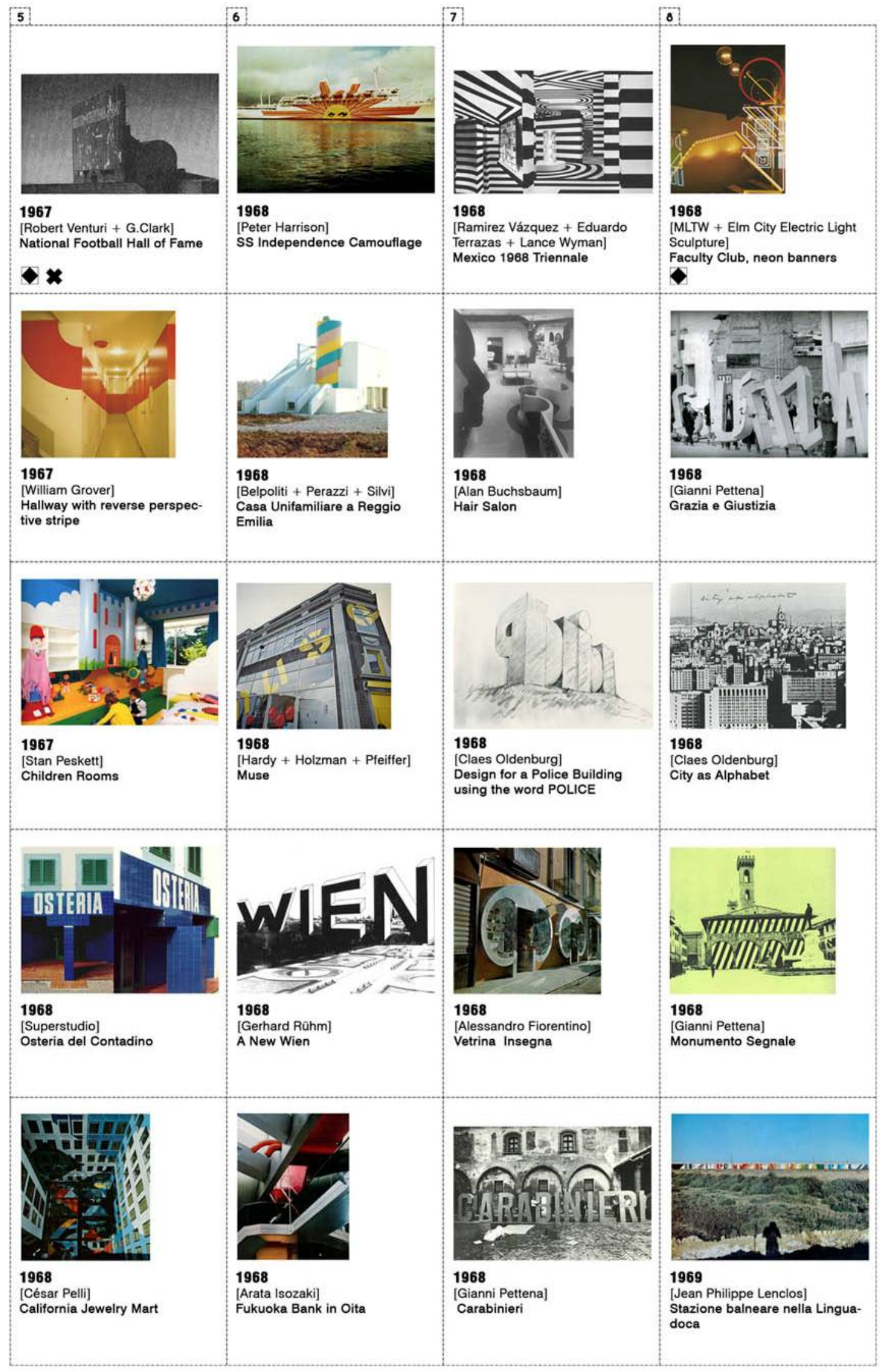




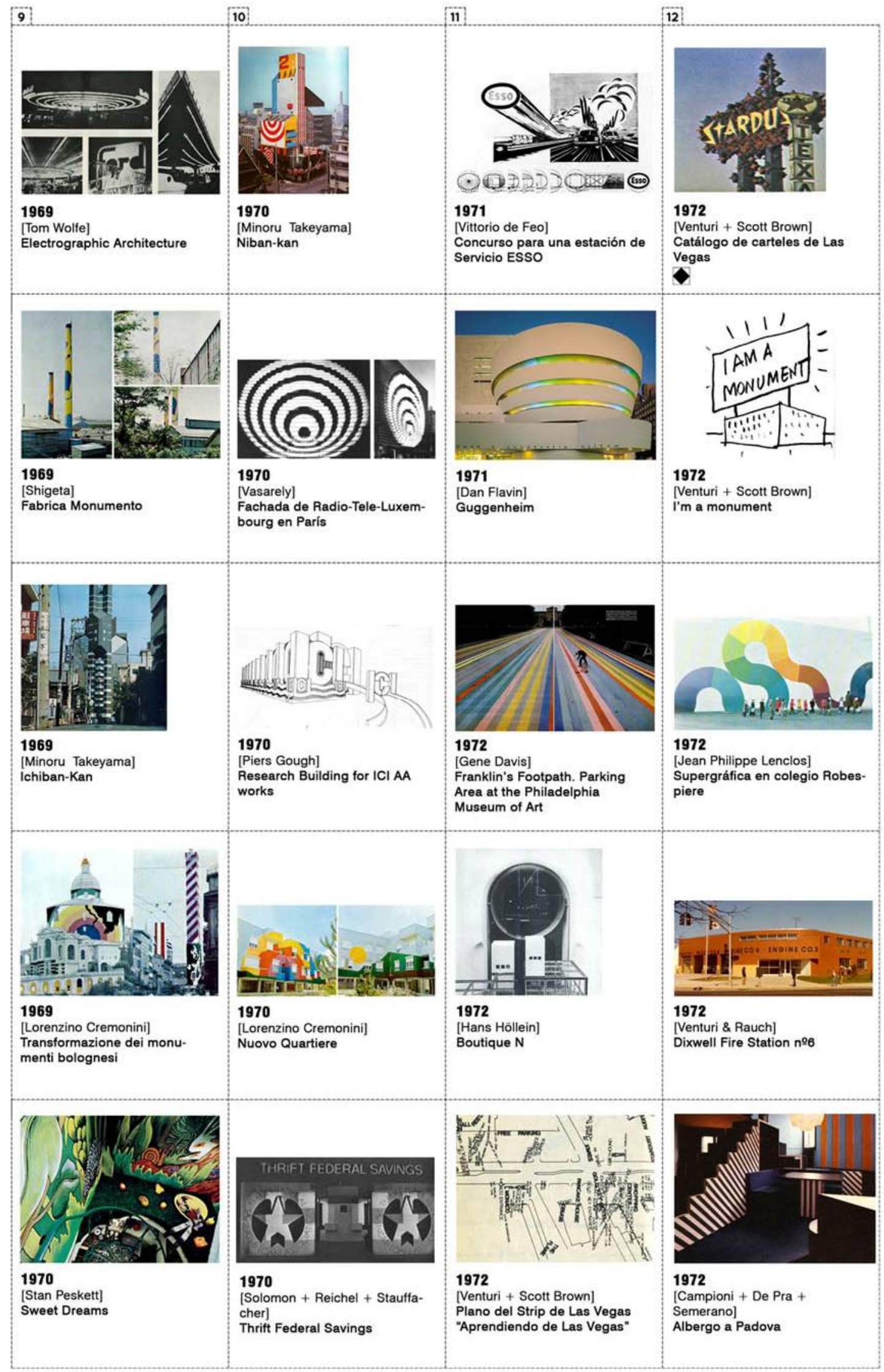




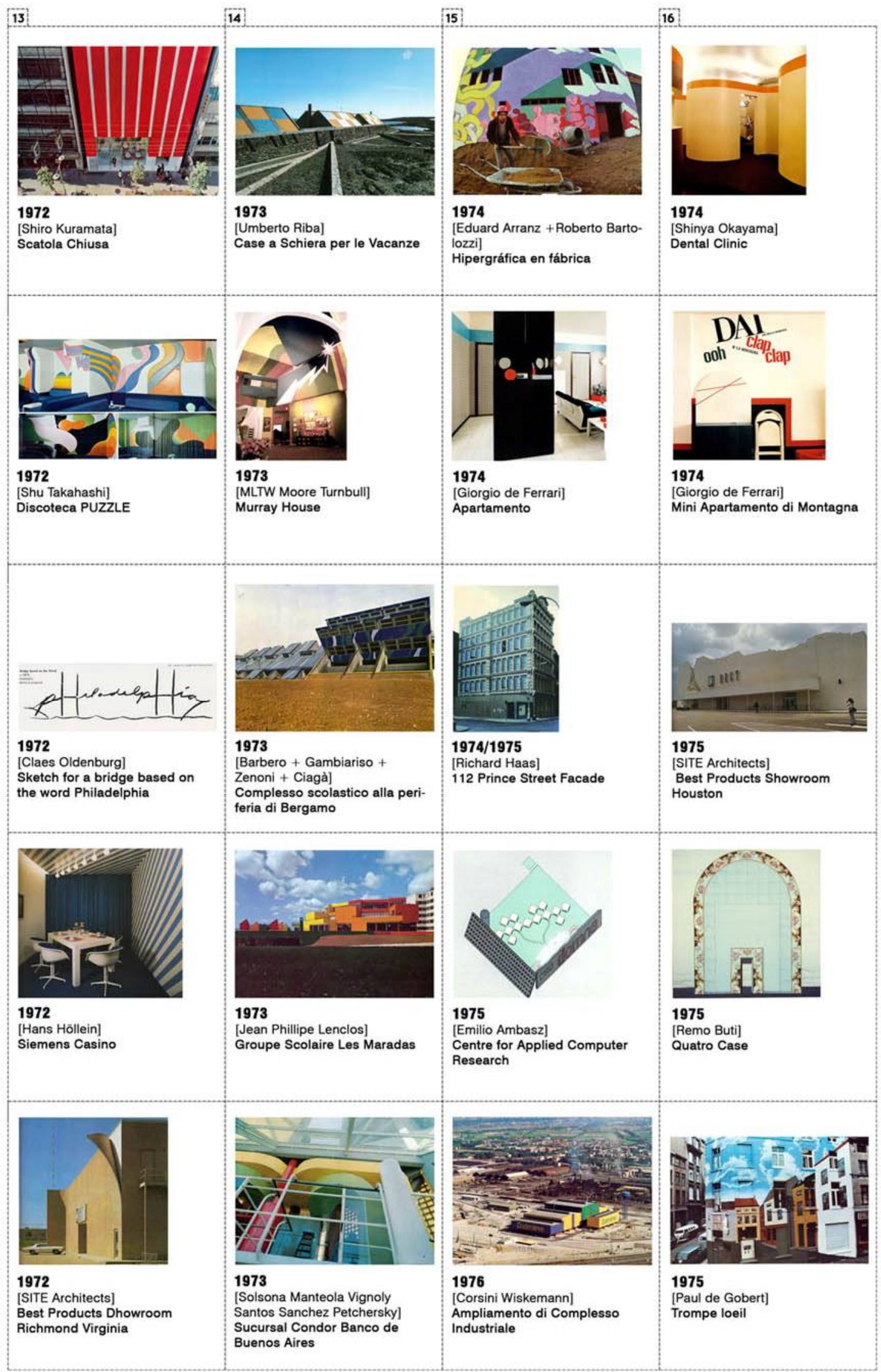




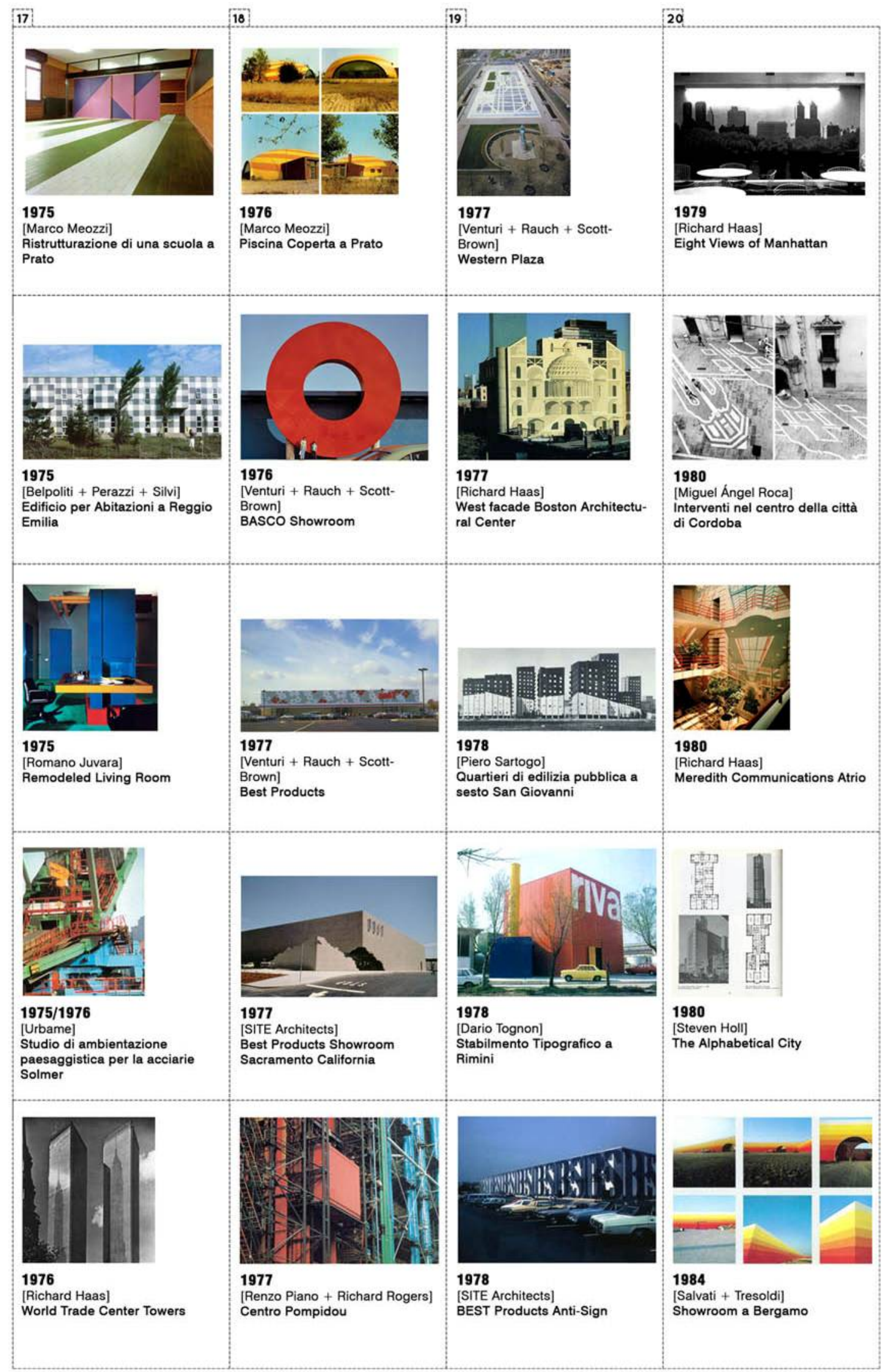




\section{[Hipergráfica] \\ Cuando la gráfica se convierte en arquitectura.}

Durante la primera mitad del siglo XX, el blanco, que simboliza la ausencia de ornamento que Adolf Loos promulgaba en su famoso texto de 1908 "Ornamento y Delito", se convirtió en el color protagonista de gran parte de la arquitectura del movimiento moderno. Ya sea por las distorsiones surgidas por la manera en la que esta arquitectura se exponía en los medios de comunicación de masas como defiende Beatriz Colomina en "Privacidad o Publicidad. La arquitectura moderna como Medio de Comunicación de Masas"310 (1994), o entendido como una vestimenta nueva u ornamento codificado para expresar una serie de propiedades concretas, como explica Mark Wigley en "White Walls, Designer Dresses, The Fashioning of Modern Architecture" (1995), la ausencia de color manifestada por el color blanco aparece como signo de identidad castrador durante gran parte del siglo XX.

"Vi cómo los antiguos habían construido y cómo siglo tras siglo, año tras año, se habían emancipado de la ornamentación. Por lo tanto tuve que retomar desde el punto en el cual la cadena se había roto. Una cosa que supe: para permanecer en el camino de este desarrollo, la arquitectura tenía que ser aún más sencilla." 311 (Adolf Loos, 1910)

"El ornamento es un crimen, como un tatuaje en un cuerpo humano, un signo de degeneración." ${ }^{312}$ (Adolf Loos, 1908)

"Toda la moral, la superioridad ética, funcional e incluso técnica de la arquitectura moderna se ve adornada por la blancura de sus superficies."1313 (Mark Wigley, 1995, p.15)

Esta nueva manera de vestirse de la arquitectura moderna parecía sin embargo bastante incompatible con la ansiada búsqueda de una equiparación de la experimentación arquitectónica en relación a otras artes y con la antes citada ansiada relación con la cultura material de una incipiente sociedad de consumo. Desde mediados de los sesenta y principios de los setenta, la arquitectura "intelectual" empieza a llenar sus elementos arquitectónicos, tanto exteriores como interiores, de grandes flechas, letreros enormes, números gigantes, trazados geométricos y sobre todo color $^{314}$, desafiando así el carácter

310 COLOMINA, Beatriz. Privacidad y publicidad: La arquitectura moderna como medio de comunicación de masas. CENDEAC. Murcia, 2010. Ed. original: Privacy and Publicity. Modern Architecture as Mass Media. The MIT Press. Cambridge, 1994

311 LOOS, Adolf. Architektur (1910). En: GRAVAGNUOLO, Benedetto. Adolf Loos: Teoría y obra. Editorial Nerea. San Sebastián, 1988 (1982). p.27.

312 LOOS, Adolf. Ornament und Verbrechen (1908). En: GRAVAGNUOLO, Benedetto. Adolf Loos: Teoría y obra. 1988. p.22.

313 "The whole moral, ethical, functional and even technical superiority of modern architecture is seen to hang on the whiteness of its surfaces"

WIGLEY, Mark. White Walls, Designer Dresses. The Fashioning of Modern Architecture. MIT Press. Cambridge, 1995. p.15.

314 Un color que protagonizará incluso textos-manifiesto como: 
monocromo moderno y equiparándose con aquella arquitectura comercial mundana a través de una serie de estrategias gráficas, que el crítico de arte Ray C. Smith denominará como "Supergraphics"1315. Sobre esas gráficas de gran formato Smith publica varios artículos a finales de los años sesenta en la revista Progressive Architecture. Si bien el prefijo "Super" se populariza en la década de los años veinte y treinta como signo de exclamación, éste adquirirá un valor superlativo en los sesenta. Ya en 1957, Bergen y Cornelia Evans escriben sobre él":

"Es una interesante reflexión sobre nuestro tiempo democrático y de producción en masa, que el prefijo súper, especialmente en Estados Unidos, deba ser sin reservas un término de elogio. Cualquier cosa, lo que está por encima de lo normal o es excesiva, al parecer admirable, lo adquiere. Tenemos supermercados, superautopistas, super-estaciones de servicio, y superhéroes..."116 (Bergen y Cornelia Evans, 1957)

El concepto "supergráfica" sugiere a la vez un cambio de escala y ese valor superlativo tan utilizado por la cultura pop, así como el carácter superficial de una gráfica utilizada como "nueva" manera de revestir la arquitectura. Así es como la supergráfica enlaza con "el principio de revestimiento"317 de Semper y el origen textil de la arquitectura. Muchos arquitectos incorporan esta gráfica superlativa como una herramienta proyectual efectista, semántica, contemporánea y barata, a pesar del valor residual que hasta ese momento se le había dado en la concepción de los edificios, como expresa de esta manera el argentino César Pelli:

"La Supergráfica es una cosa menor, pero... se trata de una ampliación de la gama de lo que supone la arquitectura. Pintar solía ser algo que estaba fuera de los límites de la disciplina. Por lo que esta nueva situación supone una ruptura, pensar que en sí mismos los colores pueden convertirse en arquitectura. Es una herramienta más. No es la respuesta a todo, pero en muchos casos es la mejor respuesta."1318 (César Pelli, 1971, p.30)

MIKELLIDES, Byron; PORTER, Tom. Color for Architecture. Studio Vista. Londres, 1976.

Manifiestos llegados desde ámbitos divergentes, en este caso también de la pintura, de mano de Fernand Léger:

LÉGER, Fernand. Fonctions de la peinture. Gonthier, Meditations. París, 1965.

Para nuevas percepciones en el uso color y su relación con la ciudad. Ver:

DOHERTY, Gareth. New Geographies vol.3. Urbanisms of Color. Harvard University Press. Boston, 2010.

315 SMITH, C.Ray. Supergraphics. En: PA Progressive Architecture, noviembre 1967. p.132-137.

316 "It is an interesting reflection on our democratic and mass-produced times that the prefix super, especially in America, should be so unreservedly a term of commendation. Anything, which is above the ordinary or is excessive is, apparently admirable. We have supermarkets, superhighways, super service stations, and superheroes..."

Cita de Bergen y Cornelia Evans en:

SMITH, C. Ray. Supermannerism: new attitudes in post-modern architecture. Dutton. Nueva York, 1977. p.221.

317 FANELLI, Giovanni; GARGIANI, Roberto. El principio del revestimiento. Prolegómenos a una historia de la Arquitectura Contemporánea. Akal. Madrid, 1999.

318 "Supergraphics is a minor thing, but... it is a widening of the range what architecture is. Paint used to be something outside in the pale. And this is a breaking from that- that colors in themselves can become architecture. It is one more tool. It is not the answer to everything but in many cases it is the best answer" 
A pesar de la demonización a la que los recursos gráficos habían sido sometidos durante el movimiento moderno, estas estrategias presentan claros y exuberantes referentes históricos, desde las grandes inscripciones en los edificios de las culturas prehispánicas o de los indígenas de Norteamérica, pasando por el trompe l'oeil, siendo incluso utilizada en las obras de agentes inmersos en el movimiento moderno como el mexicano Juan O'Gorman en la Biblioteca de la UNAM (1949-1955), recubierta con un mosaico de piedras naturales que evoca una simbología derivada de la tradición prehispánica, tratamiento que también utilizó para la construcción de su propia vivienda en 1956.

\section{La supergráfica como revestimiento. Distorsiones espaciales, técnicas de camuflaje y renovación urbana.}

Uno de los primeros ejemplos de utilización de supergráfica como forma de revestimiento interior $^{319}$ aparece en 1962 de la mano de Venturi y Short, en la renovación del restaurante "Grand's" [1B] en Philadelphia. A lo largo de las paredes laterales interiores, fueron pintadas las letras del nombre del establecimiento en gran tamaño sobre un fondo de cuadrados blancos y grises. De esta manera ese nombre se convierte en la decoración de todo el espacio. A pesar de ser un proto-experimento, el proyecto demuestra esa capacidad de la gráfica para convertirse en protagonista del espacio arquitectónico.

En proyectos posteriores como "Graphic for the Office of Moore Turnbull" (1965) [1C] diseñado por Dough Michels, se explotará la capacidad escalar de los supergráficos, al convertirlos en estrategias de camuflaje de elementos arquitectónicos indeseados, en este caso, un trazo rojo y blanco convierte estanterías y radiadores en piezas más integradas con la pared del estudio, o de distorsión, al abandonar la diferenciación clásica de muro y suelo para unificarlos y confundirlos a través del gráfico de gran formato. Al mismo tiempo, Charles Moore se encuentra realizando por aquella época su proyecto para el Sea Ranch (1965- 1966) con su estudio MLTW ${ }^{320}$, para el que encargan la "decoración" de la sala de baños "Bathhouse for Sea Ranch Condominium" (1966) [2E] a Barbara Stauffacher. La artista llena el espacio de líneas de colores, flechas y letreros que enfatizan las complicadas relaciones espaciales y estructurales del edificio. Este proyecto supone el inicio ${ }^{321}$ de una serie de artículos de Ray C. Smith sobre supergráfica a finales de los sesenta en "Progressive Architecture". A pesar de que el edificio ya se había publicado con anterioridad en la revista ${ }^{322}$, este artículo centra la atención en los supergráficos realizados por Bárbara para el interior de la sala de baños. Ambos artículos denotan también las dificultades que encuentran los proyectos de supergráficos para ser representados en revistas fundamentalmente impresas en blanco y negro, volviendo a refrendar así las teorías defendidas por Colomina sobre la despigmentación de la arquitectura en relación a la manera en que se difundía a través de los mass-media. Un año más tarde, en el proyecto para su propia casa, "House in New Haven" (1967) [4B], el propio Moore, que se había trasladado de Berkeley a Yale para hacerse cargo del departamento de arquitectura de esa universidad, sacará mayor partido aún de la capacidad de cambio de escala, distorsión y camuflaje de la supergráfica, al convertir toda la vivienda en un verdadero campo de

Supergraphics. Special Report. En: Approach, spring 1971. p.30.

319 Obviamente vinculada a autores de prestigio y no como la denostada "arquitectura comercial".

320 Moore, Lyndon, Turnbull and Whitaker.

321 SMITH, C.Ray. Bathhouse graphics. Make it happy, kid. En: PA Progressive Architecture, marzo 1967. pp.158-161.

322 Thirteenth Annual P/A Design Awards. En: PA Progressive Architecture, enero 1966. 
experimentación de esos recursos formales. Los gráficos adquieren aquí un carácter tridimensional al ser combinados con todo tipo de aberturas, volúmenes u objetos asociados a los mismos. Ese proyecto coincide además con la popularización de esta manera de "revestir" la arquitectura, a partir de la publicación de varios supergráficos en la revista LIFE del 3 de Mayo de 1968, dónde ya Moore expone de manera explícita la capacidad de juego de estas estrategias:

"Moore llama a los supergráficos: un dispositivo magnífico para jugar con la escala. Convierten una habitación en un juguete. ${ }^{.1323}$ (Moore, 1968, p.82)

En la citada casa que Moore diseña para sí mismo, destacará el diseño del hall principal, en el que aparecen una serie de discos gigantes recortados y superpuestos en diferentes planos, algunos de ellos fuertemente coloreados, generando una gran variedad de relaciones visuales distorsionadas con el resto de la vivienda, sobre las que el propio Moore explica en este párrafo:

"Quería que estos gráficos formaran parte de un mundo cada vez más grande. Es una manifestación tardía del complejo Piranesi. El siglo XVIII se esforzó por dibujar a la gente demasiado pequeña, y yo pensé que podía conseguirlo, haciendo los gráficos dos veces más grande. Aparecen de esta manera como grandes ruedas girando sobre ti. ${ }^{1124}$ (Moore, 1967, p.159)

Esta manera de usar la supergráfica como estrategia heredera de Piranesi, se encuentra entre el grupo de "habilidades arquitectónicas" denominadas por C. Ray Smith como "Supermannerism ${ }^{325 "}$ o supermanierista, por sus condiciones superlativas relativas al uso del cambio de escala y los juegos formales que la emparentan con el manierismo, comparación ya evidente en "Complejidad y Contradicción en la Arquitectura" (1966) de Venturi. Esos continuos juegos interiores aparecen en intervenciones como las distorsiones perspectivas usadas por William Grover en "Hallway with reverse perspective stripe" (1967) [5B], en el que dibuja una línea roja en contra de la perspectiva a lo largo de un pasillo de siete puertas y nueve metros de longitud para reducir la extensión visual del mismo, o las ilusiones ópticas diseñadas por Hugh y Tiziana Hardy como "Supergraphic Cone" (1966) [3A], un cono generado mediante anamorfosis para su propio apartamento de Nueva York, sólo visible desde una posición determinada. Paralelamente aparecen también distorsiones de escala en la relación a elementos concretos dentro del ámbito de la vivienda como "Telephone Locator" (1966) [2C] de Dough Michels, una gran flecha de pizarra que sitúa al teléfono como elemento principal de su casa de New Haven. Muchas de estas intervenciones se emparentan con las experimentaciones llevadas a cabo en los sesenta en el contexto del Op

323 "Moore calls supergraphic: a magnificent device for playing with scale. They make a toy out of a room."

It's Supergraphics! En: Life, 3 de Mayo de 1968. pp.79-82.

324 "I wanted these graphics to seem like part of an ever bigger world. It is a latter-day manifestation of a Piranesi complex. The 18th Century got its kicks by drawing the people too small, and I thought I could get mine by making the graphics twice too big. These are like pieces of great whee/s rolling around and grinding over you"

SMITH, C. Ray. Implications of Giants. En: PA Progressive Architecture, mayo 1967. pp.147-160.

325 Cuyo libro manifiesto es:

SMITH, C. Ray. Supermannerism: new attitudes in post-modern architecture. Dutton. Nueva York, 1977. 
Art "optical art" y los trabajos de ilusiones ópticas de Víctor Vasarely, Briget Riley y Supernova o el conceptualismo de artistas como Sol Lewitt.

De manera simultánea al nacimiento del concepto "Supergraphics" aparece en Italia el término "Superarchitettura", acuñado por los miembros primigenios de los grupos de arquitectos florentinos Archizoom y Superstudio:

"La Superarquitectura es la arquitectura de la superproducción, del superconsumo, de la superinducción al consumo, del supermercado y de la gasolina super." 326 (Archizoom, Superstudio, 1966)

En la segunda exposición de "Superarchitettura" ${ }^{27}$, varios de los proyectos asociados a esta nueva manera de hacer arquitectura utilizarán estrategias de supergráfica, tanto en la imagen exterior de las propuestas, como ocurre en el "Centro Culturale nel Castelo dell'Imperatore a Prato" (1967) [3E] de Massimo Morozzi o la "Atrezzatura per il tempo Libero a Prato" (1966) [2B] de Andrea Branzi ${ }^{328}$, como en otros proyectos de interiorismo. La supergráfica invade incluso el propio mobiliario diseñado para la exposición, destacando entre los objetos expuestos un prototipo del sofá "Superonda" (1967) [3D] de Archizoom, comercializado posteriormente por Poltronova. Tanto unos como otros presentan estampados superficiales de ondas o juegos geométricos de intensos colores como forma de adhesión Pop a la sociedad de consumo a la que iba encaminada esa nueva "Superarquitectura". De todos ellos, sólo Superstudio experimenta en 1968 con la supergráfica de manera real en un proyecto de remodelación de una pequeña hacienda y su reconversión en comedor de una empresa, camuflando una columna al convertirla en parte del cartel de entrada en la "Osteria del Contadino" [5D]. Desde 1968 hasta mediados de los setenta, Italia se consolidará como centro de experimentación de estas supergráficas, con ejemplos muy variados y una amplia difusión en revistas como Domus y Casabella ${ }^{329}$.

La internacionalización del uso de la supergráfica genera el contexto para un vasto campo de experimentación en torno a esos "efectos especiales hiper-gráficos", como por ejemplo en "L'art de vivre Auditorium" (1967) [4A] de Jean Philippe Lenclos, en el que a un volumen ortogonal escalonado tanto en planta como en sección, el autor superpone una geometría diagonal, generando una indefinición del volumen así como una percepción visual de amplitud en un recinto muy reducido. La supergráfica no solamente invade las tipologías relacionadas con el ocio y el comercio, también da el salto a la vivienda del lado del "Do It

326 "La superarchitettura è la architettura della superproduzione, del superconsumo, della superinduzione al superconsumo, del supermarket, del superman e della benzina super"

Branzi, Corretti, Deganello, Morozzi e Natalini, alla galleria Jolly2, via s.Bartolomeo 17, Pistoia, dal 4 al 17 dicembre 1966. Cartel de la exposición "Superarchitettura".

327 A la primera exposición de Pistoia de Diciembre de 1966 le sucede otra en Módena en marzo de 1967, con una ampliación de miembros de ambos colectivos y hasta 10 proyectos asociados a los mismos.

328 Ambos, proyectos finales de carrera de dos de los miembros de Archizoom con el profesor Domenico Cardini.

329 Referencio aquí alguno ejemplos en ambas revistas (además de los ya referenciados):

CAMPIANO, Adriano. Architettura Compressa. En: Casabella, n³71, noviembre 1972. pp.51-56.

Due ipotesi di organizzazione sulla struttura dei percorsi. En: Casabella, n³76, abril 1973. pp.36-44.

BELPOLITI, Maurizio; PERANZI, Arturo; SILVI, Sandro. Due episodi nel paesaggio. En: Domus, n585, septiembre 09/1978. pp. 10-15. 
Yourself", coincidiendo con el boom en los años setenta de los libros de decoración ${ }^{330}$, como una estrategia sencilla y barata de personalización del espacio doméstico.

Mientras la supergráfica en interiores va encaminada a la generación de juegos perspectivos y distorsiones espaciales, su influencia en el exterior de los edificios presenta una labor más cercana al camuflaje. En la rehabilitación del "California Jewelry Mart" (1968) [5E], César Pelli propone la utilización de grandes formas geométricas en tonos blancos y azules con pequeñas áreas de rojos y amarillos en las paredes de un patio interior, combinados a su vez con unos lucernarios de vidrio-espejo en la zona inferior del mismo, que, junto a las sombras proyectadas, generan un paisaje interior caleidoscópico. Una estrategia parecida será utilizada por el arquitecto Lorenzino Cremonini en 1970 para el diseño de un "Nuovo Quartiere" [10D] en San Pietro in Casale. En este proyecto se aborda el exterior de varios edificios de un nuevo barrio a partir de una mezcla de dibujos geométricos de vivos colores que se desintegran y mezclan con elementos naturales figurativos como arcoíris, soles y nubes, que "hacen desaparecer la arquitectura, exaltándola a la vez"1131. Piero Sartogo por su parte, utiliza en el "Quartiere di edilizia pubblica a Sesto San Giovanni" (1972-1978) [19C] una gráfica bicolor con blanco en la parte inferior y negro en la superior para hacer desaparecer esta última del gran volumen de los edificios de hasta quince plantas en un barrio obrero de Italia.

Las estrategias proyectuales de supergráfica exterior se diversifican y combinan las técnicas de camuflaje, distorsión y cambio de escala antes citadas con la reformulación de soluciones pictóricas históricas como el trompe l'oeil ${ }^{332}$. En este sentido destacan los trabajos de arquitectos como Richard Haas o Paul Gobert, recuperando las posibilidades de estas técnicas tanto en interiores como exteriores, a través de diversos juegos visuales arquitectónicos. Un ejemplo significativo es el trabajo de Haas, superponiendo las secciones dibujadas en las fachadas de los edificios, en "West facade Boston Architectural Center" (1977) [19B].

Uno de los mayores potenciales de la supergráfica se revela en su capacidad de renovación urbana a través de la pintura colectiva de grandes murales, debido a su efectivo cambio instantáneo y a la generación de comunidad al poder desarrollar el proceso de pintura como un acto colectivo:

"Otra razón para el fomento de la decoración exterior es que genera la palabra participación. Con la pintura, la propia comunidad puede actuar. Lee Harris Pomery explica. Ellos no pueden construir edificios y poner ladrillos, pero pueden pintar. Eso tiene un valor real social." ${ }^{333}$ (C. Ray Smith, 1977, p.197)

330 Por citar algunos de estos libros de decoración de éxito popular, se han consultado:

FISHER, Karen. Living for today. Viking. Nueva York, 1972.

BETTER HOMES AND GARDENS (editor). Better Homes and Gardens Decorating Book. Meredith Corporation. Nueva York, 1975.

331 CREMONINI, Lorenzino. Costruito in campagna, fuori Bologna. En: Domus, n505, diciembre 12/1971. p.10.

332 Trompe l'oeil. New Pesrpectives. En: Domus, n543, febrero 02/1975. pp.41-43.

LAPIETRA, Ugo. Richard Haas, l'architettura dipinta. En: Domus, n593, abril 04/1979. pp.27-29.

DORFLES, Gillo. Decorazione Trompe L'oeil. En: Domus, n505, septiembre 09/1983. pp.74-77. 
Otro de los rasgos fundamentales de la hipergráfica como potencial elemento de renovación urbana es su temporalidad. En este sentido, el estudio de los arquitectos Hardy, Holzman y Pfeiffer la utilizan en 1968 para la rehabilitación de un antiguo showroom de automóviles en el deprimido barrio de Brooklyn y su reconversión temporal en museo infantil. Toda la fachada del antiguo edificio es invadida por una supergráfica amarilla diagonal con el nombre del museo "MUSE" [6C], que no respeta la antigua disposición de llenos o vacíos del edificio, como si la rotulación de un paquete gigante se tratara. Así es como se enfatiza no sólo el carácter efímero del uso temporal que alberga el edificio reconvertido, sino una manera de entender la flexibilidad de la ciudad a través de usos efímeros en estructuras urbanas ya consolidadas. Es ese potencial renovador el que lleva al italiano Gianni Pettena a convertir el "Palazzo d'Arnolfo a San Giovanni Valdarno" en un "Monumento segnale" [8D] para la muestra del Premio Masaccio de 1968. Mediante la instalación de cartones pintados con líneas diagonales blancas y negras en la fachada del palacio, el arquitecto italiano convierte el edificio en foco visual de la plaza, en un lugar como el centro histórico de Florencia en el que el monumento ya no supone un hito sino una continuidad urbana, transmitiendo así la capacidad de intervención en el tejido urbano históricamente consolidado a través de la hipergráfica. Propuestas posteriores como "Transformazione dei monumenti Bolognesi" (1969) [9D] de Lorenzino Cremonini, también reivindicarán con supergráfica la apropiación del espacio público de la ciudad.

"El arquitecto Gianni Pettena había de esta manera, con inteligencia y humor, invertido lo habitual: el antiguo palacio/monumento renacentista se convertía en una compacta señal, el volumen arquitectónico se reducía al carácter bidimensional de la fachada; la lectura de los diversos elementos arquitectónicos, pórtico, galería y torre, se concentraba en una visión gráfica unitaria; el interior se uniformaba con el exterior, dónde se exhibían otras obras, el contenedor de la muestra y sus funciones se convierten, en definitiva, en objetos y experiencia visiva al mismo tiempo."334 (Trini, 1968, p.56)

La supergráfica, relacionada con el espacio público, expande su uso asociado a los paramentos verticales de los edificios para convertirse en generadora de nuevas situaciones espaciales a través del plano horizontal. Así es como en 1972 el artista Gene Davis pinta "Franklin's Footpath" [11C], un paseo de líneas de colores de ciento veintiséis metros de longitud para la reconversión temporal del aparcamiento del museo de Arte Contemporáneo de Philadelphia en Lewiston en un paseo peatonal que llega hasta la entrada, potenciando la perspectiva del mismo e invitando al ciudadano a recorrer ese camino. Años más tarde, en el proyecto para la "Western Plaza" (1977) [19A] en Washington de Robert Venturi y Denisse Scott-Brown, los arquitectos transgreden el tamaño de este espacio público al reproducir, a menor escala, gran parte del distrito de Columbia diseñado por el francés Pierre L’Enfant. De

333 "Another reason for fostering exterior decoration is that overworked word involvement. $<<$ With paint, the community itself can get into the act $>>$. Lee Harris Pomery explains. $<<$ They can't build buildings and lay bricks, but they can paint. That has real social value $>>$."

SMITH, C. Ray. Supermannerism: new attitudes in post-modern architecture. 1977. p.197.

334 "L'architetto Gianni Pettena aveva cosí, con intelligenza e ironia, ribaltato qualche abitudine: il vecchio palazzo monumento rinascimentale diventava un segnale compatto, il volumen architettonico si riduceva alla bidimensionalitá della facciata; la lettura dei diversi elementi, porticato, loggia e torre, si concentrava in una simultanea visione grafica; l'allestimento interno si uniformava con quello esterno dove sostavano altre opere; il contenitore della mostra e le sue funzioni diventano, insomma, essi stessi ogetto e esperienza visiva."

TRINI, Tommaso. Masaccio a UFO. En: Domus, n466, septiembre 09/1968. p.56. 
esta manera la supergráfica vuelve a convertirse en un recurso formal inocuo y banal, ya que las líneas del trazado no potencian ninguna dirección ni siquiera generan juegos espaciales, sino que se presentan como simple homenaje a una parte de la ciudad en un espacio público cercano.

\section{La marca como espacio arquitectónico.}

La construcción de espacios mediante estrategias de supergráfica encontrará en empresas y comercios a los cómplices perfectos como lugares de experimentación ${ }^{335}$. Ambos dependen de nombres y anagramas como símbolos de su identidad, susceptibles de convertirse también en nuevos recursos arquitectónicos a la hora de diseñar espacios asociados a los mismos. Es en este contexto que en 1965, Hans Höllein diseña una nueva sucursal en Viena para un negocio de velas de lujo, la "Retti Candle Shop" [1D]. El arquitecto austríaco invierte la situación habitual de escaparate a la altura de los ojos de los paseantes y cartel con el nombre encima para fusionarlo en un solo motivo. Una fachada exterior confeccionada a partir del anagrama de la empresa Retti, una doble R, mediante la cual se construye una estrecha puerta con un óculo encima que prescinde del escaparate ${ }^{336}$. El resultado se asemeja a la mirilla de una puerta gigante, que funciona tanto en la escala próxima, mediante la relación interior-exterior, como en la urbana, por reproducir el anagrama de la marca Retti a gran tamaño.

"Sin ningún tipo de escrito y sin ninguna señal, todo el portal se convierte en un reclamo por su tamaño y forma, un símbolo de escala arquitectónica: reconocible desde lejos (por encima del flujo constante de vehículos que recorren la carretera y fuera, para sus propias proporciones, del ritmo y del aspecto de la fachada."1337 (Höllein, 1966, p.17)

La esencia del logotipo plateado de la marca se propaga por todo el sofisticado y reducido interior como si de un objeto tallado se tratase, como si toda la tienda fuera ahora el nuevo anagrama de la empresa. El arquitecto austríaco utilizará recursos gráficos desde la fase de construcción, pues la valla de obras se cubre con un enorme cartel con tres mujeres astronautas anunciando la próxima apertura.

El mismo recurso proyectual asociado al logotipo o marca, será adoptado por el italiano Alessandro Fiorentino en 1968 en "Vetrina Insegna" [7D] o por el propio Höllein en la "Boutique Christa Metek" (1967) [4D] también en Viena. En este último proyecto, todos los elementos de la fachada, la puerta, el escaparate, la ventilación general e incluso la rejilla de

335 La boutique se convertirá en centro de debate arquitectónico y lugar de experimentación durante las década de los sesenta.

Boutiques. A new world of color. En: PA Progressive Architecture, diciembre 1967. pp.120-127.

336 En un fotomontaje anterior, Höllein reproducirá el logo literalmente a partir de un relieve del mismo, prescindiendo del mismo en la solución final al depurar el diseño, ya que no es necesario ese relieve para la comprensión del logotipo de la marca.

337 "Senza alcuna scritta e senza alcuna insegna, l'intero portale per la sua dimensione e sagoma è un richiamo, è un símbolo in scala architettonica: risconsocible da lontano (sopra il continuo flusso di macchine che corre nella strada e staccato, per proporzioni proprie, dal ritmo e dall'aspetto della facciata."

HÖLLEIN, Hans. Candele a Vienna. En: Domus, n²38, mayo 05/1966. pp.17-20. 
salida de la calefacción y aire acondicionado de la tienda, se integran a la misma mediante el logotipo de la marca. Los elementos arquitectónicos se convierten en la gráfica, en el símbolo de la tienda. En ambos casos Höllein diseña los logotipos y las tiendas, entendiendo que ambos asuntos pertenecen a un mismo proceso. Toda la arquitectura surge de la propia marca y viceversa. Höllein seguirá trabajando en esa misma línea durante años, en proyectos como la "Svoboda Exhibition" (1967) [4E] o la "Boutique N" (1972) 338 [11D].

Por otra parte, en 1970, en su proyecto para la sucursal bancaria "Thrift Federal Savings" (1970) [10E], Daniel Solomon, David Reichel y Barbara Stauffacher repetirán el logotipo de la entidad hasta la extenuación a través del sistema de iluminación y las particiones de la tienda. De esta manera el logotipo se deforma, se expande y pierde su literalidad para ir convirtiéndose en recurso arquitectónico. Una estrategia parecida será utilizada por Ramirez Vázquez, Eduardo Terrazas ${ }^{339}$ y Lance Wyman, en el "Pabellón de México para la XIV Triennale de Milán" [7A], explotando el diseño del logo para las olimpiadas de México'68 de Wyman por todo el interior del pabellón, aprovechando así la supergráfica de franjas negras y blancas para la construcción del espacio arquitectónico.

La adaptación de logotipos para la generación de espacios presenta nuevas alternativas a la de la fachada-escaparate en proyectos como el de la "Fachada de Radio-Tele-Luxembourg en París" [10B], dónde el artista Vasarely construye con luz el logotipo de la radiotelevisión luxemburguesa en la fachada de dicho edificio, o el "Concurso para una estación de servicio ESSO" (1971) [11A] de Vittorio de Feo. En este último caso, el arquitecto italiano utiliza la extrusión de la forma exterior ovoide del logotipo de la marca para generar un único volumen cilíndrico que funciona a la vez como marquesina cuando se levanta del suelo o albergando los servicios y tienda de la misma cuando llega a tocarlo. La marca se convierte así en el único recurso formal y de uso de la propuesta, en una aplicación radical de lo que podría denominarse como "Logo-tecture".

\section{El edificio-cartel. Carteles publicitarios convertidos en arquitectura.}

Frente a la construcción de edificios-anuncio a partir del cambio de escala de alguno de sus productos en venta, la conocida estrategia "duck" o "edificio-pato" venturiano, aparecen otras alternativas, usadas con mayor asiduidad en Las Vegas y centros comerciales, que son aquellas que convierten al edificio en mero soporte del rótulo-anuncio, una situación que el propio Venturi define como "The Decorated Shed", con una difusa traducción en castellano como "tinglado decorado". La preeminencia de los rótulos ${ }^{340}$ frente al contenedor es total, diseñados para una ciudad en la que el automóvil y en su defecto, la vista del edificio desde el mismo, se convierten en las principales estrategias de diseño.

338 HÖLLEIN, Hans. Un negozio nel centro di Vienna. En: Domus, n517, diciembre 12/1972. pp.40-41.

HÖLLEIN, Hans. Mobili nel museo. En: Domus, n448, marzo 03/1967. pp.24-29.

339 TERRAZAS, Eduardo. Creation of Environment: México'68. En: KEPES, Gyorgy. Arts of the environment. Brazilier. Nueva York, 1972. pp.198-207.

340 En 1976, Venturi, Rauch y Scott-Brown comisariarán y diseñarán la exposición "Signs of life: symbols in the American city ", casi una apología del cartel publicitario como símbolo de la vida urbana americana.

VENTURI, Robert; SCOTT-BROWN, Denisse; RAUCH, John. Signs of life: symbols in the American city. Renwick Gallery of the National Collection of Fine Arts. Washington D.C, 1976. 
"La señal gráfica en el espacio ha pasado a ser la arquitectura en este paisaje." ${ }^{341}$ (Venturi, 1972, p.34)

"Cuando los sistemas de espacio y estructura están directamente al servicio del programa, y el ornamento se aplica con independencia de ellos. Llamaremos a este tipo el tinglado decorado (Decorated Shed)." ${ }^{342}$ (Venturi, 1972, p.114)

Las condiciones de aparición del edificio-cartel serán por lo tanto dos: un entorno urbano basado en el automóvil, favoreciendo la aparición de esa superescala, y una necesidad de las tipologías comerciales por anunciarse dentro del caótico paisaje urbano de las ciudades. Sin duda alguna estos serán los condicionantes para el diseño de la "Fire Station n4" (19651966) [2D] en Columbus por parte de Venturi y Rauch:

"A cien kilómetros por hora, la Estación de Bomberos número 4 de Venturi y Rauch en Columbus, Indiana, es inmediatamente reconocible. En la parte superior de la torre de la manguera de secado hay un gran número 4. Un patrón de ladrillo blanco, aparentemente superpuesto en el edificio de ladrillo rojo, es como gran cartel publicitario pegado." ${ }^{\prime 343}$ (C. Ray Smith, 1977, p.190)

Un lenguaje parecido será utilizado por los mismos arquitectos en 1972 para el diseño de la "Estación de bomberos en Dixwell, New Haven" [12D]. En este proyecto sin embargo, se prioriza la gráfica del edificio, con grandes letras en relieve con datos relativos a las unidades que trabajan en el edificio, operación similar a la del cartel que supone la entrada de la "Guild House" [1E] de 1965. En ese proyecto, Venturi y Scott-Brown combinan también la pintura blanca sobre el revestimiento de ladrillo rojo para convertir un elemento arquitectónico en cartel del edificio. La contradicción que presenta la transformación de estos tres edificios en anuncios, se debe a su carácter de equipamientos públicos, alejados del mundo publicitario de centros comerciales, por lo que aquí la supergráfica va de nuevo encaminada a la monumentalización de lo público más que a un fin publicitario, convirtiendo la imagen exterior en un soporte auto-referencial, en edificios-anuncio de lo cotidiano, como una estación de servicios o un centro de la tercera edad. Una exaltación de la identificación como alternativa de futuro frente a lo institucionalizado e igualitario. En este sentido, Venturi presenta en "Aprendiendo de Las Vegas" (1972) su dibujo "I'm a monument"344 [12B] como recomendación para las arquitecturas monumentales totalitarias representantes de la burocracia tecnócrata, representadas por las megaestructuras como continuadoras del movimiento moderno. Venturi llega a proponer ese carácter monumental en casi todo lo construido justificando así el protagonismo de la semántica de los proyectos, buscando mecanismos para cargar de esa supuesta identidad a la arquitectura. Las Vegas se convierte así en el cómplice ideal de Venturi, con miles de edificios representados por

341 VENTURI, Robert; SCOTT-BROWN, Denisse; IZENOUR, Steve. Aprendiendo de Las Vegas. 1978 (1972). p.34.

342 VENTURI, Robert; SCOTT-BROWN, Denisse; IZENOUR, Steve. Aprendiendo de Las Vegas. 1978 (1972). p.114.

343 "At sixty miles per hour, Venturi \& Rauch's Fire Station 4 in Columbus, Indiana, is immediately recognizable. At the top of its hose drying tower is a large numeral 4. A white pattern of brick, seemingly overlaid on the red brick building, is like a pasted-on advertising poster"

SMITH, C. Ray. Supermannerism: new attitudes in post-modern architecture. 1977. p.190.

344 VENTURI, Robert; SCOTT-BROWN, Denisse; IZENOUR, Steve. Aprendiendo de Las Vegas. 1978 (1972). p.194. 
carteles gigantes intentando decir "aquí estoy yo", plasmados en documentos como el "Plano del Strip de Las Vegas" [11E], una ciudad entendida a través del mensaje de sus rótulos o el "Catálogo de carteles de Las Vegas" [12A] como guía definitiva de la arquitectura de la ciudad.

Entre 1969 y 1970 el arquitecto japonés Minoru Takeyama utiliza la supergráfica en sus edificios "Ichiban-Kan" [9C] y "Niban-kan" [10A] en Tokio, convirtiendo a ambos en referentes visuales de un barrio en el que el ocio supone el foco de actividad más importante. De esta manera la supergráfica y la volumetría transforman ambos edificios en una señal dentro del tejido urbano de la ciudad, a partir de una singularidad que responde al concepto de "mojón" de Kevin Lynch ${ }^{345}$, como lugar exterior referencial a través de sus características formas geométricas de vivos colores, carácter que ha perdurado a pesar de los diversos motivos gráficos que han soportado en las posteriores remodelaciones. Una fotografía del "Niban-kan" se convirtió en la portada ${ }^{346}$ del libro de Charles Jencks "The Language of Postmodern Architecture" 347 de 1977. Dicha fotografía se adaptó también a la nueva supergráfica del edificio en la portada de su reedición de 1991. Frente a un espacio cargado de referentes semánticos directos a partir de carteles luminosos con el nombre de cada uno de los negocios de ocio de Shinjuku, los edificios de Takeyama se vuelven singulares a partir de la abstracción de su hipergráfica geométrica.

La conversión de un edificio como soporte de un anuncio independiente a su propia función o contenido es ficcionado por los fotógrafos Emil Perauer y Alain Bernardin en 1967 para su libro de fotografías sobre el club erótico "Crazy Horse Saloon" [4C] de París. En él superponen la imagen de portada de un desnudo de una de las chicas principales del espectáculo a un descomunal e impersonal edificio de viviendas de veinte plantas asomado a la estación de trenes de Montparnasse en París. La imagen generará una doble controversia, por un lado la producida por la gigantesca imagen de una chica desnuda visible desde un gran área de la ciudad, por otra, la imagen totalmente impersonal de más de mil doscientas ventanas del mismo tamaño. Ambas imágenes superpuestas serán comentadas en 1968 en una editorial de la revista francesa AMC por su director Philippe Boudon ${ }^{348}$ y referenciadas en Architectural Design en enero de 1969 con el título "Hay dos tipos de desnudos"349, por la controversia que genera esta imagen de superposiciones obscenas.

La supergráfica abandonará su carácter exclusivamente pictórico para asociarse con elementos tecnológicos. Una de esas hibridaciones será la que Tom Wolfe bautiza en 1969 como "Electrographic Architecture" [9A], o supergráfica construida con elementos luminosos, especialmente el neón, elemento inserto tanto en la cultura popular como en las experimentaciones espaciales artísticas ${ }^{350}$, dentro de lo que se denominará como "Architecture of the night"1351 o "Arquitectura de la noche". En 1971 Dan Flavin iconiza aún más

345 LYNCH, Kevin. The Image of the City. MIT Press, 1960. Chicago, 1960.

346 También fue portada del número de "The Architectural Design" de Enero de 1977.

AD, The Architectural Design, Post-Modernism, enero 1977. portada.

347 JENCKS, Charles. The Language of Post-Modern Architecture. 1977.

348 BOUDON, Philippe. Editorial. En: AMC Architecture Mouvement Continuité, SADG nº1968.

349 Two types of nudity. En: AD The Architectural Design, enero 1969. p.10.

350 Dan Flavin, Billy Apple, Martial Raysse o Robert Whitman, entre otros. 
el museo Guggenheim de Nueva York con bandas de neones de colores [11B]. En 1968, en un edificio proyectado por MLTW, Moore, Lyndon, Turnbull y Whitaker, los miembros de la Elm City Electric Light Sculpture diseñan y construyen una gran parte de la señalética con neones, "Faculty Club, neon banners" [8A]. Tom Wolfe, ni crítico de arte, ni historiador o arquitecto, sino escritor, critica el retardo de ese interés de artistas y arquitectos por las capacidades plásticas del neón, el elemento que revolucionaba las formas arquitectónicas en 1968, Ilevaba utilizándose de manera masiva desde hacía más de diez años, habiendo sido inventado en los años veinte.

"Lo que está sucediendo en la arquitectura de hoy en día es una revolución. Se trata de un reajuste completo de la estética que lo pone más acorde con la era espacial y sus materiales y formas..." ${ }^{1352}$ (Kenneth Carbajal, 1968, p.82)

"Los artistas serios y arquitectos acaban de acercarse a las ideas en las que artistas comerciales como él (en relación a Melvin Zeitvogel, un artesano del neón) han estado trabajando durante años..." ${ }^{1353}$ (Tom Wolfe, 1969, p.379)

"Los escultores serios que trabajan con la luz tienen una extraña y pasada de moda, visión de la tecnología. Tienen nostalgia por el neón. Un neón que se introdujo en el negocio de la señalética eléctrica a finales de los años 20 y que disfrutó de una gran moda en el momento. ${ }^{1354}$ (Tom Wolfe, 1969, p.382)

La idea de que cualquier edificio tiene la capacidad de convertirse en anuncio o monumento de sí mismo, asociada a estas "nuevas tecnologías", es experimentada de manera radical en la propuesta de Venturi, Scott-Brown y Rauch para el concurso del "National Football Hall of Fame" de 1967 [5A]. En el edificio se prioriza su imagen exterior a través de un mega pantalla electrónica, dos veces más alta que el resto del edificio, que convierte el espacio exterior en el que se inserta también en museo a través de la interactividad de la pantalla, como el propio Venturi describe en la memoria del proyecto:

"La parte frontal está hecha con uno de esos sistemas de pantalla de luces intermitentes. Uno simplemente no puede ver el espacio, forma y estructura a través del estacionamiento, que trabaja en todo el complejo equipo de sistemas de comunicación. Nuestros medios de comunicación híbridos incluyen elementos simbólicos y de representación, es decir, carteles y palabras, junto con los elementos

351 El término "Architecture of the night" fue atribuido a Raymond Hood, titulando así un artículo de Febrero de 1930 en el boletín de la General Electric Company.

NEUMANN, Dietrich. Architecture of the Night. The Illuminated Building. Prestel. Munich, 2002. pp.6-7.

352 "What is happening in architecture today is a revolution. It's a complete readjustment of aesthetics that puts it more in step with the Space Age and its material and forms..."

Carbajal, Kenneth. Progressive Architecture, octubre, 1968. p.82.

353 "Serious artists and architects are only just now approaching the ideas commercial artists like him have been working with for years..."

WOLFE, Tom. Electrographic Architecture. En: AD The Architectural Design, julio 1969. p.379.

354 "Serious light sculptors have a strangely old-fashioned, rear-view taste in technology. They have a nostalgia for neon. Neon was introduced into the electric sign business in the late 1920s and enjoyed quite a vogue."

WOLFE, Tom. Electrographic Architecture. 1969. p.382. 
abstractos de espacio, forma y estructura. Los símbolos de arquitectura enriquecen el significado. Se pueden evocar las asociaciones instantáneas cruciales para los vastos y complejos espacios de hoy en día, de velocidades rápidas, programas complejos y, tal vez, de unos sentidos saciados que sólo responden a los estímulos más audaces $^{11355}$ (Venturi, 1968, p.76)

De esta manera la imagen exterior del edificio se reduce a una gran pantalla, que dependiendo de las posibilidades de reproducción de la misma puede convertirse en cualquier otra cosa. La forma arquitectónica se convierte así en una anécdota. Una sistemática parecida es adoptada por Emilio Ambasz en 1975 para el "Centre for Applied Computer Research" [15D] en Ciudad de México, un proyecto en el que una de las paredes del complejo se convierte en una gran pantalla interactiva con la que la comunidad, que vivirá en el entorno cercano también diseñado por Ambasz, puede interactuar a través de mensajes, sirviendo el edificio de medio de comunicación e icono de todo el conjunto.

\section{La ciudad alfabética. Hipergráfica $=$ hipermensajes.}

Ya en 1773, Johann David Steingruber escribe su tratado "Alphabet Architektur" sobre el potencial arquitectónico del alfabeto. Dos años más tarde, diseñará un castillo para el príncipe Carl Alexander de Anspach con una planta basada en sus iniciales que nunca llegará a construirse, pero que formará parte del libro "Fantastic Architecture" 356 de Conrads y Sperlich. En 1980, Steven Holl vuelve a buscar ese potencial en planta que la arquitectura alfabética ${ }^{357}$ oculta bajo la trama urbana. En ambos casos, el potencial semántico del alfabeto queda relegado a un simple juego o estructura formal de disposición de la planta, en el caso de Steingruber quizá para embaucar a un egocéntrico monarca, pero en ninguno de los dos casos ese alfabeto será percibido por los usuarios de esas arquitecturas.

"En la Ciudad Alfabética - las partes contiguas de ciudades que se desarrollaron según el planeamiento de la retícula - se repiten los edificios que son similares a letras. La "U", "E", "L" o la "f" dependen de sus estructuras adyacentes para tener sentido. Se convierten en "letras muertas" cuando aparecen como edificios exentos.

Este folleto busca el cemento de unión conceptual de la planificación urbana y la arquitectura a partir de dos secciones. La primera se refiere a los diferentes tipos

355 "The front is made out of one of those flashing light board systems. You just can't see the space, form and structure across a teaming parking lot with a mixture of other media. Our mixed media include... symbolic and representational elements, that is billboards and words, along with the abstract elements of space, form and structure. Symbols with architecture enrich meaning. They can evoke the instant associations crucial for today's vast spaces, fast speeds, complex programs and, perhaps, jaded senses which respond only to bold stimuli."

VENTURI, Robert. A Bill-Ding-Board Involving Movies, Relics and Space. En: Architectural Forum, n³, abril 1968. p.76.

356 CONRADS, Ulrich; SPERLICH, Hans G. Fantastic Architecture, 1963 (1960). p.87.

357 La inclusión de inscripciones, letreros y rótulos en edificios es tan antiguo casi como la propia arquitectura. Un buen compendio de referencia utilizado:

BARTRAM, Alan. Lettering in Architecture. Lund Humphries Publishers Limited. Londres, 1975. 
arquitectónicos que se desarrollaron en la trama urbana definida en las ciudades. La segunda cataloga una serie de retículas generadoras." 358 (Steven Holl, 1980, p.1)

Uno de los referentes populares más conocidos en torno a la ciudad alfabética será el cartel de HOLLYWOOD. Desde su instalación en el Monte Lee, en el barrio de Hollywood Hills de Los Ángeles en 1923 con motivo de una campaña publicitaria, su imagen, por las continuas reproducciones del mismo en los medios, se convertirá en uno de iconos alfabéticos más conocidos. Su capacidad de representación semántica es tal que ha sido incluso objeto de manipulaciones espontáneas como medio de "decir cosas al mundo", desde el "Hollyweed", para reivindicar la ley que despenalizaba el consumo de marihuana en 1976, hasta el "Holywood", en septiembre de 1987, con motivo de la visita del papa Juan Pablo II a Los Ángeles. En 1968, Gerhard Rühm diseña una nueva Viena o "New Wien" [6D], a partir de las letras de la ciudad, un proyecto crítico sobre el exceso de "representación" de las ciudades que será incluido en "Fantastic Architecture"359 (1969), esta vez compilado por Vostell y Higgins. Rhüm critica la capacidad semántica del cartel como cara visible de una ciudad, convirtiendo la propia ciudad en un slogan publicitario. En sentido contrario, Claes Oldenburg visiona una "City as Alphabet" en 1968 [8C] como posible propuesta, que enfatice la capacidad semántica de una hipergráfica construida con letras-edificio como manera de generar distintas identidades dentro de la homogénea ciudad de Los Ángeles.

"Las letras se convierten en puntos de referencia de la comunidad. Uno puede decir: Yo vivo por la L, lo puede ver desde la autopista". ${ }^{360}$ (Oldenburg, 1971, p.81)

Oldenburg también proyecta en 1968 "Design for a Police Building using the word POLICE", [7C] una oficina de policía a partir de las letras "POLICE". Este edificio no sólo se convierte nuevamente en anuncio de sí mismo, en un híbrido entre el "duck" y el "the decorated shed" de Venturi, sino que además supedita sus usos internos a los recursos formales de la letras, en un cambio del estudio de los tipos en planta hecho por Steven Holl al trabajo en sección. En esa búsqueda de esta capacidad espacial del alfabeto, de la misma manera que había ocurrido en el cambio de escala de objetos para ser habitados, Oldenburg genera una serie de tipos arquitectónicos en las que diversas características alfabéticas se convierten en funcionales. De esta manera, las letras " $H$ " de la palabra "Philade/phia" se transforman en las patas de apoyo de un "Puente basado en la palabra Philadelphia" (1972) [13C]. También otros arquitectos, como Piers Gough, experimentarán en torno a esa transposición literal de conversión de caracteres en elementos arquitectónicos, en este caso, las siglas de una empresa, "ICl", se convierten en la estructura portante y cerramiento de la sede de la empresa en su trabajo de la Architectural Association "Research Building for ICl. AA Works" de 1970 [10C].

358 "In the Alphabetical City - the contiguous portions of cities that evolved on gridirons plans - certain letter-like buildings recurred. The "U", " $E$ ", " $L$ " or the "I" type depend on their adjoining structures for meaning. They become "dead letters" when left stranded as free-standing buildings.

This pamphlet searches for the conceptual cement binding urban planning and architecture. It is in two sections. The first concerns different building types which evolved on a defined grid patterns in cities. The second catalogues a variety of grid types."

HOLL, Steven. The Alphabetical City. Pamphlet Architecture\#5, marzo 1980. Princeton Architectural Press. New York / San Francisco, 1980. p.1.

359 HIGGINS, Dick; VOSTELL, Wolf. Fantastic Architecture. Something Else Press. Nueva York, 1969.

360 "The characters become landmarks of the community. One may say: I live down by the L. You know, you can spot it from the freeway."

OLDENBURG, Claes; HASKELL, Barbara, Object into Monument. Pasadena Art Museum. Ward Ritchie Press. Pasadena, 1971. p.81. 
Sin embargo, para arquitectos como Gianni Pettena la gráfica debe abandonar el carácter estático de los edificios para convertirse en parte del espacio urbano. En sus happenings "Carabinieri", "Grazia e Giustizia" y "Milite Ignoto" de 1968 [7E], en repulsa por la condena en Palermo de un hombre por declarar su homosexualidad, Pettena convierte el cartel, cómplice arquitectónico de la arquitectura del poder por su carácter semántico y monumental, en unas letras de cartón que se pasean por la ciudad, que pueden cambiar de mensaje, que son participativas y que están al alcance de la mano de los usuarios. 


\section{Catálogo // [Activadores urbanos]}

Las imágenes están referenciadas por números en la zona superior de las columnas verticales [del 1 al 7] y letras en la zona izquierda de las filas horizontales [de la A a la E].

Todas las referencias están ordenadas cronológicamente.

Referencias de imágenes del [1B] a [7A]. Cada uno de los proyectos referenciados gráficamente en el catálogo presentan antes de su nombre un código con un número en relación a su columna vertical y una letra en relación a su fila horizontal.

\section{Ejemplo:}

[7E] "Cloud 9" (1962) de Buckminster Fuller. Buscar referencia en la columna 7 y la fila E del catálogo referenciado al principio del capítulo.

[Nota]: no todos los referentes gráfico del catálogo están referenciados en el texto por lo que se recomienda una lectura del mismo antes de comenzar la del propio texto.
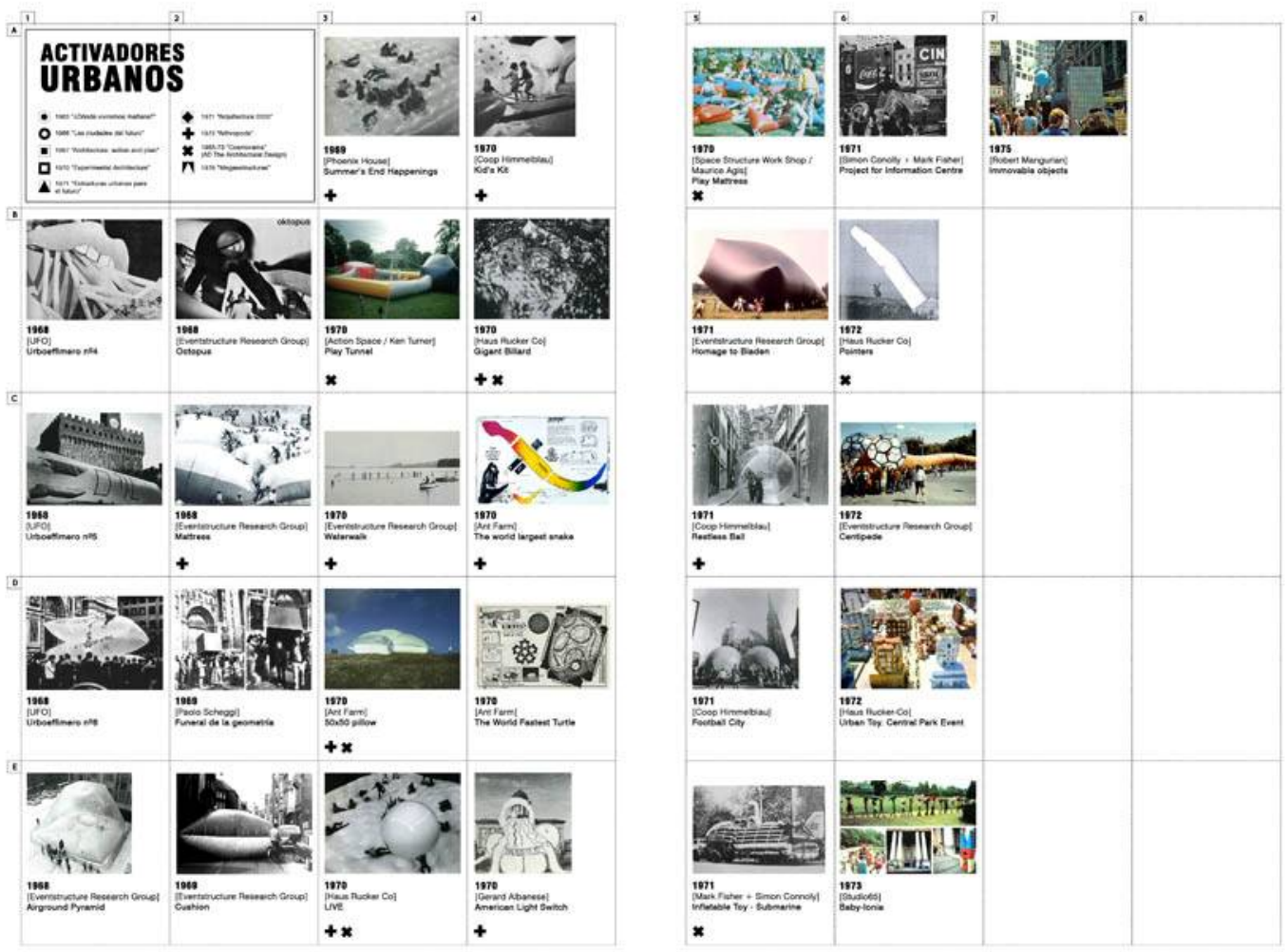


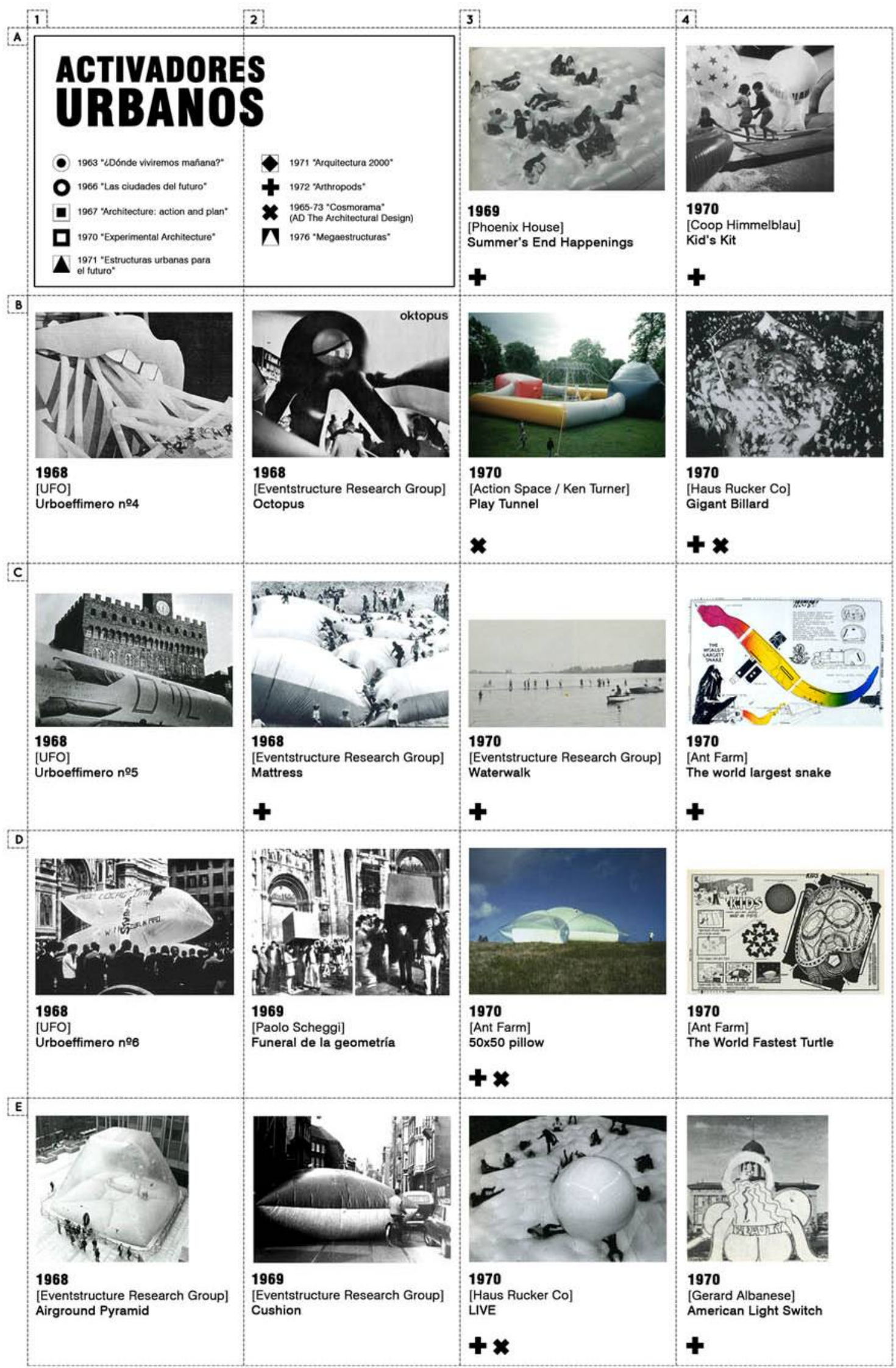




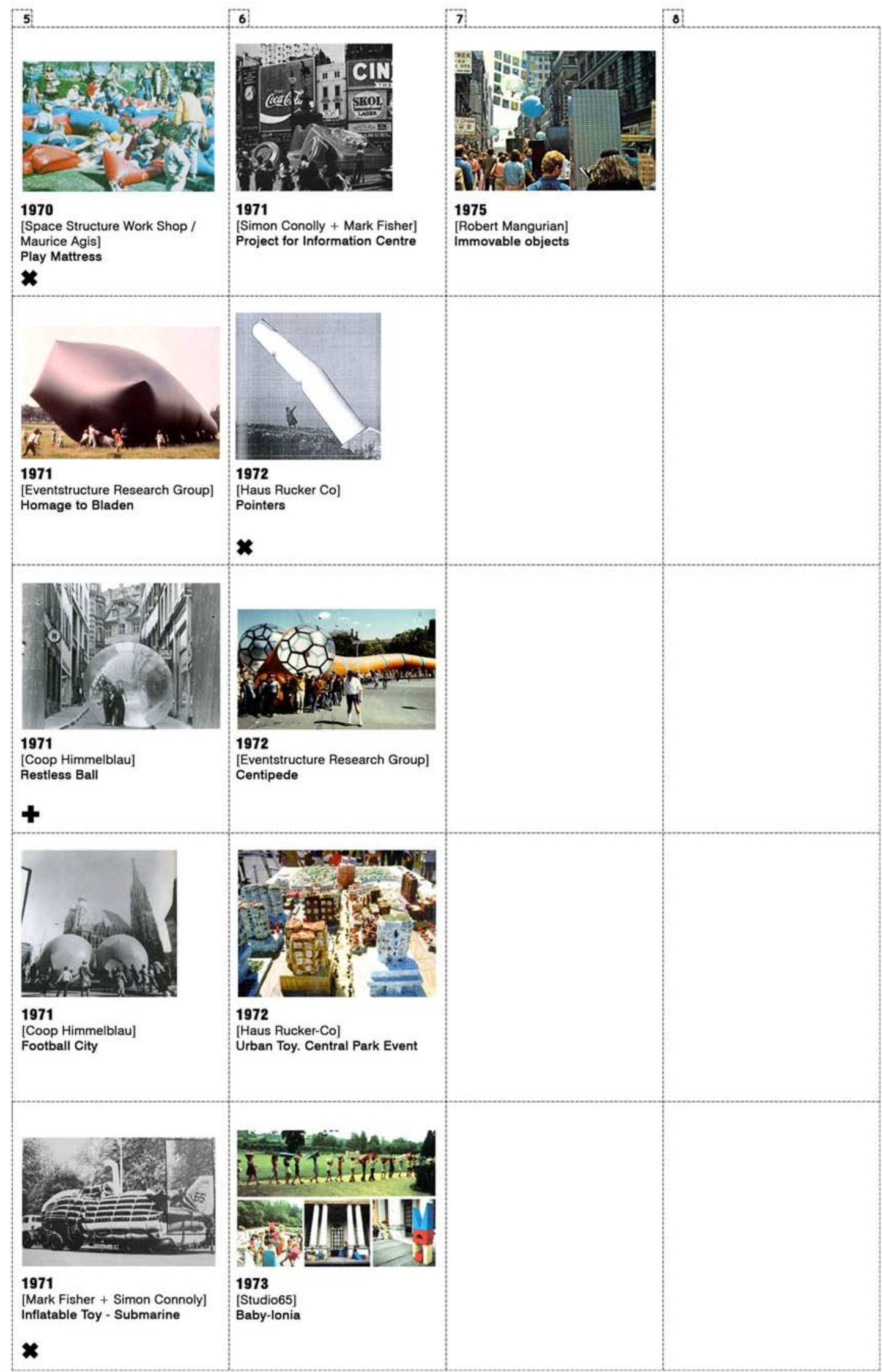




\title{
[Activadores urbanos] Objetos cotidianos convertidos en estructuras ambientales.
}

Una de las alternativas de futuro relacionadas con el cambio de escala gravita en torno a la apertura de la disciplina arquitectónica a nuevos formatos más inclusivos, de la misma manera que el arte había estado haciéndolo a partir de líneas de trabajo como el "Art Environment"361, desarrollado desde principio de los años sesenta a partir de "happenings"362 por artistas como Allan Kaprow en "Fluids" (1967), Claes Oldenburg con "Sports" (1962), Jim Dine y su simulacro de accidente automovilístico en "Car Crash" (1960) o Robert Whitman con "Mouth" (1961). Cuando los happenings abandonan el espacio privado de las galerías para considerar la ciudad como territorio privilegiado para la participación y la acción, despertarán el interés de grupos de arquitectos que encuentran en estos formatos una manera de reivindicar de manera simultánea arquitectura y ciudad, como explica Jeffrey Shaw, uno de los arquitectos fundadores del grupo multidisciplinar ERG, Eventstructure Group Research:

\begin{abstract}
"Una forma alternativa de situaciones ambientales... que es en sí misma tan indeterminada como posible, dependiente de las formas de acción e invención de los participantes, funcionó para re-imaginar tanto la arquitectura como su nueva materialidad casi inestable, activada mediante los eventos de participación de los habitantes. ${ }^{1163}$ (Shaw, 1969, p.48)
\end{abstract}

La generación de estructuras ambientales ${ }^{364}$ como objetos arquitectónicos capaces de modificar el espacio urbano, generando patrones de participación y acción directa del usuario, requerirá, por una parte, de una materialidad que se ajuste a las condiciones de la escala urbana y a su corta temporalidad, por otra, de una semiología que le acerque al usuario de a pié. Ambos condicionantes serán suplidos por estructuras neumáticas de materiales plásticos formalmente referenciadas a objetos "conocidos" de gran tamaño, de nuevo en una operación de reinterpretación pop arquitectónica.

"Las estructuras neumáticas aparecen en este momento como uno de los medios más útiles de la realización de este programa. Pero no como una fantasía futurista sobre el papel, sino como un evento en funcionamiento posible, frente al monolito institucional en su propio seno." ${ }^{165}$ (Shaw, 1969, p.49) 361 KAPROW, Allan. The Shape of the Art Environment. En: Essays on the Blurring of Art and Life. University of California
Press, Berkeley y Los Ángeles, 1993. pp.90-96.

362 En enero de 1958 la frase acuñada por Kaprow es generalizada por la revista estudiantil de la Rutgers University Antologist.

363 "An alternative form of environmental situation... which is in itself as undetermined as possible, depending for its life and forms on participant action and invention, functioned to reimagine architecture as both event of a new, almost unstable materiality and event activated by inhabitant participation"

Concepts for an Operational Art. En: Art and Artists, nº. 10, enero 1969. p 48.

364 "Strutture ambientali" fue el título del seminario dirigido en 1969 por Giulio Carlo Argan para debatir en torno a las conexiones entre los experimentos espaciales-arquitectónicos y las motivaciones políticas para transformar el imaginario social de la época.

ARGAN, Giulo Carlo. Relazione introduttivo al convegno sulle strutture ambientali. Rimini, septiembre 1968. 


\section{Cambio de escala de objetos políticos.}

En 1967, cinco arquitectos recién diplomados por la Universidad de Florencia, forman el grupo UFO ${ }^{366}$. Durante el año 1968, realizan de febrero a junio una serie de "performances" en distintas localizaciones de Florencia que denominan como "urboeffimeri", término derivado de la contracción en italiano de "urbano" y "efímero". En ellos transforman objetos de consumo cotidianos o representativos de la cultura visual del momento, convirtiéndolos en estructuras ambientales urbanas. El primer "urboeffimero" nace de las protestas de la Universidad de Arquitectura de Florencia en el palacio de San Clemente. Uno de los miembros del grupo, Lapo Binazzi, es desde 1968 profesor asistente del curso de Semiología de Umberto Eco en la misma universidad y conocerá las teorías del mismo en relación al icono y la alteración de sus significados. De esta manera, mientras los "Urboeffimero $n^{\circ} 1, n^{\circ} 2$ y $n^{\circ} 3^{\prime 367}$ se realizan a través de un simple tubo hinchable de plástico mediante una serie de rituales concretos pero sin un uso figurativo. En "Urboeffimero $n^{\circ} 4$ " [1B] reciclan el material de los anteriores para crear unos espaguetis Buitoni de gran tamaño, símbolo de una Italia conservadora "che mangia la pasta", junto a unos labios pop construidos con papel couché. Para "Urboeffimero $n^{\circ} 5$ " [1C] construyen una gran pasta de dientes convertida en un cohete espacial con el lema "Colgate con Vietcong", apropiándose del lenguaje norteamericano en contra de la guerra de Vietnam. Finalmente "Urboeffimero $n^{\circ} 6^{\prime 368}$ [1D] se convertirá en una gran "S", con ambiguo significado entre el símbolo del dólar y el emblema de los grandes supermercados Salvari, muy populares en Italia. La apropiación de símbolos y su cambio de escala para la adecuación a la ciudad, será utilizada de esta manera por el grupo UFO para sus acciones de agitación-propaganda tangenciales a las tensiones sociales derivadas de "mayo del 68" 369.

Una sistemática parecida será utilizada en 1969 por el también italiano Paolo Scheggi en el festival de intervenciones urbanas "Campo Urbano", celebrado en Como el 21 de Septiembre de 1969 en la performance "Funeralle della geometría" [2D]. Scheggi simula en ella un funeral por las calles de la ciudad portando los volúmenes de formas geométricas como esferas, pirámides o cubos. De esta manera, el cambio de escala se produce por el ajuste de las formas geométricas al entorno urbano a partir de la portabilidad de las mismas, relacionándose con un proceso urbano como es el de un funeral. La crítica sin embargo abandona el carácter social-reivindicativo de los "urboeffimeri" para convertirse en una denuncia simplemente disciplinaria. Otro ejemplo de cambio de escala político se vislumbra

365 "Pneumatics seem at this moment to be one of the most useful means of realizing this program. But not as a futuristic fantasy on paper, but as an event in operation now, confronting the institutional monolith in its midst".

Concepts for an operational art. En: Art and Artists, no 10, enero 1969. p 49.

366 Lapo Binazzi, Riccardo Foresi, Vittorio Maschietto, Patrizia Cammeo y Sandro Gioli.

367 "Urboeffimeri $n^{\circ} 1, n^{\circ} 2$ y $n^{\circ} 3^{\circ}$ " publicados originalmente en:

Effimero urbanistico scala 1/1. En: Marcatré, 37-40, Roma. pp.198-209.

368 "Urboeffimeri $n^{\circ} 4, n^{\circ} 5, n^{\circ} 6$ y $n^{\circ} 7^{\prime}$ " publicados originalmente en:

Urboeffimeri avveneti scala 1/1. En: Marcatré, 41-42, Roma. pp.76-82.

369 La relación con "mayo de/ 68" será totalmente explicitada en textos y proyectos del grupo francés Utopie. Ver:

BUCKLEY, Craig; VIOLEAU, Jean-Louis (editores). Utopie. Texts and Projects, 1967-1978. Semiotexte. Los Ángeles, 2011.

DESSAUCE, Marc (editor). The Inflatable Moment. Pneumatic and Protest in '68. Princeton Architectural Press. Nueva York, 1999. 
a través del proyecto "American Light Switch" (1970) [4E] de Gerard Albanese. En este caso proponiendo una gran estructura neumática a modo de teatro efímero para concursos de belleza que pudiera convertirse en un monumento efímero en los terrenos de la Casa Blanca en Washington D.C. Albanese abandona la participación espontánea de los proyectos anteriores para proponer programas alternativos de denuncia a partir del cambio de escala antropomórfico de una miss mundo-pop convertida en centro de eventos.

\section{Cambio de escala de objetos cotidianos.}

Esa generación de nuevos "sucesos urbanos" participativos encuentra en el cambio de escala de objetos cotidianos, aquellos por los que el usuario de a pié se siente identificado, una herramienta utilitaria en cuanto a la capacidad de atracción del objeto se refiere, siendo su materialización más habitual la de una estructura neumática de grandes dimensiones. En este tipo de investigaciones urbanas, destacan los trabajos de varios colectivos de arquitectos: Ios norteamericanos Ant Farm ${ }^{370}$, el dúo australiano-holandés denominado como ERG Evenstructure Research Group ${ }^{371}$, Ios austríacos Coop Himmelblau ${ }^{372}$ y Haus Rucker$\mathrm{Co}^{373}$, o el dúo británico formado por Mark Fisher y Simmon Connolly. Las similitudes entre todos ellos son bastante evidentes, su formación en torno a los años 1967 y $1968^{374}$, su interés por el "entorno" urbano, los procesos participativos y las estructuras neumáticas, así como su carácter asociativo. También evidentes resultan los paralelismos en los "objetos cotidianos" elegidos para ser transformados por los cambios de escala para su adecuación al espacio público. Algunos de los más recurrentes serán objetos domésticos relacionados con "lo confortable", desde cojines o almohadas gigantes como "50x50 pillow" (1970) [3D] autoconstruido por Ant Farm o "Cushion" (1969) [2E] de ERG, un cojín gigante situado en diversas localizaciones urbanas de Ámsterdam o en el "Camden Art Festivals" de Londres, hasta grandes colchonetas como "Matress" [2C], una estructura de 18×18 metros de planta y 3 metros de altura construida para ser colonizada por los niños que acudían al festival "Kind en Leefmillieu" (niños y entorno) celebrado en Ámsterdam en 1972 y que anteriormente había formado parte de una pirámide transparente en "Airground Pyramid" (1968) [1E].

La mayor parte de estas intervenciones estarán relacionadas con eventos artísticos, construyéndose también como estructuras interiores de algunas exposiciones en galerías y museos. "Kid's Kit" (1970) [4A] de Coop Himmelblau, una serie de esferas de vinilo y poliéster de diferentes tamaños como juego gigante o "Gigant Billiard" (1970) [4B], una de las estructuras neumáticas exhibida en la exposición "LIVE", expuesta del 7 de Febrero al 15 de marzo de 1970 en el Museo del Siglo XX de Viena. Esta última adoptará un entorno más urbano en mayo de 1970 al convertirse en un super-juguete colectivo en las inmediaciones del Museum of Contemporary Crafts de Nueva York. Este tipo de intervenciones reivindican su carácter público fuera de instituciones o museos, ya que surgen como activadores urbanos a partir de procesos de acción y participación. Esta crítica al museo y su excesiva institucionalización se hace explícita en proyectos como "Homage to Bladen" [5B] de Evenstructure Research Group, una réplica a gran escala, hinchable y habitable, de una obra

\footnotetext{
370 Colectivo fundado en 1968 por Chip Lord y Dough Michels.

371 Formado desde 1968 por Theo Botschuijver y Jeffrey Shaw.

372 Con Wolf D. Prix, Helmut Swiczinsky y Michael Holzer como fundadores también en 1968,

373 Creado en 1967 por dos arquitectos, Laurids Ortner y Günter Kelp Zamp y un pintor, Klaus Pinter.

374 Más tarde en el caso de Fisher y Connolly que por esa fecha aún eran alumnos de la Architectural Association.
} 
de Ronald Bladen, situada en 1971 en el parque aledaño al museo Sonsbeek, en el que se exponían varias obras del mismo autor.

\section{Juegos y juguetes urbanos.}

El uso de estos juguetes urbanos, como intermediarios para una "re-apropiación de la ciudad" se extenderá, ya sea a través de balones de fútbol gigantes con los cuales interactúan los viandantes, en "Football City" (1971) [5D] de Coop Himmelblau, o en "Restless Sphere" (1971) [5C], a través de una esfera neumática de cuatro metros de diámetro que permite moverse por la ciudad mediante una visión distorsionada de la misma. De manera bastante distinta interpretarán el juego urbano los napolitanos Studio65. Mediante su juego de piezas gigantes "Baby-Ionia" (1973) [6E], convierten a los niños en constructores de una ciudad ficticia a partir de un cambio de escala de las piezas de juegos de construcciones de madera, que aumentan su tamaño hasta unas dimensiones de 150×150×30 centímetros, con las que poder simular situaciones urbanas a menor escala en el propio espacio urbano circundante. A esos juegos urbanos gigantes se les unen todo tipo de intervenciones participativas de carácter extensivo y paisajístico, como "Waterwalk Tube" (1970) [3C] de ERG, un tubo hinchable de 250 metros de longitud y 3 metros de diámetro situado sobre el lago Masch, en Hannover, Alemania, conectando ambos lados del mismo de manera que permitiera a los transeúntes caminar sobre las aguas. Aunque relacionadas con el land art, la mayor parte de estas intervenciones destacará sin embargo por el éxito de participación y acción urbana que proponen, más que por una experimentación ritual de intervención en el paisaje.

El desarrollo del concepto "Urban Toys" o "Juguetes Urbanos", será uno de los objetivos principales perseguidos por Haus Rucker-Co a través de su "Program of Urban Landscaping", una investigación en relación al cambio de escala y el uso del espacio público. La primera de esas intervenciones, "Pointers" (1972) [6B], sitúa a un gran dedo neumático de 13 metros de altura frente al aeropuerto de Nuremberg, indicando a los pasajeros la dirección del centro de la ciudad. De la misma línea de trabajo nacerá "Urban

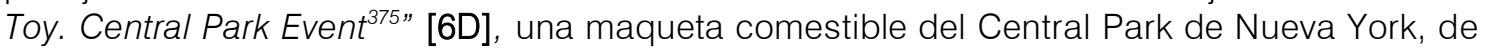
$2.50 \times 6.00$ metros, construida a partir de base de galletas, vainilla y todo tipo de dulces, que fue devorada el domingo, 30 de abril de 1972, en el mismo parque de la ciudad, conmemorando el 150 aniversario del nacimiento de Frederick Olmsted, diseñador del mismo y fundador de la rama de paisajismo en la disciplina de arquitectura en Estados Unidos.

\footnotetext{
"Urban Toy es una maqueta comestible de Central Park, de 8x20 pies, que será presentada al público como banquete urbano... Urban Toy se basa en el concepto de que la ciudad debe ser entendida como un paisaje público." ${ }^{\text {776 }}$ (Haus Rucker-Co, 1972 (1992), p.49)
}

375 Será importante también la capcidad mediática de este tipo de proyectos. En relación al "Urban Toy. Central Park Event" de Haus Rucker-Co, ver:

Urban Toy. Central Park Event. En: New York Magazine, 22 Mayo de 1972. p.4.

376 “Urban Toy, an edible 8'x20' scale model of Central Park will be presented to the public for an urban feast... Urban Toy is based on the concept that the city is a public landscape"

HAUS RUCKER-CO. Urban Toy. En: BOGNER, Dieter (editor). Denkräume-Stadtträume 1967-1997, Haus Rucker-Co. Ritter Verlag. Klagenfurt, 1992. p.49. 
Esa idea de Haus Rucker-Co de entender la ciudad como un paisaje público, se extenderá a otros proyectos como la performance "Immovable Objects" [7A] diseñada por Robert Mangurian de Studio Works. En ella, del 18 de Junio al 8 de Agosto de 1975 decenas de edificios representativos de la ciudad de Nueva York adquirieron un carácter dinámico y participativo al convertirse en disfraces que una cabalgata de voluntarios portaba recorriendo las calles en las que se encontraban los mismos edificios reales representados. De esta manera Mangurian enseña a los transeúntes los iconos inamovibles de la ciudad a través de sus antagonistas dinámicos. Sobre la misma idea de paisaje, experimentarán otra serie de proyectos de estructuras ambientales, utilizando el cambio de escala de animales como apuesta romántica de una nueva re-naturalización de la ciudad y señuelo a la vez de una participación juvenil. A ese tipo de propuestas pertenecen dos intervenciones de ERG, el calamar gigante "Octopus" (1968) [2B] o el ciempiés "Centipede" [6C] de 30 metros de largo, transportado por niños por las calles de Melbourne durante el Moomba Festival en 1972. Los cambios de escala vuelven así a la propuesta de "monumentos desacralizados" de Oldenburg, aunque esta vez el carácter blando y efímero que les confieren las estructuras neumáticas, convierte estas estructuras en monumentos habitados, hedonistas, participativos, diseñados para una ciudad entendida como paisaje de "Io público". Ese carácter público vendrá reforzado a través de propuestas como el libro "Inflatocookbook, publicado en 1971 por Ant Farm, en el que aparecen decenas de estructuras neumáticas, muchas de ellas derivadas de cambios de escala como "the World largest snake" [4C] o "the World fastest Turtle" [4D] con las instrucciones necesarias para poder construirse "Do It Yourself", ampliando así el carácter de lo público a la propia autoconstrucción del espacio urbano por parte del usuario. 


\section{Catálogo // [Ciudad interior]}

Las imágenes están referenciadas por números en la zona superior de las columnas verticales [del 1 al 16] y letras en la zona izquierda de las filas horizontales [de la A a la E].

Todas las referencias están ordenadas cronológicamente.

Referencias de imágenes del [1B] a [16E]. Cada uno de los proyectos referenciados gráficamente en el catálogo presentan antes de su nombre un código con un número en relación a su columna vertical y una letra en relación a su fila horizontal.

\section{Ejemplo:}

[7E] "Cloud 9" (1962) de Buckminster Fuller. Buscar referencia en la columna 7 y la fila E del catálogo referenciado al principio del capítulo.

[Nota]: no todos los referentes gráfico del catálogo están referenciados en el texto por lo que se recomienda una lectura del mismo antes de comenzar la del propio texto.

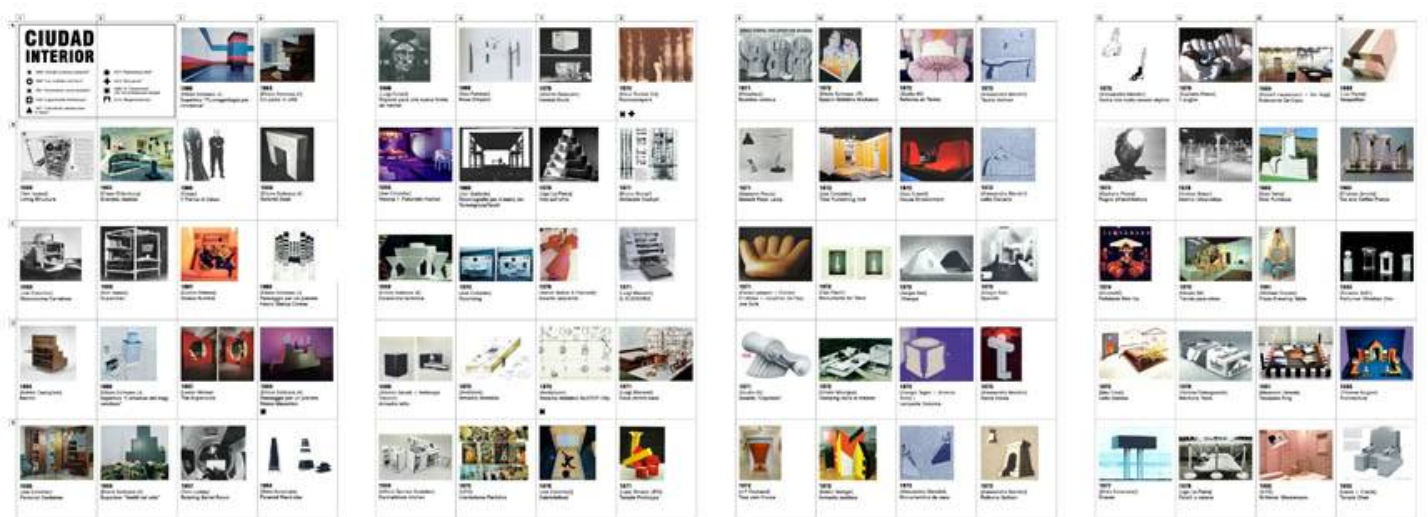




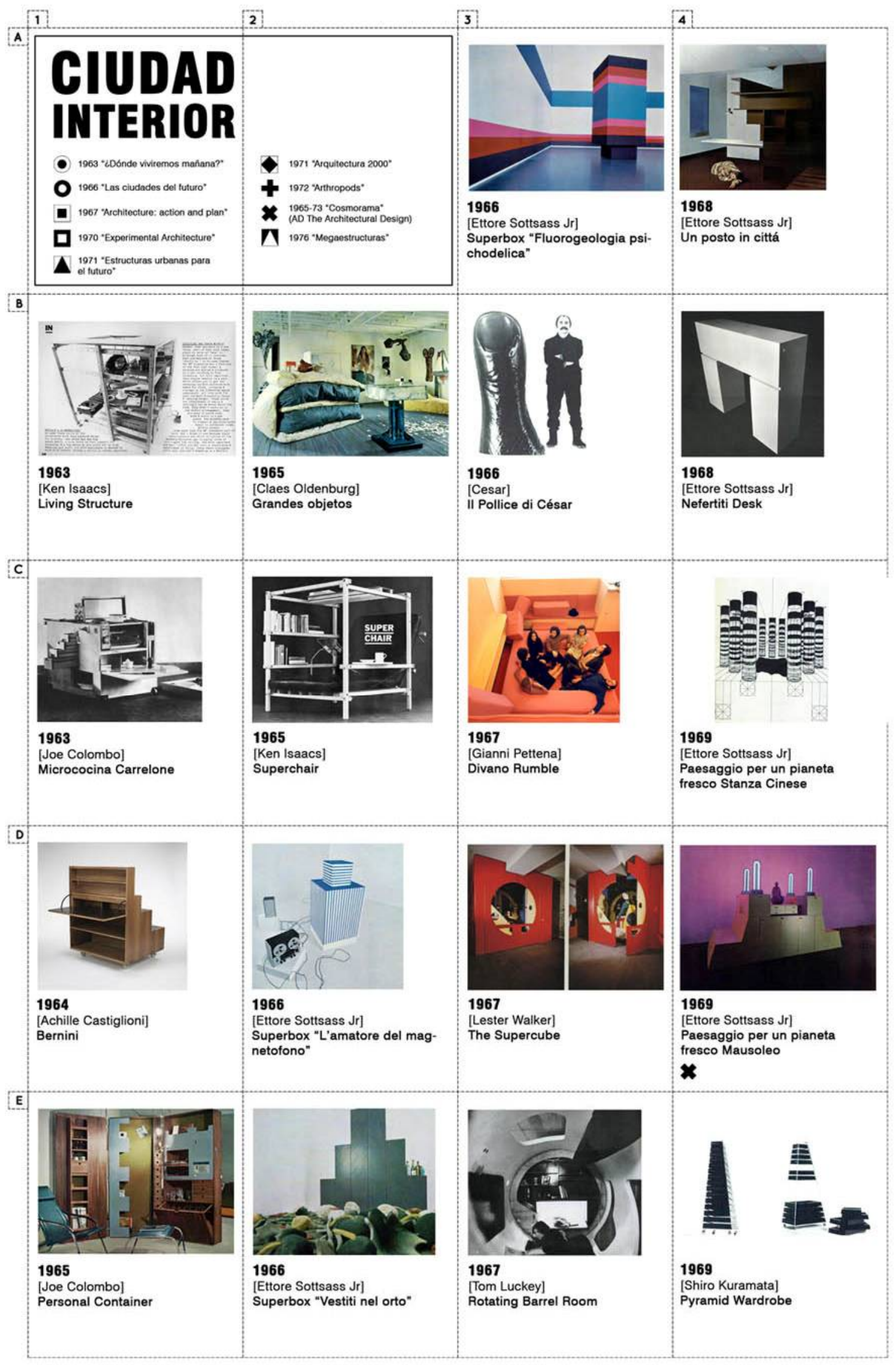




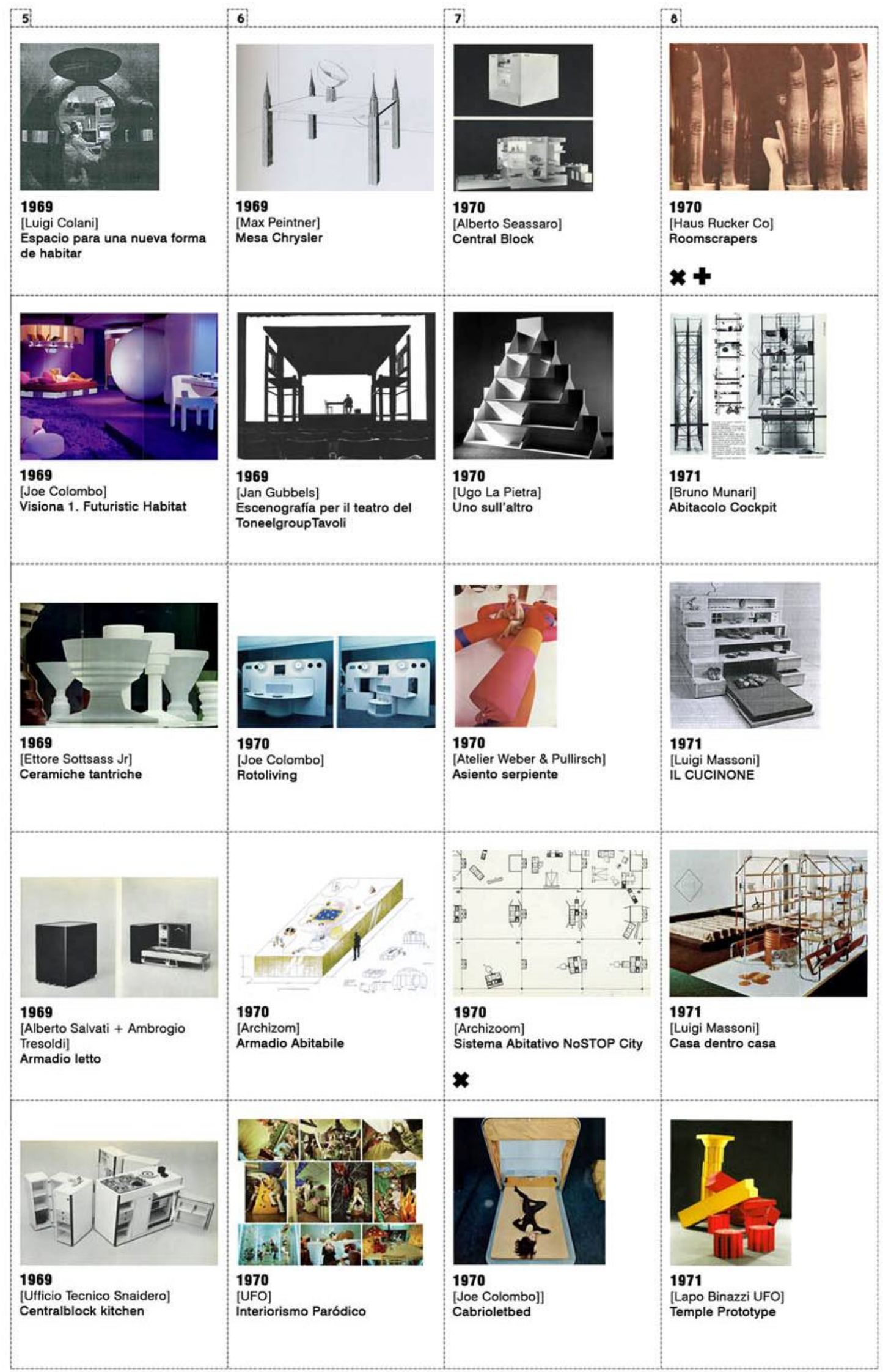




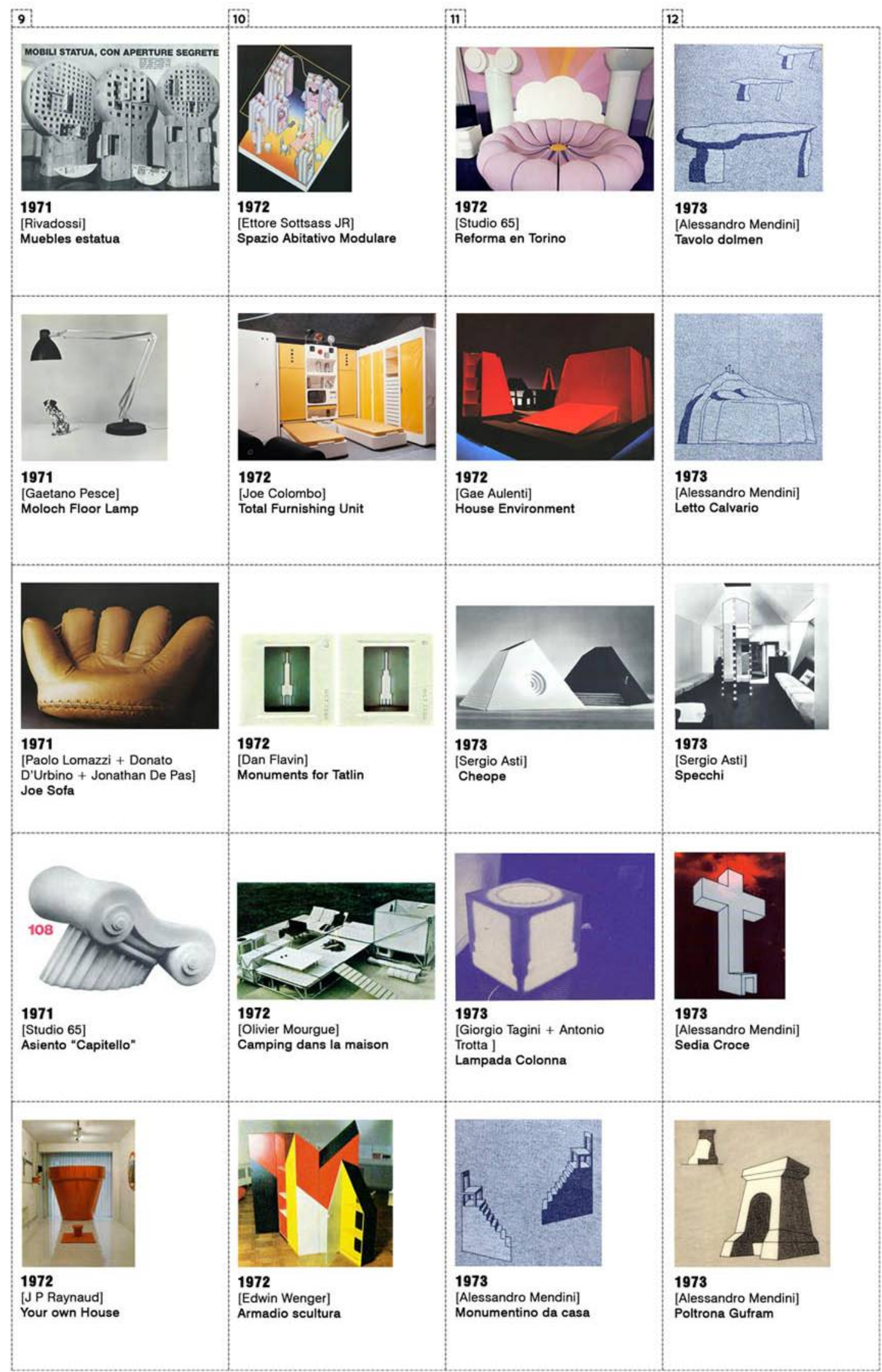




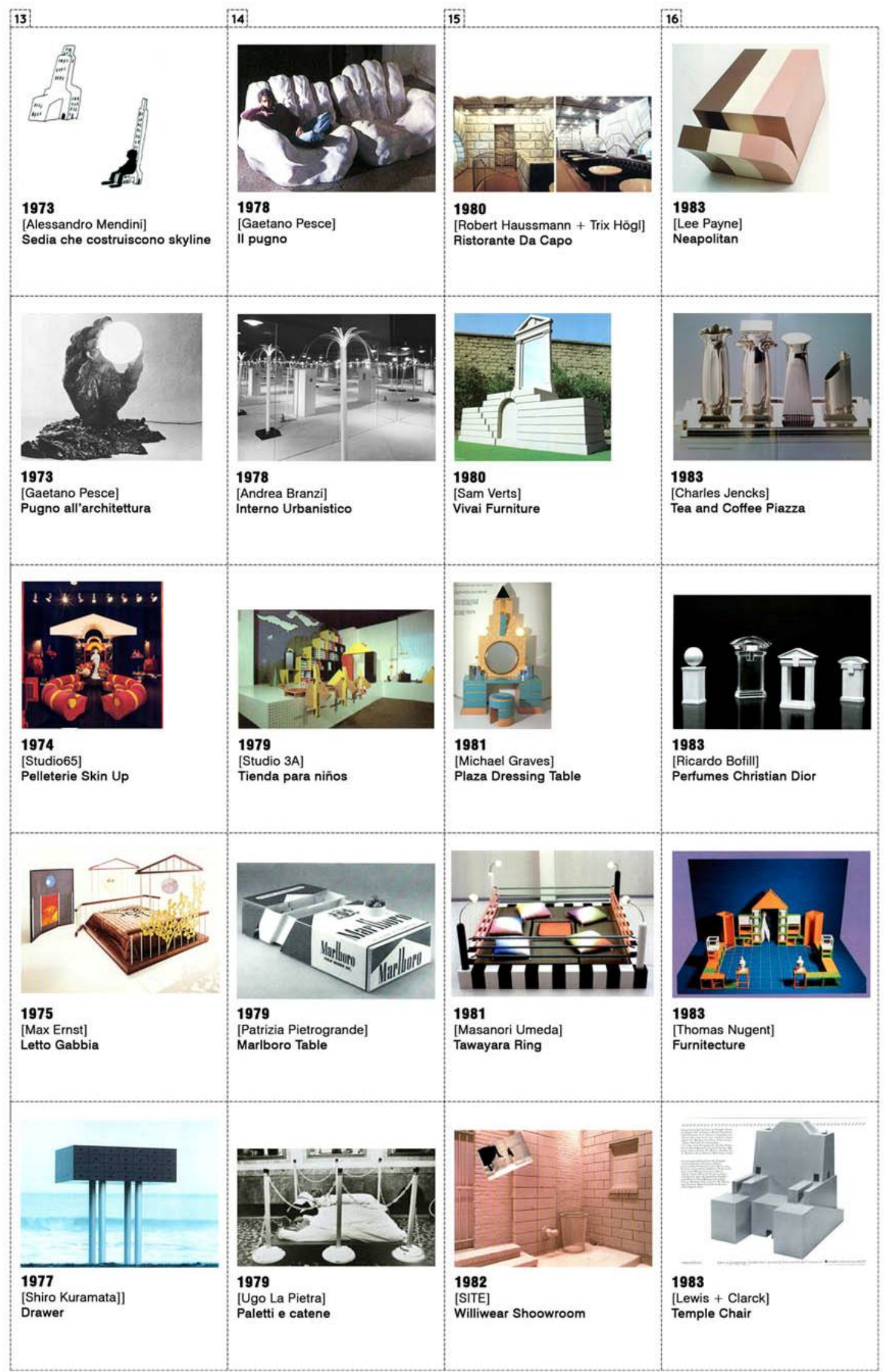




\section{[Ciudad interior] \\ El diseño de mobiliario e interiorismo como urbanismo.}

El concepto "paisaje doméstico" aparece en 1972 de la mano de Emilio Ambasz y la exposición del MOMA "Italia: the New Domestic Landscape"377 de la que él mismo es comisario. Entender el interior como un paisaje y lo doméstico como ambiente independiente de la arquitectura que lo circunda tiene un posible origen en el texto de 1969 de Joe Colombo "Anti-Design"378, en el que el diseñador italo-americano explica su teoría de un hábitat pensado por medio del diseño y no siguiendo las formas jerárquicas impuestas por la arquitectura. De esta manera, el mobiliario se desvincula del contenedor, apareciendo como un sistema de elementos autónomos, móviles y programáticamente independientes. Esta liberación del paisaje interior frente al exterior permite la transferencia de elementos entre uno y otro como explican Colombo y Ambasz con apenas tres años de diferencia:

"El diseño de mobiliario era el producto final de un proceso que se inicia a partir de las dimensiones macroscópicas externas al problema: la arquitectura de determinadas zonas urbanas, que a su vez coordinan el interior, que al final se llena de objetos y piezas de mobiliario cuyo diseño no está coordinado con el resto del proceso. El análisis del problema debería, por tanto, partir del centro hacia fuera, al contrario de lo que ha sido considerado como lo normal hasta hoy en día."1379 (Joe Colombo, 1969, p.28)

"El ambiente interno se convierte, entonces, en el teatro para la recreación de las formas y secuencias de comandos introducidos desde el exterior. Pero en este proceso, es inevitable asignar a estos niveles otras importaciones de significado y por lo tanto modificar su estructura."1380 (Emilio Ambasz, 1972, p.143)

"Por lo tanto, un entorno doméstico, equipado para la introducción y transformación de las noticias del mundo pueden contribuir al proceso de hacer y romper esquemas y significados urbanos. ${ }^{.1381}$ (Emilio Ambasz, 1972, p.143)

377 "Italia: the New Domestic Landscapes" fue exhibida en "The Museum of Modern Art" de Nueva York del 26 de Mayo al 11 de Septiembre de 1972.

378 COLOMBO, Joe. Anti-Design. En: Casabella, n³42, noviembre 1969. pp.28.

379 COLOMBO, Joe. Anti-Design. 1969. p.28

380 "The domestic environment becomes, then, the theater for the reenactment of forms and scripts introduced from the outside. But in this process, we inevitably assign to these importations other levels of meaning and thereby modify their structure"

AMBASZ, Emilio. Design Process. En: AMBASZ, Emilio (editor). Italia: the New Domestic Landscapes. Achievements and Problems of Italian Design. The Museum of Modern Art. Nueva York, 1972. p.143.

381 "Thus, a domestic environment equipped for introducing and transforming news of the world may contribute to the process of making and breaking urban patterns and meanings"

AMBASZ, Emilio. Italia: the New Domestic Landscapes. 1972. p.143. 


\begin{abstract}
"Así como el paisaje natural reemplazó el medio divino para convertirse en la principal preocupación del hombre del Renacimiento, un nuevo paisaje construido por el hombre, en parte ambiente socio-cultural y en parte no humano, se ha convertido en el marco omnipresente del pensamiento del hombre contemporáneo y su imaginario colectivo. ${ }^{1382}$ (Emilio Ambasz, 1972, p.145)
\end{abstract}

Esta transferencia no sólo incide en un cambio de escala de objetos cotidianos para la reformulación del ambiente interior sino en un potencial de transformación del "entorno urbano" a partir de la experimentación interior en esos nuevos "paisajes domésticos". De esta manera, el interiorismo y el diseño de mobiliario reinterpretarán ese paisaje doméstico redescubierto a partir de estrategias de distorsión escalar: objetos cotidianos convertidos en mobiliario, muebles proyectados como si fueran edificios o funciones específicas de la casa totalmente empaquetadas.

\title{
De las habitaciones dentro de habitaciones al Super-mobiliario.
}

La experimentación de Joe Colombo en relación a esa búsqueda de autonomía de los objetos de mobiliario dentro del espacio doméstico se expresa a modo de manifiesto en dos de sus diseños de principios de los años sesenta. Tanto en "Micro-cucina Carrelone" (1963) [1C] como en "Personal Container" (1965) [1E] Colombo explora en torno a la compactación máxima de dos usos domésticos como son la cocina y la zona de esparcimiento después del trabajo. En ambos diseños experimenta también con la personalización de los objetos dentro de la vivienda compartida, ya que la micro-cocina está pensada para "satisfacer el hobby masculino de la gastronomía" 383 y el mueble contenedor "diseñado para crear una zona personal en un salón, resume y condensa en sí mismo toda una habitación"334. La reducción de un uso específico dentro de la vivienda a un elemento de mobiliario presenta en estos proyectos de Colombo el concepto de "compacto", mobiliario que a través de su volumen exterior equipa un espacio. También en una dirección parecida, el diseñador Ken Isaacs desarrolla sus prototipos "Living Structures" 385 , objetos de auto-construcción asociados a sistemas de bricolaje, que a través de una trama tridimensional ortogonal materializada a partir de listones de madera o "Matrix System" pueden ir configurando diferentes espacios; hibridando situaciones espaciales, usos y mobiliario. Durante toda la década de los cincuenta y sesenta, Isaacs experimentará con este tipo de estructuras en su curso de diseño de la Rhode Island, y las popularizará a través de su publicación en secciones de bricolaje de revistas norteamericanas como "Popular Science" 386 , magazines de actualidad

\footnotetext{
382 "As the natural landscape replaced the divine milieu in becoming Renaissance man's primary area of concern, so a newly emerging manmade landscape, part socio cultural environment and part nonhuman environment, has become the allpervading framework of contemporary man's thought and imagery"
}

AMBASZ, Emilio. Italia: the New Domestic Landscapes. 1972. p.145.

383 "Questo mobile contiene tutta l'atrezzatura necesaria per soddisfare l'hobby maschile della gastronomia, dice l'autore"

Una cucina minima su ruote, disegnata da Joe Colombo. En: Domus, n418, septiembre 09/1964. p.24.

384 "...pensato per creare in un soggiorno una appartata zona personale, riassume e racchiude in sé tutta una stanza"

Nuovi mobili italiani. En: Domus, n432, noviembre 11/1965. pp.36-37.

385 Isaacs había desarrollado su primera "Living Structure" en 1949 en su casa de Peoria, Illinois.

386 Isaacs es editor consultor de Popular Science y escribe artículos sobre diseños suyos "Do It Yourself", se han referenciado aquí los relacionados con "Matrix System": 
como "Life" ${ }^{387}$ y la compilación de planos y detalles de montaje que conformará su posterior libro "How to build your own Living Structures"388 de 1974. La diversidad de estos espacios habitables dentro del propio interior de la vivienda variará desde el híbrido entre cama, y zona de comedor de la "Living Structure" de 1963 a la especialización de la "Super-chair" (1965) [2C] como zona de lectura. Ambos diseñadores actúan como agentes de un cambio de escala significativo en el espacio doméstico a partir de usos de la vivienda convertidos en super-mobiliario o mini-habitaciones, conceptos a evolucionar, ya sea a través de cada una de las líneas propias de investigación que ambos plantean o mediante distintas hibridaciones de las mismas. En Estados Unidos principalmente, proliferarán los proyectos basados en el "Do It Yourself" propuestos por Isaacs, asociados a estrategias de supergráfica, como "The Supercube" (1967) [3D] de Lester Walker o "Rotating Barrell Room" (1967) [3E], un sistema de dormitorio diseñado por Tom Luckey a partir de un volumen cilíndrico equipado en su perímetro con aberturas que contiene un sofá, una mesa y una cama, pudiendo ser utilizados en las distintas posiciones de este cilindro móvil, situado en el interior de una habitación existente.

Otros de esos proyectos que experimentan con la estrategia de "habitaciones dentro de habitaciones" tendrán sin embargo como referente destacado la estética espacial de la película "2001: A Space Odyssey"389 (1968), totalmente alejada de la relacionada con la autoconstrucción. De esta manera, esos proyectos abandonan paulatinamente el carácter modular de los prototipos de Ken Isaacs para adoptar geometrías más ergonómicas, de formas suaves, asociadas a la construcción a medida que ofrecen los materiales plásticos. Proyectos como "Espacio para una nueva forma de habitar" (1969) [5A] de Luigi Colani o la propuesta de Joe Colombo para la exposición de Bayer "Visiona 1. Futuristic Habitat" [5B] aparecen como cápsulas independientes, totalmente equipadas, construidas en fibra de vidrio blanca. Sus interiores suaves construyen paisajes domésticos totalmente análogos a la famosa película de ciencia-ficción de Stanley Kubrick.

A partir de 1969, la emancipación del mobiliario promulgada por Colombo y el advenimiento de la cápsula espacial propician la multiplicación de este tipo de elementos de mobiliario. Muchos de esos diseños, exclusivamente italianos, como "Armadio Letto" (1969) [5D] de Alberto Salvati y Ambrogio Tresoldi o "CentralBlock" (1970) [7A] de Alberto Seassaro, serán también referenciados en la anteriormente citada exposición de 1972 "Italia: the New Domestic Landscapes". La propuesta de Joe Colombo para la misma, "Total Furnishing Unit" [10B], hibrida los modelos "cápsula" y "compacto" para convertir una vivienda en un supermueble equipado con zonas habitables en su interior y un perímetro lleno de mecanismos de apertura. Armarios que se desplazan para convertirse en muros, camas que se despliegan delimitando una habitación o una cocina reducida a una simple pared equipada, todo ello en materiales plásticos de líneas redondeadas y en una aséptica gama de colores de tonalidades blancas y amarillas. Así es como todos los elementos de una vivienda se reducen a un mueble equipado con independencia de su contenedor. Esta propuesta

ISAACS, Ken. How to build the Superchair. En: Popular Science, marzo 1968. pp.160-165.

ISAACS, Ken. The Living Cube 4x4, un example of Ken Isaacs' Matrix Projects. En: Popular Science, marzo 1969. p.216.

ISAACS, Ken. Instant Housing for your country site. En: Popular Science, julio 1972. pp.88-91.

387 ISAACS, Ken. Home in a Cube. En: LIFE, 11 de octubre de 1954.pp.91-92.

388 ISAACS, Ken. How To Build Your Own Living Structures. Harmony Books. Nueva York, 1974.

389 Referenciada en multitud de ocasiones en revistas de arquitectura. En este caso, Ettore Sottsass adjunta dos páginas a todo color en su artículo:

SOTSASS JR, Ettore. Memorie di panna montata. En: Domus, n472, marzo 03/1969. pp.43-47. 
canaliza los experimentos anteriores de Colombo sobre mobiliario dinámico realizados en piezas como "Rotoliving" (1970) [6C], una cocina-pared con mesa giratoria que convierte al conjunto en comedor o cocina, o "Cabrioletbed" (1970) [7E], una cama-pared que se despliega como si de una capota se tratara.

Esta idea de mobiliario de usos amplificados o "Supermobiliario" es desarrollada por proyectos como "Il Cucinone" (1971) [8C] de Luigi Massoni, que alberga una cocina, una mesa de trabajo y una cama en una escalera, o el "Divano Rumble" (1967) [3C] de Gianni

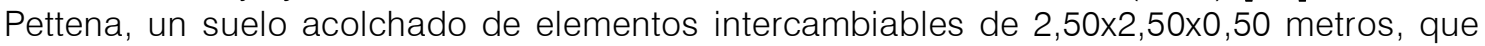
constituye por sí mismo todo un salón entero. Esa desconexión entre interior y exterior preconizada por estos elementos será llevada al límite en la propuesta "No-Stop City" (1970) [7D] de Archizoom, una ciudad interior como si de un mega-supermercado se tratase, con su propio clima artificial controlado, que se ordena a partir de las distintas configuraciones de un mobiliario interior reducido a los elementos casi indispensables para el desarrollo de la vida. Un planteamiento similar será también utilizado posteriormente por Ettore Sottsass Jr. en su propuesta "Spazio Abitativo Modulare" de 1972 [10A]. En este proyecto, el arquitecto italiano empaqueta todas las necesidades de mobiliario de una vivienda en un sistema de módulos que pueden ser equipados con todo tipo de elementos intercambiables. Su carácter neutro, formalizado a partir de unos contenedores grises, apuesta por una desaparición del objeto, que indiferenciado, sólo depende ya de las necesidades de cada una de las situaciones domésticas concretas.

"El mobiliario no tiene ningún vínculo formal con el grupo étnico del propietario. Él usará más o menos contenedores, será propietario de más o menos cajas, resolviendo finalmente el problema en términos de cantidad y no de calidad."1390 (Sottsass, 1972, p.162)

Ese nuevo paisaje doméstico plantea un entendimiento del espacio de la vivienda como si de una ciudad interior en miniatura se tratase, generando así propuestas contrapuestas. Proyectos de mobiliario super-especializado para su desaparición simbólica, de renaturalización del interior o de aprovechamiento del pintoresquismo que la palabra "paisaje" le confiere, como es el caso de "Camping dans la maison" (1972) [10D] de Olivier Morgue, que diseña una línea de mobiliario móvil para una vivienda como si de una serie de elementos de camping se tratasen.

\section{Urbanismo de interiores. Edi-muebles, mobiliario diseñado como edificios.}

Esa idea de ciudad en miniatura coincide con la interpretación del mobiliario como si de un conjunto de edificios se tratase, generando una suerte de urbanismo de interiores y aumentando el interés de los arquitectos hacia este nuevo campo de experimentación arquitectónica. Ya en 1966, Ettore Sottsass diseña la serie de armarios "Superbox" [2D] para la firma Poltronova a partir de una serie de elementos exentos construidos como si fueran volúmenes arquitectónicos, pintados con supergráficas abstractas de motivos geométricos y vivos colores, similares a algunos de los trabajos que Daniel Buren estaba realizando por

390 "They have no formal link with the owner's ethnic group. He will use more or less containers, own more or less boxes, and will finally resolve the problem in terms of quantity rather than quality" 
aquella época ${ }^{391}$. Ambas estrategias, irán encaminadas según Sottsass a un "decondizionamento" 392 del objeto, a través de su carácter exento y del uso de la gráfica como si de un camuflaje se tratara. Sin embargo, ya en la publicación del proyecto en Domus, ese carácter de desaparición física del objeto se contradice con unas fotografías desde abajo que hacen que los muebles aparezcan como grandes monumentos dentro del espacio doméstico.

\begin{abstract}
"Aislados en el centro de la habitación y envueltos de colores, no sólo hacen que uno se olvide de las paredes, la presencia de la pared, sino que no se refieren a ningún otro tipo de armario, a cualquier otra función que las relaciones mutuas entre el objeto y el medio ambiente. Hacen pensar en aquellos monumentos solares monolíticos de los que se nos escapa el significado, pero de la que podemos hacer un uso psíquico ilimitado. ${ }^{11393}$ (Sottsass, 1967, p.37)
\end{abstract}

El carácter arquitectónico de estos muebles es evidente. "L'amatore del magnetófono" [2D] aparece como un edificio al uso, superpuesto a un podio blanco, compuesto por un cuerpo con líneas verticales azules y una coronación retranqueada del resto. En "Fluorogeologia psichodelica", [3A] el edificio-mueble se levanta del terreno y se contextualiza mediante una repetición de sus colores en la pared, mientras que "Vestiti nel orto" [2E] aparece como un rascacielos escalonado de la ciudad de Nueva York, fotografiado con el punto de vista muy bajo y superpuesto a una alfombra con motivos vegetales como si fuera una maqueta de una de las instantáneas de la ciudad que pueden tomarse desde Central Park. Una estrategia similar es utilizada por el mismo Sottsass en "Nefertiti Desk" (1968) [4B], un escritorio con reminiscencias de arco de triunfo que mantiene la simplicidad geométrica y la supergráfica de "Superbox". Sólo tres años después en "Paesaggio per un Pianeta Fresco" [4C], una exposición de sus trabajos en el Museo Nacional de Estocolmo del 1969, Sottsass sustituirá su discurso de desaparición del objeto por el de una búsqueda de identidad en el paisaje doméstico a través del significado de cada uno de los muebles:

"En cualquier caso, la idea es que todo el mundo empieza a crear en torno suyo a partir de de lo más inesperado y fantástico, porque la creación del lenguaje es el primer derecho de todos, aunque intentemos impedirlo, negarlo. ${ }^{1394}$ (Sottsass, 1969, p.54)

La búsqueda de esa capacidad semántica del espacio doméstico por parte de Sottsass le llevará a un cambio de escala figurativo en sus piezas de mobiliario, formalizadas esta vez sí

391 CRUZ SÁNCHES, Pedro A. Daniel Buren. Nerea. San Sebastián, 2005. pp.31-33.

392 "Decondizionamento" sugiere la falta de presencia física del objeto. Tema principal de la revista Pianeta Fresco n²/3 de 1968, del que Sottsass es editor:

Pianeta Fresco, n²/3, equinozio invernale, 1968. Tecnologia del decondizionamento.

393 "Isolati nel mezzo della stanza e fasciati di colori, non solo fanno dimenticare le pareti, la presenza del muro, ma non rimandano a nessun altro armadio, a nessun'altra funzione che la mutua relaciones tra oggetto e ambiente. Fanno piuttosto pensare a quei monumento Solari monolitici di cui sfugge il significato, ma di cui possiamo fare un uso psichico illimitato"

SOTTSASS JR, Ettore. Mobili 1966. En: Domus, n449, abril 04/1967. pp.37-46.

394 "Ad ogni modo l'idea é che tutti cominciano a crearsi intorno l'ambiente più imprevisto e fantástico; perché la creazione del linguaggio é il primo diritto di tutti, anche se continuamo a impedircelo, anzi, a negarcelo"

SOTTSASS JR, Ettore. Sottsass a Stoccolma. En: Domus, n474, mayo 05/1969. pp.49-54. 
deliberadamente como pequeños edificios. La pieza de mobiliario "Mausoleo" (1969) [4D], expuesta en la citada exposición de Estocolmo, es diseñada como un módulo exento de almacenaje y sofá integrado, coronado con cuatro de sus lámparas "Asteroide" y una estatua de Buda en el centro como si fuera un templo budista a escala reducida. Ese carácter litúrgico es detectado también por Emilio Ambasz en diseños anteriores como las "Superbox":

"Reconociendo que en nuestra sociedad el objeto a menudo sirve como un fetiche, algunos diseñadores tratan de subrayar esa cualidad mediante la asignación a sus diseños de una calidad explícitamente ritual. Se le da forma escultórica al objeto como si se concibiese como un retablo para la liturgia doméstica." ${ }^{1395}$ (Ambasz, 1972, p.94)

La concepción de muebles como edificios no sólo responde a una sacralización del espacio doméstico, sino también a una búsqueda formal en el diseño de interiores a partir de esa apreciación de nuevo paisaje fabricado por el hombre que supone la reinvención de "/o doméstico". Los homenajes arquitectónicos se sucederán, desde la estantería zigurat "Uno sull'altro" (1970) [7B] de Gianni Pettena o la torre de almacenaje vertical "Pyramid Wardrobe" (1969) [4E] del japonés Shiro Kuramata, a los diseños irónicos de Max Peintner para la "Mesa Chrysler" (1969) [6A], en la que construye las patas de una mesa con cuatro reproducciones a escala reducida del emblemático edificio neoyorkino, coronando el conjunto con una antena parabólica gigantesca. Estas reproducciones aprovechan tanto modelos "contemporáneos", como la megaestructura reinterpretada por Bruno Munari en la estantería habitable "Abitacolo Cockpit" [8B]; como ejemplos "clásicos", con Luigi Massoni diseñando una estantería habitáculo con forma de vivienda tradicional en "Casa dentro casa" de 1971 [8D]. Todos estos juegos formales aprovechan de manera reiterada todo tipo de elementos arquitectónicos como excusa para el diseño. Giusseppe Rivadossi utiliza la reproducción de cientos de pequeñas ventanas, en su serie de "Muebles estatua" (1971) [9A], para generar compartimentos secretos en estas estanterías con forma de edificios fantásticos y Archizoom rediseñan su "Armadio Abitabile" (1970) [6D] como lo harían con alguna de sus propuestas de edificios mono-mórficos de gran escala frente al paisaje con las que estaban trabajando de manera simultánea. Gae Aulenti incluso llegará a compatibilizar el diseño de elementos modulares con la idea de monumentalización del mobiliario doméstico en "House Environment" de 1972 [11B]. Para este proyecto concebirá una serie de pirámides domésticas, que funcionan como estanterías y limitadores espaciales, mediante la combinación de tres elementos de plástico modulares.

Estas "arquitecturizaciones" o "monumentalizaciones" no afectan exclusivamente al mobiliario sino que llegan a contaminar todo el rango de objetos con influencia en el espacio doméstico, desde las series de fuentes y platos con formas arquitectónicas de la "Ceramiche tantriche" (1969) [5C] de Sottsass o el vaso con forma de pirámide truncada similar a la de un templo "Cheope" (1973) [11C] de Sergio Asti, hasta los neones de Dan Flavin en su serie "Monuments for Tatlin" (1972) [10C], simulando distintas siluetas de rascacielos norteamericanos. Las mismas reproducciones de rascacielos son utilizadas icónicamente también por Asti a través en "Specchi" (1973) [12C], un armario con acabado de espejos y bombillas, que intenta equiparar el espacio de una simple habitación con el de

395 "Recognizing that the object in our society often serves as a fetish, some designers underscore that quality by assigning to their designs an explicitly ritualistic quality. The object is given sculptural form as conceived as an altarpiece for the domestic liturgy"

AMBASZ, Emilio. Italia: the New Domestic Landscapes. 1972. p.94. 
una calle de Manhattan. Estas reinterpretaciones tendrán a Alessandro Mendini como su máximo representante gracias a su serie de mobiliario "Oggetti a uso spirituale":

"A través de esta investigación en los límites del diseño he intentado cuestionar los criterios de diseño para el uso funcional del objeto en favor de un uso espirituall1396 (Mendini, 1974, p.45)

La prioridad otorgada por Mendini al uso espiritual frente al funcional, ya no trata de incorporar nuevos significados a la resolución de problemas funcionales sino todo lo contrario. El objeto no sólo se convierte en instrumento de crítica arquitectónica, hipótesis esbozada en su artículo "Impossibilitá d'uso"397, sino también en un monumento arquitectónico como homenaje a lo doméstico. En "Letto Calvario" [12B], "Tavolo Dolmen" [12A], o "Sedia Croce" [12D], diseños realizados entre 1973 y 1974, Mendini evidencia un giro radical en la sistemática del cambio de escala. Ya no es la arquitectura la que se nutre del cambio de escala de objetos cotidianos o simbólicos para aumentar su espectro formal, sino que en sentido inverso, es ella la que se introduce de una manera literal en "otras disciplinas", convirtiéndolas en "arquitectónicamente auto-referenciales". Esa autoreferencialidad arquitectónica encontrará en la "Poltrona Gufram" ${ }^{398 " ~(1973) ~[12 E], ~ d i s e n ̃ a d a ~}$ por el propio Mendini, uno de sus más importantes objeto-manifiesto: un sillón de goma como réplica fidedigna de un arco del triunfo a escala reducida que aprovecha la zona del arco para construir la superficie de asiento. El paisaje doméstico no es sólo ya una ciudad interior como explicita Andrea Branzi en 1978 en su "Interno Urbanistico" [14B] sino un banco de pruebas de reinterpretaciones históricas, como evidencian las simulaciones de sillería en las paredes de mármol interiores del "Ristorante da capo" (1980) [15A] de Robert Haussmann y Trix Högl, el juego de volúmenes de la "Plaza Dress Table" (1980) [15C] de Michael Graves, o la reivindicación de la columna jónica hecha por el colectivo napolitano Studio65 en su asiento "Capitello399" (1971) [9D], o por Antonio Trotta y Giorgio Tagini con la "Colonna Lampada" (1973) [11D]. Dichas reinterpretaciones se reproducirán también de nuevo en otros formatos, desde los juegos de café y té de la marca Alessi diseñados a partir de los años ochenta por arquitectos como Charles Jencks, Aldo Rossi o el propio Michael

396 "Con una ricerca svolta ai limiti del design il tentativo di contestare il criterio dell'oggetto ad uso funzionale a favore di quello dell'oggetto ad uso spirituale"

MENDINI, Alessandro. Oggetti ad uso spirituale. En: Domus, n535, junio 06/1974. pp.45-47.

397 MENDINI, Alessandro. Impossibilitá d'uso. En: Casabella, n³92-393, agosto-septiembre 1974. pp.6-7.

398 Que tendrá en 1984 una reinterpretación, la "Temple Chair" diseñada por Lewis \& Clarck en 1984 y ganadora del Concurso Surface \& Ornament de Formica:

DORFLES, Gillo. Surface and Ornament. En: Domus, n646, enero 01/1984. pp.62-64.

399 Ampliamente publicado y referenciado en artículos relacionados con diseño y comunicación:

Design e mass media. En: Casabella, n³79, julio 1973. pp.52-53.

Eurodomus, 4. En: Domus, n512, julio 07/1972. p.160.

Domus Rassegna. En: Domus, n532, marzo 03/1974. pp. 613-614.

Tambien referenciado como mobiliairo en proyectos de otros autores, apareciendo fotografiado en los interiores de esos proyectos:

La casa albero. En: Domus, no512, julio 07/1972. p.91

Abitare a Lucca. En: Domus, n564, octubre 10/1984. p.44. 
Graves, hasta líneas de perfumes, como la de Ricardo Bofill para Christian Dior en 1981, e incluso casas de muñecas ${ }^{400}$ como objetos en los que poder verter "ideologías" arquitectónicas. [16B] [16C]

\section{Distorsiones domésticas. Interpretaciones pop del diseño de interiores.}

El nuevo paisaje doméstico redescubierto no escapa tampoco a las distorsiones de escala literales de objetos cotidianos derivados de la cultura pop. Artistas como Oldenburg en "Grandes Objetos" (1965) [2B], César en "Il Pollice di César" (1966) [3B] o J. P. Raynaud en "Your Own House" (1972) [9E] combinarán sus cambios de escala en exteriores con estas nuevas imágenes de perversión del ambiente doméstico. También los arquitectos coquetearán con estas transferencias de escala delirantes. La gran diferencia de estas experimentaciones, en relación a las mantenidas desde mediados de los años sesenta en el ámbito del diseño de edificios, se encuentra en la dificultad de explicitación semántica que este cambio de escala produce en esos objetos pensados para el interior de la vivienda. Mientras que una tienda de patos adquiere la forma de un pato para evidenciar su función principal, en este caso a través del objeto de venta explicitado, una silla o una mesa presentan una menor capacidad de adaptación formal al cambio de escala con los elementos que la auto-referencian. La investigación en este campo irá por lo tanto encaminada a la búsqueda del potencial formal de los objetos cotidianos y sus consecuencias en la generación de espacio. En este sentido, Haus Rucker-Co diseñan unas lámparas verticales como grandes dedos de uñas pintadas de escala aumentada, "Roomscrapers" (1970) [8A], o Paolo Lomazzi, Donato d'Urbino y Jonathan De Pas, transforman una mano abierta en su famoso "Joe Sofa" (1971) [9C]. Al igual que en el diseño de edificios, también existirá en esta transferencia una serie de elementos o iconos que se repiten de manera obsesiva. La misma mano cerrada le sirve a Gaetano Pesce para diseñar el sillón "Il Pugno" [14A] en 1978 o portando una esfera luminosa, construir la lámpara de mesa "Pugno all'architettura" (1975) [13B]. El mismo Pesce cambia de escala una flexo común en "Moloch Floor Lamp" (1971) [9B], una lámpara que mediante esa transformación pasará de ser lámpara de mesa a su homóloga de pié.

La experimentación con objetos irónicos apostará por una generación de paisajes oníricos como el "Interiorismo paródico" (1970) [6E] de UFO, en el que transforman el diseño de interiores en cómics espaciales tridimensionales. En diversas tiendas y negocios nocturnos de Florencia, los miembros de UFO generan discursos contrapuestos a partir de un interiorismo cargado de cambios de escala. En la tienda de deportes "Forza John!" recuperan edificantes aventuras de amor entre boys-scouts, en el restaurante "Sherwood", las aventuras dentro del famoso bosque son representadas superponiendo pintoresquismo a lo ya pintoresco, entendiendo el restaurante en sí como un lugar descontextualizado, o en la tienda de viajes "I Grandi Viaggi", reinterpretan los iconos de distintos destinos turísticos destacando el afán de estos lugares para ser "representados" por sus símbolos más característicos. Unos cambios de escala interiores que sirven a la vez de autocrítica a la propia disciplina arquitectónica. 
"Tal vez la tragedia esté ya presente en sus imágenes germinales, y por supuesto en las transmisión de estas imágenes a los que deben entenderlas, o más bien no las comprenden, ya que en realidad como puede estar sucediendo aquí, a sus ojos, está claro, nada es más tragicómico que sus medios, métodos, funciones y aspiraciones de arquitectos. ${ }^{.401}$ (Tommaso Trini, 1971, p.48)

La invención de posibles nuevos cambios de escala derivará en una explosión de situaciones detestables como en la "Marlboro Table" (1979) [14D] de Patrizia Pietrogrande, que convertirá una cajetilla de cigarrillos en una mesa, en un acto irresponsable de retroalimentación de la sociedad de consumo en su expresión más kitsch. La búsqueda semántica será ya puramente retórica, decadente y cualquier cambio de escala podrá ser justificado simplemente como cambio de escala a partir de un guiño irónico.

401 "La tragedia è forse già nelle loro immagini germinali, e sicuramente nella transmissione di queste immagini a chi dovrebbe intenderle o invece le fraintende, come può darsi che stia accadendo qui, mai ai loro occhi, è chiaro, nulla è piú tragicómico dei loro mezzi, metodi, aspirazioni e funzioni di architetti"

TRINI, Tommaso. L'UFO della parodia. En: Domus, n495, febrero 02/1971. pp.46-48. 


\section{Catálogo // [Objetualización ideológica]}

Las imágenes están referenciadas por números en la zona superior de las columnas verticales [del 1 al 8] y letras en la zona izquierda de las filas horizontales [de la A a la E].

Todas las referencias están ordenadas cronológicamente.

Referencias de imágenes del [1B] a [8E]. Cada uno de los proyectos referenciados gráficamente en el catálogo presentan antes de su nombre un código con un número en relación a su columna vertical y una letra en relación a su fila horizontal.

\section{Ejemplo:}

[7E] "Cloud 9" (1962) de Buckminster Fuller. Buscar referencia en la columna 7 y la fila E del catálogo referenciado al principio del capítulo.

[Nota]: no todos los referentes gráfico del catálogo están referenciados en el texto por lo que se recomienda una lectura del mismo antes de comenzar la del propio texto.
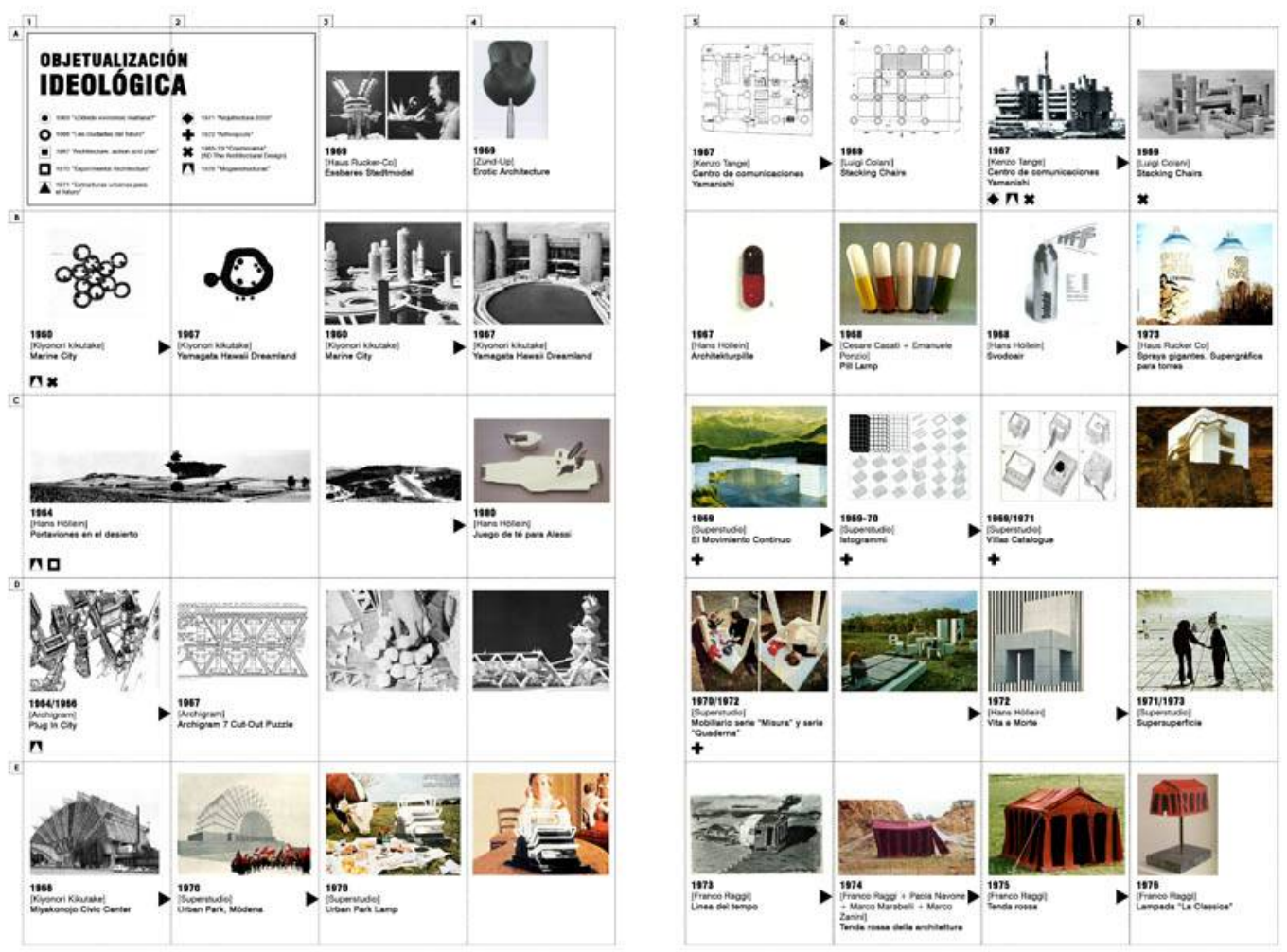


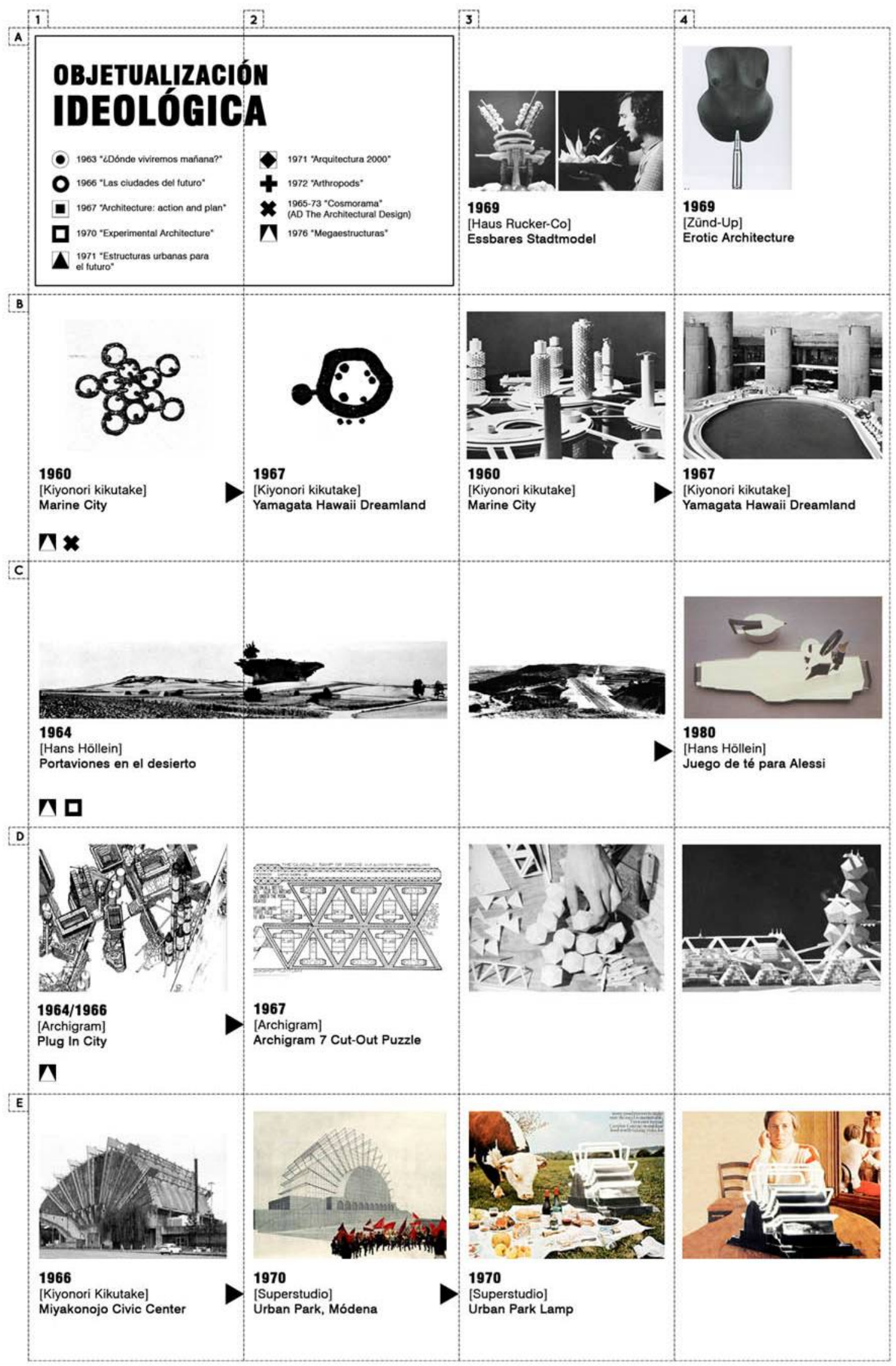




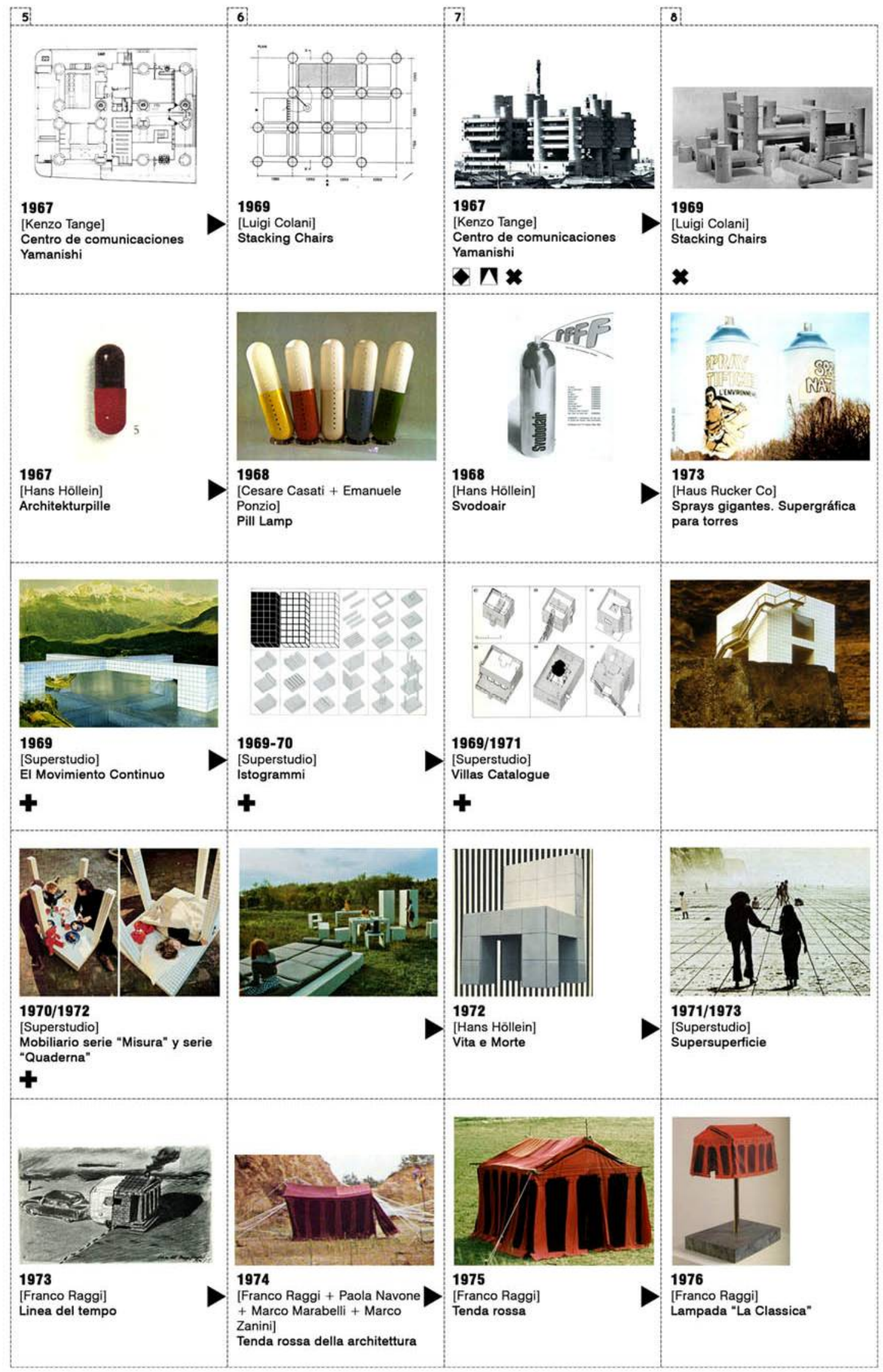




\section{[Objetualización de la ideología] Transformación de ideologías arquitectónicas en iconos objetualizados.}

Si el cambio de escala afecta a la relación de los edificios con el sistema de objetos comunes, ya sea desde su imagen exterior o en su configuración interna, esa misma operación se revela en un curioso proceso cuando es desarrollada dentro de la propia disciplina arquitectónica. De manera análoga se producen una serie de operaciones de conversión de "ideologías arquitectónicas" en objetos representativos de las mismas, ya sea a través de otros edificios, piezas de mobiliario o cualquier objeto capaz de evocarlas, en un acto auto-reafirmante sólo comprensible por un grupo reducido de "camaradas-arquitectos".

Este proceso de cambio de escala tiene en la ideología mega-estructuralista metabolista japonesa una paradigmática representación. Su carácter megalómano contrasta con la conceptualización de una arquitectura entendida como analogía biológica, que llevará a Kisho Kurokawa, uno de los principales representantes de esta ideología, a esquematizar en $1967^{402}$ gran parte de sus proyectos desarrollados hasta el momento en dos grandes grupos: los denominados como espacios porosos, o sistemas principales heterogéneos, derivados de las formas animales membranosas, y los espacios fibriformes, sistemas infraestructurales homogéneos derivados de las formas vegetales informales y lineales. Ambos sistemas son representados a través de dibujos esquemáticos como si fueran glifos japoneses. Tenemos así en esa genealogía de proyectos de Kurokawa, un ejemplo del funcionamiento de estos procesos de objetualización ideológica. Entre los espacios porosos, el glifo de su proyecto, "Helix City" [3B] de 1961 concuerda perfectamente con el sistema estructural de la "Marine City" [1B] diseñada por Kikutake en 1962 y es a su vez una sumatoria de otro de los glifos, el de la "Yamagata Dreamland Hawaii" de 1967 [2B] [4B]. Dicho proyecto, se construye mediante una estructura similar a la de la "Marine City" aunque en una ridícula versión a pequeña escala como apunta Banham:

"Ambos conceptos se combinaron en el modelo de la Ciudad Marina de 1962, y terminaron encontrando una caricaturizada versión en miniatura en tierra firme, realizada en 1967 por Kurokawa en su complejo-piscina Yamagata Hawaii Dreamland." ${ }^{403}$ (Banham, 1976, p.47)

El proyecto de la "Yamagata Dreamland Hawaii" demuestra la inoperancia del carácter aescalar de los glifos de Kurokawa. Una operación inversa se produce con otro edificio de la genealogía metabolista, el "Centro de Comunicaciones Yamanishi" (1967) [5A] [7A] de Kenzo Tange, que será transformado por Luigi Colani en un sistema de mobiliario, "Stacking Chairs" [6A] [8A], de 1969. En el "Yamanishi", un sistema de elementos estructurales primarios cilíndricos contiene a su vez todas las instalaciones y comunicaciones del edificio, mientras que el sistema horizontal se libera para conseguir espacios diáfanos fácilmente modificables. Dicho sistema, sin embargo no funcionaría así en la práctica, como demuestra de nuevo Reyner Banham:

402 KUROKAWA, Kisho. Recent Works. En: Kenchiku Bunka, n²53, vol28, noviembre 1967. pp.107-134.

He consultado también una version en castellano, debido a que el artículo de Kenchiku Bunka está en japonés:

KUROKAWA, Kisho. Dos sistemas de metabolismo. En: Cuadernos SUMMA-NUEVA VISIÓN, n²0, 1969. pp.16-23.

403 BANHAM, Reyner. Megaestructuras. 1978 (1976). p.98. 
"Las dependencias útiles debían hallarse en paralepípedos de hormigón amovibles, pero en la práctica, la construcción es convencional, de modo que el resultado, como en el Hábitat de Montreal, es en realidad una estatua monolítica que conmemora un ideal de adaptabilidad prácticamente imposible de realizar constructivamente." (Banham, 1976, p.47)

Es ese ideal de adaptabilidad el que lleva a Colani a diseñar un sistema de sillas apilables con el mismo sistema, unos cilindros que conforman la estructura principal y unas baldas horizontales para los asientos, que le permite generar gran cantidad de configuraciones a la vez que apilar hasta doscientas sillas en un metro cúbico de espacio. Así, el icono del ideal constructivo en que el edificio de Kenzo Tange se convirtió a finales de los años sesenta, será aprovechado por el diseñador suizo para generar un práctico sistema de mobiliario.

Una megaestructura será también utilizada por Archigram como punto de partida para el diseño de un objeto, aunque con fines muy distintos. En 1966, cuando los miembros de grupo inglés habían ya decidido no diseñar ninguna megaestructura más, al apostar por modelos de movilidad programática más cercanos a la libertad individual del automóvil que a la tiranía de la infraestructura, adjuntarán en el número siete de su propia revista ${ }^{404}$ un recortable en papel de una megaestructura "Do It Yourself". [1D] [2D] [3D] [4D]

"Así al trazar los gráficos para Archigram VII, en 1966, incluyeron en broma dos láminas de un juego de piezas megaestructurales de modelo recortable, una autosátira basada en que ahora todo el mundo puede hacer megaestructuras, hágase usted la suya. ${ }^{1405}$ (Banham, 1976, p.98)

Aquella megaestructura recortable de Archigram vuelve a incidir sobre el cambio de escala de una ideología para transformarla esta vez en un simple recortable, al haber decidido renunciar a ella como alternativa de futuro. El objeto crítico resultante aprovecha la semántica del ideal arquitectónico para comunicar un nuevo mensaje, que para el grupo Archigram va encaminado hacia las estructuras ligeras, la portabilidad, la capacidad de transformación del usuario y la simulación ${ }^{406}$ como nuevos paradigmas de futuro frente al carácter infraestructural pasivo de la megaestructura

\section{El objeto-manifiesto.}

La capacidad de otorgar a objetos pertenecientes al imaginario colectivo una serie de valores para su re-conversión en iconos ideológicos arquitectónicos supondrá una de las habilidades desarrolladas con más éxito por el austríaco Hans Höllein. Con "Architekturpille" [5B], o "Svodoair" [7B], proyectos coincidentes con el proceso de conceptualización del diseño que el arquitecto estaba llevando a cabo para el pabellón austríaco de la XIV

404 Archigram 7, Insert 7/1, 1966.

405 BANHAM, Reyner. Megaestructuras. 1978 (1976). p.98.

406 Archigram 8, 1968. Incluye proyectos como 1967 "Control and Choice Dwelling", que incide en la capacidad de transformación del usuario de su espacio doméstico, 1968 "Instant / Moment Village", un pueblo ambulante instantáneo o 1968 "Ideas Circus", una propuesta de un centro educativo móvil para retroalimentar los lugares dónde viaja a través de seminarios, proyecciones, exposiciones, etc... 
Triennale de Milán de 1968, Höllein transformará una píldora o un bote de spray en referentes singulares de una nueva arquitectura. Con ambos elementos como objetos referenciales de su célebre "Todo es arquitectura", una parte de la disciplina arquitectónica pondrá sus ojos en la generación de estructuras ambientales en las que lo matérico deja de ser el principal objetivo arquitectónico, al entender la arquitectura como un ente primario, ritual y casi existencial, más allá de la propia disciplina. Ambos objetos serán también a su vez reinterpretados por arquitectos o diseñadores una vez han sido éstos convertidos en iconos. Por una lado, Cesare Casati y Emanuele Ponzio diseñan en 1968 la lámpara "Pill Lamp" $^{\prime 407}$ [6B] aprovechando esa iconicidad tan en boga de la píldora como nuevo argumento arquitectónico. Haus Rucker-Co transforman varios años después dos torres de agua en sprays gigantes con un recurso de super-gráfica ${ }^{408}$ en su propuesta para el concurso de "Remodelación del Chateau d'eau en Marne-la-Vallée" [8B]. Mientras Casati y Ponzio simplemente acuden al recurso formal de la píldora y su repercusión mediática, no solamente arquitectónica, para diseñar una lámpara de gran éxito comercial, los miembros de Haus Rucker-Co fueron los alumnos aventajados de la ideología ambiental de Höllein, desarrollando varias propuestas de artefactos distorsionadores espaciales dentro de su programa "Mind Expander" de 1968 a 1970. Sin embargo, ya en 1973, el colectivo austríaco había abandonando ese tipo de propuestas que trabajaban con la construcción de ambientes perceptivos, desviando sus experimentaciones efímeras hacia sistemas de representación más simbólicos. El proyecto se convierte por lo tanto en una renuncia irónica a las ideas expresadas por el "Svodoair". El propio Höllein convertirá años después uno de sus objetos más icónicos como es el portaaviones abandonando en el desierto, transformado en seductora mega-ciudad tecnomórfica en su famoso collage, para pasar a ser la forma adoptada en "Juego de café y té" (1980) [4C] diseñado para la firma Alessi. Ambos objetos, el fotomontaje "Aircraft-carrier in the desert" (1964) [1C] [2C] [3C] y el juego de té, son emparentados por el austríaco en una misma hoja del catálogo ${ }^{409}$ de la retrospectiva sobre su trabajo expuesta en 1987 en el Centro Pompidou bajo el nombre "Méthapores et metamorphoses". De la "Expectativa" del portaviones en el desierto como alternativa de futuro a la "Excentricidad" 410 de ese juego de té materializado en reluciente plata.

Los arquitectos que más utilizarán ese recurso de conversión de ideología arquitectónica en objetos serán los italianos de Superstudio. Para el concurso "Urban Park" (1970) [2E] en Módena recuperan el diseño del "Miyakonojo Civic Center" (1966) [1E] del japonés Kiyonori Kikutake. Aprovechando el recurso estructural-formal de unas grandes cerchas radiales exteriores a la cubrición del edificio, Superstudio no sólo lo repite explícitamente en su propuesta, sino que una vez que el concurso se hubo perdido, diseñan una lámpara de neones dispuestos según la misma estructura radial.[3E] [4E]

"El diseño fue llevado hasta el límite de la retórica, con una arquitectura como resultado de un collage de citas de los arquitectos que han intervenido con sus ideales revolucionarios en la historia. Pero, al mismo tiempo hemos incorporado al

407 Expuesta en la exposición "Italia: the New Domestic Landscape" del MOMA.

408 Ambos posicionamientos son referenciados por Dominique Rouillard en:

ROUILLARD, Dominique. Superarchitecture. Le Futur de l'architecture 1950-1970. Éditions de la Villette. Paris, 2004.

409 HÖLLEIN, Hans. Hans Höllein. Méthapores et metamorphoses. Album de l'exposition. Centre Georges Pompidou. París, 1987. p.22.

410 Ambos proyectos son calificados de esta manera por Höllein en la publicación antes citada, "Expectative" para el proyecto de 1964 y "Excentrique" para el de 1980 
conjunto una irónica crítica saludable: el diseño era también el de una lámpara destinada a iluminar nuestras solitarias comidas. ${ }^{1411}$ (Superstudio, 1970)

De esta manera, la apropiación del icono arquitectónico será utilizada para la generación de un objeto de consumo como la lámpara, volviendo a la idea del icono que abandona el ámbito contextual arquitectónico del edificio, para multiplicarse hasta el infinito como objeto dentro de la sociedad de consumo. Sin embargo, el fin implícito en estos trabajos de cambio de escala realizados por Superstudio parecería que hubiera sido el contrario, según el discurso pronunciado por Adolfo Natalini en su conferencia de 1971 en la Architectural Association de Londres:

"Si el diseño no es más que un incentivo para consumir, entonces debemos rechazar el diseño. Si el diseño no es más que la codificación de los modelos burgueses de propiedad y de la sociedad misma, entonces debemos rechazar la arquitectura. Si la planificación de la arquitectura y la ciudad no es más que la formalización del injusto presente social, entonces debemos rechazar la planificación urbana y sus ciudades...

Hasta que todas las actividades de diseño estén dirigidas a satisfacer las necesidades primarias. Hasta entonces, el diseño debe desaparecer. La arquitectura será una de las principales superestructuras de poder. Podemos vivir sin arquitectura...

La construcción de una sociedad revolucionaria es posible a través de una fase de crítica radical y concreta de la sociedad actual - de su forma de producir, consumir o vivir, ...

Nuestro trabajo hoy en día tiene un sentido preciso en torno a la actividad de reconocimiento crítico de las posibilidades revolucionarias de la arquitectura." 412 (Natalini, 1971 (2003), p.168)

Esta llamada a una desaparición de la arquitectura, del diseño, del objeto al fin y al cabo, será uno de los ideales desarrollados por los grupos florentinos Superstudio y Archizoom o el arquitecto milanés Ettore Sottsass Jr, a través de nuevos conceptos como los promulgados por los propios Archizoom en "Le stanze vuote"413 o "la distruzione degli oggetti" ${ }^{\text {"14 }}$. Mientras el primero propone una serie de habitaciones con objetos simbólicos a

411 Web del arquitecto Cristiano Toraldo di Francia, uno de los miembros de Superstudio: www.cristianotoraldodifrancia.it

412 "If design is merely an inducement to consume, then we must reject design; if design is merely the codifying of the bourgeois models of ownership and society, then we must reject architecture; if architecture and town planning is merely the formalization of the present unjust social divisions, then we must reject town planning and its cities... until all design activities are aimed towards meeting primary needs. Until then, design must disappear. Architecture is one of the superstructures of power. We can live without architecture... The construction of a revolutionary society is possible through the phase of radical, concrete criticism of the present society - of its way of producing, consuming, living... Our work today has this precise sense of critical reconnaissance activity into the revolutionary possibilities of architecture."

NATALINI, Adolfo. Inventory, Catalogue, Systems of Flux... A Statement. En: LANG, Peter (editor). Superstudio: life without objects. Skira. Milano, 2003. p.168.

413 ARCHIZOOM. Le stanze vuote e i gazebi. En: Domus, n462, mayo 05/1968. pp. 52-54.

Originalmente diseñados para:

Pianeta Fresco, n²/3, equinozio invernale, 1968. Tecnologia del decondizionamento.

414 ARCHIZOOM. La distruzione degli oggetti. En: IN, 2-3 (2), 1971. pp.4-13. 
modo de miradores o "gazebi", sin seguir ningún precepto funcional o preestablecido sino a través de un origen simbólico, el segundo vaticina una destrucción del objeto doméstico a través de su disolución en simples partículas.

Esa anunciada desaparición de la arquitectura ${ }^{415}$ será materializada por Superstudio mediante la idea de la "Superficie neutra", término que nace de la mano de su proyecto de 1969 "El Monumento Continuo" [5C], y por el cual el grupo italiano propone una desaparición paulatina de la propia arquitectura, a través de la mediación de una superestructura homogénea cuyo interior albergue todas las funciones posibles para el desarrollo de la vida y cuyo exterior se engalane mediante una "malla universal homogénea", una retícula cuadrangular de fondo blanco con distintos grados de transparencia y líneas ortogonales negras. La misma malla universal será también utilizada en la construcción de los "istogrammi" ${ }^{416}[6 \mathrm{C}]$, dibujos asociados a la formalización de objetos de distintos tamaños construidos a partir de esa malla, que se va adaptando a las diferencias escalares y formales de los mismos, pero manteniéndolos siempre sujetos a su rigidez proporcional y geométrica.

"La superficie de estos histogramas era homogénea e isotrópica: cada problema espacial y todos los problemas de sensibilidad se retiraban cuidadosamente. Los histogramas también representaban <Las Tumbas de los arquitectos... $>^{1417}$ (Superstudio, 1972, p.36)

Esa muerte de los arquitectos preconizada por los miembros de Superstudio es también simbolizada en su proyecto de "Villas Catalogue" (1969-1971) [7C] [8C], un catálogo de viviendas en las que a partir del uso de los "istogrammi" son despojadas de cualquier preocupación semántica o cualitativa, derivando en una aséptica seriación de modelos que pudieran ser elegidos por los posibles clientes. Con ambos proyectos, Superstudio participa en la investigación colectiva "L'Invenzione della superficie neutra", una muestra de ambientes diseñados por Ettore Sottsass Jr, Archizoom Associati, los propios Superstudio, George Snowden y Clino Trino Castelli, organizada por la empresa de laminados plásticos ABE PRINT.

Este número de IN supone el acuñamiento de "Arquitectura Radical " por parte de Germano Celant, artículo también publicado en Domus:

CELANT, Germano. Senza titolo. En: Domus, n496, marzo 03/1971. pp.47-48.

415 La idea de "evasión" hacia el diseño y la arquitectura viene referenciada en bastantes artículos de la época con especial mención del escrito en 1973 por Franco Raggi "Radical Story":

RAGGI, Franco. Radical Story. En: Casabella, n³82, octubre 1973. pp.37-45.

416 En estadística, un histograma (istogramma en italiano) es una representación gráfica de una variable en forma de barras, donde la superficie de cada barra es proporcional a la frecuencia de los valores representados.

417 "La superficie di tali istogrammi era omogena ed isótropa: ogni problema spaziale ed ogni problema di sensibilità essendo accuratamente stato rimosso. Gli istogrammi si chiamavano anche <Le Tombe degli Architetti..."

SUPERSTUDIO. Dall catalogo degli Istogrammi alla serie misura. En: Domus, n517, diciembre 12/1972. pp.46-48.

Es interesante comprobar como casi simultáneamente, las series Misura y Quaderna son publicadas por Superstudio como elementos reivindicativos o totalmente comerciales. Como contrapunto a la publicación antes referenciada de Domus:

SUPERSTUDIO. Testimonianza a quadretti. En: Casabella, n³76, abril 1973. pp.46-47. 
"En el diseño de los entornos, los autores se proponen desarrollar y representar el tema de un espacio definido por superficies neutras destinadas a neutralizar hasta el punto de cortar todos los lazos y condicionantes lingüísticos preexistentes. ${ }^{1418}$ (1972, p.1)

Sin embargo, esa negación del carácter semántico resultará imposible mediante una estética, la de la malla universal homogénea, que no sólo se popularizará en el ámbito arquitectónico ${ }^{419}$, sino también en el mundo del diseño. Así es como sus "istogrammi" se convierten en el ingrediente fundamental de sus series de auto-producción de mobiliario "Misura" [5D] y "Quaderna" [6D], para la marca italiana de reconocido prestigio mundial Zanotta. La malla universal destinada a buscar una superficie homogénea que desvinculase a los objetos de toda señal semántica se convierte en un reclamo estético más de las élites de diseño. Un reclamo que se utilizará en una gran número de proyectos posteriores. La instalación de Höllein en la Biennale de Venecia de 1972, "Opera e Comportamento, Vita e Morte, Situazioni quotidiane" ${ }^{\prime 40}$ [7D], se articula mediante una serie de objetos de mobiliario construidos a partir de esa misma malla universal aunque de mayor tamaño, llegando a convertirse en portada de la revista Casabella. Esa "desaparición de los objetos" y su posterior reaparición, transformados en piezas icónicas del mundo del diseño, será criticada en varios artículos sobre los grupos Archizoom, Superstudio y Ettore Sottsass Jr escritos por Charles Jencks, en los que el autor inglés denominará a todos ellos como los "Supersensualist"

"Hablan de la eliminación del fetichismo y de la redundancia semántica. Uno se acuerda del período de Le Corbusier y su limpieza al vacío de la arquitectura moderna. Todos los resultados de esta purgación, como los de Le Corbusier, se convierten en nuevos objetos de culto: fantásticamente sensuales piezas metafísicas de mobiliario vendidas a los nuevos Borghese de Milán a través de uno de los muchos puntos de venta: Poltronova, Cassina, Knoll International..." ${ }^{1422}$ (Jencks, 1972, p.18)

\footnotetext{
418 "Nel disegno degli environments gli autori si propongono di sviluppare e di rappresentare il tema di uno spazio definito da superfici neutre, anzi, neutralizzare al punto che ese hanno tagliato definitivamente qualsiasi légame linguistico preexistente e condicionante"
}

SUPERSTUDIO. L'invenzione della superficie neutra. En: Elementi: quaderni di studi, notizie ricerche cahiers d'études, nouvelles recherches, $\mathrm{N}^{\circ} 3$ / 1973. pp.1-23

419 La influencia de la malla en la arquitectura japonesa de principios de los setenta es total. Muchos de los trabajos de esa época de Arata Isozaki lo corroboran.

420 SKREINER, Wilfred. L'architettura trovata. En: Casabella, n³71, noviembre 1972. pp.25-27.

421 JENCKS, Charles. The Supersensualists. En: AD The Architectural Design, junio 1971. pp.345-347.

JENCKS, Charles. The Supersensualists. Part II. En: AD The Architectural Design, enero 1972. pp.18-21.

422 "They speak of the elimination of fetishism and semantic redundancy. One is reminded of Le Corbusier's vacuum cleaning period of modern architecture. All the results of this purgation, like Le Corbusier's, turn into new objects of worship: fantastically sensual pieces of metaphysical furniture sold to the Borghese of Milan through one of the many outlets: Poltronova, Cassina, Knoll International, etc..."

JENCKS, Charles. The Supersensualists. Part II. AD 1972. p.18. 
Otro caso singular será el protagonizado por Franco Raggi y su proyecto "Tenda rossa della architettura"423. Un dibujo suyo de 1973, "Linea del tempo" [5E], reproduce la metamorfosis del Partenón griego en caravana tirada por un automóvil, simbolizando el paso hacia una arquitectura móvil y ligera, que a su vez no perdiera esas connotaciones simbólicas representadas por el templo clásico. Esta misma idea, será ejecutada en 1975 en el seminario "Architetture Culturalmente Impossibili" [6E] organizado por el colectivo Cavart de Padova. Allí, junto a Paola Navone ${ }^{424}$, Marco Marabelli y Marco Zanini, construirán con alumnos el proyecto "Tenda rossa dell'architettura" [7E], un templo dórico pintado a mano con técnica "povera" en una sábana, sujeta con una estructura principal de cañas y unos tirantes de cuerda exteriores. Dicho objeto, incluido dentro de sus "paradojas construidas", se apropia de la iconicidad del Partenón para transgredirla en su propuesta de una arquitectura que incorpore el objeto simbólico en el mundo tecnológico de la movilidad y la superproducción. Sin embargo, un año después, su "Tenda rossa" aparece ya como simple icono de nuevo. Más allá del Partenón al que representa, esa "Tenda Rossa" se convierte en "Lampada La Classica" [8E], un objeto de consumo, intranscendental e incluso no funcional. El cambio de escala de iconos arquitectónicos servirá de esta manera a sus creadores como símbolo auto-referencial, perdiendo cualquier capacidad crítica de la que hubiera gozado con anterioridad, negando incluso las ideologías radicales que habían supuesto su revolucionario nacimiento.

Casabella, n401, mayo 1975, portada.

424 Paola Navone escribe en 1974 junto a Bruno Ornaldoni el primer compendio de arquitectura radical:

NAVONE, Paola; ORLANDONI, Bruno. Architettura Radicale. Documenti di Casabella. Casabella. Milán, 1974. 


\section{Capítulo 5. PERVERSIONES NATURALES.}

Cada una de las predicciones arquitectónicas de futuro antes citadas realiza una aproximación a las nuevas relaciones arquitectónicas suscitadas a partir de la primera mitad del siglo XX entre los conceptos, aparentemente dicotómicos, natural y artificial. Estas relaciones van desde la contraposición absoluta generada entre la megaestructura y el paisaje en el que se inserta, suscitada por Banham, hasta la construcción de "Bioestructuras" como una de las organizaciones estructurales derivadas de las mismas, propuesta por Dahinden. La confrontación de ambos términos surge ya desde perspectivas arquitectónicas a través de analogías biomórficas en las obras de organicistas como Gaudí, Wright, Guedes, Kiesler, Soleri, Bruce Goff, O'Gorman, Couelle o Pascal Haüsermann, sin embargo serán utilizadas como recursos arquitectónicos formales más que como posicionamiento constructivo en relación al contexto natural circundante. De esta manera aparecen dos debates arquitectónicos a partir de dicha relación entre natural y artificial: por un lado, una serie de estrategias de camuflaje efectivo con el fin de hacer de la arquitectura artificial un objeto invisible dentro de su contexto natural, por otro lado, la incorporación de la naturaleza dentro de lo construido en un intento de re-naturalizar la ciudad, como única posibilidad de reducir el impacto de la misma sobre los paisajes ya devastados por ella.

- [Ciudad Paisaje], la ciudad convertida en paisaje como alternativa a la megaestructura.

- [Edificios Camuflaje], tácticas de camuflaje para edificios proyectados como naturalezas artificiales.

- [Naturaleza Equipada], cómo equipar la naturaleza y con naturaleza.

- [Re-Naturalizar la Ciudad], una vuelta a lo salvaje en la ciudad.

-[Naturalezas Domésticas], nuevos paisajes naturales domésticos. 


\section{Catálogo // [Ciudad Paisaje]}

Las imágenes están referenciadas por números en la zona superior de las columnas verticales [del 1 al 14] y letras en la zona izquierda de las filas horizontales [de la A a la E].

Todas las referencias están ordenadas cronológicamente.

Referencias de imágenes del [1B] a [14B]. Cada uno de los proyectos referenciados gráficamente en el catálogo presentan antes de su nombre un código con un número en relación a su columna vertical y una letra en relación a su fila horizontal.

\section{Ejemplo:}

[7E] "Cloud 9" (1962) de Buckminster Fuller. Buscar referencia en la columna 7 y la fila E del catálogo referenciado al principio del capítulo.

[Nota]: no todos los referentes gráfico del catálogo están referenciados en el texto por lo que se recomienda una lectura del mismo antes de comenzar la del propio texto.
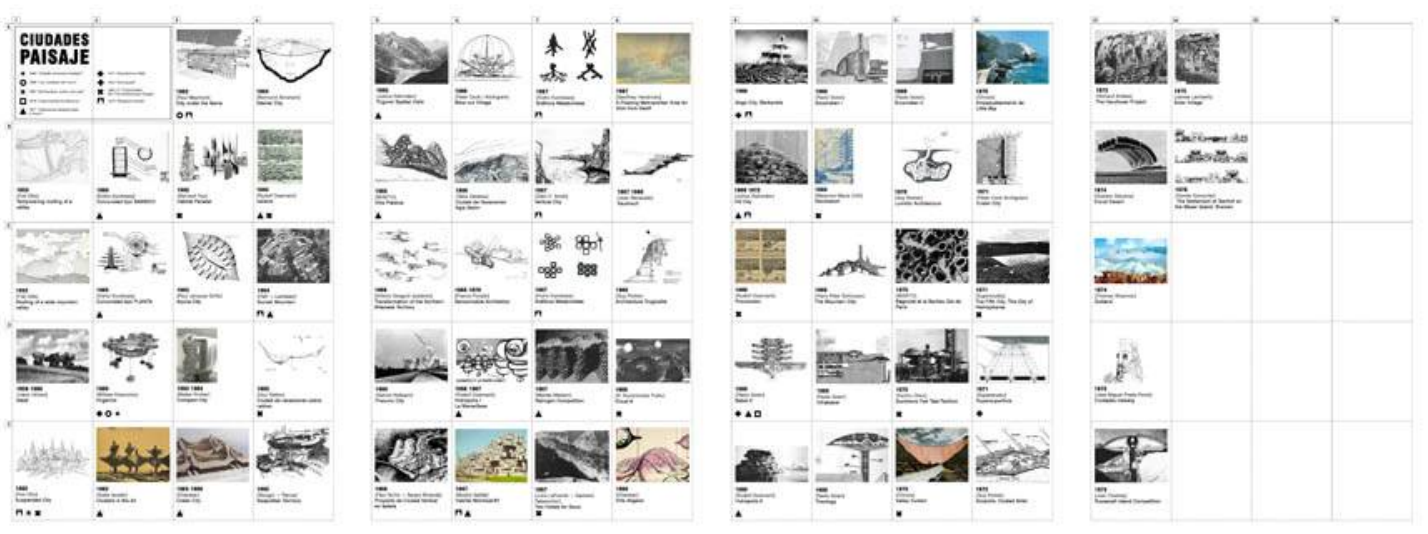


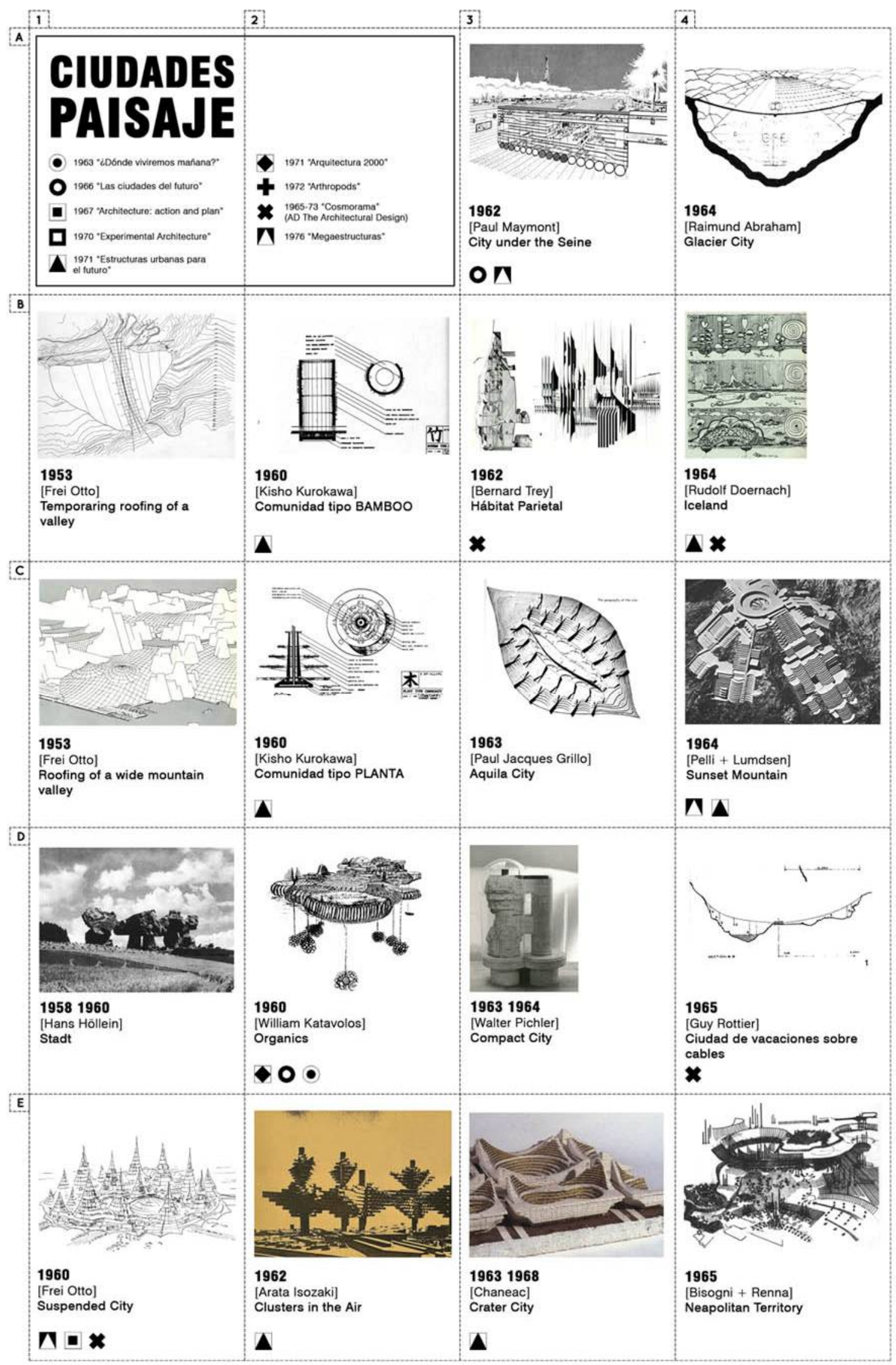




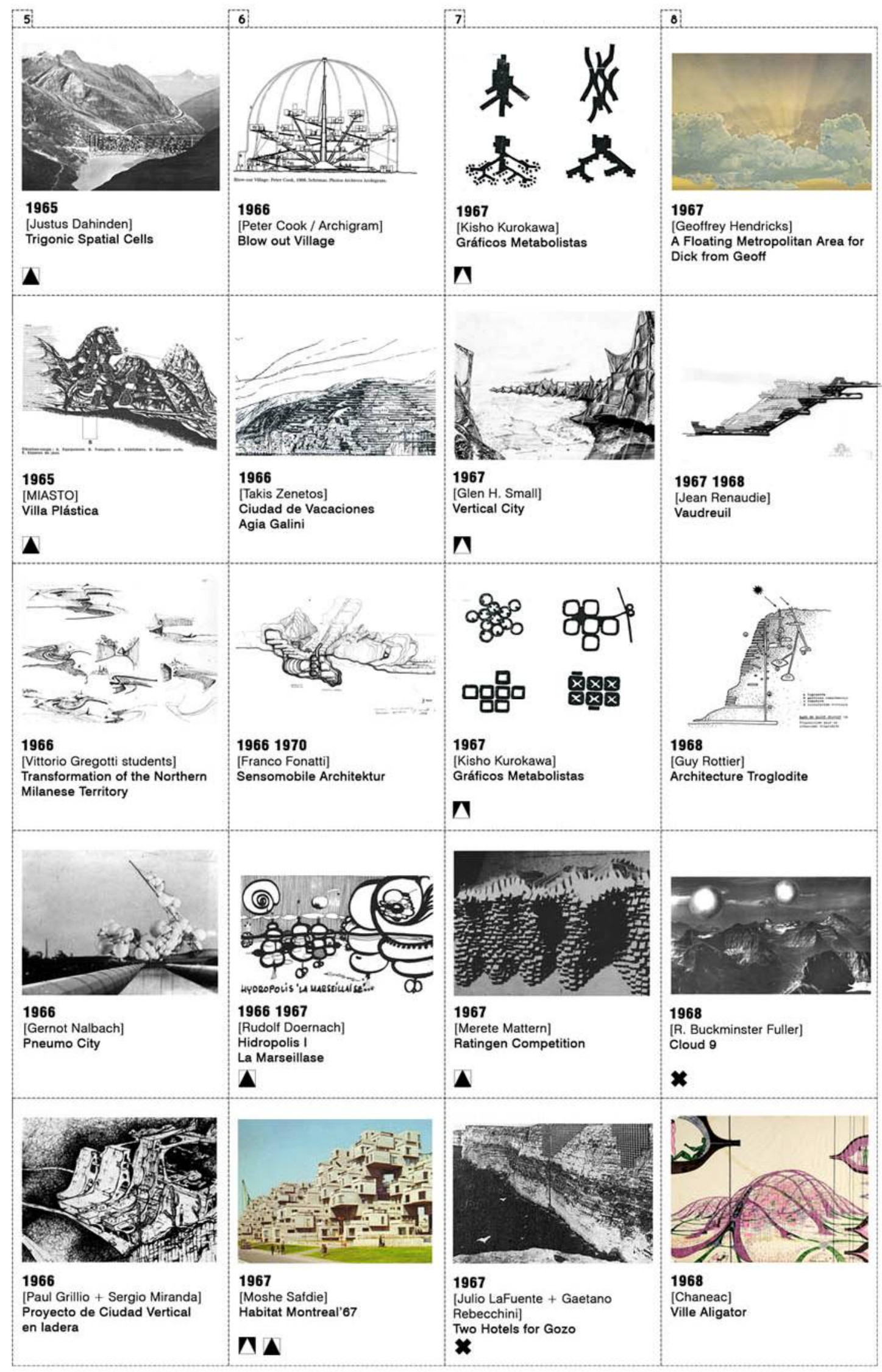




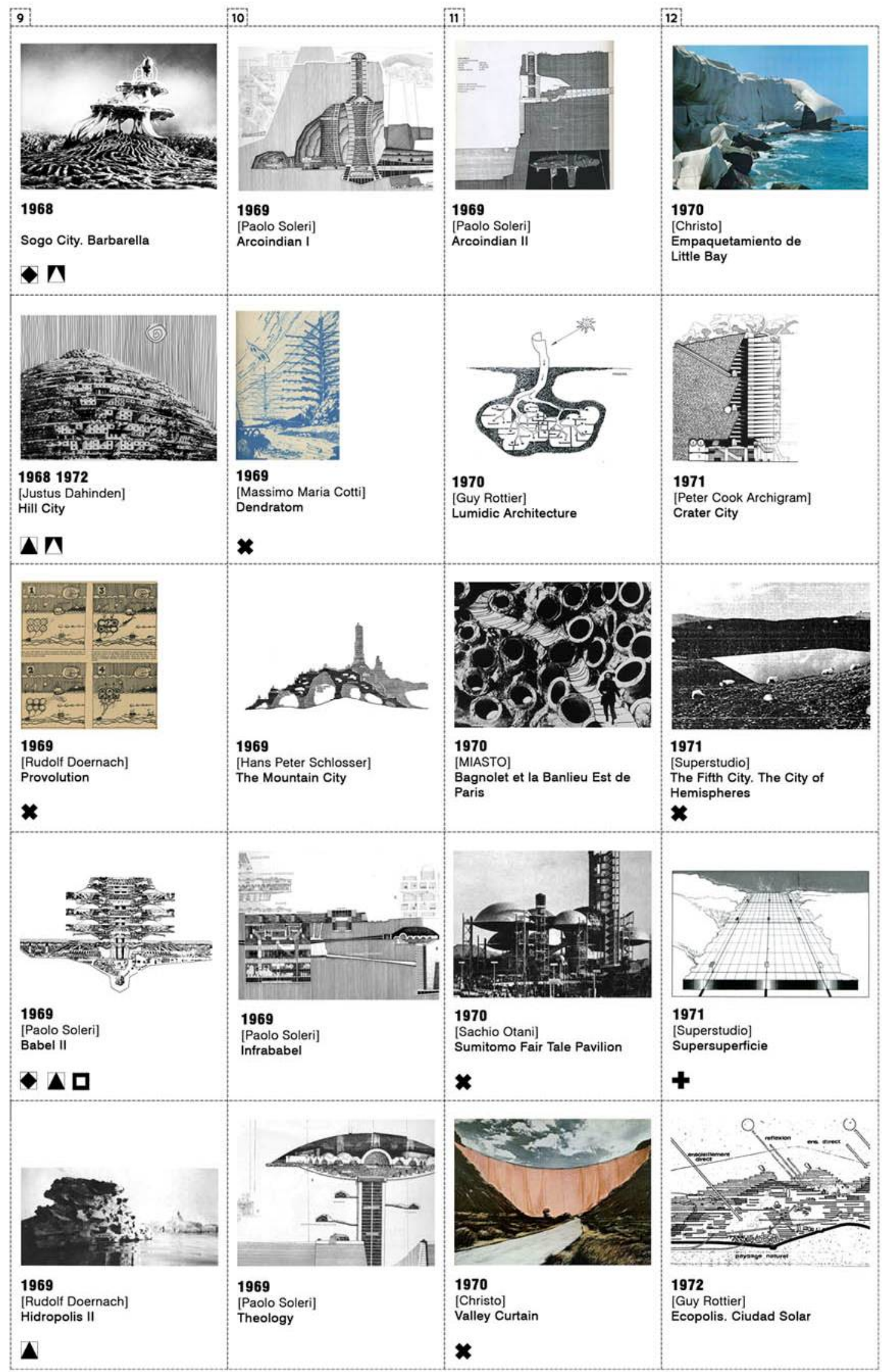




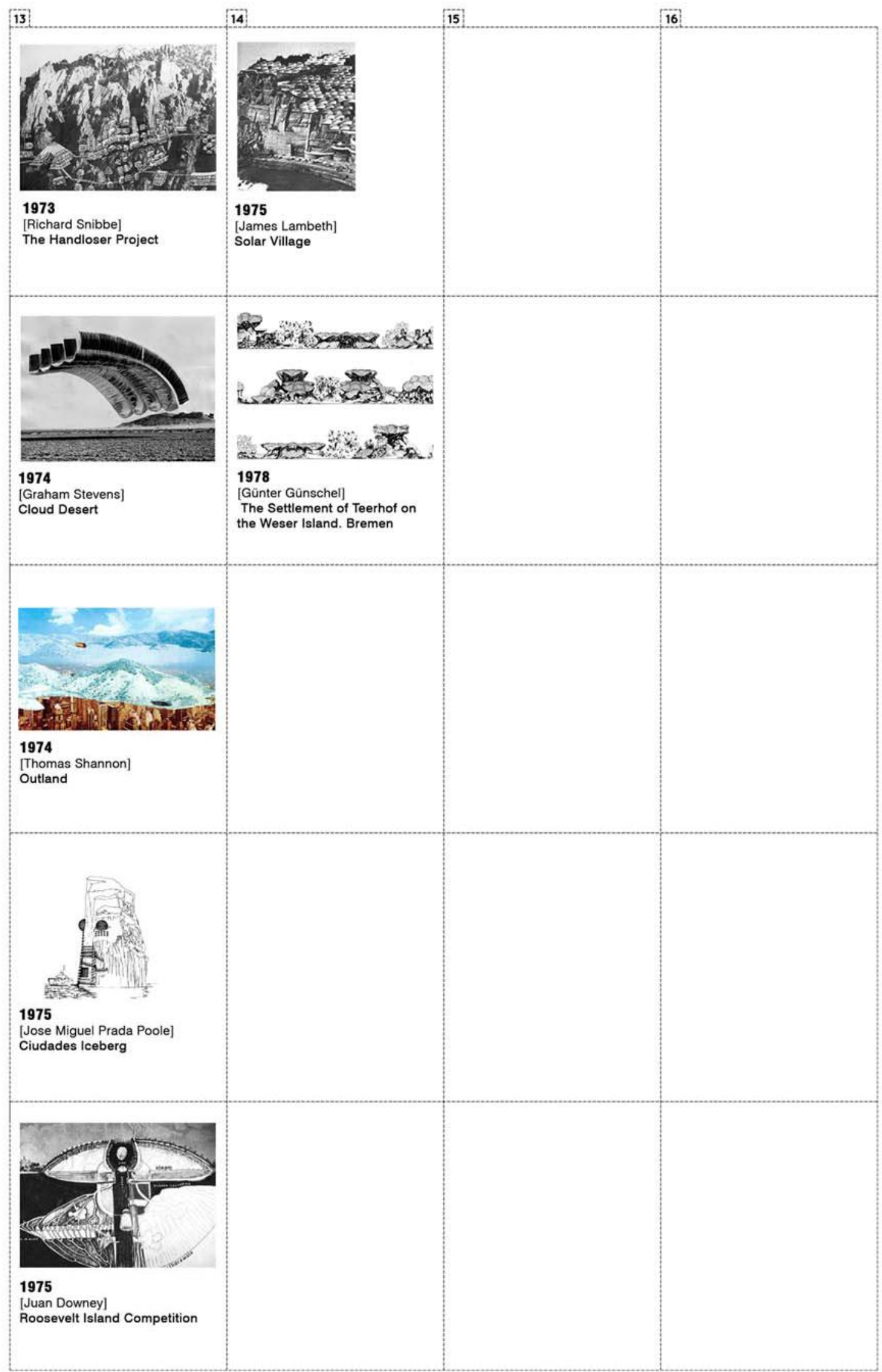




\title{
[Ciudad Paisaje] \\ La Ciudad convertida en paisaje como alternativa a la megaestructura.
}

La influencia e impacto en el paisaje de la megaestructura, así como el cambio radical de escala que ésta supone como edifico-ciudad, suscitarán un debate entre los términos natural y artificial representado en términos como la "Cittá-territorio". Dicho concepto será acuñado por Manfredo Tafuri ${ }^{425}$ y reafirmado por Ludovico Quaroni ${ }^{426}$ y Carlo Aymonino, en relación al curso de 1961-62 en la Escuela de Arquitectura de Roma, en torno a un proyecto de "Centro Direzionale en Centocello", por el cual esa "ciudad-territorio" es definida como cuerpo conceptual de las relaciones en la ciudad y lo que ocurre tanto dentro como fuera de ella.

\begin{abstract}
"El Centro Direccional aparece así en la cultura urbanística internacional y en la italiana en particular, como clave de cambio de la nueva ciudad, convirtiéndose en elemento central de la re-estructuración urbana a partir de su papel como mediador entre planificación y arquitectura." ${ }^{427}$ (Tafuri, 1962, p.27)
\end{abstract}

De esta manera, el concepto de "Cittá-territorio", no sólo propone una relación de apertura e incluso simbiosis entre arquitectura y planificación urbana, sino también entre ciudad y paisaje, o lo que es lo mismo entre las distintas definiciones y límites entre lo artificial, hasta ahora representado por la ciudad y la acción humana, y lo natural, tantas veces confundido como paisaje. Aparecen así dos polos radicales de actuación frente a esta dicotomía, por un lado una máxima diferenciación entre arquitectura y naturaleza, posicionamiento para el que el fotomontaje tecnomórfico de Hans Höllein "Aircraft Carrier City in Landscape" (1963-1964) supone un importante símbolo, por otro, una serie de propuestas de simulación natural o camuflaje, cuyas estrategias van encaminadas a una simbiosis, confusión e indefinición de esos límites. Como consecuencia, la inserción paisajística llega a considerarse en muchas propuestas como protagonista del diseño arquitectónico frente a las anteriores consideraciones formales y funcionales, como explicará Vittorio Gregotti en relación a los trabajos de sus propios alumnos de 1966 para el proyecto "Transformation of the Northern Milanese Territory" o los estudios y propuestas "Neapolitan Territory" (1965) [4E] realizadas por Salvatore Bisogni y Antonio Renna.

"Por lo tanto, la enseñanza de arquitectura no se centra en el problema de la ciudad, a pesar de la importancia dada a la densidad de población y la estratificación. Su principal esfuerzo se dedica a la creación de sistemas ambientales como zonas especiales, sin distinción entre los ambientes naturales y artificiales." ${ }^{428}$ (Gregotti, 1969, p.113)

\footnotetext{
425 TAFURI, Manfredo; PICCONATO, Giovani; QUILICI, Vieri. Città territorio: verso una nuova dimensione. En: Casabella,
} n²70, diciembre 1962. pp. 16-25.

426 AYMONINO, Carlo. La Città territorio: un esperimento didattico sul Centro direzionale di Centocelle in Roma. Facoltá di Architettura, Universitá di Roma. Roma, 1964.

427 "Il centro direzionale è così apparso alla cultura urbanistica internazionale, ma in particolare italiana, come chiave di volta della nuevo città: elemento centrale della ristrutturazione urbana, ma anche elemento mediatore tra pianificazione e architettura"

TAFURI, Manfredo. Studi e Ipotesi di lavoro per il sistema direzionale di Roma. En: Casabella, n²64, junio 1962. p.27.

428 "Therefore it does not focus on the problem of the city, notwithstanding the importance given to population density and stratification. Its main effort is devoted to creating environmental systems as special areas, without distinction between natural and artificial environments" 


\section{La Ciudad como paisaje artificial.}

Desde mediados de los años cincuenta, supeditadas al gran desarrollo de las estructuras textiles y neumáticas, surgen algunas propuestas que abordan estos nuevos caminos de simbiosis o hibridación entre natural y artificial, utilizando la superposición de dichas estructuras a paisajes naturales, tratando así de reproducir formalmente situaciones paisajísticas dentro de los mismos. En 1953 Frei Otto recupera el paisaje fantástico "Valley as a blossom ${ }^{429 "}$ "diseñado en 1919 por Bruno Taut, a través de la propuesta "Roofing of a wide mountain valley" [1C], por el que propone cubrir todo una valle de los Alpes Suizos, y convertirlo en un gran invernadero artificial. A pesar de que todavía Otto no responde a una situación urbana a la manera de la "Città territorio", si despliega una serie de estrategias de inserción en el paisaje a partir de grandes estructuras que no sólo se acomodan a la geometría de las montañas sino que generan una especie de lago artificial verde como paisaje posible. De la misma manera, y también aparentemente inspirada por la "Alpine Architektur" de Taut, el mismo Otto configura su propuesta para "Suspended City" [1E] de 1961 como si de un macizo artificial de montañas que irrumpe en medio del paisaje se tratara; a partir de estructuras textiles que intentan construir un nuevo paisaje en diálogo formal con el existente a pesar de no perder su lógica estructural. Ambos proyectos generan a su vez una dicotomía entre la ligereza de las propuestas y la pesadez de los elementos que reproducen, ya sean valles o montañas, pero siempre en pos de esa incorporación de las propuestas arquitectónicas al contexto circundante. Sin embargo la postura de Frei Otto no parece buscar un camuflaje efectivo, sino una incorporación geométrica de elementos artificiales a unidades de paisaje, como ocurre en "Temporary Roofing of a Valley" (1953) [1B], proyecto en el que utiliza dos macizos montañosos como soporte, propuesta que presenta grandes paralelismos con proyectos posteriores del artista Christo como "Valley Curtain" (1970) [11E], una gran tela que cierra la perspectiva del valle del río Colorado. Sistemáticas similares son utilizadas en proyectos como "Trigonic Spatial Cells" (1965) [5A] de Justus Dahinden o la "Ciudad de Vacaciones sobre Cables" (1965) [4D] de Guy Rottier.

Frente a la ligereza y expansión de las propuestas anteriores, uno de los posicionamientos más utilizados deriva en la búsqueda de gran compacidad como posicionamiento ecológico, con Paolo Soleri como principal estandarte, en contraposición a posturas tecnocráticas de expansión como la "Ecumenopolis" "30, de Constantinos Doxiadis:

"El paisaje natural no es el marco más apropiado para la compleja vida de la sociedad. El hombre debe hacer el paisaje metropolitano a su propia imagen: un bulto energético físicamente compacto, denso y tridimensional, no una tenue película de materia orgánica. El paisaje artificial debe ser un paisaje de múltiples niveles, un sólido de tres dimensiones coherente." ${ }^{\text {"311 }}$ (Soleri, 1969, p.13)

De esta manera ligereza y compacidad se presentan como posturas a hibridar mediante analogías formales derivadas de toda suerte de de accidentes naturales como metáforas de

GREGOTTI, Vittorio. New Directions in Italian Architecture. Studio Vista. Londres, 1968. p.113.

429 Dicha analogía entre ambos proyectos se referencia en:

CONRADS, Ulrich; SPERLICH, Hans G. Fantastic Architecture. 1963. pp.122-123.

430 DOXIADIS, Constantinos. Ecumenopolis: The Settlement of the Future. Athens Technological Organization, Athens Center of Ekistics. Atenas, 1967.

431 SOLERI, Paolo: Arcology. The City in the image of man. The MIT Press. Boston,1969. p.13. 
ese paisaje "natural". El árbol, la roca, la montaña, el río, la nube o el prado, se establecen como referentes principales de esas unidades de paisaje natural, de manera similar a como lo fueron en el pasado. Así, unidades de paisaje como el cielo, simulado en el "Templo de la Razón" (1793) y el "Cenotafio de Newton" (1784) de Étienne-Louis Boullée o la roca, reproducida en la puerta de entrada a las salinas de "Arc et Senans" (1775) de Ledoux, son ahora aplicados a la imagen exterior del conjunto y a la escala ciudad y no como elementos particulares.

\title{
De las analogías biológicas organizativas a la ciudad-árbol.
}

La búsqueda de un orden dependiente de estructuras biológicas se convierte en fundamento principal de líneas de pensamiento como el metabolismo japonés desde finales de los años cincuenta. Las analogías entre el funcionamiento de organismos vivos como los sistemas celulares y las ciudades parece inevitable. Surgen así analogías entre el corazón y la ciudad, como la representada por el libro de Víctor Gruen de 1964 "The Heart of Our Cities" Candilis, Josic y Woods en "Proposition pour un hábitat évolutif" en 1961 o Arata Isozaki en "Clusters in the Air" (1962) [2E], o entre el anteriormente citado sistema celular y una ciudad entera diseñada ex-novo, como la "Cluster City. Metamorphosis" (1965) de Kisho Kurokawa. La evocación de esas analogías conducen al propio Kurokawa a catalogar sus proyectos hasta 1967 a través de sus "Gráficos metabolistas" de las formas animales y los sistemas celulares, de carácter membranoso y Espacios Fibriformes, de tipo informal vegetal y desarrollo lineal.

Estrategias biológicas similares serán ensalzadas por autores como Peter Cook o Louis Armand como fuente de experimentación de la forma arquitectónica, en relación al valor propio del objeto o bien como inspiración para una búsqueda experimental de asociaciones organizativas:

\begin{abstract}
"Recientemente se ha producido un desarrollo de la arquitectura experimental que sugiere que el crecimiento, el cambio y la metamorfosis pueden ser posibles en algo que se había pensado hasta ahora como un tipo más bien estático relacionado con el artefacto. El inicio del uso de estas asociaciones naturales y similitudes biológicas como base para el diseño, es interpretativo y no tienen que expresarse como una forma o caparazón que sugiera una forma animal. Otro enfoque similar sugiere que un edificio, o una serie de edificios, pueden proceder en su relación y en su cohesión orgánica en la forma en que se produce el crecimiento floral. La hoja y el tallo, el árbol y la raíz son frecuentemente utilizadas como formas asociativas." ${ }^{1434}$ (Peter Cook, 1970, p.50)
\end{abstract}

432 GRUEN, Victor. The Heart of our Cities. The urban Crisis: Diagnosis and Cure. Thames and Hudson. Nueva York, 1965.

433 Fuente original en japonés: Kenchiku Bunka, n²53, vol28, 1967.

Se ha consultado la traducción española en: Cuadernos SUMMA-NUEVA VISIÓN, n²0, 1969, Buenos Aires, p.23.

434 "More recently there has been a development out of experimental architecture that suggests that growth, change and metamorphosis may be possible in something which has hitherto been thought of as a rather static type of artifact. These natural associations and biological similarities, when they are started as a basis for the design, are interpretative and do not need to express themselves in any form or armature that particularly suggests an animal form. Another similar approach suggests that a building, or a series of buildings, might proceed in their relationship and in their organic cohesion in the way that floral growth occurs. The leaf and the stem, the tree and the root are frequently stated as associative forms." 
"Los arquitectos trabajarán a partir de las leyes biológicas. Los números de oro no

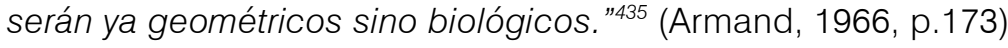

Sin embargo, estas analogías biológicas, en las que la estructura organizativa tipo árbol resulta la de mayor éxito entre los arquitectos de la época, serán fuertemente criticadas por arquitectos estructuralistas como Christopher Alexander, por su inoperancia para generar sistemas complejos de ciudad:

"El árbol, a pesar de ser considerado tan limpio y hermoso como un dispositivo mental, a pesar de que ofrece una forma sencilla y clara de dividir una entidad compleja en unidades, no describe correctamente la estructura real de las ciudades, y menos la estructura de las ciudades que necesitamos. Ahora, ¿cómo es que tantos diseñadores han concebido las ciudades como árboles?" ${ }^{436}$ (Christopher Alexander, 1966, p.7)

Algunas de estas ciudades-árbol, no sólo utilizan la analogía asociativa sino que llegan incluso al extremo de representación formal del árbol en sí, como construcciones casi paródicas de esa falta de complejidad que alegaba Alexander. En este sentido, mientras Kisho Kurokawa justifica sus ciudades-árbol "Bamboo Type Community" [2B] y "Plant Type Community" (1960) [2C], a partir de las analogías biológicas del pensamiento metabolista megaestructuralista, Peter Cook aprovecha en "Blow Out Village" (1966) [6A] la simbología del tallo y las ramas para utilizarlos como estructura y comunicadores de energía e información entre el cuerpo central comunitario y las viviendas satélite alojadas en brazos neumáticos que simulan la apertura y cierre de una flor. Otras propuestas como "Dendratom" (1969) [10B] de Massimo Maria Cotti, aparecen como metáforas visuales muy alejadas de una propuesta arquitectónica coherente, confirmando de manera caricaturesca la crítica de Alexander mediante un cambio de escala desorbitado del árbol. Paul Jacques Grillo va más allá en ese cambio de escala, para desarrollar su proyecto de ciudad "Aquila"437 (1963) [3C] como si de una gran hoja de árbol se tratara, sin ni siquiera prestar atención a una posible organización funcional más allá de la propia forma de hoja. Incluso el propio Paolo Soleri, que tan claro presenta conceptualmente la distinción entre paisaje natural y artificial, utiliza la metáfora asociativa para diseñar su ciudad por niveles "Babel II" (1965-68) [9D], como un gran árbol en el que las raíces se presentan como la zona productiva de la ciudad, el tronco como sistema de comunicaciones y unas viviendas situadas en ramas, aprovechando las condiciones más óptimas de soleamiento.

Propuestas como "The Settlement of Teerhof on the Western Island" (1978) [14E] de la serie "Cristalizaciones" de Günter Günschel, combinan analogías formales y organizativas, así como una mejor adecuación escalar de la nueva ciudad para constituir un asentamiento a modo de bosque habitado, en el que vegetación y edificios se hibridan:

COOK, Peter. Experimental Architecture. 1970. p.50.

435 RAGON, Michel. Las couvades del future. 1970 (1966). p.173.

436 "The tree - though so neat and beautiful as a mental device, though it offers such a simple and clear way of dividing a complex entity into units- does not describe correctly the actual structure of naturally occurring cities, and do not describe the structure of cities which we need. Now, why is it that so many designers have conceived cities as tress?"

ALEXANDER, Christopher. A City is not a Tree. En: Design, n²06, 1966. p.7.

437 GRILLO, Jean Jacques. Three cities: Aquila, Poseidon, Aegean. Department of Architecture, Rice University. Houston, 1963. 
"Desde lejos nos parece ver la silueta de un denso bosque contra el cielo de la mañana. A medida que nos acercamos, vemos que las formas son mucho más variadas, más tridimensionales, y exuberantes. ${ }^{1138}$ (Günter Günschel, 1981, p.302)

Charles Jencks otorga a los biomorfismos un papel fundamental como gran alternativa de futuro, ya sea a través de la asociación o la estructura formal, ligadas en el imaginario popular a las ciudades utópicas de las películas de ciencia-ficción, como ocurre con "Sogo City" del film "Barbarella" (1968) [9A], con su versión mecanicista materializada en el "FairyTale Pavilion" [11D] de la exposición de Osaka'70 de Sachio Otani. "Sogo City" preconiza para Jencks una fusión total entre lo artificial y lo natural en un posible futuro donde lo suave camufla las nuevas alternativas de confort generadas por la máquina. Se trata de ese futuro de pelo sintético propuesto por Reyner Banham:

"De todos los materiales agradables al hombre, la piel con pelo es el más amable porque es el pariente más próximo de nuestra superficie y crece en algunos de nuestros sitios más amables; pero en términos más objetivos y cuantificables tiene también propiedades físicas que harían valiosa su invención si no existiese: flexibilidad, absorción de los choques, aislamiento térmico, ser absorbente acústico y responder selectivamente a la luz reflejada." ${ }^{\prime 439}$ (Banham, 1968, p.629)

Un futuro biomórfico de pelo sintético será la gran conclusión de Jencks en su vaticinio para una Arquitectura del año 2000:

"Además, cuando la biología llegue a ser la mayor metáfora de los años noventa, la tradición intuitiva explotará en un estallido de imágenes biomórficas acomodadas al desarrollo individual y orgánico." ${ }^{440}$ (Jencks, 1971, p.107)

\section{La naturaleza como soporte. De la Ciudad-Roca a la Ciudad-Montaña.}

A través de las "Arcologías", término resultante de la hibridación entre arquitectura y ecología, Paolo Soleri propone el uso de recursos, materiales y colores autóctonos junto al aprovechamiento de accidentes naturales para generar "nuevos contextos" en los que el hombre pueda conectarse con la naturaleza. Todos sus proyectos de "Arcologías", más que a una localización concreta, responden a situaciones paisajísticas determinadas por accidentes naturales genéricos como acantilados, márgenes de los ríos o bahías, entendidos como unidades de paisaje catalogables. Estas estrategias de acomodación al paisaje natural utilizadas por Soleri serán contempladas por Banham como iconografía histórica posible de las megaestructuras, desde los pueblos italianos construidos en ladera,

438 "From far we seem to see the silhouette of a dense forest against the morning sky. As we approach, we see that the
forms are much more varied, more three-dimensional, and luxuriant"

Invention: Piranesi und Architekturphantasien in der Gegenwart, 13. Dezember 1981 bis 10. February 1982, Deutscher Werkbund Niedersachsen und Bremen, 1981. p.302.

439 BANHAM, Reyner. Triumph of Software. En: New Society, 31/10/1968. pp.629-630.

440 JENCKS, Charles. Arquitectura 2000. 1975 (1971). p.107. 
hasta los asentamientos indios que aprovechan las oquedades en los acantilados. Así es como asentamientos como Mesa Verde en Colorado, alcanzarán especial relevancia mediática ${ }^{441}$ a partir de la exposición "Architecture without Architects" Bernard Rudofsky en el MOMA en 1964. Este último posicionamiento es utilizado por Soleri para la construcción de sus proyectos de ciudad "Infrababel" [10D], excavada como lo son las minas de mármol en la Toscana, "Arcoindian I" [10A], "Arcoindian II" [11A], o "Theology" [10E], como reminiscencias a esos asentamientos indígenas en la frontera entre México y Estados Unidos. Estrategias parecidas serán utilizadas en proyectos diversos, bien aprovechando horadaciones existentes en acantilados como el proyecto de Bernard Trey "Hábitat Parietal" (1962) [3B] o generando una superposición entre la geometría rocosa y la geometría de la nueva propuesta en "Two Hotels for Gozo" (1967) [7E] de Julio LaFuente y Gaetano Rebecchini, ambos con gran difusión en revistas arquitectónicas ${ }^{443}$ de la época. También Guy Rottier utiliza la misma sistemática de excavación, como parte de "Lumidic Architecture" [11B], una serie de ciudades subterráneas equipadas con sistemas de espejos que captan la luz iluminando el interior como una de las opciones posibles de lo que él denomina "L'architecture troglodyte" en 1968 [6C]. Ambos posicionamientos teóricos se formalizan en su proyecto "Ecopolis" (1972) [12E], en el que reproduce esas estrategias lumínicas superpuestas a otro de los modelos de camuflaje en el paisaje derivadas de la ciudad-montaña. De esta manera, Rottier apuesta por una villa ecológica a partir de la gestión de recursos de la misma y su inserción camuflada en el paisaje.

La ciudad-montaña, es utilizada como recurso estructural por muchas propuestas asociadas con las megaestructuras, utilizando el esquema tipológico aterrazado que Banham y Dahinden ${ }^{444}$ definen como esencial en un diseño muy eficaz para un soleamiento óptimo de la viviendas. Mientras que "Sunset Mountain" (1964) [4C] de César Pelli y A.J. Lumsden utiliza la montaña como soporte, excavando una parte que será después restituida de manera artificial a partir de plataformas escalonadas, la "Ciudad de Vacaciones Agis Gallini" (1966) [6B] de Takis Zenetos, utiliza una geometría topográfica de bandas para ir superponiéndose a la montaña sin tener que realizar esa labor de excavación. Paul Grillo y Sergio Miranda, superponen su "Ciudad Vertical en ladera" (1966) [5E] a una estructura natural existente, utilizando un talud como soporte estructural de la misma manera que lo hace Peter Cook en "Crater City" de 1971 [12B].

441 Con referencias visuales en dos de las citadas predicciones arquitectónicas:

COOK, Peter. Experimental Architecture. 1970., p.19

BANHAM, Reyner: Megaestructuras. 1978 (1976). p.16.

442 RUDOFSKY, Bernard. Architecture Without Architects: A Short Introduction to Non-Pedigreed Architecture. Museum of Modern Art. Nueva York, 1964

4431967 "Two Hotels for Gozo” de Julio LaFuente y Gaetano Rebecchini publicado en:

Nesting. En: AD The Architectural Design, octubre 1967. p.440.

AA L'Architecture d'Aujourd'hui, junio-julio 1967, nXX, p.LXXXIV.

1962 "Hábitat Parietal" de Bernard Trey referenciado en:

TREY, Bernard. Habitat Parietal et Rythmes. En: AA L'Architecture d'Aujourd'hui, Recherches, n 115, junio-julio 1964. pp.114-115

444 El propio Dahinden tiene su propio proyecto de ciudad montaña, materializada en la "Hill City" (1968-1971), una versión naturalizada de lo que era su propuesta "Kyriat Ono. Una Ciudad del Ocio". 
Otras propuestas abandonan esa idea de utilizar la naturaleza como soporte. Así es como en ejemplos como "Crater City" (1963-1968) [3E] de Chaneac, la topografía es generada de manera totalmente artificial aunque siguiendo patrones naturales, construyendo topografías urbanas, de la misma manera que operan otros proyectos como "Vertical City" (1967) [7B] de Glen H. Small, "The Mountain City" (1969) [10C] de Hans Peter Schlosser, "Hill City" (1968-1972) [9B] de Justus Dahinden o la propuesta para la "Ratingen Competition" (1967) [7D] de Merete Mattern. Todas ellas experimentan con una búsqueda de topografía artificial habitada, paradigma en el que el "Habitat de Montreal" [6E] de Moshe Safdie, se convierte en icono fundamental, a medio camino entre la industrialización y la construcción de un nuevo paisaje montañoso superpuesto a la ciudad existente.

De manera simultánea a la metáfora de la ciudad-montaña aparece la de la ciudad-roca, encontrando en los primeros trabajos de Hans Höllein y Walter Pichler grandes aliados, en esa búsqueda de hibridación formal entre arquitectura y escultura ${ }^{445}$.

"¿Qué distingue a la arquitectura de la escultura? En mi opinión, las distinciones clásicas entre las artes ya no son válidas, ya que las artes se fusionan. Se convertirán en estructuras que dan forma al mundo y las vidas humanas, en las que es posible vivir como uno desea y crea conveniente. ${ }^{1446}$ (Höllein, 1962, p.32)

Es a partir de esa reivindicación de una fusión de las artes que Höllein genera los collages para el proyecto "Stadt" (1958-1960) [1D], en los que una hipotética ciudad emerge en el paisaje como un gran macizo rocoso, imagen compartida por Pichler, quién sin embargo, diseña una serie de geometrizaciones en su roca habitada en la búsqueda de una "Compact City", proyecto desarrollado entre 1963 y 1964 [3D], abandonando así la idea de recreación natural.

De una manera mucho más radical, "Plastic City" (1965-67) [5B] del equipo de trabajo MIASTO, formado por Michel Lefebvre, Jan Karczewski y Witold Zandfos, se presenta como una ciudad topográfica en materiales plásticos, en los que ya no existen trazas de aterrazamientos funcionales sino una serie de superficies continuas que simulan un paisaje de montañas de hasta ciento cincuenta metros de altura, que se estructuran a partir de una serie de canalizaciones superiores que contienen todas las instalaciones y medios de comunicación de la ciudad, y que sirven además como vértebras estructurales de todo el conjunto. Esta sistemática la repetirán en su proyecto de 1970 "Bagnolet et la banlieue Est de Paris" [11C], aunque esta vez convirtiendo esa topografía plástica en una cubierta transpirable de mucha menor escala, prescindiendo así de los sistemas de transporte imbricados con la estructura. En una de sus imágenes, MIASTO se atreve a desafiar a las megaestructuras tecnológicas derivadas de la "futurología" del GEAM, al superponer en un mismo dibujo su nueva ciudad-montaña camuflaje a una megaestructura como forma totalitaria ante el paisaje. Propuestas parecidas como "Sensomobile Architektur" (1966-1970) [6C] del austríaco Franco Fonatti, se alinean con esta manera informal de construir nuevos

445 El trabajo de ambos será expuesto conjuntamente en:

Höllein, Hans; Pichler, Walter: Architektur, work in progress: 8. Bis 12. Mai 1963, Galerie St. Stephan. Viena, 1963.

446 "What distinguishes architecture from sculpture? In my opinion, the classical distinctions between the arts are no longer valid, as the arts will merge. They will become structures that shape the world and human lives, in which is possible to live as one wishes and sees fit."

HÖLLEIN, Hans. Back to Architecture (1962). En: PORSCH, Johannes; ARCHITEKTURSENTRUM WIEN (editores). The Austrian Phenomenon: Architecture Avantgarde Austria 1956-1973. Birkhäuser Boston INC. Boston, 2005. p.35. 
prototipos posibles de ciudad-montaña. Estos proyectos aprovechan las capacidades formales de los materiales plásticos a la hora de generar estructuras de carácter orgánico como emuladores de "lo natural", sistemática que había sido ya testada por arquitectos como William Katavolos en "Floating City" de 1960 [2D], totalmente construida a través de sistemas de plástico pulverizados con los que el usuario puede configurar las envolventes e incluso el mobiliario de su propia vivienda, promulgando un futuro de materiales plásticos "Do It Yourself".

"Una nueva arquitectura es posible con la matriz de la química. El hombre debe dejar de fabricar y manipular, y en lugar de eso, permitir que la arquitectura suceda. Hay un camino más allá de la construcción en los principios de las olas, las parábolas y las líneas de la plomada más allá de los medios con los que se ahora se conforman. Así que deben liberarse de la arquitectura tradicional y convertirlos en patrones orgánicos. Los nuevos descubrimientos de la química han conducido a la producción de materiales en polvo y líquido que, adecuadamente tratados con agentes de activación determinados, se expanden, catalizan y se vuelven rígidos. ${ }^{1447}$ (William Katavolos, 1960, p.32)

\title{
Ciudades Iceberg y paisajes productivos.
}

Las estrategias de camuflaje con materiales plásticos aplicadas al territorio iniciadas por Katavolos, tal y como se menciona en el punto anterior, serán llevadas mucho más allá en el trabajo de Rudolf Doernach con la construcción de lo que él mismo denomina como "Biotectura"448, un término derivado de la fusión entre "biología" y "arquitectura".

"Si tratamos de definir la relación entre las disciplinas de la biología y la arquitectura, nos encontramos con que la distinción primitiva entre los fenómenos animados e inanimados no es particularmente útil. En primer lugar, tenemos sistemas biológicos que luego dan origen a la arquitectura como sistema complementario."1449 (Doernach, 1971, p.194)

\footnotetext{
447 "A new architecture is possible with the matrix of chemistry. Man must stop making and manipulating, and instead allow architecture to happen. There is a way beyond building just as the principles of waves, parabolas and plummet lines exist beyond the mediums in which they form. So must architecture free itself from traditional patterns and become organic. New discoveries in chemistry have led to the production of powdered and liquid materials which, when suitably treated with certain activating agents, expand to great size and then catalyze and become rigid."
}

KATAVOLOS, William. Organics. Steendrukkerij de Jong \& Company. Amsterdam, 1961. p.32.

448 La sección Cosmorama de Architectural Design realizó una gran cobertura de la "Biotectura" de Doernach:

DOERNACH, Rudolf. Biotecture. En: AD The Architectural Design, febrero 1966. pp.95-96.

DOERNACH, Rudolf. The Ice-lands Cometh. En: AD The Architectural Design, marzo 1968. p.154.

DOERNACH, Rudolf. Provolution. En: AD The Architectural Design, abril 1969. pp.182-183.

DOERNACH, Rudolf. Plant-Animal-Man-Eco. En: AD The Architectural Design, marzo 1971. p.131.

\begin{abstract}
449 "If we try to define the relationship between the disciplines of biology and architecture, we find that the primitive distinction between animate and inanimate phenomena is not particularly helpful. We first had biological systems which then gave rise to architecture as a complementary system"
\end{abstract}

DOERNACH, Rudolf. Biotecture. En: DAHINDEN, Justus. Urban Structures for the Future. 1972 (1971). p.194. 
Las investigaciones de Doernach en torno a la generación de estructuras arquitectónicas marinas construidas con plásticos le llevan a experimentar con materiales que puedan albergar microorganismos con capacidad para convertirse en recurso alimentario para el hombre, en un proceso de simbiosis capaz de generar paisajes productivos. Dichas estructuras marinas, "Hidropolis I. La Marseillase" (1966-67) [6D] e "Hidropolis II" (1969) [9E], constituyen los primeros prototipos proyectuales de la denominada "Edible Architecture" o "arquitectura comestible" derivada de la obsesión de Doernach por el problema de la alimentación humana y que es paralela a muchas investigaciones de grandes compañías de plásticos de la época, en torno a la producción de alimentos sintéticos. En su posterior proyecto "Provolution" (1969) [9C], Doernach da un paso más al presentar sus estructuras comestibles como capaces de generar nuevas comunidades marinas, más allá del objeto o paisaje artificial generado. Doernach será uno de los pioneros en aplicar proyectualmente las teorías ecológicas de McHale en torno a la generación de ecosistemas cerrados, sin obviar la inserción de los mismos en los paisajes ecosistémicos ya existentes. El arquitecto alemán experimenta incluso con propuestas de "habitabilidad" de nuevos paisajes como posibles alternativas de futuro. A partir de este posicionamiento nacen propuestas como "Iceland" (1964) [4B], ciudades-iceberg artificiales generadas mediante un proceso de condensación, en las cuales los usuarios podrían excavar sus espacios habitables en un proceso de construcción parecido al de la "Spray Plastic House" (1961) diseñada por David Greene de Archigram. Con la misma obsesión de construcción de una "Ciudad Iceberg" (1975) [13D], José Miguel de Prada Poole supedita la creación del espacio a la substracción de calor del agua, de manera que el usuario sea capaz de construir mallas de energía como encofrados invertidos para la construcción de espacios dentro de la ciudad:

"Mediante la extracción de calor, el agua se podría convertir en una ciudad flotante de hielo mantenida constantemente por un grupo energético. La desaparición del aporte energético supondría la desaparición del espacio urbano." 450 (Prada Poole, 1977, p.36)

\section{Excavando en el terreno para una desaparición de la arquitectura. La Ciudad-Río, la Ciudad-Reflejada.}

Las propuestas que utilizan la excavación del terreno como estrategia de inserción en el paisaje a través del mínimo impacto visual, encuentran en el interés suscitado por el urbanismo subterráneo un gran aliado. Michel Ragon, gran defensor de la capacidad prospectiva del mismo, apuesta en sus múltiples predicciones por proyectos de arquitectura subterránea como el icónico "Paris sous la Seine" (1962) [3A] de Paul Maymont. En el mismo, el arquitecto francés proyecta una ciudad lineal subterránea de hasta doce niveles bajo el Sena, convirtiéndose el propio río en el camuflaje perfecto de esta propuesta de densificación de la ciudad de París. A pesar de que no tiene unos objetivos de mínimo impacto en el territorio, esta sistemática será utilizada en numerosas ocasiones como estrategia de mímesis frente a paisajes desbordantes. Raimund Abraham por ejemplo la utiliza en "Glacier City (1964)" [4A], de la serie "Linear Cities", Superstudio lo hace en varias versiones del "Monumento Continuo" (1969-70) como la "Supersuperficie" (1971-72) [12D] o la "Fifth City. The City of Hemispheres" [12C], y Archizoom a su vez en "No Stop City" (19691970). 
Para Superstudio, sin embargo, la metáfora de la ciudad río se presenta en relación a lo que Filiberto Menna considera como "Arquitectura Reflejada" arquitectónico que se traduce en su malla continua y en cómo ésta puede llegar a convertirse en reflejo de lo existente. En todas ellas, la ciudad-río, satisface las estrategias de desarrollo lineal, incorporándose a su vez al paisaje circundante de manera natural, evidenciando esa "desaparición de la arquitectura" que promulgaban los miembros de Superstudio.

\section{La Ciudad-nube. La ligereza al extremo.}

La más romántica de las metáforas naturales, la nube, también se convierte en referente formal en proyectos de ciudad que promulgan la climatización artificial y la ligereza máxima como alternativas de futuro. Será en ese sentido en el que Buckminster Fuller utilizará en 1967 sus esferas geodésicas neumáticas para construir "Cloud 9" [8D], ciudades volantes de milla y media de diámetro, a modo de nubes manufacturadas artificiales.

"Así se fabrican las nubes. Como esferas geodésicas se hacen más grandes de media milla de diámetro convirtiéndose en estructuras flotantes. Esas esferas geodésicas flotantes pueden ser diseñadas para flotar en altitudes de miles de metros. El peso de los recursos humanos que se añadirá a estas nueve nubes prefabricadas será relativamente insignificante. ${ }^{1452}$ (Fuller, 1967, p.98)

Inspirado por ellas, Geoff Hendricks, diseña sus "Sky City" y "Cloud City" en 1968 [8A], en un intento de transponer la identidad aérea de las nubes y el cielo a la ciudad. Otros proyectos de simulación de nubes nacen en entornos de experimentación artística como ocurre con "Desert Cloud" (1972-1974) [13B] de Graham Stevens, proyecto realizado a partir de estructuras neumáticas reflectantes que vuelan por el desierto, o proyectos como "Pneumo City" (1966) [5D] de Gernot Nalbach. A pesar de los intentos de grupos de arquitectos como Coop Himmelblau o Evenstructure Research Group, la ciudad-nube no irá más allá de un estado metafórico natural, tal y como se evidencia en propuestas como "Outland" [13C] diseñada por Thomas Shannon en 1974, una isla flotante generada mediante hologramas, que recrea una suerte de parajes naturales a medio camino entre el estado vaporoso de la nube y la exuberancia de la vegetación de la superficie verde terrestre.

\footnotetext{
451 MENNA, Filiberto. A Design for New Behaviors. En: AMBASZ, Emilio (editor). Italia: the New Domestic Landscapes. Achievements and Problems of Italian Design. 1972. pp.405-414.

SUPERSTUDIO. Reflected Architecture. LANG, Peter (editor). Superstudio: life without objects. Skira. Milano, 2003. pp.8492.

452 "Thus are clouds manufactured. As geodesic spheres get larger than one-half mile in diameter they become floatable cloud structures. Such sky-floating geodesic spheres may be designed to float at preferred altitudes of thousands of feet. The weight of human being added to such prefabricated "cloud nines" would be relatively negligible"
}

SKY, Alison; STONE, Michelle. Unbuilt America. 1976. p.98. 


\section{Catálogo // [Edificios camuflaje]}

Las imágenes están referenciadas por números en la zona superior de las columnas verticales [del 1 al 14] y letras en la zona izquierda de las filas horizontales [de la A a la E].

Todas las referencias están ordenadas cronológicamente.

Referencias de imágenes del [1B] a [14C]. Cada uno de los proyectos referenciados gráficamente en el catálogo presentan antes de su nombre un código con un número en relación a su columna vertical y una letra en relación a su fila horizontal.

\section{Ejemplo:}

[7E] "Cloud 9" (1962) de Buckminster Fuller. Buscar referencia en la columna 7 y la fila E del catálogo referenciado al principio del capítulo.

[Nota]: no todos los referentes gráfico del catálogo están referenciados en el texto por lo que se recomienda una lectura del mismo antes de comenzar la del propio texto.

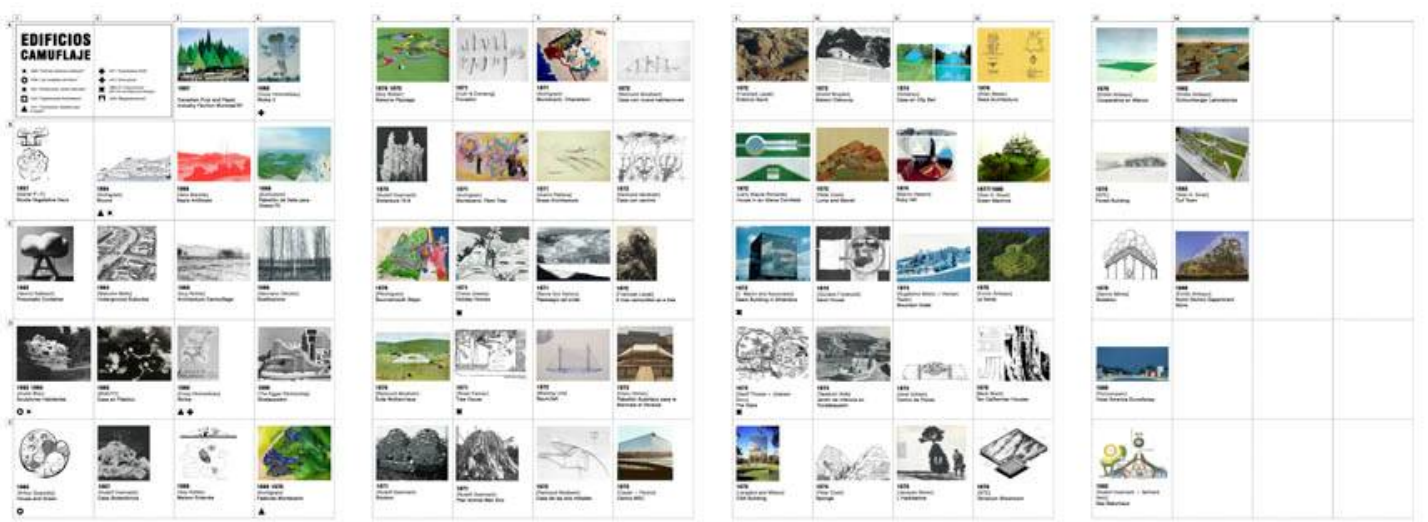




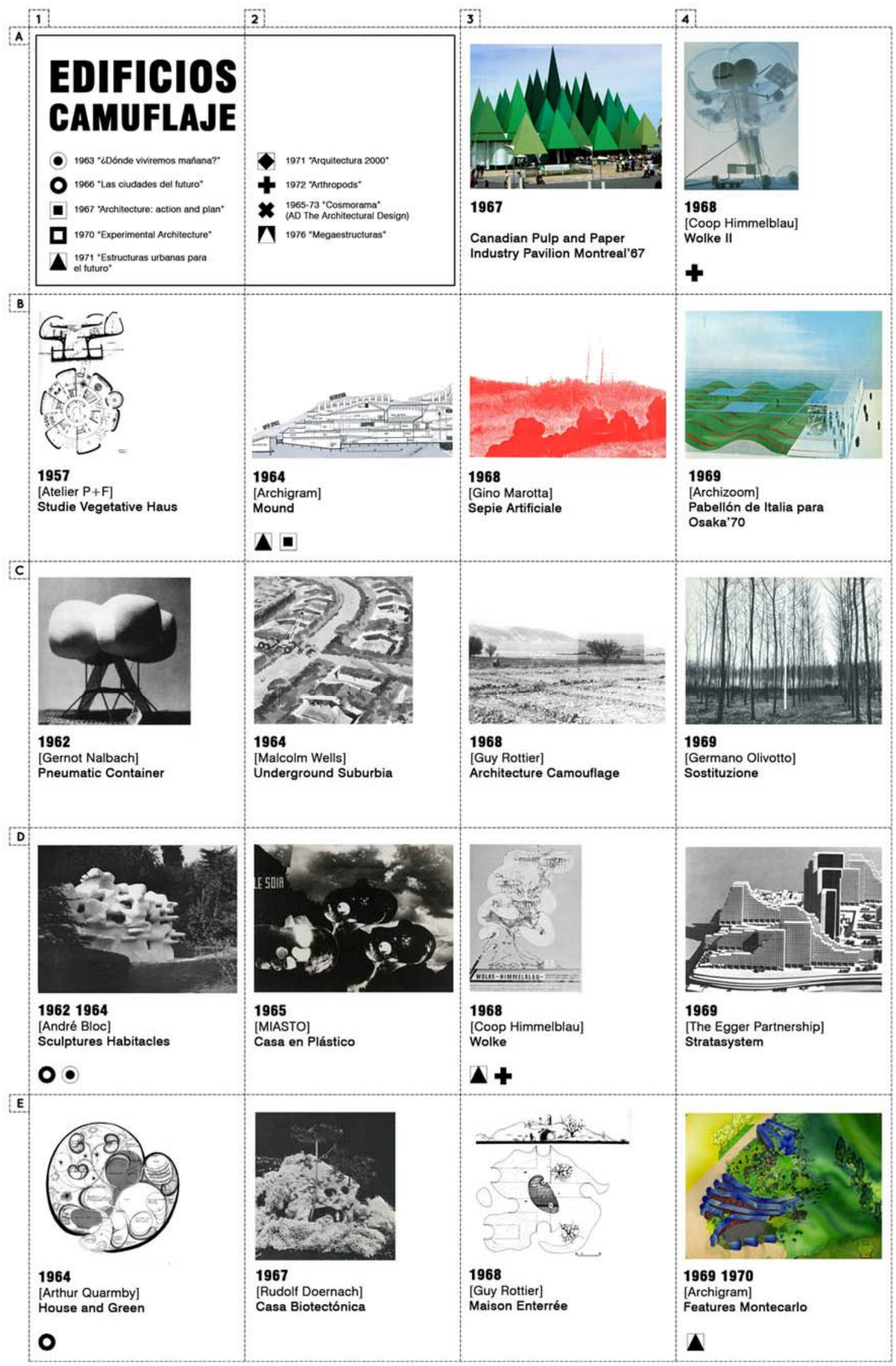




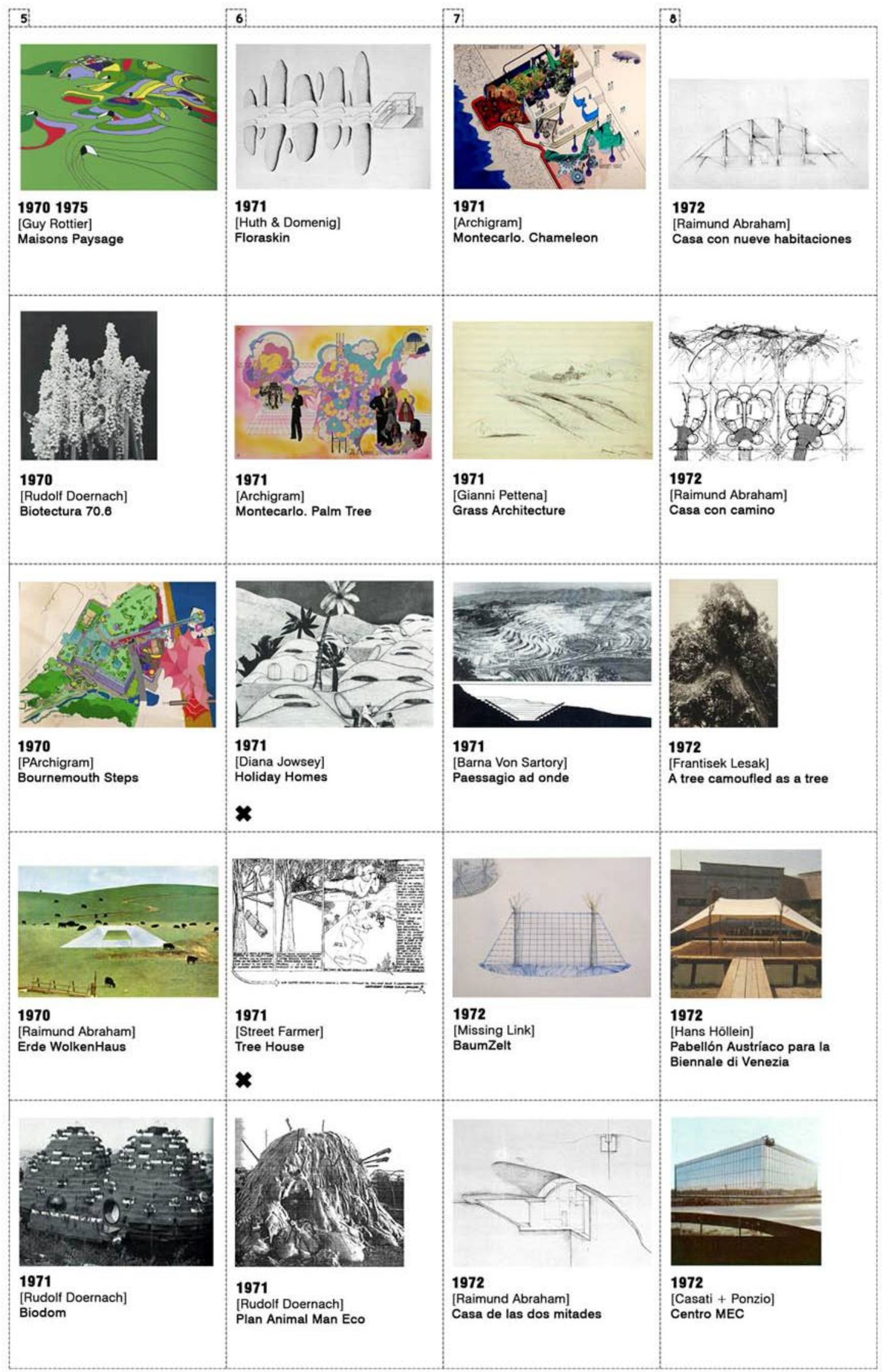




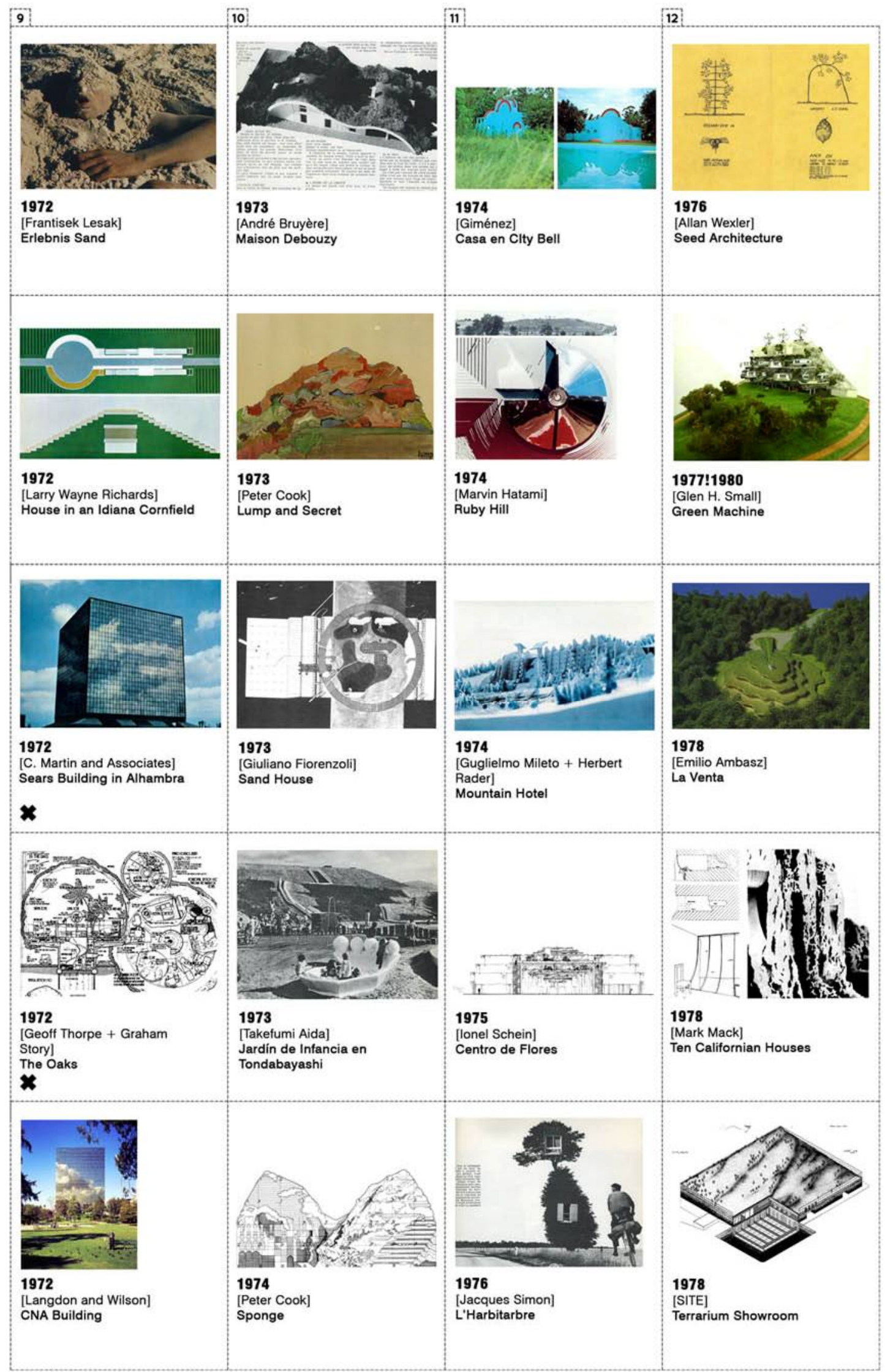




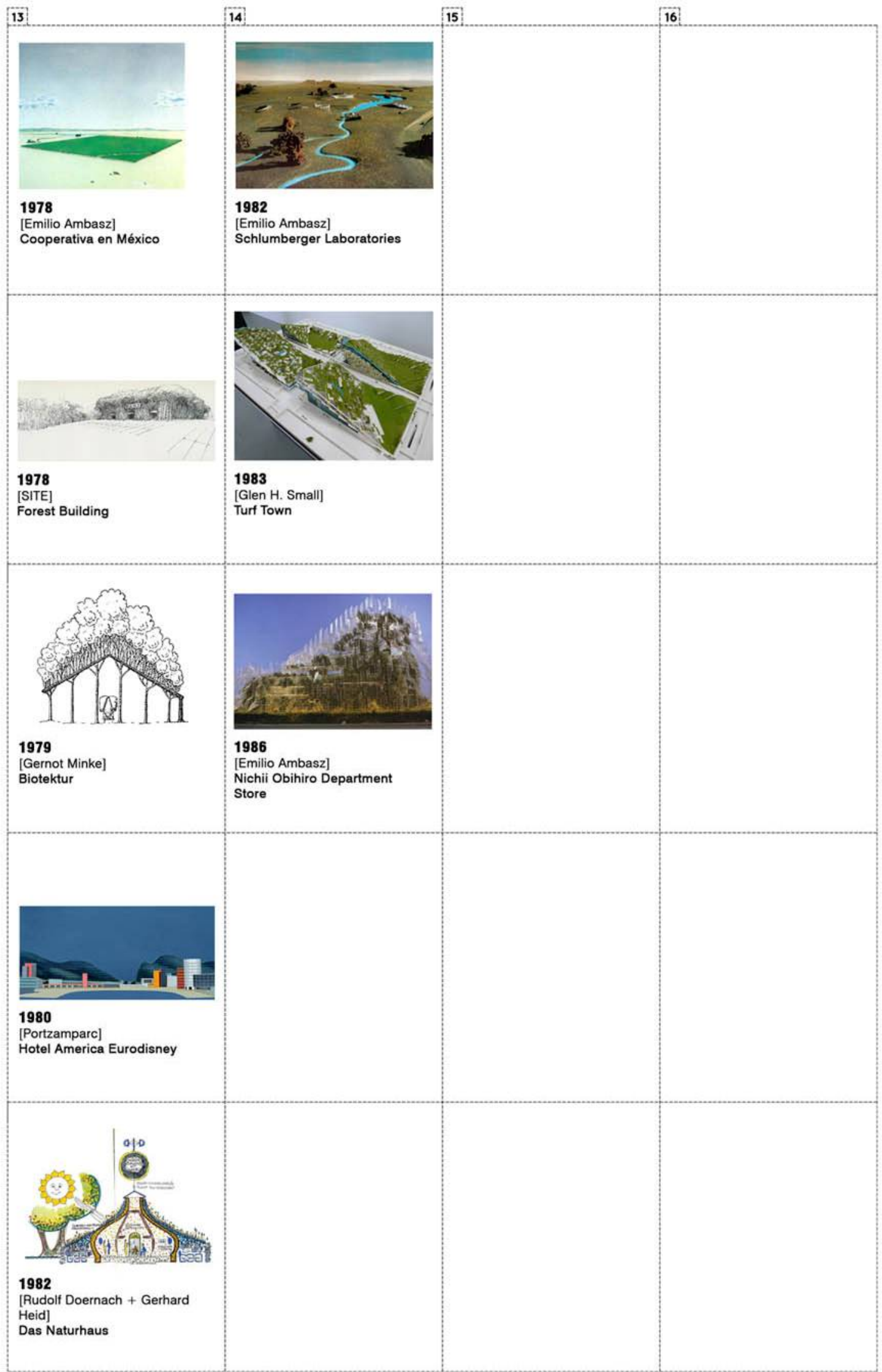




\section{[Edificios Camuflaje] Tácticas de camuflaje para edificios proyectados como naturalezas artificiales.}

Los mismos conceptos destilados por las simulaciones paisajísticas derivadas de la "cittáterritorio" y asociadas a la gran escala y la planificación, encontrarán en el edificio singular a un gran aliado para la experimentación de distintas técnicas de camuflaje que diluyan la antítesis histórica entre natural y artificial, o lo que es lo mismo entre ese edificio y el paisaje en el que se inserta. Así, los arquitectos repetirán las mismas metáforas naturales cuando se trata de aplicarlas como estrategia formal en el diseño de edificios.

\section{Cambio de escala. De la montaña a la rocalla. El objeto arquitectónico como unidad autónoma de paisaje.}

Para Michel Ragon, la existencia de lo que indistintamente denomina como "arquitecturaestructura" o "arquitectura-escultura"453, está fundamentada en una cuestión formal estructural derivada del avance tecnológico de nuevos materiales como el hormigón o los materiales plásticos ${ }^{454}$ como alegato en contra del ángulo recto ${ }^{455}$ promulgado por el movimiento moderno como fuerza dominante de la arquitectura hasta mediados del siglo XX. El mismo autor también vincula a estos proyectos una serie de analogías naturales derivadas del huevo, la cáscara o el árbol. Esas "arquitecturas-escultura" de arquitectos como Jacques Couelle o Pascal Haüsermann, serán construidas en lugares de alto valor paisajístico a partir de distintas estrategias de emulación de formas aparentemente naturales. Sin embargo ese cambio de escala radical en el paso de la ciudad al edificio, les hará perder esa capacidad de mímesis, para convertirse en elementos singulares más cercanos a la rocalla que a la montaña. Este efecto puede vislumbrarse en proyectos como las "Sculptures Habitacles" (1962-1964) [1D] de André Bloc. En ellas, el arquitecto francés coquetea con la idea de una arquitectura troglodita, e incluso con esa demonizada "rocalla" iconizada en el siglo XIX en proyectos como el "Palais Idéal" de Cheval ${ }^{456}$, reproduciendo ese elemento natural roca, de

\footnotetext{
453 "Creo haber sido el primero en emplear las palabras Escultura-Arquitectura y Arquitectura-Escultura en mi libro: Où vivrons-nous demain? de 1963"
}

RAGON, Michel. Las ciudades del futuro. 1970 (1966). p.83.

454 Mientras para Ragon, el plástico será considerado como un material secundario en esa revolución formal, para otros autores como Quarmby o Cook, se convertirá en principal protagonista, a partir de sus distintas posibilidades de industrialización, compartiendo eso sí, varios de los proyectos entre los tres autores.

455 Ragon será especialmente tendencioso con esta "muerte del ángulo recto", utilizando en sus libros expresiones como:

"La vulgaridad del ángulo recto está muerta"

RAGON, Michel. Las ciudades del futuro. 1970 (1966). p.80.

456 Esa estética rocallista de la obra de Joseph Ferdinand Cheval será emparentada con obras derivadas de las "crafts" norteamericanas de principio de siglo XX, entre ellas las icónicas "Watts Towers" de Simone Rodia, las casas de desierto de Bruce Goff o la casa del mexicano Juan O'Gorman, bajo el sobrenombre de "arquitectura fantástica":

COLLINS, George R., SCHUYT, Michael; ELFFERS, Joost. Fantastic Architecture. Personal and Eccentric Visions. Henry N. Abrahams Inc. Nueva York, 1980.

CONRADS, Ulrich; SPERLICH, Hans G. Fantastic Architecture. The Architectural Press. Londres, 1963. Ed. original: Fantastische Architektur. Verlag gerd Hatje. Stuttgart, 1960. 
una manera totalmente descontextualizada, situada en un bosque frondoso, y artificializada a partir de un cambio de escala en el objeto arquitectónico y un monocromatismo blanco de factura natural casi imposible.

Entender el objeto arquitectónico, en este caso bajo la escala del edifico, como unidad autónoma de paisaje será una estrategia ampliamente difundida y utilizada desde mediados de los años sesenta. La "Maison Enterrée" (1968) [3E], las también denominadas explícitamente "Maisons Paysage" (1970-1975) [5A] de Guy Rottier, o la "Maison Debouzy" (1973) [10A] de André Bruyère, utilizan esas mismas técnicas de mímesis natural que la rocalla del jardín pintoresco, para convertirse en un pequeños montículos la primeras, y una topografía extremadamente peluda la segunda, generando un proceso de singularización más que de mímesis con el lugar. Raimund Abraham irá mucho más allá con su serie de dibujos bajo el sobrenombre de casas-paisaje, como "Casa con camino" [8B], "Casa con nueve habitaciones" [8A] o "Casa de las dos mitades" [7E], todas ellas construidas a partir de topografías artificiales ridículamente modificadas para la reproducción de paisajes oníricos a pequeña escala, toda una declaración de intenciones al incorporar la singularidad del paisaje a una vivienda individual totalmente personalizada ${ }^{457}$. De manera parecida, viviendas ancladas en las rocas se convierten en refugios para escaladores, otras, al ser atravesadas por un camino, en hábitats para amantes del jogging, como ocurre en la propuesta "Californian Houses" (1978) [12D] de Mark Mack, en otro acto romántico de transferencia literal de identidad entre el morador y su vivienda.

A pesar de esa escasa capacidad de mímesis con el paisaje, las técnicas de edificiomontaña, o mejor dicho, rocalla, se suceden a través de una serie de posicionamientos muy heterogéneos. Uno de los más utilizados será el de la polivalencia formal de la roca, que combinada con una exuberante vegetación, constituye uno de los modelos de edificiopaisaje más repetidos. En ese sentido, "Mound" [2B], diseñado en 1964 por Archigram y su exitoso hermano "Features Montecarlo" [4E], desarrollado entre 1969 y 1970, pueden ser considerados como iconos de esta manera de operar. Ambos proyectos camuflan, bajo una topografía aparentemente salvaje, sendos edificios multiusos de uso masivo, que funcionan a través de esa imagen singular que les ofrece la rocalla, dentro de los contextos urbanos en que se insertan. De esta manera, la naturalización no sólo se convierte en reclamo sino en un intento de re-naturalizar la ciudad densa más allá de la aparición de las periféricas ciudades jardín inglesas ${ }^{458}$ :

"Desde principios de la década de los sesenta nos quedamos fascinados con la idea de la formación de una loma. Ésta cuenta con un gran número de vínculos conceptuales: la idea de una ciudad concebida como si fuera un edificio, la agregación de lo distinto a lo ya distinto de los organismos amorfos, sus múltiples significaciones, que van más allá de los edificios individuales y sobre todo la noción

AA L'Architecture d'Aujourd'Hui, nº102, Architectures Fantastiques, junio-julio 1962.

457 Dicha personalización es explícitamente declarada por Abraham, que dedicará cada una de esas viviendas-paisaje a las personalidades concretas de muchos de sus amigos, ya sean Walter Pichler, Hermann Nitsch o Jonas Mekas.

ABRAHAM, Raimund. Raimund Abraham. Obras y proyectos. Catálogo de la exposición. Colegio Oficial de Arquitectos de Madrid. Madrid, 1983.

458 "Mound" es propuesto de manera velada por Cook como alternativa a esa ciudad jardín inglesa en su libro analizado en el capítulo de Predicciones:

COOK, Peter. Architecture: action and plan. 1967. pp.32-34. 
de construcción de un lugar como un suelo con toda clase de artefactos móviles como si de plantaciones se tratasen..." ${ }^{459}$ (Archigram, 1972, p.120)

La misma idea de construcción de un lugar a partir de tierra, naturaleza y artefactos, será esbozada por Archigram en su proyecto "Bournemouth Steps" (1970) [5C], en el que la colina generada en Montecarlo se complejiza, barroquiza y se hace mucho más exuberante, en una posición más ambigua entre lo natural y lo artificial, proceso que continuará en las propuestas "The Palm Tree" [6B] y "Chameleon" $460 "$ [7A]. Ambas propuestas suavizan la idea radical de equipamiento enterrado y artefactos plantados para hibridarlos en un amplio catálogo de analogías naturales que ocultan un equipamiento. Proyectos como "Floraskin" (1971) [6A] de Huth y Domënig también coquetean con la posibilidad de conjugar naturaleza salvaje e hiper-tecnificación en la misma propuesta, dicotomía perfectamente expresada en la intervención artística "Bull and Mechanical Cow" (1978) de Antonio Paradiso.

"En ambos esquemas el uso del montículo, el ablandamiento del paisaje natural y de los elementos diseñados y mecanizados era a la vez evidente y ambiguo. Estos esquemas representan una continuación del pensamiento del proyecto de Bournemouth, pero son, quizás, más simples, con un uso suavizado de la tecnología." ${ }^{461}$ (Archigram, 1972, p.123)

Esa idea de catálogo de reproducciones naturales diseñadas para equipar el territorio, será utilizada por Diana Jowsey en su "Holiday Homes" (1971) [6C], proyecto de $5^{\circ}$ curso en la Architectural Association, dirigido por Peter Cook, en el que genera una serie de prototipos de viviendas paisaje, desde la vivienda-duna a la vivienda-bosque, no muy diversos al equipamiento-roca o servicios-tronco propuestos por el también miembro de Archigram, David Greene. Esas estrategias de imitación de lo natural a partir de elementos plásticos equipados con tecnología, serán también utilizadas en proyectos como la "Casa Biotectónica" (1967) [2E] de Rudolf Doernach. El propio Peter Cook desarrolla de una manera más potente la idea de montículo exuberantemente natural equipado con tecnología desde su interior en propuestas como "Sponge" (1974) [10E] o "Lump and Secret Garden" (1973) [10B]. Para ilustrar "Sponge", Cook realiza una imagen manifiesto al comparar una ciudad medieval situada en una gran roca con otra similar pero cubierta de exuberante vegetación, hibridando la densidad de la ciudad compacta con la re-naturalización.

Un posicionamiento divergente a esa utilización de naturaleza exuberante, resulta de someter a la misma a diversas estrategias de geometrización, en un proceso natural explícitamente artificializado. Dichas estrategias, derivadas de las experimentaciones relacionadas con el land art, seducirá a arquitectos como Gianni Pettena, quien propone en

459 "Since the early 1960s we have remained fascinated with the idea and the formation of the mound. It has a myriad of conceptual links: to the idea of the city-as-a-single-building, to the aggregation of the unlike to the unlike in some amorphous, polyglot organism that is beyond single buildings, to the notion of place as ground and artifacts as transient plantings."

Mound, ground, and hidden delights. En: COOK, Peter (editor). Archigram. Studio Vista. Londres, 1972. p.120.

460 Ambas propuestas serán parte de un concurso interno para la realización de un casino de verano como segunda fase de su concurso ganado para Montecarlo.

461 "In both schemes the mounding and softening of natural landscape and designed elements and mechanized elements was at once obvious and-on second glance- ambiguous. These schemes represent a continuation of the Bournemouth Steps thinking but are perhaps simpler and more gentle"

The Chameleon and the Palm Tree. En: COOK, Peter. Archigram. 1972. p.123. 
1971 "Grass Architecture" [7B], una serie de dibujos presentados a la exposición bienal de arquitectura Trigon'71, a modo de diversos cortes en prados, con los que el arquitecto italiano genera todo tipo de composiciones geométricas que pueden albergar espacios arquitectónicos dentro de ellas. Barna Von Sartory a su vez utiliza una antigua cantera para proponer su "Paessagio ad onde" [7C], otra serie de cortes geométricos esta vez encaminados a transformar el terreno como si de una maqueta de curvas de nivel se tratara. La misma condición topográfica a partir de estratos será utilizada en 1978 por Emilio Ambasz, en su proyecto "La Venta" [12C]. El arquitecto de origen argentino puede ser considerado uno de los grandes referentes en cuanto a esa búsqueda arquitectónica de hibridación entre lo natural y artificial, a través de un proceso que el propio arquitecto denominará como "Greener Architecture".

Esa geometrización por estratos de unidades de paisaje, de manera análoga a como se producen en una montaña, vuelve a propiciar una interesante situación funcional en relación al soleamiento y al aprovechamiento del aterrazamiento ${ }^{462}$, recurso estructural que será utilizada en gran cantidad de proyectos. Estos proyectos trabajan con ese aterrazamiento desde perspectivas puramente funcionales, como el "Centro de Flores" (1975) [11D] de Lionel Schein, o básicamente paisajísticas como la "House in an Indiana Cornfield" (1972) [9B] de Larry Wayne Richards, que incorpora una vivienda al campo de grano circundante, cultivando los aterrazamientos de la escalinata que le sirve de cubierta. "Biodom" (1971) [5E] de Rudolf Doernach, será diseñado como un hábitat flotante autoconstruido mediante un sistema de bloques de poliestireno extruido que luego se pintan de verde y se aterrazan con vegetación para su camuflaje como elemento natural flotante ${ }^{463}$. De manera análoga, otros proyectos trabajan con la estratificación geométrica en sección, como el grupo de arquitectos The Eggers Partnership en "Stratasystem" (1969) [4D] o Guglielmo Mileto y Hebert Rader en "Mountain Hotel" [11C]. En este último ejemplo, se utiliza esa estratificación para simular perfiles de montañas en sección a través de una serie de muros portantes de hormigón paralelos. Este proyecto supone de nuevo un intento de inserción del edificio en un paisaje montañoso, utilizando la metáfora de la montaña como solución paisajística a través del lenguaje formal y el cambio de escala.

"El problema era introducir una presencia arquitectónica en el paisaje, no sólo de insertarlo de manera modesta sino más bien tratando de enriquecer el paisaje con un nuevo elemento que mantenga en la medida de lo posible, el mismo lenguaje y la misma escala de los elementos naturales." ${ }^{464}$ (Mileto; Rader, 1974, p.13)

\footnotetext{
462 Existen una gran cantidad de proyectos y edificios construidos que utilizan el aterrazamiento bien como manera de incorporarse al paisaje circundante o como búsqueda del ansiado edificio montaña, incluyendo en el nombre del proyecto dicha definición, que preconizaba el "Hábitat de Montreal" (1967) de Moshe Safdie. Una gran parte de esos ejemplos viene de países como Suiza y Alemania, con proyectos como "Wohnberg" (1967) de Erich Schneider-Wessling, "Wohnberg" (1965-1968) de Gernot Minke, varios edificios de vivienda de Team 2000 o los "Terrace Apartments" de Stucky y Meuli (1958-1961) o André Studer (1964-1967).
}

BACHMANN, Jul; VON MOOS, Stanislaus. New Directions in Swiss Architecture. George Brazillier. Nueva York, 1969.

FEUERSTEIN, Günther. Urban Fiction. Strolling through Ideal Cities from Antiquity to the Present Day. Edition Axel Menges. Stuttgart/Londres, 2008.

463 Muchas de las estrategias relacionadas con el edificio-montaña tendrán un vasto campo de experimentación en proyectos asociados al turismo que se insertan en lugares de alto valor paisajístico. Referencio aquí algunas publicaciones que presentan números especiales en torno a esta temática:

AA L'Architecture d'Aujourd'Hui, n¹31, Tourisme-Loisirs, abril-mayo 1967.

TA Techniques et Architecture, n²90, L’Architecture et les Loisirs, diciembre 1972. 
En contraposición, Archizoom utiliza una estrategia topográfica a base de ondas en su propuesta para el concurso del "Pabellón de Italia en Osaka'70" [4B], insertando un prado artificial geometrizado y dividido a través de muros de cristal que lo ordenan, en el ambiente hiper-tecnificado de la exposición universal de Osaka'70.

\section{Edificios-árbol y edificios-bosque. De la metáfora a la reproducción.}

Más allá de las analogías biológicas organizativas antes citadas, y de la fascinación estructural que tantas generaciones de arquitectos han tenido por los árboles, formalizados como columnas portantes en el "mito de la cabaña primitiva" de Laugier ${ }^{465}$, esta proliferación de simulaciones de naturalezas artificiales utiliza ese adorado árbol desde perspectivas muy distintas. Así aparece por un lado como imagen a emular, con referencias incluso al nacimiento de los órdenes clásicos, como soporte al que parasitar, o como generador de una serie de condicionantes ambientales que poder reproducir artificialmente, a través de las metáforas del árbol y el bosque indistintamente. Una metáfora, que Jencks introduce en 1977 de esta manera:

"La gente siempre ve un edificio en términos de otro, o en términos de un objeto similar; o lo que es lo mismo, como una metáfora." "466 (Jencks, 1977, p.40)

Dos de los edificios-bosque más mediáticos entre los años sesenta y setenta, el "Canadian Pulp and Paper Industry Pavilion" [3A] construido para la Exposición Universal de Montreal'67 y el proyecto "Forest Building" (1978) [13B] propuesto por el grupo norteamericano SITE para uno de los centros comerciales Best, trabajan esa metáfora de bosque de manera radicalmente opuesta aunque con las mismas intenciones comerciales asociadas a una búsqueda de singularidad. El primero, adopta la imagen de bosque para reflejar su identidad como pabellón de la industria papelera canadiense a través de una cubierta de pirámides de distintos tamaños y tonalidades de verde, que reproducen la misma abstracción de bosque de copas triangulares que se utiliza en dibujos o maquetas, presentando así una arboleda manipulada, dulcificada y casi caricaturizada, y sin embargo totalmente reconocible por el público que lo ve desde la distancia. El "Forest Building" SITE, se reivindica como el edificio-bosque por excelencia al tratar de reforestar un espacio arbolado que se ve mermado por la construcción del edificio diseñado por ellos mismos

464 "Il problema era quello di introdurre nel paesaggio una presenza architettonica, non inserendola dimessamente ma cercando anzi di arricchire il paesaggio con un elemento nuovo che mantenesse il più possibile lo stesso linguaggio e la stessa scala degli elementi naturali."

Nel Panorama. En: Domus, n532, marzo 1974. pp.12-13.

465 PACZOWSKI, Bohdan. La Maison comme Nature et la Nature comme Maison. En: AA L'Architecture d'Aujourd'Hui, n²27, junio 1983. pp.81-89.

466 "People invariably see one building in terms of another, or in terms of a similar object; in short as metaphor."

JENCKS, Charles. The Language of Post-Modern Architecture. 1977. p.40.

467 Con "Forest Building" me refiero a la primera versión dibujada en 1978 y no a la que construirán después como showroom de la compañía Best Products en Richmon, ese mismo año.

SITE. SITE La Arquitectura como Arte. Gustavo Gili. Barcelona, 1982. 
para Best Products al lado de una carretera. En este caso, este edificio-bosque geometrizado y manipulado se adapta en altura y planta al bosque existente, generando una de las imágenes más icónicas y repetidas con posterioridad en proyectos y concursos de arquitectura contemporáneos.

El uso de estrategias de manipulación de elementos vegetales para su incorporación a la arquitectura será materia fundamental de una serie de manifiestos que conjeturan en torno a la posibilidad de sistematizar estas prácticas a través de soluciones fácilmente reproducibles. La ya citada "Biotectura", iniciada en los primeros sesenta por Rudolf Doernach $^{468}$, propone que una serie de estos sistemas vivos colonicen la arquitectura aprovechando sus condiciones ambientales.

"El intento de la Biotectura es crear sistemas ambientales revitalizantes y sin efectos nocivos, como el bosque." ${ }^{" 69}$ (Doernach, 1975, p.16)

Así es como Doernach publica todo tipo de soluciones de fachadas y cubiertas verdes, además de información sobre la orientación, riego y colocación de las especies más idóneas para cada localización, en varios libros-manifiesto como "Das Naturhaus" 470 de 1982, con prólogo incluido del austríaco Hudertwasser ${ }^{471}$. El arquitecto e ingeniero alemán Gernot Minke $^{472}$ utiliza el mismo término "Biotektur" [13C] para justificar sus trabajos también sistematizados y convertidos en catálogos de cubiertas y muros de tierra y vegetación, a partir de construcciones enterradas. Minke recupera también los trabajos de Arthur Wiechula ${ }^{473}$ en los que investiga en torno a la prefabricación de elementos vivos. En ellos aparecen todo tipo de sistemas naturales utilitarios, arbustos con los que construir pérgolas o árboles con formas modificadas para soportar usos de gran escala como puentes. Minke propone un extenso catálogo de formaciones arbóreas modificadas así como los trabajos de Wiechula como propuesta de futuro de una naturaleza no sólo arquitecturizada sino prefabricada, pero sin perder por ello su carácter natural.

"Utilizar el verde vivo no sólo como remedio óptico, físico y psicológico al desgaste y los excesos del ambiente construido de manera artificial sino creando un ambiente construido natural a partir de la prefabricación de elementos vivos." ${ }^{\text {"74 }}$ (Minke, 1979, p.10)

468 El propio Doernach es fundador y director del "Biotektur Institut” con sede en Gültlingen, Alemania.

469 "L'intento della Biotectur è creare dei sistema ambientali che siano vitalizzanti e senza effetti nocivi, come il bosco."

DOERNACH, Rudolf. Biotectur. Una proposta. En: Domus, n546, mayo 1975. pp.16-17.

470 DOERNACH, Rudolf; HEID, Gerhard. Das Naturhaus. S.Fischer Verlag GmbH. Frankfurt / Main, 1982.

471 Hudertwasser será también una figura activa en la búsqueda de una re-naturalización de la ciudad:

HUDERTWASSER, Friedensreich. Haus der Kunst. Ausstellungs-Katalog. Munich, 1970.

472 Minke estará muy activo a través de la Forschungslabor für Experimentelles Bauen de la Gesamthochschule de Kassel, con prototipos como el "Biobau" de 1976.

473 WIECHULA, Arthur. Wachsende Häuser, aus lebenden Baümen entstehend. Berlín, 1925

474 "Utilizare il verde vivente non solo come rimedio, ottico, físico, psicológico, ai guasti e agli eccessi dell'ambiente costruito artificiale, ma per creare un ambiente costruito naturale prefabricando elementi costruttivi vivi “

MINKE, Gernot. Biotektur. En: Domus, n597, agosto 1979. pp.10-16. 
Muchas de estas estrategias utilizan el propio árbol como soporte natural para ser artificializado, así procede Rudolf Doernach quien cubre las ramas de un árbol con miles de pequeñas cuerdas para generar un habitáculo, estrategia muy común e incluso caricaturizada por Frantisek Lesak en "A tree camoufled as a tree" (1972) [8C], pero que aparece incluso sistematizada en varios catálogos "do it yourself" de la época como en el magazine "Street Farmer" n¹ de 1971 [6D]. El árbol será también utilizado como soporte de manera más artificiosa en el "Pabellón austríaco" [8D] diseñado por Höllein para la Bienal de Venecia de 1972, una carpa que se sostiene mediante cuatro árboles ya secos del mismo tamaño, imagen utilizada metafóricamente por Missing Link en su propuesta "Baum Zelt" [7D]. En "L'Habitarbre" (1975) [11E], Jacques Simon, incorpora ventanas tradicionales a un árbol aportando así un grado más de artificiosidad. En "59, The Oaks" (1972) [9D] Geoff Thorpe y Graham Story, construyen una vivienda en forma de árbol mediante un cerramiento de hojas plásticas translúcidas de color verde, a partir de la imagen icónica del roble, con un tronco que alberga las comunicaciones y los sistemas de control climático, en una evolución escalar de proyectos de software naturalizado como el "Rockplug" o "Logplug" de Archigram, coqueteando así con la idea de generación de un paisaje como ilusión, una naturaleza artificializada que no colonice la natural sino que la sustituya.

"El exterior debería formar parte de cualquier ilusión mayor, ya sea un bosque, un grupo de latas de sopa o de casas. 59, The Oaks es un torpe intento de producir una pieza de software arquitectónico." ${ }^{475}$ (Thrope; Story, 1972, p.662)

Esta sistemática de reproducción formal literal será utilizada en otros proyectos como "Sepie Artificiale" [3B] de Gino Marota, perteneciente a la muestra "Nuovo Paesaggio", organizada por el propio Marota junto Cesare Casati, Enrico Castellani y Emanuele Ponzio en 1968. En esta propuesta, Marota reproduce en plástico translúcido verde lo que podría ser la silueta de un campo de hierba, que superpone a un campo natural. Resulta interesante este camino abierto hacia la re-interpretación artificial de formas naturales en materiales plásticos, ya que será una de las principales estrategias utilizadas en el proceso de re-naturalización del ambiente doméstico. En la mayoría de los casos lo natural es despojado de cualquiera de sus propiedades naturales más allá de las puramente formales.

\section{Camuflaje como desaparición.}

La obsesión por la mímesis o el camuflaje tiene como consecuencia más radical la búsqueda de una desaparición de la arquitectura. A esta escala, el edificio se convierte en una renuncia a poder competir con la naturaleza.

"El hecho es, sin embargo, que no existe ningún edificio tan hermoso, tan apropiado, o tan importante, que pueda sustituir un trozo de bosque. Estamos tan preocupados por nuestros propios problemas que olvidamos la única realidad en este mundo: la Naturaleza. ${ }^{\text {"176 }}$ (Wells, 1965, p.289)

\footnotetext{
475 "The exterior should fit into any greater illusion, whether forest, groups of soup can or a house. 59, The Oaks is a clumsy attempt to produce a possible form for a piece of architectural software."
}

THORPE, Geoff; STORY, Graham. 59, The Oaks. En: AD The Architectural Design, noviembre 1972. p.662 
Más allá de situaciones de enterramiento como la anteriormente citada "arquitectura troglodita" de Guy Rottier, que él mismo llega a nombrar como "anti-arquitectura"477, o la propuesta radical "Underground Suburbia" (1964) [2C] de Malcom Wells, que presenta todo un suburbio americano sustituido por viviendas enterradas, sin variar su esquema y como medio de preservar la naturaleza, otras estrategias posibles confiarán en el reflejo de lo existente como posibilidad de desaparición del objeto arquitectónico, estrategia denominada en la ciudad-paisaje como "arquitectura reflejada". En esa misma dirección, el propio Rottier propone una "architecture camouflage" en 1968 [3C], que representa mediante un edificio que se oculta en el paisaje a partir de reproducciones fotográficas del mismo, sistemática que sólo funciona desde un punto de vista determinado y bajo unas condiciones lumínicas concretas, que la convierten en una pobre solución de equipar el territorio con el mínimo impacto visual derivada del "trompe l'oeil". Más efectiva parece la utilización de elementos constructivos como el cristal reflectante, ya utilizado por Superstudio como posible material de esa "arquitectura reflejada". De la misma manera aparecen propuestas construidas que basan su supuesta invisibilidad en la superficie reflectante de sus fachadas-espejo, como el "Sears Building in Alhambra"478 (1972) [9C], un edificio de oficinas proyectado por Albert C. Martin \& Associates, un cubo perfecto elevado sobre el terreno y cuya fachada de vidrios reflectantes refleja sólo el cielo, pareciendo obviar el extenso aparcamiento que lo rodea.

"Es el modo más simple para reflejar sobre grandes superficies verticales fenómenos naturales como el cielo o las nubes, cuando la arquitectura ya no es más un espectáculo." ${ }^{379}$ (Martin, 1972, p.8)

De esta manera justifica Martin esa renuncia a la arquitectura, al incorporar al edificio una naturaleza reducida a una imagen paisajística concreta, un efecto puramente visual en un edificio rodeado de grandes extensiones de aparcamiento dónde el cielo es lo único que poder reflejar. También los italianos Casati y Ponzio diseñarán su "Centro MEC" (1972) [8E] vidriando toda la superficie de las dos fachadas principales a lo largo de una carretera, intentando de esta manera restaurar el ambiente natural perdido, una especie de maquillaje más que un recurso efectivo de camuflaje. A partir de entonces, decenas de edificios de fachadas reflectantes serán argumentados como renuncia arquitectónica por sus autores.

476 "The simple fact remains, though, that there just isn't any building as beautiful, or as appropriate, or as important, as the bit of forest it replaces. We are so preoccupied with our own problems that we forget the only reality in this world: Nature"

SKY, Alison; STONE, Michelle. Unbuilt America. 1976. p.289.

477 ROTTIER, Guy. L'Architecture Enterrèe ou L'Anti-Architecture. En: TA Techniques et Architecture, n 313, Le Végétal et l'architecture, enero-febrero 1977. pp.36-38.

478 Tanto el "Sears Building in Alhambra" de Albert C. Martin, como el "CNA Building" de Langdon \& Wilson, ambos terminados en 1972, se convertirán en iconos del paisaje urbano californiano, sirviendo sus fachadas espejadas de referencia para la arquitectura corporativa de la costa oeste norteamericana.

WALKER, Derek (editor invitado). Los Angeles: Architectural Design Profile. Architectural Design, Londres, 1981. p.105.

479 "Ed è il modo piú semplice per avere, su grandi superficie verticali, degli spettacoli naturali sempre diversi come le nuvole, il cielo, quando l'architettura in sé non è piú uno spettacolo."

MARTIN, Albert C. I/ cielo nel Cubo. En: Domus, n514, septiembre 1972. pp.8-10. 


\section{Catálogo // [Naturaleza equipada]}

Las imágenes están referenciadas por números en la zona superior de las columnas verticales [del 1 al 8] y letras en la zona izquierda de las filas horizontales [de la A a la E].

Todas las referencias están ordenadas cronológicamente.

Referencias de imágenes del [1B] a [8E]. Cada uno de los proyectos referenciados gráficamente en el catálogo presentan antes de su nombre un código con un número en relación a su columna vertical y una letra en relación a su fila horizontal.

\section{Ejemplo:}

[7E] "Cloud 9" (1962) de Buckminster Fuller. Buscar referencia en la columna 7 y la fila E del catálogo referenciado al principio del capítulo.

[Nota]: no todos los referentes gráfico del catálogo están referenciados en el texto por lo que se recomienda una lectura del mismo antes de comenzar la del propio texto.
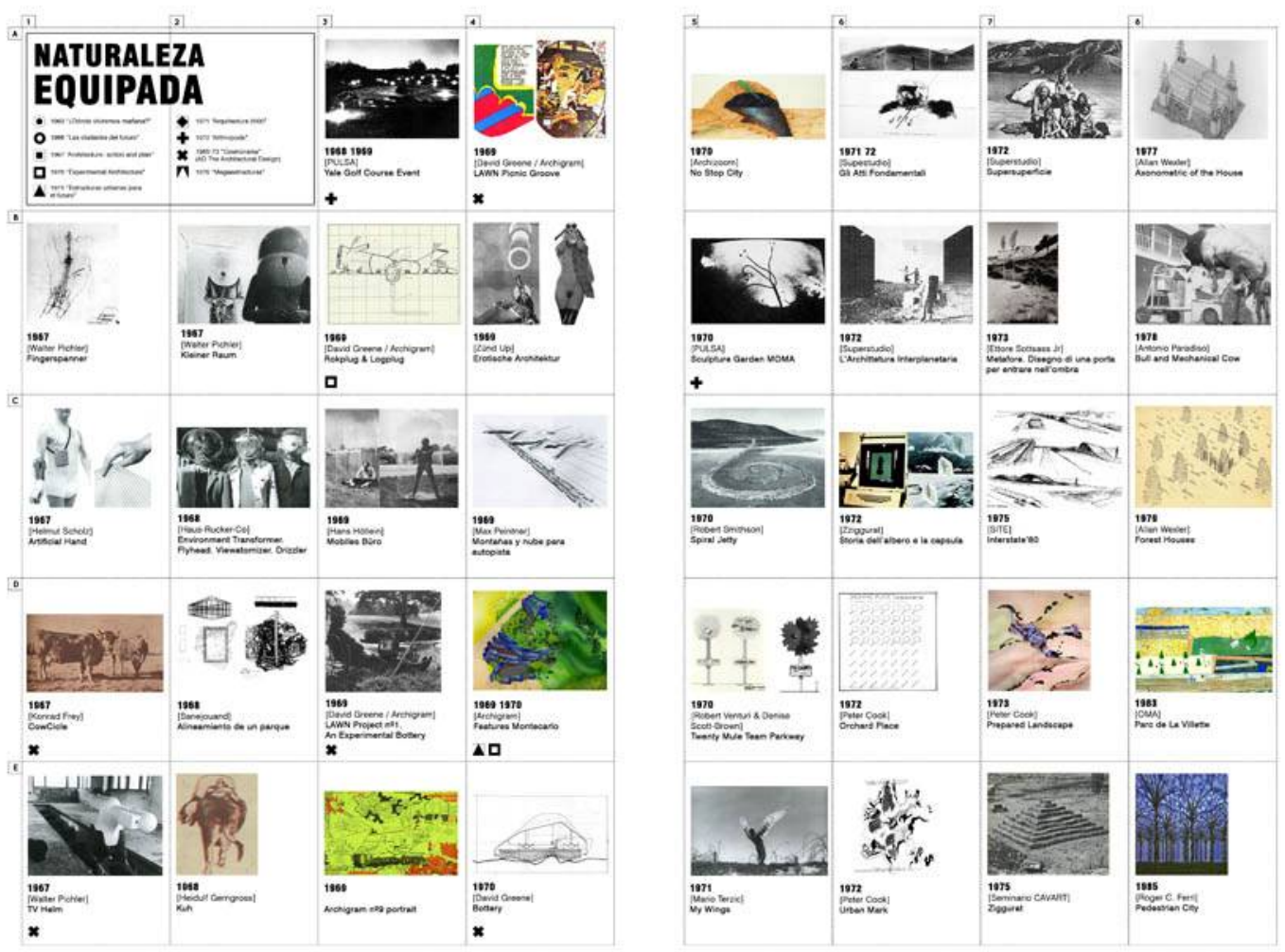


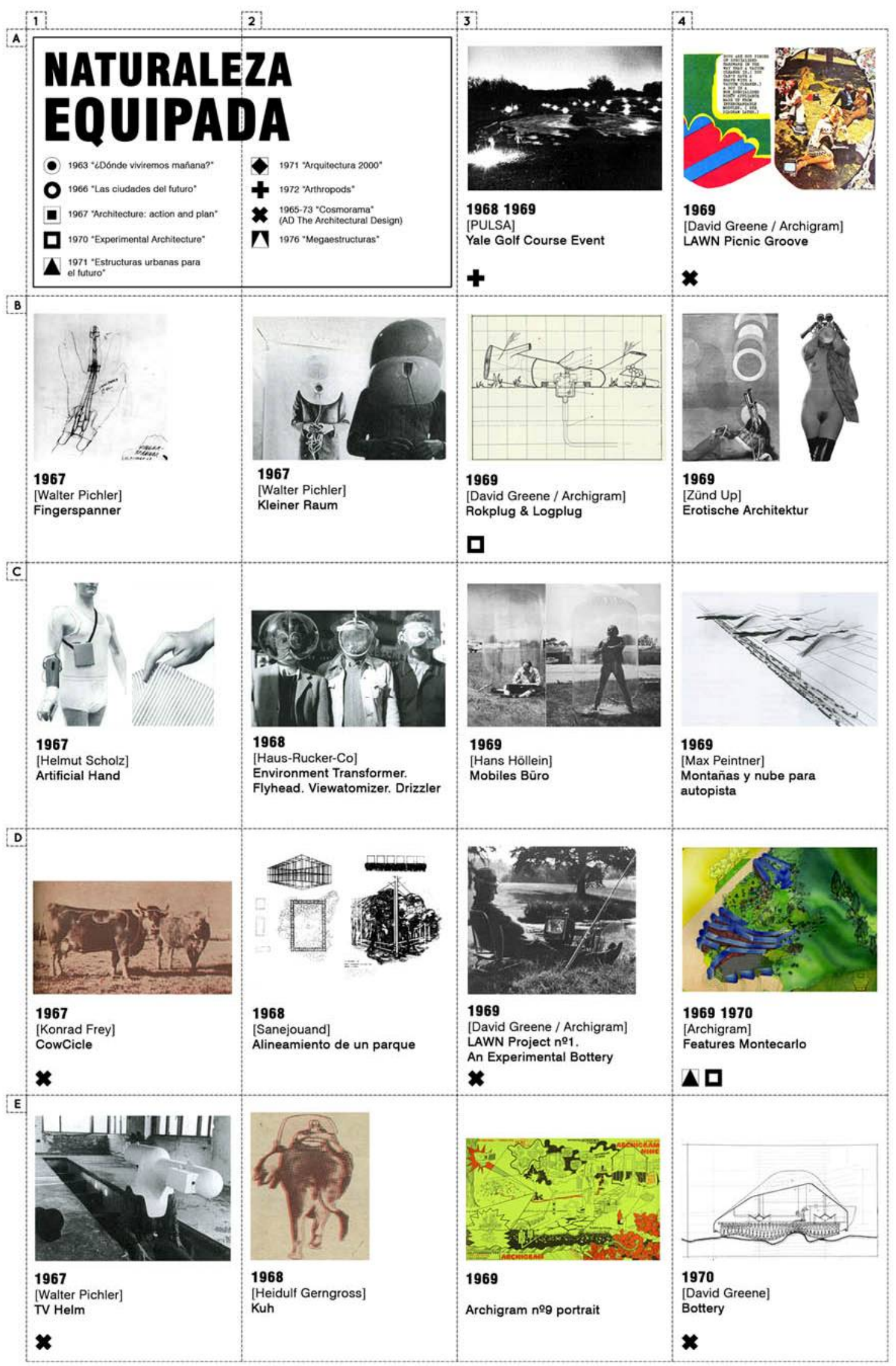




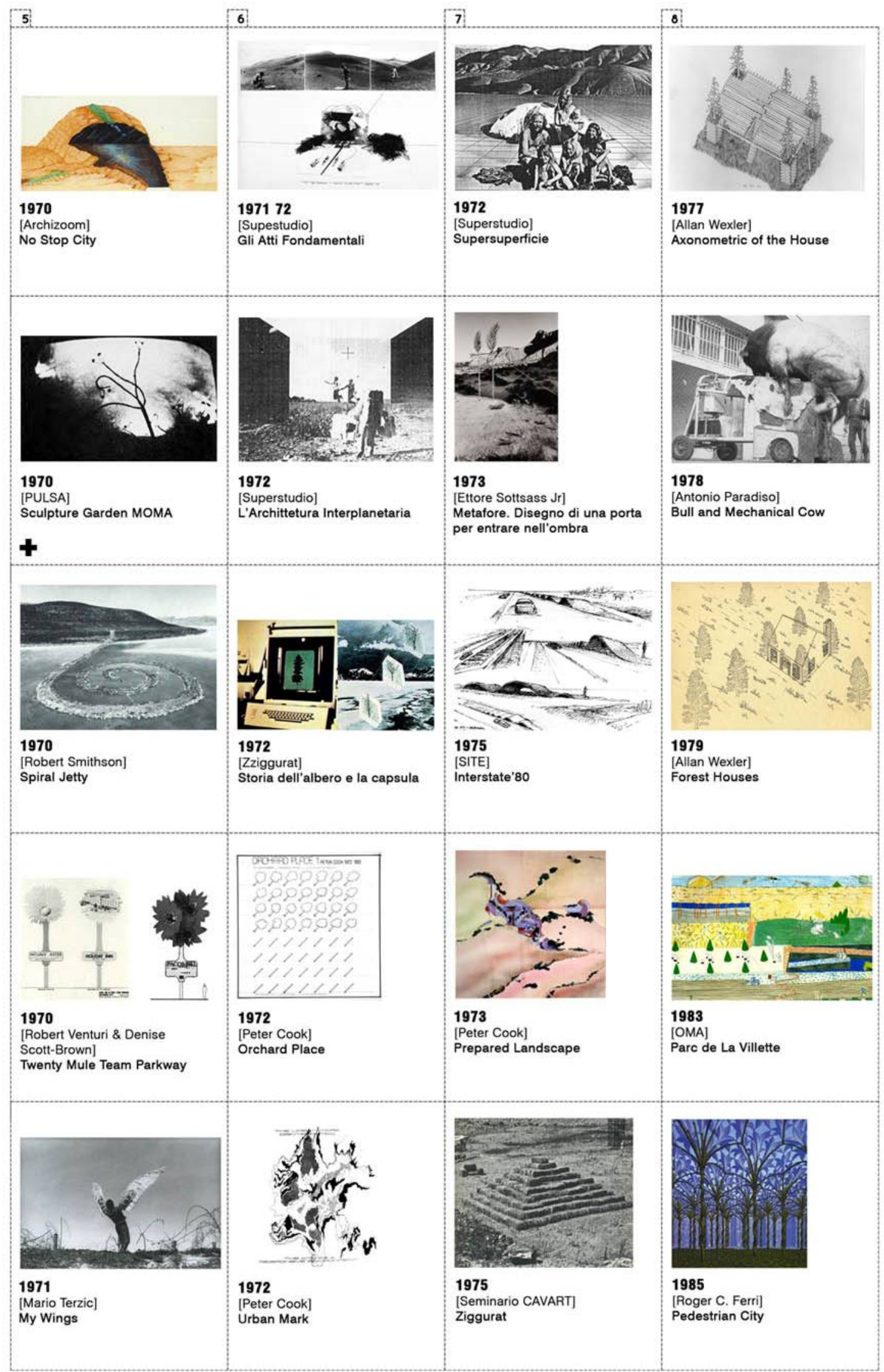




\section{[Naturaleza Equipada] Equipando la naturaleza y con naturaleza.}

La idea de una tecnología facilitadora de nuevas capacidades en el hombre, preconizada por McLuhan en "Understanding Media", abre el debate arquitectónico en torno a cómo esa tecnología artificial pueda generar nuevas alternativas de uso de lo natural. En este sentido, se presentan alternativas arquitectónicas en dos claras direcciones: por un lado, naturalezas equipadas con sistemas de energía e información para poder disfrutar del territorio natural con los mismos niveles de confort que en la ciudad, y por otro, la inserción de prótesis naturales urbanas en pos de una recuperación de los valores naturales en la ciudad. Esas estrategias operarán a diversas escalas, del hombre al territorio, de la vivienda a la ciudad, siempre auspiciadas por el sueño de esa añorada fusión entre natural y artificial.

Los nuevos estados protésicos aplicados al hombre, alternativa de futuro propuesta por McHale y Jencks simultáneamente aunque desde perspectivas muy distintas, pasan por suplantar partes del cuerpo defectuosas o inexistentes, como muestran los estudios "Artificial Hand" [1C] (1967), propuestos por Helmut Scholz como proyecto final de carrera en la Escuela de Diseño de Viena, o incorporar al hombre nuevas extensiones que mejoren sus capacidades, idea esbozada de manera romántica por Mario Terzic en "My Wings" (1971) [5E], un proyecto de alas artificiales. Como prototipos de expansión de esas capacidades humanas aparecen los proyectos de Walter Pichler "Kleiner Raum" (1967) [2B] y "TV Helmet" (1967) [1E]. Pichler materializa esas nuevas capacidades audiovisuales relacionadas con la información en sendos estados protésicos a modo de cascos equipados con las últimas tecnologías de telecomunicaciones como nuevos espacios arquitectónicos. Modelos híbridos de máquinas-persona y viceversa, se utilizarán incluso como crítica arquitectónica en "Erotische Architektur" (1969) [4B] de Zünd Up, dónde se hibridan fotografías de modelos publicitarias con partes de motocicletas y automóviles, denunciando de esta manera la vinculación identitaria entre el hombre y su coche. Dichos estados serán experimentados incluso con animales, como sucede en la propuesta "Cowcicle" (1967) [1D] de Konrad Frey o "Kuh" (1968) [2E] de Heidulf Gerngross, dos dispositivos para el control ambiental de las vacas, que harían innecesarios los actuales establos en los que residen. De la misma manera, estas prótesis tratarán de restaurar valores perdidos aplicados al territorio, posibilidad esbozada por el grupo italiano Zzigurat en "Storia dell'albero e la capsula" (1972) [6C], proyecto teórico por el que superponen microclimas individuales a cada uno de los árboles de un futuro territorio contaminado, estrategia que incluiría todos los proyectos de simulaciones climáticas de grupos como Haus Rucker-Co o Coop Himmelblau.

\section{Naturaleza equipada. La emulación como camuflaje.}

La estrategia encaminada a considerar los paisajes como sistemas productivos, es interpretada por el grupo Archigram considerando el territorio, y por consiguiente la naturaleza, como espacio público por antonomasia, espacio en el que cada usuario pueda ser capaz de configurar su propio ambiente para adaptarlo a sus necesidades de "tiempo libre", imposibles de ser satisfechas en el denso tejido urbano de la ciudad. Desde esta perspectiva, equipar la naturaleza es la consecuencia al estado nómada que miembros del grupo inglés como Peter Cook demandan a esa sociedad del futuro:

"El entorno futuro estará donde tú lo encuentres. 
En el trabajo reciente de Archigram, hemos estado interesados en la sociedad actual, pero más que esto, hemos estado viendo cómo las instalaciones se pueden movilizar más allá de las limitaciones pasadas de la ubicación y la institución, pudiendo así anteponerse a dichas limitaciones al considerar la totalidad del territorio como parte de nuestro entorno responsivo. ${ }^{1480}$ (Peter Cook, 1971, p.191)

Este futuro, que Cook materializa a través de propuestas de equipamientos móviles como "Ideas Circus" o "Instant City" (1968), será reelaborado por otro miembro del grupo, David Greene, a través de sus trabajos denominados como "Gardener's Notebook", a partir de 1968. En ellos trabaja en torno a la configuración de ese equipamiento necesario para el nuevo hombre-nómada personificado en los usuarios de campings y mobile homes, que hacen del territorio su lugar de esparcimiento y recreo. Abandona así la idea de un equipamiento que se mueve de ciudad en ciudad para extenderlo a todo el territorio a través de una red de puntos equipados. De esa idea nacen "Rockplug y Logplug" (1968) [3B], reproducciones en GRP de una roca y un tronco naturales, que albergan diversos servicios ocultos en ellos, desde tomas de corriente, agua, acceso a la tarjeta de crédito o una trituradora de residuos, equipando así ese territorio público y productivo.

"También presento aquí el Rockplug y el Logplug, un nuevo kit para abastecer las necesidades de los visitantes a través de unidades autónomas, que se funden con el paisaje y el follaje. ${ }^{1481}$ (David Greene, 1968, p.506)

Esta primera estrategia de equipamiento del territorio de Greene, supeditada a la reproducción formal de estructuras existentes, supone una búsqueda desesperada de "invisibilidad" de esos servicios tecnológicos que hagan practicable energéticamente el territorio. Las rocas o troncos como simulaciones perfectas, dejarán paso a los árbolesservicio propuestos por Roger C. Ferri en "Pedestrian City" (1985) [8E], también equipada con puntos de información y energía, pero cuya analogía biológica será formalizada de manera explícitamente artificial.

Materializado poco después como "L..A.W.N Project N01"482 (1969) [3D], Greene va más allá, abandonando la mímesis como estrategia fundamental y construyendo incluso su propia terminología como "Bot", "máquina efímera inserta en el paisaje" o "Bottery", "paisaje natural con todos los servicios", con los que especula en torno a un espacio global natural equipado que recorra la tierra, de carácter reversible, simbolizado en una imagen de un pescador viendo una televisión portátil en un entorno natural, y sobre todo sin impacto para el

480 "The Future environment will be where you find it.

In recent Archigram work, we have been interest of current society; but more than this, we have been seeing how facilities can be mobilized so that previous limitations of location and institution can be overridden by regarding the whole of a territory as part of a responsive environment"

COOK, Peter. Environment and Architecture. Conference, October 1969. En: DAHINDEN, Justus. Urban Structures for the Future. 1972 (1971). pp.189-191.

481 "Also introduced here is Rockplug and Logplug, a new kit for the node owner to supply the needs of autonomous unit visitors, that blend into the landscape and foliage."

GREENE, David. Are You Sitting Comfortably? Then l'll Begin' / 'Gardener's Notebook. En: AD The Architectural Design, septiembre 1969. pp. 506-507.

482 L.A.W.U.N. son las siglas de Locally Available World Unseen Network, Red Mundial localmente disponible e invisible. 
territorio, camuflado en un acto invisible de artificialización de la naturaleza. La arquitectura se reduce así a una relación entre esos dispositivos y la acción humana.

"La imagen de este hombre en el río agrupa la mayor parte de las imágenes y de las influencias que produjeron este proyecto. El ambiente transitorio no especializado se hace posible por el desarrollo de un hardware portátil muy sofisticado." ${ }^{1483}$ (David Greene, 1970, p.385)

Estas propuestas demuestran la confianza de Greene y Archigram en una tecnología formalizada a través del robot, Ilegando incluso en "LAWN Picnic Groove" (1969) [4A] a utilizar referencias de robots ya comercializados como el robot cortacésped MowBot o el de extinción de fuegos FireBot. En "Features Montecarlo"484 (1969) [4D] Archigram combina la casuística de artefactos diseñados por Greene con la idea de edificio-camuflaje materializado como colina verde al borde del mar, que encierra debajo todo tipo de equipamientos, desde comedores para banquetes de bodas, presentaciones de películas 0 shows de circo. Esta diferenciación radical entre un interior flexible y heterogéneo y un exterior con apariencia totalmente natural, será uno de los arquetipos arquitectónicos más deseados en la búsqueda de la desaparición total del edificio frente al paisaje.

"En ningún otro lugar de Mónaco hay un parque que se pueda utilizar, el único existente, el Jardín Exótico es remoto y demasiado escarpado. Aquí podría construirse ese lugar, junto a la playa, que extendiera sus servicios de manera complementaria a la atmósfera y la experiencia. El Rockplug y el Logplug de David Greene nos proporcionó una buena pista: un claro cubierto de hierba bajo una arboleda, con puntos de servicio a intervalos de seis metros. ¿Qué tal un teléfono - sombrilla - cama de aire - Ventilador - aparato de TV que usted contrata sin enchufe? Llame para conseguir unas bebidas. Manténgase en este lugar fresco. Ninguna roca o registro serán necesarios en esta ocasión, sólo un limpio agujero en el suelo como si fuera un hoyo de golf. ¿Y las actividades calefactadas? ¿Los eventos? Están dentro." 485 (Archigram, 1970, pp.104-105)

La portada del magazine "Archigram No9" [3E], dibujada por Tony Rickaby, reproduce un jardín doméstico del futuro. En él se incorporan de manera invisible todos los inputs tecnológicos de equipamiento a través de micrófonos, sensores, videocámaras o sistemas de riego automáticos que amplifiquen las posibilidades de intercambio entre hombre y naturaleza a partir del propio jardín de la vivienda. Siguiendo con la imagen de jardín equipado, en el proyecto de 1972 "Orchad Place" [6D], Cook especula con esa posibilidad a partir de disposiciones regulares utilizadas en lugares aparentemente "naturales" como son

483 "The picture of this man by the river collects together most of images and influences that produced this project. The transient non-specialized environment is made possible by the development of sophisticated portable hardware"

GREENE, David. Gardener's Notebook: L.A.W.U.N. Project Number One. En: AD The Architectural Design, agosto 1970. pp. $385-387$.

484 Archigram Competition: Monte Carlo. En: AD The Architectural Design, septiembre 1970. pp. 7-16.

485 "Nowhere else in Monaco is there a park that you can use, the Jardin Exotique is remote and steep. Here could be a place, next to the beach, that extends its services but is complementary in atmosphere and experience. David Greene's Rockplug/Logplug provided a clue: a grassy blank with trees, with service outlets at 6 meters intervals. How about a telephone - parasol - airbed - fan - TV appliance that you hire and plug in? Call for drinks. Keep cool. No rock or log needed this time, just a neat hole in the ground like a golf-hole. And the hot features? The events? They are inside"

Features as an idea. En: COOK, Peter (editor). Archigram. 1972. pp.104-105. 
los huertos. De esta manera, asemejará ambos paisajes como posible hibridación entre los sistemas naturales y artificiales, una mezcla entre huerto-equipado y equipamiento-huerto:

"Éste es otro tipo de huerto... uno artificial si se quiere, que tiene servicios y aseos en cajas y que no está limitado a la simple cubrición en forma de paraguas de los árboles. ${ }^{1186}$ (Peter Cook, 1972, pp.104-105)

Sistemáticas parecidas serán posteriormente utilizadas por el propio Cook en proyectos como "Urban Mask" (1972) [6E] o "Prepared Landscape" (1973) [7D] en la que el equipamiento gana protagonismo produciéndose una evidente lucha entre lo artificial y lo natural más que un intento de camuflaje o inserción en el paisaje.

\section{Redes invisibles de energía e información. Otra vez la desaparición de la arquitectura.}

Volviendo a las infraestructuras destinadas a equipar energéticamente el territorio, posibilitando así la vida humana a lo largo y ancho de la superficie de la tierra, la "Supersuperficie" (1970-72) [7A] de Superstudio y su derivado "Gli Atti Fondamentali" [6A], enuncian a partir de ellas una desaparición total de los objetos de consumo prescindibles, al equipar ese territorio a partir de una malla geométrica de energía que deje paso a la arquitectura existente en los actos humanos fundamentales, la vida, la ceremonia, la educación, el amor y la muerte. Este posicionamiento evidencia una visión de una forma de vida alternativa reduccionista. A pesar de las imágenes totalitarias de una malla que todo lo inunda, la principal idea inherente en estos trabajos de Superstudio es bastante similar a las desarrolladas por David Greene en "Bottery" [4E], propuesta que consistía en generar una red de enchufes universales invisibles repartidos por todo el territorio, que lo hagan transitable, habitable, de una manera homogénea y abierta, una superescala que puede incluso llegar hasta la luna, una de las especulaciones de Superstudio en "Architettura Interplanetaria" de 1972 [6B].

"Podemos imaginar una red de energía e información que se extiende a todas las áreas habitables. La vida sin trabajo y una nueva humanidad potenciada son posibles gracias a este tipo de red. "1487 (Superstudio, 1972, p.242)

Las experimentaciones reales en torno a la generación de mallas de energía superpuestas al territorio son desarrolladas de manera significativa por el grupo multidisciplinar norteamericano Pulsa. En "Yale Golf Course Event" (1968-1969) [3A], los miembros de Pulsa despliegan sobre el campo de golf de la Universidad de Yale, una matriz de altavoces, micrófonos y luces, controlados a partir de un ordenador central, generando así interacciones a tiempo real entre el puesto de control y los usuarios del campo, a modo de

486 "This is another kind of orchard...an artificial one if you like, it has servicing and lavatories in boxes and there is limited structure in the form of umbrellas from which things can be draped."

COOK, Peter. Orchard place. En: CROMPTON, Dennis; JOHNSTON, Pamela. A Guide to Archigram 1961-74. Academy Editions. Chicago, 1994. pp.372-373.

487 "We can imagine a network of energy and information extending to every properly inhabitable area. Life without work and a new potentialized humanity are made possible by such a network"

SUPERSTUDIO. Superstudio. En: AMBASZ, Emilio (editor). Italia: the New Domestic Landscapes. 1972. p.242. 
red de intercambio de información universal. De manera parecida, en 1970 equipan la terraza del MOMA de Nueva York con "Sculpture Garden" [5B], una red de células fotoeléctricas, pequeñas estaciones meteorológicas, micrófonos y cámaras que repite a pequeña escala esa red de información preconizada por Superstudio. A pesar de que la estrategia principal de Pulsa será la de generar una red tecnológica de intercambio de información imbricada a la estructura física del territorio o la ciudad, las ideas de Pulsa se encontrarán con las de Superstudio en relación a la desaparición de la arquitectura de objetos o artefactos en pos de un nuevo orden basado en el intercambio de información y energía, de una red superpuesta a la naturaleza.

"La historia total de los objetos artificiales, incluyendo la actual tecnología de la comunicación y el transporte, es un sistema de artefactos. El sistema más grande de artefactos en la actualidad es la ciudad, pero pronto será sustituida por las redes globales de comunicación y otros grandes sistemas de información. Para que estos sistemas sean utilizados con éxito, nuevas políticas y procedimientos inherentes a ellos deben ser empleados. ${ }^{1488}$ (Pulsa, 1972, p.208)

488 "The total history of man-made objects, including the present technology of communication and transportation, is an artifact system. The largest artifact system presently in existence is the city; but it will soon be superseded by global communication networks and other large-scale information systems. In order for these systems to be used successfully, new politics and procedures which are inherent in them must be employed"

PULSA. The City as an Artwork. En: KEPES, Gyorgy. Arts of the environment. Brazilier. Nueva York, 1972. pp.208-221. 


\section{Catálogo // [Re-naturalizar la ciudad]}

Las imágenes están referenciadas por números en la zona superior de las columnas verticales [del 1 al 16] y letras en la zona izquierda de las filas horizontales [de la A a la E].

Todas las referencias están ordenadas cronológicamente.

Referencias de imágenes del [1B] a [16A]. Cada uno de los proyectos referenciados gráficamente en el catálogo presentan antes de su nombre un código con un número en relación a su columna vertical y una letra en relación a su fila horizontal.

\section{Ejemplo:}

[7E] "Cloud 9" (1962) de Buckminster Fuller. Buscar referencia en la columna 7 y la fila E del catálogo referenciado al principio del capítulo.

[Nota]: no todos los referentes gráfico del catálogo están referenciados en el texto por lo que se recomienda una lectura del mismo antes de comenzar la del propio texto.

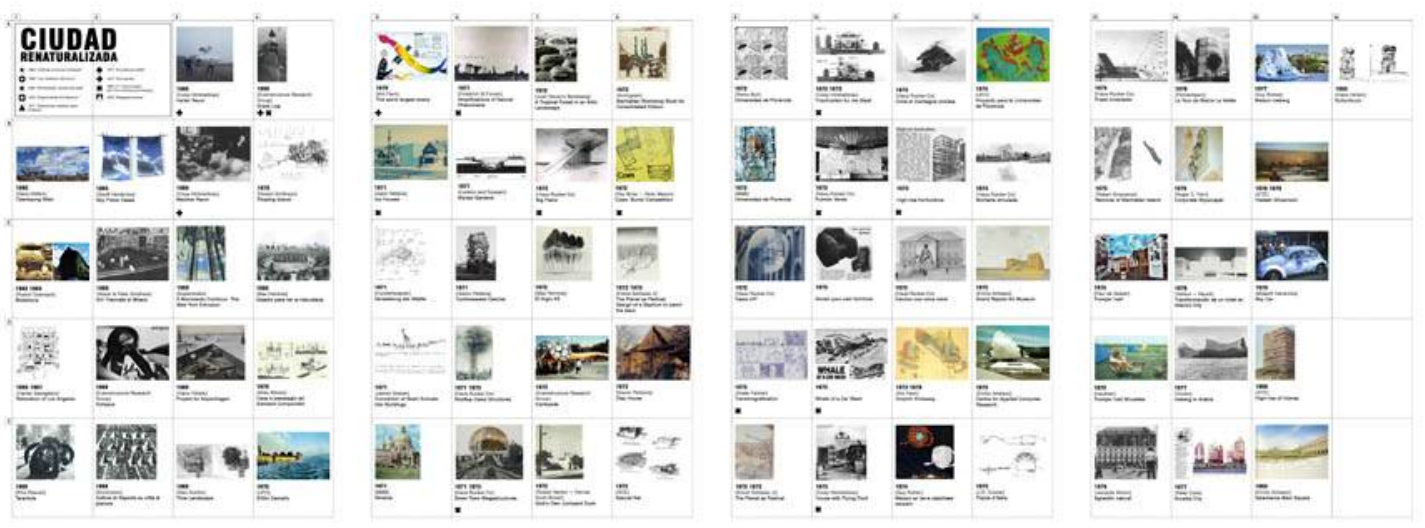




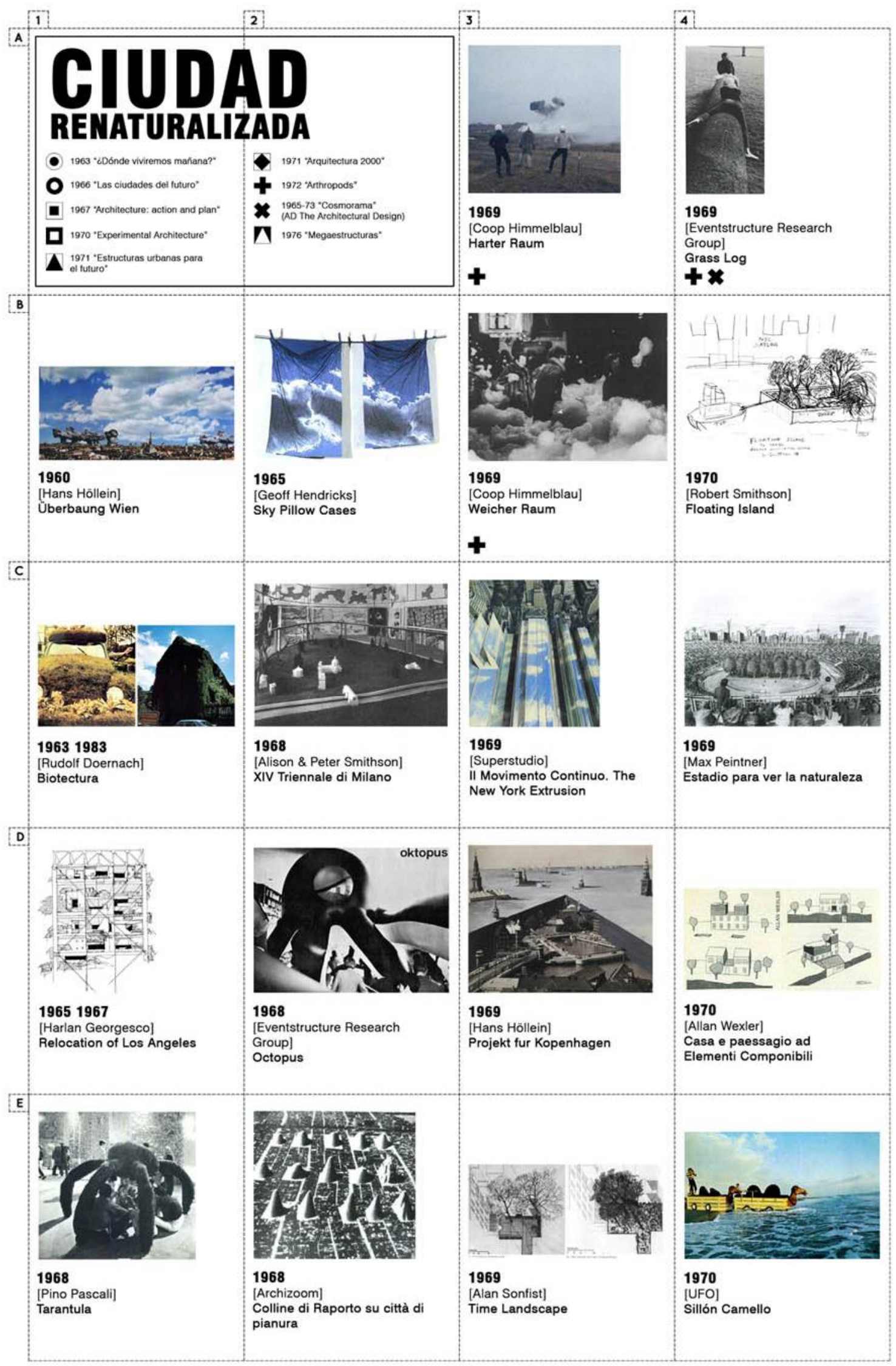




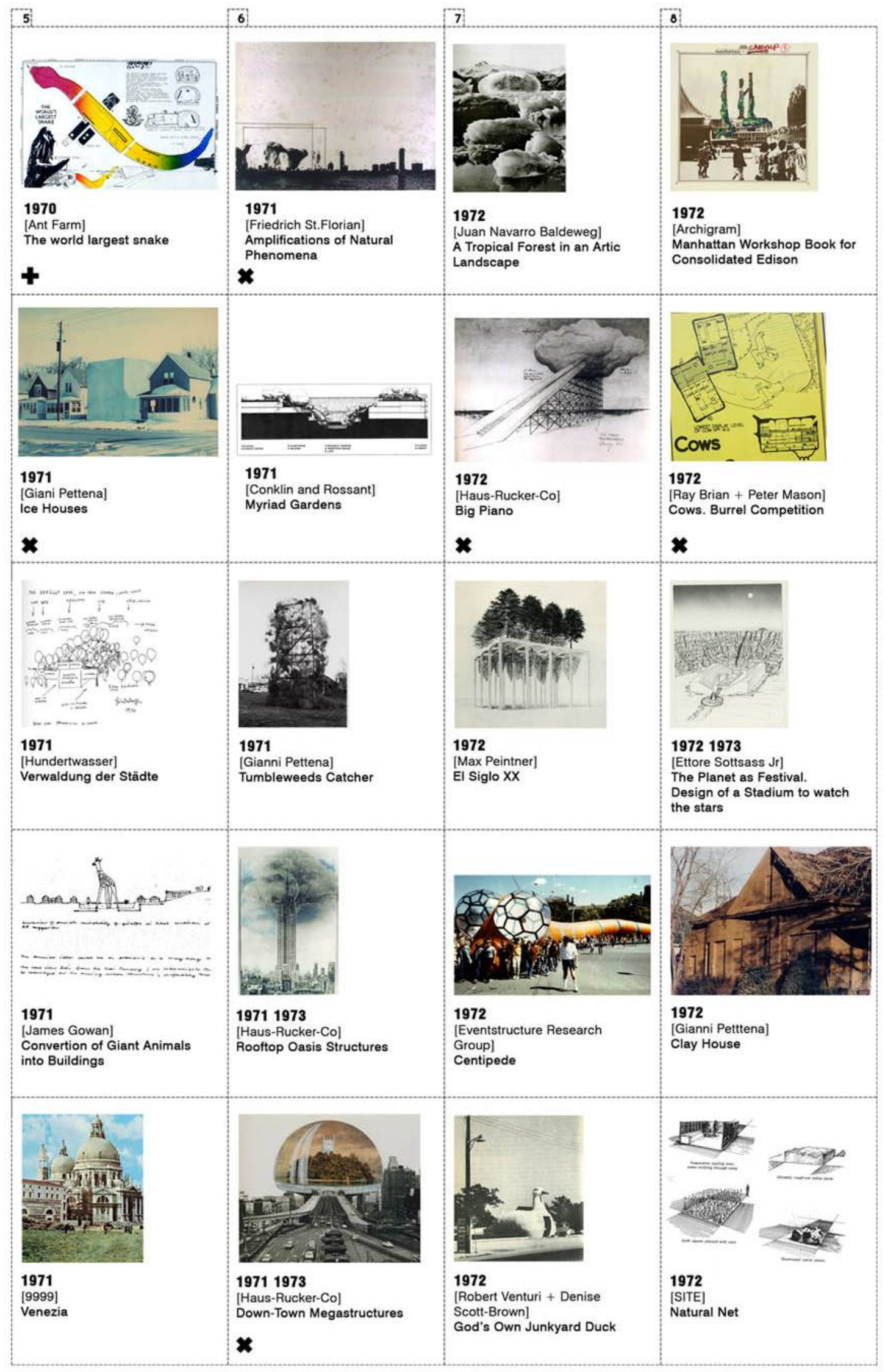




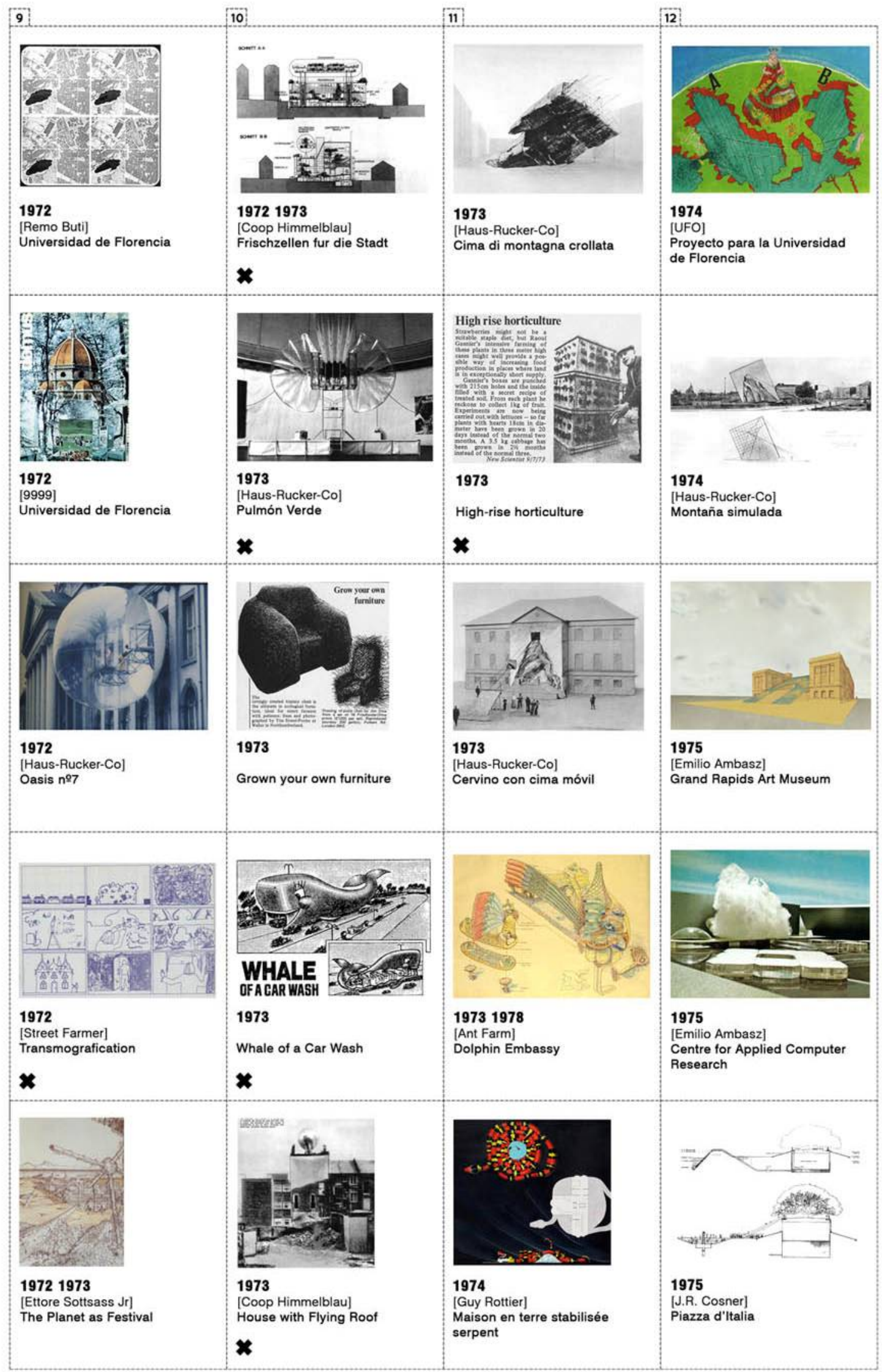




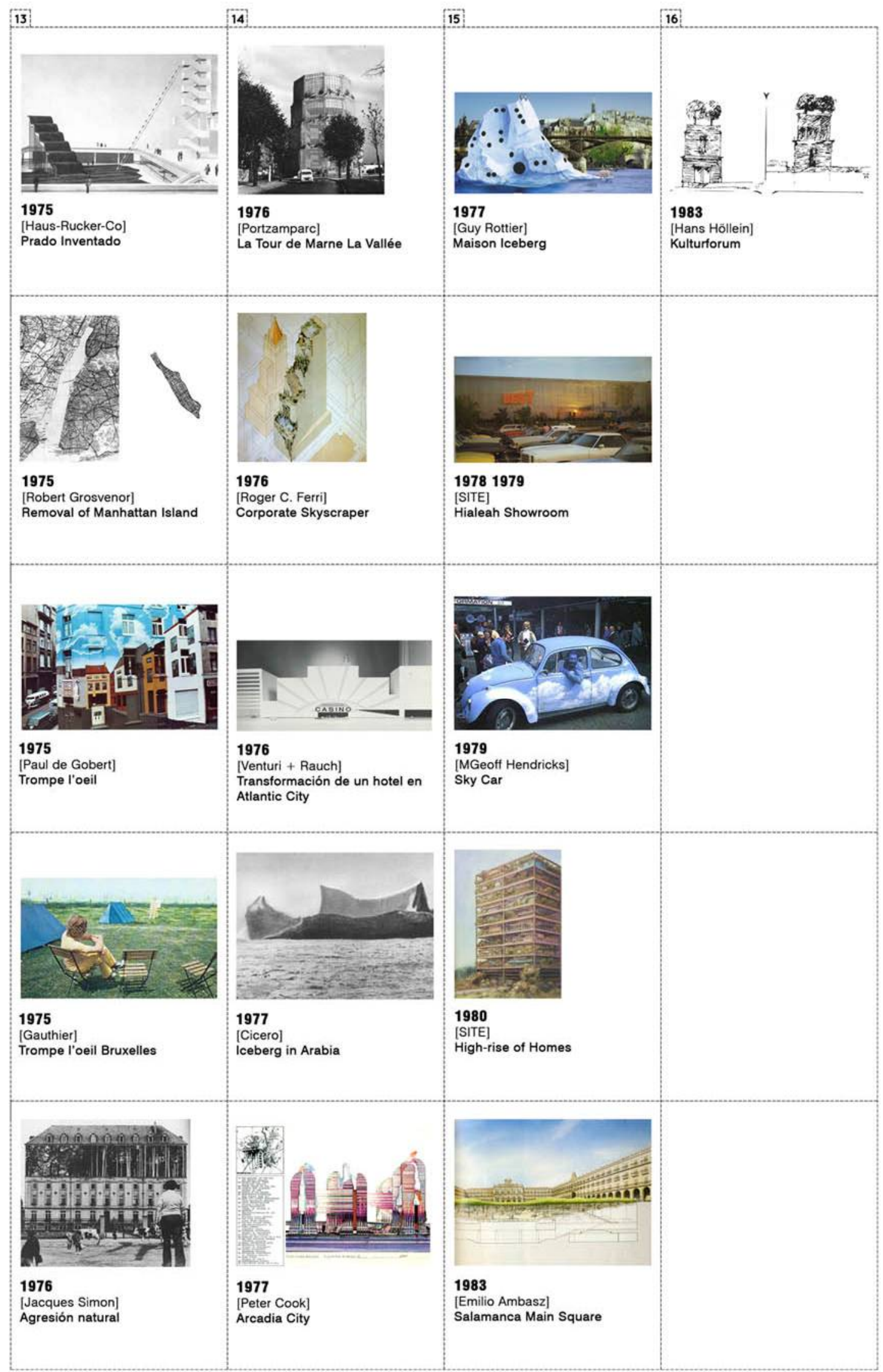




\section{[Re-Naturalizar la Ciudad] Hacia una vuelta a lo salvaje en la ciudad.}

La idea de devolver la ciudad a un estado primigenio de simbiosis con la naturaleza será una de las búsquedas más comunes entre las denominadas, en esta tesis, perversiones naturales desde finales de los años cincuenta. Esa vuelta a una naturalización de la ciudad supone el leitmotiv principal de la propuesta de Alison y Peter Smithson para la XIV Triennale de Milán de 1968, en la que presentan una maqueta de la ciudad de Florencia como un tapiz verde sobre el que sólo se asientan los edificios más representativos de la ciudad. [2C]

"Florencia como un ideograma para un paraíso sobre la tierra, con los edificios más importantes sobre un paisaje de jardín virgen." ${ }^{489}$ (Smithson, 1968, p.235)

Esta imagen de ciudad verde ideal no difiere mucho de las principales propuestas de gran parte de los proyectos urbanos del movimiento moderno, sin embargo llega a generar un concepto contrapuesto, ya que no supone una sistemática de ocupación de un paisaje existente sino una destrucción de partes de la ciudad para devolverla a un estado anterior. Una vuelta a lo salvaje de la ciudad consolidada mediante inserción de naturaleza de una manera radical. Ese retorno será también propuesto por Alan Sonfist, que plantea como primera hipótesis la elección del período al que referenciar esa vuelta. En su proyecto "Time Landscape" (1969) [3E] sugiere la reforestación de un patio de manzana de Nueva York para devolverlo a su estado de bosque pre-colonial.

"El Time Landscape es una recreación contemporánea de los fenómenos naturales que una vez existieron en un lugar en particular. Se trata de un monumento público en honor a la historia de estos elementos en la ciudad. Diferentes períodos de tiempo pueden ser seleccionados para dicha recreación." ${ }^{" 900}$ (Sonfist, 1969, p.123)

\section{Replantar la ciudad. Vuelta a lo salvaje.}

La imagen de una Florencia salvaje propuesta por los Smithson en 1968 será retomada en 1971 por el grupo florentino 9999, quienes proponen un "bosque de secuoyas cibernéticas" para el "Concurso de la Nueva Universidad de Florencia" [9B], en el que árboles artificiales de cientos de metros de altura se superponen a la ya consolidada e histórica ciudad italiana ${ }^{491}$. Un proceso de re-naturalización radical similar será utilizado en "Salvataggio di Venezia" [5E], en el que el mismo grupo propone sustituir los canales y una laguna que habían sido su medio económico en el pasado por inmensas praderas verdes en un intento de nueva utopía natural.

489 SMITHSON, Alison y Peter. Transformations of the City. En: AD The Architectural Design, abril 1968.p.235.

490 "The Time Landscape is a contemporary recreation of the natural phenomena that once existed on a particular site. It is a public monument honoring the history of these elements in a city. Different periods of time can be selected for re-creation"

SKY, Alison; STONE, Michelle. Unbuilt America. 1976. p.123.

491 Una imagen de un proyecto que ni siquiera estará entre los galardonados del concurso pero que será una de las portadas de la revista Domus en 1972:

Domus, n509, abril 1972, portada. 
"Sesenta y un años después de los futuristas, la idea de una Venecia enterrada reaparece a través del signo opuesto: no la industria sino la naturaleza, el Verde, representará la utopía. Los Monumentos permanecerán como arquitecturas gigantes aislados." ${ }^{492}$ (9999, 1971, p.52)

La idea de una utopía como vuelta urbana a lo salvaje se extiende y es así como Ettore Sottsass presenta en su propuesta teórica "Il Pianeta come Festival" (1972) [9E] una serie de arquitecturas fagocitadas por una exuberante y salvaje vegetación. Entre ellas, desde los icónicos rascacielos de Manhattan hasta la "Walking City" diseñada en 1964 por Ron Herron de Archigram sucumbirán ante cantidades ingentes de naturaleza exacerbada.

"La descentralización explosiva de la distribución de bienes de consumo ha pulverizado las ciudades, eliminadas de la faz de la tierra. De esta manera han sido fagocitadas por las junglas, los pantanos, los desiertos." 493 (Sottsass Jr, 1972, p.43)

Una imagen parecida aparece en el fotomontaje "The Empire State Building" (1972) [6D] perteneciente al proyecto "Roof Top Oasis Project" de Haus Rucker-Co, en el que el icónico rascacielos neoyorquino sirve de tronco a una estructura arbórea super-escalada que aparece como nueva coronación del mismo. Éste será uno de los muchos collages que el grupo austríaco generará a través de ese mismo proyecto de colonización verde de las azoteas de Nueva York a partir de exuberantes oasis. También mediante su investigación "Down Town Megastructures" (1971) [6E], imaginan exuberantes remansos como lugares de descongestión del centro de las ciudades. Ambos coquetean con la idea de un lugar climáticamente acondicionado para la generación de nuevos ecosistemas ajenos al tejido de la ciudad, una especie de nuevos zoológicos o jardines botánicos llenos de vida pública no reglada, lugares cuyo contraste con lo existente queda ejemplificado en el proyecto de Juan Navarro Baldeweg "A Tropical Forest in an Artic Landscape" (1972) [7A]. Los programas de re-naturalización de la ciudad a través de vegetación se sucederán, ya sea mediante la anteriormente citada "Biotectura" de Rudolf Doernach, la cual llega a especular con proyectos de coches en los que toda su superficie exterior fuese cubierta por un manto de vegetación, o alguno de los tantos manifiestos de re-plantación radical propuestos por autores como Hundertwasser en "Verwaldung der Städte" (1971) [5C], por el que reivindica cualquier superficie horizontal como perteneciente a la naturaleza:

"Las superficies horizontales pertenecen a la naturaleza, las verticales a los humanos. Esto significa que toda superficie horizontal al aire libre pertenece a la vegetación y que los humanos podemos sólo reclamar lo vertical. Para poner esto de diferente manera: la naturaleza libre debe desarrollarse allí dónde la nieve cae en invierno." 494 (Hundertwasser, 1958, p.48) 492 "Sessantun'anni dopo i futuristi, I'idea di Venezia interrata ricompare sotto il segno opposto: non l'industria ma la natura,
il Verde, impersona l'utopia. I Monumenti rimangono, architetture giganti, isolate"

9999. Venezia? En: Domus, n506, enero 1972. p.52.

493 "La descentralización explosiva de la distribución de bienes de consumo ha pulverizado las ciudades, eliminadas de la faz de la tierra. De esta manera han sido fagocitadas por las junglas, los pantanos, los desiertos"

SOTTSASS JR, Ettore. /l Pianeta come festival. En: Casabella, n³65, mayo 1972. pp. 41-46. 
De una manera parecida, los miembros del colectivo Street Farmer ${ }^{495}$ reivindican el "verde" en la ciudad, a través de su publicación análoga ${ }^{496}$ y en concreto a través de un proceso de re-naturalización simbólica denominado como "Transmogrification" (1971) [9D].

"Una tira cómica titulada Transmogrification, impresa en tinta azul, narra poéticamente el consumo de la ciudad por las fuerzas naturales, como los edificios se transforman en arbustos, un cuervo se come un rascacielos, y el hombre se concibe a través de las relaciones sexuales con la ciudad." 497 (Colomina, 2010, p.125)

Esa invasión natural propuesta por Street Farmer se materializa no sólo en las superficies horizontales como territorio propio de la naturaleza reivindicadas por Hudertwasser sino en todo tipo de objetos arquitectónicos materializados a la escala del edificio. Si ya en 1972 Archigram presenta el cartel del "Manhattan Workshop Book for Consolidated Edison" [8A] con unas chimeneas fabriles asaltadas por la vegetación, en 1976 la imagen de Roger Ferri para su proyecto "Corporate Skyscraper" [14B] se convertirá en icono de re-naturalización al superponer a un rascacielos corporativo de muro cortina, un paseo rocoso, selvático, escalonado a partir de todas las alturas de los seis volúmenes que componen el edificio. Esta imagen de la retícula cartesiana del rascacielos es fracturada por una naturaleza derivada de la rocalla, incluyendo lagos e incluso fauna autóctona.

"La torre está construida con la máxima edificabilidad permitida bajo la ley actual de zonificación. Mantiene la pared de la calle durante once pisos, a continuación, se retranquea para recibir un paisaje de montaña construido a partir de la roca excavada en la obra. El paisaje se planta con flora nativa de la región del valle de Hudson, poblándose con fauna resistente a la cautividad, como aves, peces, conejos e incluso venados. ${ }^{1498}$ (Ferri, 1976, p.108)

494 "The horizontal belongs to nature, the vertical to humans. That means everything horizontal in open air belongs to vegetation; humans can claim only the vertical. To put this in different terms: Free nature must rule everywhere the snow falls in winter."

HUDERTWASSER. Forest take over the city. En: PORSCH, Johannes; ARCHITEKTURSENTRUM WIEN (editores). The Austrian Phenomenon: Architecture Avantgarde Austria 1956-1973. Birkhäuser Boston INC. Boston, 2005. p.49.

495 Street Farmer estará formado por los estudiantes de la Architectural Association, Peter Crump y Bruce Haggart.

496 Street Farmer, n¹, Londres, 1971. El magazine tendrá dos numeros publicados por el colectivo Street Farmer, formado por alumnos de $5^{\circ}$ año bajo la tutela de Peter Cook.

497 "A comic strip entitled Transmogrification, printed in blue ink, poetically narrates the consumption of the city by natural forces, as buildings transform into shrubbery, a crow eats a skyscraper, and man is conceived through sexual intercourse with the city"

COLOMINA, Beatriz; BUCKLEY, Craig (editores). Clip, Stamp, Fold. 2010. p.125.

498 "The tower is built to the maximum floor area allowed under present zoning law. It maintains the street wall for eleven stories, then sets back to receive a mountainscape assembled from bedrock excavated from the building site. The landscape would be planted with flora native to the Hudson Valley region, and populated with fauna hardy to captivity, such as birds, fish, rabbits and deer"

COLLINS, George R., SCHUYT, Michael; ELFFERS, Joost. Fantastic Architecture. Personal and Eccentric Visions. Henry N. Abrahams Inc. Nueva York, 1980. p.108. 
Una sistemática parecida será usada por Peter Cook en muchas de las imágenes de las diferentes versiones realizadas para "Arcadia City" (1976-1978) [14E] junto a Christine Hawley. En ellos, toda la malla regular de la ciudad aparece seccionada por la incursión de vida natural salvaje, representada a la manera pintoresca del jardín inglés que Cook tanto veneraba. Esta ruptura radical de elementos arquitectónicos reglados también aparece en proyectos como los "Myriad Gardens" (1971) [6B] de Conklin y Rossant, unos grandes almacenes enterrados cuyo vacío central se configura mediante cañones naturales a cuatro alturas, construyendo así un parque aterrazado continuo como única fachada.

"En el borde del centro de negocios de la ciudad de Oklahoma, un estrato subterráneo de 25 metros de profundidad con agua clara corriendo por él será aprovechado para crear un cañón en el que, a través de cuatro niveles, todas las nuevas funciones del edifico tendrán su acceso y fachada. ${ }^{1499}$ (Conklin; Rossant, 1971, p.55)

Un híbrido entre la sección de "Myriad gardens" y "Arcadia City" de Cook será utilizada por Emilio Ambasz para su proyecto de reutilización de la antigua "Union Station de Kansas City". En él da continuidad a un parque aledaño convirtiendo el interior del edificio en un cañón artificial de hasta cuatro niveles, con pequeños lagos, cascadas de agua y diversas especies naturales sobre un fondo de rocas escarpadas. Será el propio Ambasz quién construya, ya en la década de los noventa en Japón, el esquema de paseo natural superpuesto a un edificio corporativo propuesto por Ferri. El "Fukuoka Prefectural International Hall", será diseñado como un edificio acristalado en el que una de sus fachadas se convierte en un exuberante jardín escalonado de descanso para los trabajadores del edificio, que pueden pasear por él como si de un jardín vertical se tratase. Un esquema parecido es utilizado con anterioridad por el propio Ambasz para la conversión de una antigua estación de correos a museo en su proyecto "Grand Rapids Art Museum" (1975) [12C], superponiendo una estructura escalonada que sirve de entrada al edificio, la cual utiliza como cascada de agua artificial, simulando esos grandes rápidos que hacen alusión al nombre de la ciudad.

La preservación de esa ciudad jardín que demanda Cook y que tantas veces aparece como paradigma de ciudad natural se convierte en otra de las obsesiones más recurrentes en la búsqueda arquitectónica de re-naturalización de la ciudad. En ese sentido, como modo de combatir la super-extensión a través del sprawl que esas organizaciones requieren, el apilamiento aparece como estrategia aparentemente efectiva. Entre 1965 y 1967, Harlan Georgescu desarrolla el proyecto "Relocation of Los Ángeles" [1D], por el cual propone que todo el área conurbana de la ciudad sea albergada en grandes rascacielos construidos mediante unas plataformas en las que se acomodan nuevas tipologías de vivienda con jardín diseñadas por el propio Georgescu. Una estrategia similar será utilizada por SITE en 1980 en su icónico proyecto "Highrise of Homes" [15D], para el que dibujan una serie de plataformas apiladas que albergan todo tipo de viviendas de suburbio norteamericanas, desde los cottages de ladrillo con chimenea a las mobile homes, pasando por sistemas de caravana. La imagen que produce es mucho más impactante que la de Georgescu, ya que SITE no intentan diseñar nuevas tipologías de vivienda con jardín sino que directamente superponen las ya existentes a esa estructura de rascacielos. De esta manera, el interés del proyecto radica en su capacidad de absorción del paisaje urbano ya existente en la ciudad-jardín. Una especie de "all you can eat architecture" en el que se combina la tan ansiada densidad

499 "On the edge of the central business of Oklahoma City, a 25-ft-deep underground stratum of clear stream water will be tapped and revealed to create a canyon where, in four levels along its walls, all new functions will have their Access and frontage."

SKY, Alison; STONE, Michelle. Unbuilt America. 1976. p.55. 
urbana del rascacielos con el sistema idílico de vivienda con jardín de los suburbios como paradigma de vida campestre.

A pesar de que la vegetación se convierte en la gran protagonista de ese proceso de renaturalización de la ciudad, otro tipo de estructuras naturales serán también introducidas de manera radical en el corazón de la ciudad. La metáfora de la montaña vuelve a convertirse en elemento clave de re-naturalización. Así es como Höllein superpone una gran ciudad-roca a la consolidada Viena en "Überbaung Wien" (1960) [1B] o Archizoom una serie de protuberantes colinas en un tejido urbano de baja densidad en "Colline di raporto su città di pianura" (1968) [2E], denunciando así los excesos de las extensivas zonas periféricas frente al territorio. La colina superpuesta al tejido urbano será también utilizada por Remo Buti en su propuesta para el "Concurso de la Universidad de Florencia" (1971) [12A] como cortocircuito en la ciudad de Florencia, una colina que UFO también utiliza de manera irónica en su propuesta para el mismo concurso. La misma pretensión será reivindicada por Gianni Pettena en sus propuestas "Ice Houses" (1971) [5B] y "Clay House" (1972) [8D], por

las que cubre de hielo o brea viviendas típicas de un suburbio norteamericano en Salt Lake City como victoria de la naturaleza frente a la agresión de los suburbios.

"Un hogar típico de clase media en Salt Lake City se convierte en un no-hogar, viejo, apretado, hasta que el sol haga que la creta se agriete y caiga. Un proceso en el tiempo. Puesto en marcha por los efectos naturales. ${ }^{1500}$ (Pettena, 1972, p.54)

Todo ese proceso queda perfectamente ejemplificado por la imagen "Estadio para ver la naturaleza" (1969) de Max Peintner, en el que un bosque aparece como principal protagonista de un evento celebrado en un gran estadio repleto de gente, con el único fin de contemplar esa naturaleza representada por la vegetación, añorada, inalcanzable, imposible. El mismo romanticismo se destila en "Design of Stadium to watch the Stars" [8C], uno de los dibujos de Sottsass Jr. para "Il Pianeta come Festival", que aboga por la construcción de un estadio especial a las afueras de la ciudad para poder ver desde él las estrellas, acto convertido en espectáculo masivo y necesario en una ciudad cubierta por el smog.

\section{La naturaleza como equipamiento. La naturaleza utilizada como kit.}

El proceso de re-naturalización de la ciudad mediante grandes extensiones de naturaleza, ya sea a través de las metáforas del bosque, la jungla, el desierto, la montaña e incluso el campo cultivado se presenta como un imposible por las implicaciones urbanas a gran escala que ello conlleva. Así es como otras propuestas llevan a repensar sobre esas inserciones naturales como procesos de acupuntura, entendiendo la naturaleza como un equipamiento más e incluso como un kit destinado a la construcción del paisaje urbano. Uno de los proyectos que mejor ejemplifican esta idea será la "Floating Island" (1970) [4B] de Robert Smithson, un jardín flotante compuesto por una barcaza densamente ajardinada con vegetación baja y árboles, remolcada por un pequeño barco alrededor de la isla de Manhattan. Este jardín portátil no sólo se convierte en un equipamiento verde más para la ciudad sino que lo hace rompiendo el carácter estático de "lo natural". Una situación parecida será imaginada por Allan Wexler en "Casa e paessagio ad elementi componibili"

500 "Una casa middle-class tipica di Salt Lake City diventa una non-casa, antica, ermetica, finché al sole la creta non si screpola e cade. Processo nel tempo. Messa in moto di effetti naturali"

PETTENA, Gianni. Conversazione a Salt Lake City. En: Domus, n516, noviembre 1972. pp.53-56. 
(1970) [4D], proyecto de universidad desarrollado en la Rhode Island School of Design bajo la tutela de Raimund Abraham, en el que Wexler dibuja los elementos naturales como un kit prefabricado que se utiliza de la misma manera que los elementos de construcción, generando diversas tipologías mediante la conjunción de piezas del kit, usando indistintamente aquellas construidas o naturales. Jack R. Cosner por su parte utiliza un gran árbol móvil a través de un sistema hidráulico que lo hace subir o bajar según el nivel del mar como monumento principal en su propuesta para el concurso de la "Piazza d'talia" (1975) de Nueva Orleans [12E]. Esa reducción de la naturaleza a un sistema de quita y pon genera una gran diversidad de artefactos posibles encaminados a activar ese proceso de renaturalización de la ciudad. De esta manera los oasis gigantes propuestos por Haus RuckerCo en sus proyectos "Downtown megastructures" o "Rooftop Oasis" antes citados, se convierten en micro-jardines "plug-in" en propuestas reales como "Oasis $n^{\circ} 7^{\circ}$ " [9C] para la documenta de Kassel de 1972 o como declaración de intenciones en "House with Flying Roof" (1973) [10E]. Este taller desarrollado por Coop Himmelblau en Londres junto a alumnos de la Architectural Association, se utiliza para transformar mediante hipergráfica y un balón de helio un edificio en desuso en una nueva vivienda que podría equiparse mediante un jardín volador transportado como si de un zeppelín se tratara, una reducción de escala de su propuesta de jardín hinchable superpuesto a la ciudad de Viena propuesto en el proyecto "Frischzellen fur die Stadt" (1972-1973) [10A].

Ante esa imposibilidad de construcción de una nueva realidad urbana natural a gran escala, el recurso de simulación natural de manera totalmente artificializada a través de su imagen o su forma será bien acogido como estrategia alternativa encaminada a una pseudo-utopía de lo natural. Los miembros de Haus Rucker-Co intentarán en varios proyectos incorporar esa montaña que pueda llegar a desestructurar el tejido de la ciudad, superponiendo una hipergráfica de una montaña de escala reducida a la entrada del museo Haus Salve Hospes en "Cervino con cima móvil" (1973) [11C], mediante una instalación urbana tridimensional en el que simulan una montaña cayendo en "Cima di montagna crollata" (1973) [11A] o por medio de un gran cartel de una montaña a punto de sumergirse en un lago real en las afueras de una localidad austríaca en "Montaña simulada" (1974) [12B]. De esta manera Haus Rucker-Co pasan de una búsqueda de naturalezas reales insertas como pulmones salvajes de la ciudad a utilizarla sólo a través de su imagen.

\begin{abstract}
"La creación de espacios verdes en la ciudad suele ir ligada a lugares para el tiempo libre y el ocio, por lo que son muy significativos. Se trata de un paisaje natural que se convierte en un elemento de arquitectura efímera. La naturaleza y el concepto de la misma será recreados. La reproducción de un trozo único de naturaleza y la posibilidad de insertarlo en la vida cotidiana son hechos esenciales para la ciudad... Las copias de la realidad natural se convierten así en parte integrada del paisaje urbano." ${ }^{501}$ (Ortner, 1977, p.28)
\end{abstract}

La utilización de naturalezas se convierte así en una cuestión puramente escenográfica en proyectos como "Prado Inventado" (1975) [13A], en el que el grupo austríaco combina elementos naturales reales modificados como un prado verde ondulado con otros totalmente artificiales que pretenden simular sus respectivos naturales, como el suelo de vidrio que rodea todo el conjunto intentando representar una zona de agua. De la misma manera, en

501 "La creazione di ambienti verde nelle città, per la ricreazione e il tempo libero, è quindi molto significativa. Si trata di un paesaggio naturale che diventa una componente della architettura provvisoria. La natura stessa, ed il concetto di natura, vanno ri-creati. La riproduzione di pezzi unici di natura e la possibilità di collocarli nella vita quotidiana sono fatti essenziali per la città. Copie di realtà naturali diventano parte integrante dell'ambiente urbano."

ORTNER, Laurids. Architettura Prowisoria. En: Domus, n569, abril 1977. pp.25-32. 
"Big Piano" (1972) [7B], proponen una gran escalera soportada por un sistema de andamiaje para acceder al interior de una gran nube simulada mediante un máquina de niebla como las utilizadas en los sets de rodaje de las películas hollywoodienses. Esa nube artificial también será incorporada por Emilio Ambasz al diseño de su "Centre for Applied Computer" (1975) [12D] como un elemento arquitectónico más que cumple incluso una función de enfriamiento del edificio en el cálido clima de Ciudad de México.

"Sobre la plataforma se libera una nube que, concebida como elemento arquitectónico, también sirve para volver a meter el agua evaporada en el estanque y para refrescar el exterior del edificio." ${ }^{1502}$ (Ambasz, 1975, p.1)

El proyecto de SITE para los almacenes BEST, "Hialeah Showroom" (1978-1979) [15B], será una de esas experimentaciones que mejor entienden la capacidad escenográfica de las reproducciones naturales. Los arquitectos norteamericanos superponen un invernadero muy estrecho a la cerrada fachada de uno de los centros comerciales, Ilenándolo de exuberante vegetación y pintando el fondo de azul. De esta manera, el vidrio de la fachada acristalada genera una serie de reflejos del horizonte, que combinados con las siluetas de las palmeras del invernadero consiguen la apariencia de un paisaje mitad real mitad reflejado como seductora fachada.

Entender la naturaleza como un kit genera todo tipo de operaciones de control sobre ella a través de dos estrategias principales: mediante métodos de modificación de la misma, aumentando así sus posibilidades funcionales o por medios de sistemas que permitan reproducir procesos naturales en el interior de la ciudad. La primera, relacionada con esa idea de "Biotektur" de Minke de poder prefabricar elementos vivos naturales, genera todo un catálogo de soluciones, desde asientos setos como "Grown your own Furniture" (1973) [10C] o "Grass Log" (1969) [4A] propuesto por ERG, hasta plantaciones verticales para densificar cultivos dentro de la ciudad "Highrise Horticulture"503 (1973) [11B]. El proyecto "Natural Net" (1972) [8E] de SITE propone equipar una universidad norteamericana a partir de una malla de follies naturalizadas, consiguiendo así un catálogo de situaciones singulares, desde pirámides de agua, rocallas que sirven de iluminación, plantaciones de maíz o zonas para refrescarse mediante agua evaporada, en una mezcla de procesos naturales, naturalezas artificiales y paisajes aislados transportados al centro de la vida universitaria. Todos estos kits gravitan entre lo puramente figurativo, como las propuestas de cielos insertados en la ciudad a través de manteles colgados en "Sky Pillow Cases" (1965) [2B] o coches "Sky Car" (1979) [15C] de Geoff Hendricks, a las más sofisticadas técnicas de simulación, como los hologramas de fenómenos naturales propuestos por Friedrich St.Florian en "Amplifications of Natural Phenomena" (1971) [6A]. También explotarán este carácter de "proceso natural simulado" proyectos como "Weicher Raum" [3B] y "Harter Raum" [3A] de Coop Himmelblau, en los que los arquitectos austríacos tratan de construir simulaciones reales de procesos pseudo-naturales en la ciudad, desde tormentas de espuma a grandes explosiones que generan densas nubes de humo a su alrededor, reivindicando así ese carácter descontrolado de los procesos naturales como parte del paisaje urbano construido.

502 "Sulla piattaforma si libera una nuvola che, concepita come elemento architettonico, serve anche per immettere di nuovo l'acqua evaporata dal baccino e per rafreddare gli esterni dell'edificio"

AMBASZ, Emilio. Edifici Mobili Galleggianti. En: Domus, n546, mayo 1975. pp.1-4.

503 Muchas de esta ingeniosas propuestas de naturalezas modificadas aparecerán publicadas en la sección Cosmorama de Architectural Design, sobre todo a principios de los setenta. 


\section{Animales-nostalgia.}

Todas esa re-naturalizaciones antes citadas van encaminadas de un modo u otro hacia una nostalgia de "lo salvaje". De esta manera, animales gigantes serán materializados mediante estructuras neumáticas entendidas como activadores urbanos, como ocurre en las instalaciones anteriormente citadas "Octopus" (1968) [2D] y "Centipede" (1972) [7D] de Evenstructure Research Group, o "The world largest snake" (1970) de Ant Farm, a los que se les suman otros experimentos análogos de materializaciones y usos diferentes, como "Tarantula" (1968) [1E] de Pino Pascali, cuya dimensión le sirve para convertirse en un habitáculo, o el mobiliario urbano con forma de camello "Sillón Camello" [4E] del colectivo italiano UFO.

Continuando esta línea de experimentación, aparecen otra serie de perversiones de fauna a gran escala a partir de evocaciones programáticas, desde el archiconocido "God's Own Junkyard" popularizado por Venturi y Scott-Brown en su "Aprendiendo de Las Vegas" o la "Maison en terre stabilisée serpent" (1974) [11E] diseñada por Guy Rottier, al proyecto "Conversion of Giant Animals into Buildings" [5D] propuesto en 1971 por James Gowan. Monumentos todos ellos a una fauna expulsada hace mucho tiempo de la ciudad o recluida en parque temáticos o zoológicos, monumentos que nos devuelven al gran elefante, "Triumphal Elephant", proyectado en Los Campos Elíseos por C.F. Ribart en 1758 $8^{504}$.

504 Vuelvo a referenciar varios proyectos, artículos y publicaciones para ver la importancia de estos cambios de escala de animales convertidos en edificios:

DEZZI BARDESCHI, Marco. Elefantica, owero il colosso abitato. En: Casabella, n³91, julio 1974. pp.12-14.

DEZZI BARDESCHI, Marco. Elefantica, dalla Bastiglia a Las Vegas. En: Casabella, n³94/, octubre 1974. pp.14-16. 


\section{Catálogo // [Naturalezas domésticas]}

Las imágenes están referenciadas por números en la zona superior de las columnas verticales [del 1 al 16] y letras en la zona izquierda de las filas horizontales [de la A a la E].

Todas las referencias están ordenadas cronológicamente.

Referencias de imágenes del [1B] a [16E]. Cada uno de los proyectos referenciados gráficamente en el catálogo presentan antes de su nombre un código con un número en relación a su columna vertical y una letra en relación a su fila horizontal.

\section{Ejemplo:}

[7E] "Cloud 9" (1962) de Buckminster Fuller. Buscar referencia en la columna 7 y la fila E del catálogo referenciado al principio del capítulo.

[Nota]: no todos los referentes gráfico del catálogo están referenciados en el texto por lo que se recomienda una lectura del mismo antes de comenzar la del propio texto.

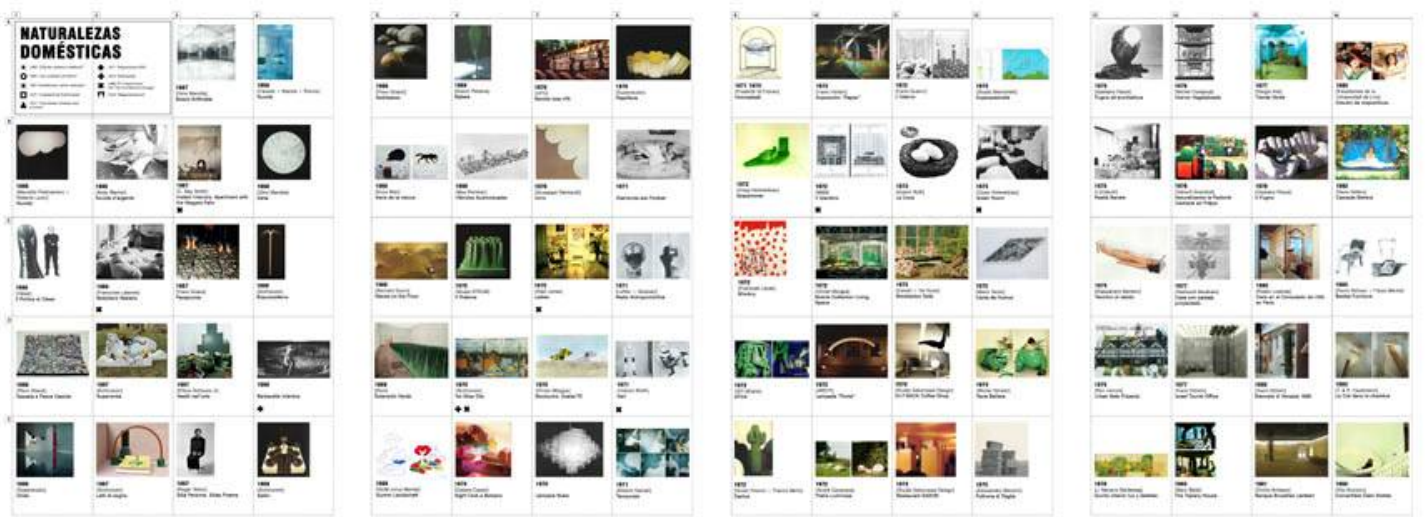




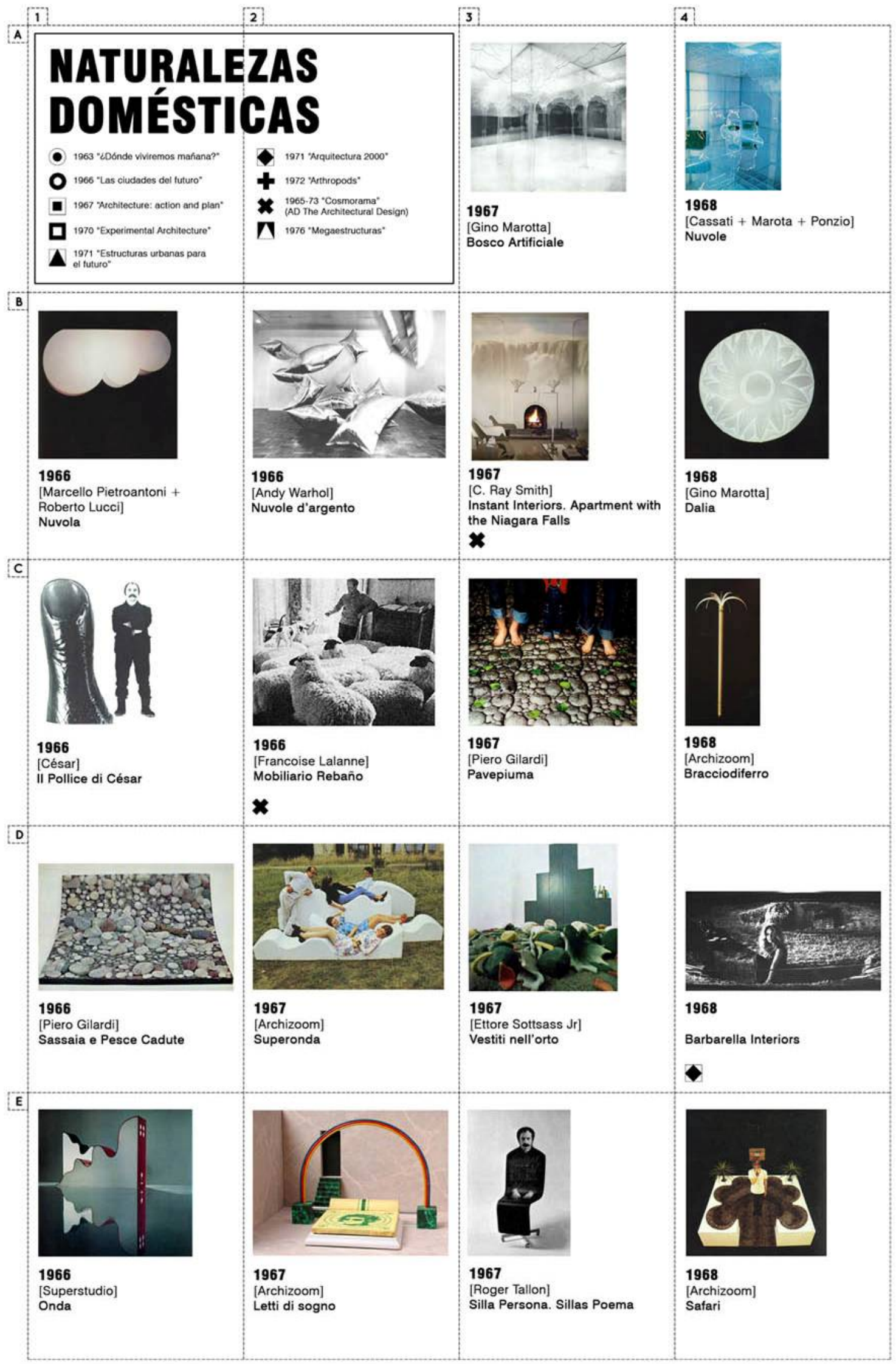




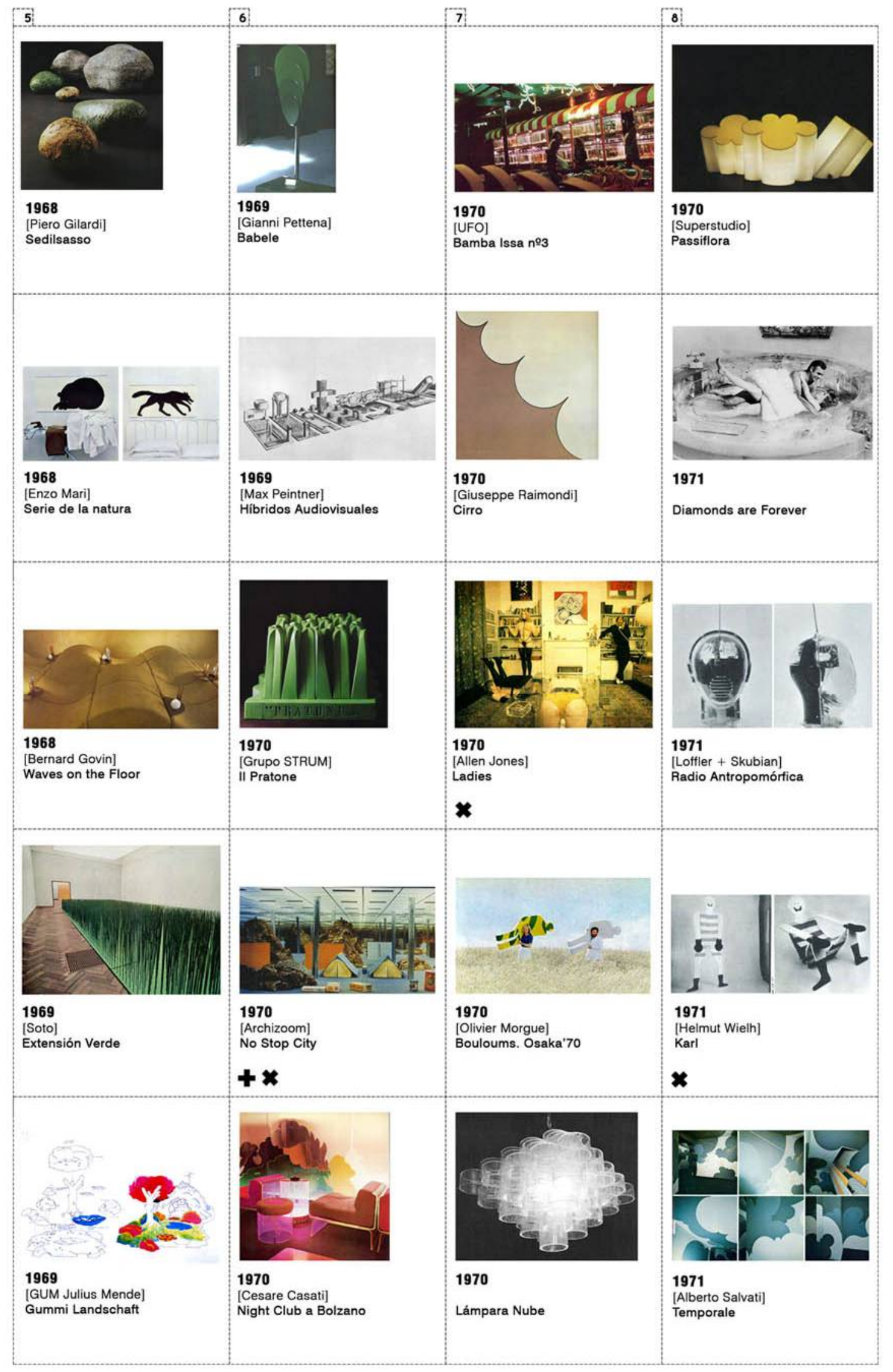




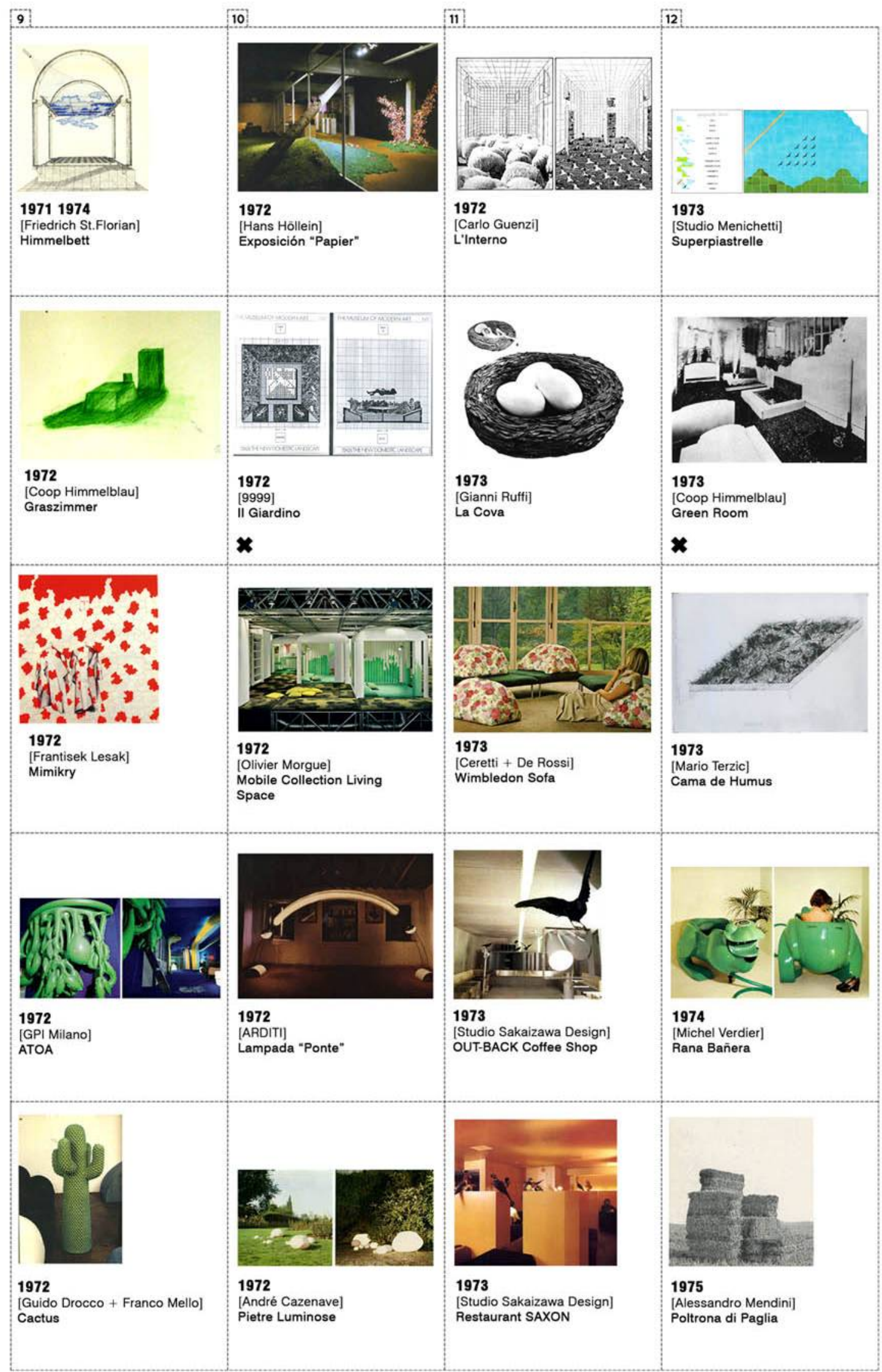




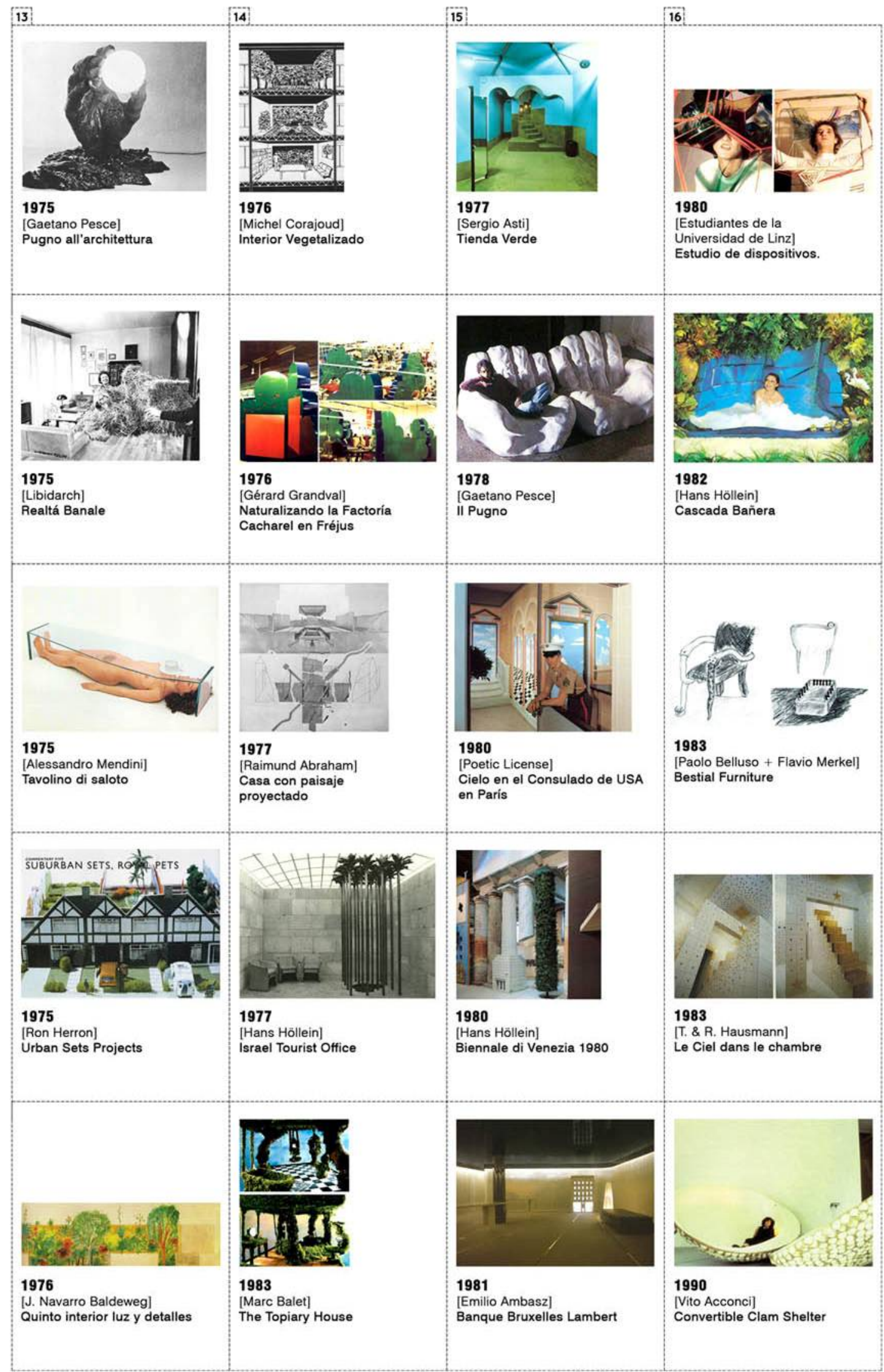




\section{[Naturalezas Domésticas] Nuevos paisajes naturales domésticos.}

El espacio doméstico no escapará tampoco a ese proceso de re-naturalización que se estaba gestando en el espacio urbano. Más allá de todo el elenco de sistemas de inserción del verde natural en el interior de las viviendas mediante patios interiores, jardineras o invernaderos, la simulación artificial de naturalezas salvajes encuentra en la escala doméstica un lugar muy propicio para su experimentación formal y utilitaria. La industrialización de los materiales plásticos y la incorporación de los mismos al hogar, favorecen en gran medida la aparición de todas estas réplicas naturales que transportan al ambiente doméstico a un tiempo anterior más próximo a "Io salvaje". Así es como el campo de experimentación en esta dirección trabajará, bien utilizando las superficies que contienen ese espacio doméstico, suelos, techos o paredes, o a través de un amplio catálogo de objetos naturales re-diseñados para poder equipar estos nuevos paisajes domésticos.

\section{Superficies naturales. Entre el cielo y la pradera.}

Si la pintura sobre paredes y techos de elementos naturales, ya sean cielos, parras con uvas u horizontes, había sido una práctica común de integración pictórica de la naturaleza con la arquitectura, el movimiento moderno extirpará toda posibilidad de utilización de lo figurativo como delictivo ornamento encaminado a pervertir el espacio arquitectónico. El nuevo paisaje doméstico demandado desde Italia desde mediados de los años sesenta reivindica una vuelta a ese interior naturalizado, usando técnicas y sistemas constructivos diversos que van desde la común baldosa cerámica a las por aquel entonces sofisticadas proyecciones. Las paredes monocromas o geometrizadas de la modernidad se llenan de motivos de nubes y cielos en todas sus formas naturales posibles, desde la tranquila silueta propuesta en "Cirro" (1970) [7B] por Giuseppe Raimondi, a la simulación de un temporal pictórico en "Temporale" (1971) [8E] de Alberto Salvati, de estrellas geometrizadas y doradas en la serie "Le Ciel dans le chambre" [16D] propuesto por los Haüssmann, o de paisajes completos modulares, a partir de la combinación de doce tipos diferentes de azulejos en la serie "Superpiastrelle Salomé" (1973) [12A] de Studio Menichetti.

"Cielos con golondrinas, con nubes y golondrinas, con nubes, golondrinas y arbustos, se obtienen con los azulejos de la serie Salomé, supercerámica diseñada para la marca Impruneta. ${ }^{1505}$ (Studio Menichetti, 1973, p.54)

Los motivos pintados que aducen a lo natural se extenderán y harán más complejos, entre el realismo de los paisajes o las falsas ventanas de Richard Haas e incluso el "Cielo en el consulado de USA en París" (1980) [15C] propuesto por el grupo Poetic License o únicamente a través de abstracciones y colores planos, como hará Sergio Asti en "Tienda Verde" (1977) [15A]. En el último ejemplo, el arquitecto italiano intenta re-construir un ambiente natural a partir de un suelo de moqueta verde y un techo y paredes pintados de azul. Ese tapiz verde interior se convertirá en una obsesión, por lo que se experimentará con distintos recursos materiales y formales para conseguir un mullido suelo verde. Una moqueta que simula césped de manera artificial se convierte en el suelo de la exposición

505 "Cieli con rondini, con nuvole e rondini, con nuvole, rondini e cespugli, si ottengono con le piastrelle della serie Salomé, Superceramica della Impruneta"

Superpiastrelle. En: Domus, n525, agosto 1973. p.54. 
"Papier" (1972) [10A] de Hans Höllein, eso sí, recortada de manera natural para contrastar como vegetación sobre otra moqueta marrón de color tierra. Las tapicerías de propuestas como la "Mobile Collection Living Space" (1972) [10C] de Olivier Morgue o el sofá "Wimbledon" (1973) [11C] de Ceretti y De Rossi, simulan setos o bancos de flores para inundar así de vegetación el ambiente doméstico. Coop Himmelblau intentarán en repetidas ocasiones conseguir ese manto vegetal interno en propuestas teóricas como "Graszimmer" (1972) [9B] o "Green Room" (1973) [12B], una mezcla de plantas naturales y superficies verdes artificiales como forma de rehabilitación de espacios degradados, de manera análoga a como lo hace la "Cama de Humus" (1972) [12C] propuesta por Mario Terzic. Carlo Guenzi por su parte llegará incluso a generar hipótesis de esa vuelta de lo natural al hogar como respuesta a una arquitectura depredadora guiada por el capital en su ensayo gráfico "L'Interno Sostituito" (1972) [10B].

"Vuelven a aparecer los elementos naturales como el agua, la arena, las ovejas. La naturaleza y las plantas se apoderan del espacio que lo antinatural les había quitado." ${ }^{" 506}$ (Guenzi, 1972, p.50)

También los italianos UFO utilizan las reminiscencias naturales en la remodelación de la discoteca "Bamba Issa no3" (1970) [7A], a través de una serie de acuarios como paredes naturalizadas en las que combinan fauna y vegetación con objetos de consumo y elementos alegóricos de manera intencionada. Una especie de monumento-crítica a la evasión que supone la incorporación de la naturaleza al objeto arquitectónico.

"La naturaleza encarcelada en Las Vegas cuelga del techo de malla de alambre, cielo, estrellas, hierba, frutas, aves, animales, vegetales, minerales, en busca de una escapada del mundo, más allá de la prisión." ${ }^{1507}$ (Lapo Binazzi, 1974, p.47)

Esa imagen de los acuarios como zona de hibridación entre natural y artificial será también comentada por Jencks en "The Language of Post-Modern Architecture" a partir de una imagen de la película "Diamonds Are Forever" (1971) [8B] en la que un James Bond, caracterizado por Sean Connery, retoza con Tiffany Case en una cama transparente, construida mediante paredes de acuarios, generando un "ambiente natural de dos amantes rodeados por más de tres mil peces tropicales"1508, imagen que se contrapone a la del sofá peludo de la película "Barbarella" (1968) [4D], que supuso una especie de revolución de "/o blando" a la que se unieron gran cantidad de arquitectos y diseñadores de mobiliario.

Otros nuevos ambientes serán generados a través de la capacidad de emulación de los materiales plásticos. Por ejemplo, Cesare Casati construye el filtro acústico de su proyecto "Night Club a Bolzano" (1970) [6E] a partir de una serie de láminas plásticas de PVC transparente que combinadas con otras verdes y rosas simulan las siluetas de matorrales y

506 "Rientrano gli elementi naturali: l'acqua, la sabbia, le pecore. La nature e le piante si reimpossessarono dello spazio che l'antinaturale aveva loro sottratto"

GUENZI, Carlo. L'Interno Sostituito. En: Casabella, n³64, abril 1972, p.50.

507 "La natura imprigionata a Las Vegas pende dal soffito di rete metallica, cielo, stelle, erba, frutti, uccelli- Animale, vegetale, minerale per una evasione alla rovescia nel mondo, oltre la prigione"

UFO Zorro. En: Domus, n539, octubre 1974. pp.46-47.

508 JENCKS, Charles. The Language of Post-Modern Architecture. 1977. p.77. 
nubes, generando una profundidad en dicha cortina tridimensional que retrotrae a una situación de paisaje natural brumoso. Una manera similar de trabajar con la profundidad del paisaje en las paredes se vislumbra en la reforma interior realizada por Emilio Ambasz en el "Banque Bruxelles Lambert" (1981) [15E] al recrear una especie de atardecer de un paisaje montañoso a partir de la superposición de relieves escalonados e iluminados, difuminados en primer plano por una cortina tejida, simulando un ambiente brumoso bajo el que cambiar tus divisas o abrir una cuenta corriente.

Aunque menos explorados, los sistemas de proyección permitirán la incorporación de esas naturalezas de una manera instantánea como propone Ray C. Smith en su "Instant Interiors Apartment with the Niagara Falls" (1967) [3B], proyectando las cataratas del Niágara en el salón de su apartamento en Nueva York. También St.Florian coqueteará aunque de manera hipotética con la posibilidad de viviendas decoradas con paisajes proyectados, ya sea en su "Casa con paisaje proyectado" (1977) [14C] o en "Himmelbett" (1971-1974) [9A], una habitación sobre la que sobrevuela un cielo generado mediante técnicas derivadas del holograma. Las posibilidades de emulación de estos sistemas, utilizados sólo de manera gráfica por grupos como Archigram o Haus Rucker-Co, y de una manera más experimental por EAT, Pulsa o Eventstructure Research Group, parecen infinitas aunque dependientes al desarrollo de las tecnologías que las posibilitan.

\section{Objetos salvajes para equipar los nuevos paisajes domésticos.}

Una de las estrategias catalogada por Ambasz en "Italia: New Domestic landscapes" entre esos nuevos objetos capaces de generar paisajes domésticos será la relacionada con aquellos capaces de emular situaciones naturales.

"Otros diseñadores buscan no añadir nada más, para no alterar el perfil de nuestro medio ambiente; ellos utilizan en sus diseños las formas de la naturaleza." (Ambasz, 1972, p.94)

Lámparas-nube como "Nuvola" (1966) [1B] de Marcello Pietroantonio y Roberto Lucci, o "Passiflora" (1970) [8A] diseñada por Superstudio, o lámparas-flor como "Dalia" (1968) [4B] de Gino Marota serán algunas de estas perversiones naturales domésticas construidas en materiales plásticos. También formarán parte de la exposición del MOMA los sistemas de suelo "Sedilsasso" (1968) [5A] y "Pavepiuma" (1967) [3C] de Piero Gilardi, reproducciones de cantos gigantes construidas con espuma de poliuretano, convirtiendo las duras rocas en asientos a través de un suelo super-blando y confortable. Esa capacidad de pervertir las propiedades de los elementos naturales originarios hará que las piedras falsas diseñadas por André Cazenave, "Pietre Luminose" (1972) [10E], se conviertan en lámparas de jardín mediante una carcasa translúcida exterior con forma y textura de piedra y una lámpara en el interior.

509 "Other designers seek neither to add anything to, nor to alter, the profile of our environment; they use the device of giving their designs the guises of nature"

AMBASZ, Emilio (editor). Italia: the New Domestic Landscapes. 1972. p.94.

Dichos elementos de mobiliario referenciados por Ambasz se encuentran fotografiados en el mismo catálogo de la exposición:

AMBASZ, Emilio (editor). Italia: the New Domestic Landscapes. 1972. pp.99-101. 
Otra capacidad interesante de transgredir lo natural corresponde a la de las diferentes relaciones de escala existentes entre el elemento original natural y la nueva reproducción artificial. De esta manera, "Il Pratone" (1970) [6C] diseñado por los miembros del grupo Strum $^{510}$, ganadores del premio de diseño "Sintesis Idee'70", simula una serie de hebras de hierba a escala gigante que se convierten en elementos verticales entre los que poder sentarse debido a la flexibilidad de la espuma de poliuretano con la que están construidos, una especie de cambio de escala y material de la "Extensión Verde" (1969) [5D] propuesta por el artista venezolano Soto. Detrás de varias de las reproducciones más irónicas e intencionadamente pop se encuentra la empresa italiana de muebles Gufram, que utilizará esos diseños como seña de identidad ${ }^{511}$. Entre ellos, los citados "Pratone", "Pavepiuma", "Sedilsasso" o el exitoso "Cactus" (1972) [9E] diseñado por Guido Drocco y Franco Mello.

Las metáforas naturales a imitar siguen siendo las mismas que las utilizadas en otras escalas: La nube convertida en estantería gracias al plástico por Cassati, Marota y Ponzio en "Nuvole" (1968) [4A], una topografía reconstruida a través de cojines modulares rellenos de espuma en el sillón [5C] "Waves on the Floor" (1968) de Bernard Govin o incluso nuevos bosques artificiales. El "Bosco artificiale" (1967) [3A] de Gino Marota se diseña como un sistema de compartimentación y estanterías en metacrilato transparente, generando a partir de sus formas arbóreas una especie de ambiente parecido al existente entre las copas de los árboles. "Naturalizando la factoría Cacharel" (1976) [14B], aparece como una serie de mobiliario-árbol que esconde todo el almacenaje de una fábrica de tejidos. La exuberancia llega casi al extremo en ejemplos como la "Cascada Bañera" (1982) [16B] propuesta por Hans Höllein, una bañera-jacuzzi construida en materiales plásticos como si fuese una abrupta roca de acantilado con cascada-ducha incorporada.

El anteriormente citado cambio de escala, opera por lo tanto de manera indistinta a través de procesos que gravitan entre el gigantismo y la miniaturización. "La Cova" (1973) [11B], pieza de mobiliario diseñado por Gianni Ruffi, funciona como un nido gigante en espuma de poliuretano que incluye unos huevos gigantes a modo de cojines y en cuyo diámetro cabe una persona tumbada. De manera análoga, Vito Acconci diseña el sofá "Convertible Clam Shelter" (1990) [16E] como si fuera una almeja gigante. Por el contrario, tanto la lámpara [1E] "Onda" (1966) de Superstudio, como el sillón "Superonda" (1967) [2D] de Archizoom, se construyen a partir de una disminución de escala y geometrización de las que podrían ser una olas marinas en día de marejada. Así mismo, la lámpara-palmera en acero y plástico "Bracciodiferro" (1968) [4C] también diseñada por Archizoom, constituye una reproducción a un tercio de la escala de la palmera original en la que se basaba, de manera parecida a las utilizadas por Höllein en su proyecto para la "Israel Tourist Office" (1977) [14D]. La mesa "Babele" (1969) [6A] de Gianni Pettena, simula una especie de árbol de copa redondeada adaptado a lo que será una mesa con soportes verticales que se despliegan horizontales a distintos niveles. "Safari" (1968) [4E] de Archizoom, ni siquiera buscará ya la reproducción literal al utilizar estampados de leopardo y pequeños maceteros con mini-palmeras de plástico para transportar al usuario a un ambiente africanizado. Lo mismo que el arcoírislámpara diseñado para el conjunto "Letto di sogno" (1967) [2E], destinado a generar una atmósfera de culto a Bob Dylan más que un nuevo paisaje natural artificializado. Esta

510 Formado en esa época por los arquitectos turineses Giorgio Ceretti, Piero DeRossi y Ricardo Rosso.

511 La mayor parte de mobiliario de este tipo de GUFRAM aparece referenciado en la revista Domus, ya sea en la parte comercial de la publicidad, ya dentro de artículos de diseño o como trabajo referenciado de arquitectos o diseñadores. 
componente irónica y de trabajo con lo "kitsch" será también detectada por Ambasz en una serie de objetos catalogados en la exposición del MOMA.

"Otros grupos están más preocupados con la manipulación irónica de los significados socio-culturales vinculados a las formas que en el cambio de las mismas. Ellos diseñan objetos kitsch deliberadamente como forma de meter las narices en objetos creados para satisfacer los deseos de identificación y estatus social del usuario. ${ }^{1512}$ (Ambasz, 1972, p.94)

A pesar del grado de especialización de estas simulaciones artificiales, existirán también propuestas que intentan incorporar directamente elementos propiamente naturales aunque descontextualizados o manipulados a ese paisaje doméstico. El grupo Libidarch propone un mobiliario de paja genérico para el interior de la vivienda media italiana en sus irónicas imágenes de descontextualización de objetos cotidianos convertidos en elementos arquitectónicos denominadas como "Realtá Banale" (1975) [13B]. Alessandro Mendini convertirá estas balas de paja en posible objeto de consumo a través de "Poltrona di Paglia" (1975) [12E]. También "/l Giardino" ${ }^{13}$ [10B], propuesta del grupo florentino 9999514, se configura como un interior doméstico construido a partir de un huerto perimetral y una cama de aire y agua al interior, una especie de vuelta al paraíso transformada en salón de tu propia casa.

Dos proyectos teóricos ejemplifican perfectamente esta capacidad de entender los interiores domésticos como nuevos paisajes salvajes, "No-Stop City" (1970) [6D] diseñada por Archizoom y "Suburban Sets" (1974-1975) [13D] de Ron Herron. La primera mediante un posicionamiento radical de ciudad interior totalmente enterrada en la búsqueda de un nuevo estado de libre intercambio de personas y objetos que termine con la abolición de estos últimos, el segundo como manera de entender el ambiente doméstico como si de un set de cine se tratara, con infinitas opciones de configuración y re-configuración continuas, "un lugar en el que poder rodar una película de amor o de vaqueros" ${ }^{\prime 515}$.

"El mito naturalista de la libre competencia coloca a la ciudad de los intercambios y el comercio para garantizar las condiciones ideales del libre-mercado, antes de darse cuenta del equilibrio natural entre los intereses en conflicto, en el marco general de la realización de la armonía entre la tecnología y la naturaleza." ${ }^{516}$ (Archizoom, 1970, p. 50)

512 "Other groups are more concerned with ironic manipulation of the cultural meanings attached to existing forms, rather than with changing these forms. Specifically, they design deliberaty kitsch objects, as a way of thumbing their noses at objects created to satisfy the desire for social status and identification."

AMBASZ, Emilio (editor). Italia: the New Domestic Landscapes. 1972. p.94.

Dichos elementos de mobiliario referenciados por Ambasz se encuentran fotografiados en el mismo catálogo de la exposición:

AMBASZ, Emilio (editor). Italia: the New Domestic Landscapes. 1972. p.108.

513 Propuesta perteneciente a la exposición "Italia: New Domestic Landscapes" tras ganar el concurso para jóvenes arquitectos italianos convocado en el contexto de la muestra.

Ambasz, Emilio (editor). Italia: the New Domestic Landscapes. 1972. pp.276-281.

514 Compuesto por Giorgio Birelli, Carlo Caldini, Fabrizio Fiumi y Paolo Galli,

515 COOK, Peter. Passi Lunghi, Passi Corti. Archigram projects 1973-1974. En: Casabella, n 398, febrero 1975. pp. 20-31. 
Mientras "No Stop City" reduce el ambiente doméstico a unas plantas homogéneas e infinitas, sólo divididas por pequeños electrodomésticos que equipan el espacio, tiendas de campaña innecesarias debido a la climatización óptima del conjunto y pequeños accidentes naturales artificialmente generados, "Suburban Sets" entiende la fachada del suburbio inglés burgués ${ }^{517}$ como el inicio de un set de cine, manteniendo el estilo victoriano al exterior y personalizando cada uno de los interiores con vegetación, rocallas, artefactos electrónicos variados y generadores espaciales, desde truss con luces hasta decorados o furgonetas equipadas. Se trata de dos ejemplos de paisajes domésticos que sintetizan las estrategias de nueva ocupación del espacio de la vivienda en pos de la flexibilidad espacial y la confianza en el objeto, a través de esos nuevos paisajes domésticos reclamados por Ambasz desde la institución artística.

\section{Animales VS Hombres.}

Las últimas de las metáforas formales utilizadas en el paisaje doméstico serán tanto la figura humana, que también detecta Ambasz para la citada exposición, como la reproducción de animales salvajes ese momento de nostalgia por lo salvaje anteriormente citado.

"Para unos pocos diseñadores, las premisas culturales predominantes hoy en día no tienen validez y pueden proporcionar sólo una falsa base para cualquier investigación formal. Desprovistos de cualquier firme referente, volverán, en un intento de autodesaprobación de lo puro, a la figura humana como fuente de toda verdad formal." (Ambasz, 1972, p.94)

A los ejemplos catalogados por Ambasz, la estantería en metacrilato transparente en forma de torso "Venere 70" (1970) de Alfredo Pizzo Greco, y el sillón con formas voluptuosas de mujer "UP5 Donna" (1969), diseñado por Gaetano Pesce, se le sumarán otros diseños posteriores del mismo Pesce basados en la forma de la mano humana, como la lámpara en forma de mano que sujeta una esfera luminosa "Pugno all'architettura" (1975) [15B] o el sillón mano cerrada "Il Pugno" (1978). Más allá de estas piezas basadas en partes, el cuerpo humano entero será también utilizado de distintas maneras, a partir de su silueta sentada, para conformar un perfil monocromo usado como plano de asiento en "Bouloums" (1970) [7D], una propuesta de mobiliario para el pabellón francés de Osaka'70 por parte de Olivier Morgue, o reproduciendo a todo color la propia imagen del diseñador para la "Silla

516 "Il mito naturalistico della libera concorrenza poneva la città degli scambi e del comercio a garantiré le condizioni ideale del mercato, realizando l'equilibrio naturali tra gli opposti interessi, nel quadro generale della raggiunta armonia tra tecnica e natura"

ARCHIZOOM. No Stop City. Residential Parkings. Climatic Universal System. En: Domus, n496, marzo 1971. pp.49-55.

517 En 1975 , una propuesta similar para la residencia de la Reina de Inglaterra "Sets fit for the Queen" ganó el $2^{\circ}$ premio del concurso de vivienda Shinkenchiku de ese año, que tenía por tema "casa para una Superestrella". El escenario generado para ellos se combina con una serie de elementos de habitabilidad (generadores de espacios, electrodomésticos robot...) enmascarados en los distintos Sets pertenecientes a la familia real: el público, el ceremonial, el oficial, el familiar y el privado.

518 "For a few designers, the cultural premises predominant today have no validity and can therefore provide only a false basis for any formal inquiry. Devoid of any firm referents, they return, in a somewhat self-deprecatory attempt at purification, to the human figure as the source of all formal truth"

AMBASZ, Emilio (editor). Italia: the New Domestic Landscapes. p.94. 
Persona ${ }^{519 "}$ (1967) [3E] de Roger Tallon. Helmuth Wielh utilizará también la figura humana para generar una silla a través de las articulaciones de sus brazos y sus piernas al plegarse en "Karl" (1971) [8D], mientras Allen Jones hace lo propio con maniquíes de mujeres en diferentes posiciones para soportar mesas de cristal en la serie de mobiliario "Ladies" (1970) [7C]. Alessandro Mendini diseñará "Tavolino di Saloto" (1975) [13C] en metacrilato transparente y forma de ataúd y lo presentará comercialmente con un cuerpo desnudo de mujer en su interior.

De la misma manera figurativa, los animales también aparecen en ridículas propuestas como "Rana Bañera" (1974) [12D] de Michel Verdier, los animales fuera de escala de Les Lannanes utilizados en su propia vivienda o propuestas más sofisticadas de interiorismo como la utilizada por los japoneses Studio Sakaizawa en "Out Back Coffee Shop" [11D] y "Saxon Restaurant" (1973) [11E]. En ambos diseños se utilizan distintas especies de pájaros en relación a cada uno de los diferentes ambientes, cuervos negros en un ambiente más gris y sobrio para el coffee shop de ambiente nocturno o loros y guacamayos para el restaurante más luminoso y colorido. Propuestas como "Bestial Furniture" (1983) [16C] de Paolo Belluso y Flavio Merkel, retoman la tradición histórica de utilizar partes de animales para generar diversos elementos en piezas de mobiliario, de nuevo una estrategia que parece agotada con las interesantes piezas elaboradas entre otros por Piranesi con algunos siglos de anterioridad. 


\section{Capítulo 6. HACIA UNA ARQUITECTURA VIRTUAL.}

Un concepto fuertemente asociado a todas las predicciones, aunque desde aproximaciones distintas, será el diseño de "ambientes" o "environments" como alternativa de futuro frente a la obsoleta construcción de "espacios". Esos nuevos ambientes tienen la capacidad de distorsionar, simular o transgredir los valores físicos visuales tradicionales de la arquitectura a partir de estrategias supeditadas a los nuevos avances tecnológicos de control perceptivo, anticipando lo que denominaremos como "arquitectura virtual".

Una primera aproximación a esa arquitectura virtual se produce a través de la generación de climas artificiales. Para Michel Ragon, en "¿Dónde viviremos mañana?" (1963) o "Las Ciudades del Futuro" (1966), la única solución urbana pasa por la idea de climatizar grandes porciones del planeta a la manera de Buckminster Fuller, Yona Friedman o Frei Otto, o la colonización de nuevos lugares, ya sean los océanos o nuevos planetas. Por su parte, John McHale trabaja en torno al concepto de una ecología global, un nuevo mundo interconectado a partir del concepto de "Aldea Global" de McLuhan, y supeditado a los avances derivados de la carrera espacial y la exploración submarina para un mejor aprovechamiento de los recursos y una autosuficiencia climática.

Esas distorsiones perceptivas experimentadas en los nuevos "environments" son a las que Peter Cook se refiere al afirmar que "el futuro de la arquitectura se encuentra en el cerebro" 520 . Visiones, simulaciones, estimulantes, simbiosis, palacios de la diversión o proyecciones son los términos que Cook utiliza para ir definiendo los caminos hacía esa nueva arquitectura que "engaña" y reside en el cerebro, que supone el capítulo final de su predicción "Experimental Architecture". De manera similar, Jim Burns en su predicción "Arthropods" (1972) despliega una amplia serie de proyectos de arquitectura virtual. Todas esas experimentaciones en torno a la generación de "ambientes perceptivos" o "arquitectura virtual" se ordenarán a partir de tres estrategias fundamentales:

- [Climas artificiales], el control climático como herramienta para una desaparición de la arquitectura.

- [Distorsionadores autónomos de la percepción] o "todo es arquitectura".

- [Simulaciones espaciales], experimentos en torno a la generación de ambientes temporales.

520 "The future of architecture lies in the brain"

Cook, Peter. Experimental Architecture. 1970. p.133. 


\section{Catálogo // [Climas artificiales]}

Las imágenes están referenciadas por números en la zona superior de las columnas verticales [del 1 al 10] y letras en la zona izquierda de las filas horizontales [de la A a la E].

Todas las referencias están ordenadas cronológicamente.

Referencias de imágenes del [1B] a [10D]. Cada uno de los proyectos referenciados gráficamente en el catálogo presentan antes de su nombre un código con un número en relación a su columna vertical y una letra en relación a su fila horizontal.

\section{Ejemplo:}

[7E] "Cloud 9" (1962) de Buckminster Fuller. Buscar referencia en la columna 7 y la fila E del catálogo referenciado al principio del capítulo.

[Nota]: no todos los referentes gráfico del catálogo están referenciados en el texto por lo que se recomienda una lectura del mismo antes de comenzar la del propio texto.
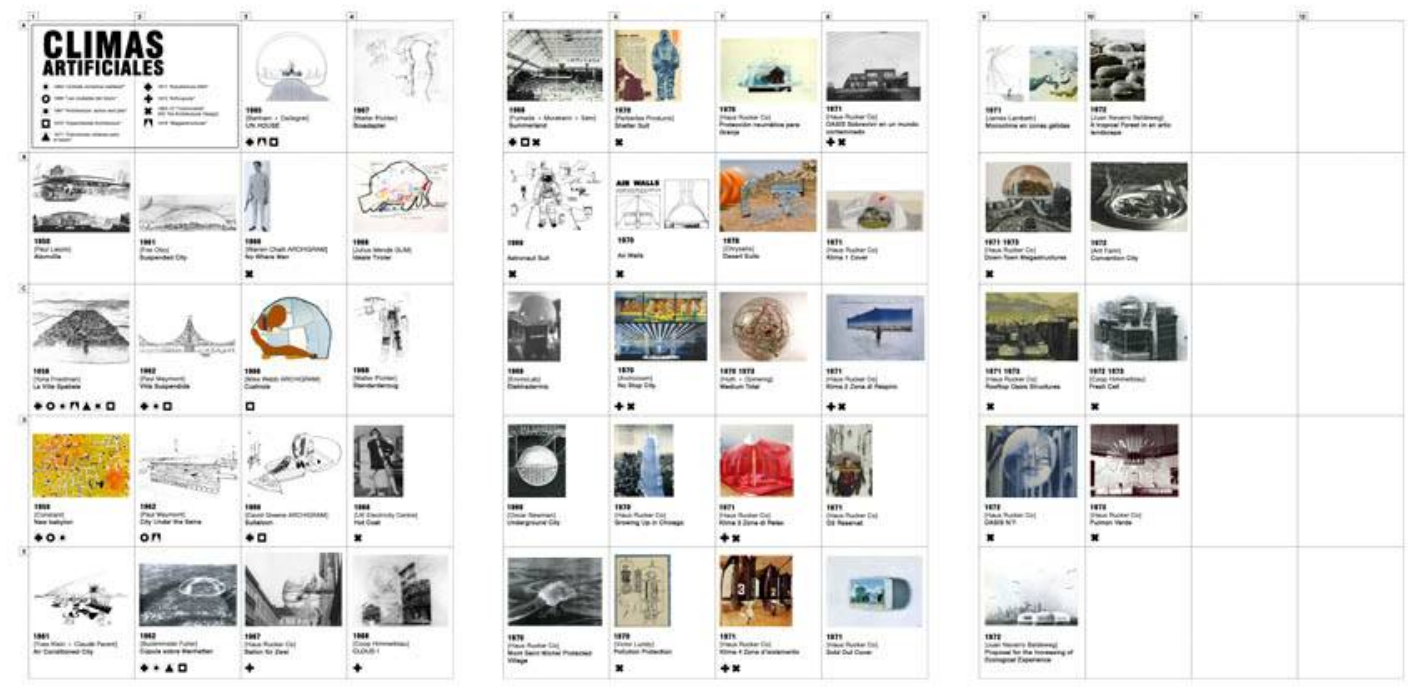


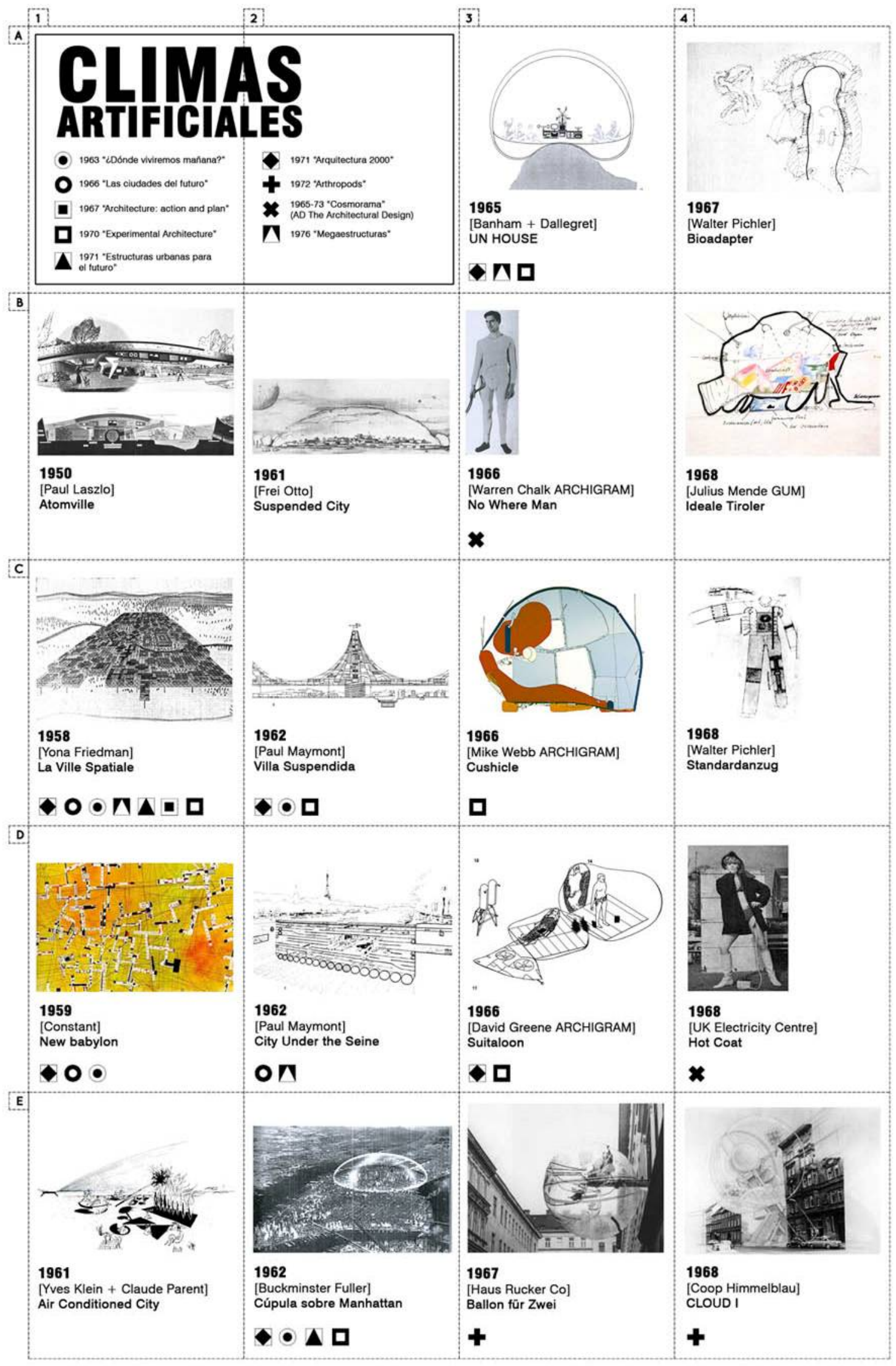




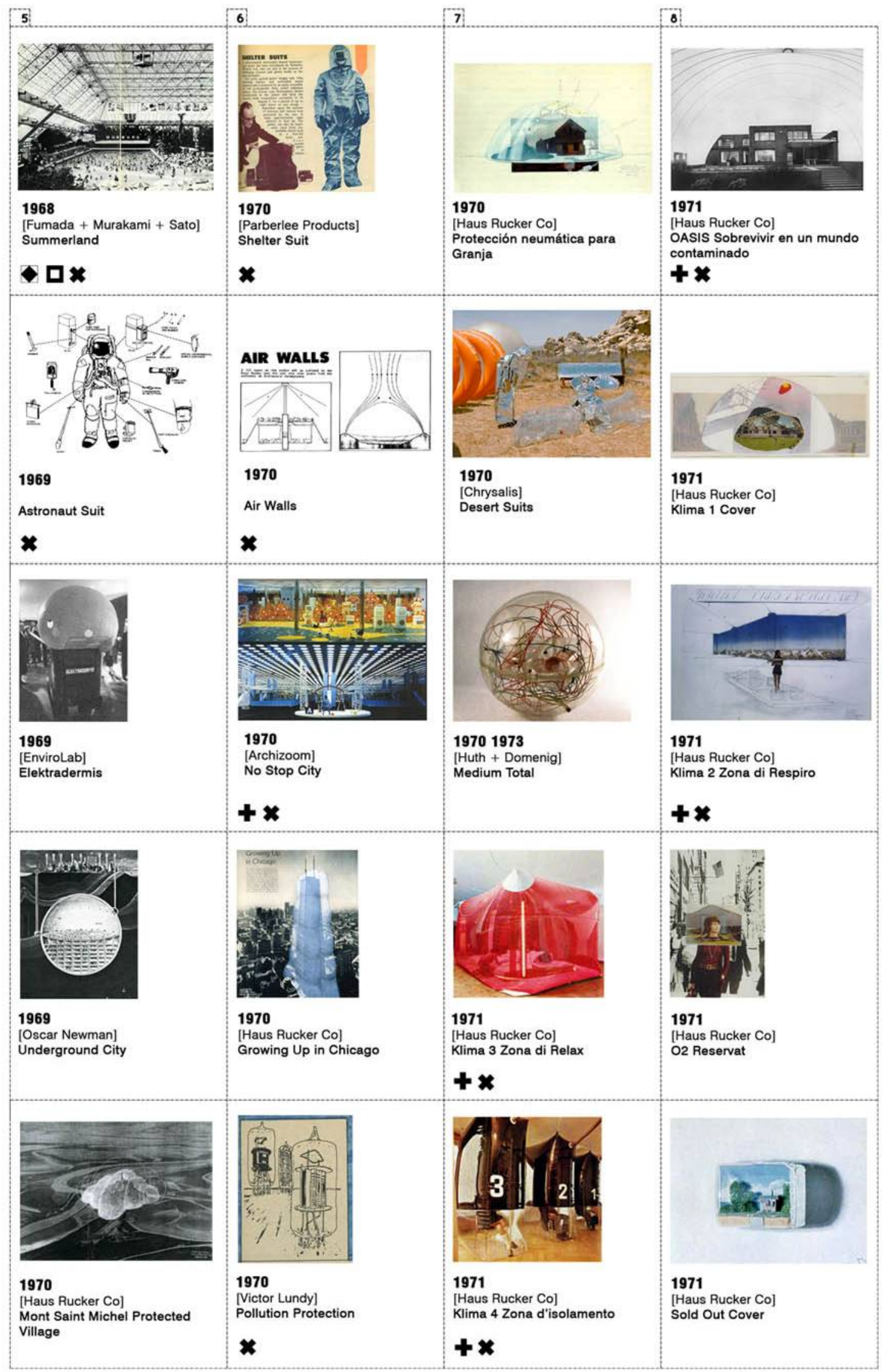




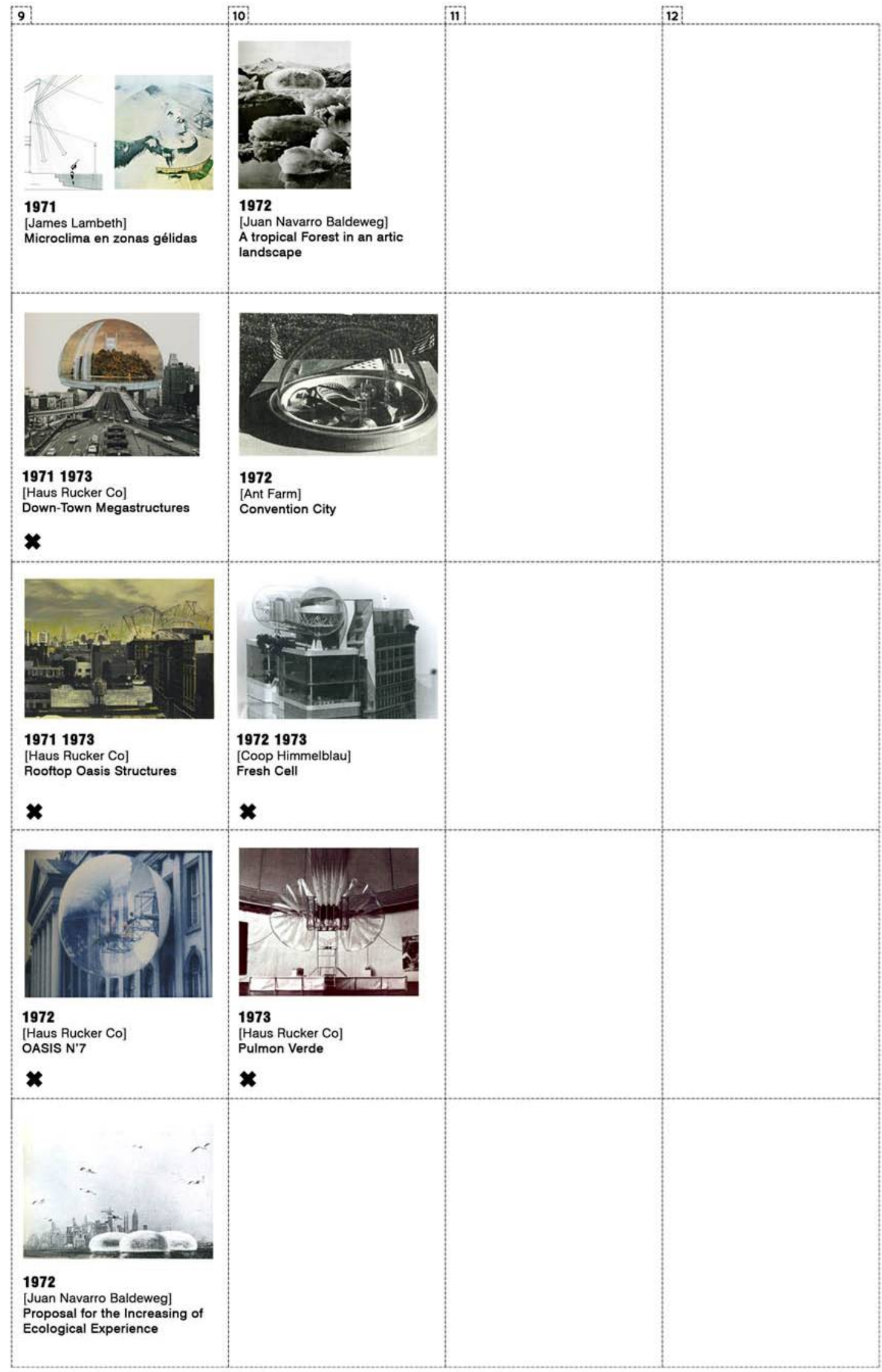




\section{[Climas artificiales] Estrategias de control climático.}

A principios del siglo XIX, la búsqueda desarrollada desde ámbitos en principio ajenos a la arquitectura en torno a la generación de climas artificiales se encuentra estrechamente emparentada con la evolución de una tipología arquitectónica concreta como es el invernadero y el desarrollo de un material como el vidrio. Estas experimentaciones van desde los prototipos realizados por el jardinero John Claudius Loudon en 1817 en su finca de Bayswater hasta la consolidación de este tipo de edificaciones como modelo institucionalizado e icono de la industrialización a través del Crystal Palace, concebido por el también jardinero Joseph Paxton para albergar la Exposición Universal de 1851 en Londres ${ }^{521}$.

Casi setenta años después, en 1919, Bruno Taut imagina esa arquitectura de vidrio como una gran cúpula climática en su propuesta utópica "Alpine Architektur". Sin embargo, no será hasta la aparición en 1927 del prototipo de Buckminster Fuller para su "Dymaxion House", en el que la mecanización climática y por lo tanto su control y posterior simulación, Ileguen a considerarse como alternativas de un futuro próximo en el ámbito arquitectónico. Reyner Banham explica en "The Architecture of the Well-tempered Environment"522 cómo ese modelo de núcleo central de la "Dymaxion House" fulleriana tiene sus precedentes en ejemplos de arquitectura popular norteamericana como la "American Woman's Home", proyectada en 1869 por Catherine Beecher. En la que se compila todo el núcleo de instalaciones de la vivienda bajo una apariencia de vivienda convencional victoriana. Los siguientes prototipos de Fuller, como la "Wichita House" (1944), incidirán en esa compactación de la maquinaria de la vivienda en un núcleo central para conseguir su autonomía frente al cerramiento, modelo ambiental que se radicalizará en su propuesta posterior "Skybreak Dwelling" de 1949. Este último proyecto consigue aunar las experimentaciones de empaquetamiento de todo el mobiliario de una vivienda propuestas en "Autonomous Package" (1949) y el desarrollo de diversas técnicas de construcción asociadas a la geometría geodésica. Fuller propone así una desconexión total entre el cerramiento, esa cúpula que le otorga un clima totalmente controlado, y el sistema de mobiliario de la misma, que se despliega desde un paquete de transporte al antojo del usuario.

Uno de los acontecimientos históricos que también acelera la experimentación arquitectónica en relación a los climas controlados será la explosión de la bomba atómica durante la II Guerra Mundial| ${ }^{523}$. En relación directa a este evento aparecen propuestas como "Atomville" [1B], un modelo de ciudad diseñado en 1950 por Paul Laszlo, en el que unas viviendas subterráneas dependientes de un sistema general de instalaciones de climatización se presentan como solución para un posible futuro distópico consistente en 521 Efrén García Grinda y Cristina Díaz Moreno inician con ellos sus “Formas del aire 1.0” para la generación de una
Arquitectura Respirable:

DÍAZ MORENO, Cristina; GARCÍA GRINDA, Efrén. Formas del aire 1.0+Arquitectura respirable. En: Obradoiro n³2, Revista do Colexio Oficial de Arquitectos de Galicia, Cuaderno 01, 2004. pp.10-40.

DÍAZ MORENO, Cristina; GARCÍA GRINDA, Efrén. Arquitectura Respirable. Genealogía. En: Breathable. Universidad Europea de Madrid. Madrid, 2009. pp.58-80.

522 BANHAM, Reyner. The Architecture of the Well-tempered Environment. The Architectural Press Ltd. Londres, 1969.

523 VIDLER, Anthony. Air War and Architecture. En: HELL, Julia; SCHÖNLE, Andreas. Ruins of Modernity. Duke university Press. Durham, 2010. pp.29-40. 
millones de hogares norteamericanos que adoran y recelan a la vez de la tecnología atómica, como muestra el artículo de la revista "Popular Science" de octubre de 1954:

"Para algunos, la perfección de la bomba de hidrógeno ha significado una profunda ansiedad, para otros, se cumple la promesa de paz permanente. Laszlo mira más allá de los dos y lo ve como el comienzo de un período de progreso sin precedentes de los cuales tiene que venir una nueva forma de vida." ${ }^{.524}$ (Kerr, 1954, p.156)

"Cuando el dominio del hombre sobre el átomo mantenga la vida, las innovaciones se pondrán tan de manifiesto que la casa Dymaxion de Fuller y su cúpula geodésica parecerán pasadas de moda. Cuando digo que la familia del futuro vivirá bajo tierra, me consideran como un pesimista. Digamos que espero lo mejor, pero queremos estar preparados para lo peor. ${ }^{.1525}$ (Laszlo, 1954, p.156)

\section{De la búsqueda de un clima global a la desaparición de la arquitectura.}

Los modelos "Skybreak" de Fuller y "Atomville" de Laszlo, proponen un control climático terrestre o subterráneo que abandona el carácter individual del ambiente doméstico derivado de su nacimiento para adaptarse a la escala "ciudad", construyendo así una serie de modelos urbanos encaminados a una climatización global. Ya en 1958, la "Ville Spatiale" [1C] diseñada por Yona Friedman se presenta como una gran cobertura climatizada que propicia una movilidad entendida como flexibilidad ante el cambio como principal valor demandado por la nueva sociedad emergente. Dicha estructura homogénea es capaz de renovar ciudades ya consolidadas como París o Nueva York, o disponerse sobre nuevos territorios, como en la propuesta de puente sobre el canal de La Mancha de 1964. Friedman con "Ville Spatiale" y Constant Nieuwenhuys con "New Babylon" (1959-1974) [1D] se convierten en los primeros megaestructuralistas ${ }^{526}$ en involucrar el concepto de "Homo Ludens" de Huinzinga, partiendo de la necesidad de una ciudad en la que el ocio sea uno de los componentes principales de la vida urbana. Un ocio que, contradictoriamente, representa por un lado uno de los grandes peligros para el futuro, así lo auguran pronosticadores como Dennis Gabor, y por otro lado se contempla como el principal motor de cambio de las tipologías urbanas desde el punto de vista de futurólogos como Michel Ragon ${ }^{527}$.

\footnotetext{
524 "To some, perfection of the hydrogen bomb has meant profound anxiety; for others, it holds the promise of permanent peace. Laszlo looks beyond both and sees it as the beginning of a period of unprecedented progress out of which must come a new way of life"
}

KERR, Carson. At Home, 2004 A.D. En: Popular Science, octubre 1954. p.156.

525 "When man's mastery of the atom will maintain life. Innovations will become apparent that will make Bucky Fuller's Dymaxion house and his geodesic dome appear old-fashioned. When I say that the family of the future will go underground, I'm immediately categorized as a political pessimist. Let us say I hope for the best, but would want to be prepared for the worst"

KERR, Carson. At Home, 2004 A.D. En: Popular Science, octubre 1954. p.156.

526 BANHAM, Reyner. Megaestructuras. 1978 (1976). p.60.

527 Ragon dedica un capítulo al tema del ocio en "¿Dónde Viviremos mañana?" (1963), "IX. Civilización del ocio y espectáculos del porvenir", y hasta tres capítulos en "Las Ciudades del Futuro" (1966), Primera Parte, "Capítulo 6. La revolución del ocio se halla en curso" y Segunda Parte, "Capítulo 8. La revolución por el ocio". 
"Los pisos se dividirán en diferentes áreas vecinas comunicadas, artificialmente acondicionadas, que proporcionarán la capacidad de crear una infinita variedad de entornos, facilitando a sus habitantes la deriva y sus frecuentes encuentros fortuitos. ${ }^{.1528}$ (Constant, 1959, p.129)

Esa capacidad de diferenciación de espacios con simples cambios de acondicionamiento ambiental tiene como precedente construido la "Maison a cloisons invisibles" diseñada por Nicolas Schöffer para el "Salon des Travaux Publics" celebrado en París en 1955. Dicha vivienda, patrocinada por marcas como Philips Electronics y Saint-Gobain, propone una planta en forma de cerradura en la que la diferenciación espacial se realiza solamente a partir de diferencias de temperatura, entre zonas frías y calientes, y variaciones lumínicas, con gamas de azules y rojos. Una radicalización de esa experiencia será propuesta por el artista Yves Klein y el arquitecto Werner Ruhnau, con dibujos de Claude Parent, en "Air Conditioned City (1958)" [1E]. En este proyecto teórico, este equipo multidisciplinar propone la climatización de grandes extensiones geográficas a través de techos y corrientes de aire inducidas técnicamente, que sirven no sólo de protección frente a las inclemencias del tiempo sino como elementos generadores de ambientes habitables al relacionarse con otros sistemas como fuentes, cortinas y nubes de vapor coloreado o paredes de agua y fuego. Todos estos sistemas serán desarrollados y ampliados entre 1958 y 1962 por Klein y Ruhnau, formando parte de la "Architecture de L'Air".

"Este aire acondicionado se conseguirá no tanto a través de milagros tecnológicos, sino fundamentalmente a partir de una transformación de la sensibilidad humana en función del cosmos. La teoría de la inmaterialización niega el espíritu de la ciencia ficción.

A través de la evolución de la sensibilidad, una nueva dimensión se transformará en el futuro, guiada por el espíritu, el clima y las condiciones espirituales en la superficie de nuestro planeta. ${ }^{1529}$ (Klein; Ruhnau, 1960, p.171)

Esta condición de inmaterialidad propuesta por Klein y Ruhnau se relaciona con la demandada por Buckminster Fuller para su propuesta "Dome over Manhattan" de 1962 [2E] o por Frei Otto en "Essai d'une visión d'avenir" de 1961 [2B]. Ambos proyectos presentan también grandes superficies climatizadas a partir de membranas pretendidamente inmateriales, una cúpula geodésica de 3,5km sobre un gran área de Manhattan como forma más efectiva de generar un gran volumen interior climatizado en el caso de Fuller y una mezcla de cubiertas textiles y neumáticas en los esbozos de Otto. Sin embargo mientras

528 "Les diférents étages seront divisés en des espaces voisinants et communiquants, artificiellement conditionnés, qui offriront la possibilité de créer une variation infinie d'ambiances, facilitant la dérive des habitants et leurs fréquentes rencontres fortuites"

NIEUWENHUYS, Constant. Une autre ville pour une autre vie. En: IS, n³, déc, 1959, en: ROUILLARD, Dominique. Superarchitecture. Le Futur de l'architecture 1950-1970. Éditions de la Villette. Paris, 2004. p.129.

529 "This air-conditioning will be achieved not so much through technological miracles as essentially through a transformation of human sensibility into a function of the cosmos. The theory of immaterialization negates the spirit of fictitious science.

Through evolved sensibility, a new dimension guided by the spirit, the climate and the spiritual conditions on the surfaces of our earth will in future be transformed"

KLEIN, Yves; RUHNAU, Werner. Project for an aerial architecture. en: CONRADS, Ulrich. Programs and Manifestoes on 20thCentury Architecture. Lund Humphries. Londres, 1970 (1964). p.171. 
Otto aboga por la colonización de climas hostiles, en una especie de tecno-utopía ecológica que derivará en multitud de proyectos de ciudades en la Antártida o el desierto, la radicalidad de Buckminster Fuller consiste en la superposición de un clima controlado a la ciudad arquitectónica por excelencia como es Nueva York. Su gran membrana de cubrición, a parte de una búsqueda de un confort climático, también supone una de las ideas desarrolladas posteriormente por grupos radicales italianos: la desaparición de la arquitectura auspiciada por un clima global totalmente configurable.

"El clima artificial que hemos generado es demasiado uniforme y falto de incentivos. Ahora vamos a ser capaces de modificarlo para que la atmósfera generada dentro de nuestros ambientes sea verdaderamente saludable y sostenible." p.90)

"Con un terreno completamente cerrado por una cúpula, la eliminación de la lluvia, el viento, la nieve y los insectos, supondrá que las mismas viviendas serán también eliminadas." ${ }^{.531}$ (Fuller, 1949 (1973), p.194)

Ambos proyectos, derivados del desarrollo de las estructuras neumáticas y textiles, se posicionarán como modelos teóricos a gran escala y empezarán a tener un fuerte desarrollo desde mediados de los años cincuenta auspiciados por la explosión en el mercado de los materiales plásticos. De igual manera, los manuales escritos sobre estos materiales por Arthur Quarmby ${ }^{532}$ en 1974, sobre las estructuras neumáticas por Thomas Herzog ${ }^{533}$ en 1976 y las textiles por Frei Otto ${ }^{534}$ en 1973, servirán como excelentes difusores. Ambos modelos son a la vez un precedente de propuestas utópicas en torno a esa idea de una búsqueda de grandes zonas de terrenos climatizadas. Aparecen dos vertientes principales de experimentación, por un lado, los proyectos derivados de la propuesta de Otto como prototipo de ciudad suspendida, con ejemplos posteriores como la "Villa Suspendida" (1962) [2C] de Paul Maymont y por el otro, los que parten de la cúpula geodésica o neumática como paradigma de una climatización total, y desarrollada a partir de dos modelos operacionales: la cúpula como membrana protectora de lo existente ante un futuro de contaminación extrema o como generadora de "nuevos lugares", exuberantes oasis a medio camino entre el invernadero y el parque zoológico.

La desaparición de la vivienda propuesta por Fuller será el punto de partida de proyectos como "No-Stop City" (1970) [6C] de Archizoom, que aparecerá incluso publicada con los

530 "Jusqu'à présent, le climat artificiel que nous créons est trop uniforme et manque de stimulant. Par la suite, nous serons à même de le modifier de telle sorte que l'ambiance à l'intérieur de nos enveloppes sera véritablement saine et viable"

OTTO, Frei. Essai d'une vision d'avenir. En: AA L'Architecture d'Aujourd'Hui, nº102, Architectures Fantastiques, junio-julio 1962. pp.89-93.

531 FULLER, R. Buckminster; MARKS, Robert. The Dymaxion World of Buckminster Fuller (1960). Anchor Press. Nueva York, 1973. p.194.

532 QUARMBY, Arthur. Materiales plásticos y arquitectura experimental. Gustavo Gili. Barcelona, 1976. Ed. original: The Plastics architect. Pall Mall Press. Londres, 1974.

533 HERZOG, Thomas. Pneumatic Structures. A Handbook of Inflatable Architecture. Oxford University Press. Nueva York, 1976.

534 OTTO, Frei; TROSTEL, Rudolf; SCHLEYER, Friedrich K. Tensile structures; design, structure, and calculation of buildings of cables, nets, and membranes. MIT Press. Cambridge. 1973. 
sobrenombres "Climatic Universal System"535, un "sistema de climatización universal", o "Residential Parkings", "parkings residenciales". Esta propuesta de Archizoom aprovecha por un lado el modelo de ciudad subterránea propuesto por Maymont en "City under the Seine" (1962) [2D], y por otro la capacidad tecnológica de climatización demostrada en la construcción de los grandes supermercados norteamericanos, diseñados por arquitectos como Victor Gruen desde medidos de los años cincuenta ${ }^{536}$ y popularizados mediante su difusión en revistas como la norteamericana "Progressive Architecture"1537. Los miembros de Archizoom diseñan una ciudad interior con niveles diferenciados, de grandes volúmenes públicos decorados con jardines artificiales semejantes a los existentes en las grandes avenidas de esos centros comerciales, zonas de ocio como cines y teatros y áreas residenciales con su propio aparcamiento. La propuesta sin embargo elude la diferenciación volumétrica para jerarquizar toda la ciudad soterrada a partir de niveles con secciones indiferenciadas pero con plantas heterogéneas que van adecuando sus tramas a los diferentes usos. Para Archizoom, "esta nueva ciudad rendida al capital debe corresponderse a una cadena de montaje climatizada y por lo tanto habitable"1538. Las viviendas se reducen a núcleos básicos de instalaciones dispuestos como estanterías de un supermercado y la climatización, entendida como recurso básico de inducción al consumo, se convierte así en cómplice de esa desaparición de la arquitectura:

"El mito de la competencia natural lleva a la ciudad de los intercambios y el comercio a garantizar las condiciones óptimas del mercado, antes de realizar el equilibrio natural entre los intereses en conflicto en el marco general de armonía entre la naturaleza y la técnica.

Hoy en día el uso de medios electrónicos reemplaza la práctica directa urbana: el consumo inducido artificialmente permite una penetración más profunda en la realidad social que los canales de información frágiles de la ciudad.

La metrópolis deja de ser un lugar para convertirse en una condición, es un hecho proprio que esta condición se distribuye uniformemente en el fenómeno de lo social a través del Consumo.

El tamaño futuro de la Metrópoli coincide con la del Mercado."1539 (Archizoom, 1971, p.50)

535 ARCHIZOOM. No-Stop City. Residential Parkings. Climatic Universal System. En: Domus, nº496, marzo 1971. pp.49-55.

Anteriormente había sido publicada con menos exhaustividad en la revista Casabella pero todavía sin la acepción de "NoStop City" sino como "Città, Catena di Montaggio del Sociale", "Ciudad, Cadena de Montaje de lo Social".

ARCHIZOOM. Città, Catena di Montaggio del Sociale. En: Casabella, n³50-351, julio - agosto 1970. pp.43-52.

536 GRUEN, Victor. Two Gruen Shopping Centers. Valley Fair and Bay Fair. En: PA Progressive Architecture, octubre 1968. pp.136-145.

537 Ver:

HARDWICK, M.Jeffrey. Mall Maker. Victor Gruen. Architect of an American Dream. University of Pennsylvania Press. Philadelphia, 2004

538 Es también innegable el paralelismo entre la propuesta y las secciones de las trincheras excavadas por el $126^{\circ}$ regimiento de Infantería Inglés en la I Guerra Mundial. Referencio aquí un artículo con dichas imágenes sobre la "Arquitectura de la Agresión":

Architecture of Agression. En: Casabella, n³94, octubre 1974. pp.26-29.

MALLORY, Keith; OTTAR, Arvid. The Architecture of War. Phanteon Books. Nueva York, 1973. 


\title{
Oasis urbanos, o cómo sobrevivir en un mundo contaminado.
}

"Sobrevivir en un mundo contaminado" será el sobrenombre de la exposición "Cover", en la que Haus Rucker-Co expondrá una gran parte de sus proyectos climáticos. Del 28 de febrero al 15 de abril de 1971 el grupo austríaco convierte el Museo Haus Lange de Krefeld, situado en la casa para Herman Lange (1928) de Mies Van der Rohe, en una utopía climática, aislando el edificio del exterior a través de una cúpula neumática con planta en forma de corazón.

\begin{abstract}
"Las ciudades están enterradas bajo una capa de smog. Con el polvo que respiramos llenaríamos un camión. Las calles son cámaras de gas. Los ríos, brebajes venenosos. El sol, una bombilla de 40 vatios. Las montañas de desechos se tragan la hierba y los árboles. No es ciencia ficción, ésta es la condición del Planeta Tierra." ${ }^{1540}$ (Haus Rucker-Co, 1971, p.44)
\end{abstract}

De la misma manera que para Laszlo, el peligro de un ambiente atómico se convierte en el leitmotiv principal de "Atomville", la contaminación lo será para gran parte del trabajo de Haus Rucker-Co. Basándose en la idea de una membrana invisible, hecha posible gracias al desarrollo de las estructuras neumáticas, el grupo producirá una serie de visiones distópicas en las que protegen climáticamente monumentos como "Mont Saint Michel. Protected Village" [5E], o rascacielos como el John Hancock de Chicago. Esa idea de protección frente a un mundo contaminado genera a su vez todo de tipo de proyectos a diversas escalas. Aparecen así otros proyectos encaminados a proteger edificios existentes como "Pollution Protected" (1970) [6E] de Theodore Lundy, profesor de la Universidad de Kansas, llegándose incluso al diseño de un "Medium Total" [7C], proyecto desarrollado de 1970 a 1973 por Huth y Domenig para la generación de un ambiente global de intercambio biológico, de nuevo una reducción de la arquitectura y del hombre al simple control e intercambio de sus flujos y constantes vitales con la naturaleza.

"Medium Total desarrolla un organismo para proteger contra la contaminación el espacio completo y su expansión en las zonas de condiciones ambientales extremas, el alargamiento de un proceso de pensamiento a archivo..." ${ }^{541}$ (Huth; Domenig, 1970 (2003), p.65)

539 "Il mito naturalistico della libera concorrenza poneva la città degli scambi e del comercio a garantiré le condizioni ideale del mercato, realizando l'equilibrio naturale tra gli opposti interessi, nel quadro generale della raggiunta armonía tra técnica e natura.

Oggi l'uso dei médium elettronici sostituisce la prassi urbana diretta: l'induzione artificiale al consumo permette una ben più profonda infiltrazione nella realtà sociale che non i fragili canalí di informazione della città.

La metrópoli cessa di essere un luogo per divenire una condizione; è propio tale condizione infatti che viene fatta circolare in maniera omogenea nel fenómeno sociale attraverso i Consumi.

La dimensione futura della Metropoli coincide con quella del Mercato stesso"

ARCHIZOOM. No-Stop City. Residential Parkings. Climatic Universal System. En: Domus, nº496, marzo 1971. p.50..

540 "Le città sono sepolte sotto una coltre di smog. Con la polvere che respiriamo possiamo riempire dei camión. Le strade sono camere a gas. I fiumi, decotti velenosi. Il sole, una lampadina da 40 watts. Montagne di rifuti ingoiano erba e alberi. Non è fantascienza, questa è la condizione del pianeta terra"

HAUS RUCKER CO. Aria, Aria. En: Domus, n499, junio 1971. pp.44-46.

541 "Medium Total est le développement d'un organism protecteur contre la contamination de l'ensemble de l'espace vital et l'expansion dans des zones de conditions environnementales extrèmes, par le longement d'un processus de pensé jusqu'au limès..." 
El mismo carácter reductivo aparece en la última propuesta climática de Haus Rucker-Co, "Grüne Lunge (1973)" [10D], un pulmón verde artificial para poder respirar "el verde" en ambientes urbanos. Ante ese futuro distópico de contaminación ambiental, la única oportunidad de respirar el aire de la antigua naturaleza será a través de estos generadores de aire respirable proveniente del desaparecido ambiente natural, en un acto de nostalgia de un pasado verde mejor de la humanidad. De nuevo un acto de objetualización de las zonas verdes urbanas, transformadas en un simple artefacto simulador de una naturaleza artificial, en la que el clima ya no sólo se reduce a una serie de temperaturas óptimas sino que se convierte en un tratamiento específico de las condiciones del aire que va a ser respirado por los usuarios.

\begin{abstract}
"Nuestro pulmón verde es un órgano de respiración artificial para las personas que viven en las ciudades. El aire producido es filtrado y purificado, enriquecido con esencias aromáticas artificiales, lleno de una ilusión de verde fresco. Se respira naturaleza sintética. ${ }^{.542}$ (Haus Rucker-Co, 1974, p.9)
\end{abstract}

Ese "Pulmón Verde" ya no parte como propuesta de clima global o protección frente a la contaminación, sino de preservación de unos condicionantes atmosféricos concretos que se relacionan con la idea de un oasis, entendido como zona con una serie de características naturales privilegiadas frente a un entorno climáticamente hostil. El oasis por lo tanto no supone ya una ayuda climática que posibilita una situación de confort determinada sino la simulación de un ambiente concreto. Ese mismo concepto de simulación climática había ya sido experimentado en 1971 por Haus Rucker-Co en el interior de la exposición "Cover" [8A]. En ella, "Klima $n^{\circ} 1$ " [8B] se convertía en esa membrana que protegía el museo. "Klima $n^{\circ} 2$ " [8C] correspondía a una zona de respiración mediante la reproducción del aire limpio de la montaña. "Klima $n^{\circ} 3^{\prime}$ [7D] suponía un ambiente apropiado para una zona de relax total. "Klima $n^{\circ} 4$ " [7E], se construía como un entorno individualizado que permitía ser regulado a voluntad del usuario. Incluso el suvenir de la exposición "Sold Out" [8E], simulaba uno de esos paisajes contenidos en tarros de cristal que se regalan por navidades, un objeto-crítica de una naturaleza que ya nunca volverá a ser la misma.

El centro de ocio acuático "Summerland" [5A], diseñado en 1968 por los arquitectos japoneses Minoru Murakawi, Kinji Fumada y Toshio Sato, supondrá el gran referente construido en cuanto a oasis artificiales se refiere. "Summerland" se construye a partir de una gran estructura tubular de 162x81 metros como hiper-contenedor de un ambiente tropical, una piscina de olas generadas mecánicamente o un canal de remo con viento artificial. La gran difusión del proyecto en medios, tanto en revistas de arquitectura ${ }^{543}$ como de diseño ${ }^{544}$, convertirá a ese centro de entretenimiento japonés en referente climático de varias de las predicciones antes citadas, en especial las de Charles Jencks ${ }^{545}$ y Peter

FRAC CENTRE (editor). Architectures expérimentales 1950-2000. Collection du FRAC Centre. Editions HYX. Orleans, 2003, p. 65.

542 "Il nostro polmone verde è un órgano respiratorio artificiale per la gente che vive in città. L'aria che produce è filtrata e depurata, arricchita di essenze aromatiche artificiali, caricata di illusione di verde fresco. Si respira natura sintetica"

HAUS RUCKER CO. Ecoutopia. Grüne Lunge. En: Domus, n537, agosto 1974. p.9.

543 Summerland. En: AD The Architectural Design, julio 1968. pp.318-321.

544 HUGHES-STANTON, Corin. Closed environment for living space. En: Design, n²41, enero 1969. pp.40-49. 
$\mathrm{Cook}^{546}$. Esa idea de un oasis artificial sugiere la capacidad de recreación de "ecosistemas" concretos, amplificando el concepto de jardín botánico, como sucede en la propuesta de Juan Navarro Baldeweg "Proposal for the Increasing of Ecological Experience" de 1972 [9E], o posibilitando la idea de contextos extremamente diferenciados, como en "A tropical Forest in an artic landscape" [10A], en el que la capacidad de simulación llega al extremo de superponer un bosque tropical en medio de un paisaje ártico. La recreación de estos ecosistemas, como sugiere el artista húngaro-americano György Kepes, tutor de Navarro Baldeweg en estos trabajos, adquiere así una capacidad de concienciación y experimentación por parte de los ciudadanos sobre el concepto de ecosistema.

"Los fotomontajes muestran las posibilidades de ampliar el concepto de un parque o jardín botánico. Tundra, prado, bosque tropical, o desierto se pueden crear en cada región para aumentar la concienciación individual y social y la experiencia de los ecosistemas terrestres más importantes. La membrana de la cúpula se controla neumáticamente o electrostáticamente para que la radiación solar y de la tierra estén adecuadamente filtradas, a fin de mantener las condiciones adecuadas ecológicas de temperatura, humedad, Iluvia, y la circulación de aire en un sistema casi cerrado." (Kepes, 1972, p.192)

También el oasis artificial representa para Haus Rucker-Co una válvula de escape frente al trauma urbano de densificación que sufren las ciudades, ya sea a través de pequeñas intervenciones a modo de jardines individuales como "Oasis $N^{\circ} 7$ ", prototipo construido para la Documenta $\vee$ de Kasel de 1972, o a gran escala, a través de su investigación "Urban Drive-In". A través de esta investigación, el grupo austríaco propone dos tipos de estructuras: "Down-Town Megastructures" (1971) [9B], grandes estructuras climatizadas simulando ambientes románticos en los que se mezclan exuberantes bosques de palmeras tropicales con castillos españoles y "Rooftop Oasis Structures" (1971-1973) [9C], por la que estos oasis artificiales se convierten en una alternativa urbana de ocupación de las inutilizadas terrazas de los edificios de la ciudad de Nueva York. En ellas llegarán a recrear incluso un trozo de la "Acrópolis de Atenas", primando cada vez más la representatividad y el simbolismo de sus actuaciones climáticas, abandonando así el carácter experimental de las primeras y abordando situaciones con tendencia hacia un pintoresquismo de lo natural que también se desprende en propuestas como "Ideale Tiroler" (1968) [4B] de Julios Mende. En esta última, el autor pretende simular en un reducido espacio el ambiente del Tirol, a partir de sus principales invariantes paisajísticos y climáticos, o lo que es lo mismo, a través de una especie de parque zoológico de paisajes.

545 JENCKS, Charles. Arquitectura 2000. 1975 (1971). pp.37-39.

546 COOK, Peter. Experimental Architecture. 1970. pp.146-147.

547 "The photomontages show possibilities of extending the concept of a park and a botanical garden. Tundra, grassland, tropical forest, or desert can be created in every region to increase social and individual awareness and experience of the major terrestrial ecosystems. The skin structure of the dome is controlled pneumatically or electrostatically so that the solar and earth radiation are adequately filtered in order to maintain the right ecological conditions of temperature, humidity, rainfall, and air circulation in a quasi closed system"

KEPES, Gyorgy. The Artist Role in Environmental Self-Regulation. En: Arts of the environment. Brazilier. Nueva York, 1972. p.192. 


\title{
Climas personales, el traje de astronauta como arquitectura.
}

Desde mediados de la década de los sesenta, el traje de astronauta será considerado uno de los grandes iconos arquitectónicos en cuanto a control climático se refiere. Todo el volumen de "The Architectural Design" de febrero de 1967, con John McHale como editor, promulga la importancia de la conquista del espacio exterior y los océanos como grandes alternativas para el futuro de la arquitectura. Todos los ejemplos de este número de la revista, cuyas consecuencias a pequeña escala suponen la escafandra de buzo o el traje espacial, enfatizan la necesidad de autosuficiencia y aprovechamiento de los recursos, sólo posible a partir de un control hiper-tecnificado del ambiente. En "Living," propuesto en dicho número por Robin Middleton, se da una visión de la vivienda del futuro reducida a un diagrama de flujos e intercambios entre el usuario y su medio, imagen posible gracias al desarrollo de nuevos trajes para el aislamiento sonoro o el confort climático por parte de la industria.

\begin{abstract}
"La cápsula espacial podría convertirse en nuestra imagen de ambiente vital ideal. Pero incluso ésta puede ser demasiado limitante para nuestro futuro modo de vida. El traje espacial, que es esencialmente un kit de supervivencia en caso de fallo del sistema de presurización de la cápsula, ofrece una visión del futuro menos limitada y restrictiva. Si no podemos, por control genético o químico, transformarnos en una raza de superhombres capaces de soportar las inclemencias meteorológicas, es posible que por lo menos podamos sobrevivir y disfrutar de la vida sin más que con un poco de ropa adecuadamente diseñada, sin casas, incluso sin hogar. Ya hay disponibles en el Reino Unido algunas prendas que ofrecen servicios y comodidades de los que carecen un gran número de edificios. " ${ }^{448}$ (Middleton, 1967, p.66)
\end{abstract}

Esa misma reducción que Middleton propone, había sido ya esbozada por el crítico británico Reyner Banham en su célebre artículo "A home is not a house"549 [3A], en el que enfatiza la importancia de las instalaciones de control climático dentro del ambiente doméstico y con el que critica la erección de monumentos de piedra como viviendas cuando el hogar se puede reducir a un entorno climatizado generado por una envolvente neumática y un "hardware" de instalaciones, concepto dibujado por el diseñador canadiense Françoise Dallegret para ilustrar el artículo.

"Se trata simplemente de generar un medio ambiente adecuado para lo que se va a hacer a continuación, ya sea construir un monumento de piedra, alejarse del fuego o

\footnotetext{
548 "The space capsule might become our image of the ideal living environment. But even this is too limiting for our future modes of living. The space suit, which is essentially a survival kit in case of failure of the pressurizing system of the capsule, offers a vision of the future that is less confined and restricting. If we cannot, by genetic or chemical control, be transformed into a race of supermen able to withstand the elements, we may at least survive and enjoy living with no more than adequately designed clothes, no homes, no homes even. Already clothing is available in Britain that offers amenities and comforts lacking in a great many buildings"
}

MIDDLETON, Robin. Living. En: AD The Architectural Design, $2000+$, febrero 1967. p.66.

549 BANHAM, Reyner. A Home is not a House. En: Art in America, vol 53, abril 1965. pp.70-79.

El artículo se volvió a publicar ya en 1969 en la revista británica "The Architectural Design", que es la fuente que he consultado:

BANHAM, Reyner. A Home is not a House. En: AD The Architectural Design, enero 1969. pp.45-48 
encender el aire acondicionado, todos ellos constituyen el mismo gesto humano básico destinado a producir un ambiente. ${ }^{1550}$ (Banham, 1965 (1969), p.48)

Esa nueva vivienda mínima efectivamente climatizada y equipada supone el punto de partida de varios proyectos del grupo Archigram como "Cushicle" [3C] y "Suitaloon" [3D], diseñados por Mike Webb en 1966. Ambos habitáculos habitacionales reducen al máximo su espacio arquitectónico para poder ser transportados, transformándose incluso en medios de locomoción del propio usuario. Los dos harán de su nombre toda una declaración de intenciones, "Cushicle" como contracción de las palabras "Cushion" (cojín) y "Vehicle" (vehículo) y "Suitaloon", un híbrido entre "Suit" (traje) y "Saloon" (Salón), aludiendo al carácter doméstico de las propuestas como alternativas de futuro a esa "House" como monumento del habitar, tan criticada por Banham. Ambos proyectos presentan su aparato ideológico asociado a un artículo de Warren Chalk de 1966, "No-Where Man"551 [3B], en el que se enfatiza el nuevo nomadismo como alternativa de futuro. Un nuevo hombre sin lugar concreto, con una máxima movilidad, posible gracias al desarrollo de dos campos tecnológicos; las tecnologías de comunicación y los trajes climatizados. Las primeras ilustradas por una proto-computadora en el artículo de Chalk, un híbrido entre una máquina de escribir y una televisión. Los segundos, a través de un vestido que podía ser enchufado a una red de intercambio de líquidos fríos y calientes, desarrollado por la Frankenstein Group Ltd, el mismo que ilustra el artículo "Living" de Middleton y que aparecerá de manera recurrente en los fotomontajes del "Cushicle" y el "Suitaloon"552. Otros experimentos con trajes climáticos serán desarrollados por grupos de arquitectos de la UCLA, con la que los miembros de Archigram habían mantenido una estrecha relación académica ${ }^{553}$. Alan Stanton, Denny Lord y Chris Dawson, primero como "EnviroLab" y luego junto a Mike Davies como "Chrysalis", desarrollarán varios prototipos ambientales, una membrana neumática que conforma un ambiente generado mediante cambios de presión, presentada a la Bienal de París de 1969 como "Elektradermis" [5C] o unos trajes reflectantes que teóricamente se cargaban de energía solar o "Desert Suits" (1970) [7B], que resultaron un auténtico fracaso por la falta de respiración a la que sometían al cuerpo que los llevaba puesto. ${ }^{554}$

La vivienda traje se convierte así en objeto de deseo por parte de un gran número de $\operatorname{arquitectos}^{555}$ y artistas. Walter Pichler esboza en 1967 sus dibujos para un prototipo

550 "It is not the same thing as a uniform environment. It is simply an environment suited to what you are going to do next, and whether you build a stone monument, move away from the fire or turn on the air-conditioning, it's the same basic human gesture you are making"

BANHAM, Reyner. A Home is not a House. AD enero 1969. p.48.

551 CHALK, Warren. No-Where Man. En: AD The Architectural Design, octubre 1966. p.478.

552 Architectural Design publicará varias variantes de prototipos de trajes térmicos, desde el Hot Coat (1968) diseñado por la UK Electrical Corporation al Suit Shelter (1970) de Parberlee Products.

553 Warren Chalk fue a dar una conferencia en 1967, impartiendo algunas clases de 1968 a 1969 junto a Ron Herron y Peter Cook. Ver:

ALEXANDER, Christopher James; DE WIT, Wim. Overdrive: L.A. Constructs the Future, 1940-1990. Getty Publications. Los Ángeles, 2013. pp.86-88.

554 Puede leerse este fracaso comentado por sus protagonistas en:

BROOKES, Alan. Mike Davies. En: Innovation in Architecture: A Path to the Future. Spon Press. Londres, 2004. pp.22-23.

555 Proyectos climáticos de varias escalas pueden consultarse en el número especial de "The Architectural Design" sobre estructuras neumáticas:

AD The Architectural Design, Pneu World, junio 1968. 
denominado "Bioadapter" [4A], una segunda piel adaptada al cuerpo humano como intermediaria entre el hombre y su ambiente, o en 1968 para "Standard Suit" [4C], un traje para el control climático del cuerpo como segunda vivienda. Sin embargo, más allá de propuestas esporádicas como el "Microclima en zonas gélidas" [9A] diseñado en 1971 por James Lambeth que aprovecha la radiación solar en zonas árticas o el "O2 Reservat" [8D] de Haus Rucker Co, la arquitectura generadora de climas personalizados propuesta por el traje espacial se desvanecerá como alternativa de futuro, a pesar de las lamentaciones tecnológicas de Warren Chalk:

"En un principio asociado a la iconografía del programa espacial y sus equivalentes bajo el agua, el urgente llamamiento de los años sesenta se ha enfriado para mí. El hombre ha subido y bajado de la luna, incluso jugó al golf en su superficie, y no estamos mucho mejor por ello...

Sólo con una humanidad más sofisticada, una tecnología más sofisticada, trabajando juntos en armonía, ayudaremos a los hijos de los hijos de nuestros hijos. "1556 (Chalk, 1972, p.32)

556 "Initially associated with the iconography of the space program and its underwater equivalents, the urgent appeal in the sixties has now cooled for me. Man has leapt up and down on the moon, played a golf-stroke even, and we are not much better for it. .

... Only more sophisticated humanity, only more sophisticated technology, working together in harmony, will help our children's children's children"

CHALK, Warren. An unaccustomed dream. En: COOK, Peter (editor). Archigram. Studio Vista. Londres, 1972. p.32. 


\section{Catálogo // [Distorsionadores autónomos de la percepción]}

Las imágenes están referenciadas por números en la zona superior de las columnas verticales [del 1 al 11] y letras en la zona izquierda de las filas horizontales [de la A a la E].

Todas las referencias están ordenadas cronológicamente.

Referencias de imágenes del [1B] a [11C]. Cada uno de los proyectos referenciados gráficamente en el catálogo presentan antes de su nombre un código con un número en relación a su columna vertical y una letra en relación a su fila horizontal.

Ejemplo:

[7E] "Cloud 9" (1962) de Buckminster Fuller. Buscar referencia en la columna 7 y la fila E del catálogo referenciado al principio del capítulo.

[Nota]: no todos los referentes gráfico del catálogo están referenciados en el texto por lo que se recomienda una lectura del mismo antes de comenzar la del propio texto.
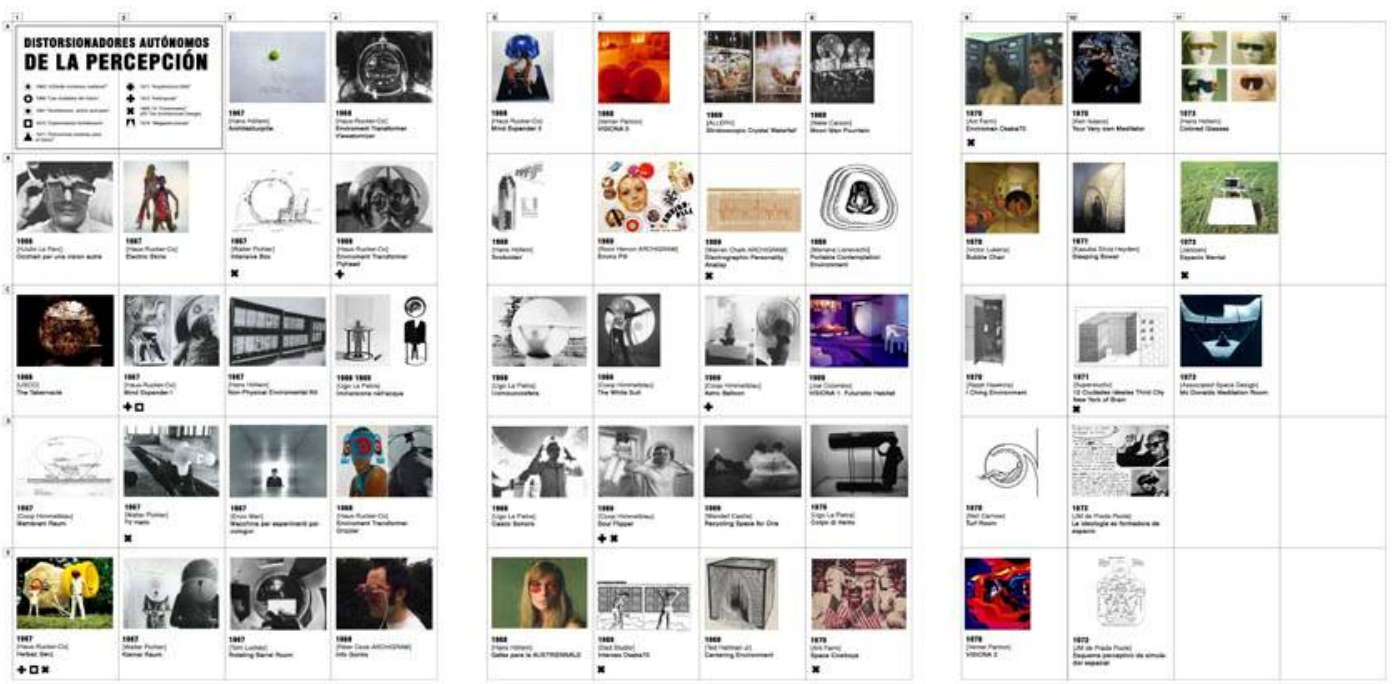


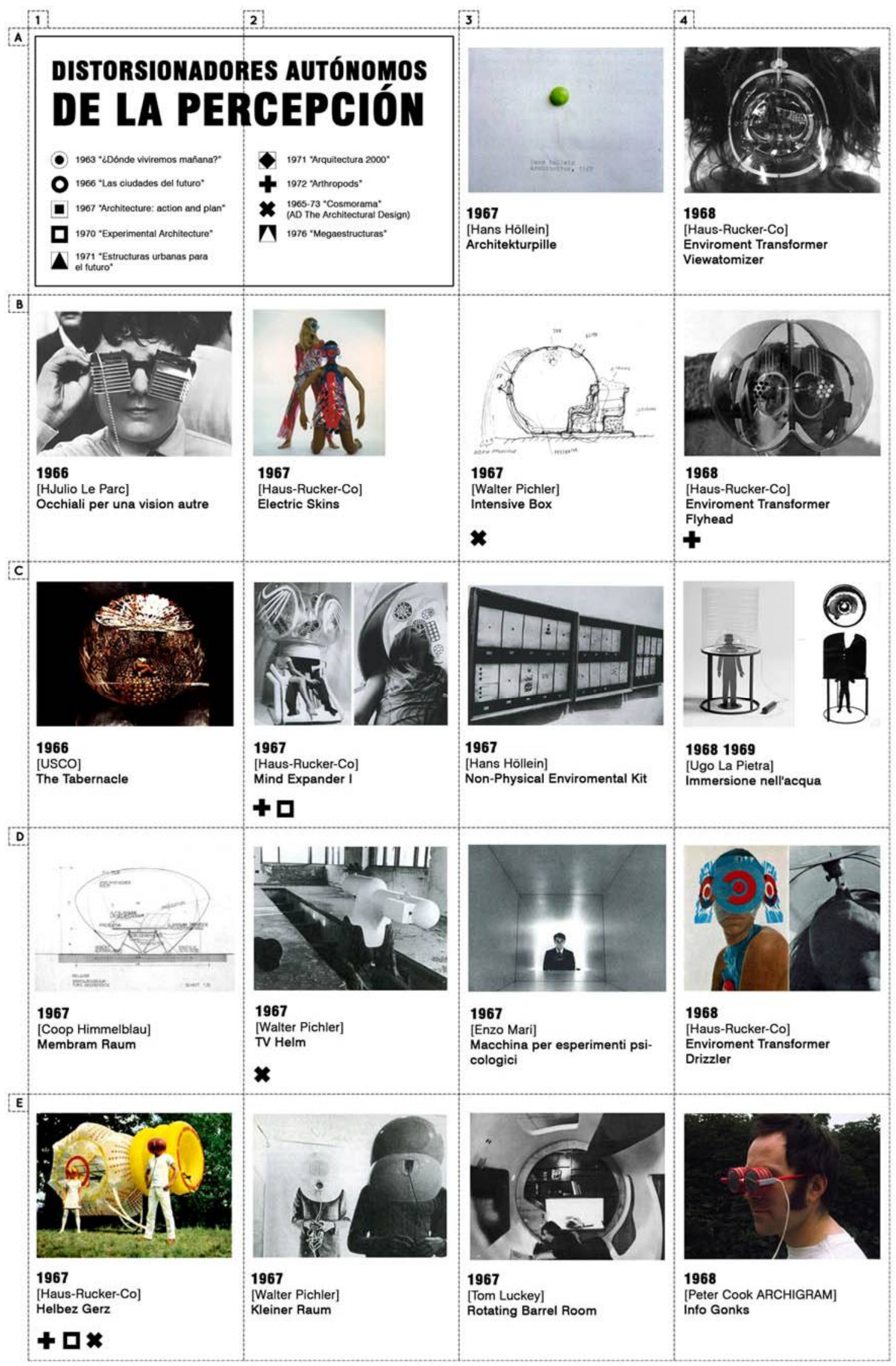




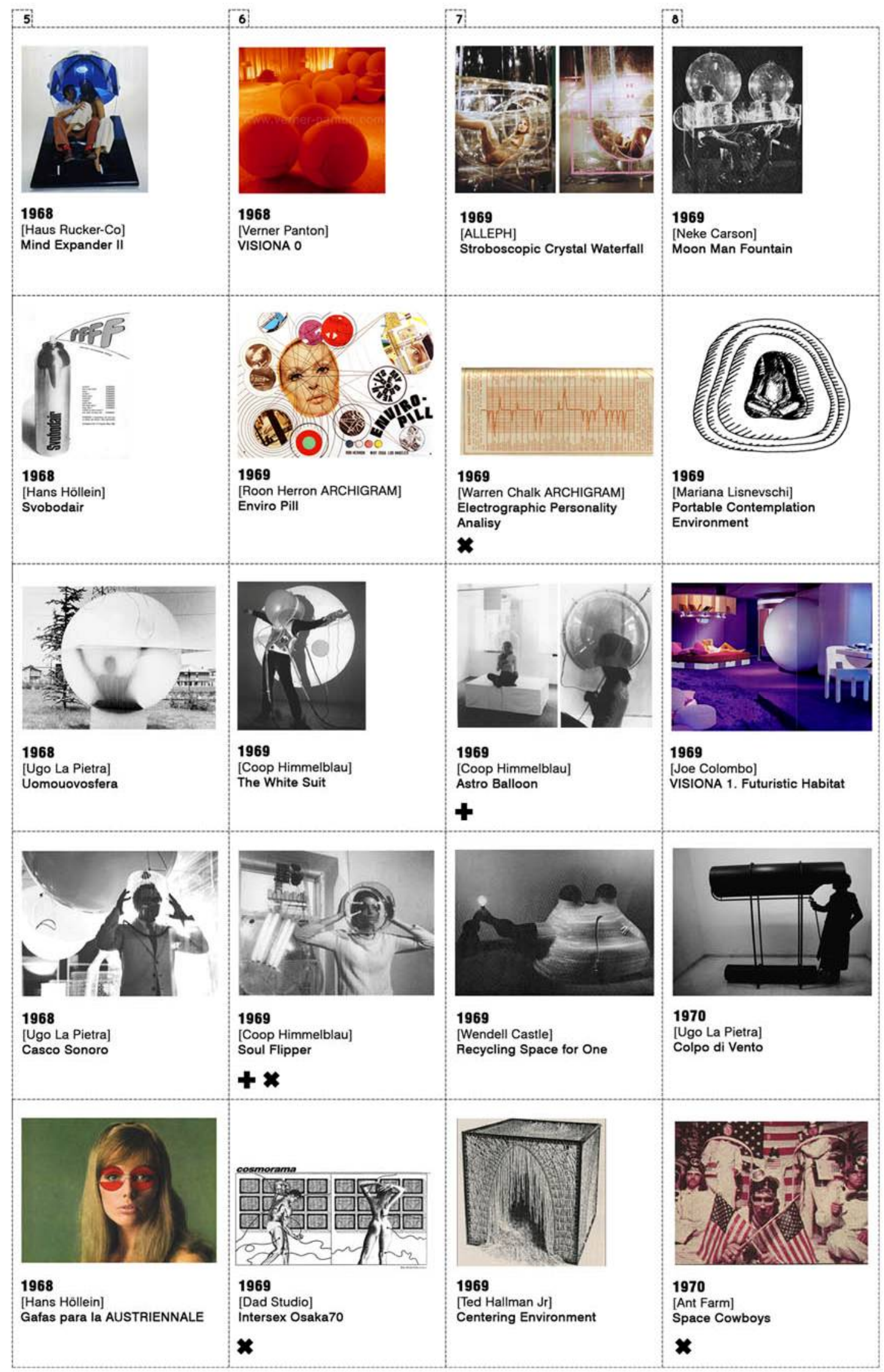




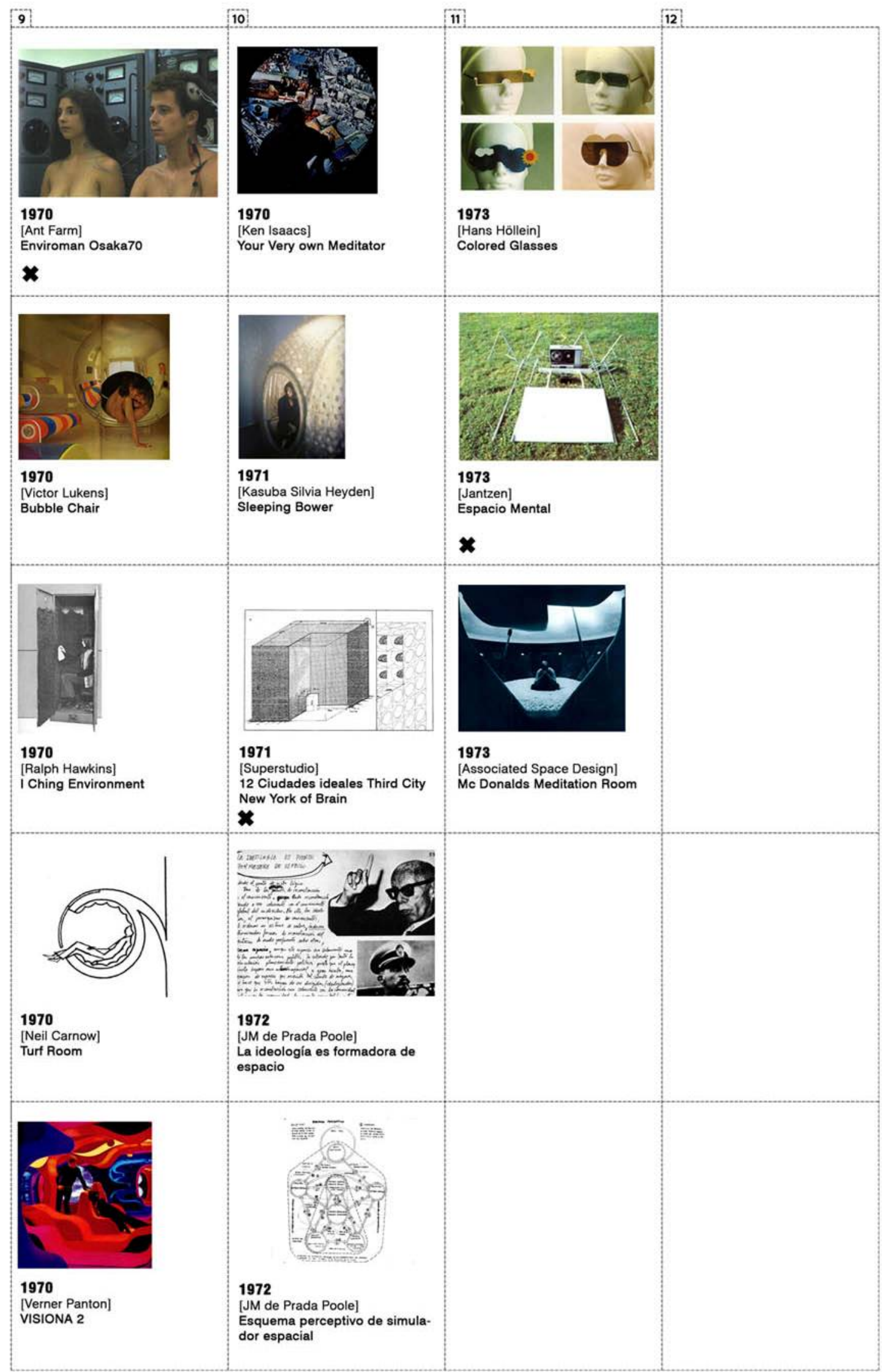




\title{
[Distorsionadores autónomos de la percepción] Todo es arquitectura.
}

En 1967, Hans Höllein desarrolla los proyectos "Architekturpille" [3A], "Svobodair" [5B] y "Non-Physical Enviromental Kit" [3C] asociados al diseño del pabellón austríaco de la XIV Triennale de Milán de 1968. De esta manera, una píldora o un spray se convierten en generadores de una arquitectura entendida como proceso mental. A través de esos icónicos objetos, Höllein proclama a los cuatro vientos su radical mensaje "Todo es arquitectura", publicado por primera vez en 1968 en la revista BAU, de la cual es también editor principal:

\begin{abstract}
"La Arquitectura es un medio de comunicación.
La Arquitectura es ritualista; es una marca, un símbolo, un signo, una expresión.

La Arquitectura es el control de la temperatura del cuerpo, la protección de una casa.

La Arquitectura es determinación; estipulación del espacio, del ambiente.

La Arquitectura es acondicionamiento, un estado psicológico.
\end{abstract}

Todos somos arquitectos. Todo es Arquitectura." ${ }^{n 57}$ (Höllein, 1968, p.2)

El alegato de Hans Höllein, "Everything is architecture", es coetáneo al "Everything is art"558 de Joseph Beuys, el "Everything we do is Music"559 de John Cage, o las experimentaciones de Lucy Lippard ${ }^{560}$ en relación a la desmaterialización del objeto artístico. Su fascinación por el potencial artístico de las nuevas tecnologías se imbrica con las ideas de Marshall McLuhan sobre la nueva "sociedad de la información" ${ }^{561}$, construyendo así un discurso de desestructuración de la disciplina arquitectónica como se había concebido hasta ese momento, proponiendo una apertura total como única manera de desarrollo conceptual tecnológico de la misma. La "Architekturpille" y el "Svobodair" se convertirán rápidamente en los nuevos iconos de una "nueva arquitectura", representando a una serie de proyectos que ya habían comenzado a experimentar con una posible "virtualización" de la arquitectura al trabajar en los difusos límites de la propia disciplina. Höllein construye así un manifiesto gráfico y escrito, incluyendo propuestas muy heterogéneas que combinan arte y arquitectura, que alcanzará una gran difusión en su tiempo, gracias a su puesto de editor en $B A \bigcup^{562}$, sus varias réplicas en otras revistas distanciadas geográficamente pero

557 "Architecture is a communication medium.

Architecture is ritualistic; it is a brand, symbol, sign, expression.

Architecture is controlling; body temperature-protecting house.

Architecture is determination; stipulation, of space, of the environment.

Architecture is conditioning; a psychological state"

Everyone is an architect. Everything is architecture"

HÖLLEIN, Hans. Alles ist Architektur. En: Bau, Heft 1/2, 1968. pp.2-27.

Höllein centrará su discurso de que "todo es arquitectura" en los dispositivos autónomos, dos años más tarde:

HÖLLEIN, Hans. Alles ist Architecture. En: AD The Architectural Design, febrero 1970. pp.60-63.

558 BEUYS, Joseph. Everything is art. En: Avalanche, n5, summer 1972.

559 CAGE, John. Everything We Do Is Music. Entrevista de John Kosler. En: Saturday Evening Post, octubre 1969

560 LIPPARD, Lucy. Six Years: The Dematerialization of the Art Object from 1966 to 1972. A CrossReference Book of Information on Some Esthetic Boundaries. Praeger. Nueva York, 1973.

561 MCLUHAN, MARSALL. Gutenberg Galaxy: The Making of Typographic Man. University of Toronto Press. Toronto, 1962. 
personalmente conectadas a Höllein ${ }^{563}$, su aparición en exposiciones ${ }^{564}$ y el puesto del austríaco como profesor de la "Academy of Arts" en Düsseldorf.

\section{Las fuentes del espacio. El cerebro como simulador espacial.}

A pesar de que el manifiesto de Höllein será utilizado más como una liberación disciplinar que como un camino de experimentación literal, aparecerán también varios proyectos que experimentan en torno a la influencia de la mente en la generación de espacio arquitectónico. Ron Herron vuelve a utilizar el carácter icónico de la píldora en "Enviro-Pill" de 1969 [6B], una pastilla para inducir entornos virtuales e imaginarios en la mente. Warren Chalk reivindica la arquitectura contenida en "Electrographic Personality Analysis"1565 [7B], un análisis electrónico de su personalidad simulado por una atracción de feria en 1969. Ant Farm propone el distópico "Enviroman" (1970) [9A] para Osaka'70, que presenta como alternativa de futuro a una pareja unida por sus cerebros y carótidas a través de cables a unos gigantescos ordenadores ${ }^{566}$. Esta visión de una arquitectura reducida a una serie de conexiones entre el hombre y una máquina que gestiona sus impulsos aparece también en otros proyectos para la exposición universal de Osaka como "Intersex" [6E], diseñado en 1969 por Billie Whistle de Dad Studio, una instalación encaminada a medir los impulsos sexuales relacionados con imágenes eróticas. La distopía generada por Superstudio en 1971, "Third City New York of Brain" [10C] irá un poco más lejos, al imaginar una ciudad de Nueva York reducida a millones de cerebros conectados a un gran suministrador común que controla los impulsos de toda la población cerebral de la ciudad. Incluso el inglés Peter Hodgkinson especulará en su artículo "Drug-In City"567 de 1969 con la posibilidad de una ciudad en la que los ciudadanos sólo estén ya interesados en los efectos de las drogas, una

562 Después de su publicación en BAU Heft 1/2, 1968, el artículo "Alles ist Architektur" volverá a ser publicado en BAU en 1968 con una reseña a su instalación para la XIV Triennale de Milán y en 1969 dentro de su gran artículo "Architektur", con proyectos sólo de arquitectos austríacos y mucho más enfocados al control ambiental:

HÖLLEIN, Hans. Austriennale. En: Bau, Heft 4 1969. pp.75-78.

HÖLLEIN, Hans. Alles ist Architektur. En: Bau, Heft 2/3 1969. pp.30-31.

563 Los proyectos de la "Architekturpille" y el "Svobodair" aparecen publicados en los siguientes artículos:

HÖLLEIN, Hans. Alles ist Architecture. En: AD The Architectural Design, febrero 1970. pp.60-63.

HÖLLEIN, Hans. Pillola Spray. En: IN nº1, enero 1971.

SUPERSTUDIO. Lettera da Graz. En: Domus, n481, diciembre 1969. pp.49-55.

HÖLLEIN, Hans. Svodoair. En: AA L'Architecture d'Aujourd'Hui, n¹39, Tendances, septiembre 1968. p.1.

564 Los proyectos de la "Architekturpille" y el "Svobodair" aparecen en exposiciones como:

AUSTRIENNALE. Pabellón austríaco en la XIV Triennale di Milano, 1968

Trigon'69. Exposición trinacional (Austria, Italia, Yugoslavia), Bienal de Graz. Del 4 de Octubre al 15 de Noviembre de 1969.

"Alles ist Architektur", Städisches Museum, Mönchengladbach, 1970

565 Dentro del artículo:

CHALK, Warren. Trying to find out is one of my constant doings. En: AD The Architectural Design, enero 1970. pp.15-16.

566 ANT FARM. Ant Farm proposal for Osaka'70. En: AD The Architectural Design, julio 1969. p.355.

567 HODGKINSON, Peter. Drug-In City. En: AD The Architectural Design, noviembre 1969. p.585. 
distopía irónica como crítica al poder de la cápsula, ya sean las usadas como estimulantes espaciales por Höllein o las viviendas de la "Plug-In City" por Archigram.

Sin embargo, más allá de distopías simbólicas y representaciones ficticias, aparecen algunos estudios como "Mental Space" [11B], realizado en 1973 por el arquitecto estadounidense Michael Jantzen, que parte del presupuesto de que los procesos operativos del cerebro producen impulsos eléctricos en relación a la percepción del espacio que pueden ser registrados. Así es como Jantzen intenta generar una reconstrucción del espacio conceptual definido por esos impulsos eléctricos del cerebro, a partir de un polígrafo que los capta, y otro aparato que los transforma en impulsos que vuelven a ser percibidos y descritos por nuestro cerebro. También el español José Miguel Prada Poole articulará un discurso a principios de los años setenta en su libro "Las Fuentes del Espacio" (1977) [10E] en torno a la inexistencia del espacio objetivo:

"El espacio objetivo es un valor en crisis. El acuerdo común sobre el espacio observado forma la conciencia colectiva espacial, que no tiene por ello mayor objetividad que la conciencia o el conocimiento espacial individual, pero que sirve mejor cuando el uso del espacio es compartido." 568 (Prada Poole, 1977, p.5)

La búsqueda de esas "fuentes del espacio" llevará a Prada Poole a determinar los umbrales de percepción visual, auditiva, gustativa, olfativa y táctil ${ }^{569}$ que permitan generar un esquema perceptivo como intermediario entre el medio real y el equivalente, aquel que percibimos, dependientes de una serie de receptores, valores genéticos y efectores que podrán ser alterados mediante una máquina, convertida en un simulador espacial.

"La máquina de generar espacio consistirá en la sustitución total de todos los estímulos que llegan al cerebro por impulsos de alimento y energía codificados que crearían una realidad paralela, de modo que el universo del observador y el del mismo cerebro nunca coincidirán, así como tampoco los espacios. Los espejismos y los hologramas son formas de creación espacial mediante sustitución." (Prada Poole, 1977, p.5)

Esta dimensión mental o espacio del conocimiento es conceptualizado por Prada Poole como "Espacio sugerido", convirtiendo a los arquitectos en lo que él denominará como "arquitectos de interiores" en cuanto a que el mero control fisiológico de las necesidades corporales y del mundo sensorial se convierte en la herramienta más potente de modificación espacial. Un espacio mental en el que incluso la ideología se convierte en fuente formadora de espacio. De nuevo "todo es arquitectura".

568 PRADA POOLE, José Miguel. Las Fuentes del Espacio. COAM Comisión de Cultura. Madrid, 1977. p.5.

569 Umbrales directamente tomados de la predicción "The Future of the Future" (1969) de John McHale, lo que hace suponer la lectura exhaustiva del mismo por parte de Prada Poole. 


\section{Gafas, cascos y otros dispositivos distorsionadores. Intensificación de la experiencia arquitectónica. La sala de meditación como nuevo equipamiento doméstico.}

Las teorías de Marshall McLuhan en torno a las nuevas extensiones tecnológicas del hombre, conceptualizadas por McHale como "Man Plus", encuentran nuevos lugares de experimentación en proyectos artísticos como "Lunettes pour une vision autre" [1B] de Julio Le Parc. En este proyecto realizado para la XXXIII Bienal de Venecia de 1966, el artista construye doce modelos de gafas que distorsionan la percepción, fragmentando la visión, coloreándola e incluso volviéndola retroactiva. De esta manera Le Parc experimenta con la interactividad de la obra de arte, que hasta ahora era ajena al espectador y de la cual el usuario se convierte en protagonista absoluto. Esa interactividad del usuario será también reclamada en la disciplina arquitectónica por Höllein a través de su frase: "Everyone is an architect", "todos somos arquitectos". La idea del uso de objetos de interacción es ya explotada por Höllein en 1968 a través de unas gafas desechables producidas cada quince segundos por una máquina, que distorsionan la visión según los colores de la bandera de Austria, como apoyo al diseño de su pabellón para la Triennale de Milán de ese año.

«Las gafas son un medio para la extensión de la espacialidad limitada de la exposición a las dimensiones urbanas y del mundo. ${ }^{1570}$ (Höllein, 1968, p.10)

Esa extensión mcluhaniana de la que Höllein habla, será una búsqueda de intensificación del espacio arquitectónico, la misma que producen las drogas, los cambios de escala o la supergráfica ${ }^{571}$. Esa intensificación de la experiencia arquitectónica sugerida a través la expansión de los sentidos más allá del predominio de lo visual, se convertirá en el principal objetivo de la investigación de Haus Rucker-Co a través de "Mind Expander Program"572, desarrollado entre 1967 y 1969. Para tal fin diseñan una serie de dispositivos como "Mind Expander I"573 (1967) [2C], que acomoda a dos personas, impidiendo la visión horizontal y descubriendo en la vertical una espacie de cojín neumático grafiado con una serie de motivos impresos en material reflectante, permitiendo así la generación de patrones vibrantes que sirven para relajar la mente del usuario.

"El Programa Mind Expander tiene como objetivo explorar y dar forma al espacio interno, el de dentro de las propias personas, descubrir y desarrollar las fuerzas psicológicas-fisiológicas. ${ }^{\text {"574 }}$ (Haus Rucker-Co, 1969 (2010), p.365)

570 "The glasses are a medium for the extension of the spatially limited exposition into urban and worldwide dimensions."

Catálogo de la exposición del pabellón austríaco para la XIV Triennale di Milano. Austriennale, 1968. p.10.

571 Todas ellas serán puestas en paralelo por arquitectos como Charles Moore. Ver:

OTERO-PAILOS, Jorge. LS Design:Charles Moore and the Delirious Interior. En: Volume, n²4, Counterculture, 2010.

572 HAUS RUCKER CO. Favola. En: Domus, n475, junio 1969. pp.18-21.

573 Harán una segunda versión mejorada en 1968, "Mind Expander II".

574 "The Mind Expander Program aims to explore and shape the inner space, space within people themselves, to discover and develop psy-phy forces"

PORSCH, Johannes; ARCHITEKTURSENTRUM WIEN (editores). The Austrian Phenomenon. 2005. p.365. 
El "Programa de Expansión Mental" de Haus Rucker-Co se completa con artefactos como "Environment Transformers", desarrollados en 1968, una serie de máscaras y cascos transformadores de la realidad perceptiva. "Viewatomizer" [4A], una máscara que pulveriza la mirada para distorsionarla. "Drizzler" [4D] una visera con un efecto óptico gracias a un gráfico fluorescente giratorio que ofrece un efecto alienante de la realidad. "Flyhead" [4B], un casco audiovisual que simula la visión fragmentada de un insecto. Todos ellos podían además ser combinados con los "Electric Skins" [2B], trajes elaborados en plástico transparente con motivos psicodélicos, que amplifican la sensación de aislamiento generada por los cascos. Una combinación parecida será utilizada en 1969 por Coop Himmelblau en "The White Suit" [6C], un casco con imágenes proyectadas y una serie de olores y sensaciones táctiles generadas por el propio vestido. Este prototipo completa así investigaciones anteriores del grupo como "Soul Flipper" [6D] o "Astroballoon" [7C], un entorno combinado de sonido, luz y definición espacial, en el que el usuario experimenta introduciendo la cabeza en un casco de color rosa, contenido a su vez en un espacio cúbico acotado con plástico semitransparente. La intensificación de la experiencia visual se realiza mediante una serie de efectos sonoros y de estímulos lumínicos generados a través de unas lámparas suspendidas, formando patrones regulares que transforman la percepción espacial del sujeto de una manera radical, sin relación aparente entre la imagen visual exterior e interior de la instalación.

Experiencias similares a la de los austríacos tienen lugar por parte de diseñadores y arquitectos italianos. "Macchina per esperimenti psicologici" (1967) [3D], diseñada por Enzo Mari para la $\mathrm{VI}$ Bienal de San Marino, propone una inmersión en una máquina para contemplar tu cara inmersa en un paisaje de reflejos. Ese mismo carácter inmersivo es también desarrollado por Ugo La Pietra a través de "Immersioni", una serie de proyectos desarrollados entre 1968 y 1971, por los que propone dispositivos a modo de experiencias sensoriales diversas como alternativa disuasoria a la hostilidad de la ciudad. "Casco Sonoro" para la XIV Triennale di Milano de 1968 [5D], un casco transparente en el que se reproducen estímulos auditivos que te aíslan del exterior visual, "Immersione nell'acqua" (1968-69) [4C], dónde el individuo se enfrenta a la sensación de una cascada de agua o "Colpo di Vento" (1970) [8D], que reproduce un golpe de viento directamente a la cara de la persona que acciona el dispositivo. El verdadero objetivo de todas ellas será permitir al ciudadano tomar conciencia de la realidad urbana alienante en la que se encuentra, para así poder retomar ese poder de acción que según La Pietra ha perdido ${ }^{575}$. A través de "Uomouovosfera" (1968) [5C], el arquitecto italiano sitúa en medio de la trama urbana una serie de cápsulas de aislamiento traslucidas que permiten disfrutar de esa libertad individual perdida en el espacio público.

Los proyectos anteriormente citados de inmersión de La Pietra coquetean con la idea de un ambiente exclusivamente diseñado para la meditación o la contemplación. "Contemplation Meditation $^{576 " ~ s e r a ́ ~ e l ~ n o m b r e ~ d e ~ l a ~ e x p o s i c i o ́ n ~ d e ~} 1970$ en el Manhattan's Museum of Contemporary Crafts, que muestra dieciséis prototipos experimentales exclusivamente relacionados con la meditación y la contemplación. Entre ellos "Stroboscopic Crystal Waterfall" (1969) [7A] del grupo Alleph o "Moon Man Fountain" [8A] de Neke Carson, que aprovechan la capacidad relajante del agua para incluirla en estas cápsulas de descanso. Todos los proyectos expuestos presentan una búsqueda experimental de simulación ambiental, a través de diversas artificializaciones de lo natural, como en "I Ching

575 LA PIETRA, Ugo. Abitare la città. Alinea. Florencia, 1983.

576 "Contemplation Environments" Manhattan's Museum of Contemporary Crafts, exposición celebrada del 20 de enero al 8 de marzo de 1970.

Some New Dodges, or Room to Ponder. En: New York Magazine, 26 enero 1970. pp.58-59. 
Environment" (1970) [9C], capsula diseñada a partir de elementos naturales, un suelo de tierra, unas paredes vegetales y un cielo pintado en el techo o de un nuevo misticismo, como en la sala de proyecciones y audio "The Tabernacle $e^{1577}$ (1966) [1C] diseñada por el colectivo de artistas USCO. "Yellow Heart" [1E], diseñado en 1968 por Haus Rucker Co, plantea un habitáculo neumático para dos personas, en el que una membrana que se infla y desinfla rítmicamente amplía la experiencia del propio cuerpo y su acompañante, intensificada a través de un cerramiento semitransparente y unos motivos geométricos que distorsionan la realidad circundante.

"El corazón amarillo te permite salir del entorno real, tiene su ritmo propio al que es necesario acomodarse. Impresiones ópticas y acústicas ayudan a los usuarios a sentir una sensación totalmente nueva, el pulso suave de la unidad te permite una relajación general física y mental. "1578 (Haus Rucker Co, 1968, p.XXXIX)

Walter Pichler diseñará en 1967 "Intensivebox" [3B], un asiento con una envolvente esférica en la que combina proyecciones, distintas situaciones climáticas e incluso olores para una intensificación total de los sentidos. A través de su proyecto "Villa Rosa" (1968), Coop Himmelblau generará un ambiente total, con diversos dispositivos individuales, el "Insider", el "Bazooka" y el "Indiskin", en el que el usuario puede controlar distintos estímulos olfativos, visuales, táctiles o auditivos a través de esos artefactos, construyendo lo que podría ser incluso una vivienda completa, e incluso una ciudad, interés desprendido por los autores al categorizar el proyecto como "Villa". De manera paralela a todos ellos, la búsqueda de un lugar de meditación alcanzará también a la experimentación doméstica desde distintas vertientes. Por un lado con Ken Isaacs, a través de los planos "Do It Yourself" del proyecto "Your own Meditator" (1970) [10A], una versión doméstica de su conocida "Knowledge Box" (1962), por otro, de la mano de diseñadores como Verner Panton o Joe Colombo y su estrecha relación con los más destacados fabricantes de muebles. A través del barcoexposición de la empresa Bayer para la feria del mueble de Colonia, denominado "Visiona", Panton y Colombo diseñarán durante tres años ese showroom como campo de experimentos en torno a esa búsqueda de espacios domésticos de meditación, utilizando recursos como cápsulas de asilamiento mullidas en el caso de Colombo o superficies onduladas continuas en el de Panton. Todo ello combinado con una gran diversidad de recursos lumínicos de relajación. [8C] [6A] [9E]

Este tipo de dispositivos también supone un nuevo campo de experimentación en torno a la relación doméstica con el mundo exterior. Mientras "Kleiner Raum" [2E], prototipo construido por Walter Pichler para la Documenta IV de Kassel de 1967, se convierte en un casco de conexión auditiva con el exterior, "TV Helmet" [2D], también de 1967, constituye explícitamente la construcción de un salón transportable miniaturizado que se adapta a la cabeza del usuario. El final de este casco se equipa con un sistema de televisión como ventana al espacio público, generando una situación de aislamiento con la realidad presencial pero de comunicación global con el mundo. La misma extensión visual a través de la televisión como comunicador extremo será propuesta por Peter Cook en "Info Gonks"

577 Uno de los proyectos pertenecientes a un "LSD Art", con gran difusión incluso en magazines de actualidad norteamericanos como la revista LIFE:

Psychedelic Art. En: LIFE, 9 septiembre 1966. pp.60-66.

578 "Le Coeur Jaune permet de quiter le milieu réel; il a son propre rythme auquel il faut s'accommoder. Les impressions optiques et acoustiques aident les usagers à ressentir une dètente totalement nouvelle, la douce pulsation de l'appareil conférant une relaxation génerale physique et psychique"

HAUS RUCKER-CO. Le Coeur Jaune. En: AA L'Architecture d'Aujourd'Hui, n¹39, Tendances, septiembre 1968. p.XXXIX. 
(1968) [4E], un par de gafas construidas con unas mini-televisiones de una pulgada y media que te permiten estar permanentemente conectado con el exterior.

Las imágenes del prototipo de Pichler o las gafas de Cook presentan a un nuevo hombre mejorado según el precepto "Man Plus" de McHale, como si de una nueva especie se tratase, una posibilidad que esboza también Jencks en "Arquitectura 2000". En autor inglés visiona un futuro de evolución del hombre a través de esos implantes extensivos, comparándolos con los trabajos sobre la evolución natural realizados por D'Arcy Thompson. 


\section{Catálogo // [Simulaciones espaciales]}

Las imágenes están referenciadas por números en la zona superior de las columnas verticales [del 1 al 18] y letras en la zona izquierda de las filas horizontales [de la A a la E].

Todas las referencias están ordenadas cronológicamente.

Referencias de imágenes del [1B] a [18C]. Cada uno de los proyectos referenciados gráficamente en el catálogo presentan antes de su nombre un código con un número en relación a su columna vertical y una letra en relación a su fila horizontal.

\section{Ejemplo:}

[7E] "Cloud 9" (1962) de Buckminster Fuller. Buscar referencia en la columna 7 y la fila E del catálogo referenciado al principio del capítulo.

[Nota]: no todos los referentes gráfico del catálogo están referenciados en el texto por lo que se recomienda una lectura del mismo antes de comenzar la del propio texto.

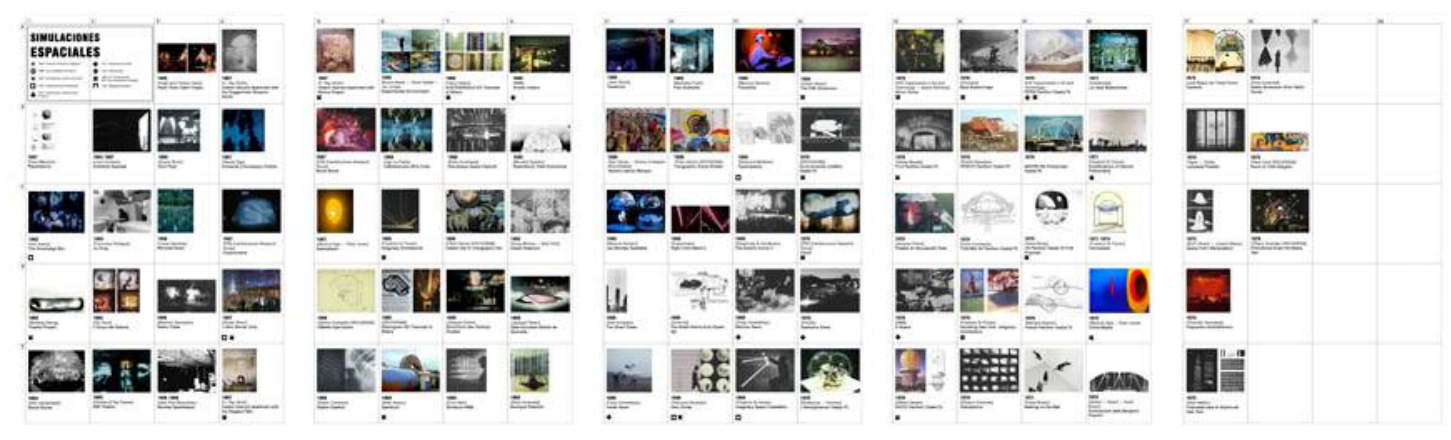




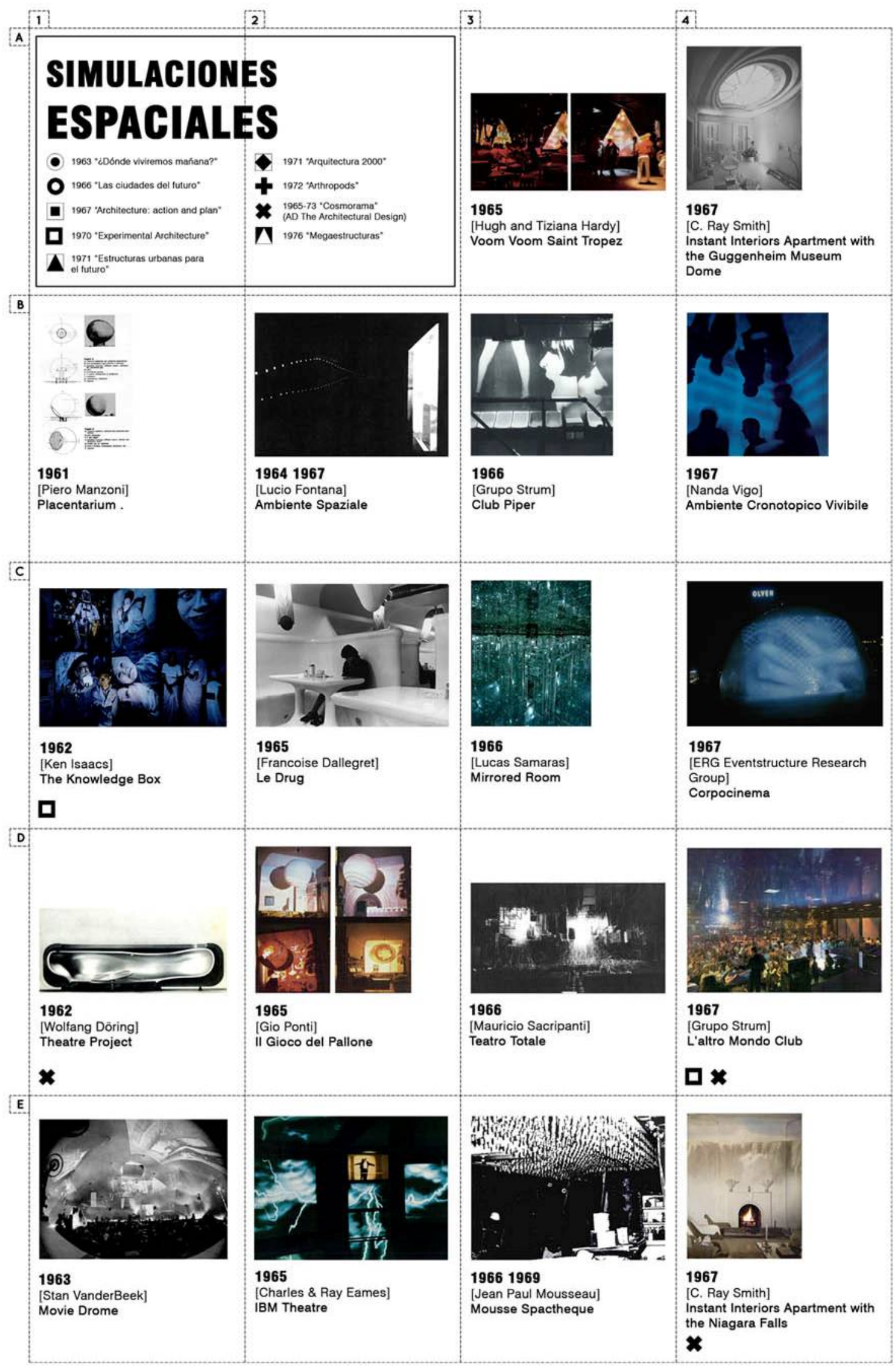




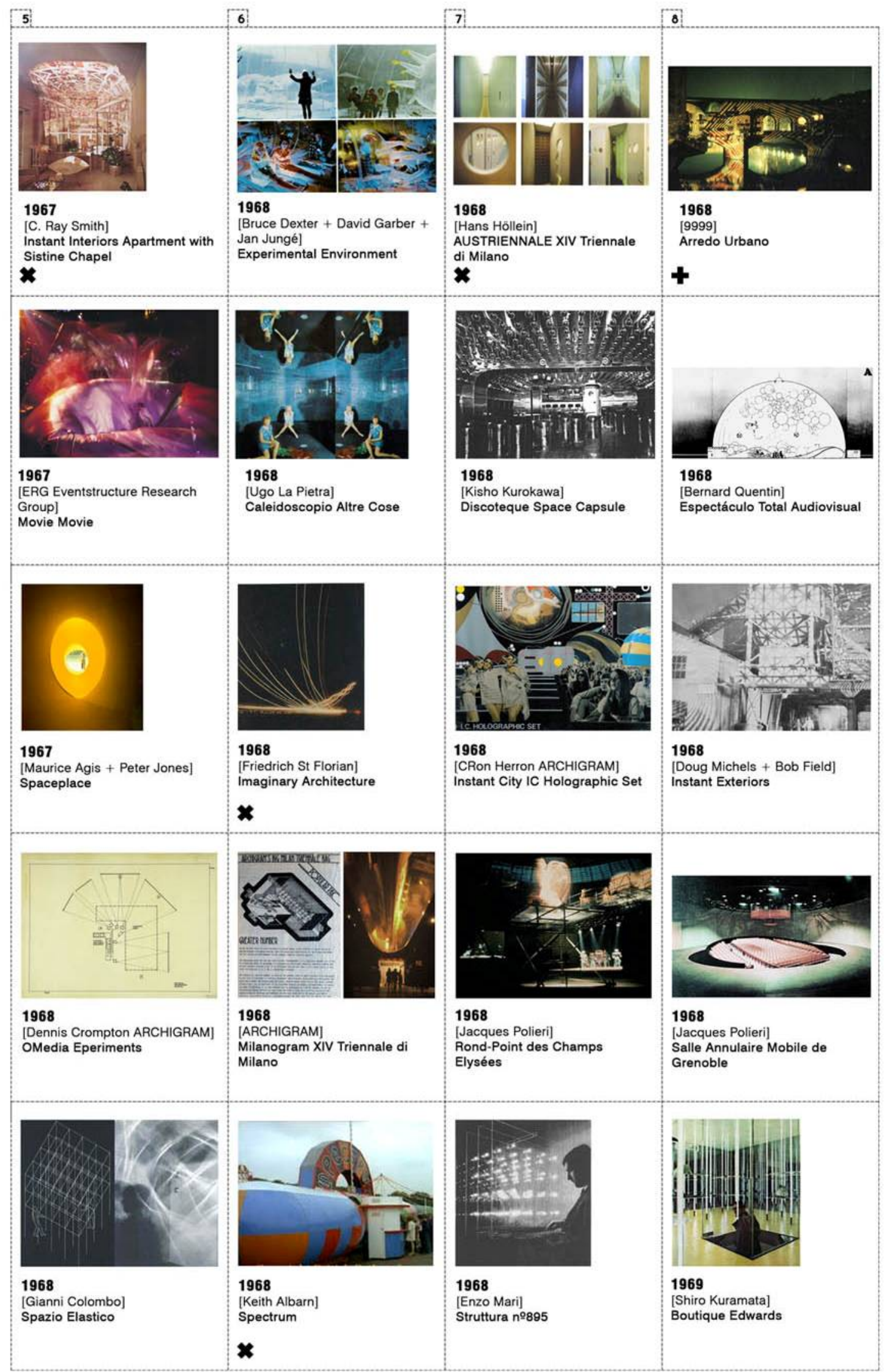




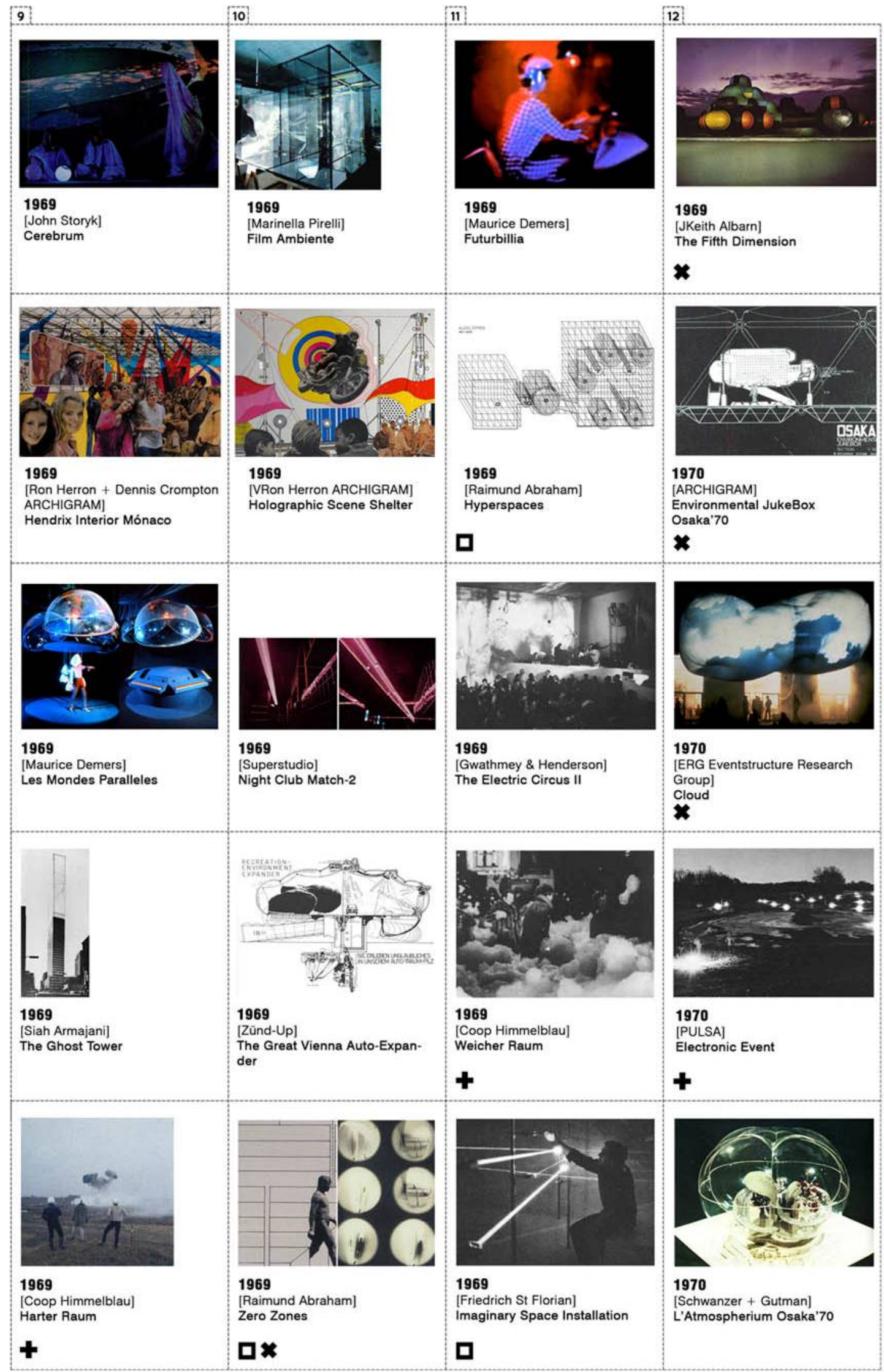




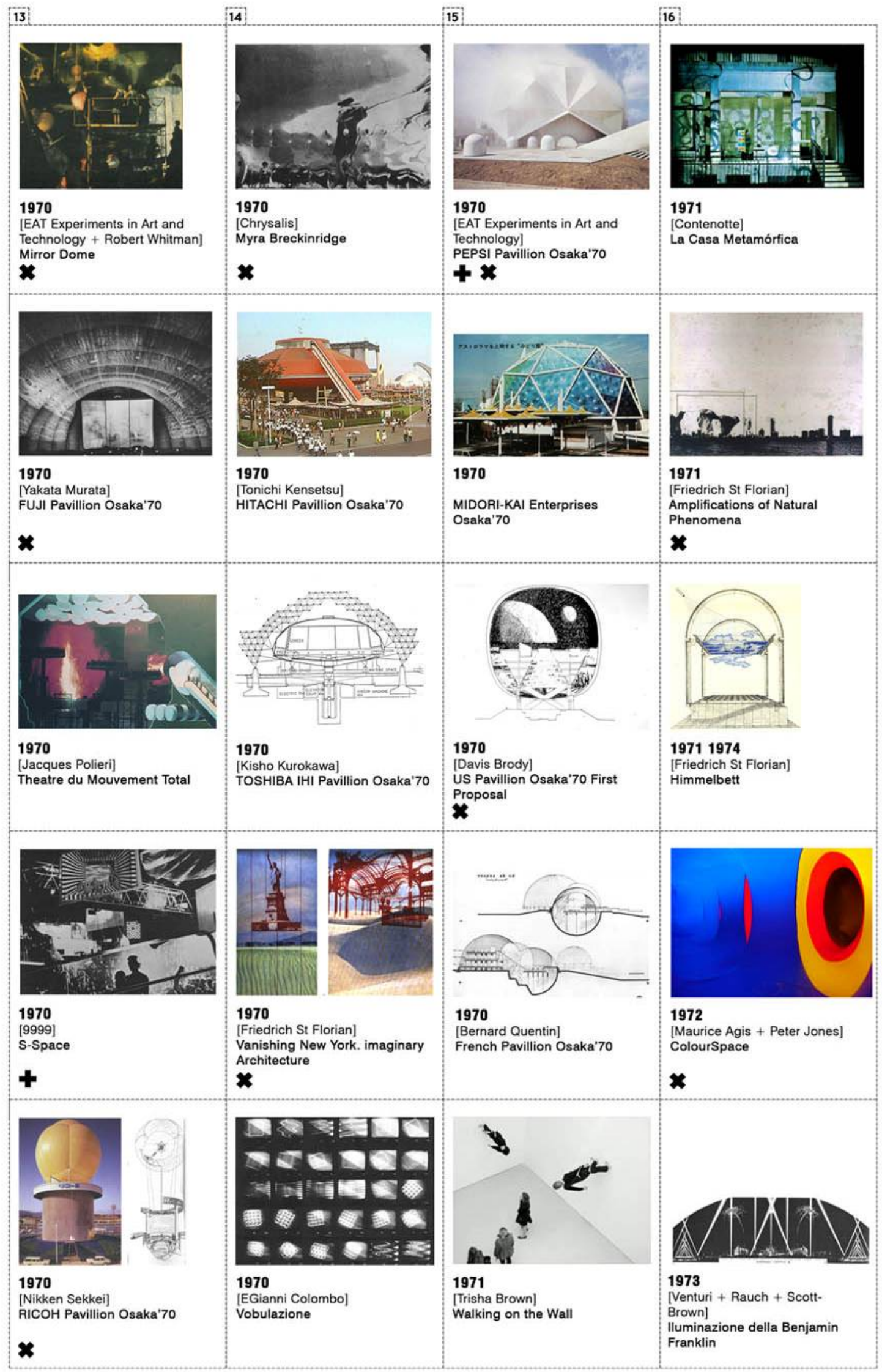




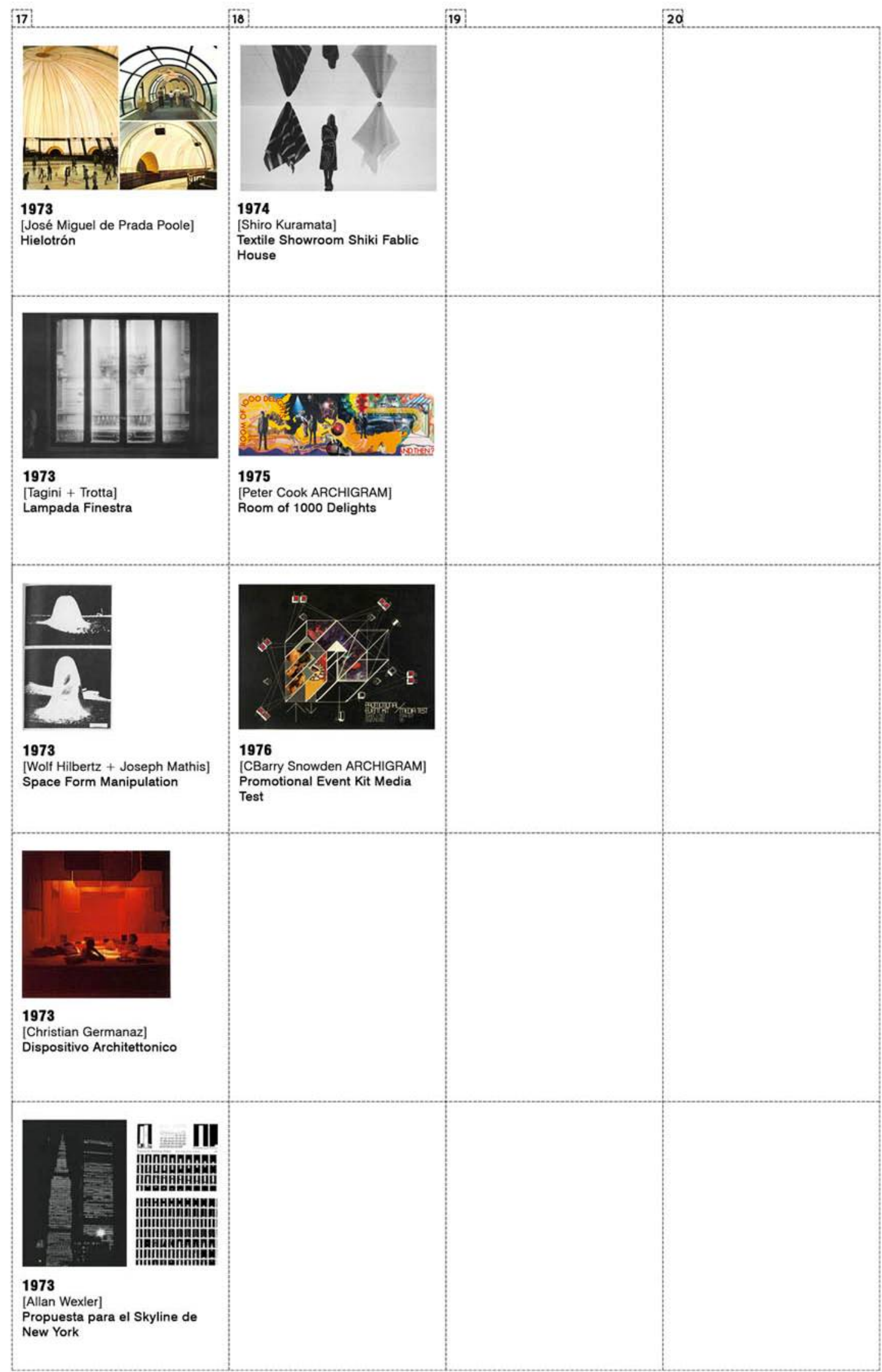




\section{[Simulaciones espaciales] Experimentos en torno a la generación de ambientes temporales.}

El paso de la civilización del trabajo del siglo XIX a la nueva sociedad del ocio del siglo XX ${ }^{579}$, postulada por personalidades como el francés Georges Hourdin, genera una explosión del denominado mundo del espectáculo y de todas las tipologías arquitectónicas asociadas al mismo. Desde mediados de los años cincuenta, el desarrollo de las técnicas de proyección, iluminación y audiovisuales en general, demandará la construcción de nuevos espacios que sean capaces de extraer el máximo potencial de dichas tecnologías a la vez que su hibridación con la experimentación que estaba produciéndose en otros contextos como el del teatro o la producción artística en general.

\section{La búsqueda del teatro total.}

A principios de los años sesenta, aparecen una gran cantidad de propuestas de "nuevos teatros" experimentales y salas de espectáculos audiovisuales. El "teatro tórico" de André Wogensky, el "teatro anular" de Guillaume Gillet, el "teatro móvil" de Werner Ruhnau, el "teatro transformable móvil" de Claude Parent, André Bloc y René Sarger ${ }^{580}$, la "sala para el espectáculo plástico y de sonido en el espacio" de Amancio Williams o el "teatro total" de Maurizio Sacripanti, son algunos de ellos. La mayoría apostará por la pérdida del carácter focal de la escena en pos de un carácter más ambiental. Uno de los más relevantes será el "Placentarium" [1B], diseñado en 1960 por Piero Manzoni para los trabajos de proyecciones de colores y puntos móviles en el espacio de Otto Piene como en "Light ballets as light performances" de 1959. El recinto principal se engloba en un espacio ovoide de unos 18 metros de diámetro, construido mediante una estructura neumática blanca en el interior y plateada en el exterior. Entre ambas, Manzoni dispone un sistema de proyectores, difusores sonoros y vibradores para generar la experiencia audiovisual completa que demandaba la obra de Piene. Un concepto parecido será utilizado por el alemán Wolfang Döring para su proyecto "Enviro-machine" de 1962 [1D], construido a partir de dos membranas plásticas, una carcasa rígida totalmente inexpresiva y cerrada en el exterior, y una estructura neumática interior pulsante, que cambia de forma a partir de un sistema de vibradores, sirviendo a su vez de superficie de proyección de todo un sistema tecnológico de imagen y sonido albergado también entre ambas estructuras. Los espectadores se sitúan en una plataforma móvil en el centro del espacio, que puede cambiar de posición permitiendo pequeños giros. La "Salle annulaire mobile" 1581 [8D], diseñada por el escenógrafo Jacques Polieri y el arquitecto André Wogensky, situará también a los espectadores en una zona de butacas circular y giratoria, descentrada, a lo largo de una planta circular circundada por superficies de proyección cilíndricas. De esta manera, el escenario no sólo aprovecha todo el perímetro de la sala sino que la posibilidad de movimiento de las butacas hace que el ángulo de visión pueda llegar a ser de $360^{\circ}$ pudiéndose incluso reproducir técnicas

579 HOURDIN, Georges. Une civilisation des loisirs. Calmann-Levy. París, 1961.

580 Ejemplos de teatros diseñados por arquitectos franceses, referenciados en las predicciones de Michel Ragon:

RAGON, Michel. ¿Dónde viviremos mañana? 1966 (1963). pp.213-220.

RAGON, Michel. Las ciudades del futuro. 1970 (1966). p.210.

581 De la que se construyó en 1960 un prototipo desmontable para el $3^{\circ}$ festival de Arte de Vanguardia de París y uno más estable en la "Maison de la Culture" de Grenoble en 1968, 
cinematográficas como el "travelling"582. Esa búsqueda de Polieri de un "Teatro del Movimiento Total", empezará en 1958, para la concepción de un espacio esférico en el que los espectadores penetran en la sala por lo alto de la esfera, descendiendo por una escalera de caracol e instalándose en pequeñas burbujas con un doble movimiento vertical y circular por el espacio. El espectáculo se desarrollaría simultáneamente sobre todo el contorno de la esfera e iría variando según los puntos de vista del espectador. Ya en 1962, tanto el arquitecto italiano Enzo Venturelli como el grupo formado por los franceses Pierre y Etienne Vago fabrican dos prototipos según los conceptos escenográficos de Polieri, que llegará a construir un prototipo real del "Teatro para el Movimiento Total" para el pabellón del grupo Mitsui en la exposición universal de Osaka'70, diseñado por Takamitsu Azuma. [13C]

Más allá de esa búsqueda teatral, nuevos experimentos para la generación de ambientes virtuales, surgirán también a partir de dos contextos totalmente divergentes: la contracultura norteamericana y las exposiciones universales. Del lado contracultural a través de una investigación en torno a nuevos formatos de experimentación sensitiva y a la distribución de recursos compartidos, y de mano de las exposiciones universales, como símbolo de poder y progreso del capitalismo avanzado y como banco de pruebas de los sistemas audiovisuales tecnológicamente emergentes, para su posterior uso masivo.

Entre los experimentos contraculturales, "Movie Drome" [1E], construido en 1963 por el arquitecto norteamericano Stan VanderBreek en el terreno de su propia casa en Stony Point, Nueva York, será considerado como uno de los ejemplos más paradigmáticos. A partir de una cúpula geodésica metálica de unos 9.5 metros de altura, elevada del terreno y a la que se accede por el suelo, el interior se convierte en una gran pantalla de proyecciones multiimagen amplificada con un equipo de sonido que se utilizará para happenings, cine experimental y todo tipo de "Image-events" o "Expanded Cinema"583. "Movie Drome" es concebido como un mediador, una herramienta de comunicación por imágenes no verbal, para la que cada comunidad podía construir su banco de imágenes y comunicarse con otros por medio de ellas, a través de un proceso que se denominará como "Culture Intercom"584. De manera paralela a esa contracultura norteamericana, grupos como Eventstructure Research Group también se encuentran desarrollando múltiples experiencias efímeras en la búsqueda de ese "cine expandido", más allá de la pantalla plana y el espectador pasivo focalizado. En "Movie Movie"585 [5B], Jeffrey Shaw, Theo Botschuyver, y Sean Wellesley-Miller de ERG, proyectan vídeos en estructuras neumáticas tridimensionales, incorporando el volumen y el movimiento de las mismas a la propia proyección, estrategia también utilizada en 1967 en "Corpocinema" [4C]. En este último, desarrollado en Rotterdam y Ámsterdam, un

582 Jacques Polieri es autor de dos números especiales sobre escenografía de la revista "Aujourd'Hui":

POLIERI, Jacques. Aujourd'Hui, Art et Architecture, n 17, Spectacles, 1958.

POLIERI, Jacques. Aujourd'Hui, Art et Architecture, n 42-43, Scénographie Nouvelle, 1963.

583 Expanded Cinema de Gene Youngblood (1970), fue el primer libro en considerar el video como una forma de arte. Describe los distintos tipos de cine resultantes de la utilización de las nuevas tecnologías, efectos especiales de cine, arte digital, videoarte, entornos multi-media y la holografía. Buckminster Fuller escribirá la introducción del libro.

YOUNGBLOOD, Gene. Expanded Cinema, Dutton. Nueva York, 1970

584 VanDerBreek defendía la idea de una cultura global interconectada a través de la imagen, de una fusión entre el cine expandido y el intercambio cultural a través del mismo.

VANDERBEEK, Stan. Culture Intercom and Expanded Cinema, a proposal. En: BATTOCK, Gregory (editor). The New American Cinema. Dutton. Neva York, 1967. p.173.

585 Desarrollado en 1967 para el "4th International Experimental Film Festival" en Knokke-le-Zoute, Bélgica y ya en 1969, en el "St. George's Arts Centre" de Liverpool. 
volumen neumático, esta vez transparente, se rellenará con distintas sustancias que deforman la proyección, ya sea humo, espuma de extinción de incendios, pelotas neumáticas o confeti, produciendo así un volumen de partículas que permite atenuar y distorsionar la proyección a la vez que adquiere formas distintas dependiendo del material introducido.

En el ámbito opuesto, el de las exposiciones universales, el "IBM Pavilion. Ovoid Theatre" diseñado por Charles y Ray Eames para la "New York World's Fair" de 1964 [2E], será considerado como uno de los ejemplos más relevantes. Construido como un volumen ovoide suspendido sobre un bosque de pilares de acero cortén, esta máquina de proyección múltiple facilita el acceso de los espectadores mediante una plataforma móvil, elevándolos hasta el centro del teatro en el que se proyectaba el espectáculo "The Information Machine" y "Think", una película de proyección sincronizada de pantalla múltiple realizada por los propios Eames, con música de Elmer Bernstein, en el que "se presenta la noción de abstracción y cómo los más importantes problemas son elaboraciones de la simple escala humana y de las técnicas que utilizamos en el día a día"586. El desarrollo de este tipo de dispositivos continuará en cada una de las exposiciones sucesivas, sin embargo será Osaka'70 la que se convierta en símbolo fundamental del desarrollo de sistemas audiovisuales encaminados a generar arquitecturas virtuales, encontrando en los pabellones de compañías japonesas relacionadas con la tecnología sus máximos exponentes.

"Habiendo hablado ya bastante de películas, arquitectura y robots, llegamos ahora a los temas reales y los equipos que se utilizaron en los medios de comunicación japoneses basados en pantallas. El tratamiento de los pabellones nacionales estaría fuera de lugar porque no sólo no son los más reaccionarios en términos de visualización, sino que además el conflicto entre la concepción formal y el significado interno casi nunca está resuelto, excepto en cuanto a la subordinación de la segunda a la primera ...

... En la mayoría de los pabellones japoneses este tipo de problemas es mucho menos evidente, a pesar de que algunos de ellos fueron concebidos antes que los equipos instalados. ${ }^{.587}$ (Martin Pawley, 1970, p.292)

586 CASATI, Cesare Maria. Teatro sospesso di Charles Eames. En: Domus, n424, marzo 1965. pp.26-32.

587 "So much about the movies, architecture and robots having been said, we now come to the actual themes and equipment worked into the Japanese media-based displays. Treatment of the national pavilions would be out of place here for not only are the most reactionary in display terms, but the conflict between formal conception and internal meaning is almost never resolved except in terms of subordinating the latter to the former...

... In most of the Japanese pavilions this kind of problem is much less obvious, even though many of them were conceived in advance of the equipment installed"

PAWLEY, Martin. Architecture Versus the Movies or Form versus Content. En: AD The Architectural Design, junio 1970. pp.288-309.

Además del artículo de Pawley, se han consultado los números especiales de varias revistas relacionados con Osaka'70:

JA The Japan Architect, n¹64, Special Edition Expo'70, mayo-junio 1970.

BLAKE, Peter. Expo'70. En: Architectural Forum, n³, abril 1970. pp.30-41.

BEST, Alastair. Expo '70. Market, place and festival. En: Design, n²59, 1970. pp. 23-73.

TANGE, Kenzo; KAWAZOE, Noburu. Osaka 70. En: AA L'Architecture d'Aujourd'Hui, nº152, noviembre 1968. pp.97-112. 
Esos pabellones japoneses son una apuesta por la adaptación de esos sistemas audiovisuales a situaciones formales de gran complejidad como Pawley sugiere. El "Fuji Pavilion" [13B], una estructura compuesta por 16 vigas neumáticas de 4 metros de diámetro y 72 metros de longitud diseñada por el japonés Yukata Murata, se convertirá en el primer lugar en el que se instale un prototipo del sistema de proyección canadiense IMAX. De la misma manera que se proyectarán motivos pictóricos en la superficie neumática para generar un ambiente mucho más envolvente y tridimensional. El "Ricoh Pavilion" [13E], diseñado por la firma de arquitectos Nikken Sekkei, destaca por su gran globo de helio como estructura portante principal así como por su sistema interior "introvision", un gran espacio cilíndrico cuyo volumen interior contiene 500,000 pequeños elementos metálicos suspendidos en el aire que al ser iluminados dan la sensación al individuo de encontrarse en un gran bloque de plástico relleno de cientos de burbujas de aire, sensación amplificada mediante un sistema de audio de 64 canales. Aparecen recorridos virtuales como el del "Hitachi Pavilion" [14B] de Tonichi Kensetsu o plateas de butacas giratorias como en el "Toshiba IHI Pavilion" [14C] de Kisho Kurokawa, completándose con nuevos sistemas como el "Astrorama" del "Midori Kai Enterprises Pavilion" [15B], un volumen geodésico de 42 metros de diámetro generado a través de una estructura triangulada cubierta con paneles GRP translúcidos que pueden ir cambiando de color según lo dicte su sistema de iluminación de 256 colores, y un espacio interior semiesférico con un sistema denominado "Ciclorama", una nueva versión del sistema multi-pantalla cinerama ruso desarrollado en 1964.

También en el contexto de Osaka, varias propuestas pertenecientes a los concursos de los diferentes pabellones internacionales experimentan caminos parecidos a los de los japoneses. El "French Pavilion" [15D] de Bernard Quentin, "L'atmospherium" [12E], propuesta para el pabellón alemán de Karl Scwanzer y Robert Gutman, la propuesta "Environmental Jukebox" [12B] de Archigram o la primera propuesta no construida del concurso para el "US Pavilion" [15C] de Davis Brody, que plantea una esfera neumática con la simulación de un vídeo a tiempo real de la luna. Sin embargo, el pabellón más experimental de la feria vendrá de manos de Estados Unidos y de la empresa norteamericana de bebidas Pepsi. El "Pepsi Pavilion" [15A], nace fruto de un proceso colaborativo por parte de artistas, ingenieros, arquitectos y otras personalidades, que en ese momento formaban parte del grupo denominado "EAT: Experiments in Art \& Technology". EAT es fundado en 1966 por Billy Klüver, Fred Waldhauer, Robert Rauschenberg y Robert Whitman tras el evento "9 Evenings: Theater and Engineering ${ }^{588 " . ~ D i c h o ~ g r u p o ~ t a m b i e ́ n ~}$ organiza la famosa exposición "Some more beginnings: Experiments in Art \& Technology"589 en 1969. La importancia de "Experiments in Art \& Technology" depende de su identidad como plataforma colaborativa interdisciplinar, como bien explican Rauschenberg y Klüver en su manifiesto:

"Mantendremos un clima constructivo para el reconocimiento de la nueva tecnología y
las artes mediante una colaboración entre grupos civilizados que de manera poco
realista están desarrollándola de manera aislada. Eliminaremos la separación del
individuo de los cambios tecnológicos y ampliaremos y enriqueceremos la tecnología
para dar al individuo variedad, placer, y nuevos caminos de exploración y una

588 Una serie de performances multimedia realizados en el "New York's 69th Regiment Armory". La reconstrucción y fotografías del encuentro fueron publicadas en 2006 por Catherine Morris:

MORRIS, Catherine. 9 Evenings Reconsidered: Art, Theater, and Engineering, 1966. Institute of Technology, List Visual Arts Centre. Massachusetts, 2006.

589 Organizada del 25 de Noviembre de 1968 al 5 de Enero de 1969 en el Brooklyn Museum of Art, para la que abrieron un concurso de trabajos que relacionaran arte y tecnología, recibiendo más de 2000 solicitudes. 
participación en la vida contemporánea. Fomentaremos la iniciativa industrial desde la primeras previsiones en lugar de un compromiso en el post-partido, y precipitaremos un acuerdo mutuo con el fin de evitar el desgaste de la revolución cultural." ${ }^{1590}$ (Klüver; Rauschenberg, 1967)

Para el citado "Pepsi Pavilion", la empresa norteamericana reunirá a un selecto grupo de ingenieros y artistas como Robert Breer, Forrest Myer o Robert Withman para diseñar una cúpula geodésica en materiales plásticos de 38 metros de diámetro, en cuyo interior se encontrará la "Mirror Dome"591 [13A], una cúpula neumática recubierta de espejos acrílicos que podía deformarse a partir de las diferencias de presión en su membrana interior diseñada por Robert Whitman en colaboración con Envirolab ${ }^{592}$. Estos últimos construirán meses después otro prototipo para la película "Myra Breckinridge" "593 [14A] bajo la formación Chrysalis ${ }^{594}$. Dicha superficie reflectante se equipa con un sistema de sonido e iluminación diseñado por David Tudor y Tony Martin, que permite ser programado o utilizado en tiempo real, generando patrones de luz y sonido para que los visitantes pudieran configurar su propio ambiente e interactuar con el resto de obras del pabellón.

"Equipos rotantes de cuatro, compuestos de artistas, científicos y personas de otras profesiones, programan las actividades de luz y sonido. Estas actuaciones son de naturaleza experimental y aprovechan al máximo el equipo técnico y las otras propiedades de la cúpula." ${ }^{.595}$ (Elsa Carmine, 1970 (1972), p.124)

En el exterior del pabellón, el artista japonés Fujiko Nakaya diseña una nube artificial generada mediante unos 2500 aspersores. La importancia de este proyecto experimental radica no sólo en su capacidad de generación ambiental sino también en su carácter colaborativo y participativo, dos de los rasgos fundamentales de los proyectos denominados como "Arthropods" por Jim Burns en su predicción, como alternativa de futuro.

590 "Maintain a constructive climate for the recognition of the new technology and the arts by a civilized collaboration between groups unrealistically developing in isolation. Eliminate the separation of the individual from technological change and expand and enrich technology to give the individual variety, pleasure and avenues for exploration and involvement in contemporary life. Encourage industrial initiative in generating original forethought, instead of a compromise in after-match, and precipitate a mutual agreement in order to avoid the waste of a cultural revolution"

Experiment in Art and Technology, Statement of purpose, 1967. E.A.T. Billy Klüver y Robert Rauschenberg. Publicado por E.A.T. Nueva York, 1967

http://www.fondation-lang/ois.org/htm//e/page.php?NumPage $=1717$

591 Reseña en la sección Cosmorama de la revista británica "The Architectural Design" sobre las pruebas realizadas de la construcción de la membrana interior en un hangar de Santa Ana, California:

Mirror Dome. En: AD The Architectural Design, enero 1970. p.2.

592 Grupo compuesto por Chris Dawson, Denny Lord y Alan Stanton,

593 También publicada en la sección Cosmorama de AD:

Myra Breckinridge. En: AD The Architectural Design, julio 1970. p.332.

594 Junto a David MacDermott y Rob Sabgster.

595 "Changing teams of four, composed of artists, scientist, and people from other professions, program the light and sound activities. These performances are experimental in nature and take full advantage of the unique technical equipment and other properties of the dome"

Burns, Jim. Arthropods. 1972, p.124. 


\section{Generación de programas arquitectónicos a partir de ambientes. La discoteca como "Palacio de la Diversión" y centro del debate arquitectónico.}

El "Fun Palace" diseñado por Cedric Price en 1961 reivindica una nueva tipología de espacios en los que las actividades se generen a partir de ambientes configurables y no de espacios prefijados, de manera que el edificio se convierta en proveedor de toda una serie de herramientas tecnológicas al alcance de un usuario que pueda configurar dichos ambientes a placer. A pesar de su carácter "no construido"596, el "Fun Palace" supondrá una de las influencias más importantes en relación a la generación de ambientes virtuales, un tema sobre el que ya Price había experimentado en proyectos como el "Circlorama Glasgow Fair"597 (1962), una sala de exposiciones neumática con un sistema de proyecciones interiores incorporado. Posteriormente, proyectos como el "Dronten Agora" (1967), el antes citado "Summerland" (1968) ${ }^{598}$, e incluso grandes centros de atracciones como "WonderLand" 599 , reincidirán en esa tipología de gran contendor equipado pero sin conseguir esa diversidad de uso que el palacio de la diversión de Price requería. Incluso otros llegarán también a auto-denominarse como "Fun Palace", como es el caso de los proyectos "Spectrum" (1968) [6E] y "The Fifth Dimension" (1969) [12A] diseñados por Keith Albarn. Ambos dispositivos se configuran como una especie de laberintos sensoriales utilizados como atracciones de ferias, que combinan su construcción en GRP, como si de grandes naves espaciales recién aterrizadas se trataran, con una serie de dispositivos ambientales como juegos de espejos, cambios de color, proyecciones interactivas y juegos de sonidos que aparecen según el visitante avanza por sus salas tubulares.

En 1962, Ken Isaacs presenta un prototipo de "Knowledge Box" [1C], una caja de madera con proyecciones en su interior con el fin de sustituir a la tradicional aula de estudio, generando un ambiente mucho más visual e interactivo en el que se compaginan las proyecciones visuales con el audio para una intensificación del aprendizaje.

"Dentro de la Knowledge Box, solo y tranquilo, el estudiante ve una procesión rápida de pensamientos e ideas proyectadas sobre las paredes, el techo y el suelo en un panóptico de imágenes, palabras y patrones de luz, dejando a la mente concluir por sí misma la conexión entre ellas." ${ }^{\text {"600 }}$ (Ken Isaacs, 1962, p.109) 596 El "Fun Palace" tiene una versión más modesta para Camden de 1964 y un prototipo construido denominado como
"Inter-action Centre" en 1972. Ver:

PRICE, Cedric. Fun Palace, Camden, London. En: AD The Architectural Design, noviembre 1967.

PRICE, Cedric. Inter-Action Centre. En: RIBA Journal, noviembre 1977.

597 Publicado en la revista de Archigram y más tarde en "The Architectural Design":

Archigram, Magazine Issue $n^{\circ} 6$, p.2.

PRICE, Cedric. Cedric Price Suplement. En: AD The Architectural Design, octubre 1970. pp.507-522.

598 Ambos proyectos, "Dronten Agora" y "Summerland", aparecen publicados en la revista "Design" bajo el sobrenombre de "Ambientes cerrados para un espacio habitable":

HUGHES-STANTON, Corin. Closed environment for living space. En: Design, n²41, enero 1969. pp.40-49.

599 WALKER, Derek (editor invitado). AD The Architectural Design Profile, n52, Animated Architecture, 1982.

600 "Inside the knowledge box, alone and quiet, the student would see a rapid procession of thoughts and ideas projected on the walls, ceiling and floor in a panoply of pictures, words and light patterns, leaving the mind to conclude for itself"

WELCH, Paul. The Knowledge Box. En: LIFE, 14 septiembre 1962. pp.109-112. 
El objetivo de Isaacs no es sólo aprovechar el desarrollo de la tecnología visual para utilizarla en labores pedagógicas sino también generar un ambiente de sobre-estimulación visual y auditiva que intensifique la percepción del alumno en relación a los nuevos medios virtuales de comunicación.

Ya sea a través de sistemas de relajación o sobre-estimulación, las estrategias virtuales de generación ambiental a partir de luz, sonido y proyecciones, se presentan como alternativas de futuro para la intensificación de nuevos usos, a partir de una amplia perspectiva que abarca desde lo educativo al ocio más desenfadado. Algunas propuestas de hibridación de actividades que relacionan el ocio con los ambientes virtuales aparecen en gran parte de los proyectos de Archigram, en los que estos sistemas se presentan como fundamentales en la definición del espacio arquitectónico, más allá de los elementos constructivos que los definen. "Hendrix Interior Mónaco" [9B], "Holographic Scene Shelter" [10B] o "Instant City IC Holographic Set", todas ellas de 1969, se convierten en imágenes fundamentales para la definición de proyectos como "Features Montecarlo" e "Instant City". En ambos, la generación espacial de ambientes con actividades concretas depende de tecnologías supeditadas a la construcción de imágenes virtuales como son la holografía o la proyección, combinadas con pequeños artefactos de equipamiento básico como gradas, escenarios o zonas de servicios, todas ellas utilizadas ya por esa época en conciertos de rock y eventos comerciales de toda índole. Otras investigaciones Ilevan al grupo austríaco Zünd Up a diseñar un simulador de lluvia y condiciones extremas de conducción en su distopía automovilística "The Great Vienna Auto-Expander" de 1969 [10D] o a José Miguel de Prada Poole a proponer un sistema de proyecciones, audio e incluso olores que intensificara la experiencia de la pista de patinaje "Hielotron" [17A], construida en Sevilla en 1973, bajo un sistema de cúpulas y pasillos neumáticos ${ }^{601}$. Más allá de estos pequeños simulacros, la generación ambiental derivada de los grandes espectáculos encontrará un cómplice perfecto en un nuevo tipo arquitectónico de ocio en ciernes desde mediados de los años cincuenta: la discoteca.

El concepto "Discotheque"602, aparece por primera vez en París en 1941 como contracción de las palabras "Disco" y "Bibliothèque", en "La Parisien. La Discotheque". La transferencia cultural después de la II Guerra Mundial y la globalización de estilos musicales como el "Rock\&Roll" y el estilo "Yé-yé" hará que esos nuevos lugares se expandan rápidamente por todo el mundo occidental.

\begin{abstract}
"Un nuevo tipo de ambiente, que no es sólo el club de noche, sino un lugar de reuniones, exposiciones y otros eventos. Es un nuevo tipo de espacio, continuamente roto y modificado por efectos de luz, un espacio ilusorio creado a partir de los dispositivos, proyectores, reflectores, así como la música es creada por instrumentos: un espacio que existe sólo cuando está en acción." ${ }^{.603}$ (Restany, 1967, p.43)
\end{abstract}

601 Según conversación con Prada Poole, dicho sistema nunca se llegaría a construir, no por viabilidad técnica, sino por ser considerado como innecesario por el constructor.

602 ORTIZ, Lori. Disco Dance. ABC-CLIO Lcc. Santa Bárbara. 2011.

603 "Un nuovo genere di ambiente, che non è solo night-club, ma luogo di reunioni, mostre, happenings. E un nuovo genere di spazio, continuamente rotto e modificato dagli effeti di luce, uno spazio illusorio creato dagli apparecchi, proiettori, riflettori, come la música è creata dagli strumenti: uno spazio che non existe se non quando è in azione"

RESTANY, Pierre. Breve storia dello stile yéyé. En: Domus, n446, enero 1967. pp.43-40. 
Esta definición de la "discoteca" hecha por el crítico de arte Pierre Restany bien podría ser la misma que Cedric Price quería para su "Fun Palace". A partir de mediados de los años sesenta, las discotecas se convierten en centro de atención de arquitectos interesados por esta arquitectura virtual, convirtiéndose en concentradores de experimentos espaciales con luz, proyección y sonido.

Ya en 1965, la discoteca "Voom Vomm" de Saint Tropez [3A], diseñada por Paul Bertrand, incorpora dos grandes estructuras de acero inoxidable, con superficies reflectantes giratorias iluminadas por varios proyectores de luz, diseñadas por Nicolas Schöffer, las mismas que el artista francés había imaginado para su ciudad "Espacio-dinámica". En Estados Unidos, los avances en holografía ${ }^{604}$, hologramas ${ }^{605}$ y otros sistemas de reproducción audiovisual, se unirán a la contracultura para la consolidación de estos ambientes discotequeros. "The Electric Circus II" [11C], situado en St.Mark's Place de Nueva York, será remodelado en 1969 por los arquitectos Gwathmey \& Henderson, transformando todo el espacio en superficie de proyección, de manera que el show lumínico se convierte en el único espacio posible, que desaparece cuando éste termina. En la escena neoyorquina destaca también el club "Cerebrum"606 [9A], diseñado en 1969 por John Storyk ${ }^{607}$, convirtiéndose en un lugar alternativo en el que se ofrecían experiencias sensoriales. No se servían bebidas ni comida, sólo espectáculos visuales y auditivos interactivos con juegos de proyecciones, estructuras hinchables, dibujos de patrones geométricos e incluso unas túnicas blancas que los visitantes tenían que ponerse a la entrada.

También en Italia, la discoteca atrajo el interés de varios grupos de jóvenes arquitectos, estandarte de la "Architettura Radicale"608. En 1966, los miembros de grupo Strum, Pietro Derossi, Giorgi Ceretti y Riccardo Rosso, diseñarán el "Club Piper" de Torino [3B], de nuevo un híbrido entre night-club, galería de arte, sala de conciertos y happenings, un anticipo de su posterior "L'Altro Mondo Club" (1967) en Rímini [4D]. El edificio, una gran nave industrial a las afueras de la ciudad, se reconvierte en discoteca a partir de una rampa de entrada iluminada con luz rosa como si de un efecto de supergráfica se tratara. La gran pista central se equipa con gradas móviles de butacas en materiales plásticos y torres de iluminación, proyecciones y sonido, como cualquiera de los proyectos de equipamiento efímero de Archigram, con un techo de aluminio reflectante ${ }^{609}$ que aumenta la percepción de espacialidad y distorsión de la zona de baile. Superstudio diseña en Florencia, el "Night Club Mach2" " 10 en 1969 [10C], un pequeño espacio configurado a través de unas bandejas

604 Destacando los estudios de combinación del rayo láser con hologramas desarrollados por el Dr.Emmeth Leith y Juris Upatnieks en la Universidad de Michigan de 1962 a 1967.

605 Tecnología inventada por el científico y futurólogo Dennis Gabor en 1947.

606 La fama de lugares como "Cerebrum" les hace ser publicados en revistas de la talla de Life:

BARTHEL, Joan. A teetotal night club where personal experience is all. En: LIFE, 4 abril 1969. pp.28-29.

607 Arquitecto por Princeton que más tarde diseñó el "Electric Lady Studio" de Jimmy Hendrix.

608 NAVONE, Paola; ORLANDONI, Bruno. Architettura Radicale. Documenti di Casabella. Casabella. Milán, 1974.

609 El proyecto será publicado en Enero de 1968 en Domus por primera vez y dos meses más tarde como imagen de la marca de ese techo metálico, debido a la gran popularidad que alcanzó el proyecto:

TRINI, Tommaso. Divertimentifici. En: Domus, n458, enero 1968. pp.13-22.

Publicidad de los paneles “Metalsadi”. En: Domus, n460,marzo 1968.

610 SUPERSTUDIO. Libreria Marzocco, Florence; Boutique Domitilla, Florence; Night Club Mach 2, Florence. En: Domus, n473, abril 1969. pp.25-30. 
perforadas metálicas de iluminación en color rosa dispuestas por el techo. Dicho sistema y unos raíles en las paredes también iluminados, en tonos rojos y amarillos, serán los únicos elementos que construyen un espacio distorsionado en el que sólo es posible la orientación a partir de ellos, unos elementos que te direccionan hacia el aseo, la entrada, la barra o el DJ. También el mismo año, el grupo italiano 9999, formado por Giorgio Birelli, Fabrizio Fiumi, Paolo Galli y Carlo Caldini, éste último a la vuelta de su viaje en 1968 a Estados Unidos con una Beca Fullbright, diseña el "Space Electronic", influenciados por night-clubs norteamericanos como "The Electric Circus" y el viaje a Las Vegas de Caldini.

\author{
"¿Por qué Las Vegas? \\ Porque queremos apropiarnos del instrumento que la genera como un medio para \\ proyectar.
}

Se puede diseñar con electricidad." ${ }^{111}$ (Caldini, 1969, p.100)

De manera casi simultánea a los estudios de Venturi y Scott-Brown para su curso sobre Las Vegas, Caldini quedará fascinado por esa posibilidad de construcción de ambientes sólo con electricidad, con la luz y el sonido como protagonistas, dejando al resto de elementos arquitectónicos como mero soporte. "Space Electronic" puede considerarse casi como un proyecto-manifiesto del grupo. Un lugar que capitalizará el ambiente de arquitectura radical florentina al convertirse en sede del "S-Space" [13D] o "Separate School for Expanded Conceptual Architecture", iniciado en 1970 por 9999 y Superstudio como lugar de discusión y trabajo, un anticipo de lo que luego resultarán los encuentros "Global Too/s"612.

"S-Space es un lugar no físico de producción, elaboración y transmisión de ideas, procesos, eventos, apariciones, profecías, recuerdos, situaciones, existencias.

"S-Space es experiencia y un catalogo para la generación de una arquitectura conceptual, expandida, imposible, imaginaria y reflexionada.

S-Space es un sistema global teórico-práctico, de didáctica experimental para el afianzamiento de estrategias mentales" 613 (9999; Superstudio, 1971, p.55)

611 "Perché Las Vegas?

Perché ci interessa appropriarci dello strumento che la crea come mezzo di progettazione. Si può progettare con l'elettricità" 9999. Las Vegas. En: Casabella, n³39/340, Arredo Urbano, julio-agosto 1969. p.100-103.

612 En la publicación del 12 de Enero de 1973 del encuentro "Global Tools" de Florencia, el "Space Electronic" aparece como "La Sede"

Global Tools. En: Global Tools, 12 enero 1973. pp.7-8.

613 Extracto del anuncio del S-Space publicado en Domus:

"S-Space é un luogo non físico di produzione, elaborazione e trasmissione di idee, processi, eventi, apparizioni, profezie, ricordi, situazioni, esistenze.

S-Space é esperienza e catalogo per l'architettura concettuale, espansa, impossibile, immaginaria e riflessa.

S-Space è un sistema globale teorico-pratico di didattica sperimentale per l'affinamento di strategie mentali"

S-Space information. En: Domus, n496, marzo 1971. p.55. 
El "S-Space" adquiere en 1971 el formato de festival de arquitectura con sede en Florencia. Superstudio presenta en él su film "Vita, morte e miracoli dell'architettura" junto al trabajo de otros arquitectos italianos como UFO, Gianni Pettena o Ugo La Pietra, así como de los británicos Street Farmer o los norteamericanos Ant Farm, evento comentado por el crítico germano Celant en Domus ${ }^{614}$ en 1972. De esta manera, la discoteca no sólo se consolida como tipo arquitectónico en auge, sino como contenedor de eventos y círculos de debate arquitectónico. "Space Electronic ${ }^{615 " ~ a p a r e c e ~ r e f e r e n c i a d o ~ e n ~ l a ~ p r e d i c c i o ́ n ~ d e ~ J i m ~ B u r n s ~}$ "Arthropods" (1972) y "L'Altro Mondo Club" en la de Peter Cook "Experimental Architecture" (1970), ambos expuestos como lugares referenciales de pensamiento arquitectónico.

\section{Experimentaciones ambientales sensoriales. Del espacio artístico al arquitectónico.}

La transferencia de estrategias y herramientas entre arte y arquitectura a partir de los años sesenta tiene una gran influencia en esas arquitecturas virtuales en torno a la generación ambiental. Muchos ejemplos de experiencias artísticas tendrán sus correspondientes experiencias arquitectónicas derivadas.

En 1966, Lucas Samaras expone en el Albright-Knox Art Gallery, su obra "Mirrored Room" [3C], una sala en la que todos los elementos, paredes, suelo, techo e incluso los objetos de mobiliario, están recubiertos de material reflectante de espejo, de manera que todo se refleja en todo y todo refleja todo al mismo tiempo, sugiriendo un espacio infinito, homogéneo a la vez que confuso. El mismo efecto espacial había sido ya utilizado un año antes por Yayoi Kusama para "Peep Show"1616, una sala hexagonal también recubierta de espejos a la que la artista japonesa superpone un techo de bombillas que se convierte en el patrón de repetición del espacio infinito generado por los espejos. Ambas piezas representan un ambiente monumental por sus ilimitadas proporciones y a pesar de sus reducidas dimensiones, un tipo de espacio que utilizarán en algunas de sus maquetas los alumnos de Leonardo Savioli en su curso "Spazio di Coinvolgimento" de 1966 a 1967. Años más tarde también los miembros de Archizoom lo adaptarán para las representaciones volumétricas de "No-Stop City," y su búsqueda de una utopía de la cantidad. De nuevo, el recurso de espacio infinito de espejos confrontados sirve de base a Andrea Branzi para desarrollar la propuesta "Interno Urbanistico" (1978) y a Superstudio en la maqueta del proyecto "Supersuperficie" para la exposición de 1972 "Italia: the New Domestic Landscape". Sin embargo, será el japonés Shiro Kuramata quién en 1969 lo incorpore a un ejemplo construido en el diseño de la "Boutique Edwards" [8E], un pequeño espacio cuadrado rodeado de espejos con cuatro estanterías construidas con neones y un pequeño ascensor de vidrio en el centro. En ella, el comprador asciende para encontrarse frente a un bosque de neones construido a partir de

\footnotetext{
El anuncio del "S-Space" también aparece en otras revistas italianas de arquitectura y diseño como Casabella:

S-Space. En: Casabella, n³56, Autori e Autoria, mayo 1971. p.25.

614 CELANT, Germano. Sulla scena dello S-Space. En: Domus, n509, abril 1972. pp.44-45.

615 El Space Electronic aparece por primera vez publicado en Casabella en 1971:

9999. Space Electronic, environment audiovisivo. En: Casabella, n³56, Autori e Autoria, mayo 1971. pp.46-49.

616 Como texto de referencia de ambos proyectos se ha consultado:
}

BATTCOCK, Gregory. Minimal Art: A Critical Anthology. University of California Press. Los Ángeles, 1968. 
la repetición de los mismos en los espejos perimetrales, generando así un efecto espacial ilimitado en un espacio de exposición verdaderamente angosto. Un efecto parecido será experimentado por Ugo La Pietra en "Caledoscopio" [6B], el probador de la boutique "Altre Cose" diseñada en 1968, en el que utiliza tres superficies de espejo y una supergráfica con motivos luminiscentes que simulan los escenarios oníricos de Kusama. El mismo Kuramata también reinterpreta otras simulaciones ambientales ya experimentadas en otras prácticas artísticas como el teatro. Aprovecha la idea de no gravedad de la performance de 1971 "Walking on the wall", de Trisha Brown, en la que varios actores son sujetados por arneses y cables blancos al techo y simulan andar y bailar por las paredes blancas de una sala. De una manera más sofisticada, Kuramata consigue en "Textile Showroom" [18A] de 1974, la ingravidez total de las telas expuestas a partir de un sistema de imanes situados en las prendas y en el techo. Al estar las prendas sujetas al suelo por delgados cables pintados de blanco nunca llegan a unirse totalmente, consiguiendo que las mismas graviten en el espacio sin ningún tipo de sujeción, al camuflarse el cable con el color blanco de toda la sala.

La idea de una malla regular de elementos de luz que pueda ser distorsionada sobre la que investiga el artista italiano Gianni Colombo en "Spazio elastico" (1968) [5E], será utilizada por los norteamericanos PULSA ${ }^{617}$ en "Yale Golf Course Electronic Event" (1969) [12D] en un intento de "confrontar la actividad tecnológica de la ciudad con la estructura psíquica de la misma"1618. También Enzo Mari trabajará con una malla tridimensional de luz, aunque esta vez a partir de un cubo de 64 puntos de luz, con 64 interruptores, generando así figuras volumétricas en el espacio según sus posiciones de apagado/encendido. Ese mismo proceso es utilizado a escala urbana por Allan Wexler en "Proposal for Manhattan Skyline" de 1973 [17E]. El arquitecto norteamericano diseña un protocolo por el que los trabajadores del World Trade Center podrán cambiar la imagen del edificio y convertirlo en cualquier otro con la utilización del apagado y encendido de la luz de sus ventanas. Así es como a partir de la malla homogénea de los huecos de la fachada se transforman las torres en monumentos como la Torre Eiffel o el Taj Mahal, en otros rascacielos de la ciudad como el Empire State, cambiar su forma a placer o convertirse en un edificio anuncio simplemente con un efecto de luz, cambiando de esta manera no sólo el ambiente lumínico de la ciudad, sino la manera en que el edificio construye el paisaje urbano a través de su skyline.

"Antes de salir de la oficina cada tarde, consulte su calendario, dejando las luces encendidas si la palabra ON corresponde a esa fecha, o apagadas si por el contrario es la palabra OFF la que aparece. Los días de luces apagadas, la cortina tendrá que permanecer también cerrada.

Su cooperación ayudará a crear cambios excitantes en el skyline de la ciudad de Nueva York" ${ }^{\prime 19}$ (Allan Wexler, 1973, p.465)

617 Un grupo de arquitectos, ingenieros y artistas que trabajaban sobre la generación de ambientes industriales, urbanos y naturales.

618 PULSA. The City as an Artwork. En: KEPES, Gyorgy. Arts of the environment. Brazilier. Nueva York, 1972. pp.208-221.

619 "Before leaving your office each evening, consult your calendar, leaving lights on if ON corresponds to that date, or off if the word OFF appears. OFF lights must remain on during an off evening, close curtains.

Your cooperation will help create exciting changes on the New York City Skyline"

WEXLER, Allan. Proposal for Manhattan Skyline. World Trade Center Evening. En: AD The Architectural Design, agosto 1974. p.465. 
En 1969, Friedrich St.Florian, arquitecto austríaco y profesor de arquitectura en la Rhode Island School of Design, diseña una instalación lumínica para el Moderna Museet de Estocolmo, "Imaginary Space" [11E], uno de los experimentos de lo que denomina como "Arquitectura imaginaria".

"El espacio sintético y la arquitectura imaginaria, aquella que existe cuando es activada con algún propósito, tomarán el puesto de la arquitectura construida y permanente. ${ }^{n 620}$ (St.Florian, 1970, p.52)

En la instalación, ese propósito del que habla St.Florian, será la propia presencia de los visitantes en la muestra, que al entrar a la sala donde se expone "Arquitectura imaginaria", activan un láser de helio-neón, que combinado con un sistema de espejos genera un volumen geométrico complejo construido sólo con la propia luz y la interacción del visitante. St.Florian también aborda la necesidad de que dicha instalación pudiera "no sólo ser activada sino manipulada por el propio usuario"621, por lo que realizará investigaciones en torno a la creación de un simulador espacial de luz, a partir de un "Imaginary Ceiling", compuesto por dos láser de 15 megawatios y un sistema de 45 reflectores móviles que pueden ser programados para generar varias configuraciones del techo de una sala de exposiciones. Esa misma interacción con el usuario, es también propuesta en la misma exposición por Raimund Abraham con "Zip-Zones" [10E], una instalación con volúmenes triangulares descendentes entre los que los usuarios pueden pasear, activando una serie de células fotoeléctricas a su paso y un sonido "Zip" distinto en cada una de las posiciones. De esta manera, el espacio se construye a través de los volúmenes existentes y la interacción y situación espacial de los usuarios, codificada a través de una serie de sonidos concretos. Esta búsqueda de "la cuarta dimensión de la arquitectura"622 es también desarrollada en la instalación "Hyperspaces" [11B] en la Architectural League of New York (1969), junto al técnico de sonido Gerald Shapiro, una concatenación de tres espacios con ambiente lumínico constante, una serie de volúmenes de plexiglás camuflados en un ambiente difuso y asociados a una serie de sistemas de sonido que varían según la cercanía del usuario a ellos.

Otro tipo de experiencias trabajarán con ambientes lumínicos construidos a partir del color, "Spaceplace" (1967) [5C] o "Colourspace" (1972) [16D], diseñados por Maurice Agis y Peter Jones, o cualquiera de los ambientes diseñados con luces de colores estridentes por Verner Panton, como grandes referentes. Todas ellas encontrarán sus alter-ego arquitectónicos, en los nuevos sistemas de ambientes lumínicos ofertados por las casa comerciales de iluminación como el "Dispositivo Architettonico" [17D]. Dicho sistema de iluminación diseñado conjuntamente por Christian Germanaz en colaboración con la Societtà Elettrica, dispone de una serie de elementos en el techo que pueden ser manipulados a partir de una combinación de cuatro colores de iluminación y varias posiciones, generando así a una diferenciación de ambientes lumínicos según las actividades que se desarrollen en la vivienda, combinaciones similares a las demandadas por Nanda Vigo en "Ambiente Cronotopico Vivibile" de 1967 [4B].

620 "Spazio sintetico e architettura immaginaria, quella che existe solo quand'è attivata per qualche scopo, prenderanno il posto della architettura costruita e permanente"

NATALINI, Adolfo. Imaginary Architecture. En: Domus, n491, octubre 1970. pp.49-53.

621 ST. FLORIAN, Friedrich. Immaginary Architecture. En: AD The Architectural Design, noviembre 1970. p.541.

622 ABRAHAM, Raimund. Hyperspaces. En: AD The Architectural Design, julio 1969. pp.383-384. 
En 1965, Gio Ponti relata fascinado los juegos con proyecciones sobre las paredes y tres balones-lámpara regalo de Noguchi, que él, los Eames, el crítico de arquitectura Joseph Rykwert y el galerista Sam Kaufman, realizaron en una velada nocturna desarrollada en su propia casa denominada como "/l gioco del Pallone" [2D].

"Proyectábamos diapositivas sobre un trozo de muro, alguno, quizá Joseph Rykwert robó un proyector, la imagen saltó sobre los muros, debajo de los muebles, sobre el balón enorme; sobre los muros aparecieron ventanas que hacían entrar el sol, y sobre el balón lo hacían desaparecer y las imágenes se separaban de la pared. Un prodigio...

... Las paredes se convirtieron en aire, campos, agua..." ${ }^{623}$ (Gio Ponti, 1965, p.52)

De una manera mucho menos prosaica, C. Ray Smith, descubre en la proyección de imágenes un recurso formal de gran potencia, tanto en su uso en interiores como exteriores, estrategias que define como "Instant Interiors" e "Instant Exteriors".

"Después de la comida instantánea, el sueño y los sueños instantáneos, los ambientes son un producto de nuestra era instantánea. Interiores instantáneos: ¿Por qué no?" ${ }^{24}$ (C.Ray Smith, 1967, p.178)

En varios artículos publicados en Progressive Architecture de 1967 y 1968, C.Ray Smith evidencia no sólo la capacidad transformadora de esta operación, sino su carácter móvil, sistemático, transformable y efectista, ya sea en el salón de tu casa o en la fachada de un edificio de oficinas. Esa capacidad transformadora será experimentada por Smith a través de una serie de experiencias con proyectores realizadas en 1967 en su propio apartamento de Nueva York. En "Instant Interiors Apartment with the Sistine Chapel" [5A] superpone una imagen de la capilla Sixtina al espacio de comedor haciendo coincidir una cenefa decorativa de la habitación con la de la capilla italiana de manera que el espacio de la sala se continúa en el del edificio histórico. En "Instant Interiors Apartment with the Guggenheim Museum" [4A], una imagen del lucernario del Museo Guggenheim parece construir un nuevo lucernario en el salón. En "Instant Interiors Apartment with the Niagara Falls" [4E], incorpora sutilmente una imagen de las cataratas del Niágara a la pared de su chimenea, convirtiéndose en una especie de papel, lo que le lleva a denominar estas estrategias como el nuevo "Electric Wallpaper" o "Papel Pintado Eléctrico". Todas estas experiencias derivan de trabajos artísticos, como los de Thomas Wilfred y Earl Reiback para "Lumia"625 o Josef Svoboda para

623 "Proiettavamo delle diapositive su un tratto di muro: qualcuno, chissà, Joseph Rykwert urtò il proiettore, l'immagine saltò sui muri, sopra i mobili, sul pallone enorme: sui muri aperse le finestre, fece entrare il sole, sul pallone, lo fece scomparire e le immagini si separano dalla parete. Un prodigio...

... Le parete diventanva aria, campi, acqua..."

PONTI, Gio. // Gioco del pallone. En: Domus, n427, junio 1965. pp.52-53.

624 "After instant food, instant sleep and instant dreams, now turned-on environments are a product of our instant age. Instant Interiors: Why not?"

SMITH, C. Ray. Instant Interiors. En: PA Progressive Architecture, junio 1967. pp.176-179.

625 Aunque Thomas Wilfred murió en 1968, en 1971 el MOMA exhibió una gran retrospectiva de sus trabajos relacionados con el uso artístico de la luz principalmente desarrollados a principios de los años sesenta: 
"Laterna Magika"626. Incluso las imágenes de Smith serán llevadas por Jack Lenor Larsen a la New York Home Fashions League para intentar la comercialización de este nuevo tipo de decoración interior más acorde con nuestra era mcluhaniana.

"Esta nuevo método cinético, flexible, modificable de generar ambientes contiene un mensaje significativo para la era espacial. Su carácter inclusivo, todas las alusiones a las épocas pasadas de nuestra vida visual e incluso todos los materiales a nuestra disposición, produce ese "todo de una vez" que describió McLuhan"627 (C. Ray Smith, 1977, p.303)

A pesar de que otros arquitectos como Archigram habían experimentado también con proyecciones, bien de manera totalmente técnica como Dennis Crompton en 1968 en [5D] "Media Experiments", una investigación sobre las maneras de expandir el sistema de televisión para generar hibridaciones con el resto de la vivienda, o de una manera mucho más poética, como St.Florian en "Himmelbett" (1971-1974) [16C], proyecto que representa un gran salón adornado con el holograma de un cielo en el techo, será Ray C. Smith quién mejor sintetice el potencial de simulación de las proyecciones tanto en el interior de la vivienda como desde una condición exterior más urbana. A su llamada sobre proyectos relacionados con su artículo "Instant Exteriors" desde Progressive Architecture, responderán en 1968 arquitectos como Dough Michels y Bob Feild, que habían experimentado en una fábrica con una serie de ambientes exteriores nocturnos, experimentado para una beca de la Washington Gallery of Modern Art relacionada con la revitalización del patrimonio industrial. Estos "Instant Exteriors" ${ }^{28}$ [8C] reproducen patrones geométricos, instantáneas de Bob Dylan o imágenes de guerra sobre los silos de la fábrica, cambiando por completo el paisaje industrial existente. El 25 de Octubre de 1968, el grupo italiano 9999, realiza un experimento de proyecciones sobre el Ponte Vecchio en Florencia, denominado como "Happening Progettuale" $629[8 \mathrm{~A}]$. Utilizando tres proyectores de diapositivas, proyectan sobre el histórico puente florentino imágenes de astronautas, nodos de autopistas de Los Ángeles de su viaje a Estados Unidos y patrones de dibujos geométricos. De esta manera los italianos también reivindican ese poder transformador de los sistemas de proyección en el ámbito urbano. Dicho potencial será también experimentado por otros como Eventstructure Research Group. En su instalación de 1970 para el Stedelijk Museum de Ámsterdam, "Cloud" [12C], construyen un globo-nube neumático con proyecciones de un cielo de día en una situación nocturna, una simulación artificial de un fenómeno atmosférico que se intensifica con una serie de cortes sonoros de ruido de viento y tormentas. Una misma simulación de fenómenos atmosféricos había sido experimentada por Höllein en el pabellón austríaco para XIV Triennale de Milán en 1968. Höllein diseña aquí una serie de pasillos en los que el usuario sea capaz de experimentar varios efectos ambientales, estar dentro de una tormenta de nieve o atrapado en medio de una multitud de gente. También St.Florian reivindica esta

"Thomas Wilfred: Lumia", MOMA Museum of Modern Art of New York, del 9 de agosto al 20 de septiembre de 1971.

626 Josef Svoboda presentará junto al director de teatro David Radok sus instalaciones multimedia "Laterna Magika" y "Polyekran" en el pabellón checo de la exposición de Bruselas de 1958.

627 "This kinetic, flexible, changeable new method of creating environment has meaningful messages for the space age. Its all-inclusiveness, all allusions to all periods to all aspects of our visual life, our physical and even our projected materials available to us, produced the all-at-onceness that McLuhan described"

SMITH, C. Ray. Supermannerism: new attitudes in post-modern architecture. 1977. p.303

628 SMITH, C. Ray. Instant Exteriors. En: PA Progressive Architecture, marzo 1968. pp.154-155.

629 Publicado en el número 339/340 de Casabella sobre "Arredo Urbano", "Mobiliario urbano":

9999. Happening progettuale. En: Casabella, n³39/340, Arredo Urbano, julio - agosto 1969. pp.98-99. 
simulación de procesos en "Amplifications of Natural Phenomena" de 1971 [16B], en el que diseña varias simulaciones de fenómenos naturales para las celebraciones del Río Charles en Boston, buscando un contraste entre la realidad urbana y la ficción de la naturaleza en su estado más salvaje, a partir de Icebergs gigantes o tormentas espectaculares. De manera inversa, el mismo St.Florian ya había planteado en "Vanishing New York" de 1970 la simulación de monumentos de Nueva York como la Estatua de la Libertad en la sabana de Suráfrica o el Monumento a Vittorio Emmanuelle en el desierto de Arizona, buscando el máximo contraste entre real y simulado para la intensificación total de la experiencia urbana naturalizada. 


\section{Capítulo7. LA MOVILIDAD COMO OPCIÓN DE FUTURO.}

La movilidad había sido un concepto o valor casi residual en cuanto a la arquitectura como disciplina autónoma se refiere. Relegada a una condición de "nomadismo", derivada de contextos de emergencia o pasados insignes, se convertirá en protagonista del pensamiento arquitectónico a partir de inicios del siglo XX. Si bien el movimiento moderno confecciona modelos urbanos dependientes de dichos sistemas, por otro lado casi nunca experimentará con la posibilidad real de nuevas "arquitecturas de la movilidad" más allá de sus experimentos urbanos con el automóvil. Serán los miembros del Team X, con Peter y Alison Smithson como principales referentes, quienes enuncien la necesidad de posicionar esa movilidad como uno de los principales conceptos de influencia para una "nueva arquitectura", una movilidad muy condicionada por la sensación onírica de libertad que el coche ofrece como sistema individual de transporte.

"La movilidad se ha convertido en la principal característica de nuestro período. Una movilidad física y social, el sentimiento de un cierto tipo de libertad... Y el símbolo de esta libertad es el automóvil."630 (Smithson, 1958, p.385)

La convergencia en el Congreso CIAM XI ${ }^{631}$ de 1959 en Otterlo (Holanda), de las teorías metabolistas y del Team $X^{632}$ refleja la importancia de la movilidad como opción global, con una predominancia de la movilidad física basada en las infraestructuras de transporte pero secundada por una serie de intercambios de energía e información, abordando estrategias urbanas derivadas de nuevos conceptos como la obsolescencia o el reciclaje.

"El Forum holandés de 1959 daba como las cuatro primeras técnicas de edificación de ciudades, que pueden hacer a una comunidad más comprensible:

1. Desarrollar los sistemas de caminos y comunicaciones como una infraestructura urbana, y comprender las consecuencias del flujo y la movilidad sobre la arquitectura. 2. Aceptar la dispersión implícita en el concepto de movilidad; repensar los modelos de densidad aceptados y la ubicación de funciones en relación con los nuevos métodos de comunicación.

3. Entender y usar las posibilidades ofrecidas por una tecnología de lo perecedero, crear un tipo de medio ambiente con diferentes ciclos de cambio para las diferentes funciones.

4. Desarrollar una estética apropiada a las técnicas y escalas operativas de la construcción mecanizada. "633 (Bayón, 1966, p.36)

630 "Mobility has become the characteristic of our period. Social and Physical mobility, the feeling of a certain kind of freedom... And the symbol of that freedom is the individually owned motor car"

SMITHSON, Allison y Peter. Mobility. En: AD The Architectural Design, octubre 1958. pp.385-388.

631 NEWMAN, Oscar (editor). CIAM '59 in Otterlo. Stuttgart, 1961.

Con contribuciones de J. Bakema, G. Candilis, G. de Carlo, J. Coderch, R. Erskine, A. van Eyck, B. and D. van Ginkel, G. Grung, H. Haan, O. and Z. Hansen, A. Josic, C. Polonyi, E. Rogers, A. Roth, A. and P. Smithson, J. Soltan, K. Tange, J. Voelcker y S. Woods.

632 RISSELADA, Max; VAN DEN HEUVEL, Dirk (editores). Team 10 1953-1981. In Search of A Utopia of the Present. NAI Publishers. Rotterdam, 2005.

633 BAYÓN, Mariano. Arquitectura y Movilidad. En: Arquitectura, n 95, noviembre de 1966. pp.31-36. 


\section{Catálogo // [La ciudad del automóvil]}

Las imágenes están referenciadas por números en la zona superior de las columnas verticales [del 1 al 20] y letras en la zona izquierda de las filas horizontales [de la A a la E].

Todas las referencias están ordenadas cronológicamente.

Referencias de imágenes del [1B] a [20D]. Cada uno de los proyectos referenciados gráficamente en el catálogo presentan antes de su nombre un código con un número en relación a su columna vertical y una letra en relación a su fila horizontal.

\section{Ejemplo:}

[7E] "Cloud 9" (1962) de Buckminster Fuller. Buscar referencia en la columna 7 y la fila E del catálogo referenciado al principio del capítulo.

[Nota]: no todos los referentes gráfico del catálogo están referenciados en el texto por lo que se recomienda una lectura del mismo antes de comenzar la del propio texto.

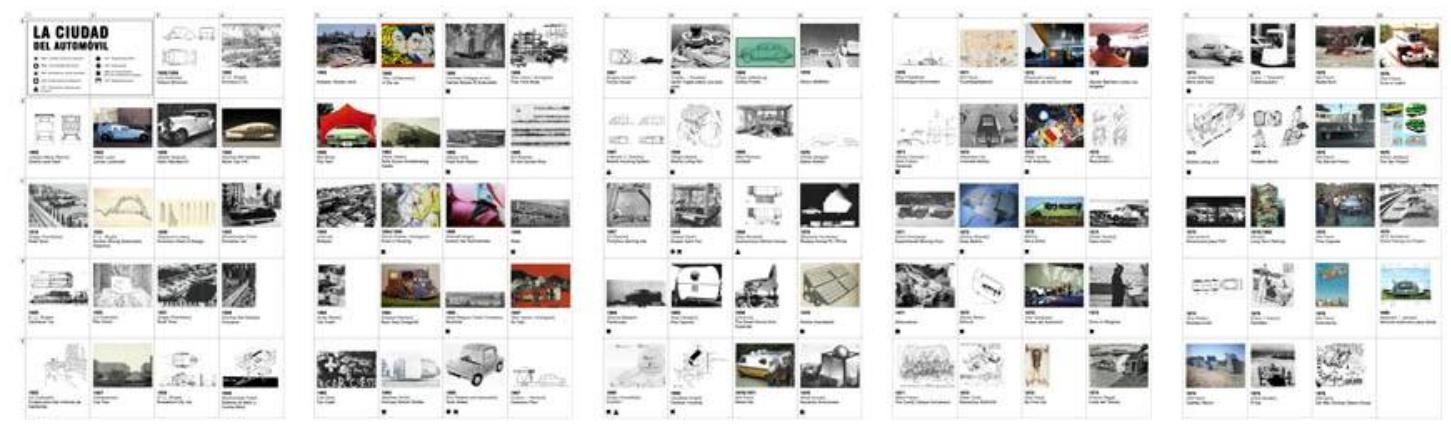




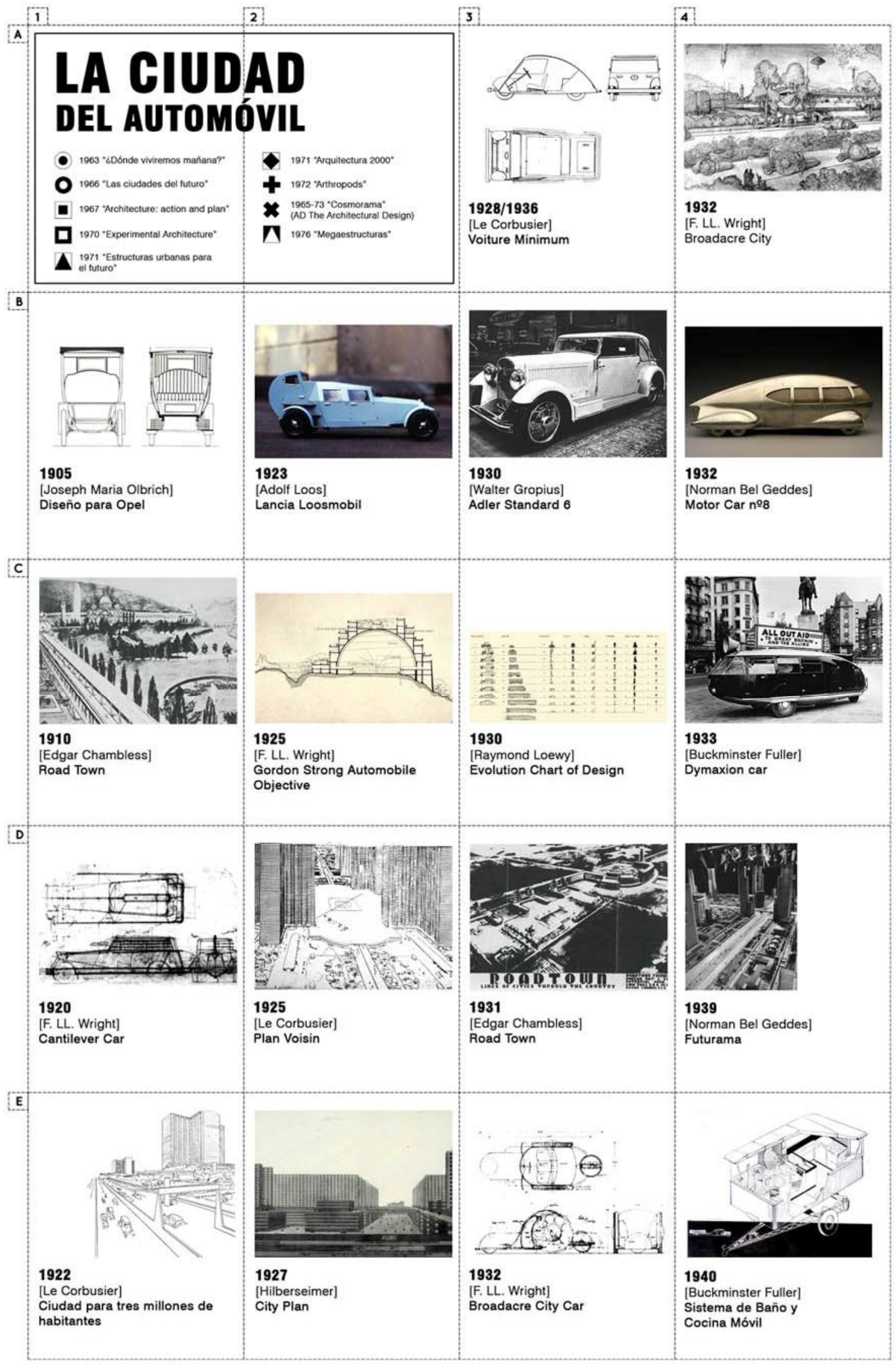




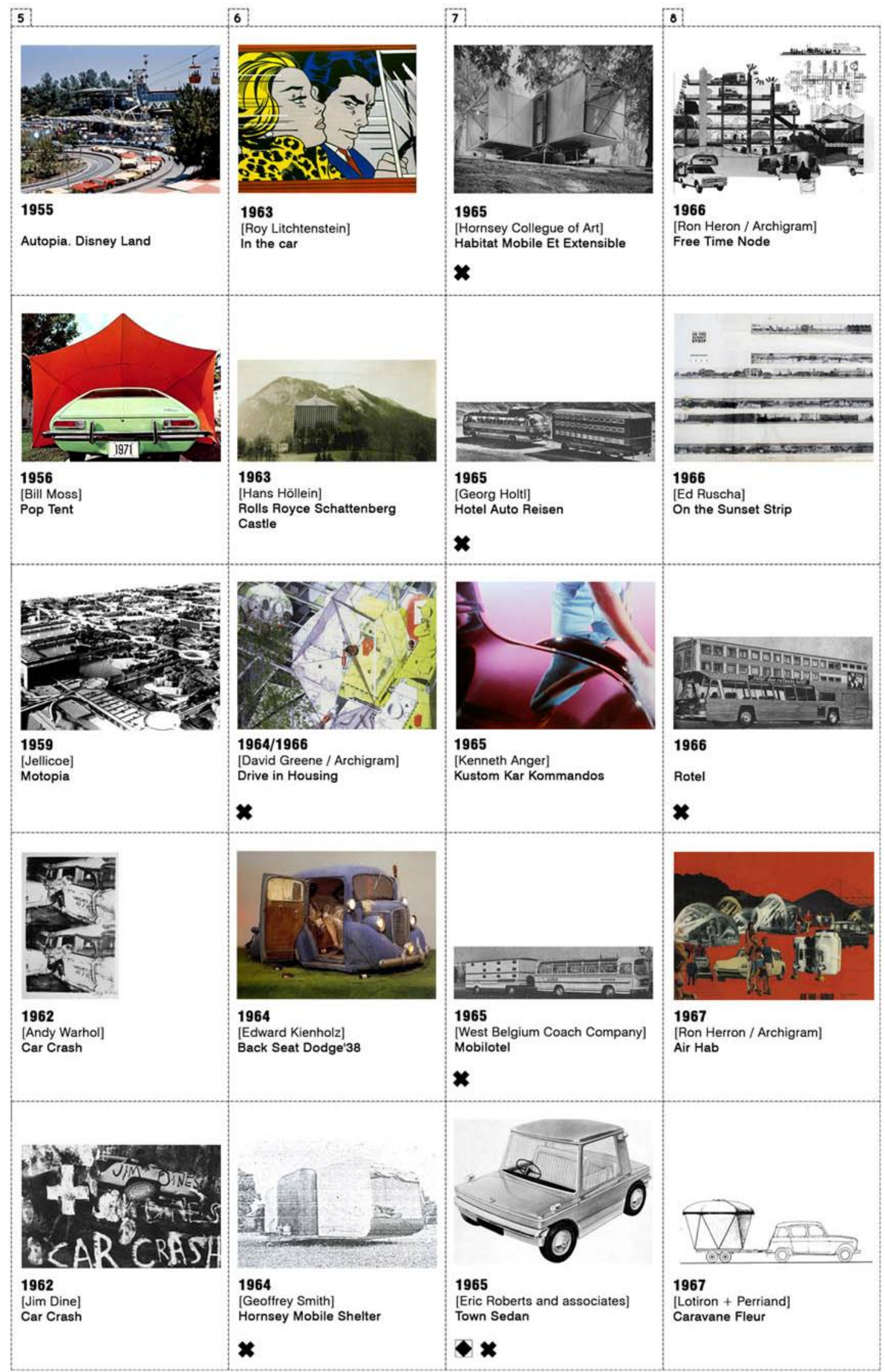




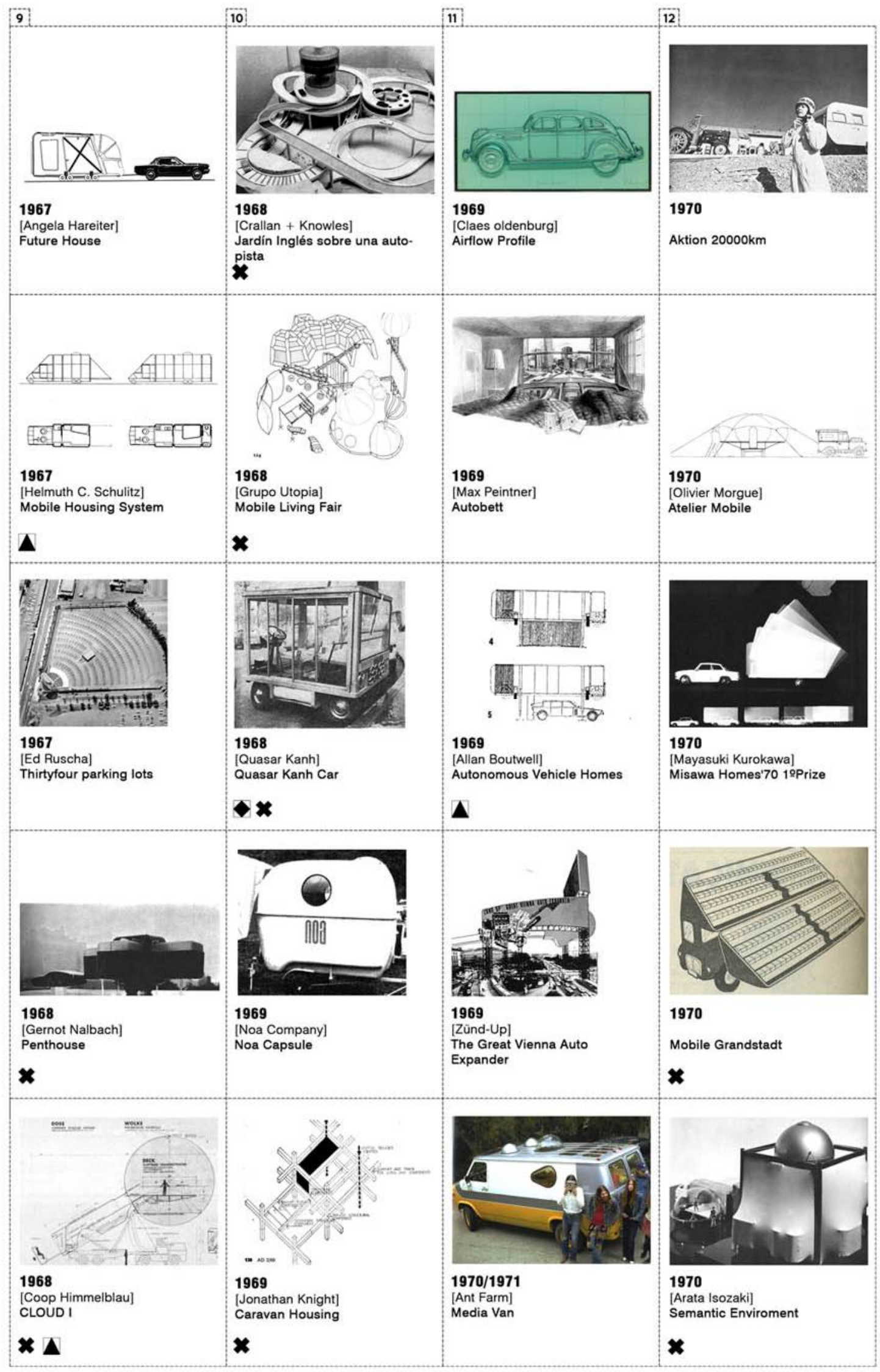




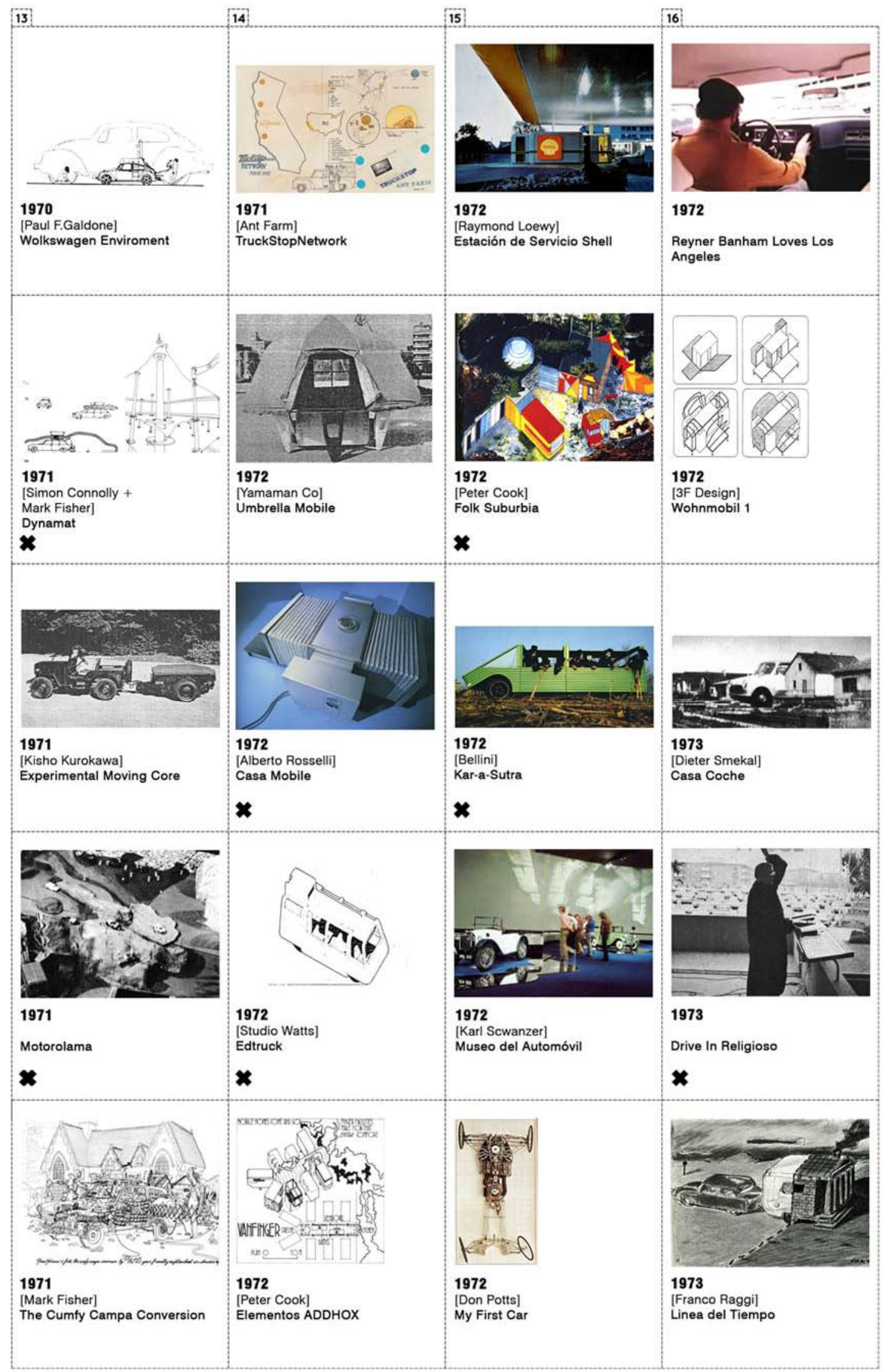




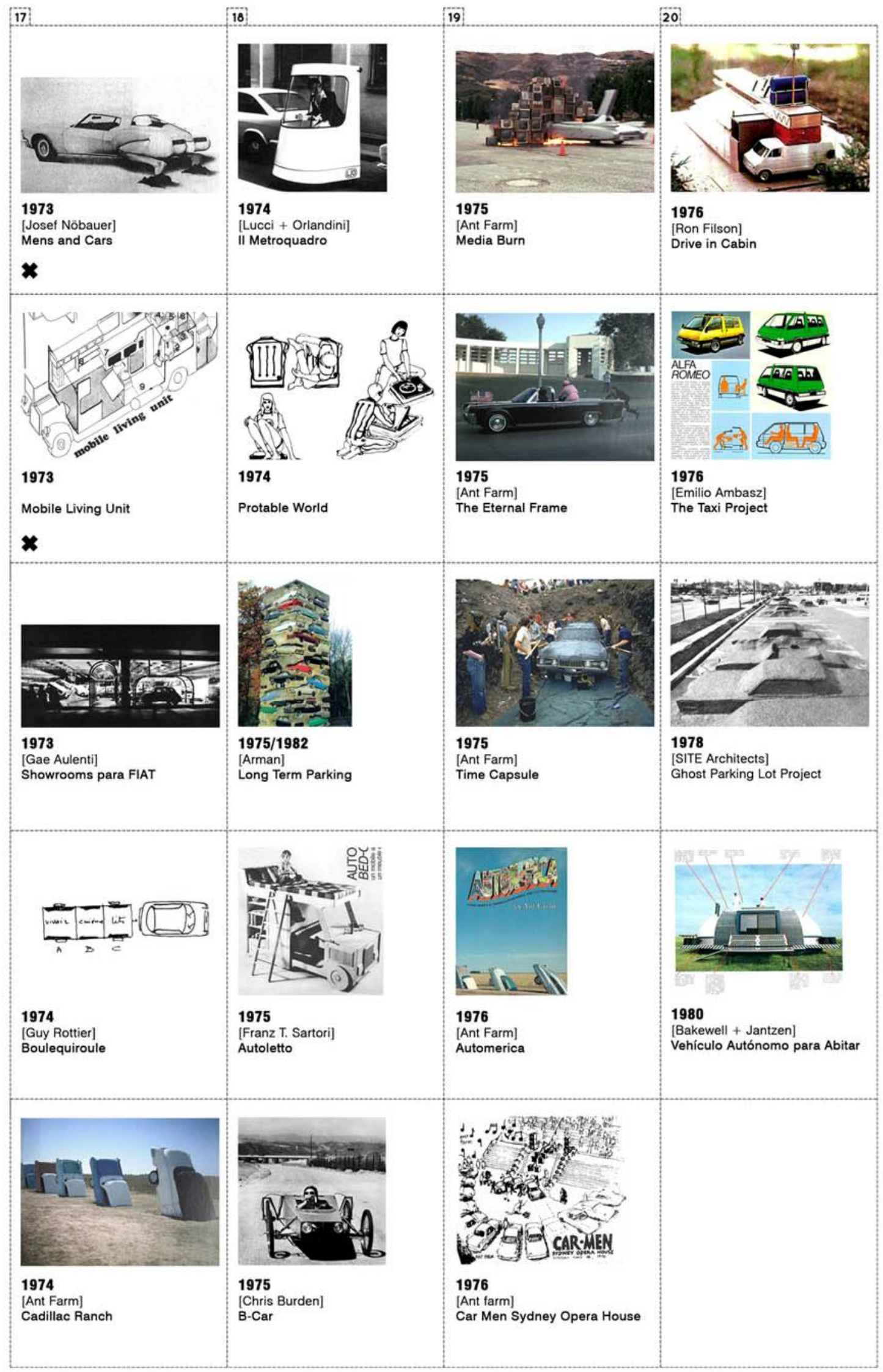




\section{[La ciudad del automóvil] El automóvil como diseñador de la ciudad.}

Desde que en 1893 Heny Ford y Karl Benz construyeran sus primeros coches de cuatro ruedas, la seducción de un gran número de arquitectos por ellos ha sido muy intensa. La fascinación por la máquina perfecta materializada en el coche, será demandada por muchos de ellos para sus arquitecturas, experimentando con todo tipo de estrategias que reprodujeran las bondades del automóvil, diseñando al mismo tiempo coches que pudieran llegar a convertirse en manifiestos de cuatro ruedas que expresaran sus ideales arquitectónicos.

\section{Arquitectos diseñando automóviles y automóviles diseñando ciudades.}

Ya en 1905, Joseph Maria Olbrich realiza algunos diseños preliminares de un futuro automóvil Opel [1B], marca para la que también diseña el proyecto de los comedores para trabajadores de la empresa. Será sin embargo a partir de la inserción del automóvil en la esfera social durante los años veinte cuando se solidifiquen los coqueteos entre arquitectos y automóviles. Le Corbusier no sólo utiliza la funcionalidad mínima del Citroën, como metáfora perfecta de su vivienda para ser producida en masa, la "Maison Citrohan" de 1923, sino que fotografía todas sus casas con vehículos de lujo delante, generando así el claro paralelismo entre máquina y arquitectura que había propagado a los cuatro vientos en "Vers une architecture" a través de las metáforas maquinistas del transatlántico, el aeroplano y por supuesto el automóvil:

"Si las casas fuesen construidas industrialmente, en serie, como los chasis, veríamos surgir rápidamente formas inesperadas, pero sanas, defendibles, y la estética se formularía con una precisión sorprendente."634 (Le Corbusier, 1923, p.105)

La "Ciudad para tres millones de habitantes" de 1922 o el "Plan Voisin" de 1925, proyecto patrocinado por la marca de automóviles del mismo nombre, eran ciudades proyectadas a la escala del automóvil, con grandes avenidas de circulación que aparecen pobladas de cientos de ellos en sus dibujos. Le Corbusier no se conforma con proyectar villas o ciudades para automóviles, sino que diseñará también "Voiture Minimum" [3A] entre 1928 y 1936, una extensión de su búsqueda arquitectónica de viviendas mínimas traducida a un vehículo para un público masivo, de dimensiones más reducidas que los existentes en su época, optimizado hasta hacerlo accesible a una clase media y obrera creciente en la Francia de los años treinta ${ }^{635}$.

También Wright mantendrá una estrecha relación con los automóviles ${ }^{636}$, fascinado por sus formas orgánicas perfectamente modeladas, llegando a escribir en su autobiografía en relación a su flamante Auburn Cord del 29:

634 LE CORBUSIER. Hacia una arquitectura. Ediciones Apóstrofe. Barcelona, 1977 (1923). p.105.

635 AMADO, Antonio. Voiture Minimum. Le Corbusier and the Automobile. The MIT Press. Cambridge, 2011.

636 FRANK LLOYD WRIGHT FOUNDATION. Frank Lloyd Wright's Automobiles. En: Quarterly 8, nº 2, 1997. 
"Lo más parecido a un coche bien diseñado que jamás había visto fuera de Europa. Y aquí me llegan los sentimientos hacia mi coche Cord, él debe ser el héroe en alguna parte de esta autobiografía...

... el mejor diseño desde mi punto de vista racional que se haya puesto en el mercado... y ciertamente parecía convertirse en mi vivienda." ${ }^{637}$ (Wright, 1943, p.411)

En 1920 el propio Wright esboza unos bocetos del "Cantilever Car", reconfigura todo el interior de su Lincoln Continental Cabriolet en 1941 e incluso diseña un prototipo de automóvil, "The Road Machine" (1932) [3E], a la medida de su modelo de ciudad de baja densidad "Broadacre City" [4A], una ciudad que sería inconcebible para Wright sin el apoyo de tres avances tecnológicos fundamentales: "la automatización de los medios de producción y venta, la radio y el teléfono como medios de comunicación y el automóvil como medio de transporte fundamenta/"638. El automóvil se convertirá en pieza fundamental de toda su arquitectura, de sus viviendas, de la misma manera que lo será también en la década de los cincuenta y sesenta en las "Case Study" californianas, y como "usuario" final en sus múltiples diseños de estaciones de servicio y en todo tipo de edificios exclusivos para los coches, desde show-rooms a drive-up de carretera.

Otros de los grandes maestros de la modernidad trabajarán también en el diseño de automóviles, Adolf Loos, con sus bocetos del "Loosmobil" [2B] para Lancia de 1923 o Walter Gropius. Los diseños de este último llegarán incluso a materializarse en la construcción del chasis del "Adler Standard 6" [3B] presentado en la Feria del Automóvil de Paris en Octubre de $1930^{639}$. El norteamericano Norman Bel Geddes diseña varias versiones de automóviles como objetos-manifiestos de sus formas aerodinámicas o "streamline" ${ }^{\text {"640 }}$, como el "Motor Car $n^{\circ} 8$ " (1932) [4B] e incluso la ciudad del futuro "Futurama" [4D], la gran sensación de la "New York World's Fair" de 1939, una ciudad completamente diseñada para los automóviles de la General Motors, empresa patrocinadora de ese pabellón del futuro. De los sistemas viarios diseñados por el norteamericano llegará incluso a publicarse un libro denominado como "Magic Motorways"641 en 1940. Geddes realiza una transferencia bidireccional directa a través del "streamline" desde los coches a la arquitectura y viceversa, ya sea en el propio pabellón que contenía "Futurama" como en sus diseños de mobiliario o viviendas. Una misma transferencia se produce también a través del término "Dymaxion" propuesto por Buckminster Fuller. El "Dymaxion Car" de 1933 [4C], el "Dymaxion Bathroom" de 1936, la "Dymaxion House" y su prototipo de 1945 "Wichita House" o el "Dymaxion Map" de 1954. Bajo un mismo término ${ }^{642}$, Fuller realiza un intercambio de propiedades como la eficacia, construcción industrializada y progreso, con el automóvil como punta de lanza de la triada, de la misma

637 "The nearest thing to a well-designed car I had ever seen outside Europe. And right here the feelings come to me the Cord should be heroic in this autobiography somewhere...

... the best design from my streamline standpoint ever put on the market... and it certainly looked becoming to my houses"

WRIGHT, Frank Lloyd. An Autobiography. Pomegranate. San Francisco, 1943, p.411.

638 WRIGHT, Frank Lloyd. Broadacre City: A New Community Plan. En: Architectural Record, nº77, 1935. p.244

639 MARGOLIUS, Ivan. Automobiles by Architects. Wiley-Academy. Nueva York, 2000.

640 Un "streamline" popularizado por su libro "Horizons":

GEDDES, Norman Bel. Horizons. John Lane. Nueva York, 1932.

641 GEDDES, Norman Bel. Magic Motorways. Random House Books. Nueva York, 1940.

642 Resultado de la interacción entre "Dynamic (dinámico)", "maximum (máxima)" y "Tension (Tensión)". 
manera que Le Corbusier hace con su "Casa Citrohan" o Geddes con el diseño a través del proceso aerodinámico "streamline". A pesar de esa transferencia de ida y vuelta, diseñadores y arquitectos utilizarán el automóvil como un anhelo de perfección y evolución, como un referente hacia el que debieran tender sus diseños y arquitecturas como bien explicita el diseñador Raymond Lewis en su diagrama "Evolution Chart of Design"643 de 1930 [3C].

Durante la segunda mitad del siglo XX, la relación automóvil-arquitecto sigue siendo muy estrecha y estos últimos, junto a diseñadores de mobiliario y producto continuarán intentando generar plusvalías en el diseño de los mismos, en este caso buscando una relación menos agresiva con el espacio público peatonal, al que el automóvil ya había casi fagocitado. Así es como aparecen propuestas para automóviles urbanos de una o dos plazas, que ocupen menor tamaño y optimicen su uso exclusivamente urbano. "Town Sedan"644 (1965) [7E] de Eric Roberts and associates, "Quasar Kanh Car"1645 (1968) [10C] o "II Metroquadro"646 (1974) [18A] diseñado por Roberto Lucci y Paolo Orlandini, son algunas de esas propuestas, que tuvieron durante finales de los sesenta y principios de los setenta una gran repercusión en revistas de arquitectura. Arquitectos diseñando automóviles que mejorarán la ciudad ya diseñada por y para el automóvil ${ }^{647}$, muchas de ellas derivadas de utopías automovilísticas radicales generadas durante la primera mitad del siglo XX, desde las varias versiones de "Road Town" (de 1910 y 1931) [1C] [3D] del norteamericano Edgar Chambless a la icónica "Motopía" (1959) [5C], del británico G.A. Jellicoe, de la cual se llega a publicar un libro homónimo ${ }^{648}$. Ambas propuestas se fundamentan en una neo-ciudad jardín de edificios bajos en los que los automóviles circulan sobre las cubiertas, que incluso en "Motopía" serán deformadas para convertirse en rotondas, demostrando así la supremacía absoluta del automóvil como referente principal para el diseño de la ciudad.

Esa predominancia del automóvil en la ciudad se manifiesta también en una serie de usos asociados de manera exclusiva al mismo. Los "show-rooms para FIAT" (1973) [17C] diseñados por Gae Aulenti tratando de devolver en su interior de manera perversa los pasos peatonales suprimidos por el automóvil en la ciudad, los "Drive-In Religiosos" [16D] que proliferarán en Los Ángeles, automóviles convertidos en piezas de museo ${ }^{649}$ dando paso a los museos de automóviles o edificios comerciales exclusivos para el coche ${ }^{650}$ son una buena muestra de ese apoderamiento del automóvil de la ciudad. El automóvil llega a convertirse en objeto hedonista más allá de su propia funcionalidad relacionada con la

643 LOEWY, Raymond. Industrial Design. Faber \& Faber. Londres, 1979. p.74.

644 LANDAU, Royston. New Directions in British Architecture. Studio Vista. Londres, 1968. pp.114-115.

645 Kanh Car. En: AD The Architectural Design, abril 1968. p.223.

646 II Metro Quadro. Mini Vehicle. En: Domus, n 539, octubre 1974. p.41.

647 Existe una gran bibliografía al respecto, al ser la relación entre automóvil y arquitectura muy fructífera durante todo el siglo XX. Sin embargo

GARTMAN, David. From Autos to Architecture: Fordism and Architectural Aesthetics in the Twentieth Century. Princeton Architectural Press. Nueva York, 2009.

648 JELLICOE, G.A. Motopia. A Study in Evolution of Urban Landscape. Frederick A. Praeger. Nueva York, 1961.

649 SILK, Gerald. Automobile and Culture. Museum of Contemporary Art. Los Angeles, 1984.

The Machine as Seen at the end of the Mechanical Age, MOMA, 1968, comisariada por K.G. Pontus Hultén, del 15 de noviembre de 1968 al 9 de febrero 1969

650 El fallido proyecto del "Helicoide de Caracas" podría ser considerado como máximo exponente de esos edificios diseñados exclusivamente para el automóvil. 
movilidad en proyectos como "Jardín Inglés sobre una autopista" (1968) [10A] en el que Kranan y Knowles diseñan un conjunto de carreteras sinuosas con pinturas geométricas para potenciar la sensación de velocidad y disfrute del automóvil. También aparecen incluso proyectos-manifiesto en contra de esa supremacía como "The Great Vienna Auto Expander" (1969) [11D] de Zünd Up, una mega-estructura en forma de pinball que sobrevuela Viena y a la que sólo puedes acceder en coche, pudiendo disfrutar de todo tipo de atracciones, desde conducción sobre una pista helada a un simulador de tormentas, todo para amplificar esa sensación de control y libertad que te proporciona la conducción de tu automóvil.

\section{Culto al automóvil.}

El culto al automóvil rendido por diseñadores, arquitectos y artistas llega a su plenitud en los años sesenta, en el que el coche se convierte en icono cultural por excelencia. Desde su nacimiento, el automóvil ha sido fuente de inspiración para gran cantidad de artistas, para los futuristas como objeto-fetiche que mejor expresaba su pasión por el movimiento ${ }^{651}$, para Moholy Nagy como expresión geométrica de la modernidad expresada en "Pneumatiks" (1924) o para Duchamp en su búsqueda del potencial artístico de objetos cotidianos, utilizando una gran número de referencias a la tecnología del automóvil, desde latas de gasolina hasta engranajes, en la obra de 1923 "Grand Verre". Sin embargo, en la primera mitad del siglo XX, el culto al automóvil deriva de una perfección geométrica, de una exaltación del dinamismo, de una percepción del mismo como objeto autónomo y no tanto como modificador socio-cultural de referencia.

En 1955, la fascinación de Richard Hamilton por las máquinas y la velocidad le lleva a organizar la célebre exposición "Man, Machine and Motion"652, en la que ya el título anticipaba el estado de simbiosis entre el hombre, la máquina y la movilidad. Desde entonces, la imagen del automóvil como objeto de culto irá asociada a su presencia como objeto de consumo de masas y sus consecuencias sociales y culturales, desde sus espacios propios en la ciudad a su impacto sobre el territorio. Ese culto al automóvil se vuelve apocalíptico en el dual "Car Crash" (1962) [5D] [5E], una serie de litografías de Andy Warhol manipulando accidentes de automóviles y la performance en el que el artista Jim Dine intenta simular su propio accidente o en "In the Car" (1963) [6A], en el que Roy Lichtenstein muestra a una pareja supuestamente enojada en el interior de su automóvil. La vida en el automóvil se convierte de esta manera en una prolongación de la vida en la vivienda o el trabajo. Esa vida secreta queda reflejada en instalaciones como "Back Seat Dodge'38" (1964) [6D] de Edward Kienholz, donde muestra a una chica masturbándose en el asiento trasero de su coche después de haberse emborrachado, asociando explícitamente el automóvil como el lugar del sexo no permitido dentro de la vivienda paterna. El automóvil se convierte en una prolongación de la personalidad de su dueño, como demuestra el vídeo "Kustom Kar Kommandos" (1965) [7C] de Kenneth Anger, en el que el artista refleja la conversión del automóvil en objeto sexual fetiche entre los jóvenes varones norteamericanos. También el artista Josef Nöbauer trabaja con esa fusión entre coche-identidad-usuario en su dibujo "Men and Cars" de 1973 [17A], en el que inventa un objeto híbrido entre hombre y automóvil.

651 Por citar algunas obra destacaré las pinturas "Dinamismo d'un automobile" (1913) de Luigi Russolo o "Velocità d'automobile + luce + rumore" (1913) de Giacomo Balla.

652 Ver: MASSEY, Anne. The Independent Group: Modernism and Mass Culture in Britain, 1945-1959. Manchester University Press, Manchester, 1995.

BANHAM, Reyner. Man, Machine and Motion. En: AR Architectural Review, n¹18, julio 1955. pp.51-53. 
Posiblemente el grupo de arquitectos norteamericanos Ant Farm, con Chip Lord y Doug Michels a la cabeza, es uno de los que más intensa y bipolarmente han trabajado con las consecuencias sociales y la iconografía del automóvil al mismo tiempo. En su instalación "Cadillac Ranch" de 1974 [17E], patrocinada por el millonario del petróleo y mecenas Stanley Marsh, enterrarán diez modelos de Cadillac en un campo visible desde la icónica ruta 66, utilizando la imagen del mítico modelo de automóvil americano para criticar el expansionismo urbano desembocado por el uso masivo del automóvil pero a la vez convirtiéndolo en una de las imágenes más icónicas asociadas al automóvil en toda Norteamérica ${ }^{653}$. Un monumento consciente al automóvil en el que utilizan el ángulo de las pirámides para la inclinación de los Cadillac, un monumento de la generación beat retratada en "On the Road" de Jack Kerouac y del mundo de los nómadas de la contracultura mostrada por "Easy Rider". La misma adoración por los automóviles clásicos norteamericanos les lleva a utilizar un Oldsmobile Vista Crusier del 68 como contenedor de los objetos donados por ciudadanos para "Citiziens Time Capsule" [19C], una cápsula del tiempo enterrada en 1975 para ser abierta en el año 2000. En esa ambivalencia irónica se posiciona el Cadillac El Dorado Biarritz modificado y estrellado contra una pirámide de televisiones en su acción de 1975 "Media Burn" [19A], reflejo de la supremacía norteamericana y objeto-protesta de unos mass-media totalmente controlados por el poder, de una insatisfacción por los contenidos simplistas y manipuladores de la televisión convencional, la misma que retransmitió una y otra vez el asesinato del presidente Kennedy en Dallas, que será recreado por Ant Farm junto a los miembros de otro colectivo artístico de la bahía de San Francisco, T. R. Uthco654. "Eternal Frame" (1976) [19B] constituye una crítica a la preponderancia de la cultura de masas, del seguimiento de la cultura y la sociedad por medio de la televisión. De nuevo un automóvil como protagonista fundamental de la historia de los Estados Unidos.

La adoración por el automóvil también supone cierto culto a la ciudad del automóvil, entre las que sin duda Los Ángeles y la figura de Reyner Banham destacan como máximos exponentes. Una utopía del automóvil o "Autopía" [5A], que desde 1955 fue una de las atracciones estrella de Disney Land, así como la cuarta ecología de la apología de Banham sobre Los Ángeles, que demuestra el síndrome de libertad del mismo conduciendo por el Strip en el documental "Reyner Banham loves Los Ángeles" de 1972 [16A]. Una utopía de la movilidad en la que el automóvil jugará el papel principal en la conjunción eficiente, rápida y pragmática del coche privado y la autopista pública, que según Banham transportan al angelino "a un estado especial de consciencia, en el que la intensificación de la concentración para abrirse paso a través de un caudal arrollador, orgánico y caótico se traduce en una percepción igualmente intensificada de la libertad."1655

653 Una de las imágenes más icónicas del automóvil en Norteamérica, relacionada con la cultura del "Road-trip". Un monumento que visitan más de 300.000 personas al año en la actualidad. Ver:

IOWA STATE UNIVERSITY FOR THE SOCIETY FOR COMMERCIAL ARCHEOLOGY (editor). Roadside America: the automobile in design and culture. Universidad de Michigan. Chicago, 1990.

KIRBY, Doug; SMITH, Ken; WILKINS, Mike. The New Roadside America: The Modern Traveler's Guide to the Wild and Wonderful World of America's Tourist Attractions. Simon \& Schuster. Nueva York, 1992.

654 Compuesto por Diane Andrews Hall, Doug Hall y Jody Procter.

655 "The First time I saw it happen nothing registered on my conscious mind, because it all seemed so natural - as the car in front turned down the off-ramp of the San Diego freeway, the girl beside the driver pulled down the sun-visor and used the mirror on the back of it to tidy her hair"

BANHAM, Reyner: Los Angeles. The Architecture Of Four Ecologies, Harper and Row. Los Ángeles, 1971. pp.195-226. 
El fotógrafo Ed Ruscha también celebra la ciudad de Los Ángeles y su dependencia del automóvil desde su libro de fotografías de 1966 "Every Building on the Sunset Strip", en la que el boulevard principal de la ciudad aparece como un desierto de peatones plagado de flamantes Cadillac y Mustang. El propio Ruscha fotografía esos "lugares exclusivos" del automóvil en la ciudad, las gasolineras en "Twenty six Gasoline Stations" de 1963 o en "Thirtyfour parking lots" de 1967 [9C], unos aparcamientos que serán también conmemorados por Venturi y Scott-Brown como elementos fundamentales del paisaje urbano de las ciudades, comparándolos incluso paisajísticamente con los jardines que rodeaban Versalles en "Learning from Las Vegas":

"El estacionamiento es el parterre del paisaje de asfalto. Los patrones de líneas de estacionamiento orientan tanto como los patrones de pavimentación, aceras, bordes y tapis vert dan dirección en Versalles. La red de farolas sustituye al obelisco, a las filas de urnas y estatuas como punto de identidad y de continuidad en el vasto espacio." (Venturi, Scott-Brown, 1972, p.13)

En 1978 el grupo de Miami SITE interviene en ese "parterre postmoderno" sepultando bajo asfalto varios coches de desguace en "Ghost Parking Lot Project" [20C]. El parking se convierte así en lugar de estudio y de actuación, en lugar de culto al automóvil y en uno de los grandes problemas de la dictadura del coche en las ciudades norteamericanas de segunda mitad del siglo XX.

\section{El automóvil como vivienda móvil. El auge del caravaning.}

El automóvil se convierte en esa prolongación de la vivienda, un lugar donde continuar e incluso sustituir la acción doméstica. El "Kar-a-Sutra" [15C] diseñado por Mario Bellini para "Italia: the New Domestic Landscape"657, propone un diseño de automóvil humanizado, un lugar donde socializar, un automóvil fusionado con el espacio doméstico.

"Ahora, de inmediato, tenemos que acabar con los parámetros del sistema automóvil-hombre y hacer del coche un espacio humano móvil, destinado a los ritos humanos y no a los derivados de la automoción." ${ }^{658}$ (Bellini, 1972, p.202)

La misma humanización estará implícita en la serie de dibujos del austríaco Max Peintner titulada "AutoBett" (1969) [11B], en la que se reproducen escenas domésticas en el espacio

656 "The parking lot is the parterre of the asphalt landscape. The patterns of parking lines give direction much as the paving patterns, curbs, borders, and tapis vert give direction in Versailles; grid of lamp posts substitute for obelisk, rows of urns and statues as point of identity and continuity in the vast space."

VENTURI, Robert; SCOTT-BROWN, Denisse; IZENOUR, Steven. Aprendiendo de Las Vegas. 1978 (1977). p.13.

657 El propio Ambasz se encargará de volver a llevar el automóvil al MOMA en 1976 en la exposición "The Taxi project" de 1976. Ver:

AMBASZ, Emilio. The Taxi Project: Realistic Solutions for Today. The Museum of Modern Art. Nueva York, 1976.

658 "Now, immediately, we must do away with the parameters of the AUTOMOBILE-MAN system and instead make the car a MOBILE HUMAN SPACE, intended for human and not automotive rites."

BELLINI, Mario. Kar-a-.sutra. En: AMBASZ, Emilio (editor). Italia: The New Domestic Landscape. 1972, p.202. 
de un automóvil que va surcando sinuosas avenidas de varios carriles. De manera contraria las imágenes de proyectos como "Casa Coche" (1973) [16C] de Dieter Smekal o "Wolkswagen Environment" (1970) [13A] de Paul F.Galdone, reproducen escenas en las que el automóvil ya ha sustituido a la propia vivienda, bien como monumento formal en los suburbios en los que impera o como vivienda móvil a través de una estructura neumática que reproduce la silueta del propio automóvil. Esa misma sustitución de la antigua y obsoleta vivienda será el objetivo de proyectos como "The Cumfy Campa Conversion" (1971) [13E] del británico Mark Fisher, remodelación lujosa de un coche para su reconversión como objeto hedonista para el disfrute del viaje. Desde cámaras de video, duchas portátiles, minibar, amplificadores de sonido y todo tipo de "gadgets" posibilitados por un generador de energía para disfrutar $100 \%$ del coche, como si de una arquitectura al uso se tratase. El nomadismo de la propuesta de Fisher derivará de todos los prototipos de vivienda móvil desarrollados por sus "maestros"659 de Archigram en la primera mitad de los sesenta, en espacial la "Drive In Housing" [6C] diseñada entre 1964 y 1966 por David Greene.

Pocos años después Archigram abandonarán esa idea de supremacía del automóvil como icono de emancipación y libertad para considerarlo una pieza más del mobiliario de la vivienda, un componente más de esos "Popular Pak" que pueden equipar nuestra vivienda, que generen en ella rangos muy elevados de flexibilidad a través de su movilidad y sus períodos de obsolescencia. De esta manera el automóvil no se convierte en modelo de cambio de la vivienda sino en su prolongación, y es ahí donde todo tipo de híbridos como la caravana entran en juego como extensiones móviles de la misma.

"La caravana es lo más cercano a una arquitectura desechable que el mercado puede ofrecer ... En contra de la solución estándar de la vivienda permanente, la caravana es pulcra, como una gran pieza de equipamiento, acogiendo un lugar para todo, como una oficina bien ejecutada; con aparatos en miniatura a escala con el espacio, como una casa de juguete, es tan cómoda como el coche el espacio calefactado del coche del año, y como el coche, la caravana representa una nueva libertad." ${ }^{160}$ (Alison and Peter Smithson, 1958, p.385)

"La verdadera ventaja del coche eléctrico es que se convirtiera en un pedazo de superficie lo suficientemente pequeño como para ser entrelazado con las estructuras urbanas existentes. Además de esto se puede hacer lo suficientemente seguro mediante control automático como para ser considerado no como otro tipo de coche, sino como un objeto más del mobiliario de la vivienda." ${ }^{1661}$ (Cook, 1970, p.119)

659 Mark Fisher será uno de los "alumnos aventajados" de Peter Cook en la AA de finales de los sesenta y principios de los setenta.

660 "Caravans are the nearest to an expendable architecture that the market has to offer... For against the standard solution of the permanent dwelling, the caravan is neat, like a big piece of equipment; host a place for everything, like a well-run office; has miniature appliances in scale with the space, like a toy home, is as comfortable as this year's space-heated car, and like the car, the caravan represents a new freedom"

SMITHSON, Allison y Peter. Caravan, Embryo. Appliance House. En: AD Architectural Design, septiembre 1959. p.385.

661 "The real advantage of the electric car is that it would be give a piece of moving surface small enough to be intertwined with existing urban structures. Besides this it can be made safe enough by control for it to be thought of not as another kind of car but as a mobile piece of furniture."

COOK, Peter. Experimental Architecture. 1970. p.119. 


\section{Catálogo // [La ciudad instantánea]}

Las imágenes están referenciadas por números en la zona superior de las columnas verticales [del 1 al 16] y letras en la zona izquierda de las filas horizontales [de la A a la E].

Todas las referencias están ordenadas cronológicamente.

Referencias de imágenes del [1B] a [16C]. Cada uno de los proyectos referenciados gráficamente en el catálogo presentan antes de su nombre un código con un número en relación a su columna vertical y una letra en relación a su fila horizontal.

\section{Ejemplo:}

[7E] "Cloud 9" (1962) de Buckminster Fuller. Buscar referencia en la columna 7 y la fila E del catálogo referenciado al principio del capítulo.

[Nota]: no todos los referentes gráfico del catálogo están referenciados en el texto por lo que se recomienda una lectura del mismo antes de comenzar la del propio texto.
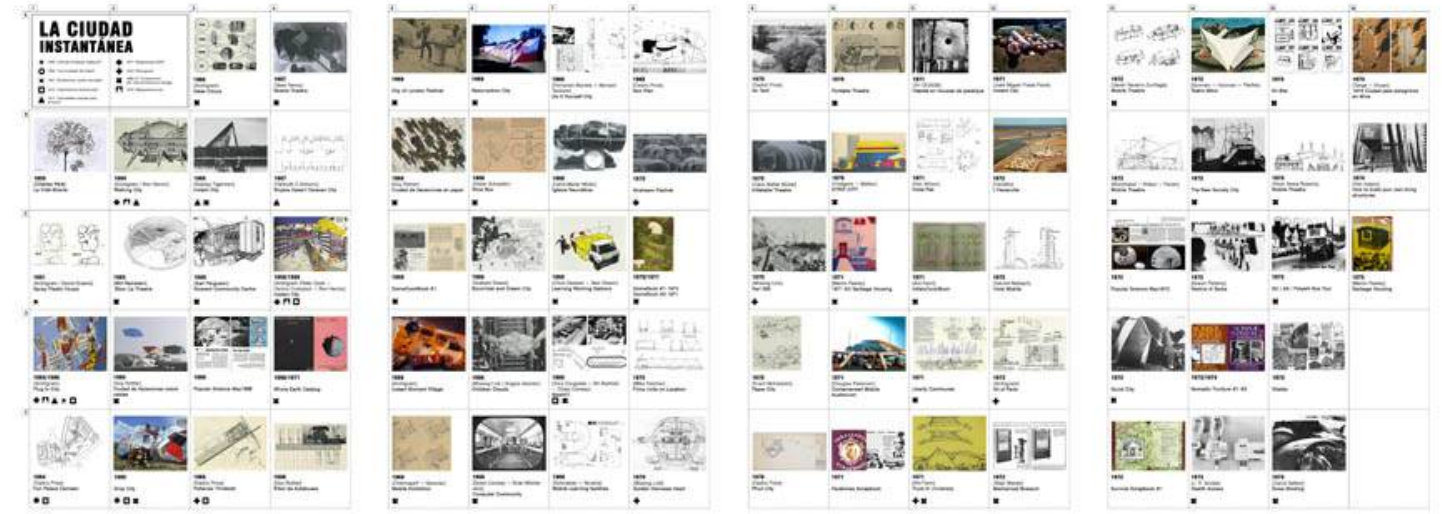


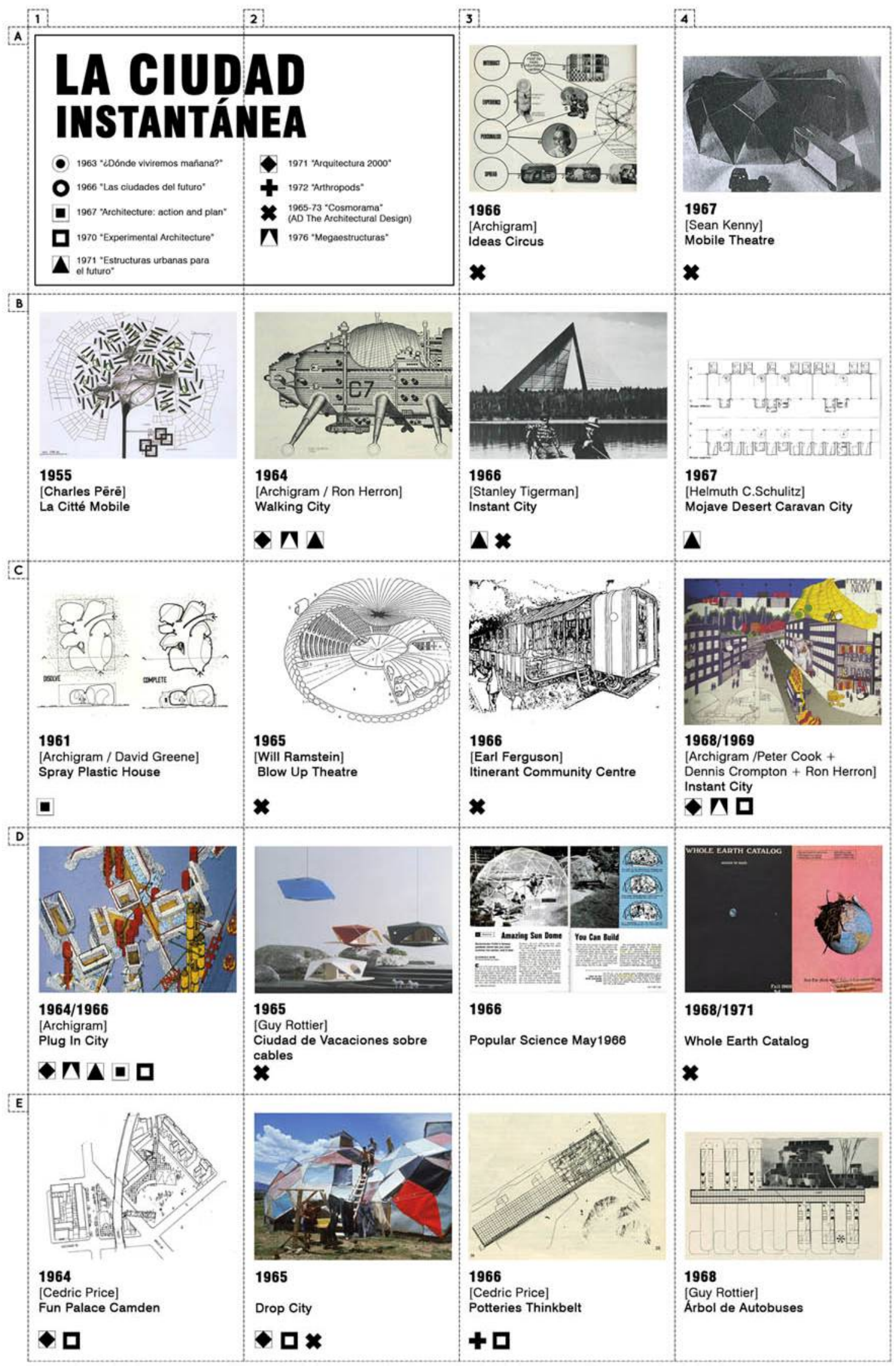




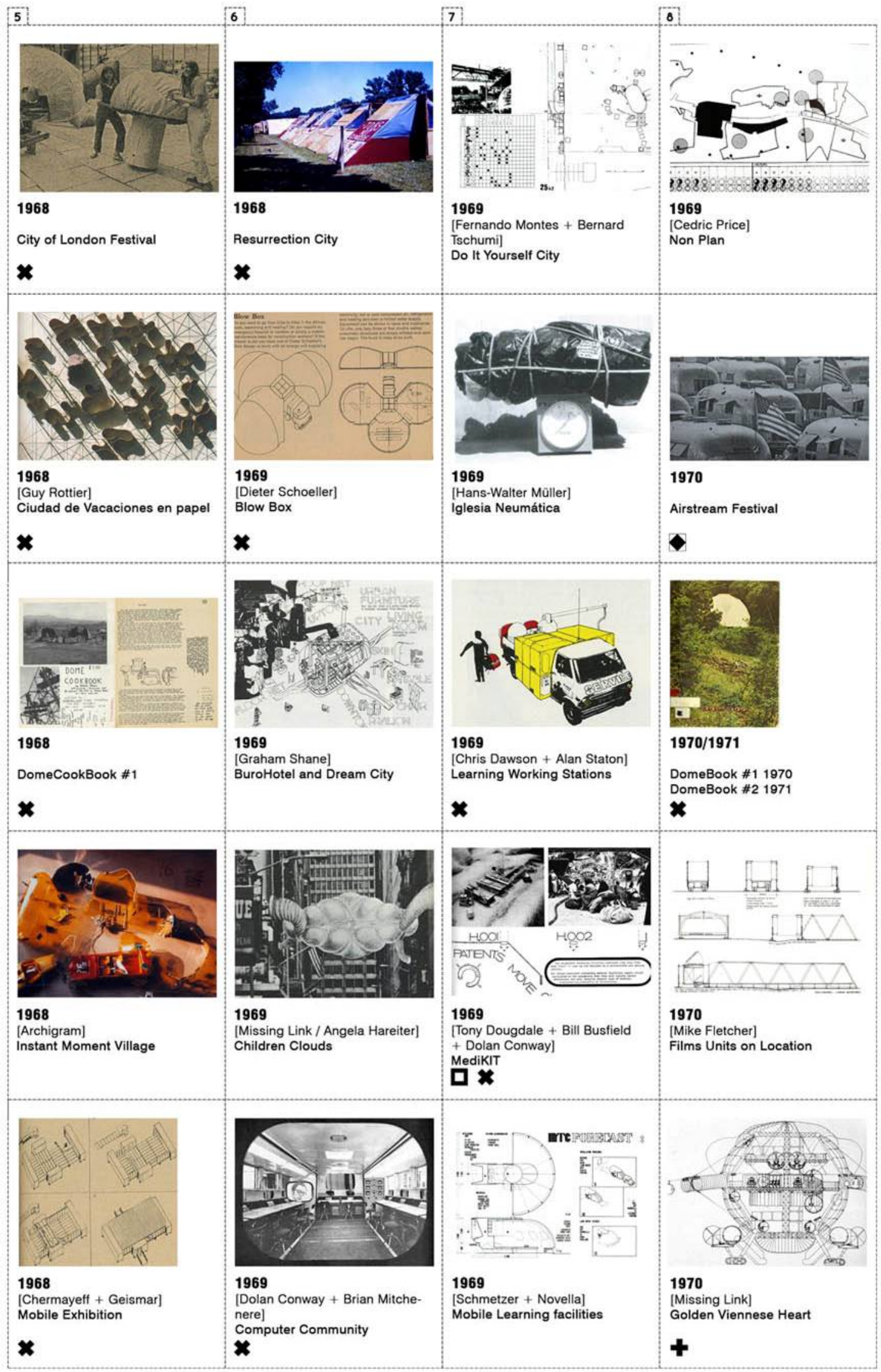




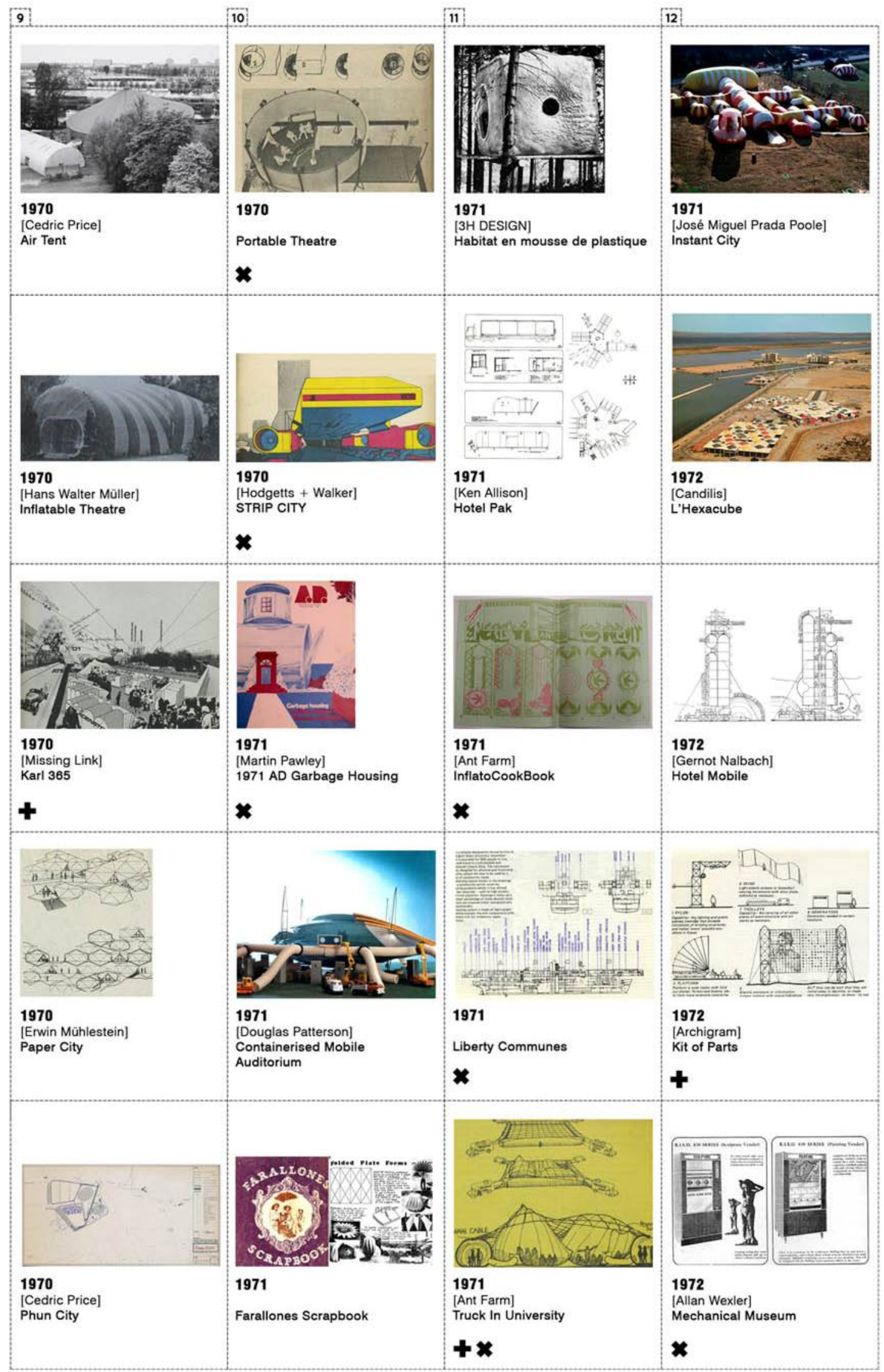




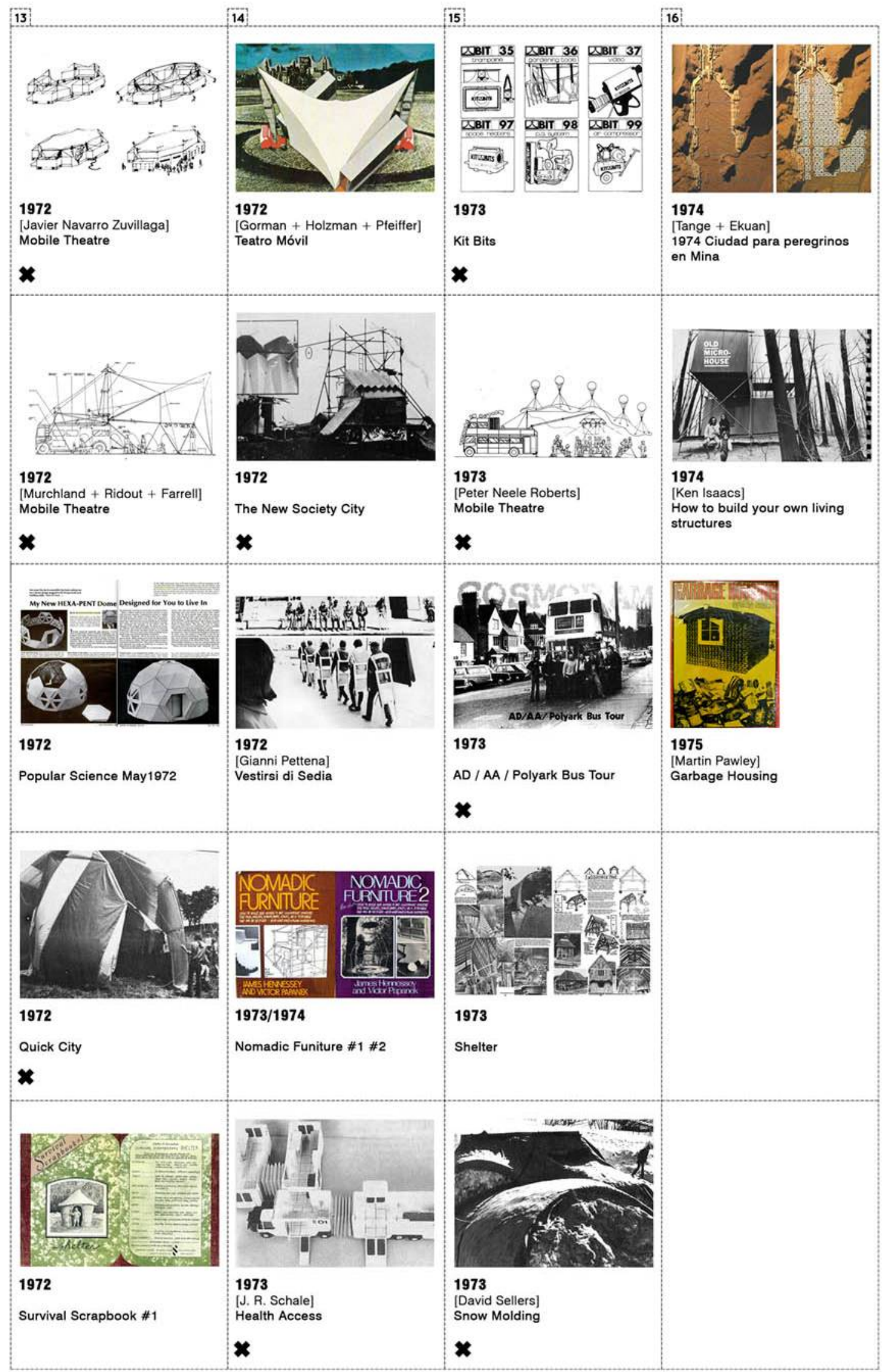




\section{[La Ciudad Instantánea] La búsqueda de una ciudad flexible y efímera.}

La idea de una ciudad móvil que avanza por el territorio como si de una gran refinería de personas se tratase, será caricaturizada en 1964 como "Walking City" [2B] por Ron Herron de Archigram, intentando conciliar de manera irónica la idea de edificio-ciudad destilada por las megaestructuras con la ausencia de impacto en el territorio de los pueblos nómadas. Así es como Herron trata de implicar a la arquitectura en el proceso de construcción de ciudades móviles ya existentes, como eran los portaaviones o las plataformas petrolíferas ${ }^{662}$. Ambos posicionamientos antagónicos, la movilidad a partir de un sistema de conexiones infraestructurales y la generación de equipamientos ligeros de fácil montaje-desmontaje, serán los principales referentes estratégicos de un gran número de proyectos que tratan de vislumbrar las posibilidades de una ciudad cambiante, flexible y efímera, conceptos ya destilados en propuestas como la "Plug In City" [1D] de Archigram o "Potteries Thinkbelt" (1964-1966) [3E] de Cedric Price. Ambas investigaciones iniciadas de manera casi simultánea en $1964^{663}$, a partir de una infraestructura receptora y una serie de módulos, ya sean viviendas o cualquier tipo de equipamientos, que puedan ser reemplazados con el tiempo, bajo criterios de caducidad y reciclaje. Si bien las sistemáticas derivadas de estos ejemplos, y sus numerosos proyectos tangenciales, como el plug-in o la utilización de componentes compatibles serán bien definidos en la segunda parte de la tesis, es interesante comprobar la búsqueda de independencia de ese hardware infraestructural de ciertas propuestas que confían en el carácter efímero de la utilización de sistemas de montaje fácilmente exportables, así como soportes no reglados ni tecnificados sino derivados de las infraestructuras ya existentes en la obsoleta ciudad consolidada.

\section{De la ciudad de emergencia a la de vacaciones como "prototipos"'" posibles.}

Los períodos de postguerra fueron grandes desencadenantes de un sinfín de soluciones prácticas de "ciudades efímeras" a partir de dos situaciones contrapuestas. Por un lado los alojamientos "provisionales" de guerra, que harán que la prefabricación de viviendas ligeras sufra un fuerte avance tecnológico, con coqueteos explícitos entre los "popes" de la apuesta industrializada como Fuller ${ }^{664}$ y el sistema político imperante, por otro, las ciudades "temporales" de refugiados o damnificados como consecuencia de los diversos conflictos armados de la primera mitad del siglo XX. Si en el primer caso Estados Unidos y la figura de Fuller pueden considerarse como un ejemplo paradigmático, en el segundo, también junto a

662 Ya Banham enfatiza el claro paralelismo entre la Walking City y la plataforma petrolífera Shivering Sands Fort, frente a Whitstable, Kent (1943), que alguno de los miembros de Archigram afirmaba conocer desde niño.

663 Es interesante la vinculación de ambos proyectos en publicaciones realizadas como traducciones del artículo original, conexión que en ningún caso aparece en el artículo original.Ver:

PRICE, Cedric. PTB. Potteries Thinkbelt. A plan for an advanced educational industry in North Sttafordshire. En: AD The Architectural Design, octubre 1966. pp. 484-498.

BAYÓN, Mariano. PTB. Potteries Thinkbelt. En: Arquitectura, n96. pp.55-58.

664 Uno de los mejores análisis en torno a las conexiones entre Buckminster Fuller y el ejército americano es el texto "Fluid Geographies. Politics and Revolution by Design" de Felicity Scott, en el que compila vínculos entre los proyectos más significativos de Fuller y los intereses colonialistas o controladores del sistema de poder norteamericano. Ver: 
los casos concretos de Estados Unidos ${ }^{665}$ e Inglaterra, el contexto francés resultará imprescindible como generador de prototipos posibles para alojamientos de urgencia a partir de planes generales de vivienda, muchos de ellos publicados desde 1945 por las principales revistas de arquitectura del país, tanto "L'Architecture d'Aujourd'hui" 666, como "Techniques et Architecture"667, en los que sin duda los prototipos de Jean Prouvé se convertirán en grandes referentes. Por otro lado, también Francia destacará en la producción de viviendas de vacaciones móviles, ya sea a través de los primeros prototipos de Charles Louvet como la "Carling-Home" desarrollados a principios de los años veinte, o propuestas como la "Villa Nomade" (1926) de Raymond Russel, un pequeño autobús modificado como si de un hotel móvil se tratase ${ }^{668}$, auspiciando el auge del turismo "ligero" de acampada tan afianzado en el país galo669, o bien en los prototipos en materiales plásticos que aparecen desde finales de los años cincuenta como posible vivienda de vacaciones efímera. Dichos prototipos serán diseñados por destacados arquitectos como Jean Maneval o Guy Rottier. Este paso de una ciudad de emergencia a otra lúdica de vacaciones se produce en un período de unos pocos años en contextos concretos como Francia o Inglaterra, auspiciado por predicciones en torno a la sociedad del ocio de autores como Michel Ragon o Dennis Gabor o proyectos derivados del "Homo Ludens" de Huizinga como la "New Babylon" de Constant. Así será como a las imágenes reales de caravanas y mobile homes construyendo verdaderas ciudades como la "Airstream Festival" (1970) [8B], llegadas desde Norteamérica, se le superpondrán los numerosos proyectos de ciudades vacacionales ${ }^{670}$ a partir de módulos plásticos prefabricados como "Hexacube" (1972) [12B]

665 A pesar de no haber sido atacada, el caso de Estados Unidos puede considerarse como un precedente inédito, ya que la movilización de población y el auge como consecuencia de las "Mobile Homes" en el período de la II Guerra Civil fue increíble. A pesar de no ser este extenso tema objeto de esta Tesis, facilito aquí algunas publicaciones consultadas sobre el tema:

EILER, Keith E. Mobilizing America: Robert P. Patterson and the War Effort, 1940-1945. Cornell University Press. Ithaca, 1997

HART, John Fraser; RHODES, Michelle J; MORGAN, John T. The Unknown World of the Mobile Home. Johns Hopkins University Press. Baltimore, 2003.

WALLIS, Allan D. Wheel Estate: The Rise and Decline of Mobile Homes. Johns Hopkins University Press. Baltimore, 1997.

NOYES, Phil. Trailerama. Gibbs Smith. Layton (Utah), 2012.

DAVIES, Colin. The Prefabricated Home. Reaktion Books. Londres, 2005.

666 En el primer número publicado de "L'architecture d'aujourd"hui", mayo-junio 1945, bajo la dirección compartida de André Bloc y Pierre Vago, la reconstrucción será uno de los tema principales del número, dedicando un número especial en el número de julio y agosto de ese mismo año, junto a compendios de soluciones internacionales en años precedentes.

AA L'Architecture d'Aujourd'hui, nº1, mayo-junio 1945.

AA L'Architecture d'Aujourd'hui, n², Solutions d'urgence, julio-agosto 1945.

AA L'Architecture d'Aujourd'hui, n4, Industrialisation du batiment, abril 1946.

667 Es interesante comprobar en el número de julio de 1945 de "Techniques et Architecture", un elenco de soluciones internacionales ligeras derivadas especialmente de los casos concretos de USA e Inglaterra, frente a los sistemas esencialmente "pesados" propuestos para la reconstrucción francesa. Ver:

TA Techniques et Architecture, n¹1-12, julio 1945.

668 Ambos ejemplos referenciados en:

WILLEIM, Veronique. Maisons Mobiles. Collection Anarchitecture. Editions Alternatives. París, 2004.

669 POULAIN, Élisabeth. France: L'esprit du camping. Editions Cheminements. París, 2005. 
de Candilis y Blomstedt, viviendas transportadas por ferrocarril como en la "Cité Mobile" (1955) [1B] de Charles Péré e incluso viviendas que penden de cables como en la "Ciudad de Vacaciones sobre cables" (1965) [2D] de Guy Rottier. La mayoría de estos ejemplos reproducen a pequeña escala los elementos de una ciudad tradicional de baja densidad, generando prototipos posibles en relación al impacto sobre el territorio de las mismas y la obsolescencia, así como experimentando con nuevos materiales efímeros como el papel en proyectos como "Paper City" (1970) [9D] de Erwin Mühlestein, o la "Ciudad de vacaciones en pape/" (1968) [5B] de Guy Rottier. En esta última el arquitecto francés propone incluso un aquelarre cuando termina el verano para hacerla desaparecer. Sin embargo ninguno de ellos supondrá una alternativa real a la ciudad predominante, por más que existan prototipos que apuestan por la densificación como la "Mojave Desert Caravan City" (1967) [4B] de Helmut C. Schulitz o el proyecto "Liberty Communes" (1971) [11D] de Brand Griffin, que reincide en la idea de un transatlántico como posible ciudad no sólo vacacional.

\section{Equipamientos instantáneos.}

La fascinación por el neo-nomadismo que el automóvil, las caravanas, tiendas de campañas y otros artefactos comerciales destinados a una creciente movilidad del usuario, causó en los posicionamientos de grupos como los ingleses Archigram un cambio radical, pasando de pensar en la infraestructura megaestructural como alternativa de futuro, a trasladar la mirada hacia una serie de proyectos de viviendas efímeras radicales, disminuidas hasta los límites de escala del vestido, generando a través de ellas nuevas versiones de ciudades de vacaciones como "The Moment Village" (1968) [5D].

"The Moment Village nace de la hipótesis de que nada más que con un guiño o un gesto de una persona a otra persona en un coche se constituye un acto comunitario y desde cualquier punto más allá de esto se crea un pueblo. La secuencia muestra como la unión de automóviles y servicios de apoyo forman una comunidad informal." ${ }^{1671}$ (Peter Cook, 1968, p.75)

A pesar de la inocente efusividad de una arquitectura generada por un automóvil y una serie de servicios, este proyecto se convertirá en el germen de experimentos más elaborados conceptualmente como "Ideas Circus" (1966) [3A], "Oasis" (1968) y sobre todo "Instant City" (1968) [4C], una serie de servicios culturales para equipar temporalmente las aburridas ciudades de las provincias de Gran Bretaña, equiparándolas y conectándolas con los nodos principales culturales que conforman las grandes capitales mundiales como son Nueva York, Londres o París.

670 Muchas de estos prototipos aparecen en publicaciones relacionadas con su materialidad plástica y su uso específicamente relacionado con el ocio y las vacaciones. Ver:

AA L'Architecture d'Aujourd'hui, n¹31, Tourisme / Loisirs, abril-mayo 1967.

Bauwelt, nº18, 5 mayo 1969.

TA Techniques et Architecture, n²90, L'Architecture et les Loisirs, diciembre 1972.

AA L'Architecture d'Aujourd'hui, nº148, Vers une industrialisation de l'habitat, febrero-marzo 1970.

671 "The Moment Village takes the hypothesis that anything beyond a wink or a nod from a person in one car to a person in another constitutes a communal act and from any point beyond this the village is created. The sequence shows the coming together of cars and support facilities which forms a casual community"

COOK, Peter (editor). Archigram. 1972. p.75. 
"El proyecto Instant City reacciona con la idea de una metrópolis de viaje, un paquete que llega a una comunidad como muestra de las dinámicas metropolitanas y se inserta temporalmente en el centro local mientras la comunidad se recupera del choque. Se convierte así en catalizador o primera etapa de una transmisión a escala nacional de una red de información, educación, entretenimiento, juego..."672 (Peter Cook, 1968, p.86)

"Instant City" rompe con la anterior evasión al fenómeno urbano de la mayor parte de sus "ciudades instantáneas" predecesoras, intentando equipar la misma a través de un catálogo de pequeñas infraestructuras ligeras que posibilitan actividades muy diversas, como si de un circo amplificado y tecnificado se tratara.

"Desde este enfoque no es necesario rediseñarlo todo. Aquí, el cambio fundamental viene de nuestra consideración de la evolución urbana y del soporte individual: un tema central para los arquitectos es que no es necesario reemplazar todo por algo nuevo. Y esto es un cambio fundamental con respecto a la anterior arquitectura moderna. ${ }^{\circ 73}$ (Peter Cook, 1970, p.122)

"La idea de llevar un conjunto de camiones y aparatos de un lugar a otro, enganchándolos y relacionándolos con la actividad escolar, el entretenimiento y el ocio nocturno existente implica el uso de una amplia gama de técnicas de electricidad, electrónica, estructura y sistemas cinéticos, derivados de la cultura del circo tradicional. ${ }^{1174}$ (Cook, 1970, p.123)

En este caso, de la misma manera que "Features Montecarlo" supone una revisión del "Fun Palace" de Cedric Price, la "Instant City" es también deudora de experiencias anteriores ${ }^{675}$ del mismo Price en la versión del mismo para Camden de 1964, en la que el arquitecto reduce el edificio a un conjunto de pequeños cubos prefabricados customizables y colonizables y un kit de equipamiento compuesto de unidades de proyección, estructuras ligeras de protección acústica, paneles de suelo ligeros y estructuras inflables en las que lo más

672 "The Instant City project react to this with the idea of a travelling metropolis, a package that comes to a community, giving it a taste of the metropolitan dynamic - which is temporarily grafted on to the local centre - and whilst the community is still recovering from the shock, uses this catalyst as the first stage of a national hook-up. A network of information, education, entertainment, play and know yourself facilities"

COOK, Peter (editor). Archigram. 1972. p.86..

673 "It's not necessary in this approach to redesign everything. Here a fundamental change is coming from our consideration of the evolving urban region, and of individual support: a central issue for architects is that it is not necessary to replace everything by something new. And this is a fundamental change of heart from the earlier modern architecture."

COOK, Peter. Experimental Architecture. 1970. p.122.

674 "The idea of taking a set of trucks and apparatus from place to place, setting them up and latching them on to existing school, entertainment and evening activity set-ups implies the use of a very wide range of techniques from electrical, electronic, structural, kinetic, through to traditional circus lore"

COOK, Peter. Experimental Architecture. 1970. p.123.

675 Referencia declarada y publicada por el propio Peter Cook. Ver:

COOK, Peter. Experimental Architecture. 1970. p.141. 
importante serán las posibilidades de activación del barrio mediante un sistema de control ambiental y una serie de espacios flexibles. Uno de los grandes esfuerzos del proyecto no será el propio diseño en sí sino el análisis de los posibles lugares dónde podría ser situado el proyecto.

\begin{abstract}
"La creación de un entorno útil en el que los visitantes puedan elegir y participar en actividades variadas.
\end{abstract}

Las estructuras y equipos están diseñados de manera que su instalación en cualquier sitio en particular dependa tanto de su disponibilidad como de la falta de instalaciones comunales adyacente al sitio." ${ }^{1676}$ (Cedric Price, 1967, p.684)

Ambas propuestas utilizan la acción y la flexibilidad como leitmotiv principal a partir de dos estrategias fundamentales, por una parte el uso de equipamiento de catálogo y por otro el diseño de estructuras ligeras flexibles, transportables, de fácil montaje y desmontaje que posibiliten las condiciones apropiadas para el desarrollo de la acción. Sin duda alguna la conexión de ambos proyectos tiene gran relación con el origen de los grandes festivales de música, ya sea a través de ciudades efímeras ex-novo, como en el festival de Woodstock de 1969, o mediante la superposición a las ya existentes, como en los macro-conciertos organizados en el Hyde Park de Londres desde 1968. Esa relación no sólo será evidente sino explicitada en alguno de los artículos de Archigram.

"Al inicio de los setenta se puede vis/umbrar que una nueva era está comenzando. El hombre ha saltado a la luna y ha bajado a las calles. Los estudiantes se han movilizado en Woodstock, en el Hyde Park y en el campus." ${ }^{1677}$ (Chalk, 1971, p.238)

La relación con este tipo de ciudades efímeras temáticas es tan estrecha que incluso Cedric Price diseñará en sólo seis semanas una tienda móvil para la producción de rock itinerante "Hair Tent" en 1970 [9A], el mismo año en el que también diseña todo el "stage" de un festival de música completo como fue el desarrollado en la denominada "Phun City" [9E], en Ecclesden Common, primer macro-festival gratuito celebrado en gran Bretaña más allá de los conciertos del Hyde Park de Londres.

Todos estos proyectos giran en torno a la idea de que cualquier equipamiento de la ciudad es susceptible de convertirse en un espacio flexible y transportable, reducido a un simple equipamiento técnico y un espacio construido a través de sistemas modulares, extensibles, de fácil montaje y desmontaje. De esta manera, los experimentos en torno a la movilidad hasta ahora restringidos al ámbito de la vivienda de emergencia o de vacaciones, explosionarán a un sinfín de nuevos prototipos en los que cualquier uso de la ciudad será susceptible de ser movilizado. Así es como aparecen nuevas tipologías de equipamientos móviles desde un diverso número de estrategias: vehículos modificados como los hoteles

\footnotetext{
676 "The provision of a serviceable environment in which visitors may choose from and participate in varied activities. The structures and equipment are designed so that the arrangement of any particular site will take into account both the availability and the lack of communal facilities adjacent to the site"

PRICE, Cedric. Fun Palace, Camden, London. En: AD The Architectural Design, noviembre 1967. p.684.

677 "On the brink of the seventies a whole new era can be seen to be opening up. Man has jumped up and down on the moon and in the streets. Students have laid down at Woodstock and Hyde Park and on campus"
}

CHALK, Warren. Touch Not. En: AD The Architectural Design, abril 1971. p. 238. 
rodantes "Rotel" (1966) y "Hotel Auto Resien" (1965) de Georg Holtl, el uso de grúas y vehículos como soporte, como en el "Teatro Móvil" (1972) [14A] de Gorman, Holzman y Pfeiffer o el de todo tipo de sistemas industrializados, desde contenedores marítimos como en el "Containerised Mobile Auditorium" (1971) [10D] de Douglas Patterson o el reciclaje de autobuses urbanos obsoletos, como las propuestas de Guy Rottier "Árbol de autobuses" (1968) [4E]. La diversidad y expansión de usos propuestos será espectacular, aunque predominantemente relacionados con los espectáculos, desde teatros a salas de exposiciones, para llegar a abordar la movilización en otros ámbitos como la educación, en "Mobile Learning Stations" (1969) [7C] de Chris Dawson y Alan Staton, la sanidad"67, en "Medikit" (1969) [7D] de Tony Dougdale, Bill Busfield y Dolan Conway, e incluso la religión, como la "Église Gonflable" [7B], diseñada y construida por Hans-Walter Müller para la comunidad de Montigny-les-Cormeilles en 1969, que reduce a una estructura neumática y un grupo de presión las exploraciones en torno a iglesias nómadas realizadas en Francia ${ }^{679}$ desde mediados de los años cincuenta por arquitectos como Jean Prouvé o Yona Friedman.

Allan Wexler irá mucho más allá en su propuesta "Mechanical Museum" de 1972 [12E], en el que propone la expansión del museo a través de una serie de máquinas expendedoras e informativas que permitan descentralizar el área de expansión de los museos hacia las pequeñas poblaciones de provincia de la misma manera que la "Instant City" lo hace con otros equipamientos, generando así una instrumentalización de los equipamientos que los convierta en accesibles al ciudadano.

"El volumen cada vez mayor de artículos de arte y la necesidad de crear un punto de acceso múltiple por cada artículo, sugiere el uso de algunas de las herramientas que la tecnología moderna ofrece. El énfasis en la frase anterior se encuentra en la palabra herramienta. El propósito de la herramienta es facilitar el trabajo del hombre para extender su capacidad. " 680 (Wexler, p.11, 1972)

\footnotetext{
678 La labor educativa de Peter Cook y Cedric Price en la Architectural Association y la revista Architectural Design serán agentes fundamentales en la generación y difusión de proyectos asociados a la idea de equipamientos móviles, por lo que reseñaré varias publicaciones fundamentales para el gran auge de los mismos a finales de los sesenta y principios de los setenta en Gran Bretaña.
}

GOWAN, James (editor): Projects. Architectural Association. 1946-71, AA Cahiers series No.1. Architectural Association Press. Londres, 1972

Concepts of Educational Mobility. En: AD The Architectural Design, marzo 1973. pp.137-138.

SCHADE, J.R. Health Acces. En: AD The Architectural Design, mayo 1973. pp.271-272.

PRICE, Cedric (editor invitado). AD The Architectural Design, What about Learning?, mayo 1968.

679 LEBRUN, Pierre. Le temps des églises mobiles. L'architecture religieuse des Trente Glorieuses. Gollion. Infolio éditions, collection « Archigraphy. París, 2011.

680 "The increasing volume of art items and the need to create a multiple access point for every item suggests the use of some of the tools that modern technology provides. The emphasis in the preceding sentence is on the word tool. The purpose of a tool is to facilitate man's work to extend his capability"

WEXLER, Allan. Mechanical Museum. En: AD The Architectural Design, enero 1972. pp.11-12. 


\section{Ciudades "Do It Yourself"}

La instrumentalización propuesta por muchos de los ejemplos anteriores se emparenta con la aparición de todo tipo de catálogos de equipamiento que posibiliten la participación del usuario. A partir de unos sistemas generales por un lado y esos catálogos de instrucciones de uso por otro, se convierte así al ciudadano en agente de cambio de su propio espacio público. Así es como "Kit of Parts" [12D] diseñado por Archigram para la Documenta de Kassel de 1972, el conjunto de sistemas "Karl365" (1970) [9C] de Missing Link para Viena o el proyecto "Kit of Bits" (1973) [15A] para la reutilización del espacio debajo de la Westway Motorside en North Kensington diseñado por Derek Ince, Graham Story y Geoff Thorpe, utilizan ya explícitamente la nomenclatura "kit" como proyecto posibilista de instrumentalización más allá de sus aspectos formales, transportando así una figura del arquitecto como facilitador y gestor más que como diseñador de objetos arquitectónicos totalmente terminados.

"Configura tu ciudad"681 será el slogan de la propuesta de Bernard Tschumi y Fernando Montes "Do It Yourself City" (1968) [7A]. En ella proponen una ciudad como relación entre personas e ideas, en la que los objetos sólo actúan como facilitadores del intercambio de las mismas, de manera que esos objetos diseñados por ellos se presentan mediante catálogos, diagramas de usos y horarios y situaciones diagramáticamente posibilistas de relación entre ellos, en un acto de "no-planeamiento", en el que el soporte es totalmente abierto y re-configurable por los usuarios. El mismo entendimiento de una ciudad como proceso y no como objeto es el que lleva a Cedric Price a redactar junto a Reyner Banham, Peter Hall y Steve Baker "Non-Plan. An experiment in Freedom", como número especial de la revista de la que el propio Baker era editor "New Society"682. En el mismo Price niega la ciudad como una estructura coherente sino como un conjunto de sistemas inestables, en continuo proceso de re-estructuración y re-organización que imposibilita cualquier tipo de arquitectura anticipatoria. De esta manera, el proyecto "Non-Plan" [8A] busca generar las estrategias necesarias para involucrar a las comunidades ya existentes en el diseño de su entorno incluso en relación a las maneras de eludir la burocracia, convirtiéndose así en agentes de decisión del cambio urbano.

Sin embargo, la autonomía y capacidad de decisión que Price demanda para la ciudadanía requerirá de unos "profesionales" capaces de posibilitar las herramientas necesarias para instrumentalizar a ese futuro ciudadano "autónomo". De esta manera es como aparecen una serie de experiencias en torno a la generación de sistemas de montaje sencillos, materiales baratos y catálogos de instrucciones que tratan de hacer accesibles incluso los procesos de construcción para el usuario. Uno de los prototipos más laureados será el propuesto por la "Instant City" [12A] diseñada por el arquitecto español José Miguel de Prada Poole para ser construida comunitariamente durante el evento paralelo de los estudiantes frente al

681 TSCHUMI, Bernard; MONTES, Fernando. Do-It-Yourself City. En: AA L'Architecture d'Aujourd'hui, nº148, Vers une industrialisation de l'habitat, febrero-marzo 1970. pp.98-105.

682 New Society, 20 de marzo de 1969.

El artículo de Cedric Price en el mismo número será publicado íntegramente en:

PRICE, Cedric. Non-plan. En: AD The Architectural Design, mayo 1969. pp.269-273.

Ver también:

HUGHES, Jonathan; SADLER, Simon. Non-Plan. Essays on Freedom, Participation and Change in Modern Architecture and Urbanism. Architectural Press. Nueva York, 2000. 
congreso ISCID celebrado en Ibiza en 1971. Para ella, Prada Poole diseña un sistema de estructuras neumáticas en materiales plásticos así como un sistema de construcción en el que sólo se requieren unos compresores, el material plástico, tijeras y grapadoras, facilitando el montaje a través de un pequeño documento con todo el proceso de fabricación y montaje ${ }^{683}$. La "Instant City" resultará un experimento más de un proceso creciente de prototipos de ciudades efímeras construidas bajo marcos educativos que exploran las posibilidades de estos sistemas baratos y ligeros, como "City of London" de 1968 [5A], organizado entre otros por Joan Littlewood, agente fundamental en el proceso de diseño del Fun Palace, "The New Society City" [14B], organizada en 1972 por el Banco Nacional de Dinamarca o "Whiz Bang Quick City" [13D], promovida por la New York City College y dirigida por Robert Mangurian y Lester Walker. Incluso universidades como la Architectural Association llegaron a tener programas como "Polyark Bus" de 1973 [15C], dirigido por Peter Murray, en la que un autobús modificado por los propios alumnos de primer año de arquitectura recorrería durante un mes varias facultades de arquitectura de Inglaterra y Escocia, realizando talleres conjuntos en cada una de ellas, proyecto real similar a la propuesta "Truck' in University" (1971) [11E] diseñada por los norteamericanos Ant Farm como una universidad ambulante.

Sin embargo, no todas ellas serán simulaciones teóricas de ciudades auto-construidas bajo sistemas de montaje catalogados. "Resurrection City"684 [6A], una ciudad de emergencia diseñada por profesores y alumnos de varias universidades norteamericanas albergará a una población de 3000 personas durante las manifestaciones de la "Poor People's Campaign" de 1968 en Washington, la última reivindicación en la que participó Martin Luther King antes de su asesinato. La icónica "Drop City" [2E], considerada como la primera comuna hippie, fue autoconstruida en Colorado por Gene Bernofsky, Joann Bernofsky, Richard Kallweit y Clark Richert, que años antes habían asistido a los talleres de la Black Mountain College, dirigidos por John Cage, Robert Rauchensberg y Buckminster Fuller. La influencia de este último hará que las construcciones de la pequeña comunidad conjuguen la geometría geodésica con el uso de materiales reciclados como capós de coches de desguace. Así es como el icono de la industrialización instaurado en la perfección geométrica de la cúpula geodésica se convierte en abanderado de la contracultura. A pesar de su reducida escala, el impacto de la "Drop City" será tan grande que recibirá en 1966 el "Dymaxion Award for Architecture" de manos de Fuller y poblará en los años sucesivos una gran parte de las publicaciones de arquitectura más prestigiosas de todo el mundo ${ }^{685}$. Sin

683 PRADA POOLE, José Miguel. La Ciudad Instantánea, la Ciudad Cambiante. En: Arquitectura, n¹57, 1972. pp.24-38.

684 WIEBENSON, John. Planning and Using Resurrection City. En: American Institute of Planners Journal 35, n6, noviembre 1969. pp. 405-411.

Resurrection City. En: AD The Architectural Design, agosto 1968. p.351.

685 Drop City. En: AD The Architectural Design, noviembre 1967. p.453.

Le Cupole di Drop City. En: Domus, n458, enero 1968. p.1.

TREGO, Charlotte. New Life for Junked Cars. En: Architectural Forum, n¹27, septiembre1967. pp.74-75.

Drop City, Colorado. Coupoles géodésiques pour l'habitat hippie. En: AA L'Architecture d'Aujourd'hui, n¹41, Structures, diciembre 1968 - enero 1969. pp.82-84.

DOUTHIT, Peter L. Drop City: A Report from the Energy Center. En: Arts Magazine, nº 41, 1967. p.50.

BAER, Steve Baer. Dome Cookbook. Lama Foundation. Corrales, 1968.

DOUTHIT, Peter; KHAN, Lloyd. Drop City Revisited. En: KHAN, Lloyd (editor). Shelter. Shelter Publications Inc. 1973.

RABBIT, Peter. Drop City. The Olympia Press. Nueva York. 1971. 
embargo, su importancia como modelo estará relacionada fundamentalmente con dos tipos de publicaciones totalmente alejadas del ámbito arquitectónico al uso. Por un lado, Fuller entenderá a través del modelo de la "Drop City" el potencial del "Hazlo tú mismo" combinado con la geometría geodésica a partir de planos de montaje publicados en revistas populares norteamericanas como Popular Mechanics y sobre todo Popular Science, y por otro Steve Baer, seguidor de Fuller e inventor de la geometría "Zome", con la que también experimentó en la "Drop City", se convertirá a mediados de los sesenta en editor principal de varias publicaciones asociadas a la gestión compartida de recursos, planos de montaje y soluciones ecológicas, pertenecientes a la contracultura norteamericana.

\section{Planos y catálogos como recursos de emancipación arquitectónica.}

Ya desde sus primeros trabajos, Fuller había comprendido ese alcance de los magazines populares en Estados Unidos por lo que había publicado sistemáticamente sus trabajos dándose a conocer entre el público masivo que los leía asiduamente, las "4D Homes" en $1929^{686}$, la "Wichita House" en 1946687, la "Pine-Cone Dome" desarrollada con alumnos de la Cornell University en $1957^{688}$ e imágenes de proyectos construidos de sus cúpulas geodésicas a diversas escalas en varios números de $1961^{689}$ en Popular Science y sus "Deployement Units" en un artículo sobre Casas del Futuro en $1942^{690}$, de nuevo la "Wichita House" en 1946 691 , una cubierta geodésica plástica para un estadio en 1956 $6^{692}$, y una aplicación industrial de la cúpula geodésica en $1966^{693}$, en Popular Mechanics. Sin embargo será después de conocer la "Drop City", ya en 1966, cuando Popular Science empezará a publicar versiones más pequeñas de las aplicaciones de las cúpulas geodésicas como invernaderos o viviendas autoconstruidas, facilitando los planos por correo bajo un precio de $5 \$$, con los royalties de Mr. Fuller incluidos en el precio.

"Cómo obtener los planos. Desde que Fuller tiene una patente ( $n^{\circ}$ 2682235) del diseño, obtiene royalties de cada cúpula geodésica construida. Pero Popular Science hace que sea fácil para usted. Envíe un cheque o giro postal por valor de \$5 como se describe en la página anterior y obtendrá los planos sobre cómo construir paso a paso la cúpula que aquí se muestra." ${ }^{1694}$ (1966, p.112)

686 LODGE, John E. Plans to Move Homes by Airship. En: Popular Science, septiembre 1929. p.47.

687 Living in Circles. En: Popular Science, mayo 1946. pp.74-75.

688 Pine-Cone Dome is made of plywood panels. En: Popular Science, octubre 1957. p.139.

689 Metal men get many-metaled building. En: Popular Science, enero 1961. p.113.

GILMORE, C.P. Bucky Fuller's Wonderful Dome. En: Popular Science, diciembre 1961. pp.75-77.

690 Your Home of the Future. En: Popular Mechanics, octubre 1942. pp.72-77.

691 At Home in a Round House. En: Popular Mechanics, junio 1946. pp.118-119.

692 Plastic Dome for Stadium. En: Popular Mechanics, julio 1956. p.104.

693 Largest geodesic dome. En: Popular Mechanics, octubre 1966. p.146.

694 "How to get the plans. Since Fuller has a patent $\left(n^{\circ} 2,682,235\right)$ on the design, he gets royalties on every geodesic dome built. But Popular Science makes it easy for you. Send a check or money order for $5 \$$ as described on a previous page. You'll get plans and step by step on how to build the dome shown here."

RHINE, Charles E. Amazing Sun Dome You Can Build. En: Popular Science, mayo 1966. pp.109-112. 
Debido al auge de las cúpulas geodésicas autoconstruidas será el propio Buckminster Fuller quién presente en 1972 su nueva "Hexa-Pent Dome" en exclusiva para los lectores de Popular Science en los números de Mayo y Junio, en el mismo año en que la revista cumplía su centenario, con la posibilidad de adquirir unos planos más detallados por el módico precio de $15 \$$, con un gran éxito de pedidos.

"Durante años, el Do-lt-Yourselfer me ha estado pidiendo el diseño de un edificio vinculado a sus necesidades de vida y habilidades de construcción. Ahora está aquí ..."1695 (Fuller, 1972, p.128)

Desde el lado de la contracultura, Steve Baer escribe en 1968 el libro "Dome CookBook"696 [5C] sobre sus experiencias de autoconstrucción de cúpulas geodésicas y Zomes, a la vez que comienza la publicación del famoso "World Earth Catalog" [4D], que desde 1968 a 1972 cartografiará una gran cantidad de soluciones de viviendas auto-construidas, usos del suelo, sistemas de energía eficientes y ecológicos, nuevos sistemas de comunicación, generación de comunidades y sobre todo acceso y formas de utilización de las herramientas existentes ${ }^{697}$ en el mercado para la generación de un conocimiento común derivado de una vida nómada contemporánea emparentada con la contracultura norteamericana. La relación de Fuller con la publicación será muy intensa y funcionará como potenciador de esa unión fulleriana con la contracultura que había comenzado de manera casual en la adopción de la geodesia para la construcción de la "Drop City". Muy pronto este tipo de publicaciones encaminadas a la gestión de recursos compartidos empezarán a propagarse y popularizarse, cruzando el Atlántico y llegando a los arquitectos europeos a través de publicaciones como Domus, l'Architecture d'Aujourd'hui y sobre todo Architectural Design.

"World Earth Catalog. Las funciones del catálogo como una evaluación y un dispositivo de acceso. Con él, el usuario debería ser capaz de saber lo que vale la pena tener y dónde y cómo hacer para conseguirlo.

Un elemento se referencia en el catálogo si se considera:

1. Útil como una herramienta.

2. Relevante en el ámbito de una educación independiente.

3. De alta calidad y bajo costo.

4. Fácilmente disponible por correo."${ }^{1698}$ (World Earth Catalog, p.1,1969)

695 "For years the Do-It-Yourselfer has been asking me for a dome design pegged to his living needs and building skills. Now it's here..."

FULLER, Buckminster. My new Hexa-Pent Dome Designed for you to live in. En: Popular Science, mayo 1972. pp.128-131.

El artículo sigue en:

Bucky Fuller's Hexa-Pent: Dome Home You Can Build. En: Popular Science, junio 1972. pp.80-81.

696 BAER, Steve Baer. Dome Cookbook. Lama Foundation. Corrales, 1968.

697 El "World Earth Catalog" contará con 17 publicaciones regulares desde 1968 a 1972, y mucho más intermitentes desde 1974, datando la última en Diciembre de 1998, como conmemoración del 30 Aniversario.

698 "The Whole Earth Catalog functions as an evaluation and access device. With it, the user should know better what is worth getting and where and how to do the getting.

An item is listed in the CATALOG if it is deemed:

1. Useful as a tool

2. Relevant to independent education

3. High quality or low cost

4. Easily available by mail" 
Con anterioridad, el potencial del catálogo había sido enunciado por arquitectos como Price o los miembros de Archigram ${ }^{699}$ como estrategia de uso arquitectónico encaminada a una emancipación y autonomía del usuario y a un arquitecto convertido en mediador. Además, la influencia del mismo fue tal que revistas como Architectural Design adecuaron algunas de sus secciones de noticiero global a esa idea de catálogo de sistemas, apareciendo separatas como "Cosmorama", convertida así en una de las más importantes predicciones de futuro de la época.

A ambos lados del Atlántico el boom de los catálogos de herramientas y sistemas desembocará en un sinfín de propuestas que apuestan por el "Do It Yourself" como estrategia emancipatoria. "Inflatocookbook"1700 (1971) [11C], por ejemplo, con el que el grupo norteamericano Ant Farm realizan una taxonomía de estructuras y sistemas neumáticos bajo conceptos de educación expandida, culto al nomadismo y al automóvil y el uso de tecnologías de vídeo y audio para generar nuevos ambientes de expansión mental. Las continuas reediciones de "DomeBook $n^{\circ} 1$ y $n^{\circ} 2^{1701}$ [8C], (1970 y 1971) evoluciones de "Dome CookBook" de Baer publicadas por Lloyd Kahn, sobre la construcción de cúpulas autoconstruidas, desplegando un gran elenco de nuevos sistemas y materiales, que derivaran en el también famoso ${ }^{702}$ catálogo "Shelter"1703 [15D], que continuará con los sistemas auto-construidos y derivados de una vida nómada pero esta vez combinando un gran número de sistemas y tipologías tradicionales relacionadas con la autoconstrucción en el ámbito de la vivienda. Victor Papanek ${ }^{704}$ y James Hennessey, a través de los diversos números de "Nomadic Furniture"1705 [14D], también proponen una serie de soluciones D/Y y mobiliario de catálogo para un neo-nómada contemporáneo, "Farallones Scrapbook"1706(1971) [10E] con talleres D/Y en ambientes educativos o "Survival Scrapbook"1707 [13E] como guía para un modo de habitar autónomo y autosuficiente, con volúmenes sobre la vivienda, el uso a-legal del suelo, la comida, el acceso a las herramientas o la energía, serán algunos de los catálogos más importantes de la época.

Whole Earth Catalog, Fall 1969, Access to Tools. p.1.

699 Los miembros de Archigram escribirán un "recurso" en el número de Primavera de 1969 del "World Earth Catalog", que habla de esa emancipación:

ARCHIGRAM. Architecture without Architects. En: World Earth Catalog, Spring 1969. p.20.

700 ANT FARM. Inflatocookbook, n¹, enero, Sausalito, 1971.

701 EASTON, Robert; KAHN, Lloyd. Domebook, issue N¹. Pacific Domes. Califonia, 1970.

EASTON, Robert; KAHN, Lloyd. Domebook, issue No2. Pacific Domes. Califonia, 1971.

702 Shelter venderá en su historia más de 185,000 copias y las dos versiones del DomeBook más de 150,000.

703 KAHN, Lloyd. Shelter. Shelter Publications.California, 1973.

704 PAPANEK, Victor. Design for the Real World. Thames \& Hudson. Londres, 1972.

705 PAPANEK, Victor; HENNESSEY, James. Nomadic Furniture. Phanteon Books. Nueva York, 1973.

PAPANEK, Victor; HENNESSEY, James. Nomadic Furniture. 2. Phanteon Books. Nueva York, 1974.

706 Farallones Scrapbook. Momento and Manual of Our Apprenticeship in Making Places and Changing Spaces in Schools at Home and Within Ourselves. Farallones Design, 1971.

707 SZCZELKUN, Stefan A. Survival Scrapbook \#1. Shelter. Shocken Books. Nueva York, 1972.

SZCZELKUN, Stefan A. Survival Scrapbook \#2. Food, Shocken Books. Nueva York, 1972.

WILLIAMS, Dave; MUNRO, Sthepanie. Survival Scrapbook \#3. Access to Tools, Shocken Books. Nueva York, 1973. 
La proliferación de este tipo de publicaciones generará a su vez una gran sinergia entre sus autores y sobre todo una transferencia de información entre los medios institucionalizados de revistas como Popular Science, que publicitarán todos esos catálogos asociados a su idea de Do It Yourself, y todos los catálogos contraculturales publicados mediante pequeñas editoriales e incluso fanzines auto-producidos mediante fotocopias. Tal es el trasvase, que a la ya conocida relación de Fuller le seguirán caminos de ida y vuelta de diseñadores como Lester Walker y Robert Mangurian, directores de la "Quick City" (1971) y corresponsales de Popular Science, pero sobre todo Ken Isaacs, que a sus numerosos artículos ${ }^{708}$ sobre muebles Do It Yourself añadirá su famoso libro de estructuras autoconstruidas "How To Build Your Own Living Structures"709 [16B]. Esa proliferación y legitimación de la cultura del "Hazlo tú mismo", posibilitará la aparición una gran diversidad de propuestas D/Y, experimentando con materiales tan heterogéneos como los plásticos o el papel"10. Desde la hipotética "Spray Foam Plastic House" diseñada en 1961 por David Greene a los casos reales "Snow moulding" (1973) [15E] de David Sellers o el "Habitat en mousse de plastique" (1971) [11A] construido por el grupo 3H Design para la feria del plástico IKA'71. Proliferarán también una gran diversidad de escalas, que van desde ejemplos de cúpulas geodésicas gigantes a cualquier tipo de mobiliario, inclusive mediante la apropiación de la etiqueta Do It Yourself por diseñadores de reconocido prestigio como el italiano Enzo Mari, que dedica varias líneas de producto a estanterías de cartón y mobiliario en madera a través de elementos compatibles que permiten ser customizados a placer.

El salto hacia Europa de estas publicaciones favorecerá que autores como Martin Pawley enriquezcan el debate sobre la autonomía a través de su célebre artículo" ${ }^{711}$ "Garbage Housing" [10A] [16C] y su posterior libro ${ }^{712}$ del mismo nombre, en el cual Pawley articula una serie de propuestas en torno al reciclaje de productos y energía que supone un paso más en relación a esa emancipación propuesta por el catálogo. Reciclaje de materiales, catálogos de instrucciones y autoconstrucción para una emancipación total del usuario del arquitecto, para una vuelta a esa "arquitectura sin arquitectos" que demandaba Bernard Rudofsky, e incluso fuera de los procesos normativos de planteamientos, hipótesis planteada por Cedric Price en "Non-Plan: an experiment in freedom".

708 ISAACS, Ken. Build a Vacation Cluster. En: Popular Science, julio 1972. pp.88-91.

ISAACS, Ken. Guest Room in a Ten-Inch Space. En: Popular Science, septiembre 1970. pp.86-87.

ISAACS, Ken. A Modern Bowl for Sun-Bathing. En: Popular Science, febrero 1970. pp.112-113.

ISAACS, Ken. Way Out Fun House for Your Vacation Lot. En: Popular Science, julio 1969. pp.131-135.

ISAACS, Ken. How to Build the Microdorm. En: Popular Science, marzo 1969. pp.138-141.

ISAACS, Ken. More than a Matrix Idea: A Room of 2x2s. En: Popular Science, abril1968. pp.170-174.

709 ISAACS, Ken. How To Build Your Own Living Structures. Harmony Books. Nueva York, 1974.

710 Paper House Review. En: AD The Architectural Design, octubre 1970. pp.449-504.

711 PAWLEY, Martin. Garbage Housing. En: AD The Architectural Design, febrero 1971. pp.86-94.

712 PAWLEY, Martin. Garbage Housing. The Architectural Press. Londres, 1975. 


\section{Catálogo // [La ciudad de los intercambios]}

Las imágenes están referenciadas por números en la zona superior de las columnas verticales [del 1 al 16] y letras en la zona izquierda de las filas horizontales [de la A a la E].

Todas las referencias están ordenadas cronológicamente.

Referencias de imágenes del [1B] a [16E]. Cada uno de los proyectos referenciados gráficamente en el catálogo presentan antes de su nombre un código con un número en relación a su columna vertical y una letra en relación a su fila horizontal.

\section{Ejemplo:}

[7E] "Cloud 9" (1962) de Buckminster Fuller. Buscar referencia en la columna 7 y la fila E del catálogo referenciado al principio del capítulo.

[Nota]: no todos los referentes gráfico del catálogo están referenciados en el texto por lo que se recomienda una lectura del mismo antes de comenzar la del propio texto.
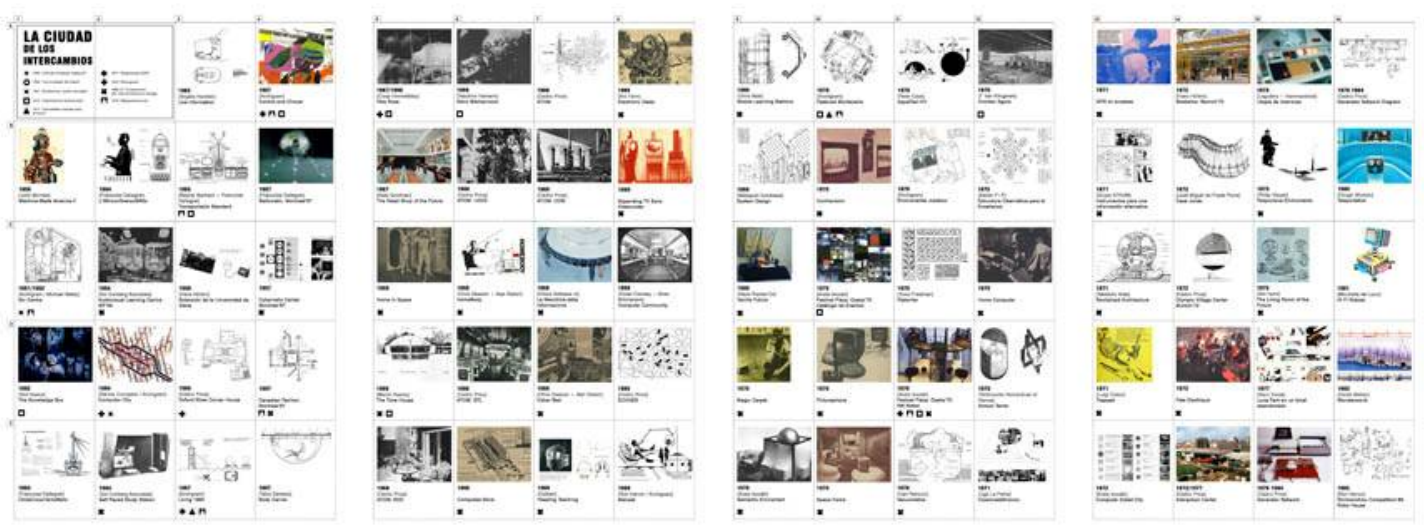


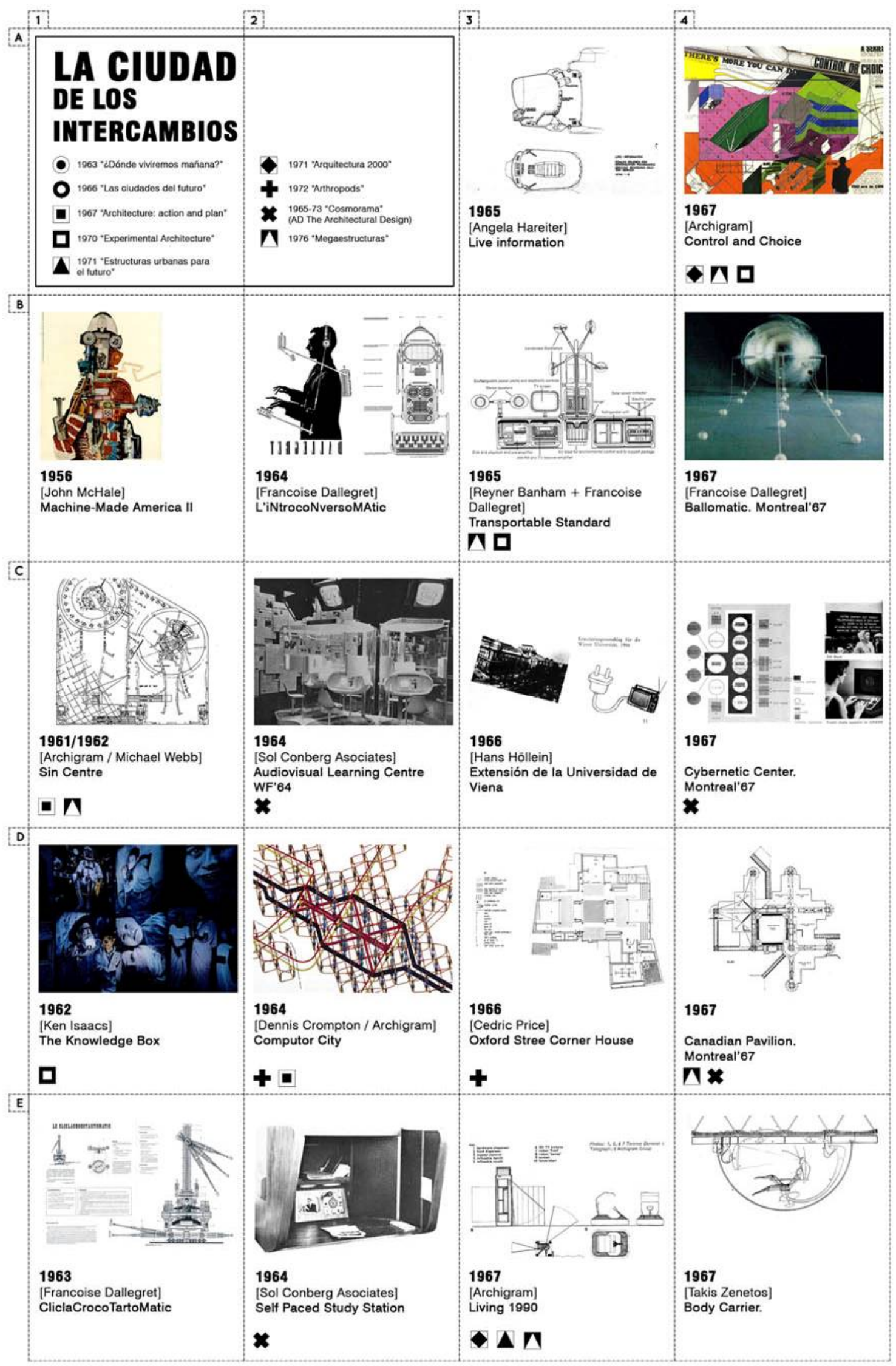




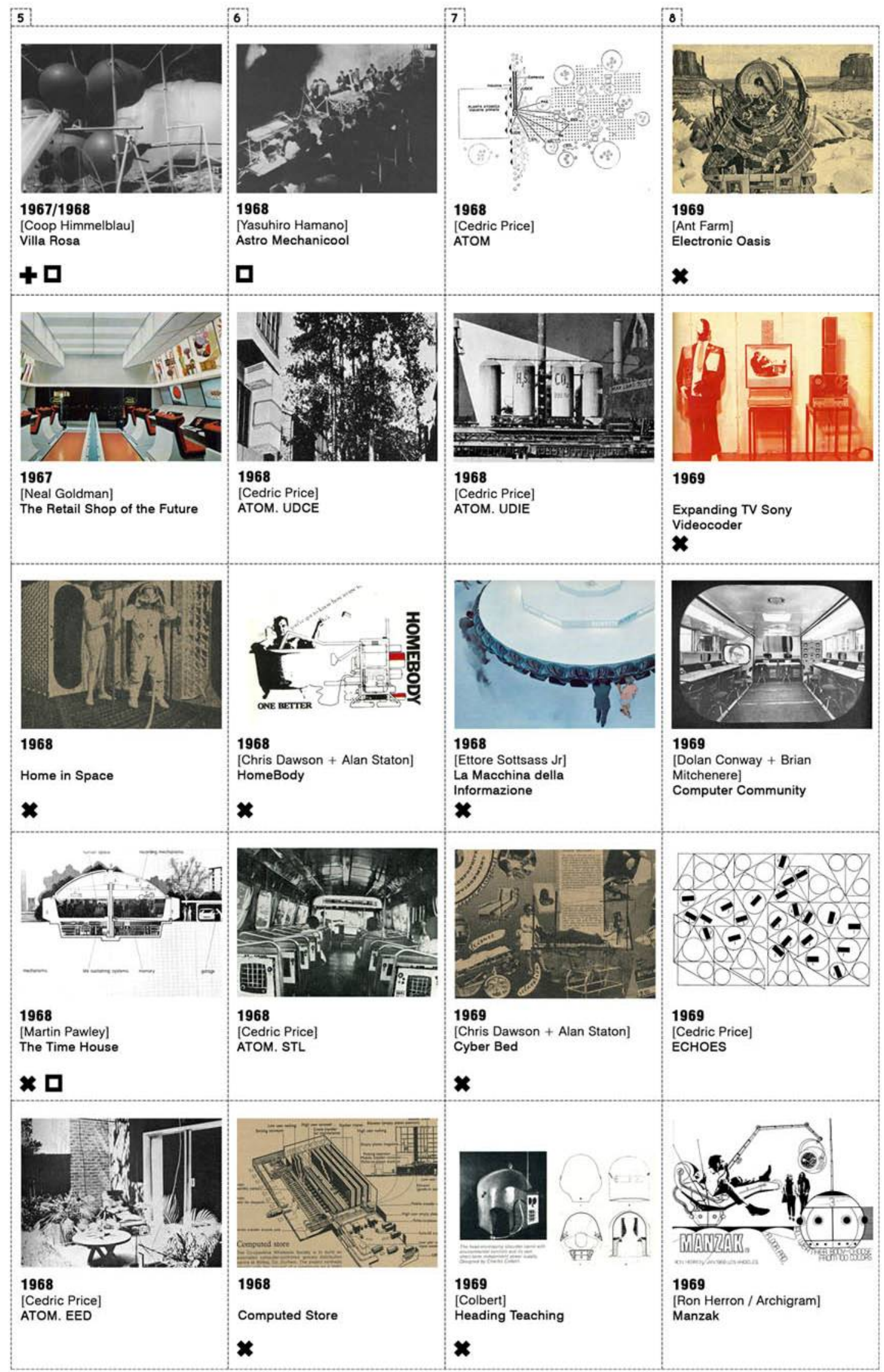




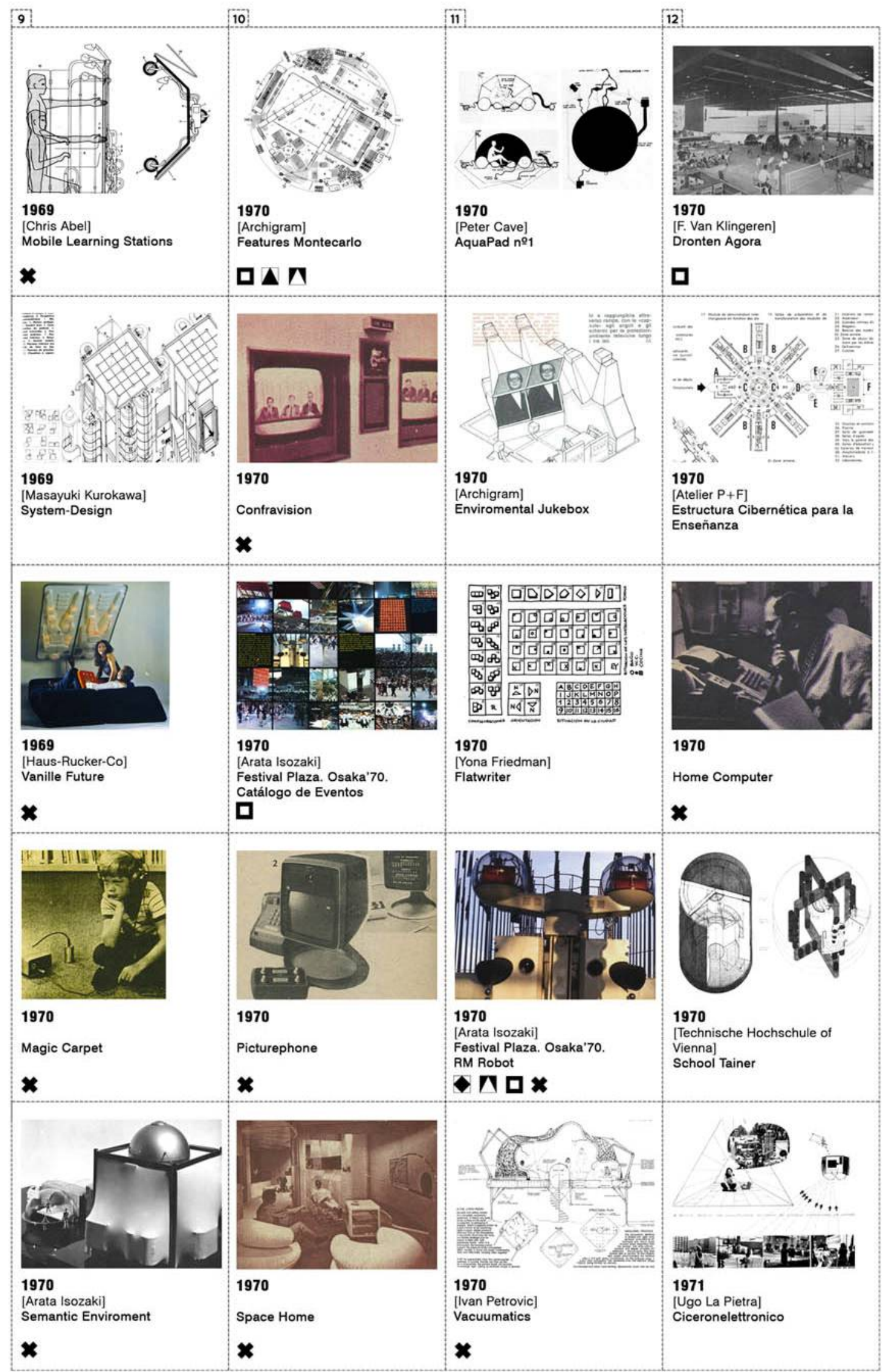




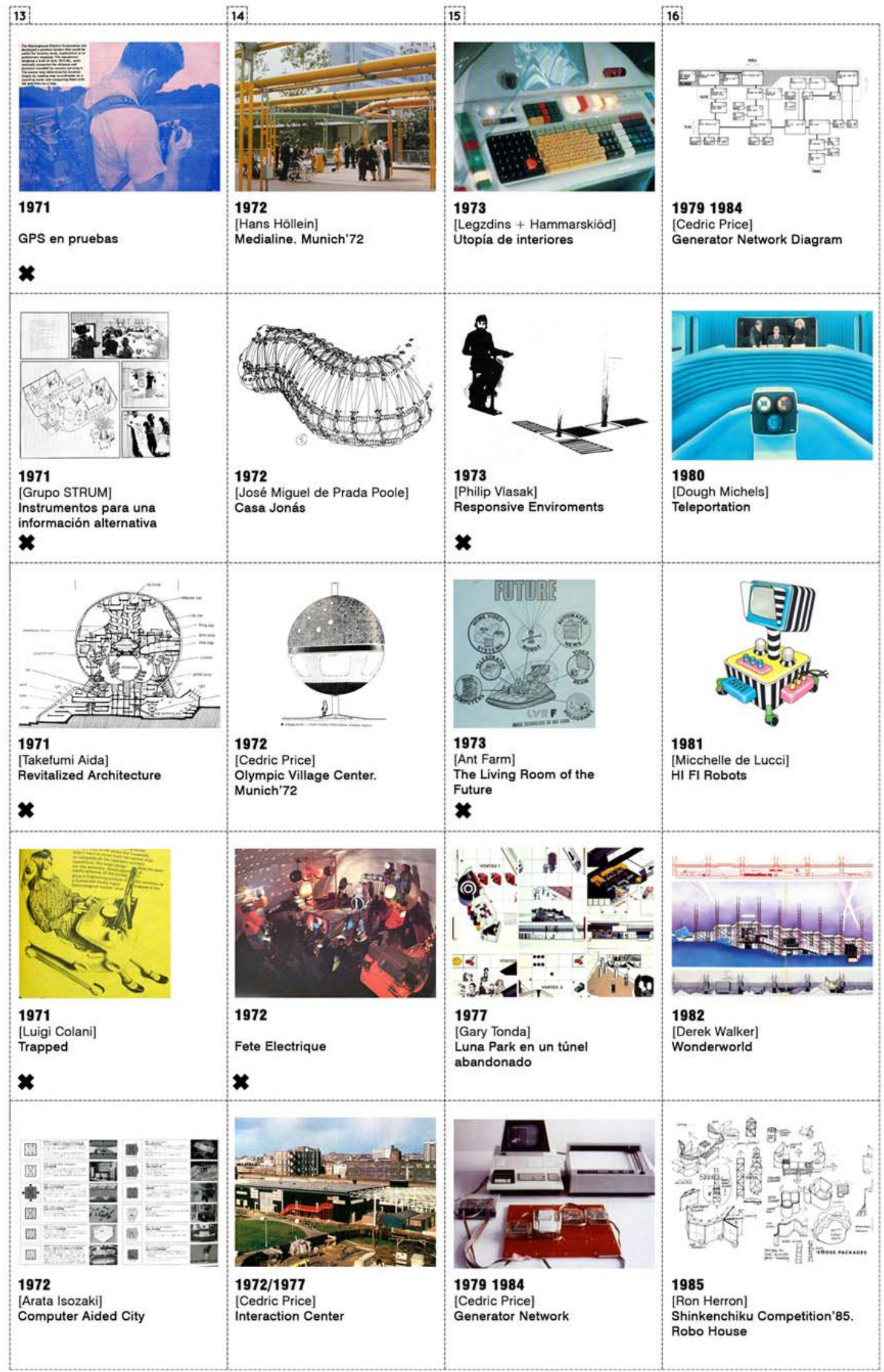




\section{[La Ciudad de los Intercambios] Intercambios de energía e información en los ambientes urbanos.}

La complejidad de flujos urbanos, de transporte, usos, energía e información, convierten a la ciudad en posibilitadora de intercambios, adquiriendo la arquitectura un papel de mediadora entre todos ellos. En dos propuesta urbanas de 1963, Archigram ejemplifica esa complejidad urbana destilada a través de una nueva concepción de la ciudad, diferenciada en sistemas estructurales o "hardware" y sistemas de acción o "software", como explicaría Peter Cook en una de las predicciones en "plan y acción"713. En ese sentido "Living City", exposición comisariada por Archigram en junio de 1963 para el Insitute of Contemporary Arts de Londres, trata de aproximarse a esa escala de la acción, una serie de fenómenos heterogéneos y difícilmente medibles y mucho menos programados o reglados, donde lo más banal puede llegar a convertirse en lo más importante.

"En una ciudad viva todos somos importantes. La trivialidad de encender un cigarrillo, o la dura realidad del movimiento de dos millones de pasajeros al día son dos de las facetas de una experiencia compartida de la ciudad. Hasta el momento, no se ha diseñado ninguna otra forma de ambiente que produzca la misma calidad de experiencias compartidas por tantas mentes con distintos intereses. ${ }^{1714}$ (Archigram, 1963, p.20)

Por otra parte "Interchange City", diseñada fundamentalmente por Ron Herron y Warren Chalk, muestra una ciudad como gran intercambiador de flujos, cada uno de ellos canalizado a través de una tubería diferente, de manera caricaturesca, donde todo parece estar controlado. Un proyecto "plan", un "hardware" que pueda llegar a organizar toda esa complejidad de la ciudad de los Intercambios. Ambos sistemas, duro y blando, intentan ser poco después conciliados en su famosa "Plug In City" (1962-1965), una ciudad donde todo parece estar programado, desde las líneas de transporte hasta los períodos de obsolescencia de los edificios, en un intento de codificación de la compleja red de intercambios derivados del fenómeno urbano. El cerebro de esa megaciudad debería haber sido "Computer City" (1964) [2D] diseñada por Dennis Crompton, un sistema de recogida de información urbana que permitía generar los cambios necesarios en la ciudad a partir de los datos recabados. Archigram define así la generación de "ambientes responsivos" a través de una analogía maquinista derivada de la incipiente computadora.

"El proyecto de la Computer City es un estudio paralelo a la Plug-In -City. Sugiere un sistema de control y detección de los recursos necesarios de toda la ciudad por el que, utilizando el potencial de la electrónica, responde a todos esos asuntos en la escala del día a día, así como de año a año, de toda la estructura de la ciudad." ${ }^{1715}$ (Archigram, 1964, p.41)

\footnotetext{
713 COOK, Peter. Architecture: action and plan. 1967.

714 "In the living city all are important. The triviality of lighting a cigarette, or the hard fact of moving two million of commuters a day are both facets of the shared experience of the city. So far, no other form of environment has been devised that produces the same quality of experience shared by so many minds and interest"
}

Extracts from Living Arts magazine n², June 1963. En: COOK, Peter (editor). Archigram. 1972. p.20.

715 "The Computer City Project is a parallel study to Plug-In-City. It suggests a system of control sensing of requirements throughout the city and, using the electronic summoning potential, makes the whole thing responsive on the day-to-day scale as well on the year-to-year scale of the city structure." 


\section{La búsqueda de ambientes responsivos.}

El ambiente responsivo demandado como opción de futuro por unos Archigram influenciados por los proyectos más radicales de Cedric Price, necesitará por lo tanto de un diseño efectivo a través de dos sistemáticas diferentes: por un lado la referente a los mecanismos de intercambio de información, ese sistema de cerebro y sensores propuesto en la "Computer City", y por otro, aquella asociada a un equipamiento arquitectónico capaz de responder al cambio, de adaptarse a las diferentes necesidades requeridas por el usuario.

Un sistema real, parecido al preconizado por "Computer City", será utilizado por primera vez en la historia de las exposiciones universales, en Montreal'67. El centro de control, programado por las empresas GE e IBM, se situaba en la isla de Sainte-Hélène, en el edificio denominado como "Cybernetics Center" [4C]. Todo el complejo estaría abierto al público excepto su sala de control, en la que había un panel de 16.5×5.4 metros con un mapa de todo el recinto y una serie de controladores que incluían desde cálculos administrativos por el que el sistema controlaba todas las finanzas generadas en la expo así como el número de visitantes de los pabellones y las entradas y salidas de los empleados. Como complemento de éste, un sistema de control de información, con pantallas repartidas por todo el recinto, visibles a unos 250 metros de distancia, en la que se anuncian todos los planes, eventos, niños perdidos, todo lo que acontecía en la programación diaria del evento, así como sistemas de información personalizados a través de micrófonos y tele-operadores, transformados en guías turísticos virtuales. También hay varios intentos en los pabellones de la feria Montreal'67 de generar edificios flexibles que puedan adaptarse a distintas configuraciones, como la propuesta para el "Canadian Pavilion" [4D], de Charney y Parnass.

Muchos de los interfaces materializados en Montreal habían sido testados como prototipos en Nueva York'64 a una escala más pequeña y con un menor grado de interconexión, como el "Audiovisual Learning Centre" [2C] diseñado por Sol Conberg Associates, y expuesto en el pabellón norteamericano. El interés de Japón por el sistema de Montreal se evidencia en la publicación en 1967 de un especial sobre el mismo en "The Japan Architect" la siguiente exposición universal sería la de Osaka'70. Allí será donde muchos de estos sistemas de monitorización, no sólo se evolucionan y sofistican sino que son imbricados con el espacio arquitectónico, a través del "Theme Plaza Pavilion" [10C], diseñado por Arata Isozaki, una mega-estructura tridimensional diseñada por Kenzo Tange que alberga el gran espacio público de la exposición. Para ello diseña una serie de dispositivos mecánicos y electrónicos, que posibilitan un máximo control responsivo y flexibilidad del espacio, adaptado a la gran cantidad de eventos que en él se desarrollaran durante toda la duración del evento y que el propio Isozaki reivindica, a la manera de Archigram, como un acto de "Soft Architecture" o "Arquitectura del Software".

"En 1970, queremos movilidad, organización y unidad. El entusiasmo de la próxima década provendrá del cambio, la movilidad, la estimulación y toda la tecnología que los haga posibles. La arquitectura se ha convertido en un medio en sí mismo, en la determinación de un entorno para sus habitantes. Además del espacio, se debe tener en cuenta el tiempo. La arquitectura debe asumir múltiples significados: su presencia ya no puede ser determinada por la forma; sino que ha de ser flexible y sensible a la

COOK, Peter (editor). Archigram. 1972. p.41.

716 Operations Control Plan. En: JA The Japan Architect, n¹33, agosto 1967. pp.34-40. 
corriente del tiempo y las necesidades de una sucesión de posibilidades. Yo lo llamo una arquitectura blanda, soft architecture. ${ }^{1717}$ (Isozaki, 1969 (1970), p.300)

Para alcanzar este tipo de espacio responsivo, Isozaki diseña artefactos como torres de control de iluminación y ambiente o gradas móviles que pueden ser reguladas en altura. El proyecto se publicará en "The Japan Architect" equipamiento y de esos eventos desarrollados a lo largo del día, una manera de aludir a ese tiempo que Isozaki, como antes haría Price, reclama para una nueva arquitectura para la Ciudad de los Intercambios. Sin embargo, y a diferencia de lo que Price demanda para el "Fun Palace", el espacio resultante no será nunca un lugar de libertad de uso sino de control, al estar las actividades anteriormente programadas y al no poder interactuar los usuarios en la configuración propia del espacio de la plaza, sino responder a lo que ella les ofrece. El "Festival Plaza" construye un espacio lleno de dispositivos a la manera de proyectos como "Features Montecarlo" (1969-1970) o mucho anteriores y también deudores de Price como el "Sin Centre" diseñado por Michael Webb, y derivado también de las experiencias de Constant en su "New Babylon" (1960) y su fundamentación de una nueva sociedad del ocio derivada del "Homo Ludens" de Huizinga, referencia absoluta junto al "Fun Palace", de un gran número de propuestas y edificios. Desde la utópica "Revitalized Architecture" (1971) [13C] propuesta por el japonés Takefumi Aida, a los construidos centros culturales holandeses, entre los que destaca el "Ágora de Dronten"719 (1970), de F. Van Klingeren, o el "Centro Pompidou" (1972-1976) de Rogers y Piano, como emblema de la flexibilidad y casi como punto final de un interesante proceso acontecido entre finales de los sesenta y principios de los setenta. Varios autores señalarán esa genealogía común entre el "Theme Pavilion" de Osaka, el "Fun Palace" y el "Centro Pompidou", entre ellos Peter Cook hablando en 1977 sobre este último.

"Por lo tanto esta idea del hangar bien equipado fue adecuada en el sentido en que podría haberse dejado de lado, o convertido en una burla conceptualmente ese énfasis de las preferencias filosóficas de los arquitectos de finales de los 60.

Algunos edificios tienen que ser construidos, como ejemplo de la preocupación de una generación, por eso tenemos el Hábitat en Montreal; la megaestructura del Theme Pavilion de Osaka ... y el Beaubourg.

Soy muy consciente de todas las prácticas de prevención de incendios y de la lógica estructural, pero la flexibilidad y ese concepto de edificio-lúdico o edificio-juguete eran la esencia de la Plug In City, el Fun Palace de Cedric Price y el proyecto de Archigram para Montecarlo. ${ }^{1720}$ (Cook, 1977, p.52)

717 "In 1970, we want mobility, organization and unity. The excitement of the coming decade will derive from change, mobility, stimulation and all the technology that makes that possible. Architecture has become a medium in itself determining an environment for its inhabitants. In addition to space it must take time into account. Architecture must now take on multiple meanings: its presence can no longer be determined by form; rather it must be flexible and responsive to the flow of time and the needs of a succession of occasions. I call such an architecture, soft architecture"

PAWLEY, Martin. Architecture Versus the Movies or Form versus Content. En: AD The Architectural Design, junio 1970. pp.288-309.

718 ISOZAKI, Arata. Festival Plaza. En: JA The Japan Architect, nº164, junio 1970. pp.XX

719 Como parte de un sistema de equipamientos públicos con ejemplos del mismo arquitecto en Lelystad y Endhoven. Ver:

Agoras. En: TA Techniques et Architecture, n²90, L'Architecture et les Loisirs, diciembre 1972. pp.104-105.

720 "De ce fait cet hangar bien équipe était adéquat en ce sens qu'il pouvait nettement laisser de côte, ou choisir de se moquer conceptuellement, l'emphase du dossier et les preferences philosophiques des architectes de la fin des années 60. 
Ya en los ochenta, los ideales de ese palacio de la diversión se configurarán a través de parques temáticos historicistas e hiper-controlados, que en el excepcional caso del noconstruido "Wonderland"721 (1982) [16D] diseñado por Derek Walker, arquitecto jefe de la ciudad de nueva construcción Milton Keynes, junto a Group Five y Ove Arup, con asesores como Frei Otto y Norman Foster, llegan incluso a utilizar una estética del "Crystal Palace" (1860) de Paxton, ejemplo que se llega a citar en la memoria explicativa del proyecto como paradigma de lo que luego serán esos contenedores industrializados de grandes luces y espacio flexible.

Será el propio Price quién llegará a materializar una versión del "Fun Palace" en el proyecto conocido como "Interaction Centre" (1972-1977) [7E], un edificio construido por fases mediante un bajo presupuesto y una gran cantidad de ingeniosas soluciones. La propuesta reproduce todas las ideas contenidas en el "Fun Palace" en relación a la importancia de la interactividad y el uso frente al objeto arquitectónico, que aparece como simple intermediario, generando las condiciones ambientales adecuadas para cada actividad concreta. Un no-edificio que incluso nace con fecha de caducidad, al ser un solar cedido por el Ayuntamiento de Londres por 27 años, con un plan de desmantelamiento incluido en el proyecto general y que a día de hoy ha sido ejecutado. Será de ésta manera, a través de esa idea de no-edificio, como Price explica en Domus las verdaderas intenciones del "Interaction Centre":

"El encargo que he recibido es de un edificio que no fuera un edificio."1722 (Cedric Price, 1978, p.17)

Los esfuerzos por traducir la acción humana en códigos que puedan ser después interpretados durante el diseño del objeto arquitectónico serán el leitmotiv principal de proyectos como "Flatwriter" [11C] o "Osaka Board" (1970) de Yona Friedman. Ambos intentan desarrollar una especie de máquina de escribir que codifica agrupaciones familiares, climatología e incluso localización dentro de la ciudad, para generar con toda esa información las posibles configuraciones de las distintas viviendas dentro de sus prototipos de "Ciudad Espacial". Años más tarde, el propio Price irá mucho más allá con su proyecto "Generator Network" (1979-1984) [15E] [16A], diseñado para los empleados de la Gilman Paper Corporation en Florida, como sistema computerizado en el que a partir de una trama estructural de 13 por 13 pies y un catálogo de componentes constructivos, pudieran surgir diferentes estructuras y arquitecturas por los condicionantes derivados de la acción de los

Certains bâtiments doivent être édifiés, comme l'exemple de la préoccupation d'une génération, c'est ainsi que nous avons I'Habitat à Montreal; la megastructure du Theme Pavilion à Osaka... et Beaubourg.

Je suis tout à fait averti de toutes les pratiques de la prévention des incendies et de la logique structurelle, mais la flexibilité et le bâtiment-jouet étaient lèssence de Plug In City, du Fun Palace de Cedric Price et du project d'Archigram pour Montecarlo"

COOK, Peter. La Parole est aux Architectes. En: AA L'Architecture d'Aujourd'hui, Le Centre Georges Pompidou, nº 189, febrero 1977. p.52.

721 WALKER, Derek (editor invitado). AD The Architectural Design Profile, n52, Animated Architecture, 1982.

722 "L'incarico che ho ricevuto a voce era per un edificio che non fosse un edificio"

Intervista a Cedric Price. En: Domus, no581, abril 1978. pp.64-65.

Una lectura parecida se hace en la primera publicación del edificio en Inglaterra:

PRICE, Cedric. Inter-Action Centre. En: RIBA Journal, noviembre 1977. pp.458-465. 
usuarios. El proyecto deviene en un código cerrado que genera una amplia red de configuraciones a través de un programa informático desarrollado por John y Julia Frazer, en paralelo a las investigaciones de Nicholas Negroponte en el MIT, autodenominada como "Architecture Machine". El "Generator Network" de Price, aparece como evolución factible de algunas de las experiencias realizadas por el propio arquitecto inglés en "ECHOES" (1968) [8D], que preconiza una sistemática de parametrización efectiva basada en la computadora como opción de futuro en torno a esa búsqueda de los denominados "ambientes responsivos".

\section{Dispositivos de intercambio de información.}

Isozaki reincidirá en su intento de diseños responsivos a través del proyecto teórico "Computer Aided City"723 (1972) [13E], en el que genera un corazón lúdico de la ciudad a partir de dos estructuras lineales construidas por diferentes plataformas y un cerramiento geodésico, en el que incorpora gráficos relacionales de cada uno de los programas e interfaces posibles para el intercambio de información y experiencias en el seno de la ciudad, con gimnasios instantáneos, sistemas de gradas y plataformas, mesas sensibles, pantallas de proyección programables o centros computerizados de conexión. De vuelta a Osaka'70, una de las grandes peculiaridades del equipamiento generado en el "Theme Festival Pavilion" [11D], será el "RM Robot", un robot de dos cabezas de 18 metros de altura equipado con sistemas de luces, sonido, generación de niebla artificial, brazos de movimiento e información. Un "RM Robot" que materializaba la obsesión japonesa por los robots, con hasta 24 pabellones de compañías japonesas en Osaka'70 que exponían sus últimos prototipos, obsesión que será transportada a otros arquitectos del mundo occidental en general y en concreto a las islas británicas a través de la sección "Cosmorama" de Architectural Design, que incluirá cualquier novedad robótica llegada desde el país nipón. El diseño de esos dispositivos de intercambio de información, que el "RM Robot" simboliza, llevaba ya casi una década en manos de unos pocos arquitectos, que estaban experimentando en ámbitos diversos, desde showrooms para empresas como a través de su aplicación directa a centros de enseñanza.

La anteriormente comentada "Knowledge Box" (1962) [1D] de Ken Isaacs puede considerarse como un de esos primeros prototipos de dispositivos de intercambio todavía bastante rudimentario y unilateral. Propuestas más evolucionadas como "Self paced Study Station" (1964) [2E] de Sol Conberg Associates, una especie de escritorio con pantalla de video y sistema de audio incluidos, o "Head Teaching" (1969) [7E], aparecerán de manera sistemática en Architectural Design ${ }^{724}$, revista que publicará profusamente el proyecto global relacionado con la enseñanza diseñado por Cedric Price en 1968 bajo el sobrenombre de "Atom" [7A] [5E] [6B] [6D] [7B]. Basado en el modelo educacional esbozado por J.E. Tirrel y A.A. Canfield en el artículo "Adiós al aula"725, Price elabora junto a estudiantes de la escuela

723 ISOZAKI, Arata. Computer Aided City. En: Kenchiku Bunka, n³10, agosto 1972. pp.137-150.

724 Algunas de estas propuestas se incluirán en un número entero de la revista dedicado a la "Enseñanza" bajo el título "What about learning?"

PRICE, Cedric (editor invitado). AD The Architectural Design, What about Learning?, mayo 1968.

725 Publicado en el citado anteriormente número de Architectural Design.

TIRREL, J.E; CANFIELD, A.A. Bye bye classroom. En: PRICE, Cedric (editor invitado). AD The Architectural Design, What about Learning?, mayo 1968.p.223. 
de arquitectura Rice de Houston, una serie de estructuras, no predeterminadamente edificios, para integrar la educación en diversos ámbitos de la vida contemporánea.

"En términos arquitectónicos y de planificación se requiere evitar el uso de una única planta física totalizadora destinada a la transmisión educativa. Sin embargo, aceptar que los servicios educacionales son una alimentación continua y esencial durante toda la vida, requiere la aceptación previa del hecho de que la educación, junto con otros servicios esenciales, debe ponerse a disposición del público valiéndose de medios y métodos comparables con las otras formas de servicios invisibles." (Cedric Price, 1968, p.22)

Así es como Price genera una serie de sistemas educativos más o menos especializados, insistiendo sobremanera en su obsolescencia, no sólo material sino también social, y en su imbricación con estructuras ya existentes, desde la industrial, a través de información sobre los procesos radiografiados en los propios centros, la comercial, trabajando con la información de los productos y sus procesos de elaboración, los transportes, con equipamiento y dispositivos imbricados al transporte público como pantallas o equipos de audio e incluso el automóvil o la vivienda, con soportes de educación a distancia con módulos intercambiables ${ }^{727}$. A su vez genera dos modelos super-especializados traducidos en objetos arquitectónicos, el Ba modelo Caja y Ba modelo carpa, en los que la educación se distribuye por modelos educativos, ya sean individuales, colectivos, según grados y materias pero nunca por componentes de edad. La diferencia radical de la propuesta es la inmersión de la educación en cada uno de los ámbitos más relevantes de la vida urbana frente a otras estrategias, centradas en el diseño de puestos individuales que amplifiquen la experiencia educativa, "Mobile Learning Stations" (1969) [9A] de Chris Abel o "School Tainer" (1970) [12D], diseñado por alumnos de la Technische Hochschule de Viena, o centros educativas hiper-tecnificados, como la "Estructura Cibernética para la Enseñanza" [12B] diseñada por H. Prader, F. Fehringer y E. Ott del Atelier P+F. Sin embargo, ya en 1966, una propuesta radical de Hans Höllein anticipaba esa hibridación de la educación en lo doméstico a través de un fotomontaje de una televisión como "Extensión de la Universidad de Viena" [3C], como forma de reivindicación de esa "educación expandida". El mismo año, Cedric Price había concebido su proyecto "Oxford Street Corner"728 [3D], proyecto para una organización privada en el que se genera un espacio en el centro de Londres a modo de gran máquina de información para unas 5000 personas, una especie de Fun Palace de la información en un inmueble del centro ya consolidado. De esta manera, el edificio contiene equipamiento para facilitar las telecomunicaciones así como para almacenar información, una especie de "servidor" materializado en un lugar al que cualquier ciudadano podía acceder desde el edificio o información para alquilar una habitación, concertar un viaje en una agencia, gestionar papeleo público o buscar empleo. El leitmotiv principal del proyecto

726 PRICE, Cedric. Átomo. En: Cuadernos Summa-Visión, n44, 1970. pp.21-26.

727 Todos ellos ampliamente explicados a través de imágenes, diagramas y texto. Indico en esta nota los nombres de todos esos sistemas en castellano, con la traducción hecha en los "Cuadernos de Summa Visión" editados en Buenos Aires:

UDIE (Unidad Demostrativa Educacional Industrial)

UDCE (Unidad Demostrativa Comercial Educacional)

STL (Servicios de Tránsito Ligero)

PAE (Playa Automovilística Educacional)

EED (Estación de Estudios a Domicilio)

728 El proyecto se incluye en el libro de Royston Landau "New Directions in British Architecture" en el capítulo titulado "Information Transfer", "Transferencia de Información".

LANDAU, Royston. New Directions in British Architecture. Studio Vista. Londres, 1969. pp.101-111. 
es generar una red de información accesible, a través de máquinas programadas para tal efecto, desde el terminal que enseña idiomas a un simulador para aprender a conducir. La unidad básica la componían unos cubículos de información de dos plazas que se situaban en un espacio abierto permitiendo así una gran combinación de posibilidades.

De manera análoga existe una experimentación en relación a ese intercambio de información relacionado con ámbitos como el comercial y materializada a través de diversos prototipos, como por ejemplo "La Macchina della Informazione" (1968) [7C], diseñada por el italiano Ettore Sottsass Jr para mostrar los productos comercializados por Olivetti a través de una gran caja cinematográfica dividida en cuarenta módulos individuales construidos en resina. En cada uno de ellos se podía ver una de las diez películas proyectadas en su interior sobre productos de la marca italiana. El japonés Yasuhiro Hamano utilizará el "Astro Mechanicool" [6A] en un desfile de moda y también Archigram propondrá varias veces todo de tipo de dispositivos para visionar su propio trabajo a través de "Environmental Jukebox" [11B], denegado en una exposición del grupo en 1968 en Oslo y en 1970 para la exposición universal de Osaka. Más allá del ámbito puramente arquitectónico y desde principios de los años sesenta, distintas empresas encargarán prototipos de tiendas futuras, algunas de ellas con eco en publicaciones de arquitectura ${ }^{729}$, como "The Retail Shop of the Future" (1967) [5B] de Neal Goldman, una especie de precursora de venta on-line con unas computadoras en las que poder elegir entre una gran lista de objetos.

Más allá de programas o usos específicos, como el ámbito de la educación o el comercial, varias propuestas de dispositivos de intercambio de información encuentran en el espacio público un inmejorable contexto de experimentación. Proyectos como "Live Information" (1965-1966) de Angela Hareiter, una máquina de la información compuesta por cápsulas especializadas equipadas con sistemas de comunicación auditiva y visual a través de proyectores. Más incisivo será el proyecto de los estudiantes de $5^{\circ}$ curso de la Architectural Association Dolan Conway y Brian Mitchenere, "Computer Community" (1969) [8C], una serie de comunidades computerizadas móviles a escala de barrio e incluso global, una especie de cibercafés que aprovechan los incipientes avances tecnológicos en materia de comunicación y que pueden ser utilizados desde el ámbito educativo, como conector de las distintas universidades inglesas, e incluso personal, pudiendo llevar tecnologías como la teleconferencia a los estratos más bajos de la sociedad. El proyecto genera un prototipo bastante creíble de espacio público expandido reducido a una serie de dispositivos de intercambio de información. Höllein propone convertir esa caravana equipada de la "Computer Community" en un sistema de tuberías equipadas en el proyecto de equipamiento para la villa olímpica de los juegos de Munich'72 denominado como "Media Line" [14A]. Un complejo entramado de tuberías recorre el espacio público de la villa equipándola con sistemas de iluminación, información visual y auditiva a través de monitores, proyectores, altavoces, zonas expositivas, acondicionamiento higrotérmico a través de tubos de aire acondicionado y zonas de sombra, así como mobiliario urbano activo, desde bancos a juegos para niños.

\section{La expertización de los electrodomésticos}

El ambiente doméstico tampoco escapa a la incursión de una amplia gama de dispositivos de intercambio de información y energía en un proceso de ampliación y expertización de los electrodomésticos. Este proceso supone una evolución de lo que comenzó como un sistema

729 America: una nuova idea per vendere. En: Domus, n448, marzo 1967. pp.34-35. 
de objetos que podían realizar una serie de tareas domésticas y que pasarán a convertirse en una manera de conexión del hogar individual con el resto del mundo global. Ese nuevo proceso, denominado por McHale como "The New Simbiosis", incluye a las máquinas en el mundo de relaciones ya existente entre hombres, animales, plantas y medio. Ese aparataje ya no es un complemento del hogar sino parte fundamental del mismo como Banham y Dallegret dejan claro en sus propuestas "Standard Living Package" [3B], un compacto tecnológico que incluye funciones de climatización, iluminación y sistemas de audio y video y "Anatomy of a Dwelling", una radiografía de todas las instalaciones de una vivienda superpuestas, pertenecientes a su propuesta-manifiesto de vivienda-burbuja "Un-House" (1965), la misma que Banham pondrá en el centro del debate arquitectónico a través del libro "The Architecture of the Well-Tempered Environment"730 (1969).

La Ciudad de los Intercambios demanda una vivienda de los intercambios por lo que de manera paralela a las experiencias realizadas por arquitectos en esta dirección, las marcas comerciales se encuentran construyendo prototipos de nuevos dispositivos que puedan llegar a introducirse en los hogares de la misma manera que lo había hecho la radio y la televisión, culpables del cambio radical acontecido en la manera de entender el hogar. La sección "Cosmorama" de Architectural Design se encargará de publicar un gran número de esas innovaciones. "Picturephone" [10D] y "Confravision" (1970) [10B], que mezclan teléfono y televisión para realizar tele-conferencias, "Magic Carpet" (1970) de Dole Electro System, una especie de alfombra a la que pueden conectarse aparatos eléctricos o "Home Computer" (1970) [12C], una apuesta por el proto-ordenador personal para el hogar desarrollada por General Electric. Muchas de estas propuestas comerciales para una vivienda del futuro, etiqueta que se utiliza para denominar a electrodomésticos y otros objetos domésticos por doquier, no escapan a la creciente estética humanoide caracterizada por la gran influencia que los robots tienen en el imaginario colectivo desde finales de los años veinte. El robot toma el ámbito doméstico en proyectos como "Living 1990" [3E], una propuesta para la exposición de 1967 patrocinada por el Weekend Telegram en la búsqueda del hogar de un futuro situado en 1990. La hipotética propuesta del grupo inglés Archigram está llena de gadgets y artefactos, desde superficies de proyección neumáticas a dispensadores de comida u olores, en pos de una adaptabilidad del espacio al gusto de cada uno de los usuarios de la vivienda, una flexibilidad deudora de la tecnología.

\begin{abstract}
"Reguladores de sonido, espacio y luz, hacen que suelo y techo pasen de duros a blandos, o se inflen en ciertas zonas cuando alguien quiera recostarse o dormir. Las mamparas, ajustables por los robots James y Fred, definen áreas menores dentro del volumen principal, en las que uno puede aislarse totalmente y sumergirse en un ambiente generado por la proyección de películas, luces, sonidos u olores. Siempre que uno quiera, dónde y cuándo lo necesite, estas transformaciones se ponen en marcha en un abrir y cerrar de ojos, sin más que apretar un botón o dar una orden oral." ${ }^{\prime 731}$ (Warren Chalk, 1967, p.146)
\end{abstract}

730 BANHAM, Reyner. The Architecture of the Well-tempered Environment. 1969.

731 "The floor and ceiling can be transformed from hard to soft as acoustic / space / light regulators or inflated in certain areas as required for reclining or sleeping. The adjustable screens of the robot towers, robots Fred and James, define smaller areas within the main volume where one can be totally enclosed, enveloped in an event generated by the projection of films, lights, sound and smellies. The push of a button or a spoken command, a bat of an eyelid will set these transformations in motion, providing what you want where and when you need it"

CHALK, Warren. Living 1990. Archigram Group. En: AD The Architectural Design, marzo 1967. pp.146-147. 
Fred y James sólo serán un ejemplo más de esa influencia del robot en la vivienda del futuro $^{732}$. Ya sean o no formalizados como futuros humanoides, la utilización de dispositivos tecnológicos asociados a usos domésticos se dispara, llegándose a convertir en verdaderos protagonistas del espacio doméstico de los sesenta. Artefactos como "Homebody" (1968) [6C] diseñado por los ex alumnos de Peter Cook en la Architectural Association, Chris Dawson y Alan Staton, un mini-robot que es capaz de frotarte la espalda en el baño o generar un espacio neumático hinchable dentro de la vivienda o "Manzak" (1969) [8E], un autómata diseñado por Ron Herron para la ayuda de las tareas domésticas del hogar. Un "Tomate Electrónico" que despliega en la vivienda una serie de dispositivos como radar óptico, cámara de televisión y sensores para golpes, una mezcla entre robot de cocina, aspiradora y centro de comunicaciones integrado. De esta manera, la mayor parte de las propuestas optan por una clara diferenciación entre el contenedor y el sistema de objetos que lo equipan, dando una mayor importancia a estos últimos, que serán diseñados hasta la extenuación, aún a riesgo de caer en caricaturizaciones de los verdaderos adelantos tecnológicos que tenían lugar en otros ámbitos de la industria o el conocimiento.

Sin embargo, existen algunos proyectos que si trabajarán con esa relación de los objetos equipamiento y su contenedor, diseñando todo tipo de dispositivos de intercambio como suelos técnicos totalmente equipados y registrables, en un claro alegato del plug-in horizontal como paradigma de la ansiada flexibilidad.

"Ya no es necesario dejar en manos del diseñador de edificios la toma de decisiones en relación a tu entorno, puedes transformarlo tú mismo."

"¿Es posible re-estructurar el espacio y el uso para responder a las intenciones de sus habitantes?"734 (Arata Isozaki, 1970, p.60)

Este protagonismo del usuario articulará el eje principal de las conclusiones de Peter Cook en su predicción de $1967^{735}$. Ese mismo año, Cook estaba preparando junto al resto de los miembros de Archigram la propuesta para la Bienal de París de 1967 "Control and Choice" [4A], fruto de experiencias anteriores como "Living 1990". El proyecto aparece como un conjunto de viviendas que se liberan de la dictadura del diseñador al generar un sistema abierto en el que el usuario puede evaluar ("control") y elegir ("choice") la forma en que configura su vivienda, dependiendo de su "manera de vivir" en cada momento. Las viviendas presentan una componente temporal dibujada mediante situaciones hipotéticas durante diversas fases de la vida del usuario, algo bastante novedoso en un panorama arquitectónico obsesionado con el tipo, como tendencia cerrada y perfecta. La estructura principal se convierte en un soporte construido a partir de una estructura tridimensional que

732 Me gustaría reseñar dos volúmenes imprescindibles en relación a los robots desde ámbitos no especializados:

MALONE, Robert. The Robot Book. Harcourt Brace Jovanovich. Nueva York, 1978.

El volumen de Design Quarterly que tiene a Michael Webb, ex-archigram como editor invitado:

WEBB, Michael (editor invitado). Design Quarterly, n¹21, Robots, Walker Art Center, 1983.

733 "The determination of your environment need no longer be left in the hands of the designer of the building: it can be turned over to you yourself"

Control and Choice. En: COOK, Peter (editor). Archigram. 1972. pp.68.

734 ISOZAKI, Arata. Soft Architecture as Responsive Enviroment. En: Kenchiku Bunka, enero 1970. p.60.

735 COOK, Peter. Architecture: action and plan. 1967. 
se va ocupando y mutando ocasionalmente. El mismo año, el griego Takis Zenetos propone una estructura muy parecida, ambas también manteniendo una preocupación en paralelo sobre la incorporación de lo natural en el ámbito de la vivienda, en la que se apoyan o cuelgan artefactos. "Body Carrier" [4E] supone una especie de dispositivo de interconexión entre el individuo y su entorno utilizado por Takis Zenetos en alguna otra de sus propuestas en torno a un "Electronic Urbanism". A modo de silla que se adapta a las distintas posturas corporales, "Body Carrier" se presenta protegido por una doble membrana transparente que se hace opaca mediante un líquido que fluye entre ambas. Dentro aparecen equipos de televisión y transmisión de voz, aire acondicionado, iluminación a partir de la activación eléctrica de partículas de fósforo. Como "Control and Choice", el proyecto nace de una confianza absoluta en la tecnología como motor de cambio del ambiente doméstico.

\begin{abstract}
"Inevitablemente, el ensamblaje tiene que ser un conglomerado de sistemas, organizaciones y aparataje técnico que permita la elección de una respuesta entre un numero de alternativas; y que explote así las distintas formas de la limitación física de una pieza de hardware frente a las ilimitadas posibilidades atmosféricas de un medio efímero... Existe un miedo natural en todos nosotros que desconfía del poder de la maquina frente a la responsabilidad humana. La dependencia de este tipo de elementos para poder desarrollar una vida emancipada es una de nuestras paradojas. " ${ }^{" 36}$ (Archigram, 1967, p.68)
\end{abstract}

Tres años después de las propuestas de Zenetos y Archigram, Arata Isozaki diseña "Responsive House" (1970) [9E], un prototipo de vivienda sensible a los cambios en la que el arquitecto japonés ve una oportunidad de experimentar hasta qué punto una casa es capaz de modificarse según el uso de sus habitantes y las condiciones variables del ambiente que les rodea, a través de una combinación de dispositivos robóticos, coincidiendo con sus fabulosos autómatas de la expo de Osaka'70 y dispositivos tradicionales como las pantallas Shoji. La misma adaptabilidad será ensayada por el proyecto "Vacuumatics" (1970) [11E], de Ivan Petrovic, que transporta la flexibilidad a la envolvente, una construcción textil que modifica su forma a través de una serie de brazos hidráulicos que responden a las órdenes dictadas por los habitantes de la vivienda. También la "Casa Jonás" (1972) [14B] diseñada por José Miguel de Prada Poole, cambia su estructura según las necesidades de su ocupante, del cual aprende. "Time House" (1968) [5D], diseñada por Martin Pawley, puede escuchar, oler, recordar, tocar, y así controlar todos las acciones del usuario, organizando las funciones básicas de sus ocupantes al grabar y recordar sus comportamientos y ayudarles a mejorarlos. De planta circular, posee un sistema motorizado de videograbación a modo de manillas de reloj y sensores que persiguen la actividad de los habitantes, la registran y almacenan en el sótano, en el que se alberga una gran computadora a modo de memoria infinita. La casa que se adapta al usuario deberá equiparse con dispositivos que puedan aprender de los comportamientos de los mismos como paradigma de entorno responsivo.

Además de esa ansiada capacidad de cambio y adaptabilidad de la vivienda a sus usuarios, otro de los caminos de experimentación muy común en estos prototipos se relaciona con la capacidad de los mismos para generar vínculos entre el ámbito privado doméstico y el público urbano, o lo que es lo mismo, para poder llegar a entender "lo privado" como extensión de "lo público" y viceversa. Para la exposición de 1972 "Italia: New Domestic

736 "Inevitably, the assembly as drawn has to be a conglomeration of systems, organizations and technical apparatus that permit the choice of one response out of a number of alternatives; and exploit the different natures of the physical limitation of a piece of hardware, against the unlimited atmospheric power of an ephemeral medium..."

Control and Choice. En: COOK, Peter (editor). Archigram. 1972. pp.68. 
landscapes", el grupo italiano STRUM, formado por Carlo Giammarco, Giorgio Ceretti, Ricardo Rosso y Pietro Derossi, intenta generar un lugar de hiper-comunicación, con máquinas de escribir, cámaras de video, posters en las paredes o dispositivos móviles para poder visualizar mensajes. Así es como definen "Mediatory City" [13B], como dispositivo de intercambio de información entre la esfera de lo público y lo privado, materializado en una especie de red social anterior al mundo hiper-conectado del "World Wide Web". De manera análoga, "The Living Room of the Future" (1973) [15C] es representado por los norteamericanos Ant Farm en una muestra en el Contemporary Arts Museum de Houston, como lugar hiper-conectado a través de la tecnología, materializada en computadoras, videocámaras, pantallas de proyección y cómo no robots. Cualquier modelo de vivienda del futuro que se preciara no podía prescindir de este tipo de dispositivos de interconexión, materiales plásticos y unidades de aislamiento bulbosas. Una caricatura de todas ellos podría ser la propuesta "Utopía de Interiores" (1973) [15A] de los suecos Legzdins y Hammarskiöld, que resume bastante bien algunos de los clichés pop más frecuentes en cuanto a un mundo futuro se refiere, un espacio diáfano blanco en el que se generan lugares de privacidad mediante estructuras móviles, en este caso una especie de medias cúpulas geodésicas, mucho plástico y tecnología aplicada con estética futurista, desde una mega pantalla y proyector a monitores integrados, teclados o sistemas de audio.

El diseño de este tipo de dispositivos llega incluso al discurso arquitectónico con propuestas como "Vanille Zukunft" (1969) [9C] de Haus Rucker-Co, a través de la que intentan dulcificar la idea de un futuro tecnológico en el que la propia tecnología se rebela contra el hombre. En su "Futuro de color vainilla" presentan la tecnología bajo formas suavizadas, edulcoradas, atractivas para el usuario, dejando de lado el carácter maquinista y frío con el que se representaban muchas de las opciones de futuro en esta época.

"El futuro aparece como frío para mucha gente. Lleno de robots crueles, rayos misteriosos y catástrofes artificiales. La manera en que nosotros vemos el futuro es de color amarillo brillante.

Como un helado de vainilla. Refrescante, de olor dulce, suave. UN FUTURO DE VAINILLA." ${ }^{737}$ (Haus-Rucker-Co, 1969, p.22)

Otro posicionamiento crítico había sido ya esbozado a mediados de los sesenta por Françoise Dallegret, que a la vez que estaba diseñando los elementos de la utopía tecnológica propuesta por Banham, caricaturizaba el poder de la máquina en trabajos como "CliclaCrocoTartoMatic" (1963) [1E], "una máquina desproporcionada que puede dar bofetadas, hacer empanadas, morderte en la pierna o darte una patada en el culo de manera completamente automática" o "L'iNtrocoNversoMAtic" (1964) [2B], "una máquina interactiva portátil que detecta y lee las intenciones psíquicas a leer, escuchar y descifrar". Ambos proyectos se alinean a una serie de diseños del canadiense, entre la fábula de la técnica, la admiración y la crítica. Ya en 1972, y también para la exposición "Italia: New Domestic Landscapes", el arquitecto Ugo LaPietra parece adivinar el curso de los acontecimientos al prevenir sobre la importancia del diseño de los dispositivos de intercambio a partir de su necesidad social y no convertidos en objetos de diseño sin más. En su "Ciceronelettronico" [12E], LaPietra trata de generar experiencias en torno a esta interconectividad entre espacio

737 "The Future is frightening for many people. Full of cruel robots, mysterious rays, and artificial catastrophes. The way we see the future, it is bright yellow. Like vanilla ice cream. Refreshing, sweet-smelling, soft. VANILLA FUTURE"

PORSCH, Johannes; ARCHITEKTURSENTRUM WIEN (editores). The Austrian Phenomenon. 2005. p.22. 
público y doméstico. Sus palabras ante el devenir del diseño de dispositivos parece a la vez revelador y lapidario ${ }^{738}$ :

\begin{abstract}
"The Domicile Cell : una microestructura dentro de los Sistemas de Información y Comunicaciones.

La propuesta para el espacio que he diseñado para la exposición New Domestic Landscapes no está destinada a ser una de las muchas contribuciones al desarrollo de la vivienda célula a través de soluciones ambientales individuales; aún menos es un intento de redescubrir a través de la invención nuevos objetos que tratan de dar una posible solución a problemas sociales, los cuales encuentran uno de sus principales puntos de venta en el ámbito doméstico". ${ }^{739}$ (Ugo LaPietra, 1972, p.226)
\end{abstract}

\begin{abstract}
738 Se han introducido en el catálogo algunas propuestas de esta vertiente de diseño por parte de arquitectos del "caparazón" o envolvente de estos dispositivos, sin tener en cuenta ningún tipo de posicionamiento al papel que estos pueden jugar en el espacio doméstico. La Pietra será bastante crítico con la adopción masiva de algunas de estas tecnologías. Reseño aquí un artículo del mismo en torno a la pérdida de la memoria colectiva derivada del centralismo generado por la televisión en el espacio doméstico:
\end{abstract}

LAPIETRA, Ugo. Ferialità Televisiva. En: Domus, n613, febrero 1981. pp.36-39.

739 "The Domicile Cell: A Microstructure within the Information and Communications Systems.

The proposal for the space that I have designed for the New Domestic Landscapes exhibition is not meant to be one of the many contributions to the development of the domicile cell through individual environmental solutions; still less is an attempt to rediscover through the invention of new objects a possible solution to the knotty social problems that find one of their chief outlets of expression in the domestic environment."

LAPIETRA, Ugo. The Domicile Cell: A Microstructure within the Information and Communications Systems. En: AMBASZ, Emilio (editor). Italia: the New Domestic Landscapes. 1972. pp.226-231. 


\section{Capítulo 8. CONCLUSIONES.}

Una vez definida y analizada la taxonomía de proyectos y estrategias proyectuales a través de las cuatro alternativas de futuro enunciadas, se han realizado varios diagramas que evidencian una serie de relaciones temporales entre cada una de ellas a modo de estudio comparado. La sistemática elegida no pretende aportar enunciaciones categóricas sino evidenciar una serie de hipótesis que podrán ser reafirmadas o negadas por nuevos estudios sobre el contexto temporal objeto de esta investigación. En cada una de éstas, hay una breve explicación del diagrama de estudio y de esas evidencias a modo de conclusiones. Se han incluido extractos de los mismos en el texto pero todos esos diagramas vienen adjuntos por lo que se recomienda también su lectura pormenorizada. 


\section{Diagramas_01 y 02 PREDICCIONES DE FUTURO}

- Se adjuntan tanto los diagramas particulares de cada una de las alternativas de futuro (diagramas 01) así como el diagrama general en el que se presentan comparadas todas las predicciones (diagrama_02).

- Se han relacionado las predicciones arquitectónicas con los proyectos pertenecientes a cada una de las alternativas de futuro, así como sus estrategias derivadas.

- Las predicciones y los proyectos se han ordenado a lo largo de una línea temporal horizontal y las alternativas y las estrategias en sentido vertical, clasificadas tal y como aparecen en el volumen de la tesis.

- Se han detectado diversas tendencias: las predicciones de Ragon son las menos diversas, ni siquiera hablan de todas las alternativas de futuro, y son las que menos proyectos aportan a la investigación, en concreto 25 proyectos catalogados entre "¿Dónde viviremos mañana?" y "Las ciudades del futuro". El resto de predicciones se mueven en una media entre 30 y 50 proyectos catalogados en cada una de ellas, salvo "Cosmorama", que es la más diversa y la única que aporta ejemplos a cada una de las estrategias derivadas de las alternativas de futuro, contando con más de 200 proyectos catalogados.

- El diagrama permite evidenciar también las diferencias temporales entre el año de producción de los proyectos y las alternativas y estrategias a las que pertenecen en relación al año de publicación de cada una de las predicciones.

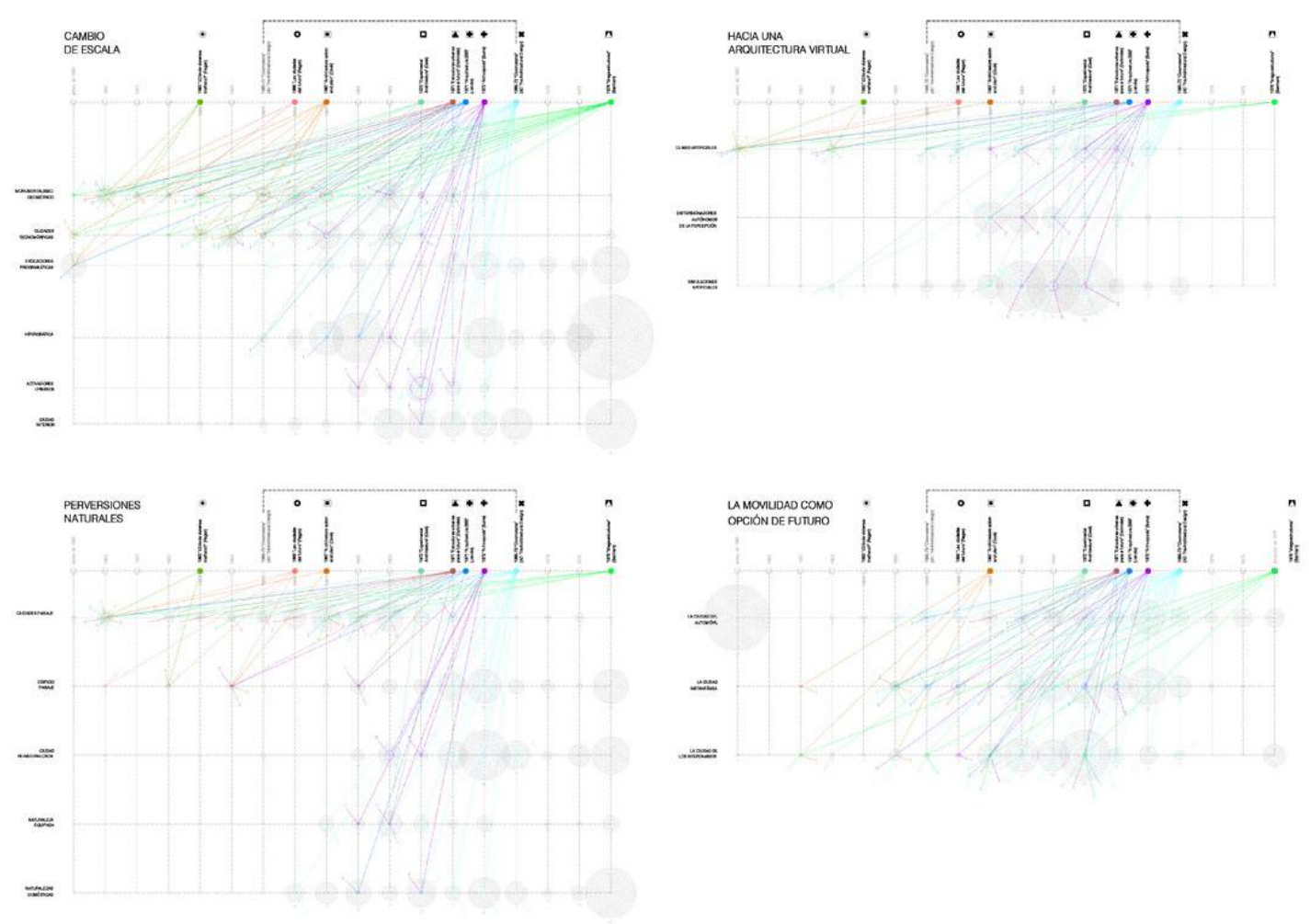

Diagramas_01 


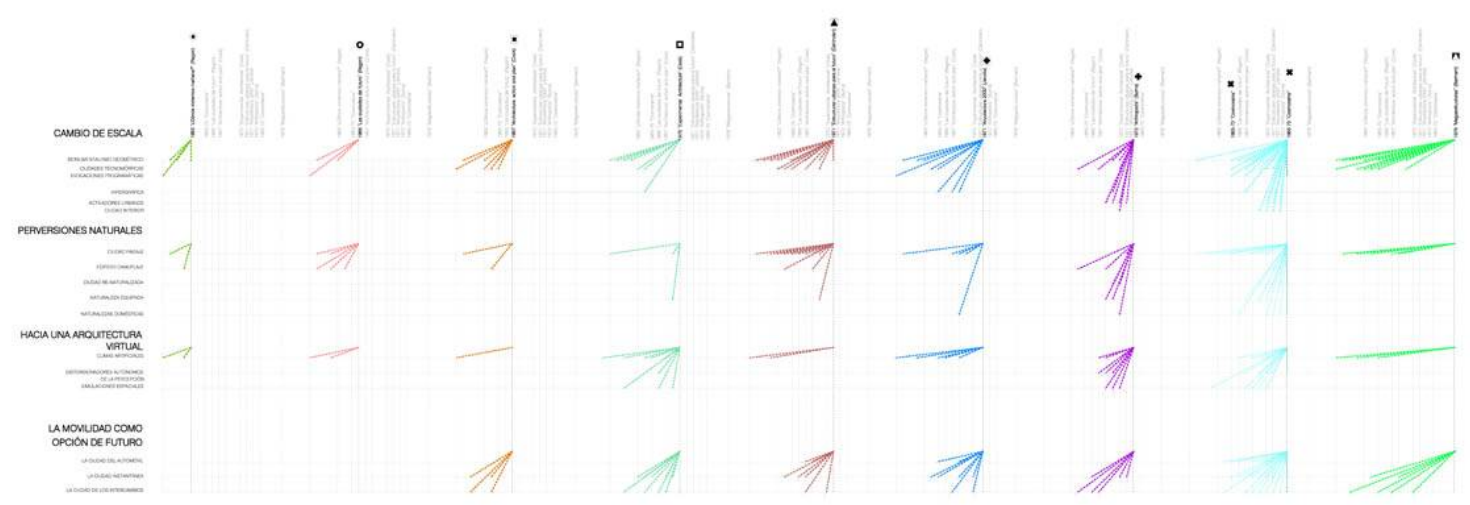

Diagramas_02 

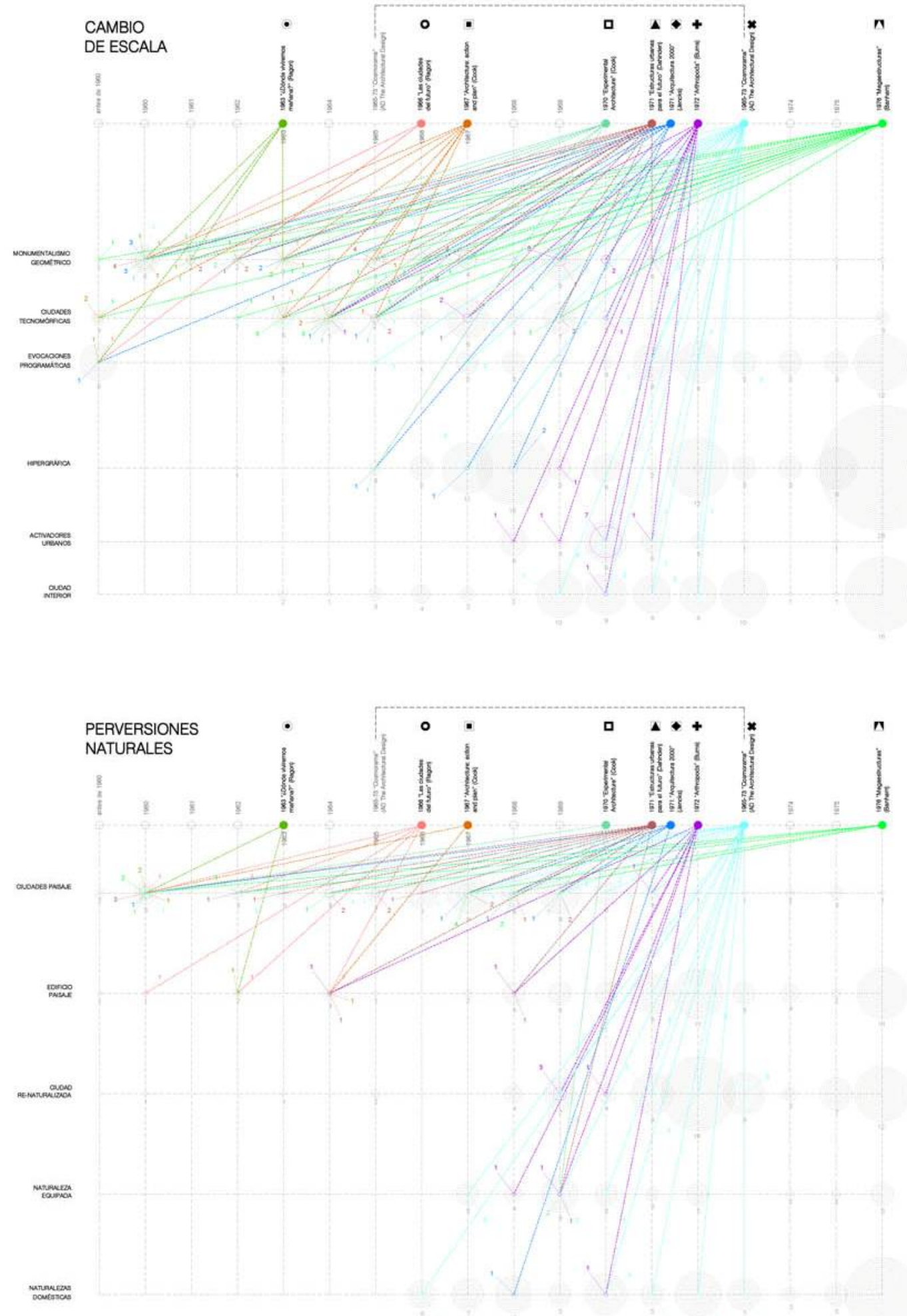

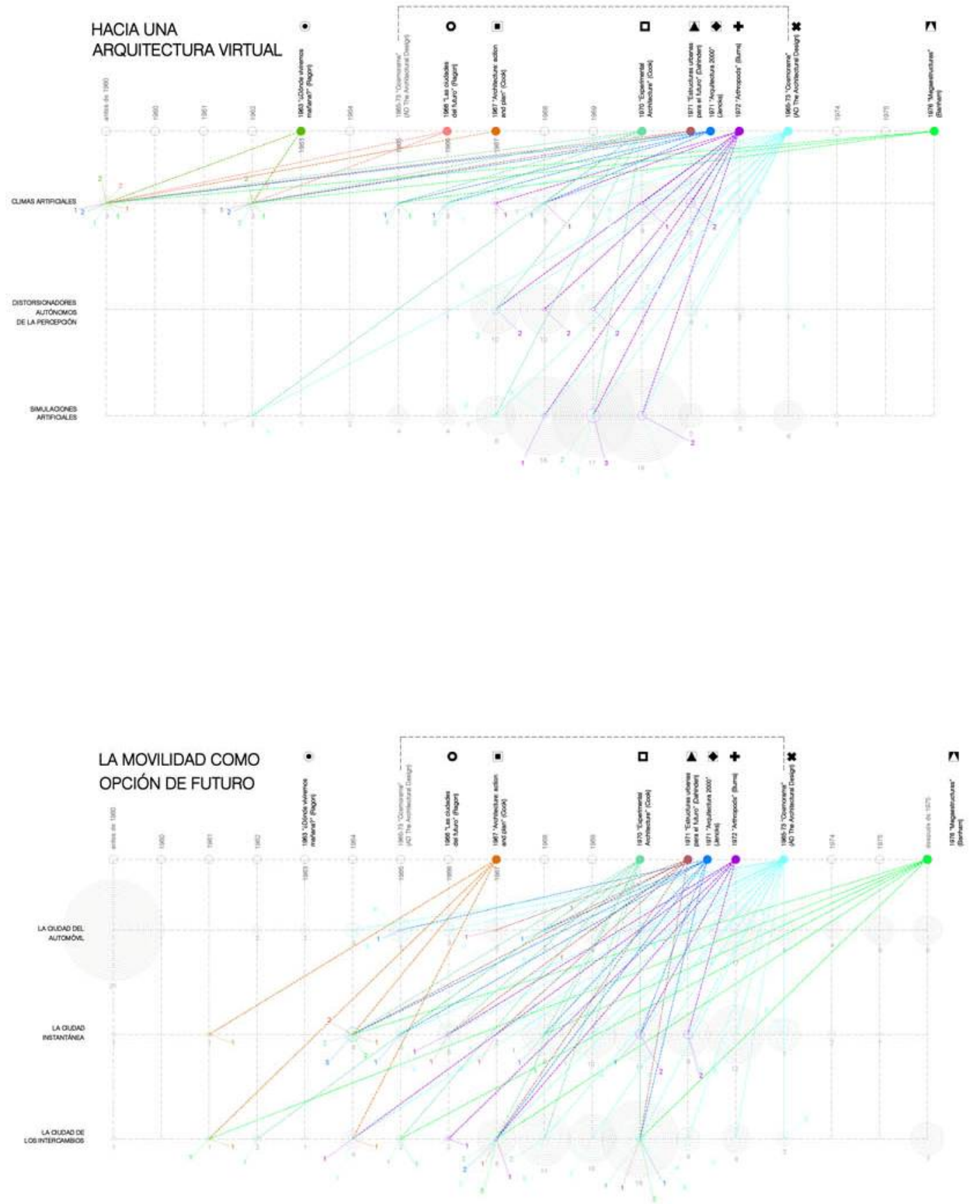
CAMBIO DE ESCALA

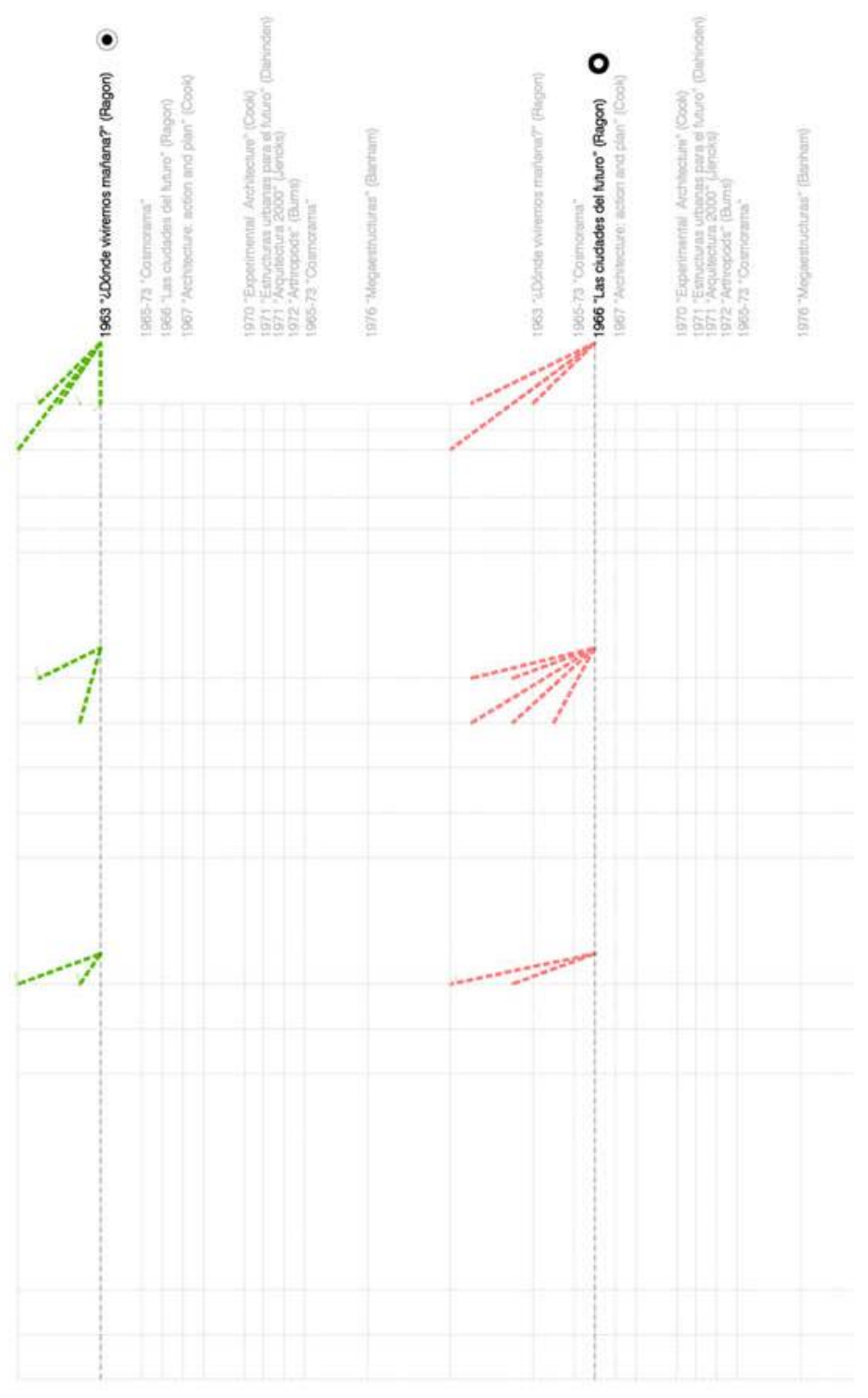




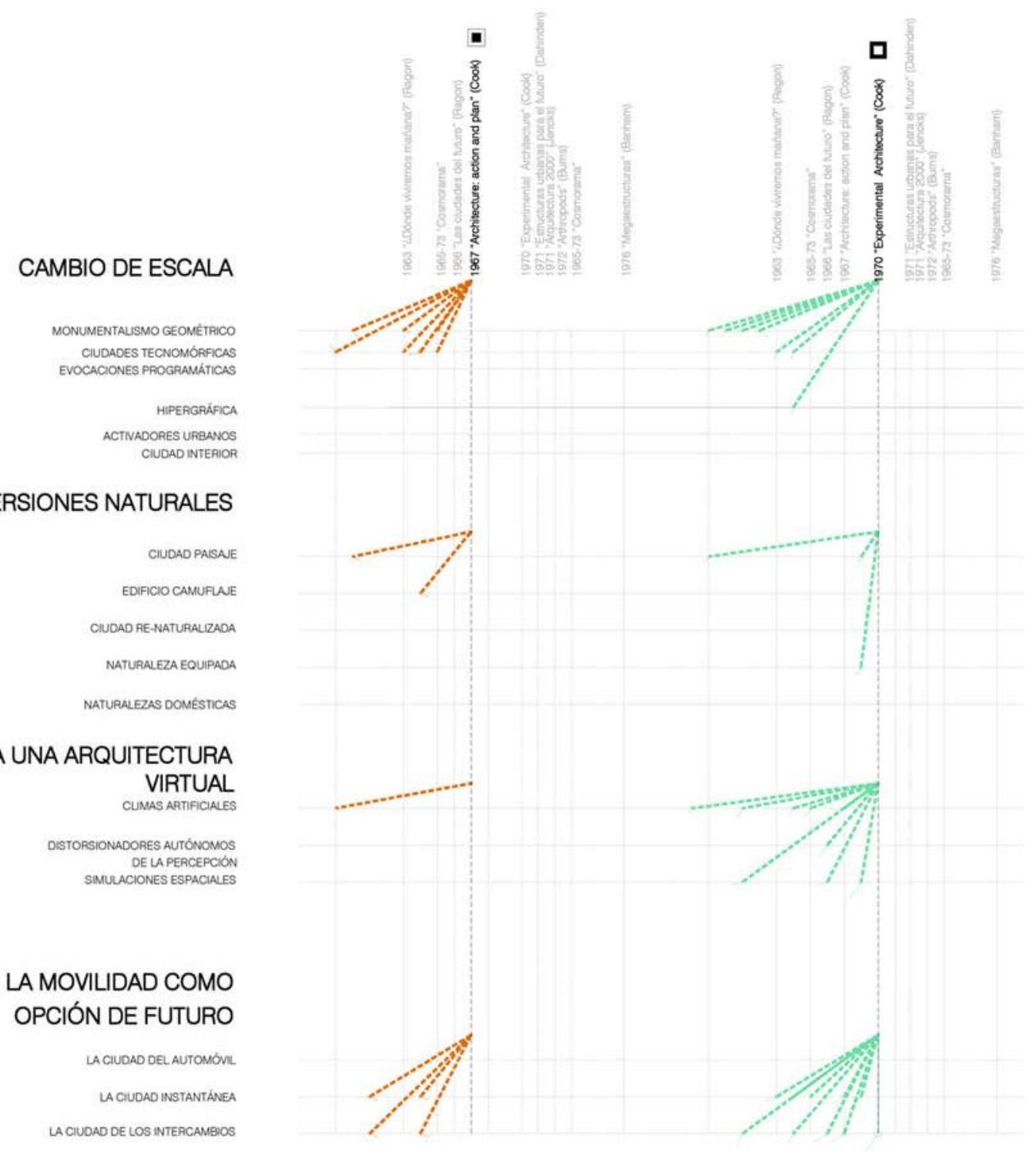




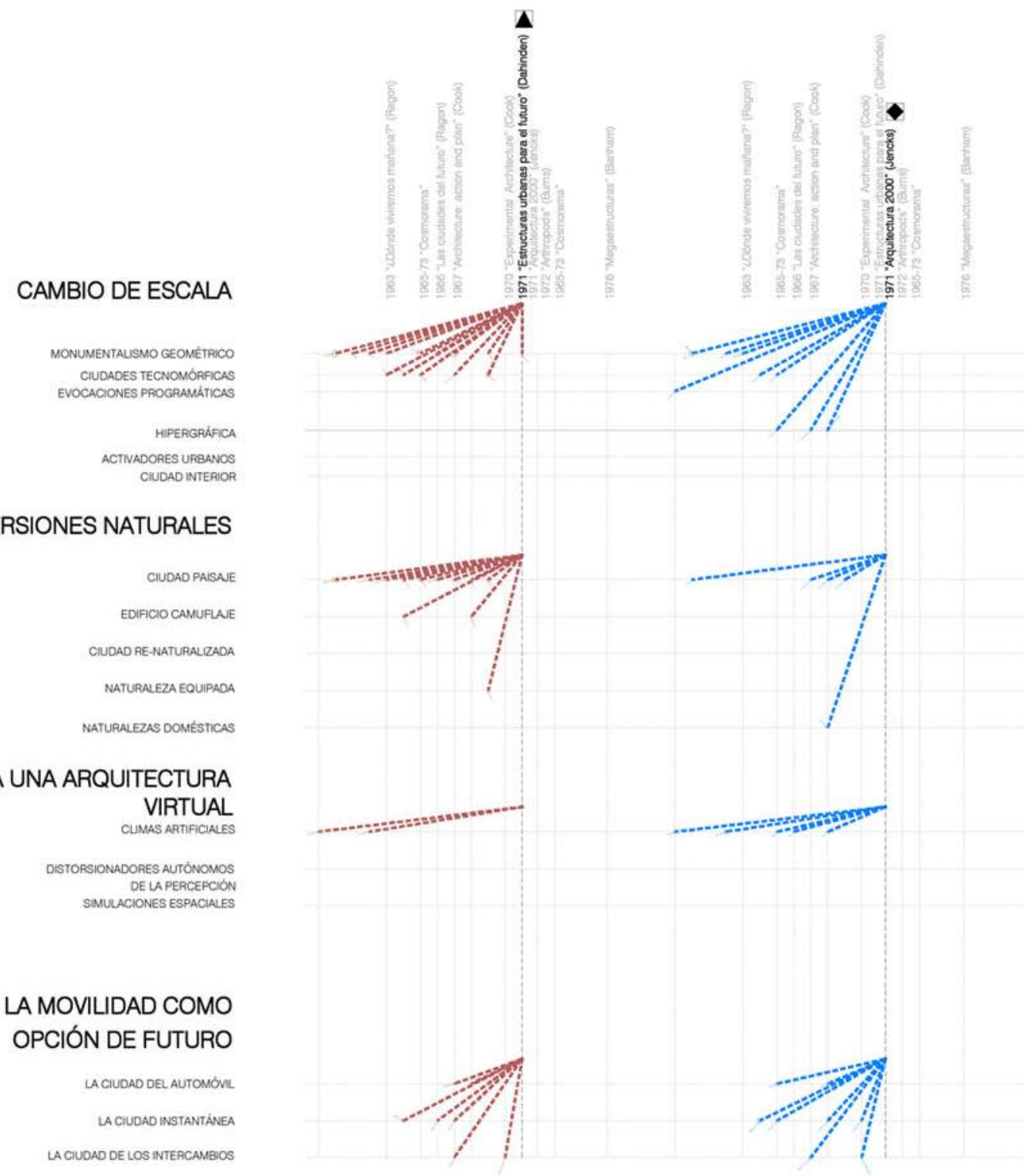




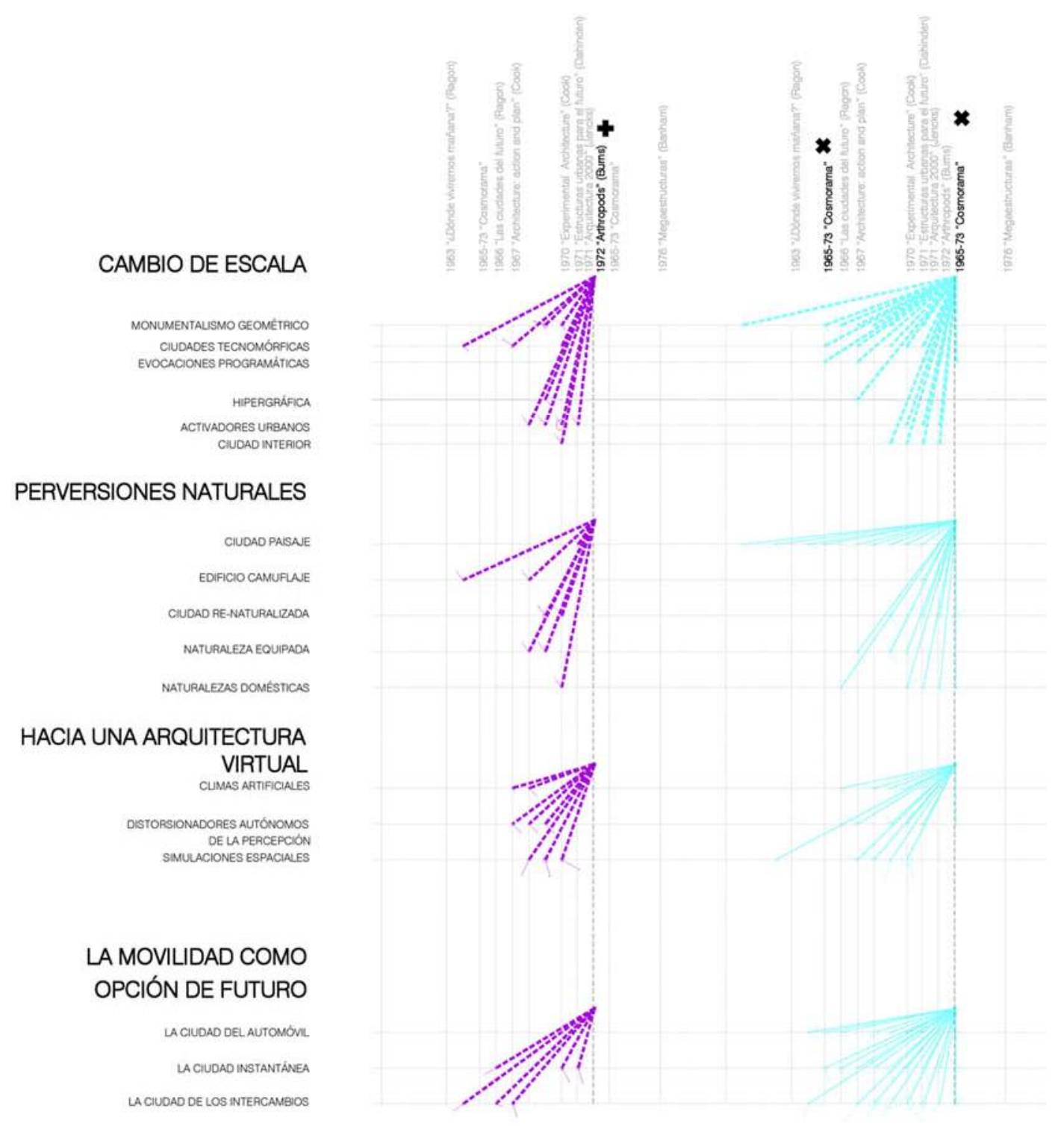


CAMBIO DE ESCALA

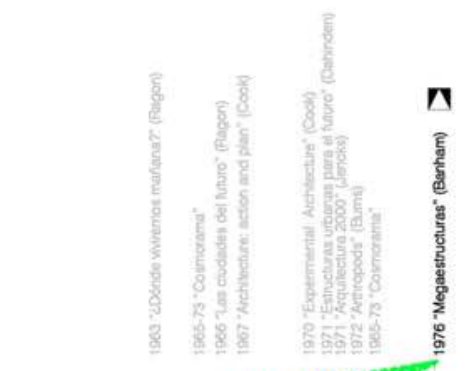

MONUMENTAUSMO GEOMÉTRICO CIUDADES TECNOMÓRFICAS EVOCACIONES PROGRAMÁTICAS ACTINADORES UREANOS CIUDAD INTERIOP

PERVERSIONES NATURALES

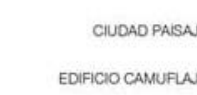

CIUDAD RE-NATUPALIZADA

NATURALEZAEQUIPADA

NATUPAITZS DONESTICS

HACIA UNA ARQUITECTURA

VIRTUAL

CUMAS APTIFICIALES

DISTORSIONADORES AUTÓNOMOS DE LA PERCEPCIÓN
SMMULACIONES ESPACIALS

\section{LA MOVILIDAD COMO} OPCIÓN DE FUTURO

LA CIUDAD DEL AUTOMÓNIL

LA CIUDAD INSTANTÃNEA

LA CIUDAD DE LOS INTEACAMBIOS

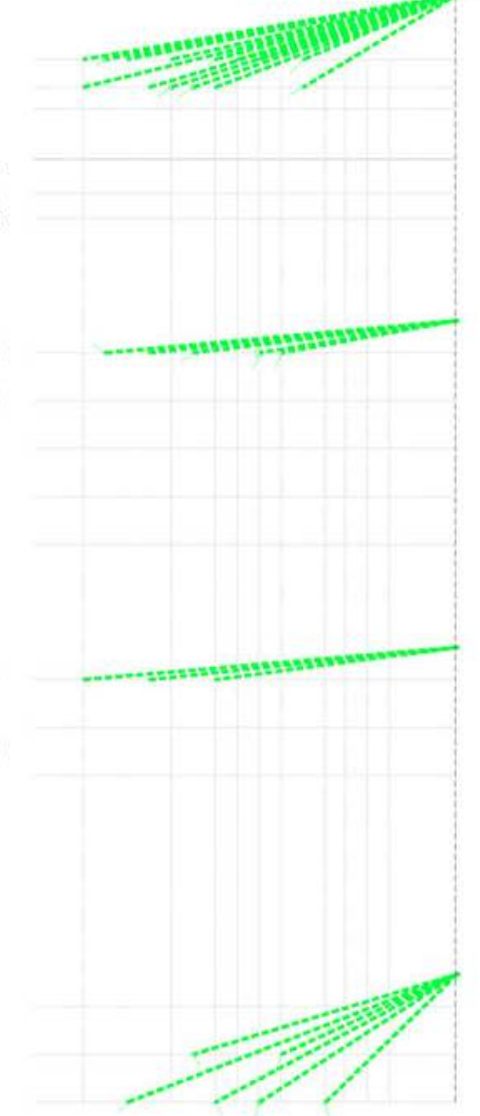




\section{Sobre las predicciones arquitectónicas.}

Todas las predicciones arquitectónicas citadas, salvo el panegírico tardío de Banham en "Megaestructuras", coinciden en un período muy acotado de diez años, de 1963 a 1973, en el que la palabra "futuro" legitimaba cada una de las prácticas asociadas a ella. También coincide el origen de sus autores con las nacionalidades de los países que ganaron la II Guerra Mundial y en los que la "Prospectiva" o la "Futurología" se habían consolidado como ciencias formales, Francia, Inglaterra y Estados Unidos fundamentalmente. Todos ellos, desde puntos de vista heterogéneos, utilizan la predicción arquitectónica como crítica al movimiento moderno de manera más o menos explícita, más allá de sus aportaciones como posibles futuros urbanos. Todos ellos, coinciden en situar los proyectos seleccionados en un contexto temporal que va desde finales de la década de los cincuenta hasta finales de los sesenta, período que corresponde con el fin de la reconstrucción de Europa y el inicio de la sociedad postindustrial y la cultura posmoderna según Lyotard ${ }^{740}$ y ese período de transición entre modernidad y posmodernidad, según teóricos de la arquitectura como Rouillard ${ }^{741}$.

Todas las predicciones, menos "Cosmorama", se publican como volúmenes cerrados, escritos por un autor concreto, como revisión de una serie de prácticas "pasadas" que encierran en ellas una componente de "futuro". Mediante la sección "Cosmorama" de la revista "Architectural Design", en cambio, diversos autores realizan un compendio de proyectos, textos y referencias que se organizan como "futuros" cambiantes, heterogéneos e incluso contrapuestos, a lo largo de los ocho años que dura la sección de la revista. De esta manera, el siempre cambiante futuro, encuentra un aliado más preciso, pero quizá menos resolutivo, en las páginas de las revistas periódicas que en los volúmenes de libros demasiado acotados, temporal e ideológicamente.

Michel Ragon, el futuro se encuentra en el urbanismo tridimensional francés.

El futuro vislumbrado por Michel Ragon es de origen francés y sólo tiene cabida en la manera en que se reinterpreta el concepto de ciudad a través del incipiente urbanismo tridimensional. Sus predicciones son las menos plurales, sólo relativas a las estrategias relacionadas con Monumentalismo Geométrico y Ciudades Paisaje, vinculadas a esas prácticas urbanas tridimensionales, o con Edificio Camuflaje, como una de las posibles materializaciones de su preconizada "Arquitectura-Escultura". Sus predicciones, las más tempranas de todas las analizadas, con origen en 1963 y 1966, suponen un acto romántico de exaltación de una ciudad utópica entendida desde el planeamiento total bajo la hipótesis, no siempre acertada y varias veces criticada, de colonizar lugares hasta ahora inhóspitos para el ser humano.

\footnotetext{
740 "Nuestra hipótesis es que el saber cambia de estatuto al mismo tiempo que las sociedades entran en la edad llamada postindustrial y las culturas en la edad llamada postmoderna. Este paso ha comenzado cuando menos desde fines de los años 50, que para Europa señalan el fin de su reconstrucción."
}

LYOTARD, Jean François. La condición postmoderna. Ediciones Cátedra. Madrid. 1987. Traducción: Mariano Antolín rato. Ed.original: La condition postmoderne: rapport sur le savoir. Minuit. París. 1979.

741 "1950-1970: la période accélere la fin de la modernité, et lui substitue discrétement la situation contemporaine. Jamais autant que durant ces deux décennies, le futur de l'architecture n'aura à ce point saisi le projet d'architecture comme une volonté de réalité."

ROUILLARD, Dominique. Superarchitecture. Le Futur de l'architecture 1950-1970. Éditions de la Villette. Paris, 2004. pp. 1112. 
Peter Cook, el futuro es Archigram.

Para Peter Cook, el futuro es Archigram. Sus dos predicciones, "Architecture: action and plan" y "Experimental Architecture", suponen dos maneras de legitimar sus propios proyectos desarrollados con Archigram en un contexto internacional. La primera de sus predicciones, de 1967, se relaciona con las experimentaciones del grupo inglés en torno a un Hardware que posibilite la libre acción del usuario, y su publicación coincide con el desarrollo del proyecto "Control and Choice", diseñado para la Bienal de París de ese mismo año, bajo planteamientos ya experimentados en su famosa "Plug In City". La segunda, de 1970, corresponde con el aún período de propaganda de la "Instant City". Este proyecto supone un cambio radical en el pensamiento del grupo inglés, al entender la movilidad a través de pequeños artefactos o Software, abandonando la idea de la infraestructura pesada y el planeamiento global de la ciudad. En ese sentido, cada una las estrategias de futuro que aparecen vinculadas a sus predicciones, tienen un proyecto de Archigram homólogo. Ciudades tecnomórficas como "Walking City", Edificios camuflaje como "Mound" o Ciudades Instantáneas como "Instant City" son algunos de los futuros preconizados por Cook.

McHale, el hombre del futuro amplificado.

McHale vaticina un hombre del futuro amplificado a través de implantes tecnológicos, que le permitan relacionarse de manera más intensa con su contexto. La casa o la ciudad se convierten así en prolongación de esas habilidades humanas amplificadas al nutrirse de los parámetros de autosuficiencia experimentados en las cápsulas lunares o los submarinos. Los arquitectos tendrán que utilizar esas tecnologías de manera efectiva o desaparecer.

Justus Dahinden, futuro catalogado.

El futuro propuesto por Dahinden es totalmente operativo, a través de un catálogo de estructuras urbanas expuestas de manera taxonómica. La diferencia temporal con Ragon, y su carácter como diseñador de este tipo de estructuras, permiten a Dahinden presentar el futuro urbano tridimensional del francés amplificado geográficamente y catalogado en una serie de alternativas operativas. De esta manera, Dahinden no se siente forzado a justificar socialmente estas estructuras, argumento bastante cuestionable por otra parte, sino a presentarlas como modelos totalmente operativos con los que trabajar.

\section{Charles Jencks, un futuro estilístico hacia la posmodernidad.}

La futurología arquitectónica se convierte en las manos de Jencks en gran aliada para el cambio de una ideología moderna a otra posmoderna. Charles Jencks convertirá su discurso futurista de "Arquitectura 2000" de 1971 en "El Lenguaje de la Arquitectura Posmoderna" de 1977, incluyendo en ambos su famoso "Evolutionary Tree"1742 aunque con serias

742 JENCKS, Charles. Architecture 2000. 1975 (1971). pp.50-51.

JENCKS, Charles. The Language of Post-modern Architecture. 1977, p.80. 
modificaciones. En el de 1977, la línea temporal se reduce al ámbito de lo que denomina como arquitectura posmoderna, por lo que de un contexto de 1920 al año 2000, en el gráfico de 1971, pasará a otro de 1955 a 1980, en su libro de 1977. Las seis tradiciones arquitectónicas del gráfico primigenio se convierten así en seis maneras de desarrollo de lo que él define como arquitectura posmoderna: historicismo, revival, neo-Vernáculo, urbanismo ad-hoc, metáfora metafísica y espacio posmoderno. El futuro encubierto vaticinado por Charles Jencks en 1971 por fin se había cumplido en 1977.

\section{Jim Burns, un futuro arquitecto como intermediario.}

La predicción de Burns presenta un futuro de la arquitectura como disciplina de diseño abierta, un futuro en el que cambiarán las maneras de organización, las aptitudes y las herramientas. De esa manera, la nueva arquitectura del futuro sólo podrá ser re-incorporada a la sociedad a través de un proceso de instrumentalización. La arquitectura se convierte así en mediadora entre un arquitecto dispuesto a diseñar soportes abiertos y flexibles que puedan ser modificados a su antojo por el usuario. El arquitecto, o grupos de arquitectos, Burns apuesta por un trabajo colectivo, se convierten así en mediadores, en intermediarios entre los usuarios y sus sistema referencial de objetos arquitectónicos.

\section{Cosmorama, un futuro como reflejo de una época.}

La predicción del futuro desde el pasado está siempre en transformación y por lo tanto es dependiente del contexto desde el que se genera. El interés de Cosmorama frente al resto de las demás predicciones es ese carácter cambiante, convirtiéndose en el reflejo de un cambio de época. Su temporalidad, a medio camino entre las décadas de los sesenta y setenta, presenta un claro reflejo de la brecha que entre éstas se produce. El paso de la infraestructura al artefacto, de impulso colectivo al carácter autónomo, de la confianza en la comunidad a la supremacía del sujeto, del planeamiento al catálogo de instrucciones. Todas ellas se convertirán en las principales muestras de ese cambio.

\section{Banham y las megaestructuras, el futuro ya pasado.}

Entre el reproche y la adoración por las megaestructuras, el futuro pasado de Banham resulta puramente académico. "Megaestructuras" es más un compendio histórico que una predicción de futuro, algo que ya Banham había presupuesto del anterior "Estructuras para el Futuro" de Dahinden ${ }^{743}$.

\footnotetext{
743 "Pero cuando Justus Dahinden publicó Stadtstrukturen für Morgen en 1971, ese morgen ya era un futuro fósil y el libro un involuntario monumento conmemorativo de un movimiento muerto y, lo más conmovedor de todo, el triste óbito de los muy amados parecía haber pasado por alto. Con Dahinden, la megaestructura se retira a la tradición visionaria de la que había surgido y está completamente a tono con los grandes diseños nacidos muertos, como el Whitehall de Íñigo Jones o el cenotafio para Isaac Newton de Boullée..."
}

BANHAM, Reyner. Megaestructuras. 1978 (1976). p.210. 


\section{Diagramas_03 ALTERNATIVAS DE FUTURO / CONTINUIDAD}

- Se han contabilizado todos los proyectos de cada una de las cuatro alternativas de futuro en una línea temporal regular que va desde 1960 a 1975, con límites anteriores y posteriores a esos años.

- Se han detectado diversas tendencias: creciente en la alternativa CAMBIO DE ESCALA, continuista en PERVERSIONES NATURALES, descendiente en LA MOVILIDAD COMO OPCIÓN DE FUTURO y rupturista en HACIA UNA ARQUITECTURA VIRTUAL.

- Se han determinado los períodos de máxima producción de cada una de las alternativas de futuro: CAMBIO DE ESCALA, de diez años (1965/1975), PERVERSIONES NATURALES de ocho (1966/1974), LA MOVILIDAD COMO OPCIÓN DE FUTURO de seis $(1967 / 1973)$ y HACIA UNA ARQUITECTURA VIRTUAL de cuatro (1967/1971).
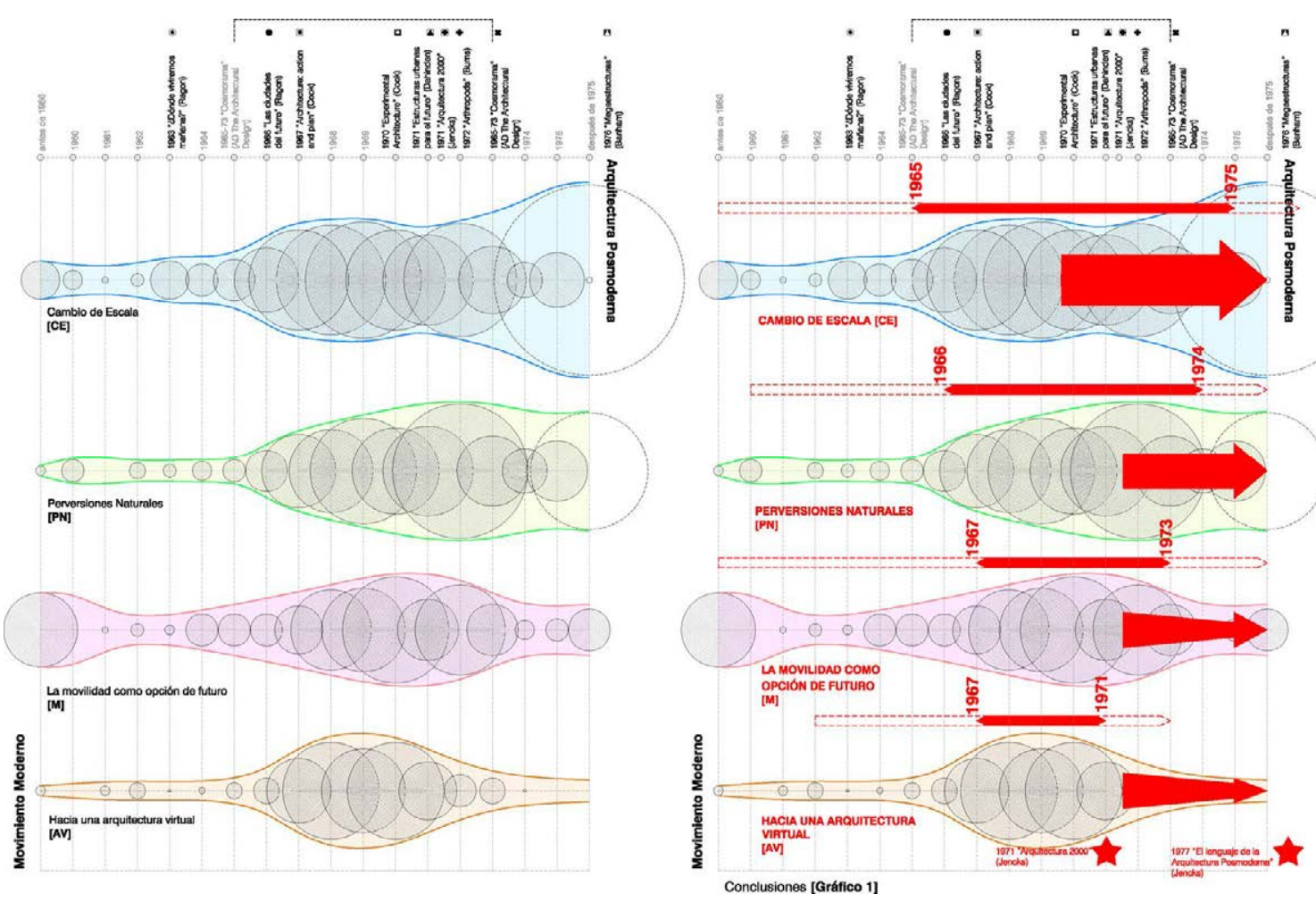

Diagramas_03 


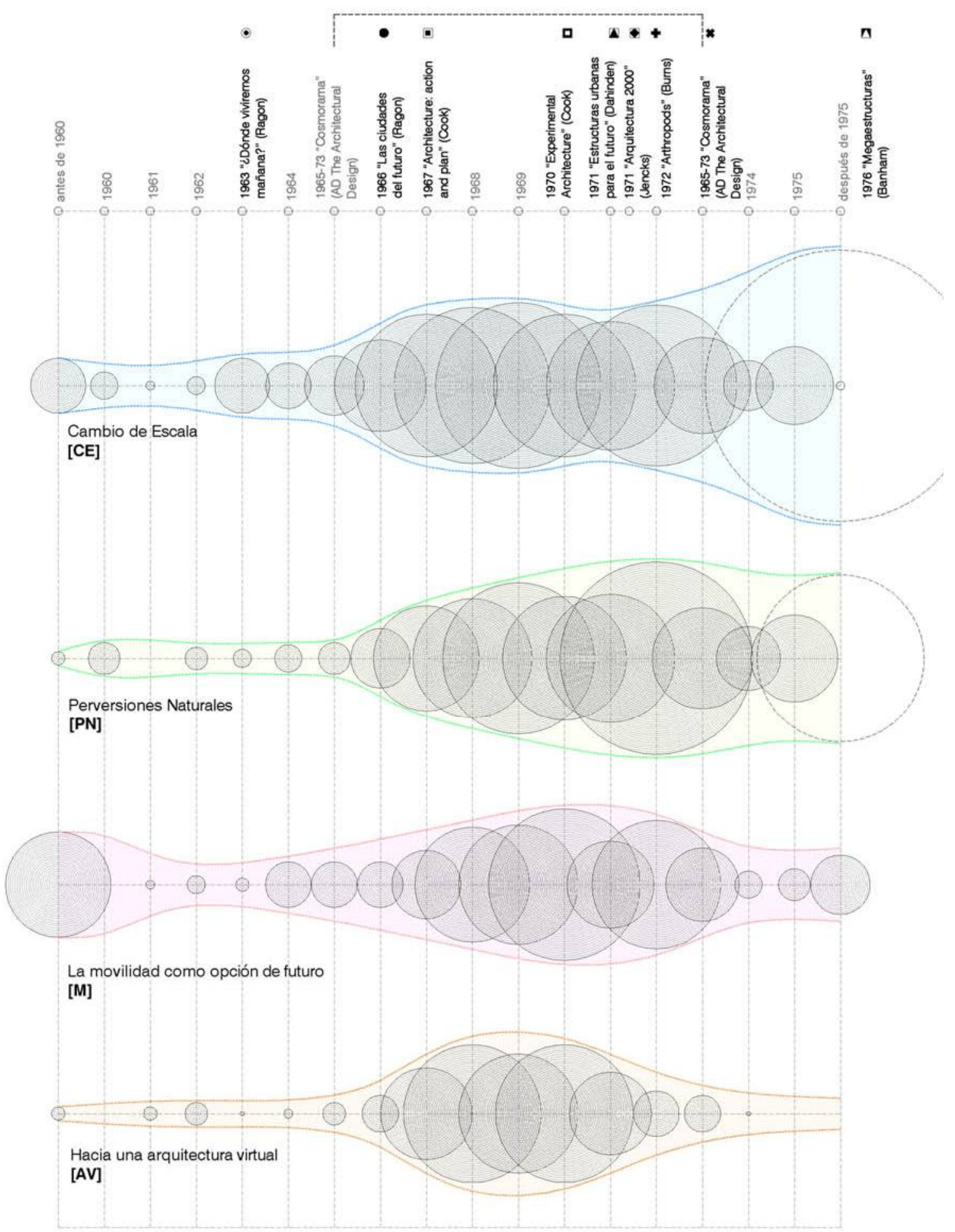




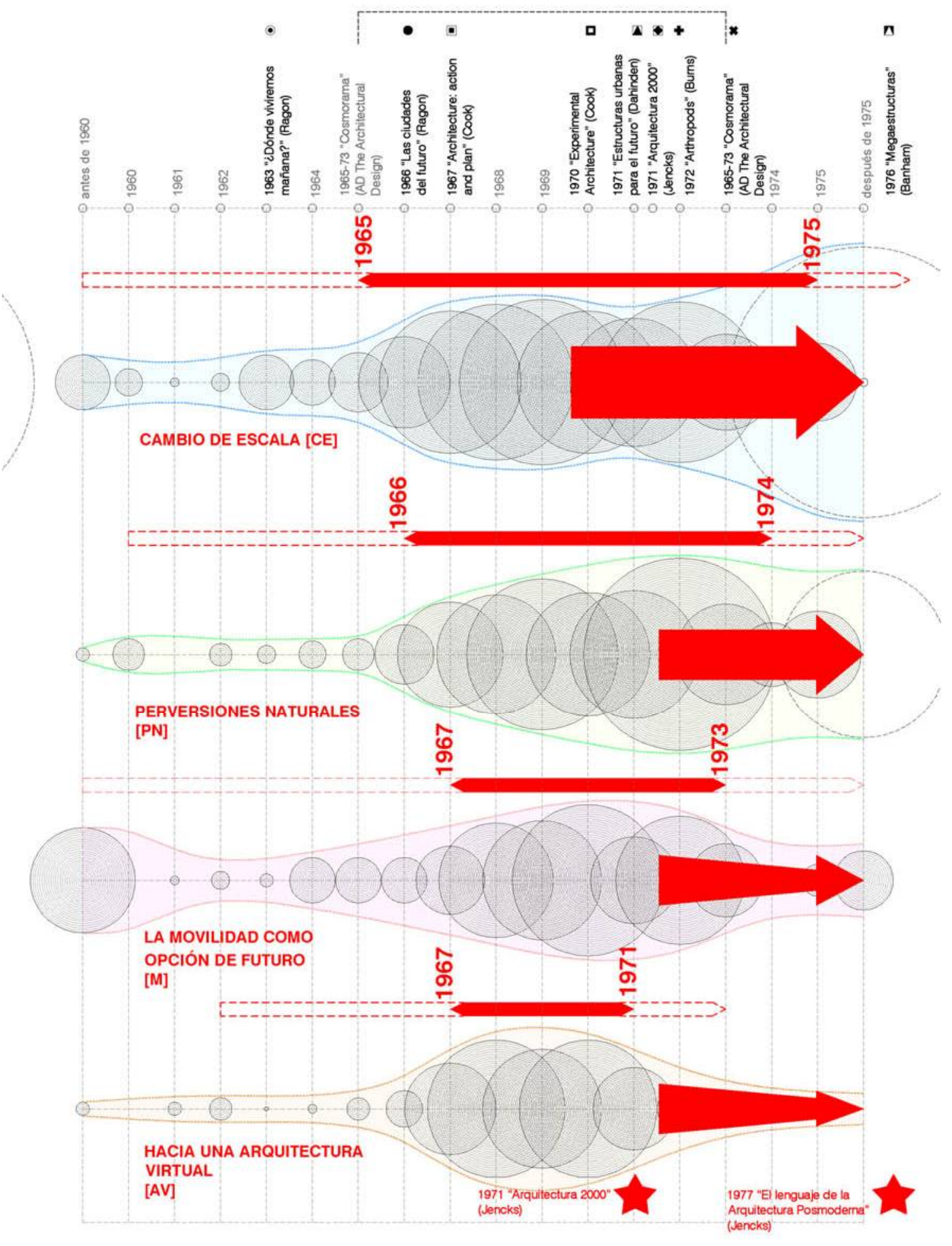




\section{Diagramas_04 ESTRATEGIAS DE FUTURO / DE LA CIUDAD AL MOBILIARIO}

- Se han diferenciado las estrategias relativas a CAMBIO DE ESCALA y PERVERSIONES NATURALES y ordenado verticalmente según su escala, diferenciadas en CIUDAD / EDIFICIO / MOBILIARIO, utilizando a la vez para los proyectos asociados a las mismas una línea temporal regular que va desde 1960 a 1975, con límites anteriores y posteriores a esos años.

- En el gráfico inferior se han unido todas esas estrategias por escalas a través de los tres grandes grupos antes citados: CIUDAD / EDIFICIO / MOBILIARIO.

- Se ha detectado una clara tendencia temporal de cambio en la escala asociado a los proyectos catalogados en cada una de las estrategias. Del interés del proyecto urbano (escala CIUDAD) desde finales de los años cincuenta hasta mediados de los sesenta, en estrategias como Ciudad Paisaje, Ciudades Tecnomórficas o Monumentalismo Geométrico, se pasará a uno más concreto, relacionado con el objeto arquitectónico, ya sea desde la escala EDIFICIO, con estrategias como Evocaciones programáticas, Hipergráfica o Edificio Camuflaje, como desde el diseño de interiores o escala MOBILIARIO, con sus respectivas estrategias Ciudad Interior y Perversiones Naturales.
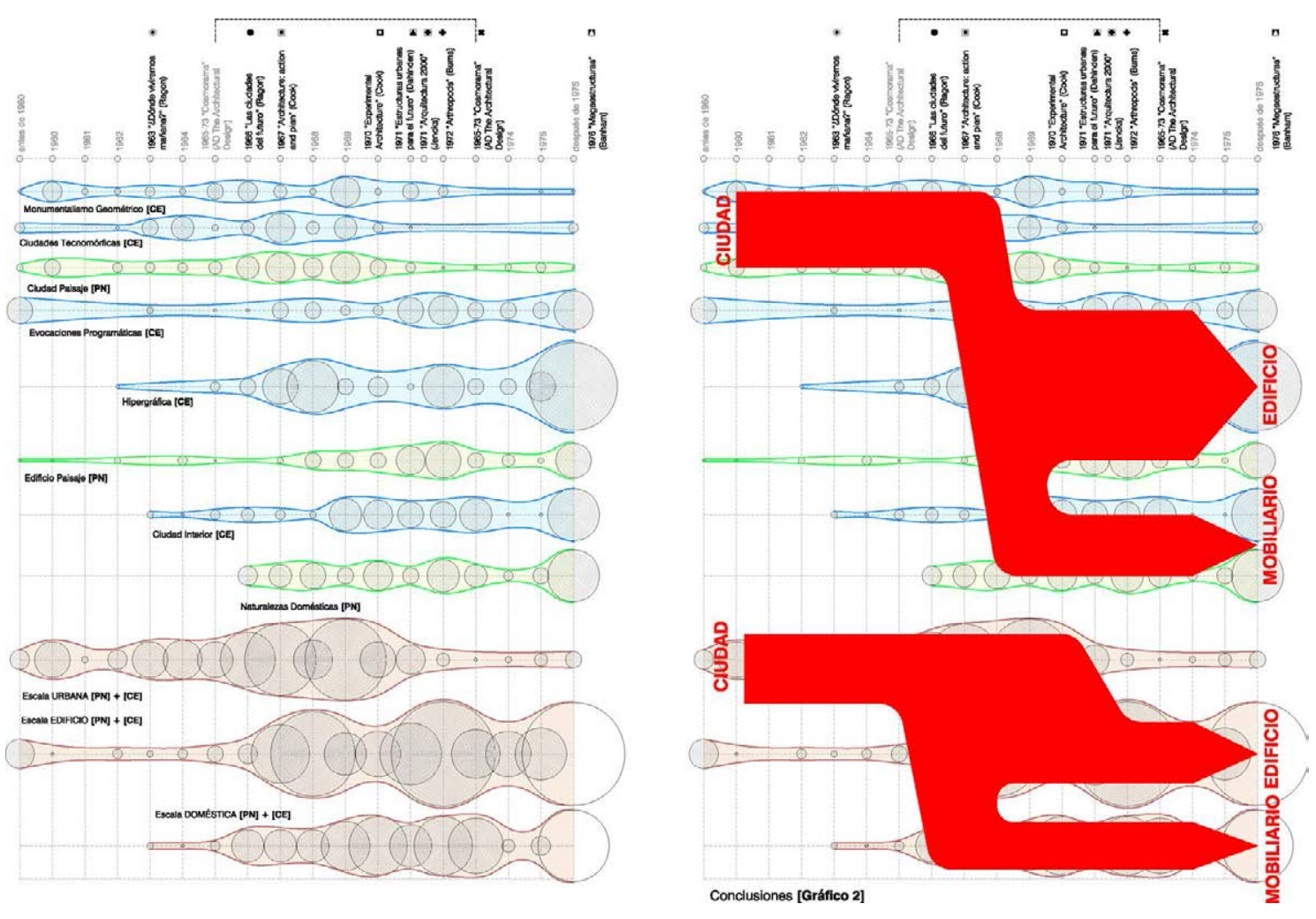

Diagramas_04 


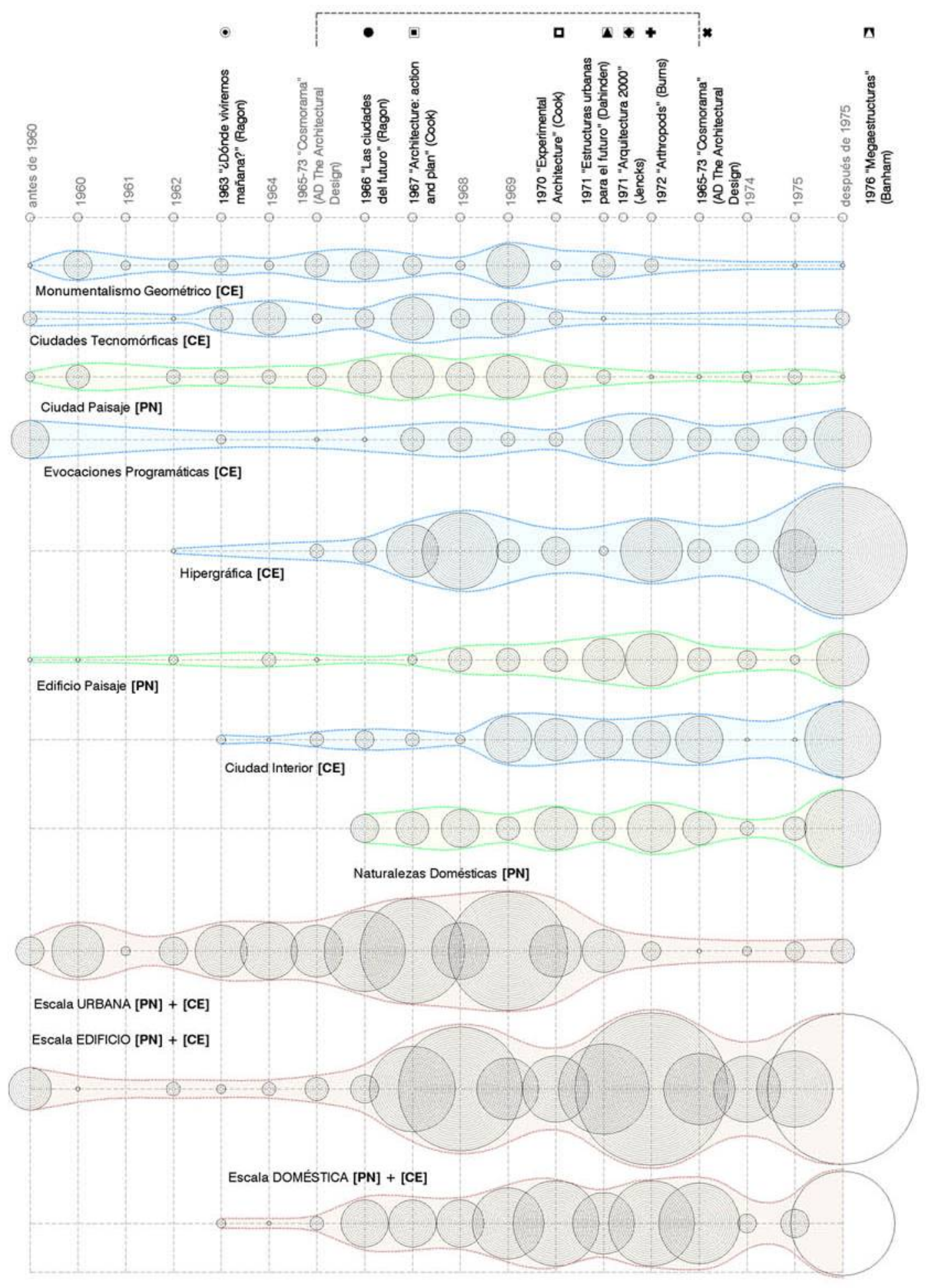




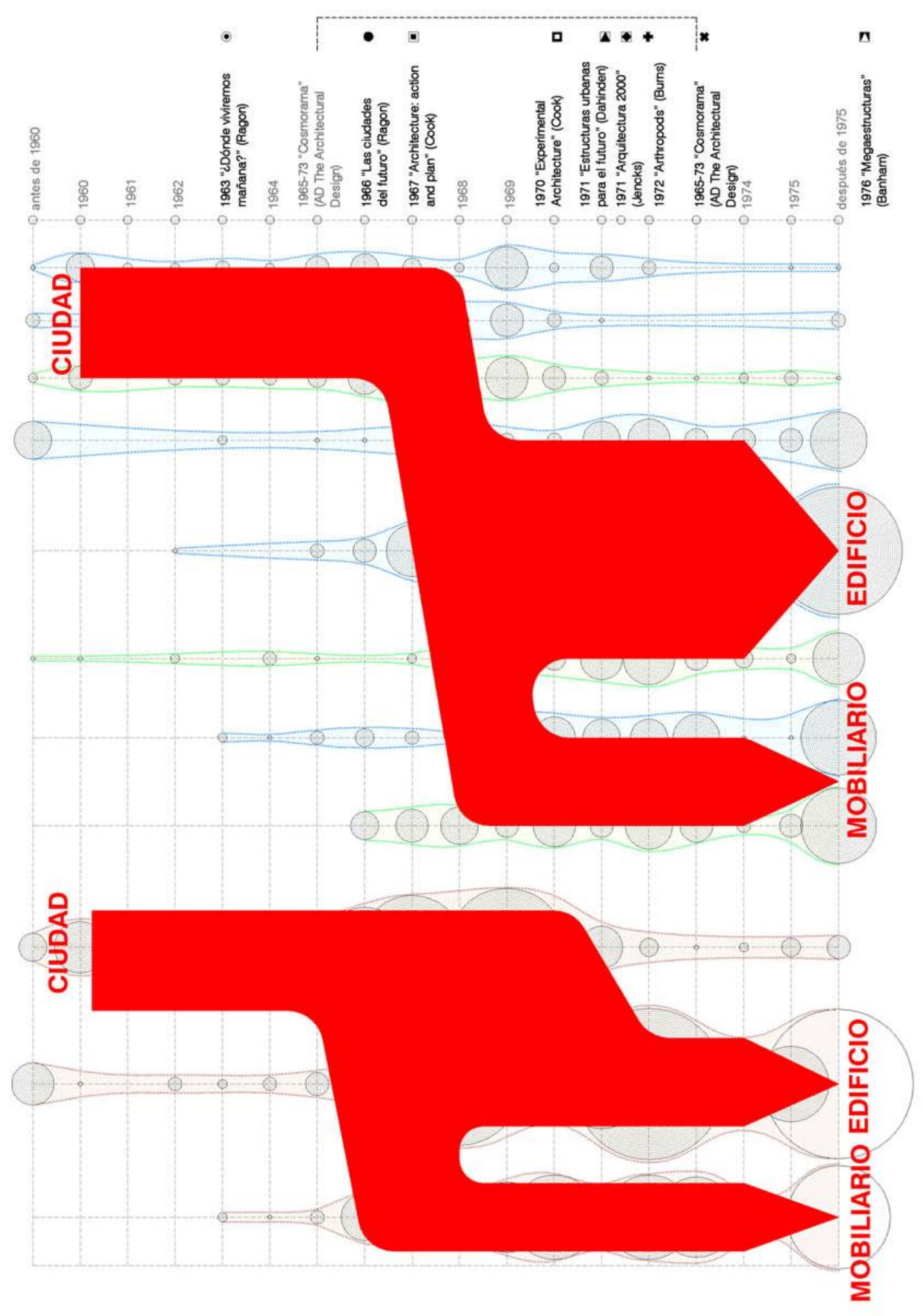




\section{Diagramas_05 CASO APLICADO / DE LOS SISTEMAS DE CIUDAD A LAS VIVIENDAS AUTÓNOMAS}

- Se han contabilizado todos los proyectos de vivienda catalogados en el Caso Aplicado. Se han diferenciado aquellos que se presentan en un contexto de ciudad y aquellos que sólo tienen en cuenta la vivienda, ya sea individual o colectiva fuera de un sistema urbano asociado a las mismas.

- El número de proyectos que utilizan un sistema de vivienda concreto y lo relacionan con otros sistemas urbanos no sólo decrece temporalmente, en relación a los proyecto que no lo hacen, durante todo el período de estudio, sino que existe un claro desplazamiento temporal entre sus períodos de máxima producción. Mientras que los Sistemas Ciudad desaparecen casi por completo en 1971, extendiendo su período de producción de 1960 a 1971, los Sistemas Autónomos alargan ese período hasta más allá de 1973, presentando todavía en 1972 altos índices de producción de proyectos. El vértice de mayor producción de proyectos de los Sistema de Ciudad se produce en 1967 mientras que será 1970 el de los Sistemas Autónomos. De esta manera también se corrobora la hipótesis del cambio de escala de la ciudad al edificio, en este caso de los sistemas de vivienda comunitarios o asociados a estructuras urbanas hacia sistemas autónomos que no presuponen sistemáticas urbanas más allá del propio objeto arquitectónico.

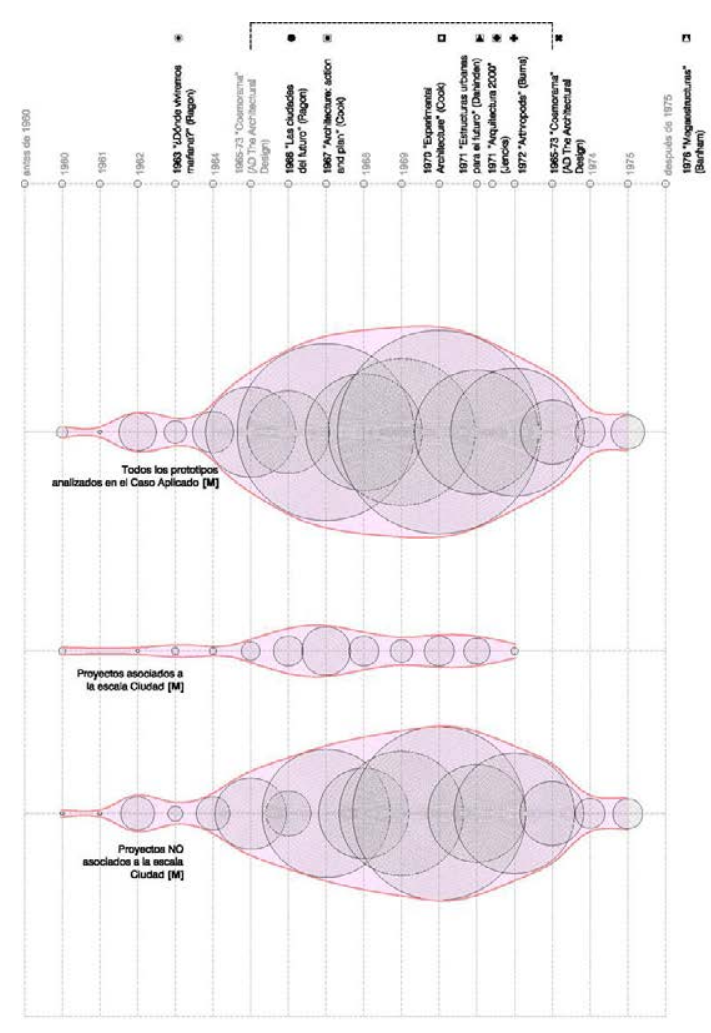

Diagramas_05

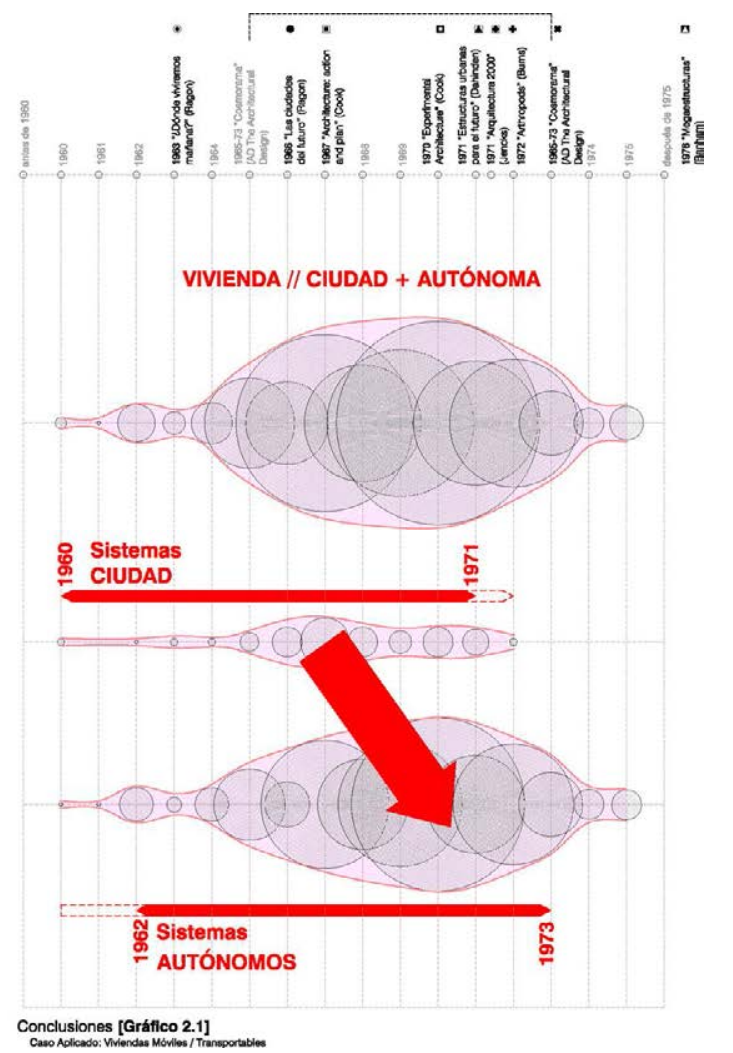

Conclusiones [Gráfico 2.1] 


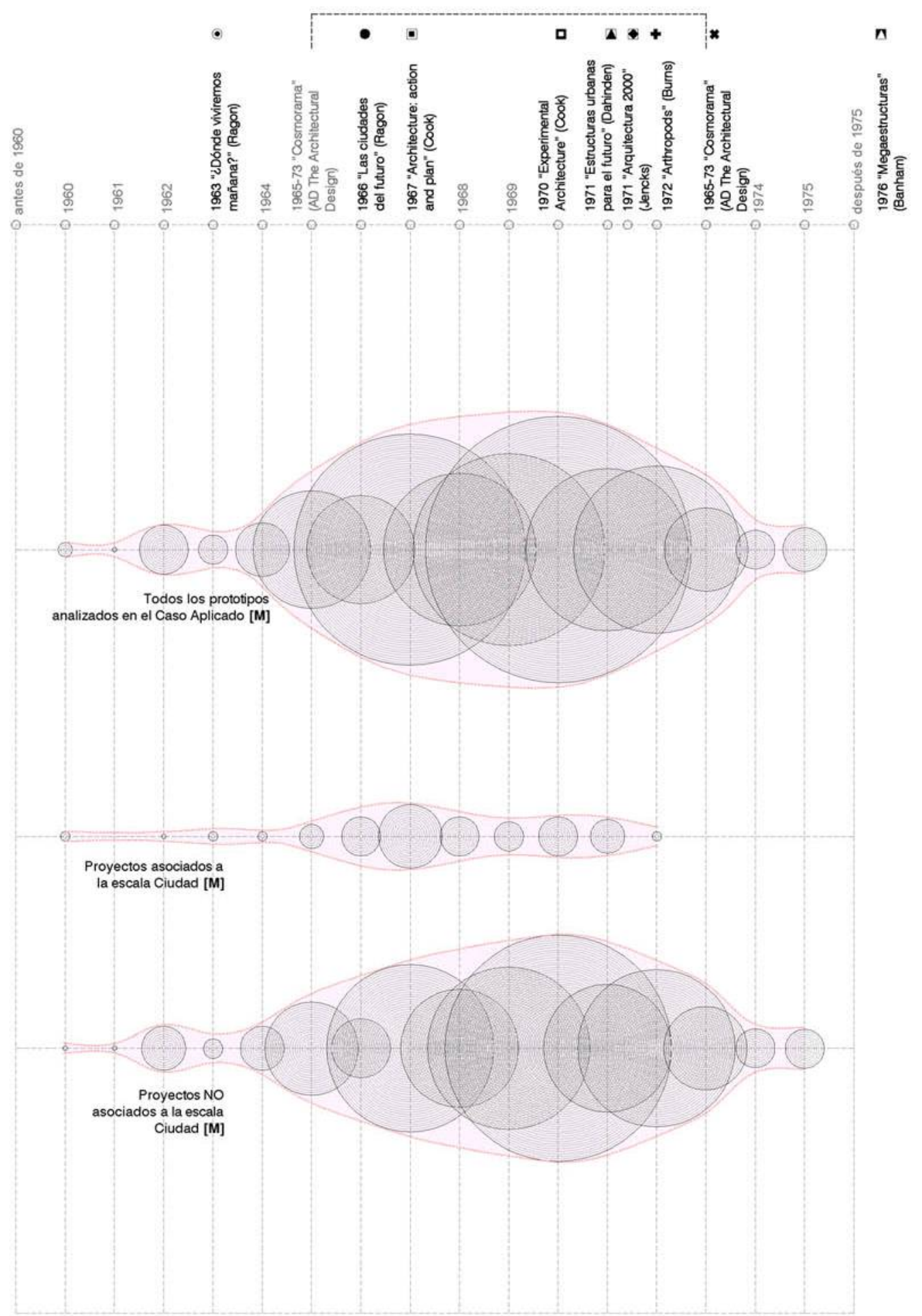




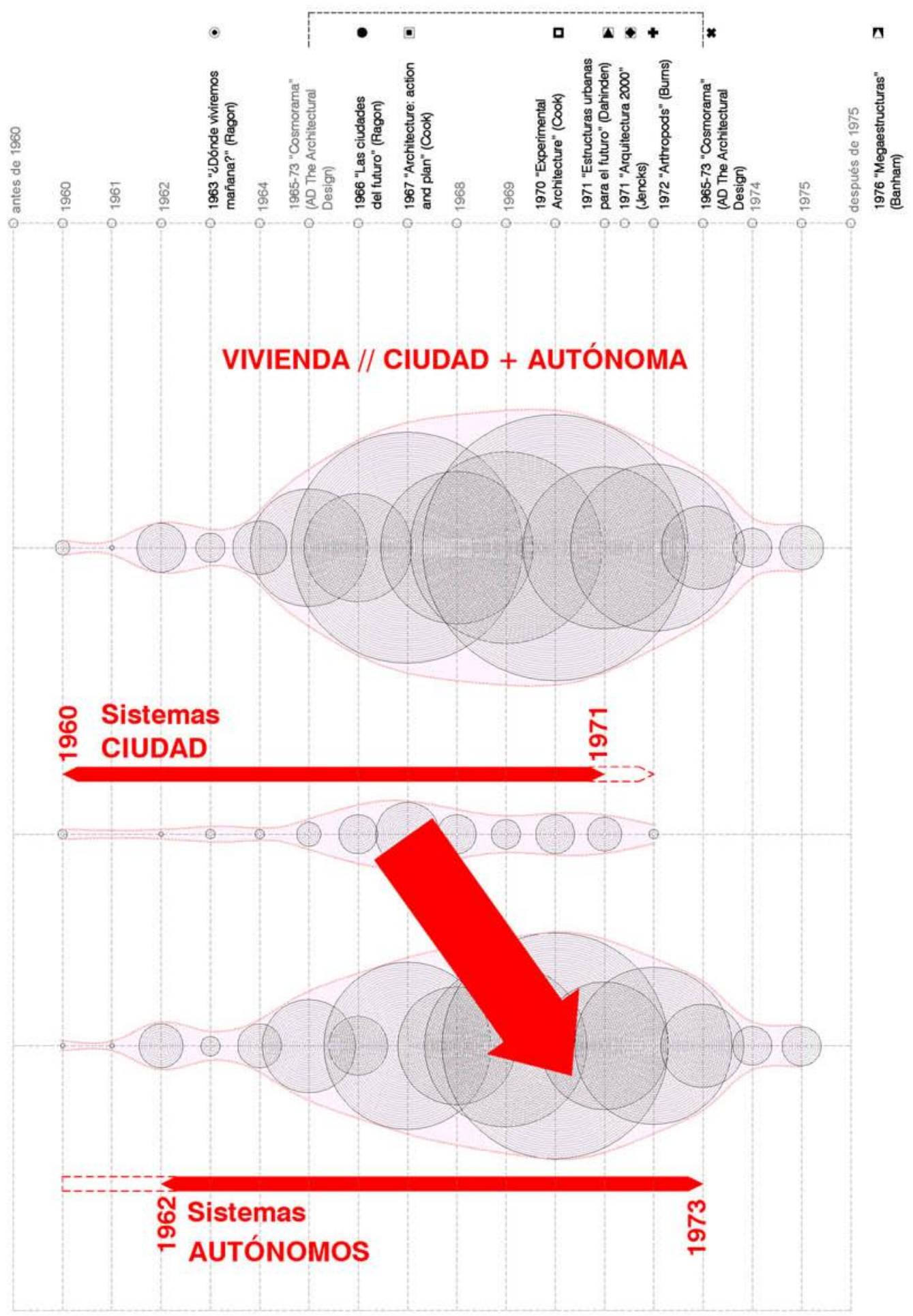




\section{De la ciudad como generadora de ideología arquitectónica al poder del objeto. Un cambio de escala.}

Durante el período comprendido entre las décadas de los cincuenta y setenta se produce un cambio de escala evidente, estrechamente relacionado con los intereses de lo que debía ser la arquitectura del futuro. El creciente interés hacia la ciudad como proyecto total, heredado del movimiento moderno durante finales de los cincuenta y primeros sesenta, se convertirá en un culto al objeto arquitectónico materializado en el edificio y en la repercusión del objeto-mobiliario como generador de espacio doméstico. A partir de mediados de los sesenta, los últimos coletazos del proyecto utópico entendido como planeamiento total ${ }^{744} \mathrm{se}$ irá extinguiendo para dar paso a un futuro basado en el diseño de objetos, ya sean edificios, mobiliario o cualquiera de sus estados intermedios.

Este cambio de escala es mucho más evidente en las alternativas de CAMBIO DE ESCALA y PERVERSIONES NATURALES, y supone una consecuencia más de su línea continuista como estrategias legítimas usadas por la posmodernidad. Las estrategias Monumentalismo Geométrico, Ciudades Tecnomóficas o Ciudad Paisaje, todas ellas asociadas a la idea de ciudad-sistema o ciudad-edificio, y por tanto a las megaestructuras, llegarán a su apogeo a finales de los sesenta, pero también a su agotamiento como sistemáticas continuistas del dicho programa moderno. Sin embargo, se incorporarán a partir de esa fecha a la escala del edificio como propuestas posibles. Las Ciudades Tecnomórficas devienen en un Tecnomorfismo como envoltura arquitectónica, un estado bizarro de lo que luego será denominado como arquitectura High Tech. Las Ciudades Paisaje, y sus estrategias derivadas de una mímesis entre natural y artificial también se incorporan al instrumental formal de los Edificios Camuflaje e incluso, en un salto menor de escala, a todas las estrategias denominadas como Naturalezas Domésticas. Este cambio general de escala afectará a otras estrategias como Hipergráfica y Evocaciones Programáticas, así como a la articulación del programa de futuro del ambiente doméstico, ya no relacionado con lo comunitario, sino entendido desde una perspectiva de la vivienda individual y la singularización de la misma, como queda patente en las estrategias catalogadas como Ciudad Interior y en algunas propuestas de personalización del hábitat relacionadas con Evocaciones Programáticas.

Este cambio de escala resulta evidente en varios procesos que tienen continuidad temporal durante el período de estudio, desde la miniaturización de las utopías climáticas de los austríacos Haus Rucker-Co al cambio del hardware al software de los británicos Archigram. Un caso singular que ejemplifica y evidencia ese cambio de escala radical, al pasar de un interés por el entorno urbano y la ciudad a otro hacia la vivienda singular, será el concurso Shinkenchiku, convocado por la revista The Japan Architect desde 1965 a la actualidad, y que también podría ser considerado como predicción debido al carácter prospectivo de muchos de sus enunciados. En el período comprendido entre 1965 y 1979 se evidencia ese cambio de una ciudad entendida como un todo, valorando la importancia de los sistemas colectivos, a una vivienda individual entendida desde la personalización y la singularidad. A pesar de ser un concurso contextualizado en Japón, su carácter internacional y conceptual como concurso de ideas, unido a su carácter periódico, le convierte en un claro identificador de ese cambio de escala en el ámbito de la vivienda, también evidente en los diagramas relativos al Caso Aplicado de esta tesis.

744 Como no podría ser de otra manera, como Jameson enfatiza en su definición del enclave utópico fundamentado en una ley de cierre que lo aisle del entorno social predominante. No es casual que un alto porcentaje de propuestas de "ciudad ideal" desarrolladas a finales de los cincuenta y primeros sesenta busquen enclaves aislados que permitan esa separación con lo existente, necesario para desarrollar una utopía. 


\section{Diagramas_06 ESTRATEGIAS DE FUTURO / TRANSFERENCIAS}

- Se han relacionado las estrategias entre las que se producen transferencias formales y escalares.

- Se han establecido dichas relaciones entre los proyectos concretos que resultan más esclarecedoras de la Objetualización Ideológica que se produce durante el contexto de estudio.

- Se han enfatizado las escalas CIUDAD / EDIFICIO / MOBILIARIO a las que pertenecen cada uno de esos proyectos para un mejor entendimiento de cómo opera esa transferencia.
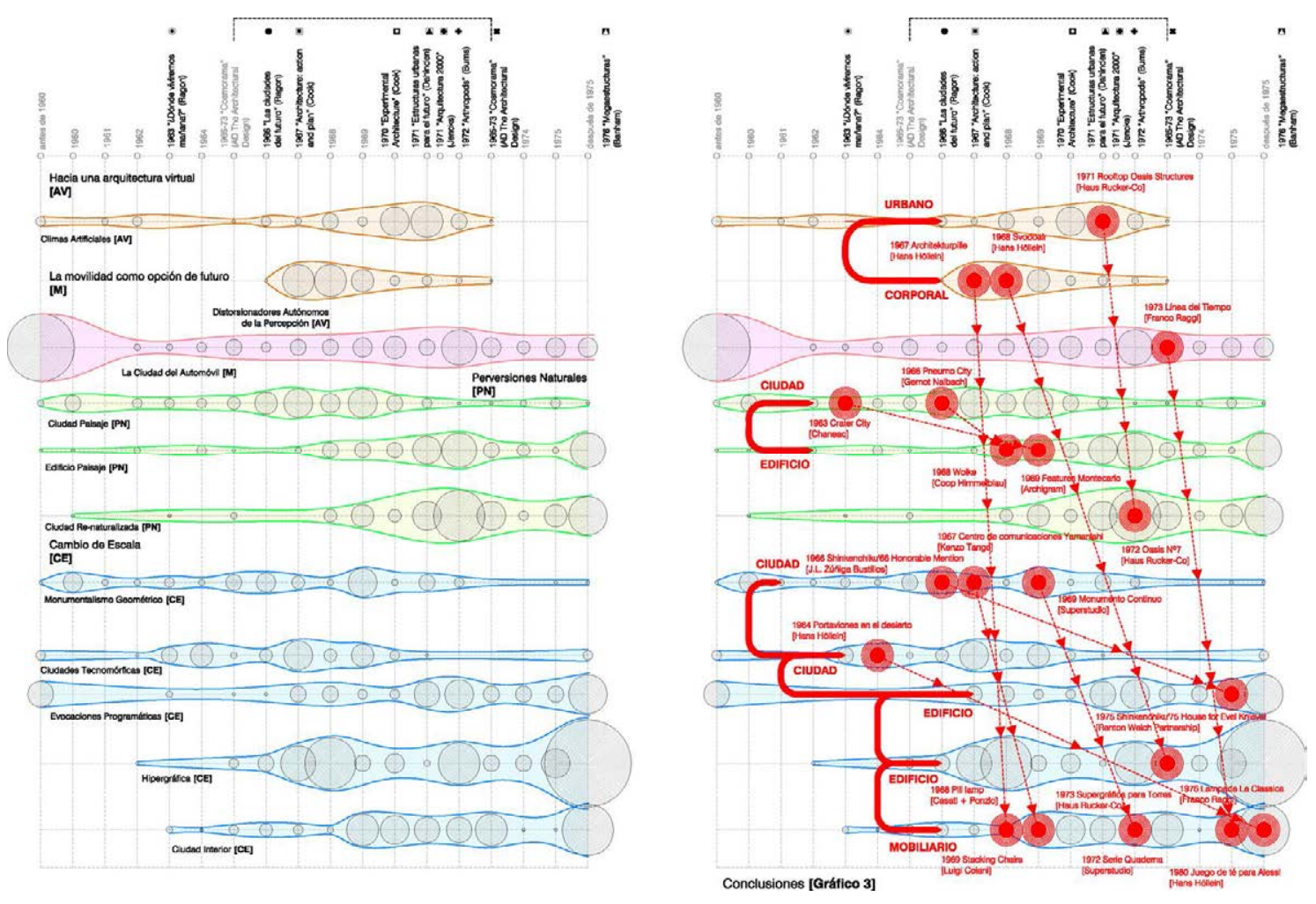

Diagramas_06 


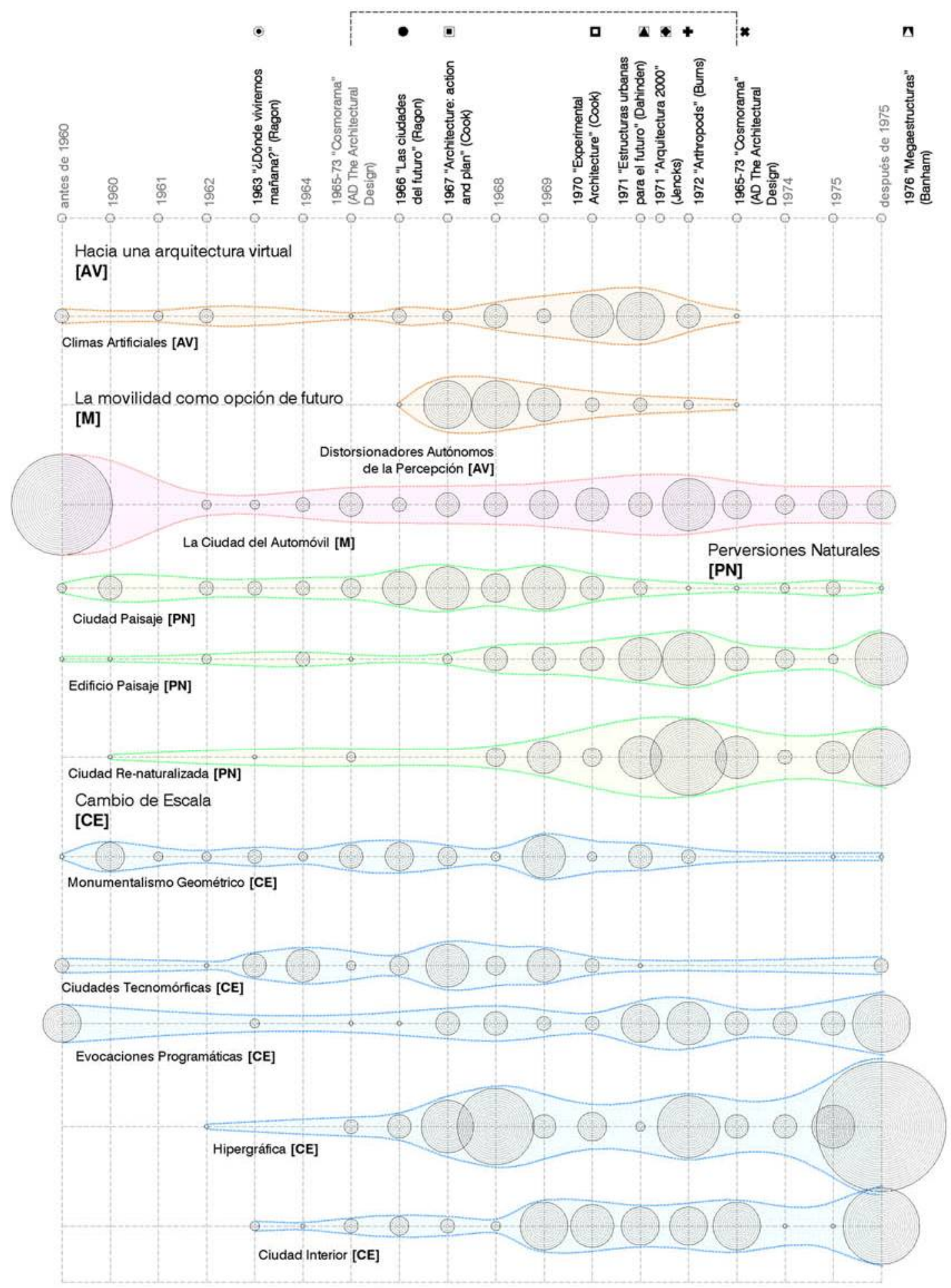




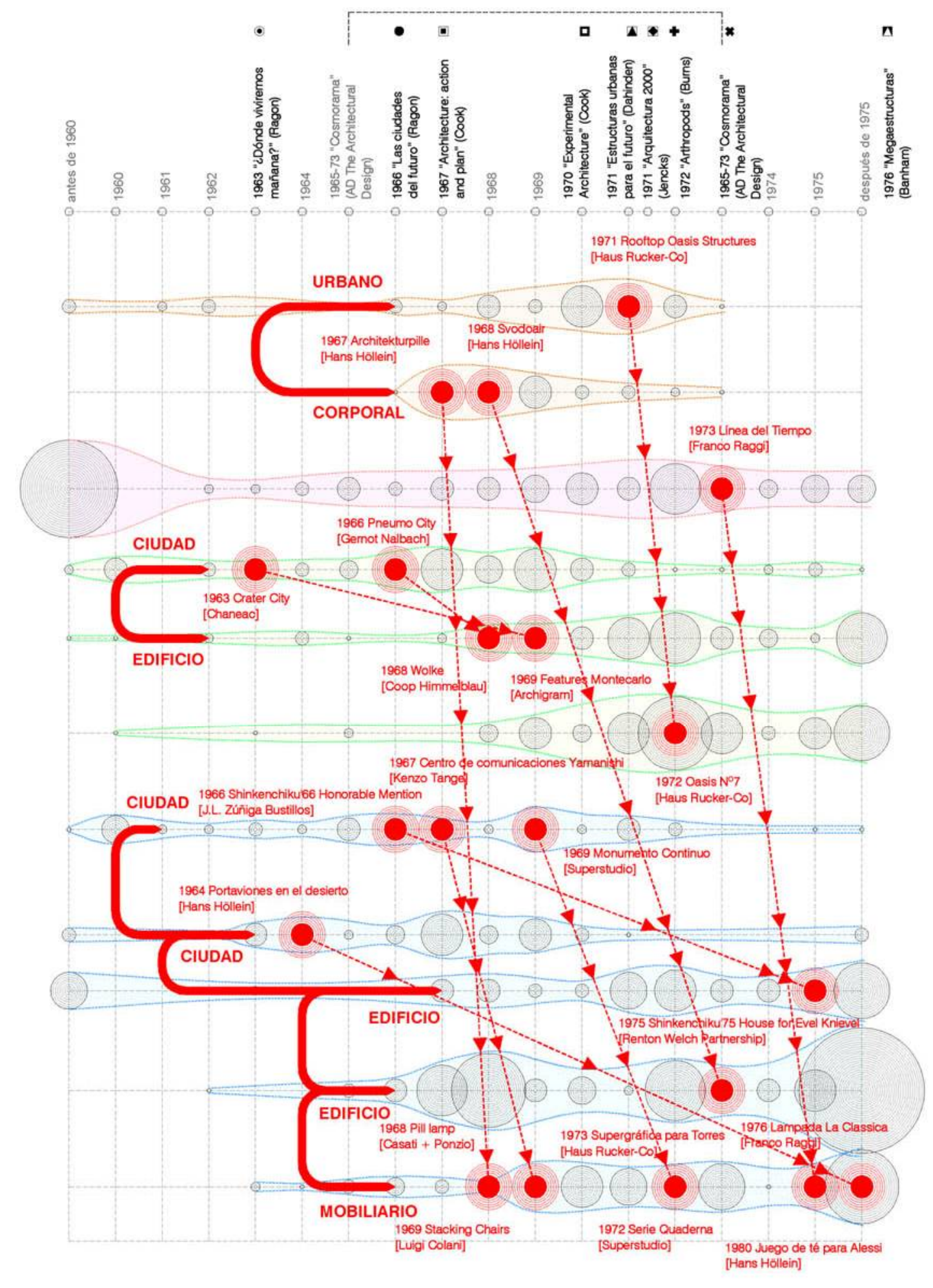




\section{Transferencias formales y escalares entre estrategias proyectuales.}

La transferencia formal y escalar entre diversas estrategias ya ha sido tratada en el capítulo Objetualización Ideológica en relación a la alternativa CAMBIO DE ESCALA, por ser allí dónde se evidencia mejor este proceso relacional. Se han utilizado pares de proyectos que utilizan unos recursos formales similares para generar proyectos muy heterogéneos, a escalas diversas, en lo que se ha denominado como proceso de objetualización de ideologías arquitectónicas. Es importante constatar que esa transformación es común a muchos de los proyectos catalogados a través de las distintas alternativas de futuro. Más allá de una transferencia entre proyectos concretos, cabe destacar como la misma se convierte en una transformación que opera a través de tres sistemáticas fundamentales. Se han utilizado algunos ejemplos cartografiados en el diagrama_06 para evidenciarlas:

- Esta transferencia de estrategias se produce de manera sistemática a través del cambio de escala CIUDAD / EDIFICIO / MOBILIARIO en cada una de las alternativas de futuro de manera aislada. Muchas de las estrategias catalogadas en PERVERSIONES NATURALES, utilizadas en la Ciudad Paisaje, se convierten pocos años después en herramientas efectivas para la configuración de Edificios Camuflaje. Las propuestas de edificios-colina de Archigram, "Mound" (1964) o "Features Montecarlo" (1969) reproducen a la escala edificio las intenciones de proyectos urbanos como la "Crater City" (1960-1963) de Chaneac. La ciudad-nube neumática, "Pneumo City" (1966) de Gernot Nalbach, se convierte dos años más tarde en el edificio-nube o "Wolke" diseñado por los también austríacos Coop Himmelblau.

- Esta transferencia entre estrategias suele presentar una disminución de escala temporal evidente. A pesar de que existen algunos casos de "invariantes" que se repiten a diversas escalas de manera más o menos intermitente, en general se mantiene como constante que la mayor parte de las estrategias formuladas para una escala CIUDAD tienen sus análogos contemporáneos en las escalas EDIFICIO O MOBILIARIO. Las Ciudades Tecnomórficas devienen en un Tecnomorfismo edificatorio y las utopías climáticas como "Rooftop Ooasis" (1971) se convertirán sólo un año más tarde en pequeños implantes naturales de renaturalización de la ciudad como es "Oasis n4" (1972), ambos propuestos por Haus Rucker-Co.

- La transferencia de estrategias entre alternativas de futuro diferentes no se presenta ya como una herramienta proyectual efectiva sino como estrategia semántica-simbólica. Así lo atestiguan todos los proyectos catalogados y caracterizados en el capítulo Objetualización Ideológica. 


\section{Diagramas_07 08 DETONANTES / MÁXIMA PRODUCCIÓN DESMOTIVĀDŌRES}

- Se han diferenciado los proyectos de cada una de las estrategias asociadas a las distintas alternativas de futuro.

- Se han determinado los períodos y los vértices de máxima producción. Estos tres indicadores, el año que marca el inicio de una tendencia o detonador, aquel de máxima producción y el que finaliza el período de máxima producción o desmotivador serán analizados en la búsqueda de proyectos concretos y su influencia a través de las predicciones arquitectónicas.
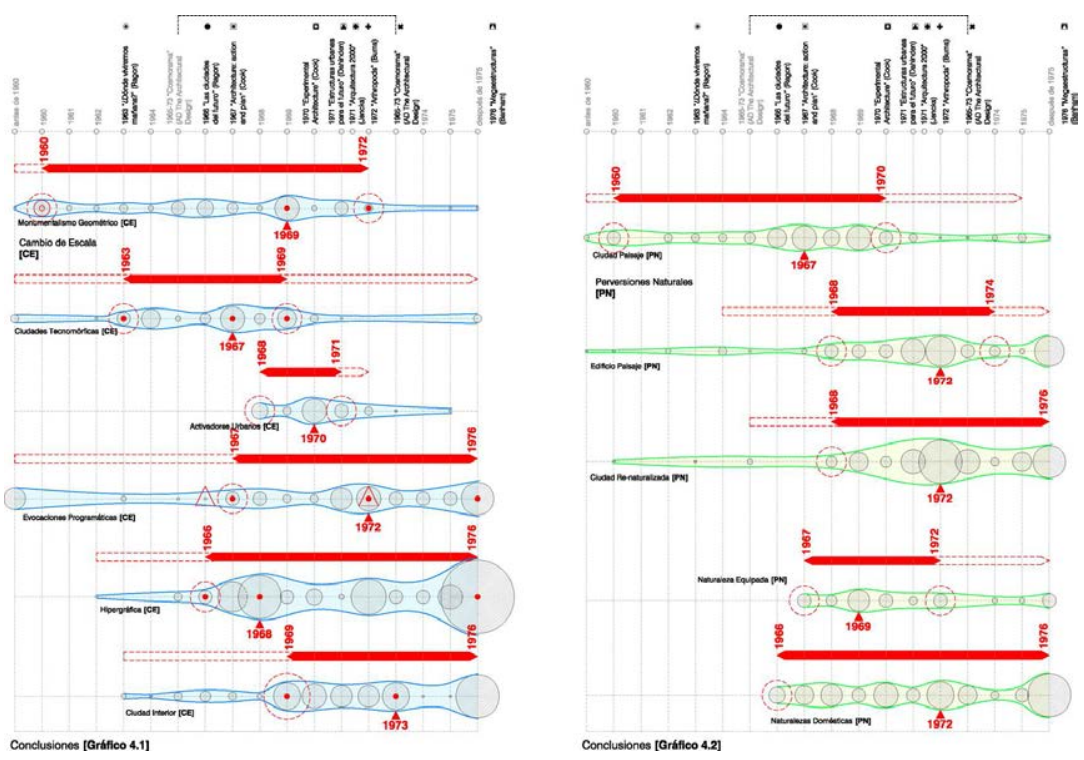

Diagramas_07 CAMBIO DE ESCALA / PERVERSIONES NATURALES
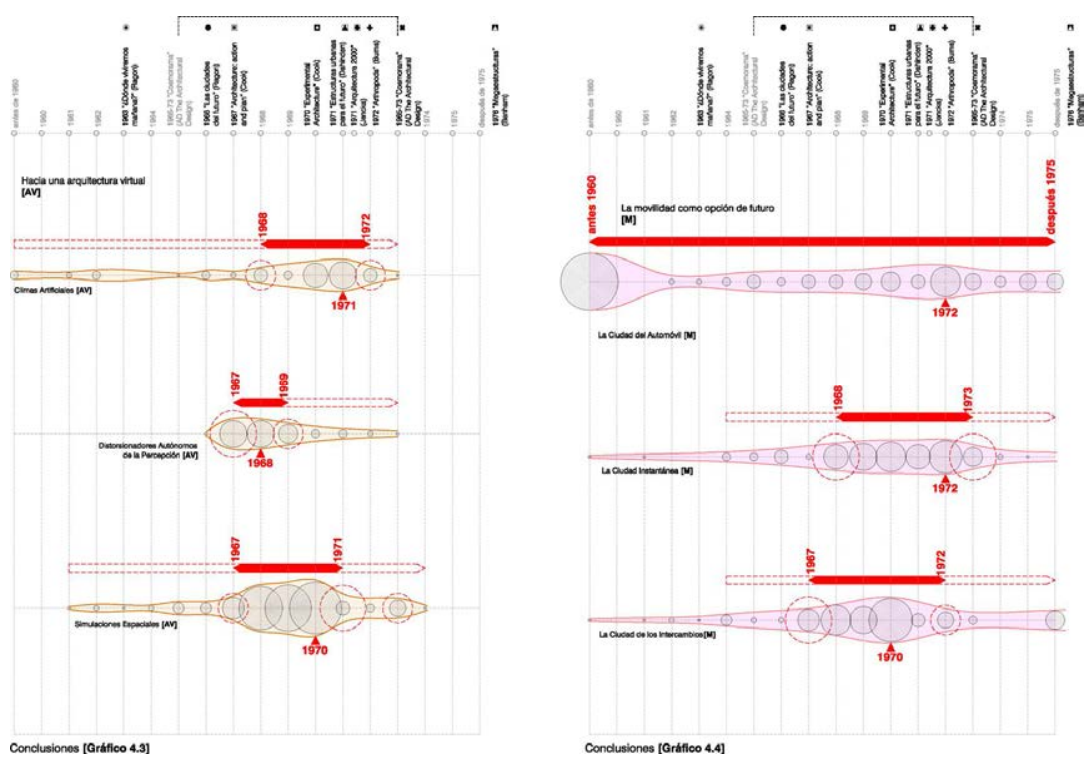

Diagramas_08 HACIA UNA ARQUITECTURA VIRTUAL / LA MOVILIDAD COMO OPCIÓN DE FUTURO 


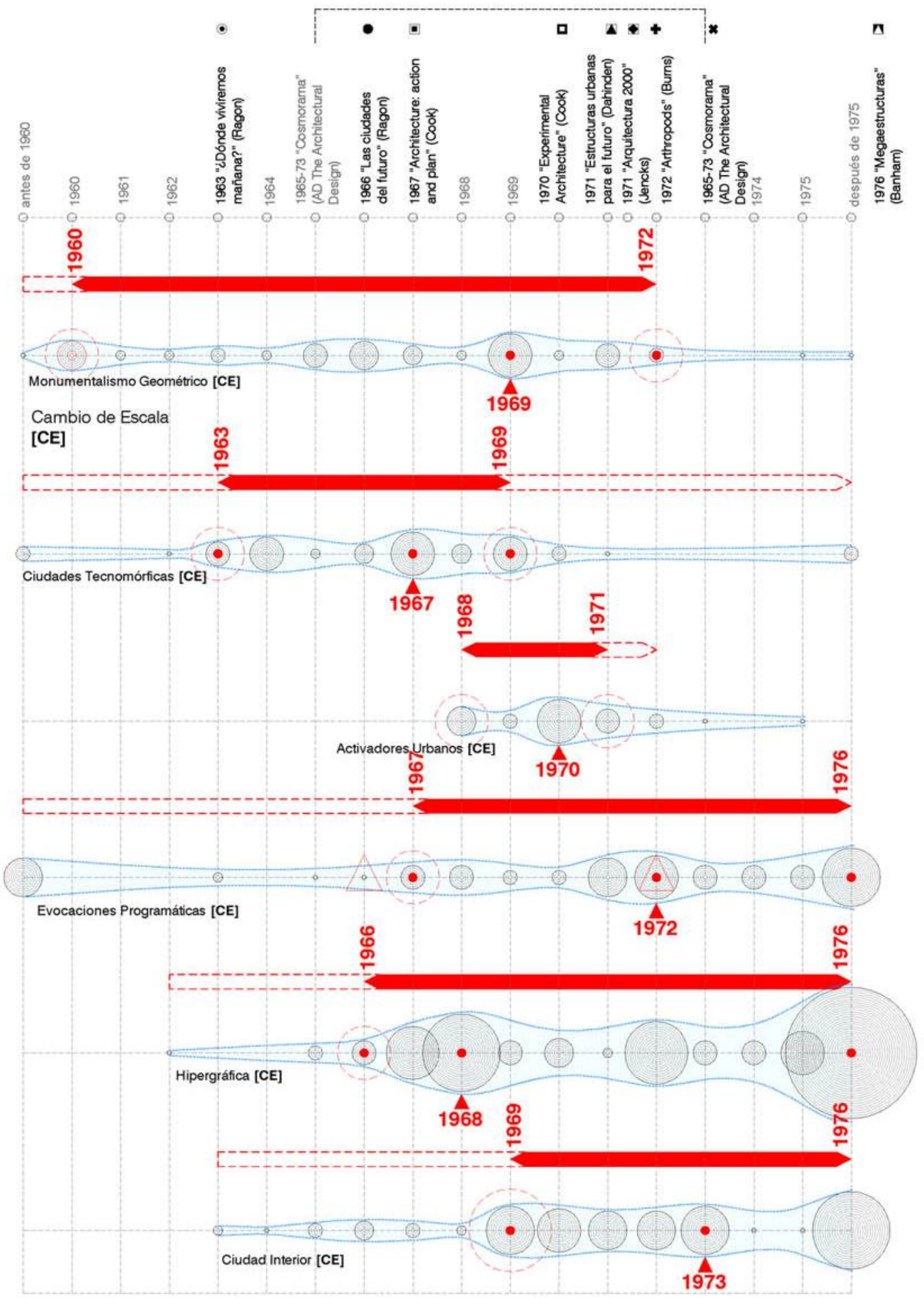




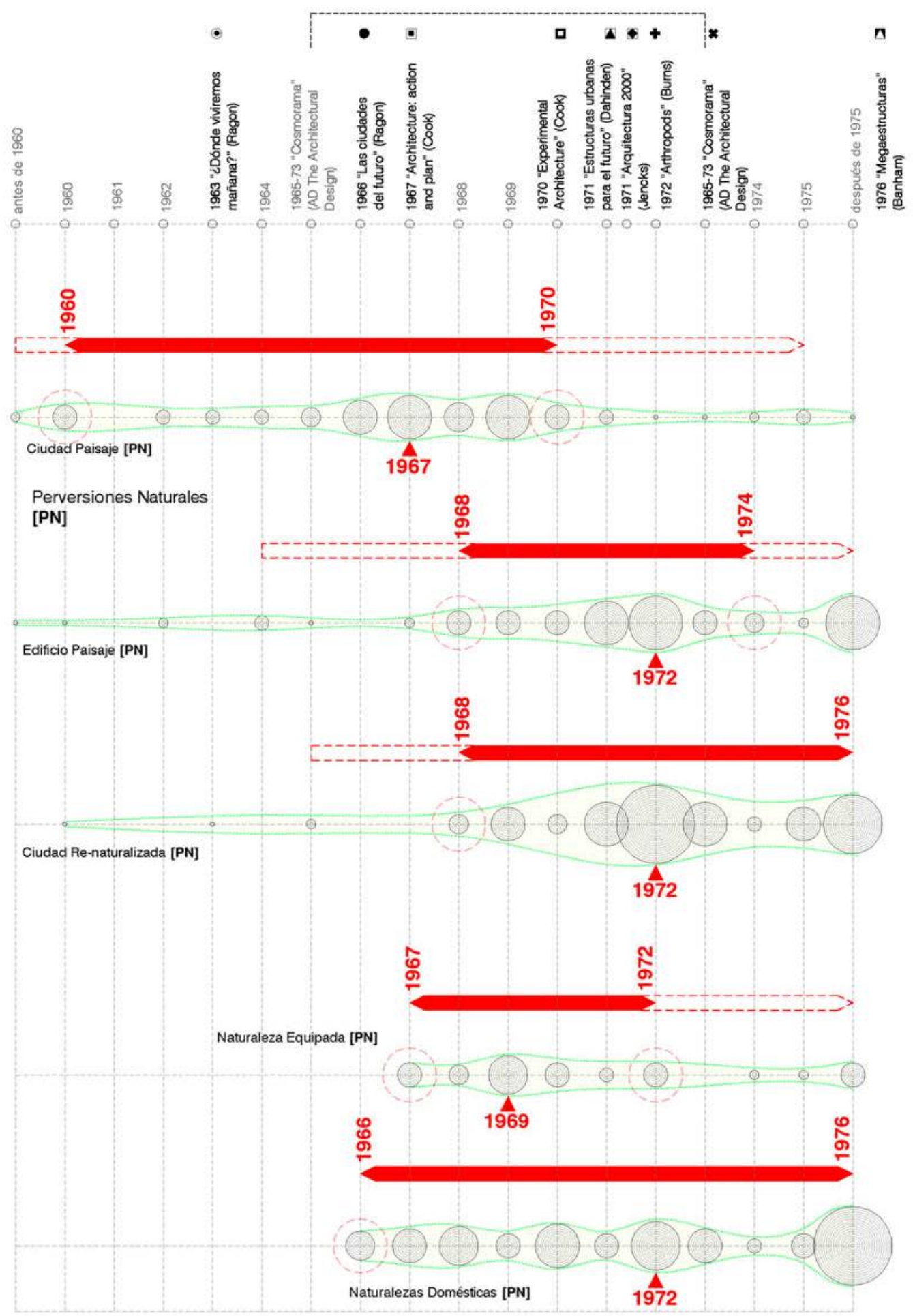




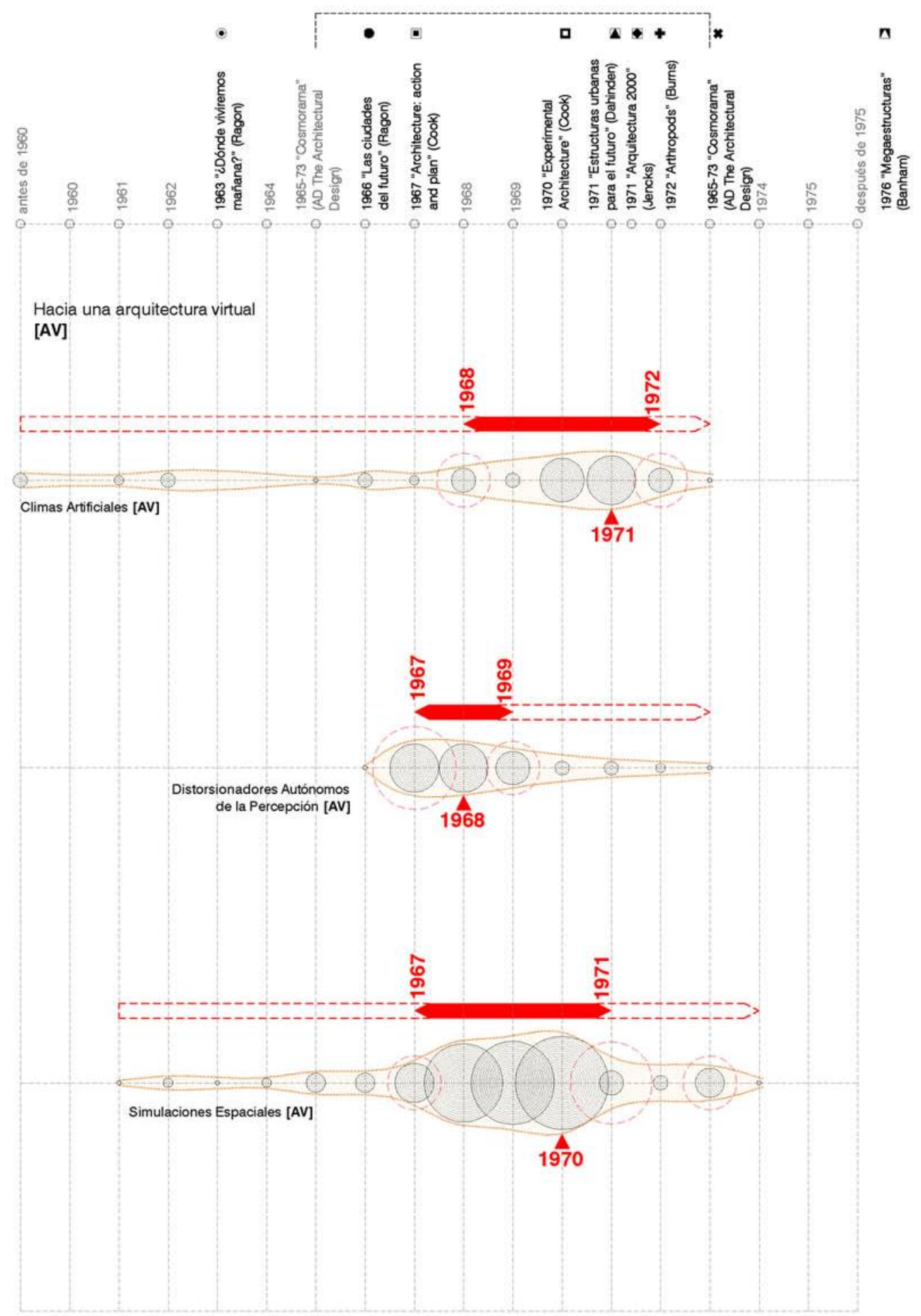




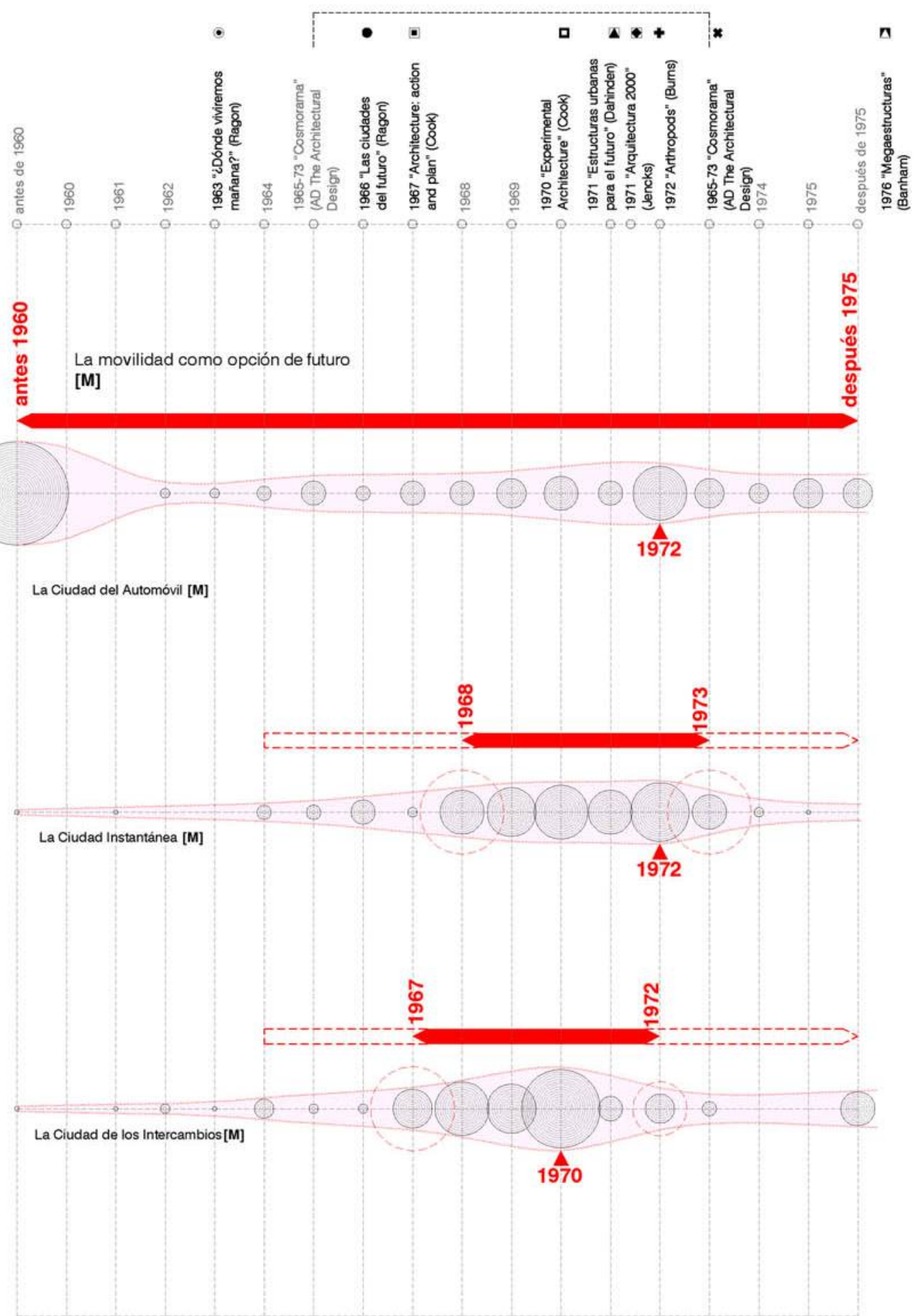




\section{Detonantes, puntos de máxima producción y desmotivadores. Sobre la importancia de la difusión arquitectónica.}

A pesar de pertenecer a contextos muy dispares, y existir como alternativas de futuro solamente a partir de las publicaciones denominadas como predicciones arquitectónicas, las estrategias derivadas de las cuatro alternativas de futuro enunciadas presentan comportamientos afines, durante el período temporal de estudio, que pueden ser tabuladas mediante una serie de detonadores, puntos de máxima producción y desmotivadores.

Cada uno de estos hitos temporales suele presentar un contexto específico, ya sea a través de congresos o grupos académicos, pero fundamentalmente vinculado a diversas publicaciones arquitectónicas. Dichos contextos evidencian la importancia de la difusión arquitectónica.

En este sentido, las publicaciones periódicas tuvieron una mayor influencia que las compilaciones, en unas vertiginosas décadas de los sesenta y primeros setenta. La fuerte periodicidad de las mismas se complementaba con la interrelación e intercambio entre publicaciones geográficamente lejanas. Las predicciones no fueron sino compilaciones de proyectos que habían sido publicados años antes en esos magazines de arquitectura. La mayoría de los autores de predicciones arquitectónicas incluyen amplias bibliografías que lo corrobora. L'Architecture d'Aujourd'Hui para Ragon, The Architectural Design para Jencks, McHale y Cook o el trabajo de Jim Burns como editor de la revista norteamericana Progressive Architecture, evidencian algunas de esas conexiones. Más allá de las particularidades de todas ellas, los detonantes, puntos de máxima producción 0 desmotivadores coinciden con contextos de legitimación siempre vinculados a esas herramientas de difusión arquitectónica. La publicidad de los proyectos metabolistas en The Japan Architect y sus relaciones internacionales con The Architectural Design en Inglaterra y L'Architecture d'Aujourd'Hui en Francia suponen un contexto de prestigio para el inicio del Monumentalismo Geométrico así como las experimentaciones de Höllein y sus máquinas descontextualizadas, unido a su puesto como editor en BAU, refuerzan la máxima producción de Ciudades Tecnomórficas en 1967, en un contexto fundamentalmente austríaco.

Resultará también fundamental la conexión de esta difusión arquitectónica con los principales eventos arquitectónicos de la época y su influencia en las distintas estrategias durante el contexto. Por ejemplo, el exceso robótico de Osaka'70 supone el punto de máxima producción de los experimentos domésticos con robots arquitectónicos, mientras que la idea de una vivienda entendida como paisaje doméstico a través del cambio de escala y el compacto no tecnificado de la exposición de 1972 de Ambasz en el MOMA, generan un claro momento desmotivador para las estrategias derivadas de la Ciudad de los Intercambios.

De manera más o menos explícita, cada una de las estrategias presenta estos hitos temporales asociados a contextos de prestigio relacionados con la difusión de arquitectura. Se ha elaborado una serie de diagramas gráficos en los que se hacen visibles estos comportamientos, con los contextos detonadores y desmotivadores y los puntos de máxima producción. 
Diagramas_09 CAMBIO DE ESCALA / Monumentalismo Geométrico / Ciudades Tecnomórficas / Evocaciones Programáticas

\author{
Diagramas_10 CAMBIO DE ESCALA / Hipergráfica / Activadores Urbanos / \\ Ciudad Interior
}

\author{
Diagramas_11 PERVERSIONES NATURALES / Ciudad Paisaje / Edificio \\ Camuflaje
}

Diagramas_12 PERVERSIONES NATURALES / Naturaleza Equipada / Ciudad Re-Naturalizada / Naturalezas Domésticas

Diagramas_13 HACIA UNA ARQUITECTURA VIRTUAL / Climas Artificiales / Distorsionadores Autónomos de la Percepción / Simulaciones Espaciales

\title{
Diagramas_14 LA MOVILIDAD COMO OPCIÓN DE FUTURO / La Ciudad del Automóvil / La Ciudad Instantánea / La Ciudad de los Intercambios
}

\footnotetext{
- Se han diferenciado los proyectos de cada una de las estrategias asociadas a las distintas alternativas de futuro.

- Se han determinado los períodos y los puntos de máxima producción. Esos tres indicadores, el año que marca el inicio de una tendencia o detonador, aquellos que definen el período de máxima producción y el que finaliza el período de máxima producción o desmotivador serán analizados en la búsqueda de proyectos concretos y su influencia a través de las predicciones arquitectónicas.
}

- Se han remarcado ciertas publicaciones o contextos que han propiciado esos detonadores, puntos de máxima publicación o desmotivadores si llegaran a existir, diferenciados para cada una de las estrategias.

- Se han situado los arquitectos más relevantes en relación a la influencia de sus proyectos en el contexto temporal.

- Se han evidenciado las distintas interpretaciones y variaciones temporales que cada una de las estrategias sufre a lo largo del período de estudio, incluido sus índices de simultaneidad. 


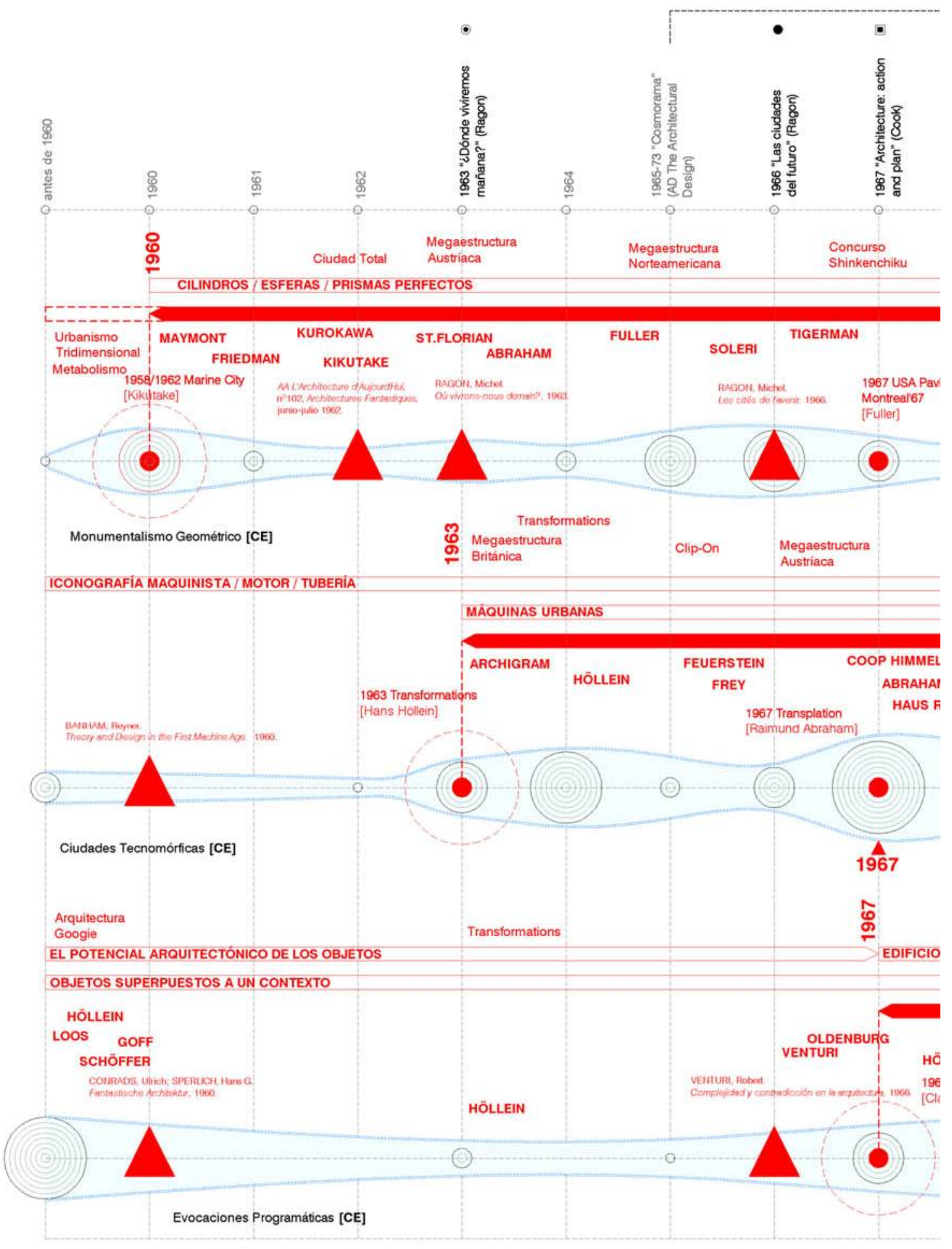




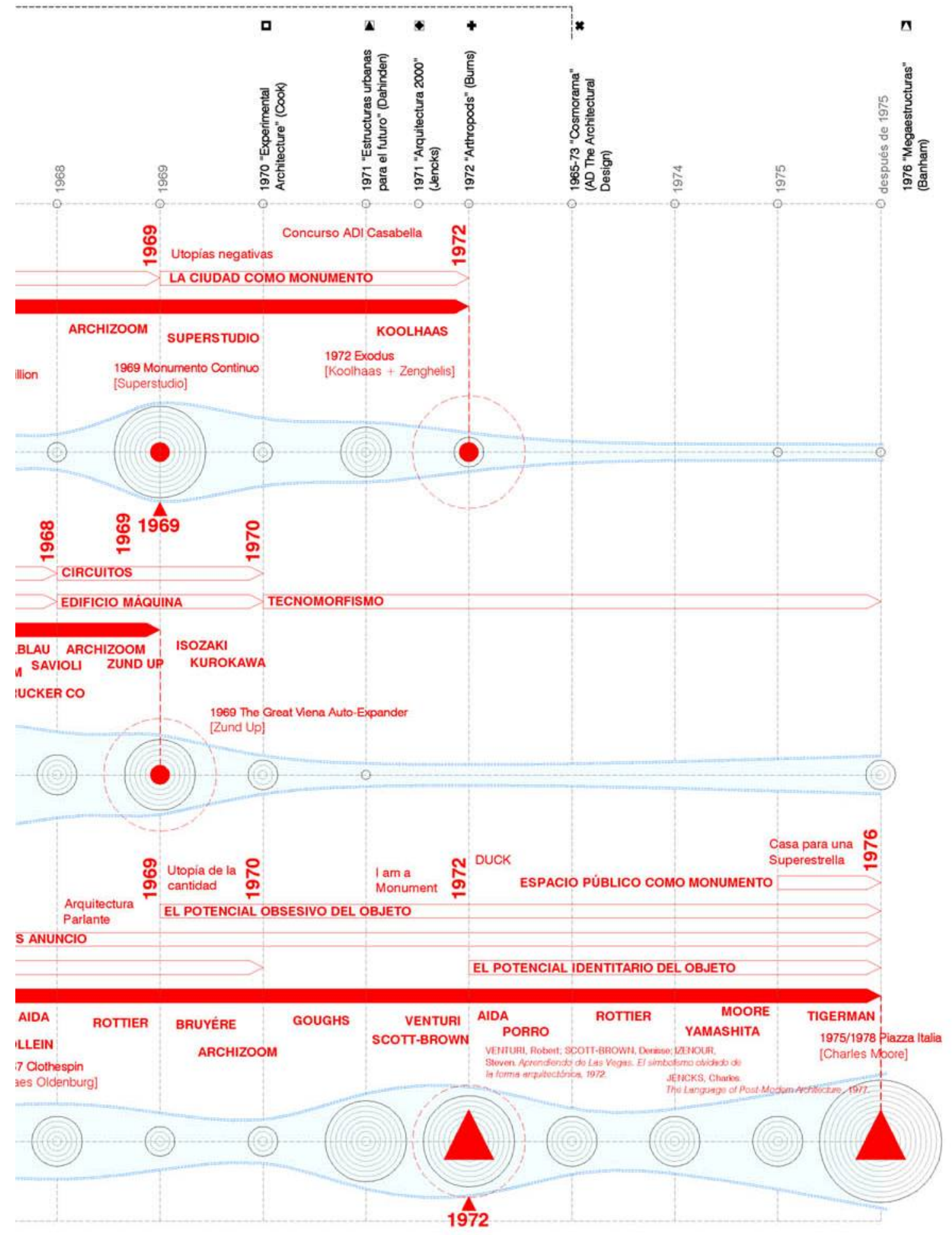




\section{[CE] Monumentalismo Geométrico}

La estrategia se presenta como alternativa de futuro durante un período de 12 años (19601972).

Detonantes: Su período de máxima producción se inicia todavía como estrategia heredera de los grandes planes urbanos del movimiento moderno y vinculada a las pretensiones de cambio urbano del denominado urbanismo tridimensional. Ese inicio también coincide con la prolífica producción y difusión del movimiento metabolista japonés, los experimentos urbanos de los utopistas franceses, comandados por Friedman y Maymont, y de los ingleses Archigram. En ese contexto, la propuesta para Tokyo denominada como "Marine City" (1958/1962) de Kiyonori Kikutake podría considerarse como proyecto insignia. La difusión de todos esos proyectos será muy grande, ya sea desde la revista francesa L'Architecture d'Aujourd'Hui ${ }^{745}$, o a partir de la gran relación entre la publicación británica The Architectural Design y varias revistas japonesas ${ }^{746}$.

Máxima producción: El punto de máxima producción, fijado en 1969, coincide con el trabajo de los italianos Superstudio denominado como del "Monumento Continuo", que iniciará el descenso de la producción al utilizar ese Monumentalismo Geométrico como crítica de una producción utópica centrada en la escala CIUDAD y basada en la planificación totalitaria. También coincide con la gran contaminación de propuestas afines y la gran decepción megaestructuralista tras las exposiciones universales de Montreal en 1967 y Osaka en 1970.

Desmotivadores: El período lo finaliza un proyecto como "Exodus" (1972) de Koolhaas y Zenghelis, que opera bajo las mismas coordenadas distópicas que varias de las propuestas anteriores desarrollados por grupos radicales italianos como Archizoom o Superstudio.

\section{[CE] Ciudades Tecnomórficas}

La estrategia se presenta como alternativa de futuro durante un período de 6 años (19631969).

Detonantes: Su período de máxima producción comienza con varios trabajos de Hans Höllein en relación al cambio de escala de iconos tecnológicos, bombillas, motores y demás accesorios mecánicos, en la serie "Transformations" (1963). Todos ellos inician una iconografía maquinista que evoluciona del motor y la tubería al circuito, y de las máquinas urbanas superpuestas a contextos urbanos históricos al edificio máquina. Por otro lado, la amplia difusión de las diversas propuestas de los británicos Archigram para sus ciudades tecnomórficas "Walking City" (1963) o "Plug In City" (1962-1965), generan un doble contexto austríaco-británico asociado a esta estrategia.

Máxima producción: El período de máxima producción corresponde a un contexto casi exclusivamente austríaco, auspiciado por la difusión de estas máquinas urbanas a través de

745 AA L'Architecture d'Aujourd'Hui, n¹02, Architectures Fantastiques, junio-julio 1962.

746 NITSCHKE, Gunter. The Metabolists of Japan. En: AD The Architectural Design, octubre 1964. pp. 509-24,

English Architects. En: Kenchiku Bunka, no. 10/11, enero 1967.

COOK, Peter. Some Notes on the Archigram Syndrome; Archigram: the Name and the Magazine. En: JA The Japan Architect, julio 1970. pp. 34-37. 
la revista austríaca Bau ${ }^{747}$, de la que Hans Höllein era editor y el éxito de difusión de la muestra "Urban Fictions" comisariada por Günther Feuerstein.

Desmotivadores: El período de máxima producción se cierra con propuestas distópicas como "The Great Viena Auto-Expander" (1969) de los austríacos Zünd Up. De la misma manera que sucede con Monumentalismo Geométrico, esta estrategia se transforma en una transferencia puramente formal a la escala edificio. En este sentido, serán Superstudio los que sugieran la posibilidad de una estética de la máquina que pueda ser incorporada a cualquier edificio, lo que deviene en un Tecnomorfismo bizarro que será seguido por un sofisticado High-Tech.

\section{[CE] Evocaciones Programáticas}

La estrategia se presenta como alternativa de futuro durante un período de 9 años (19671976) en el contexto de la investigación, sin embargo su continuidad en un contexto futuro es total.

Detonantes: Su período de máxima producción comienza en 1967 respaldado por las transferencias entre el Pop Art y la arquitectura. En relación a la difusión arquitectónica, el manifiesto de Venturi "Complejidad y contradicción en la arquitectura"1748 de 1966 y la gran polémica suscitada en torno al mismo lo sitúan como gran referente. Varios años antes, "Fantastic Architecture"749 (1960) de Conrads y Sperlich había iniciado el período de legitimación de la multitud de proyectos históricos relacionados con el cambio literal de escala de objetos.

Máxima producción: El edificio-anuncio de "Aprendiendo de Las Vegas" coincide con el vértice de máxima producción en 1972. Muchas de esas estrategias derivadas del cambio de escala de objetos cotidianos serán popularizadas a través de su publicación en revistas de arquitectura de la época. Esa difusión masiva de muchos de estos proyectos en Domus, Casabella o The Architectural Design posibilitarán un período que se incrementa en el tiempo al incorporarse a la iconografía semántica posmoderna, auspiciado por autores como Charles Jencks en algunos de sus libros-manifiesto como "The Language of Post-Modern Architecture ${ }^{1170}$ (1977) O "Bizarre Architecture"1751 (1979). Salvo raras excepciones, entre las que se encontrarían autores como Guy Rottier, Ricardo Porro, Stanley Tigerman, Takefumi Aida, André Bruyère o Gaetano Pesce, diversos arquitectos coquetean de manera muy singular con este tipo de proyectos, sin presentar líneas de trabajo realmente coherentes en relación a los mismos.

747 HÖLLEIN, Hans. Technik. En: Bau, Heft 2, 1965. p.54.

HÖLLEIN, Hans. Zukunft der Architektur. En: Bau, Heft 1, 1965. pp. 8-11.

Bau, Heft 2/3, Wien, 1969.

Bau, Heft 4/5, Graz, 1969.

748 VENTURI, Robert. Complejidad y contradicción en la arquitectura. 1974 (1966)..

749 CONRADS, Ulrich; SPERLICH, Hans G. Fantastic Architecture. 1963 (1960).

750 JENCKS, Charles. The Language of Post-Modern Architecture. 1977.

751 JENCKS, Charles. Bizarre Architecture. 1979. 


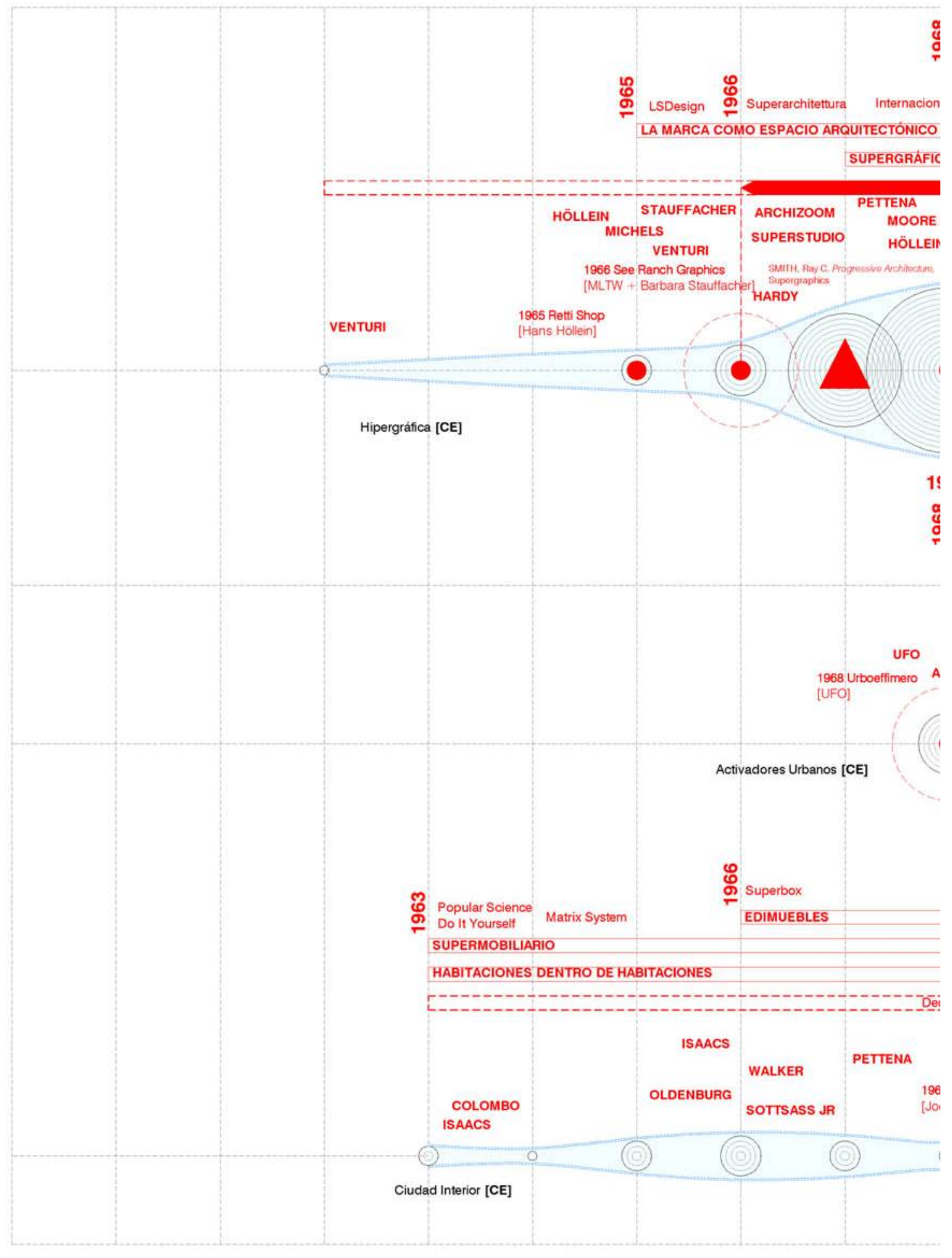




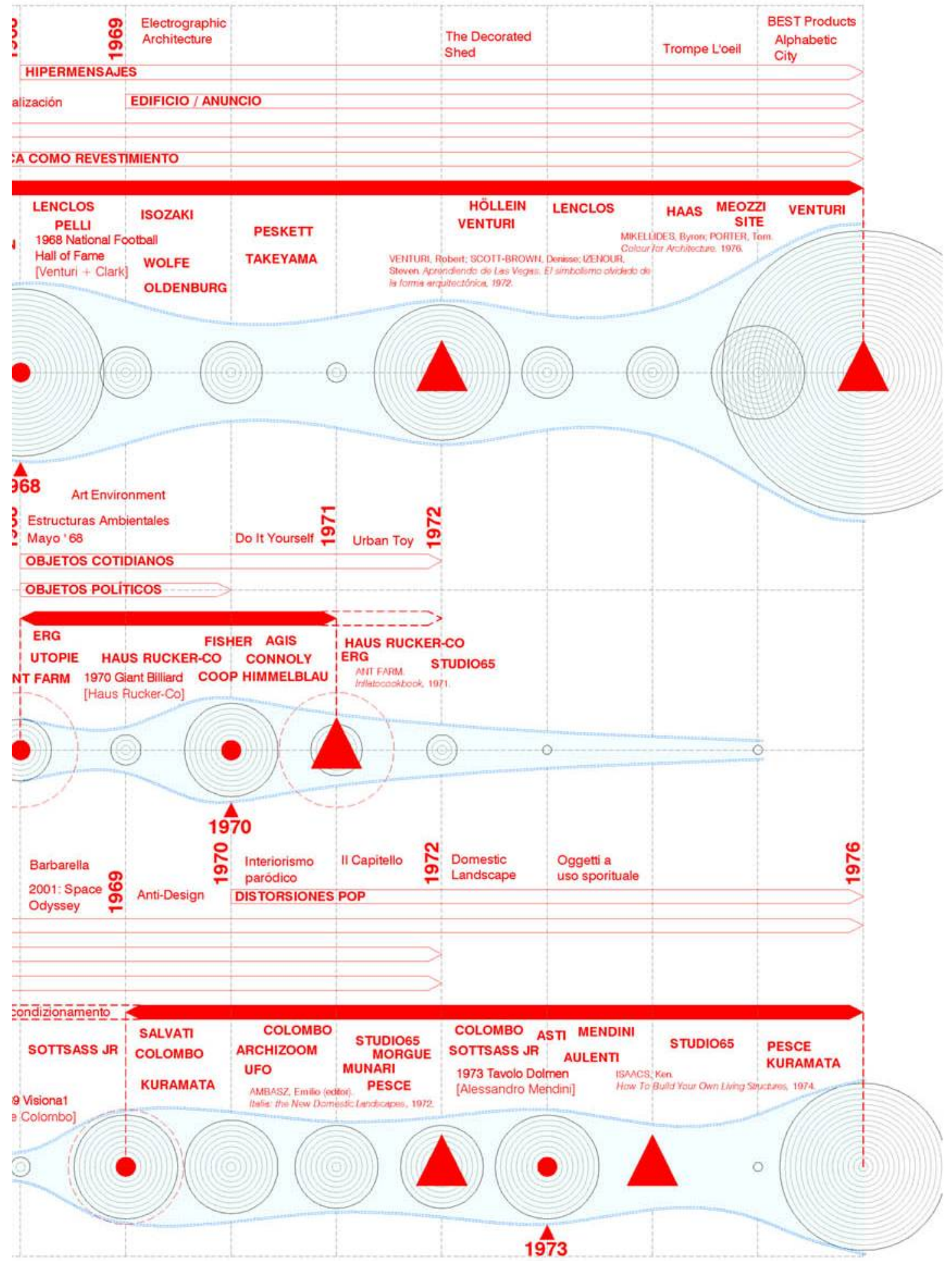




\section{[CE] Hipergráfica}

La estrategia se presenta como alternativa de futuro durante un período de 10 años (19661976) en el contexto de la investigación, sin embargo su continuidad en un contexto futuro es similar al experimentado por Evocaciones Programáticas.

Detonantes: Su período de máxima producción comienza en 1966 y presenta un carácter deliberadamente internacional. Las estrategias derivadas de las supergráficas urbanas, edificios-marca, edificios-anuncio e hiper-mensajes serán utilizadas desde finales de la década de los sesenta como sistemáticas asociadas a todo tipo de edificios, como recurso exterior e interior efectivo y barato. Las publicaciones de supergráficos desde Progressive Architecture ${ }^{752}$ por parte de C.Ray Smith generarán un efecto detonador para su expansión definitiva a publicaciones inglesas, francesas e italianas principalmente. El uso del color en los magazines de arquitectura supondrá el impulso definitivo para la evolución y desarrollo de este tipo de estrategias.

Máxima producción: De nuevo "Aprendiendo de Las Vegas" supone uno de los grandes legitimadores de edificios que trabajan con la supergráfica. Los proyectos de SITE para los almacenes BEST consolidarán la estrategia como susceptible de ser reinterpretada hasta la extenuación. La hipergráfica será legitimada a partir de mediados de los setenta por multitud de textos y proyectos como estrategia intelectual y efectiva ${ }^{753}$.

\section{[CE] Activadores Urbanos}

La estrategia se presenta como alternativa de futuro durante un período de tan sólo 3 años (1968-1971).

Detonantes: El inicio del período de máxima producción coincide con cambios sociales como los producidos en mayo del 68 y se vincula a grupos activistas muy concretos como serán los franceses Utopie, los holandeses ERG, los austríacos Haus Rucker-Co o los estadounidenses Ant Farm.

Máxima producción: Su difusión a través de manuales de recursos como el "Inflatocookbook" (1971) de Ant Farm no consiguió que los Activadores Urbanos abandonasen su carácter residual. Su carácter efímero y el interés de las propuestas por el espacio público hace que la estrategia Activadores Urbanos tenga un período de obsolescencia muy alto.

\section{[CE] Ciudad Interior}

La estrategia se presenta como alternativa de futuro durante un período de 7 años (19691976).

752 Todos esos artículos pueden ser consultados en:

SMITH, C. Ray. Supermannerism: new attitudes in post-modern architecture. University of Minnesota / Dutton. Nueva York, 1977.

753 MIKELLIDES, Byron; PORTER, Tom. Colour for Architecture. Studio Vista. Londres, 1976. 
Detonadores: La búsqueda de independencia del mobiliario frente al contenedor, preconizada por los trabajos de Joe Colombo o Ken Isaacs, puede ser considerada como detonadora de una estrategia que entiende el diseño del mobiliario como si de un urbanismo de interiores se tratara. En este sentido Popular Science en Estados Unidos y Domus y Casabella en Italia, suponen lugares imprescindibles de difusión, debido al intereses por el Do It Yourself de la primera y del diseño de mobiliario en general de las segundas.

Máxima producción: Su período de máxima producción deriva de la translación de las estrategias de cambio de escala del edificio al diseño de interiores antes citada y gravita en torno la exposición de 1972 comisariada por Emilio Ambasz en el MOMA "Italia: the New Domestic Landscape". También presenta una continuidad temporal a partir de la mitad de la década de los setenta, transformando la anterior liberación del contenedor en urbanismo de interiores en el que la referencialidad arquitectónica y estilística se convierte en pauta dominante para el diseño de mobiliario exclusivo en ese nuevo paisaje en el que se había convertido el espacio doméstico contemporáneo. 


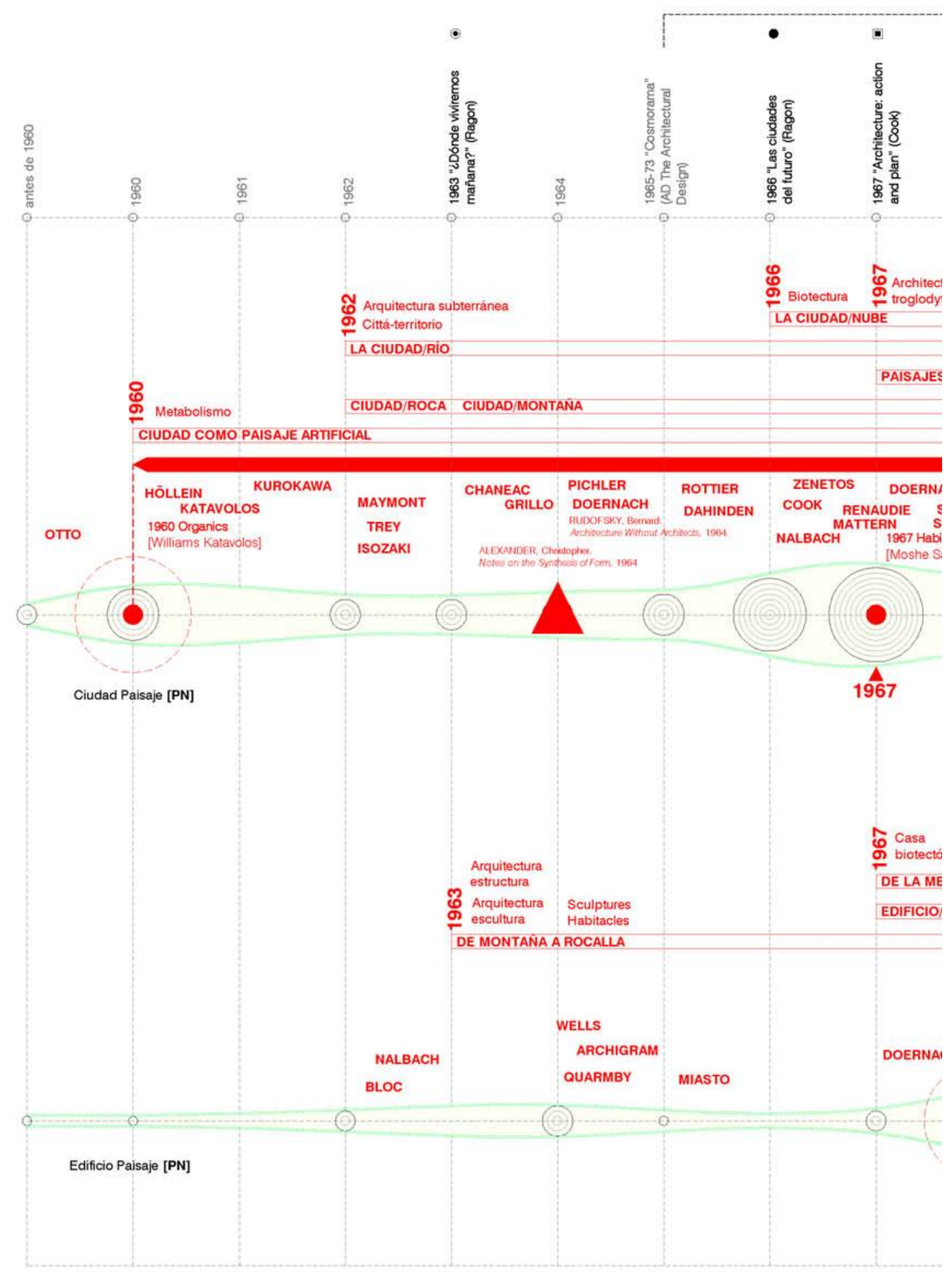




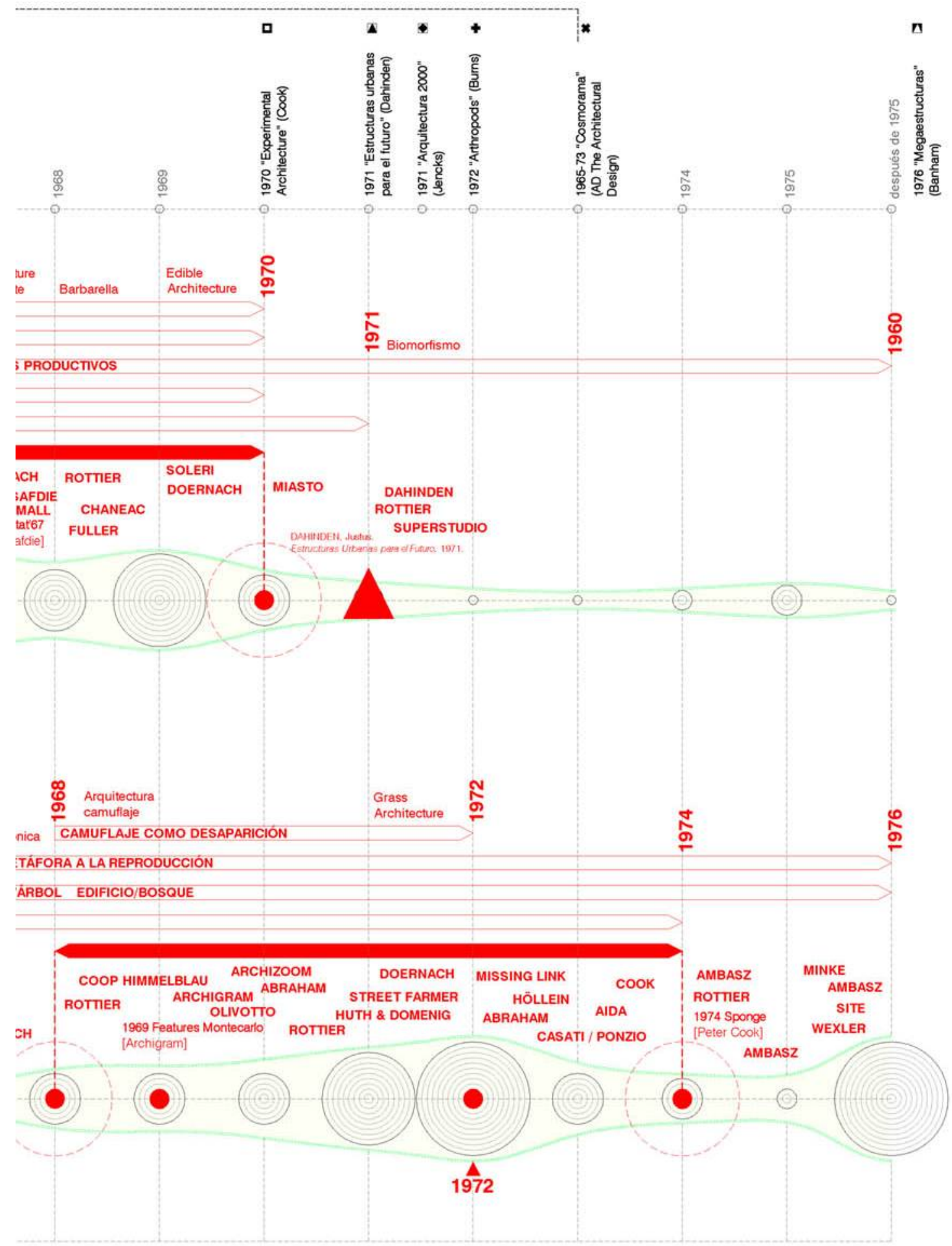




\section{[PN] Ciudad Paisaje}

La estrategia se presenta como alternativa de futuro durante un período de 10 años (19601970).

Detonantes: Su período de máxima producción comienza de manera análoga a la estrategia Monumentalismo Geométrico a partir de las experimentaciones formales relacionadas con estrategias de inserción de las megaestructuras en el paisaje. Tiene como grandes referentes las experimentaciones urbanas francesas de Chaneac, Maymont o Renaudie por un lado y la confianza en las "Arcologías" de Soleri por otro.

Máxima producción: El momento de máxima producción se sitúa en 1967 y el impacto internacional que el "Hábitat de Montreal" de Safdie tendrá a través de sus múltiples publicaciones. La exposición "Architecture without architects ${ }^{7541}$ comisariada por Rudofsky en el MOMA en 1964 y el libro "The City in the imagen of man"755, publicado por Soleri en 1969, paralelo a las experimentaciones del mismo en "Arcosanti", supondrán también dos claros referentes en los límites de ese período de máxima producción de proyectos asociados a esta estrategia.

Desmotivadores: El cambio de escala de finales de los sesenta también afectó a la estrategia Ciudad Paisaje, produciéndose una transferencia total de la experimentación realizada en la misma a la escala del edificio o Edificio Camuflaje. "Estructuras Urbanas para el Futuro" de Justus Dahinden supone un alegato póstumo de estas bio-estructuras utilizadas a escala urbana.

\section{[PN] Edificio Camuflaje}

La estrategia se presenta como alternativa de futuro durante un período de 6 años (19681974).

Detonantes: Su período de máxima producción comienza de manera difusa con experimentaciones como las realizadas por Arthur Quarmby y Rudolf Doernach, relacionadas con la inserción de estructuras de materiales plásticos en el paisaje. Uno de los detonantes más claros, por la gran popularidad que alcanzará tras ser publicado en múltiples revistas arquitectónicas de prestigio, será el proyecto "Features Montecarlo" diseñado por Archigram en 1969.

Máxima producción: El momento de máxima producción se sitúa en 1972 y coincide con la continuidad de esta estrategia en el trabajo posterior de autores como Gernot Minke, Emilio Ambasz, Allan Wexler, Guy Rottier o Peter Cook ya fuera del seno de Archigram. Sin embargo, será el arquitecto Emilio Ambasz el que destaque de entre todos ellos y convierta la idea del Edificio Camuflaje en una manera legítima de operar en relación a la naturaleza a través de la denominada como "Greener Architecture".

754 RUDOFSKY, Bernard. Architecture Without Architects: A Short Introduction to Non-Pedigreed Architecture. Museum of Modern Art. Nueva York, 1964.

755 SOLERI, Paolo. Arcology. The City in the imagen of man. The MIT Press. Boston,1969. 


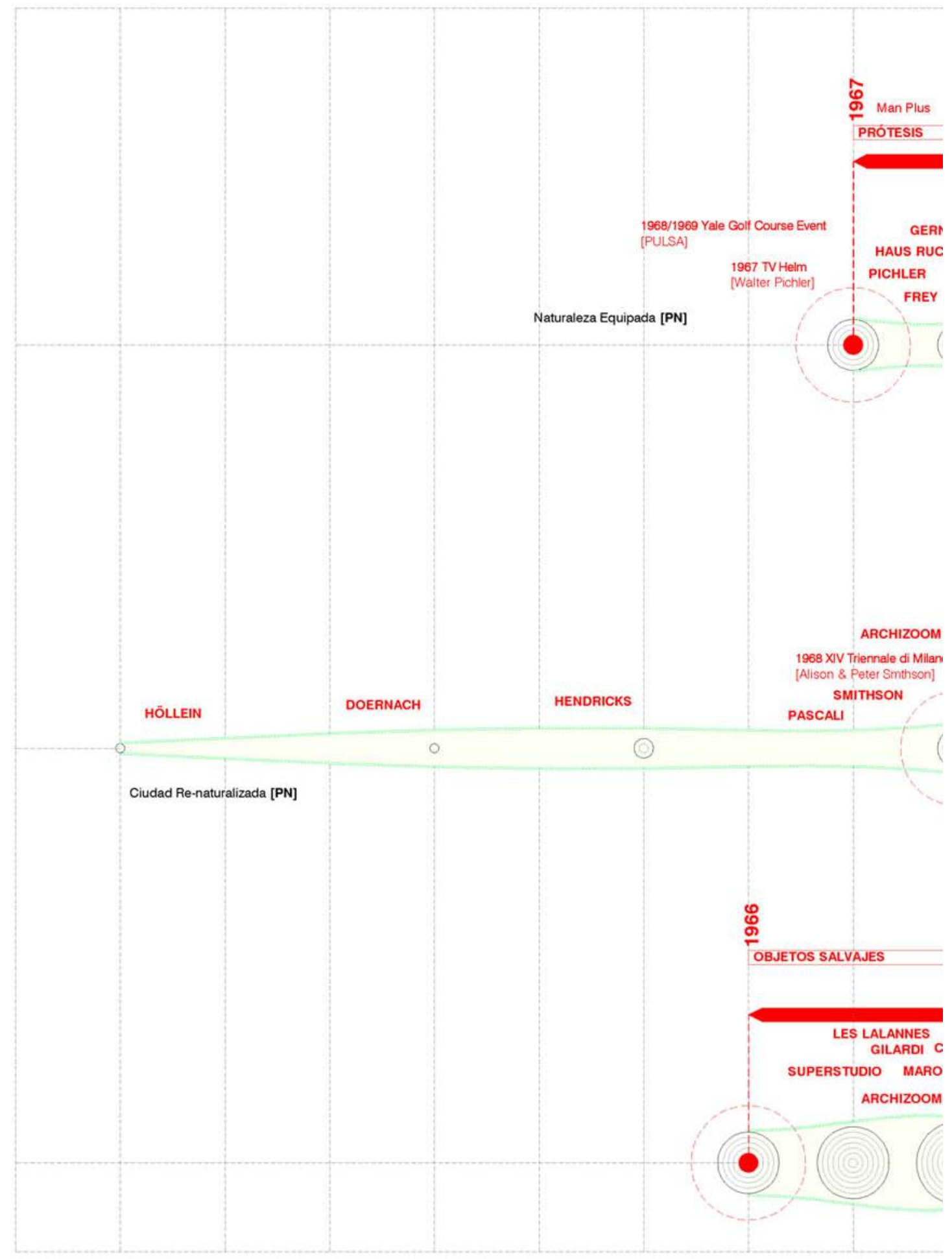




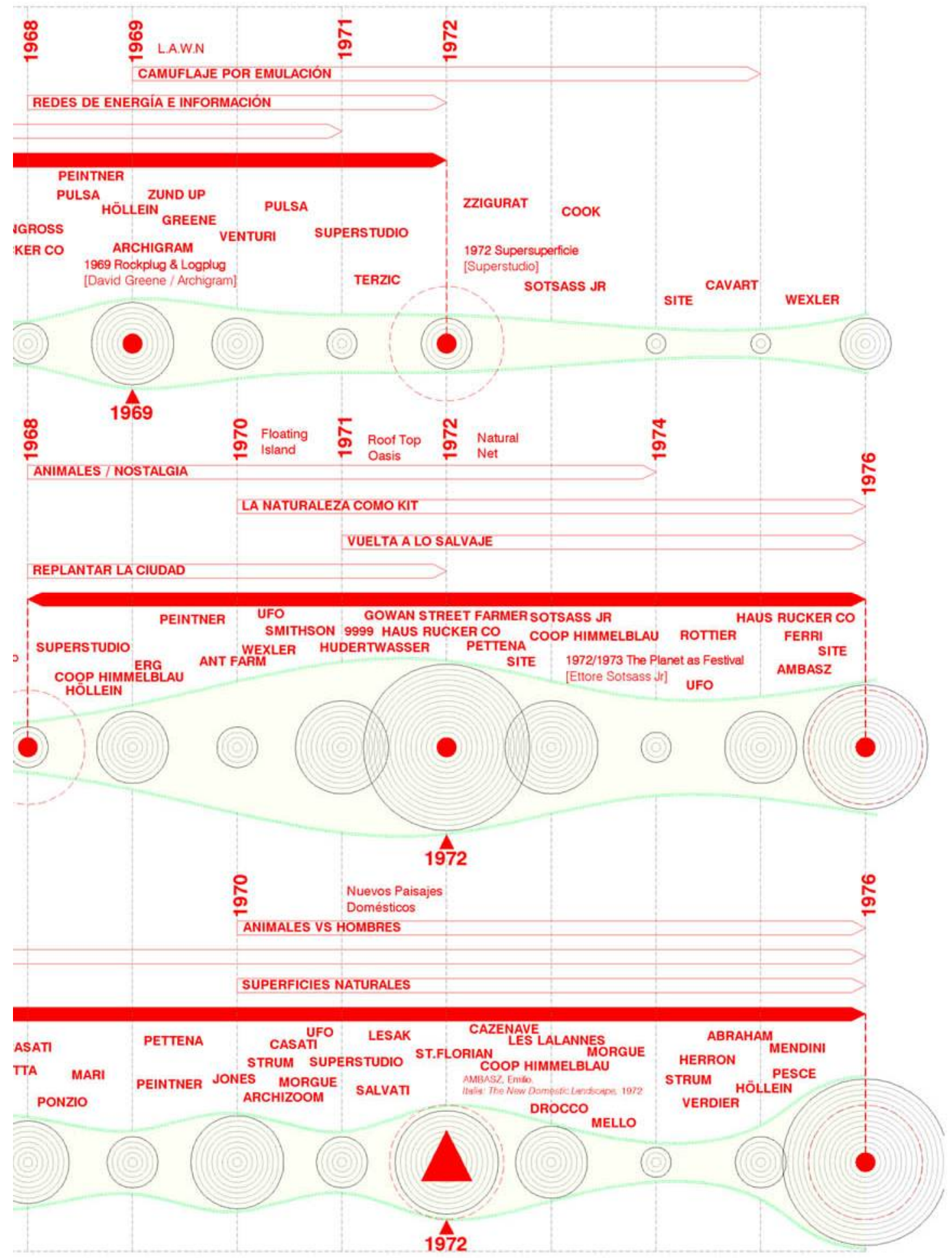




\section{[PN] Naturaleza Equipada}

La estrategia se presenta como alternativa de futuro durante un período de 5 años (19671972).

Detonantes: La estrategia se inicia con todo tipo de experimentos de prótesis de amplificación de las capacidades humanas, derivados de las teorías de Marshall McLuhan y de su difusión en el ámbito arquitectónico por parte de McHale, fundamentalmente en el especial de The Architectural Design "2000+ ${ }^{7561 .}$. El "Todo es Arquitectura"757 de Höllein también contribuye a esa legitimación de prácticas protésicas en busca de un hombre amplificado a través de una nueva naturaleza híbrida.

Máxima producción: La idea de una Naturaleza Equipada supondrá uno de los campo de experimentación más importantes para grupos como Archigram en Inglaterra, Superstudio en Italia y el grupo PULSA en USA. Sin embargo, la falta de proyectos efectivos hará que desciendan el número de proyectos asociados a la estrategia a partir de su punto de máxima producción en 1969, coincidente con el famoso proyecto de David Greene "RockPlug \& LogPlug", ampliamente referenciado por publicaciones a lo largo y ancho del planeta.

\section{[PN] Ciudad Re-Naturalizada}

La estrategia se presenta como alternativa de futuro durante un período de 8 años (19681976), en el contexto de la investigación, sin embargo su continuidad en un contexto futuro es también evidente.

Detonantes: La imagen de los Smithson para la XIV Triennale de Milán de 1968 resulta un punto de partida radical hacia una re-naturalización salvaje de la ciudad. A pesar de que la estrategia no presenta claros contextos de legitimación, la estrategia Ciudad Re-Naturalizada resultará común a muchos de esos proyectos que trabajan entre los límites de lo artificial y lo natural.

Máxima producción: A partir de esa vuelta a lo salvaje de la ciudad, se legitimarán una gran variedad de prácticas, que irán desde el entendimiento de la naturaleza como un kit, la generación de todo tipo de metáforas naturales urbanas hasta estrategias de replantado radical en el interior de la ciudad. Esa idea de Ciudad Re-Naturalizada se convertirá en una ensoñación recurrente en el contexto posterior al de esta Arqueología del Futuro.

\section{[PN] Naturalezas Domésticas}

La estrategia se presenta como alternativa de futuro durante un período de 10 años (19661976), en el contexto de la investigación, sin embargo su continuidad en un contexto futuro es también evidente.

756 MCHALE, John (editor). 2000+, AD The Architectural Design, vol67, February 1967.

757 HÖLLEIN, Hans. Alles ist Architektur. En: Bau, Heft 1/2, 1968. pp.2-27. 
Detonantes: Las experiencias de artistas vinculados con el Pop Art como Oldenburg y el auge de un cambio de escala legitimado por los trabajos de arquitectos como Robert Venturi y Hans Höllein, supondrán dos grandes detonantes para el inicio de todo tipo de reproducciones naturales en el interior de la vivienda.

Máxima producción: Esa idea de re-naturalización del ambiente doméstico llegará a su período de máxima producción en 1972, con la exposición "Italia: The New Domestic Landscape" comisariada por Ambasz. Desde entonces cualquier estrategia derivada del cambio de escala y la fusión entre natural y artificial hará que la iconografía del diseño de mobiliario se vea invadida por todas tipo de recreaciones de lo natural, en las que dejará de importar incluso el valor que esas naturalezas ficticias aporten a ese redescubierto paisaje doméstico. 


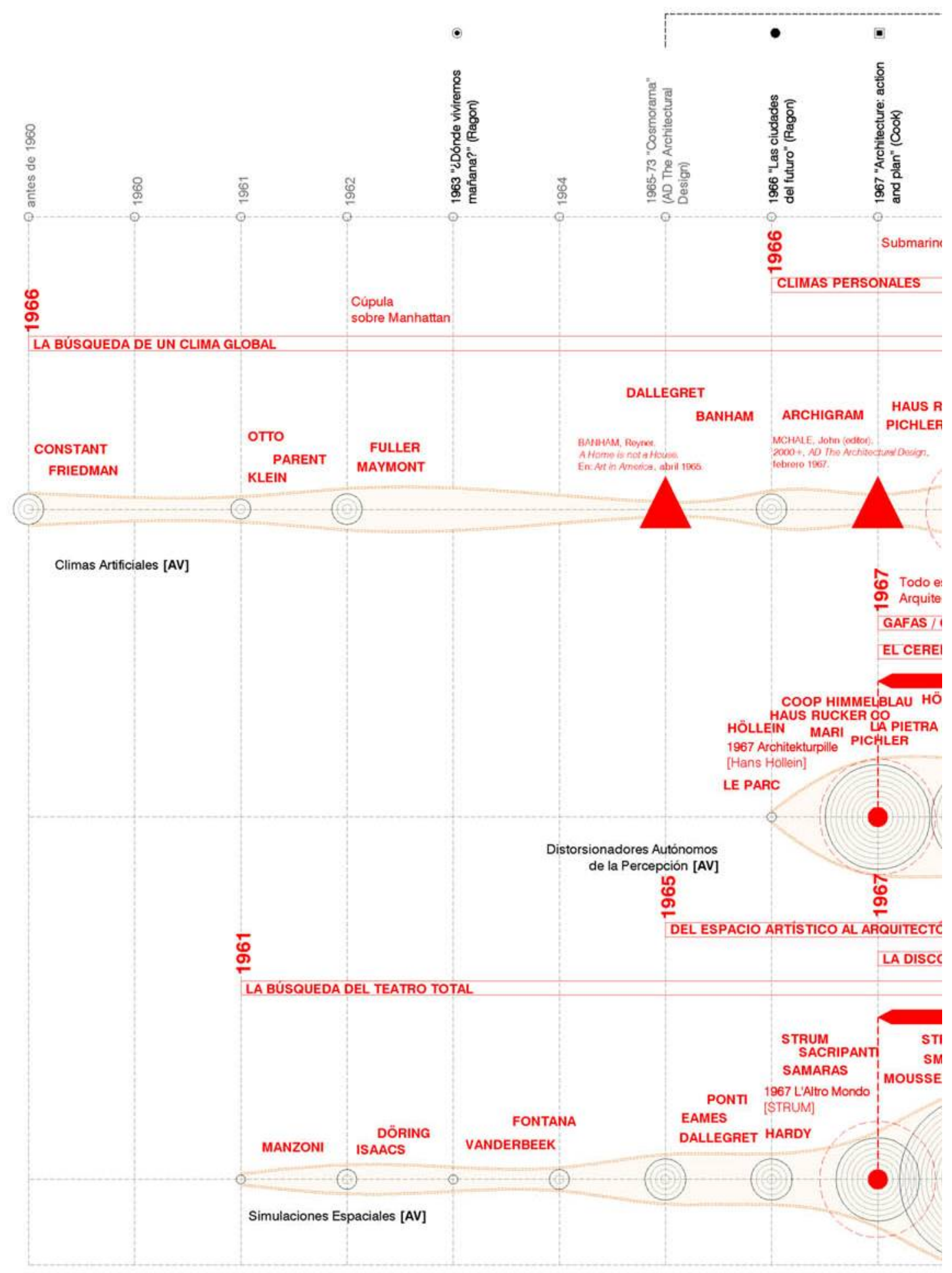




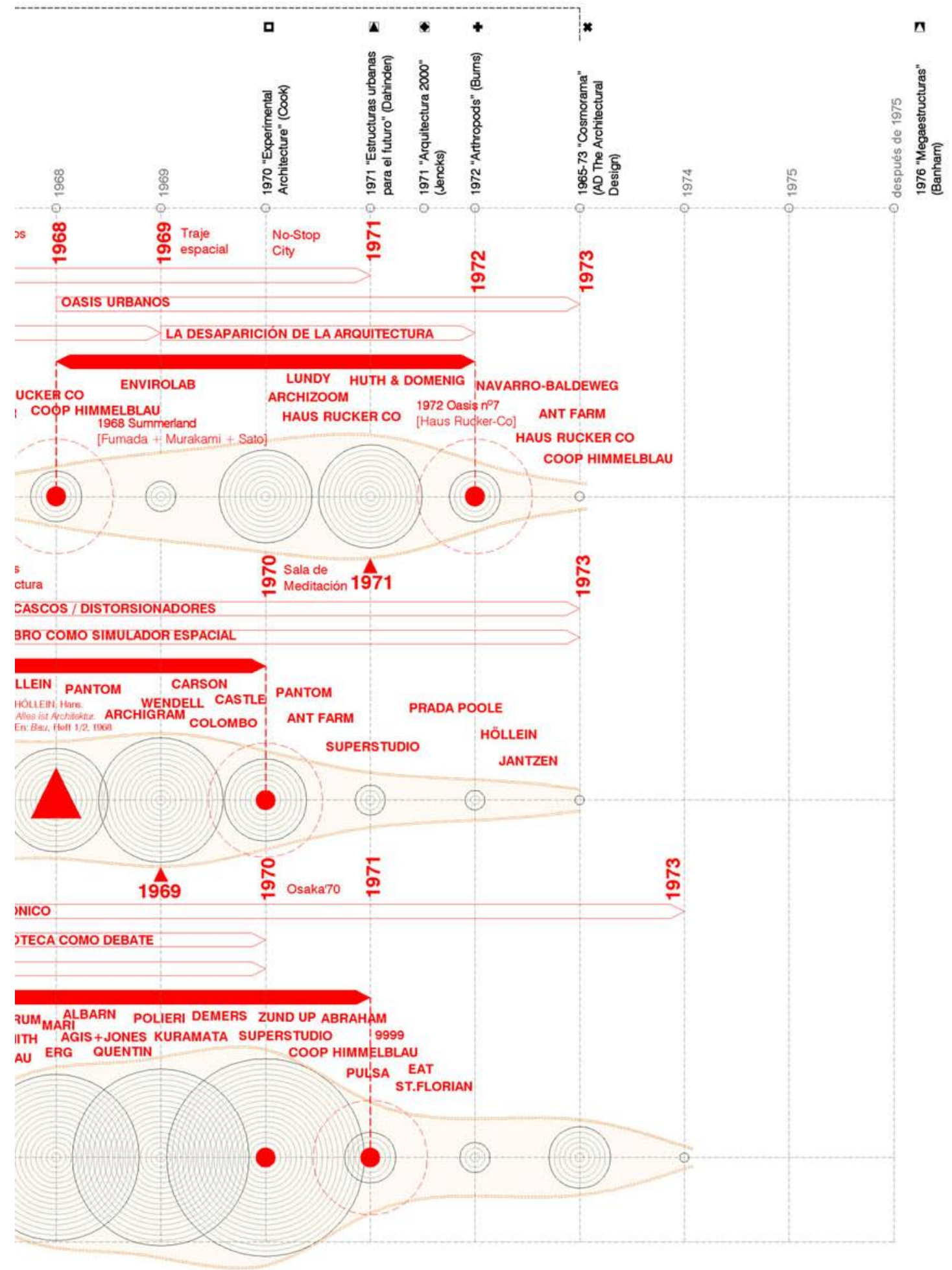




\section{[AV] Climas Artificiales}

La estrategia se presenta como alternativa de futuro durante un período de 4 años (19681972).

Detonantes: La búsqueda de un clima global se convertirá una de las grandes obsesiones para muchos arquitectos desde finales de la década de los cincuenta. Las utopías climáticas de Constant, Friedman o Buckminster Fuller supondrán un detonante para la reproducción de proyectos en busca de estrategias efectivas de climatización radical.

Máxima producción: A esa búsqueda de clima global se le sumarán las reivindicaciones climáticas de Banham en "A Home is not a House "1758 de 1965 y "The Architecture of the Welltempered Environment ${ }^{1759}$ de 1969, así como la aparición de tecnologías climáticas como el traje de astronauta, convertido en paradigma de clima unipersonal tecnificado. De esta manera aparecerán todo tipo de propuestas a varias escalas tratando de convertir al clima en protagonista del espacio arquitectónico.

Desmotivadores: La falta de referentes de éxito construidos, hace que se produzca casi una desaparición de proyectos climáticos a partir de 1972. Con un parque temático como "Summerland" o un pabellón para una exposición universal, el "Pabellón de USA" para Montreal'67, como grandes referentes a gran escala, la mayor parte de las propuestas no pasaron de prototipos malogrados como el "Oasis $n^{\circ} 7^{\prime \prime}$, construido por Haus Rucker-Co en la Documenta de Kassel de 1972.

\section{[AV] Distorsionadores Autónomos de la Percepción}

La estrategia se presenta como alternativa de futuro durante un período de 3 años (19671970).

Detonantes: De nuevo el manifiesto "Todo es Arquitectura", de Höllein, simbolizado por su icónica "Architekturpille", tendrá una gran relevancia en cuanto a que supone una legitimación de prácticas asociadas al control perceptivo. Esas experimentaciones espaciales estarán capitalizadas casi exclusivamente por grupos austríacos afines a Höllein como Haus Rucker-Co y Coop Himmelblau o italianos como Ugo LaPietra, pertenecientes a lo que se denomina como Architettura Radicale.

Máxima producción: El período de máxima producción es de sólo tres años y coincide con el trabajo antes citado de austríacos e italianos así como de la contracultura americana y su búsqueda en torno a una $L S D$ Architecture.

Desmotivadores: A partir de 1970, la mayoría de los grupos abandonan los experimentos perceptivos en torno a la idea del cerebro como simulador espacial. Destacarán sin embargo manifiestos tardíos como el libro del español José Miguel de Prada Poole "Las Fuentes del Espacio".

758 BANHAM, Reyner. A Home is not a House. En: Art in America, vol 53, abril 1965. pp.70-79.

759 BANHAM, Reyner. The Architecture of the Well-tempered Environment. The Architectural Press Ltd. Londres, 1969. 


\section{[AV] Simulaciones Espaciales}

La estrategia se presenta como alternativa de futuro durante un período de 4 años (19671971).

Detonantes: A principios de la década de los sesenta se inicia una búsqueda desesperada por cambiar los estándares espaciales de los recintos de espectáculos, para su adecuación a las nuevas formas de expresión derivadas de experimentaciones teatrales o artísticas, así como la incorporación en los mismos de las nuevas tecnologías audiovisuales.

Máxima producción: El punto de máxima producción coincide con la explosión del desarrollo de los sistemas audiovisuales en la exposición universal de Osaka'70. Durante el corto período en el que las Simulaciones Espaciales se convierten en una estrategia prestigiada en las élites arquitectónicas su producción es muy intensa. A partir de finales de los sesenta, las experimentaciones realizadas en ambientes estrictamente artísticos se empiezan a incorporar en espacios de consumo como son las discotecas o las boutiques de moda. El carácter experimental disminuye pero no así esa incorporación de tecnologías audiovisuales a lugares de consumo de masas. 


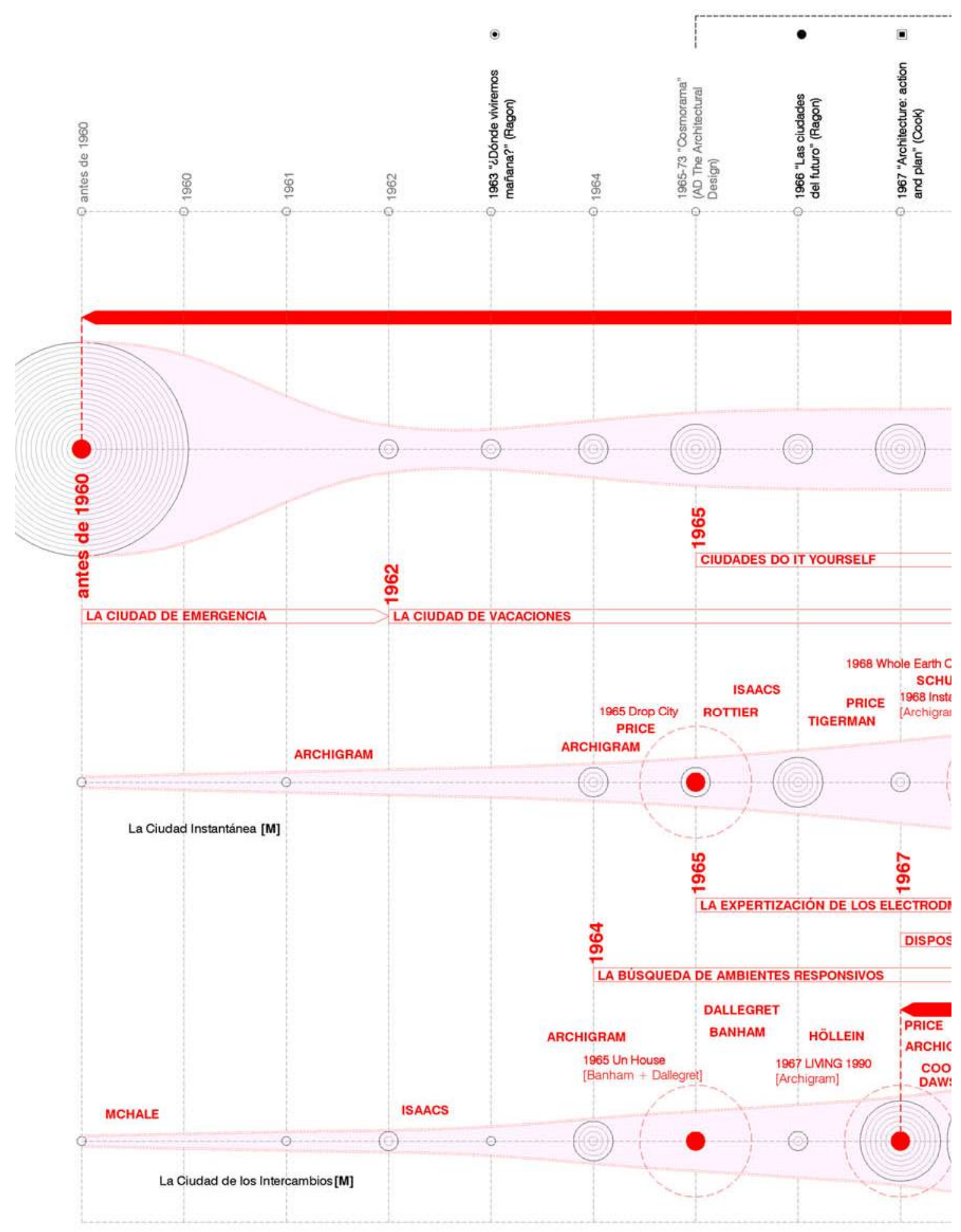




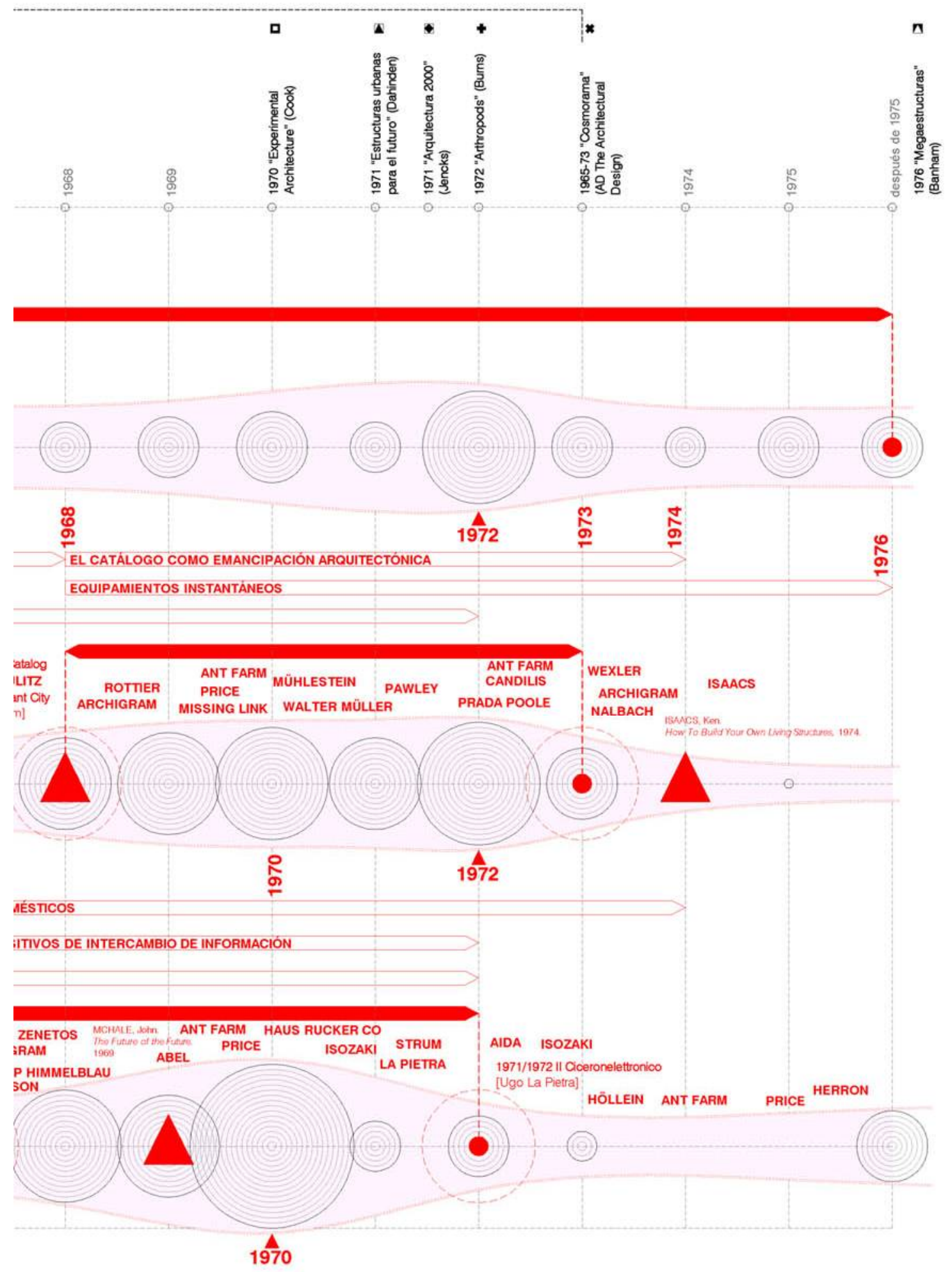




\section{[M] La Ciudad de los Automóviles}

La estrategia se presenta como alternativa de futuro durante un período de 15 años (19601975) en el contexto de la investigación, sin embargo su continuidad en un contexto futuro es también evidente.

Detonantes: La estrategia de movilidad asociada al uso del automóvil es sin lugar a dudas heredera del movimiento moderno. No presenta un detonante claro en el período pero si un cambio explícito, de ser pensada a partir de infraestructuras colectivas a convertir al automóvil en fetiche de autosuficiencia e identidad.

\section{[M] La Ciudad Instantánea}

La estrategia se presenta como alternativa de futuro durante un período de 10 años (19681973).

Detonantes: A principios de los sesenta, se producen una serie de proyectos de ciudades de vacaciones herederas de los experimentos en relación a la vivienda móvil y de fácil transporte derivadas de las ciudades de emergencia durante la reconstrucción de Europa tras la II Guerra Mundial.

Máxima producción: El período de máxima producción coincide con la legitimación de las primeras ciudades autoconstruidas dependientes de la contracultura norteamericana con la "Drop City" como máximo exponente. Del interés por la ciudad efímera de vacaciones se pasará a la de los equipamientos instantáneos, que tendrán a "Instant City" como claro referente. Su gran difusión en revistas de arquitectura y el puesto docente de Peter Cook y otros miembros de Archigram en la academia inglesa y norteamericana hará que se disparen las propuestas de equipamientos móviles a partir de esa fecha.

Desmotivadores: Los numerosos catálogos de proyectos autoconstruidos no llegan a captar la atención de los arquitectos por mucho tiempo y empieza a decrecer el interés por los mismos a partir de 1973, a pesar de su éxito durante el período de máxima producción.

\section{[M] La Ciudad de los Intercambios}

La estrategia se presenta como alternativa de futuro durante un período de 5 años (19671972).

Detonantes: A mediados de los años sesenta se produce una búsqueda de ambientes responsivos a nivel urbano y doméstico. La confianza en unos electrodomésticos amplificados llevará a muchos arquitectos a proponer soluciones domésticas que se emparentan con el mito tecnificado en la "Un House" de Banham y Dallegret.

Máxima producción: 1970 representará la exaltación y el declive de todos ellos a través de la exposición de Osaka'70 como banco de pruebas fallido. La representatividad de esas propuestas será mucho mayor que su impacto social al verse reducidas a proyectos teóricos futuristas, lo que supondrá el abandono de la experimentación en torno a esos dispositivos de intercambio de información en los ámbitos domésticos y urbano para quedar reducido a una cuestión de diseño de las carcasas exteriores de esos aparatos. 


\title{
Sobre la transferencia estética en arquitectura.
}

Esta investigación no trata de ser más que una taxonomía de proyectos, un catálogo comparado de estrategias arquitectónicas definidas por imágenes de arquitectura. Mucho se ha escrito sobre algunos de los posicionamientos aquí detectados en relación a la experimentación estética de la década de los sesenta, auspiciada bajo la etiqueta de "futuro de la arquitectura". Sin embargo, el seguimiento de esas estrategias más allá de su contexto original, evidencia ese cambio de escala citado anteriormente, como una de las conclusiones de esta investigación. Ese cambio evidencia cómo una gran parte de esos posicionamientos y estrategias, nacidos casi exclusivamente como nuevas maneras de operar en la ciudad, se convierten en referentes estéticos a utilizar en toda clase de productos más accesibles para una posmodernidad, entendida como lógica cultural derivada del capitalismo avanzado. Sin ser éste el objetivo fundamental de la tesis, se corroboran las palabras de Fredric Jameson en relación a las oscuras intenciones de la promoción cultural de las prácticas artísticas. Muchos de los proyectos aquí catalogados pertenecen a ámbitos derivados de las mismas, promocionadas por parte de un capital que requiere de una diversidad estética para poder satisfacer las necesidades visuales de sus futuros "clientes".

\begin{abstract}
"Lo que ha sucedido es que la producción estética actual se ha integrado en la producción de mercancías en general: la frenética urgencia económica de producir constantemente nuevas oleadas refrescantes de géneros de apariencia cada vez más novedosa (desde los vestidos a los aviones), con cifras de negocio siempre crecientes, asigna una posición y función estructural cada vez más fundamental a la innovación y experimentación estética. El reconocimiento de estas necesidades económicas se manifiesta en el apoyo institucional de todo tipo puesto a disposición del arte más nuevo, desde las fundaciones y subvenciones hasta los museos y otras formas de mecenazgo. ${ }^{1760}$ (Jameson, 1984, pp.17-18)
\end{abstract}

Como se ha evidenciado en el cuerpo principal de esta tesis, los casos de transferencia estética entre las experimentaciones urbanas y el sistema de consumo de objetos, ya sea como edificios o mobiliario, son numerosos y representan esa tendencia de cambio del interés por lo urbano y colectivo a finales de los sesenta y el culto al objeto de los primeros setenta. Esas supergráficas, que se reivindicaban frente al ascetismo moderno, serán convertidas en estrategias de exaltación de centros comerciales. Las prácticas radicales, asociadas a la construcción de simulaciones espaciales, transformadas en sistemas de iluminación en proyectos de interiorismo para boutiques o discotecas. Aquellas utopías naturalistas, transgredidas y caricaturizadas como interiores pseudo-salvajes construidos a partir de cactus de plástico. Son muchas las evidencias de esa capitalización de la experimentación arquitectónica desarrollada durante la década de los sesenta y primeros setenta.

760 JAMESON, Fredric. El posmodernismo o la lógica del capitalismo avanzado. Paidós Studio. Barcelona, 1991. Traducción: José Luis Pardo Torío. Ed. original: Postmodernism or the Cultural Logic of Late Capitalism. New Left Review, 1984. pp.17-18 


\section{Una Arqueología del Futuro todavía vigente.}

Con demasiada frecuencia el proyecto arquitectónico de futuro, gestado desde finales de los años cincuenta hasta principios de los setenta, suele quedar reducido a banales clichés, tales como las viviendas capsulares, los robots o las megaestructuras, todos ellos entendidos como exaltación de la idea de progreso que se venía gestando desde el final de la reconstrucción de Europa tras la II Guerra Mundial. Más allá de esa visión reduccionista, la producción arquitectónica derivada de ese contexto supone uno de los mayores momentos de experimentación arquitectónica, una fructífera búsqueda de liberación de las ataduras impuestas por el movimiento moderno como estilo unificador globalizado y, como se ha evidenciado anteriormente, motor de cambio hacia esa brumosa futura posmodernidad. Cobijados bajo el paraguas de seducción que suponía la palabra futuro, varios autores trataron de construir predicciones arquitectónicas que legitimaran esas propuestas, que operaban más allá de los límites auto-impuestos por la disciplina arquitectónica. Esa búsqueda del futuro supuso no sólo una ruptura radical con su pasado inmediato, sino también una serie de alternativas diversas, exuberantes, inclusivas y abiertas de lo que podría ser la arquitectura del futuro. A pesar de una condición a veces desestructurada, geográfica e ideológicamente, y en la mayor parte de los casos derivada de proyectos teóricos no construidos o pequeños prototipos, su influencia en nuestro presente, ese futuro imaginado, es incuestionable.

El objetivo de este trabajo ha sido por tanto construir una genealogía de ese futuro en el pasado, una taxonomía de proyectos y estrategias, un atlas visual a través de esas alternativas de futuro, organizadas a partir de una serie de proyectos arquitectónicos concretos. El fin de la tesis no es por lo tanto intentar dar coherencia a un período de una manera reduccionista sino tratar de construir un catálogo de referencias operativo. De esta manera, se ha propuesto una metodología arqueológica, donde los proyectos aparecen ordenados sin más jerarquías que las de su propia clasificación.

Si la influencia de estas referencias en su futuro próximo ya ha sido comentada en las conclusiones visuales de esta tesis, su importancia en el presente puede ser considerada aún mayor. Es desde esa influencia en el presente desde donde nace esta Arqueología del Futuro. En ese sentido, el blog asociado a esta investigación ha supuesto una herramienta fundamental, como difusor de ese imaginario colectivo tan productivo. Muchas de las estrategias arquitectónicas diseñadas en ese fructífero pasado resultan todavía innovadoras como respuesta a demandas sociales contemporáneas. Las vinculaciones entre lo artificial y lo natural, los sistemas de intercambio de información, la construcción de modelos abiertos que fomenten la participación del ciudadano o los sistemas flexibles en el ámbito de la vivienda, son sólo algunos de los temas pendientes que aún debemos abordar las nuevas y no tan nuevas generaciones de arquitectos en nuestro presente.

Esa vigencia de muchas de las alternativas de futuro, unido a la necesidad de generar catálogos operativos, es el que ha llevado a esta investigación a presentar un caso aplicado como anexo, en torno al desarrollo de la vivienda móvil, transportable y transformable en el contexto temporal de estudio. La gran evolución de este tipo de viviendas durante ese período, las convierte en referentes recurrentes de sus semejantes contemporáneos. Sin embargo, esos referentes suelen ser siempre más o menos "invariantes" y pertenecientes a los proyectos que más difusión a través de contextos de prestigio han tenido, perdiéndose así la riqueza de un período de experimentación tan prolífico. No se trata por lo tanto de ensalzar unos referentes concretos, ni una búsqueda nostálgica del pasado, sino de construir un modelo operativo de uso. 


\section{Capítulo 9. BIBLIOGRAFÍA.}

\section{Libros de referencia fundamentales}

- COLOMINA, Beatriz; BUCKLEY, Craig (editores). Clip, Stamp, Fold: The Radical Architecture of Little Magazines 196X - 197X. Actar. Barcelona, 2010.

- FEUERSTEIN, Günther. Urban Fiction. Strolling through Ideal Cities from Antiquity to the Present Day. Edition Axel Menges. Stuttgart/Londres, 2008.

- FRAMPTON, Kenneth. Historia crítica de la arquitectura moderna. Gustavo Gili. Barcelona, 1998. Traducción: Jorge Sainz. Ed. original: Modern Architecture. A Critical History. Thames \& Hudson. Nueva York, 1980.

- MigayROU, Frédéric. Arquitectura Radical. Arquitectura radical: Centro Andaluz de Arte Contemporáneo, Sevilla, enero-marzo de 2003. Junta de Andalucía. Sevilla, 2003.

- NAVONE, Paola; ORLANDONI, Bruno. Architettura Radicale. Documenti di Casabella. Casabella. Milán, 1974.

- PORSCH, Johannes; ARCHITEKTURSENTRUM WIEN (editores). The Austrian Phenomenon: Architecture Avantgarde Austria 1956-1973. Birkhäuser Boston INC. Boston, 2005.

- ROUILLARD, Dominique. Superarchitecture. Le Futur de l'architecture 1950-1970. Éditions de la Villette. Paris, 2004. 


\section{Capítulo 1. SOBRE EL PASADO DEL FUTURO}

\section{Libros de referencia}

\section{Libros sobre futurología, utopía, ciudades utópicas y Ciencia Ficción}

- ARMYTAGE, W. H. G. Visión Histórica del Futuro. Edicions 62. Barcelona, 1971. Ed. original: Yesterday's Tomorrows: A Historical Survey of Future Societies. University of Toronto Press. Toronto, 1968.

- BECKWITH, B. The Next 500 Years. Scientific predictions of major social trends. Exposition Press. Nueva York, 1968.

- BLOCH, Ernst. The Principle of Hope. MIT Press. Cambridge, 1986. Vol.1, vol.2 y vol.3.

- CHOAY, Françoise. L’urbanisme, utopies et réalites. Editions du Seuil. París, 1961.

- CHRIST, Yvan. Utopies et divagations de Claude Nicolas Ledoux. París, 1961.

- DE JOUVENEL, Bertrand. The Art of Conjecture. Basic Books. Londres, 1967.

- DE TARDE, Gabriel. Fragmentos de Historia Futura. Abraxas. Barcelona, 2001. Traducción: Miguel Giménez Sales.

- GRAS, Alain. Futurología. Martínez Roca. Barcelona, 1978. Ed. original: Clefs pour la futurologie. Editions Seghers. París, 1976.

- JAMESON, Fredric. Arqueología del Futuro: El Deseo llamado Utopía y otras aproximaciones de Ciencia Ficción. Akal. Madrid, 2009. Traducción: Cristina Piña Aldao. Ed. original: Archaeologies of the Future: The Desire Called Utopia and Other Science Fictions. Verso Books, 2005.

- MOSKOWITZ, Sam. Explorers of the Infinite. Shapers of Science Fiction. World Publishing Company. Nueva York, 1963.

- NEUER BERLINER KUNSTVEREIN. Stadt und Utopie : Modelle idealer Gemeinschaften. Fröhlich \& Kaufmann. Berlín, 1982.

- POLAK, Frederik Lodewijk. The Image of the Future. Elsevier Sdentific Publishing Company. Amsterdam / Loondres / Nueva York, 1973. Traducción: Elise Boulding.

- REES, Emma L. E. Margaret Cavendish. Gender, Genre, Exile. Manchester University Press. Manchester, 2003.

- VERCELLONI, Virgilio. Atlante storico dell'idea europea della citta ideale. Jaca Book. Milán, 1994. 


\section{Libros sobre utopías clásicas}

- ANDREAE, J.V. Christianopolis. The Ideal of 17th Century. Cosimo INC. New York, 2007. Traducción: Felix Emil Held. Ed. original: Reipublicae Christianopolitanae descriptio. Argentorati. Estrasburgo, 1619.

- BACON, Francis. Nueva Atlántida. Akal. Madrid, 2006. Traducción: Emilio García Estébanez. Ed. original: Nova Atlantis. Londres, 1626.

- BELLAMY, Edward. Looking Backward: From 2000 to 1887. Applewood Books. Bedford, 2000. Ed. original: NY Dover Thrift Edition. Nueva York, 1888.

- BUTLER, Samuel. Erewhon, o tras las montañas. Cátedra. Madrid, 2000. Traducción: Joaquín Martínez Lorente. Ed. original: Erewhon, or Over the Range. 1872.

- CAMPANELLA, Tommaso. La ciudad del sol. Akal. Madrid, 2006. Traducción: Emilio García Estébanez. Ed. original: La cittá del sole. Florencia, 1602.

- CYRANO DE BERGERAC, Savinien. El otro mundo: Los estados e imperios de la luna. Los estados e imperios del sol. Akal. Madrid, 2011. Traducción: Ramón Cotarelo García.

- DONNELLY, Ignatius. Caesar's Column. F.J. Schulte \& Co. Chicago, c1890.

- FORSTER, E. M. The Machine Stops. En: Collected Short Stories. Penguin Books. Londres, 2002. pp. 140-141.

- MORO, Tomás. Utopía. Akal, Madrid, 1997. Ed. original: Utopia. A Fruitful and Pleasant Work of the Best State of a Public Weal and the New Isle called Utopia. Leyden, 1516. 


\section{Capítulo 2. PREDICCIONES ARQUITECTÓNICAS \\ Capítulo 3. ALTERNATIVAS PARA UNA ARQUITECTURA DEL FUTURO}

\section{Libros de referencia}

- ALEXANDER, Christopher. Notes on the Syntesis of Form. Harvard University Press. Cambridge, 1964.

- BANHAM, Reyner. El brutalismo en arquitectura: ¿ética o estética? Gustavo Gili, Barcelona, 1967. Ed.original: The New Brutalism: Ethic or Aesthetic? The Architectural Press. Londres, 1966.

- BELL, Daniel. Toward the Year 2000: Work in the Progress. Daedalus, Academy of Arts and Science. Boston, 1967.

- BUSBEA, Larry. Topologies: the urban utopia in France, 1960-1970. MIT Press. Cambridge, 2007.

- FINDLING, J.E; PELLE,K.D. Historical Dictionary of World's fairs and Expositions 1851-1988. Greenwood Press, Nueva York, 1990.

- GABOR, Dennis. La Invención del Futuro. Credsa. Barcelona, 1967. Ed. original: Inventing the Future. Secker \& Warburg. Londres, 1963.

- GOWAN, James (editor): Projects. Architectural Association. 1946-71, AA Cahiers series No.1. Architectural Association Press. Londres, 1972.

- JACKSON, Anna. Expo. International Expositions 1851-2010. V\&A Publishing. Londres, 2008.

- JUNGK, Robert; GALTUNG, Johan. Mankind 2000. Allen and Unwin. Londres, 1969.

- KAHN, Herman; WIENER, Anthony. Year 2000. MacMillan and Co. Londres, 1967.

- KUBLER, George. The Shape of Time. Yale university Press. New Haven, 1962. pp.81-82.

- MAKI, Fumihiko. Investigations in Collective Form. Washington University Press. St. Louis, 1964.

- MANFRED, Clynes. Foreword to Cyborg: Evolution of the Superman. Harper \& Row. Nueva York, 1965.

- MCLUHAN, Marshall. Understanding Media: The Extensions of Man. Gingko Press. Berkeley, 1964.

- RICHTER, Markus; VAN DER LEY, Sabrina (editores). Megastructure reloaded. Visionary Architecture and Urban Design of the Sixties Reflected by Contemporary Artists. Hatje Cantz. Ostfildern, 2008. 


\section{Predicciones Arquitectónicas}

- BANHAM, Reyner. Megaestructuras. Futuro urbano del pasado reciente. Gustavo Gili, Barcelona, 1978. Ed. original: Megastructure. Urban futures of the recent past. Thames and Hudson. Londres, 1976.

- BURNS, Jim. Arthropods: new design futures. Academy. Londres, 1972.

- COOK, Peter. Architecture: action and plan. Studio Vista. Londres, 1967.

- COOK, Peter. Experimental Architecture. Studio Vista. Londres, 1970.

- Cosmorama. En: AD Architectural Design, julio 1965 - diciembre 1973.

- DAHINDEN, Justus. Urban Structures for the Future. Pall Mall Press. London, 1972. Ed. original: Stadstrukturen für morgen. Verlag Gerd Hatje. Stuttgart, 1971. Ed. castellano: Estructuras Urbanas para el Futuro. Gustavo Gili. Barcelona, 1972.

- JENCKS, Charles. Arquitectura 2000. Predicciones y métodos. Editorial Blume. Barcelona, 1975. Ed. original: Architecture 2000. Studio Vista. Londres, 1971.

- MCHALE, John (editor). 2000+, AD The Architectural Design, vol67, febrero 1967.

- MCHALE, John. The Future of the Future. George Braziller. Nueva York, 1969.

- RAGON, Michel. ¿Dónde viviremos mañana? Luis de Caralt. Barcelona, 1966. Ed. original: Où vivrons-nous demain? Robert Laffont. París, 1963.

- RAGON, Michel. Les visionnaires de l'architecture. Robert Laffont. París, 1965.

- RAGON, Michel. La Cité de l'an 2000. Casterman. París, 1965.

- RAGON, Michel. Paris: hier, aujourd'hui demain., Hachette, coll. La nouvelle encyclopédie. París, 1965.

- RAGON, Michel. Las ciudades del futuro. Plaza \& Janes. Barcelona, 1970. Ed. original: Les cités de l'avenir. Encyclopédie Planète. París, 1966.

- RAGON, Michel. Prospective et Futurologie. En: Volumen 3 Historie mondiale de l'architecture et de l'urbanisme modernes. Casterman. París, 1978.

- WRIGHT, Frank Lloyd. El Futuro de la Arquitectura. Editorial Poseidón. Barcelona, 1978. Ed. original: The Future of Architecture. Horizon Press. Nueva York, 1953. 


\section{Artículos en revistas}

\section{Artículos en AD The Architectural Design (ordenados cronológicamente)}

- Cosmorama. En: AD The Architectural Design, julio 1965. p.316.

- Ontario Government Pavillion (Fairfield y Dubois). En: AD The Architectural Design, julio 1965. p.311.

- Free Speed travel. En: AD The Architectural Design, agosto 1965. p.370.

- Habitat'67 (M.Safdie). En: AD The Architectural Design, septiembre 1965. p.4.

- USA Pavillion (R.B. Fuller), West German Pavillion (Frei Otto), West German Pavillion 3th prize (Rathe y Szabo). En: AD The Architectural Design, octubre 1965. p.435.

- Hotel Auto Reisen. En: AD The Architectural Design, noviembre 1965. p.529.

- France Pavillion (Faugeron), African complex (Fiset), Netherlands Pavillion (Eijkelenboom y Middelhock), Czechoslovakia Pavillion (Repa y Cubr). En: AD The Architectural Design, noviembre 1965. p.527.

- Archigram-Group: Chronological Account of their Work. En: AD The Architectural Design, noviembre 1965. pp. 559-572.

- British Pavillion (Sir Basil Spence). En: AD The Architectural Design, diciembre 1965. p.580.

- Soviet Pavillion (Mikhail Posokhin), Canadian National Railways Pavillion (Frank McDowell). En: AD The Architectural Design, marzo 1966. p.111.

- Rotel. En: AD The Architectural Design, mayo 1966. p.215.

- Japanese Pavillion (Ashihara). En: AD The Architectural Design, mayo 1966. p.214.

- Outdoor Play Spaces (Cornelia Hahn Oberlander). En: AD The Architectural Design, junio 1966. p.268.

- Habitat'67 (M.Safdie). En: AD The Architectural Design, agosto 1966. p.374.

- Cuba Pavillion (Garatti, Baroni y D'Acosta). En: AD The Architectural Design, octubre 1966. p.479.

- Japan Pavillion (Kawasaki). En: AD The Architectural Design, octubre 1966. p.476.

- Gyrotron (Sean Kenny), Venezuela Pavillion (Carlos Raul Villanueva). En: AD The Architectural Design, noviembre 1966. p.533.

- Disney World. En: AD The Architectural Design, abril 1967. p.153.

- AD The Architectural Design, Montreal'67, julio 1967.

- Festival Plaza (Arata Isozaki). En: AD The Architectural Design, septiembre 1967. p.375. 
- Amusement Park (Kiyoshi Awazu), Canadian Pavillion Competition (Rickson y Massey). En: AD The Architectural Design, octubre 1967. p.411.

- People Mover. En: AD The Architectural Design, noviembre 1967. p.453.

- Drop City. En: AD The Architectural Design, noviembre 1967. p.453.

- Festival Plaza Structure (Kenzo Tange). En: AD The Architectural Design, mayo 1968. p.202.

- Fuji Group Pavillion (Yutaka Murata), French Pavillion (Le Coteur y Sloan), Astrorama (Sanwa Group). En: AD The Architectural Design, junio 1968. p.251

- Resurrection City. En: AD The Architectural Design, agosto 1968. p.351.

- Takara Beautillion, Toshiba IHI Pavillion (Kurokawa). En: AD The Architectural Design, septiembre 1968. p.397.

- US Pavillion (Brody y Davis), USSR Pavillion, West German Pavillion (Schwanzer y Gutmann). En: AD The Architectural Design, octubre 1968. p.445.

- Whole Earth Catalog. En: AD The Architectural Design, mayo 1969. p.239.

- Four-Footed Friend. En: AD The Architectural Design, junio 1969. p.293.

- Electrical Industries Pavillion (Kunio Maekawa), Japan Steel Pavillion (Sakakura), Suitoma Fairytale Pavillion (Otani), Mitsui Group Pavillion (Azuma), Japanese Government Exhibit, Ricoh Pavillion (Nikken Sekkei), Festival Plaza (Tange e Isozaki), Radio and Restaurant Tower (Kikutake), Osakagram (Archigram), Takara Beautillion, Toshiba IHI Pavillion (Kurokawa), Netherlands Pavillion, (Bakema). En: AD The Architectural Design, agosto 1969. pp.412-415.

- Strip City. En: AD The Architectural Design, abril 1970. p.178.

- Whole Earth Catalog. En: AD The Architectural Design, abril 1970. pp.169-170.

- Creepy-Crawlies. En: AD The Architectural Design, abril 1970. p.198.

- AD The Architectural Design, Osaka'70, junio 1970.

- Communication Terminal Dummies. En: AD The Architectural Design, agosto 1970. p.423.

- CHALK, Warren; BARNARD, Michael. Bac-pac man. En: AD The Architectural Design, septiembre 1970. pp.436-441.

- Paper House Review. En: AD The Architectural Design, octubre 1970. pp.449-504.

- JENCKS, Charles. The evolutionary tree. En: AD The Architectural Design, octubre 1970. p.527.

- Westinghouse Electric Corporation position locator. En: AD The Architectural Design, febrero 1971. p.66.

- HAGGART, Bruce. The Italian trip. En: AD The Architectural Design, abril 1972. pp.201-202.

- The Ecological House, Recycling. En: AD The Architectural Design, mayo 1972. p.140. 
- OZKAN, Suha. Recycling Building Componentes, Ecotech. En: AD The Architectural Design, diciembre 1972. p.672.

\section{Artículos en otras revistas}

- BEHRENDT, Ernst. Plastic house of the future may come in mass produced, no up-keep parts that you arrange to suit the whole family. En: Popular Science, abril 1956. pp. 144-147.

- BLOCK, Henry; GINSBERG, Herbert. The Psychology of Robots. En: Psychology Today, abril 1968. pp. 50-55.

- BRAND, Stewart. Archigram. En: Whole Earth Catalog, spring 1969. p.20.

- BRAND, Stewart. Archigram. En: The Last Whole Earth Catalog, junio 1971. p.89.

- BURNS, Jim. Arthropods. En: Domus, n496, marzo 3/1971. p.55.

- HAYES, Leon y Lester. The latest from Paris, an all-plastic house. En: Popular Mechanics, agosto 1956. pp. 88-90.

- House of the Future at the Ideal Homes Exhibition. En: AD The Architectural Design, marzo 1956. pp. 101-102.

- Maison prefabriquee en matiere plastique. En: AA L'Architecture d'Aujourd'hui, $\mathrm{n}^{\circ}$ 58, febrero 1955. p. XXIII.

- MOORCRAFT, Colin. Experimental Architecture. En: New Sciencist, 31 de diciembre 1970. pp.611-612.

- PARNELL, Steve. Ethics VS Aesthetics Architectural Design 1965-1972. En: FIELD. A Free Journal for Architecture, Vol 4, issue 1, Ecology, University of Sheffield, 2011. pp.40-52.

- Plastic 'House of Tomorrow' built by Monsanto Chemical Company at Anaheim, California. En: Architect \& Building News, 9 de octubre de 1957. pp. 478-485.

- SCOTT HOLLIDAY, Laura. Kitchen Technologies. En: Promises and Alibis, 1944-1966 Camera Obscura (2001) 16(2 47). pp. 79-131.

- This is a house?. En: Mechanix Illustrated, septiembre 1956. pp.61-63. 


\section{Capítulo 4. CAMBIO DE ESCALA}

\section{Libros de referencia}

- AMBASZ, Emilio (editor). Italia: the New Domestic Landscapes. Achievements and Problems of Italian Design. The Museum of Modern Art. Nueva York, 1972.

- BANHAM, Reyner. Theory and Design in the First Machine Age. Architectural Press. Londres, 1960.

- BARTRAM, Alan. Lettering in Architecture. Lund Humphries Publishers Limited. Londres, 1975.

- BOGNER, Dieter (editor). Denkräume-Stadtträume 1967-1997, Haus Rucker Co. Ritter Verlag. Klagenfurt, 1992.

- BRUYÈRE, André. L'Oeuf / The Egg. Albin Michel. París, 1978.

- BUCKLEY, Craig; VIOLEAU, Jean-Louis (editores). Utopie. Texts and Projects, 1967-1978. Semiotexte. Los Ángeles, 2011.

- CHRIST, Yvan. Paris des Utopies. Editions Baland. París, 1970.

- COLOMINA, Beatriz. Privacidad y publicidad: La arquitectura moderna como medio de comunicación de masas. CENDEAC. Murcia, 2010. Ed. original: Privacy and Publicity. Modern Architecture as Mass Media. The MIT Press. Cambridge, 1994.

- CONRADS, Ulrich; SPERLICH, Hans G. Fantastic Architecture. The Architectural Press. London, 1963. Ed. original: Fantastische Architektur, Verlag gerd Hatje, Stuttgart, 1960.

- COOK, Peter (editor). Archigram. Studio Vista. Londres, 1972.

- CRUZ SÁNCHES, Pedro A. Daniel Buren. Nerea. San Sebastián, 2005.

- DESSAUCE, Marc (editor). The Inflatable Moment. Pneumatic and Protest in '68. Princeton Architectural Press. Nueva York, 1999.

- DOHERTY, Gareth. New Geographies vol.3. Urbanisms of Color. Harvard University Press. Boston, 2010.

- FANELLI, Giovanni; GARGIANI, Roberto. El principio del revestimiento. Prolegómenos a una historia de la Arquitectura Contemporánea. Akal. Madrid, 1999.

- FEUERSTEIN, Günther. Urban Fiction. Strolling through Ideal Cities from Antiquity to the Present Day. Edition Axel Menges. Stuttgart/Londres, 2008.

- FEUERSTEIN, Günther. Visionary Architecture in Austria in the Sixties and Seventies. Ritter Verlag, Klagenfurt. Viena, 1996.

- GRAVAGNuOLO, Benedetto. Adolf Loos: Teoría y obra. Editorial Nerea. San Sebastián, 1988. Ed. original: Adolf Loos. Idea Books. Milán, 1982. 
- HELLMAN, Louis. Archi-Tetes: The ID in the Grid. Willey-Academy. Londres, 2000.

- HESS, Alan. Googie Redux: Ultramodern Roadside. Chronicle Books. Los Ángeles, 2004.

- HIGGINS, Dick; VOSTELL, Wolf. Fantastic Architecture. Something Else Press. Nueva York, 1969.

- HÖLlEIN, Hans. Hans Höllein. Méthapores et metamorphoses. Album de l'exposition. Centre Georges Pompidou. París, 1987.

- ISAACS, Ken. How To Build Your Own Living Structures. Harmony Books. Nueva York, 1974.

- JENCKS, Charles. The Language of Post-Modern Architecture. Rizzoli. Nueva York, 1977.

- JENCKS, Charles. Bizarre Architecture. Rizzoli. Nueva York, 1979.

- KAPROW, Allan. Essays on the Blurring of Art and Life. University of California Press, Berkeley y Los Ángeles, 1993.

- KEPES, Gyorgy. Arts of the environment. Brazilier. Nueva York, 1972.

- LANG, Peter (editor). Superstudio: life without objects. Skira. Milán, 2003.

- LÉGER, Fernand. Fonctions de la peinture. Gonthier, Meditations. París, 1965.

- LYNCH, Kevin. The Image of the City. MIT Press, 1960. Chicago, 1960.

- MIKELLIDES, Byron; PORTER, Tom. Colour for Architecture. Studio Vista. Londres, 1976.

- MOMA. Buildings for Best Products. Museum of Modern Art. Nueva York, 1979.

- NEUMANN, Dietrich. Architecture of the Night. The Illuminated Building. Prestel. Munich, 2002.

- OLDENBURG, Claes; CARROLL, Paul. Proposals for monuments and buildings, 1965-69. Big Table Pub. Co. Chicago, 1969.

- OLDENBURG, Claes; HASKELL, Barbara, Object into Monument. Pasadena Art Museum. Ward Ritchie Press. Pasadena, 1971.

- ROUGERIE, Jacques; VIGNES, Édith. Habiter la mer. Éditions Maritimes et d'Outre-Mer. París, 1978.

- SCHÖFFER, Nicolas. La Ville cybernétique. Volumen 91 de Bibliothèque Médiations. Denoël, Gonthier, 1972.

- SMITH, C. Ray. Supermannerism: new attitudes in post-modern architecture. University of Minnesota / Dutton. Nueva York, 1977.

- SKY, Alison; STONE, Michelle. Unbuilt America: forgotten architecture in the United States from Thomas Jefferson to the space age : a book. McGraw-Hill. Chicago, 1976.

- SOLOMONSON, Katherine. The Chicago Tribune Tower Competition: Skyscraper Design and Cultural Change in 1920s. Cambridge University Press. Nueva York, 2001. 
- STERN, Robert A.M. New Directions in American Architecture. Revised Edition. George Braziller. Nueva York, 1977. p.131.

- TIGERMAN, Stanley (editor). Late entries to the Chicago Tribune Tower competition. Rizzoli. Nueva York, 1980.

- VENTURI, Robert. Complejidad y contradicción en la arquitectura. Gustavo Gili. Barcelona, 1974. Ed. original: Complexity and Contradiction in Architecture. The Museum of Modern Art. Nueva York, 1966.

- VENTURI, Robert; SCOTT-BROWN, Denisse; IZENOUR, Steven. Aprendiendo de Las Vegas. El simbolismo olvidado de la forma arquitectónica. Gustavo Gili. Barcelona, 1978 (1977). Ed. original: Learning from Las Vegas: The Forgotten Symbolism of architectural form. The MIT Press. Cambridge, 1972.

- VENTURI, Robert; SCOTT-BROWN, Denisse; RAUCH, John. Signs of life: symbols in the American city. Renwick Gallery of the National Collection of Fine Arts. Washington D.C, 1976.

- WIGLEY, Mark. White Walls, Designer Dresses. The Fashioning of Modern Architecture. MIT Press. Cambridge, 1995.

\section{Número de revistas completos}

- AA L'Architecture d'Aujourd'Hui, n¹02, Architectures Fantastiques, junio-julio 1962.

- Archigram 7, Insert 7/1, 1966.

- Archigram 8, 1968.

- Pianeta Fresco, n²/3, equinozio invernale, 1968. Tecnologia del decondizionamento.

- COUSTEAU, Jean Michel; HUSSEIN, Faroq (editores invitados). AD The Architectural Design, Inner Space, abril 1969.

- Bau, Heft 2/3, Wien, 1969.

- Bau, Heft 4/5, Graz, 1969

- The Alphabetical City. Pamphlet Architecture\#5, marzo 1980. Princeton Architectural Press. New York / San Francisco, 1980. p.1.

- PAPADAKIS, Andreas (editor). AD The Architectural Design Profiles. Doll's Houses. n46, 1983.

\section{Artículos en revistas}

- Abitare a Lucca. En: Domus, n564, octubre 10/1984. p.44. 
- ARCHIZOOM. Le stanze vuote e i gazebi. En: Domus, n²462, mayo 05/1968. pp. 52-54.

- ARCHIZOOM. Archizoom: discorsi per immagini. En: Domus, n481, diciembre 12/1969. pp.46-47.

- ARCHIZOOM. La distruzione degli oggetti. En: IN, 2-3 (2), 1971. pp.4-13.

- Arredo Urbano. Temporaneo Alternativo Festoso. En: Domus, n523, junio 06/1973. p.1.

- AGUAVIVES GARNICA, F; GOMÁ PRESAS, X; GRUPO ABIERTO DE DISEÑO. Proyecto de kiosko para la venta de naranjas. En: Cuadernos de Arquitectura y Urbanismo, $n^{\circ} 103$, julioagosto 1974. p. 31.

- BANHAM, Reyner. A clip-on Architecture. En: AD The Architectural Design, noviembre 1965. p.534.

- BELPOLITI, Maurizio; PERANZI, Arturo; SILVI, Sandro. Due episodi nel paesaggio. En: Domus, n585, septiembre 09/1978. pp. 10-15.

- BETTER HOMES AND GARDENS (editor). Better Homes and Gardens Decorating Book. Meredith Corporation. New York, 1975.

- Big Banana. En: AD The Architectural Design, mayo 1973. p.268.

- Big Split. En: AD The Architectural Design, marzo 1973. p.136.

- BLAKE, Peter. The Secret Scrapbook of An Architectural Scavenger. En: Architectural Forum, agosto-septiembre 1964, Vol.121. pp.81-114.

- BOUDON, Philippe. Editorial. En: AMC Architecture Mouvement Continuité, SADG nº1968.

- Boutiques. A new world of color. En: PA Progressive Architecture, diciembre 1967. pp.120127.

- CAMPIANO, Adriano. Architettura Compressa. En: Casabella, n³71, noviembre 1972. pp.51-56.

- Car Wash. En: AD The Architectural Design, diciembre 1973. p.755.

- CELANT, Germano. Senza titolo. En: Domus, n²496, marzo 03/1971. pp.47-48.

- CHERNIKHOV, lakov. Construction of architectural and machine forms (1931). En: AD The Architectural Design Profile, Chernikhov: Fantasy and Construction, Volume 54, 9/10-1984. pp.41-88.

- COLOMBO, Joe. Anti-Design. En: Casabella, n³42, noviembre 1969. pp.28-29.

- Concepts for an Operational Art. En: Art and Artists, n010, enero 1969. pp.48-52.

- COOK, Peter. The Mechanistic Image. En: AD The Architectural Design, junio 1967. p.288.

- COOK, Peter. Long steps short steps - Archigram projects 1973-1974. En: Casabella, n³98, febrero 1975. pp.20-31.

- CREMONINI, Lorenzino. Costruito in campagna, fuori Bologna. En: Domus, n505, diciembre 12/1971. p.10. 
- Da Vienna. Ideas Exhibition. En: Domus, n537, agosto 08/1974. pp.20-21.

- Design e mass media. En: Casabella, n³79, julio 1973. pp.52-53.

- DEZZI BARDESCHI, Marco. Elefantica, ovvero il colosso abitato. En: Casabella, n`391, julio 1974. pp.12-14.

- DEZZI BARDESCHI, Marco. Elefantica, dalla Bastiglia a Las Vegas. En: Casabella, n³94/, octubre 1974. pp.14-16.

- DEZZI BARDESCHI, Marco. Supercolossi e Supercomittenza. En: Casabella, n³83, noviembre 1973. pp.14-16.

- Domus Rassegna. En: Domus, n532, marzo 03/1974. pp. 613-614.

- DORFLES, Gillo. Decorazione Trompe L'oeil. En: Domus, n505, septiembre 09/1983. pp.7477.

- DORFLES, Gillo. Surface and Ornament. En: Domus, n646, enero 01/1984. pp.62-64.

- Due ipotesi di organizzazione sulla struttura dei percorsi. En: Casabella, n³76, abril 1973. pp.36-44.

- Effimero urbanistico scala 1/1. En: Marcatré, 37-40, Roma. pp.198-209.

- Eurodomus, 4. En: Domus, n512, julio 07/1972. p.160.

- FISHER, Karen. Living for today. Viking. Nueva York, 1972.

- HÖLLEIN, Hans. Zukunft der Architektur. En: Bau, Heft 1, 1965. pp. 8-11.

- HÖLLEIN, Hans. Technik. En: Bau, Heft 2, 1965. p.54.

- HÖLLEIN, Hans: Fragmente zur Architektur. En: Protokolle '66. Wiener Jahresschrift für Literatur, bildende Kunst und Musik. Hrsg. Otto Breicha und Gerhard Fritsch, Jugend und Volk, Wien München, 1966. p.35.

- HÖLLEIN, Hans. Transformations by Hans Höllein, Architect. En: Arts \& Architecture, mayo 1966. pp.24-25.

- HÖLLEIN, Hans. Candele a Vienna. En: Domus, n438, mayo 05/1966. pp.17-20.

- HÖLLEIN, Hans. Mobili nel museo. En: Domus, n448, marzo 03/1967. pp.24-29.

- HÖLLEIN, Hans. Architektur. En: Bau, Heft 2/3, 1969.

- HÖLLEIN, Hans. Un negozio nel centro di Vienna. En: Domus, n517, diciembre 12/1972. pp.40-41.

- ISAACS, Ken. Home in a Cube. En: LIFE, 11 de octubre de 1954.pp.91-92.

- ISAACS, Ken. How to build the Superchair. En: Popular Science, marzo 1968. pp.160-165.

- ISAACS, Ken. The Living Cube 4x4, un example of Ken Isaacs' Matrix Projects. En: Popular Science, marzo 1969. p.216. 
- ISAACS, Ken. Instant Housing for your country site. En: Popular Science, julio 1972. pp.8891.

- JENCKS, Charles. The Supersensualists. En: AD The Architectural Design, junio 1971. pp.345-347.

- JENCKS, Charles. The Supersensualists. Part II. En: AD The Architectural Design, enero 1972. pp.18-21.

- KUROKAWA, Kisho. Recent Works. En: Kenchiku Bunka, n²53, vol28, noviembre 1967. pp.107-134.

- KUROKAWA, Kisho. Dos sistemas de metabolismo. En: Cuadernos SUMMA-NUEVA VISIÓN, n²0, 1969. pp.16-23.

- It's Supergraphics! En: Life, 3 de Mayo de 1968. pp.79-82.

- La casa albero. En: Domus, n512, julio 07/1972. p.91.

- LAFUENTE, Julio. Progetto per un grande magazzino. En: Domus, n595, junio 06/1979. p.43.

- LANDAU, Royston. Mickey Mouse. The Great Dictator. The Disney game as a control system. En: AD The Architectural Design, Goes West, septiembre 1973. pp.591-595.

- LAPIETRA, Ugo. Richard Haas, l'architettura dipinta. En: Domus, n593, abril 04/1979. pp.27-29.

- MCHALE, John. The expendable ikon 1. En: AD The Architectural Design, febrero 1959. pp.82-83.

- MCHALE, John. The expendable ikon 2. En: AD The Architectural Design, marzo 1959. pp.116-117.

- MCHALE, John. The plastic Parthenon. En: Dot Zero 3, spring 1967. pp.4-11.

- MENDINI, Alessandro. Oggetti ad uso spirituale. En: Domus, n535, junio 06/1974. pp.4547.

- MENDINI, Alessandro. Impossibilitá d'uso. En: Casabella, n³92-393, agosto-septiembre 1974. pp.6-7.

- NATALINI, Adolfo; SAVIOLI, Leonardo. Spazio di coinvolgimiento. En: Casabella, n³26, julio 1973. pp.17-35.

- Nuovi mobili italiani. En: Domus, n432, noviembre 11/1965. pp.36-37.

- OLDENBURG, Claes. Bau interview mit Claes Oldenburg. En: Bau, Heft 4, 1966. pp.83-87.

- RAGGI, Franco. Radical Story. En: Casabella, n³82, octubre 1973. pp.37-45.

- RAGGI, Franco. Proposte al Concorso ADI/Casabella. La Cittá come ambiente significante. En: Casabella, no383, noviembre 1973. pp.17-35.

- SARTOGO, Piero. Hai Capito?. En: Casabella, n³79, julio 1973. p.5. 
- SKREINER, Wilfred. L'architettura trovata. En: Casabella, n³71, noviembre 1972. pp.25-27.

- SMITH, C.Ray. Bathhouse graphics. Make it happy, kid. En: PA Progressive Architecture, marzo 1967. pp.158-161.

- SMITH, C.Ray. Supergraphics. En: PA Progressive Architecture, noviembre 1967. p.132-137.

- SMITH, C. Ray. Implications of Giants. En: PA Progressive Architecture, mayo 1967. pp.147160.

- SOTTSASS JR, Ettore. Mobili 1966. En: Domus, n²449, abril 04/1967. pp.37-46.

- SOTSASS JR, Ettore. Memorie di panna montata. En: Domus, n472, marzo 03/1969. pp.4347.

- SOTTSASS JR, Ettore. Sottsass a Stoccolma. En: Domus, n²474, mayo 05/1969. pp.49-54.

- Supergraphics. Special Report. En: Approach, spring 1971. p.30.

- SUPERSTUDIO. Superstudio. Progetti e Pensiero. En: Domus, n479, octubre 10/1969. p.38.

- SUPERSTUDIO. Superstudio: discorsi per immagini. En: Domus, n481, diciembre 12/1969. pp.44-45.

- SUPERSTUDIO. Lettera da Graz. Tringon'69. Una mostra sul tema: architettura e libertá. En: Domus, n481, diciembre 12/1969. pp.49-54.

- SUPERSTUDIO. Superstudio. En: Perspecta, The Yale Architectural Journal, Volúmenes 1314, 1971. p.304.

- SUPERSTUDIO. Twelve Cautionary Tales for Christmas. En: AD The Architectural Design, diciembre 1971. pp.737-742.

- SUPERSTUDIO. Salvataggio di centri storici italiani. En: IN, n5, mayo-junio 1972.

- SUPERSTUDIO. Dall catalogo degli Istogrammi alla serie misura. En: Domus, n517, diciembre 12/1972. pp.46-48.

- SUPERSTUDIO. Testimonianza a quadretti. En: Casabella, n³76, abril 1973. pp.46-47.

- SUPERSTUDIO. L'invenzione della superficie neutra. En: Elementi: quaderni di studi, notizie ricerche cahiers d'études, nouvelles recherches, N³ / 1973. pp.1-23.

- The world largest pineapple. En: AD The Architectural Design, septiembre 1972, p.537.

- Thirteenth Annual P/A Design Awards. En: PA Progressive Architecture, enero 1966.

- TRINI, Tommaso. Masaccio a UFO. En: Domus, n466, septiembre 09/1968. p.56.

- TRINI, Tommaso. L'UFO della parodia. En: Domus, n²495, febrero 02/1971. pp.46-48.

- Trompe l'oeil. New Pesrpectives. En: Domus, n543, febrero 02/1975. pp.41-43.

- Two types of nudity. En: AD The Architectural Design, enero 1969. p.10. 
- Una cucina minima su ruote, disegnata da Joe Colombo. En: Domus, ${ }^{\circ} 418$, septiembre 09/1964. p.24.

- Urban Fiction. An Architectural Exhibition in Vienna. En: Domus, n²49, abril 04/1967. pp.4-5.

- Urban Toy. Central Park Event. En: New York Magazine, 22 de mayo de 1972. p.4.

- Urboeffimeri avveneti scala 1/1. En: Marcatré, 41-42, Roma. pp.76-82.

- VENTURI, Robert; SCOTT-BROWN, Denisse. A Significance for A\&P Lots, or Learning from Las Vegas. En: Architectural Forum, 128 n², March 1968. pp.37.43.

- VENTURI, Robert. A Bill-Ding-Board Involving Movies, Relics and Space. En: Architectural Forum, n³, abril 1968. p.76.

- WADDELL, Theodore. Undesignable. En: Design, n²48, agosto 1969. p.57.

- Winners in the Shinkenchiku residential Design Competition 1966. En: JA The Japan Architect, n¹27, enero-febrero 1967. pp.27-65.

- Winners in the Shinkenchiku residential Design Competition 1975. En: JA The Japan Architect, n²38, febrero 1976. pp.19-46.

- Winners in the Shinkenchiku residential Design Competition 1979. A House for Karl Friedrich Schinkel. En: JA The Japan Architect, n²74, febrero 1980. pp.7-52.

- WOLFE, Tom. Electrographic Architecture. En: AD The Architectural Design, julio 1969. pp.379-382.

- ZZIGURAT. Attrezzature Sull'Arno. En: Domus, n554, enero 01/1976. pp.6-9. 


\section{Capítulo 5. PERVERSIONES NATURALES.}

\section{Libros de referencia}

- ABRAHAM, Raimund. Raimund Abraham. Obras y proyectos. Catálogo de la exposición. Colegio Oficial de Arquitectos de Madrid. Madrid, 1983.

- ALEXANDER, Christopher. Notes on the Synthesis of Form. Harvard University Press. Cambridge, 1964.

- AMBASZ, Emilio (editor). Italia: the New Domestic Landscapes. Achievements and Problems of Italian Design. The Museum of Modern Art. Nueva York, 1972.

- AYMONINO, Carlo. La Città territorio: un esperimento didattico sul Centro direzionale di Centocelle in Roma. Facoltá di Architettura, Universitá di Roma. Roma, 1964.

- BACHMANN, Jul; VON MOOS, Stanislaus. New Directions in Swiss Architecture. George Brazillier. Nueva York, 1969.

- COLLINS, George R., SCHUYT, Michael; ELFFERS, Joost. Fantastic Architecture. Personal and Eccentric Visions. Henry N. Abrahams Inc. Nueva York, 1980.

- CONRADS, Ulrich; SPERLICH, Hans G. Fantastic Architecture. The Architectural Press. London, 1963. Ed. original: Fantastische Architektur, Verlag gerd Hatje, Stuttgart, 1960.

- COOK, Peter (editor). Archigram. Studio Vista. Londres, 1972.

- CROMPTON, Dennis; JOHNSTON, Pamela. A Guide to Archigram 1961-74. Academy Editions. Chicago, 1994.

- DOERNACH, Rudolf; HEID, Gerhard. Das Naturhaus. S.Fischer Verlag GmbH. Frankfurt / Main, 1982.

- DOXIADIS, Constantinos. Ecumenopolis: The Settlement of the Future. Athens Technological Organization, Athens Center of Ekistics. Atenas, 1967.

- GREGOTTI, Vittorio. New Directions in Italian Architecture. Studio Vista. Londres, 1968.

- GRILLO, Jean Jacques. Three cities: Aquila, Poseidon, Aegea. Department of Architecture, Rice University. Houston, 1963.

- GRUEN, Victor. The Heart of our Cities. The urban Crisis: Diagnosis and Cure. Thames and Hudson. Nueva York, 1965.

- HUDERTWASSER, Friedensreich. Haus der Kunst. Ausstellungs-Katalog. Munich, 1970.

- KATAVOLOS, William. Organics. Steendrukkerij de Jong \& Company. Amsterdam, 1961.

- KEPES, Gyorgy. Arts of the environment. Brazilier. Nueva York, 1972.

- LANG, Peter (editor). Superstudio: life without objects. Skira. Milano, 2003. 
- RUDOFSKY, Bernard. Architecture Without Architects: A Short Introduction to Non-Pedigreed Architecture. Museum of Modern Art. Nueva York, 1964.

- SITE. SITE La Arquitectura como Arte. Gustavo Gili. Barcelona, 1982.

- SOLERI, Paolo. Arcology. The City in the imagen of man. The MIT Press. Boston,1969.

- SKY, Alison; STONE, Michelle. Unbuilt America: forgotten architecture in the United States from Thomas Jefferson to the space age : a book. McGraw-Hill. Chicago, 1976.

- WIECHULA, Arthur. Wachsende Häuser, aus lebenden Baümen entstehend. Berlín, 1925.

\section{Números de revistas completos}

- AA L'Architecture d'Aujourd'Hui, n¹02, Architectures Fantastiques, junio-julio 1962.

- AA L'Architecture d'Aujourd'Hui, n¹31, Tourisme-Loisirs, abril-mayo 1967.

- Street Farmer, nº1, Londres, 1971.

- TA Techniques et Architecture, n²90, L'Architecture et les Loisirs, diciembre 1972.

- WALKER, Derek (editor invitado). Los Angeles: Architectural Design Profile. Architectural Design, Londres, 1981,

\section{Artículos en revistas}

- 9999. Venezia? En: Domus, n506, enero 1972. p.52.

- ALEXANDER, Christopher. A City is not a Tree. En: Design, n²06, 1966. p.7.

- AMBASZ, Emilio. Edifici Mobili Galleggianti. En: Domus, n546, mayo 1975. pp.1-4.

- Archigram Competition: Monte Carlo. En: AD The Architectural Design, septiembre 1970. pp. 7-16.

- BANHAM, Reyner. Triumph of Software. En: New Society, 31/10/1968. pp.629-630.

- COOK, Peter. Passi Lunghi, Passi Corti. Archigram projects 1973-1974. En: Casabella, nº 398, febrero 1975. pp. 20-31.

- DEZZI BARDESCHI, Marco. Elefantica, ovvero il colosso abitato. En: Casabella, n³91, julio 1974. pp.12-14.

- DEZZI BARDESCHI, Marco. Elefantica, dalla Bastiglia a Las Vegas. En: Casabella, n³94/, octubre 1974. pp.14-16.

- DOERNACH, Rudolf. Biotecture. En: AD The Architectural Design, febrero 1966. pp.95-96. 
- DOERNACH, Rudolf. The Ice-lands Cometh. En: AD The Architectural Design, marzo 1968. p.154.

- DOERNACH, Rudolf. Provolution. En: AD The Architectural Design, abril 1969. pp.182-183.

- DOERNACH, Rudolf. Plant-Animal-Man-Eco. En: AD The Architectural Design, marzo 1971. p.131.

- DOERNACH, Rudolf. Biotectur. Una proposta. En: Domus, n546, mayo 1975. pp.16-17.

- Domus Rassegna. En: Domus, n532, marzo 1974.

- GREENE, David. Are You Sitting Comfortably? Then I'll Begin' / 'Gardener's Notebook. En: AD The Architectural Design, septiembre 1969. pp. 506-507.

- GREENE, David. Gardener's Notebook: L.A.W.U.N. Project Number One. En: AD The Architectural Design, agosto 1970. pp. 385-387.

- GUENZI, Carlo. L'Interno Sostituito. En: Casabella, n³64, abril 1972, p.XX.

- MARTIN, Albert C. I/ cielo nel Cubo. En: Domus, n514, septiembre 1972. pp.8-10.

- MINKE, Gernot. Biotektur. En: Domus, n597, agosto 1979. pp.10-16.

- Nel Panorama. En: Domus, n532, marzo 1974. pp.12-13.

- Nesting. En: AD The Architectural Design, octubre 1967. p.440.

- ORTNER, Laurids. Architettura Provvisoria. En: Domus, n569, abril 1977. pp.25-32.

- PACZOWSKI, Bohdan. La Maison comme Nature et la Nature comme Maison. En: AA L'Architecture d'Aujourd'Hui, n²27, junio 1983. pp.81-89.

- PETTENA, Gianni. Conversazione a Salt Lake City. En: Domus, n516, noviembre 1972. pp.53-56.

- ROTTIER, Guy. L'Architecture Enterrèe ou L'Anti-Architecture. En: TA Techniques et Architecture, n 313, Le Végétal et l'architecture, enero-febrero 1977. pp.36-38.

- SMITHSON, Alison y Peter. Transformations of the City. En: AD The Architectural Design, abril 1968.

- SOTTSASS JR, Ettore. // Pianeta come festival. En: Casabella, n³65, mayo 1972. pp. 41-46.

- Superpiastrelle. En: Domus, n525, agosto 1973. p.54.

- TAFURI, Manfredo; PICCONATO, Giovani; QUILICI, Vieri. Città territorio: verso una nuova dimensione. En: Casabella, n²70, diciembre 1962. pp. 16-25.

- TAFURI, Manfredo. Studi e lpotesi di lavoro per il sistema direzionale di Roma. En: Casabella, n²64, junio 1962. p.27.

- THORPE, Geoff; STORY, Graham. 59, The Oaks. En: AD The Architectural Design, noviembre 1972. p.662 
- TREY, Bernard. Habitat Parietal et Rythmes. En: AA L'Architecture d'Aujourd'hui, Recherches, no 115, junio-julio 1964. pp.114-115.

- UFO Zorro. En: Domus, n539, octubre 1974. pp.46-47. 


\section{Capítulo 6. HACIA UNA ARQUITECTURA VIRTUAL.}

\section{Libros de referencia}

- GORDON, Alastair. Spaced Out: Radical Environments of the Psychedelic Sixties. Random House Incorporated. Nueva York, 2008.

- ALEXANDER, Christopher James; DE WIT, Wim. Overdrive: L.A. Constructs the Future, 19401990. Getty Publications. Los Ángeles, 2013.

- BANHAM, Reyner. The Architecture of the Well-tempered Environment. The Architectural Press Ltd. Londres, 1969.

- BATTCOCK, Gregory. Minimal Art: A Critical Anthology. University of California Press. Los Ángeles, 1968.

- DAVIS, Douglas M. Art and the Future: A History/Prophecy of the Collaboration Between Science, Technology and Art. Thames \& Hudson. Nueva York, 1973.

- DÍAZ MORENO, Cristina; GARCÍA GRINDA, Efrén. Breathable. Universidad Europea de Madrid. Madrid, 2009.

- FRAC CENTRE (editor). Architectures expérimentales 1950-2000. Collection du FRAC Centre. Editions HYX. Orleans, 2003,

- FULLER, R. Buckminster; MARKS, Robert. The Dymaxion World of Buckminster Fuller (1960). Anchor Press. Nueva York, 1973.

- HARDWICK, M.Jeffrey. Mall Maker. Victor Gruen. Architect of an American Dream. University of Pennsylvania Press. Philadelphia, 2004.

- HERZOG, Thomas. Pneumatic Structures. A Handbook of Inflatable Architecture. Oxford University Press. New York, 1976.

- HOURDIN, Georges. Une civilisation des loisirs. Calmann-Levy. París, 1961.

- KEPES, Gyorgy. Arts of the environment. Brazilier. Nueva York, 1972.

- LA PIETRA, Ugo. Abitare la città. Alinea. Florencia, 1983.

- LIPPARD, Lucy. Six Years: The Dematerialization of the Art Object from 1966 to 1972. A CrossReference Book of Information on Some Esthetic Boundaries. Praeger. Nueva York, 1973.

- MALLORY, Keith; OTTAR, Arvid. The Architecture of War. Phanteon Books. Nueva York, 1973.

- MCLUHAN, MARSALL. Gutenberg Galaxy: The Making of Typographic Man. University of Toronto Press. Toronto, 1962.

- MORRIS, Catherine. 9 Evenings Reconsidered: Art, Theater, and Engineering, 1966. Institute of Technology, List Visual Arts Centre. Massachusetts, 2006. 
- ORTIZ, Lori. Disco Dance. ABC-CLIO Lcc. Santa Bárbara, 2011.

- PRADA POOLE, José Miguel. Las Fuentes del Espacio. COAM Comisión de Cultura. Madrid, 1977.

- QUARMBY, Arthur. Materiales plásticos y arquitectura experimental. Gustavo Gili. Barcelona, 1976. Ed. original: The Plastics architect. Pall Mall Press. Londres, 1974.

- ROUILLARD, Dominique. Superarchitecture. Le Futur de l'architecture 1950-1970. Éditions de la Villette. Paris, 2004.

- YOUNGBLOOD, Gene. Expanded Cinema, Dutton. Nueva York, 1970.

\section{Números de revistas completos}

- POLIERI, Jacques. Aujourd'Hui, Art et Architecture, n 17, Spectacles, 1958.

- POLIERI, Jacques. Aujourd'Hui, Art et Architecture, n 42-43, Scénographie Nouvelle, 1963.

- AD The Architectural Design, Pneu World, junio 1968.

- JA The Japan Architect, n¹64, Special Edition Expo'70, mayo-junio 1970.

- WALKER, Derek (editor invitado). AD The Architectural Design Profile, n52, Animated Architecture, 1982.

\section{Artículos en libros}

- BROOKES, Alan. Mike Davies. En: Innovation in Architecture: A Path to the Future. Spon Press. Londres, 2004. pp.22-23.

- CHALK, Warren. An unaccustomed dream. En: COOK, Peter (editor). Archigram. Studio Vista. Londres, 1972. p.32.

- KLEIN, Yves; RUHNAU, Werner. Project for an aerial architecture. en: CONRADS, Ulrich. Programs and Manifestoes on 20th-Century Architecture. Lund Humphries. Londres, 1970 (1964). p.171.

- VANDERBEEK, Stan. Culture Intercom and Expanded Cinema, a proposal. En: BATTOCK, Gregory (editor). The New American Cinema. Dutton. Nueva York, 1967. p.173.

- VIDLER, Anthony. Air War and Architecture. En: HELL, Julia; SCHÖNLE, Andreas. Ruins of Modernity. Duke university Press. Durham, 2010. pp.29-40. 


\section{Artículos en revistas}

- 9999. Las Vegas. En: Casabella, n³39/340, Arredo Urbano, julio-agosto 1969. p.100-103.

- 9999. Happening progettuale. En: Casabella, n³39/340, Arredo Urbano, julio-agosto 1969. pp.98-99.

- 9999. Space Electronic, environment audiovisivo. En: Casabella, n³56, Autori e Autoria, mayo 1971. pp.46-49.

- ABRAHAM, Raimund. Hyperspaces. En: AD The Architectural Design, julio 1969. pp.383384.

- ANT FARM. Ant Farm proposal for Osaka'70. En: AD The Architectural Design, julio 1969. p.355.

- Architecture of Agression. En: Casabella, n³94, octubre 1974. pp.26-29.

- ARCHIZOOM. Città, Catena di Montaggio del Sociale. En: Casabella, n³50-351, julio agosto 1970. pp.43-52.

- ARCHIZOOM. No-Stop City. Residential Parkings. Climatic Universal System. En: Domus, n496, marzo 1971. pp.49-55.

- BANHAM, Reyner. A Home is not a House. En: Art in America, vol 53, abril 1965. pp.70-79.

- BANHAM, Reyner. A Home is not a House. En: AD The Architectural Design, enero 1969. pp.45-48.

- BARTHEL, Joan. A teetotal night club where personal experience is all. En: LIFE, 4 abril 1969. pp.28-29.

- BEST, Alastair. Expo '70. Market, place and festival. En: Design, n²59, 1970. pp. 23-73.

- BLAKE, Peter. Expo’70. En: Architectural Forum, n³, abril 1970. pp.30-41.

- BEUYS, Joseph. Everything is art. En: Avalanche, n5, summer 1972.

- CAGE, John. Everything We Do Is Music. Entrevista de John Kosler. En: Saturday Evening Post, octubre 1969.

- CASATI, Cesare Maria. /l Teatro sospesso di Charles Eames. En: Domus, n424, marzo 1965. pp.26-32.

- CELANT, Germano. Sulla scena dello S-Space. En: Domus, n509, abril 1972. pp.44-45.

- CHALK, Warren. No-Where Man. En: AD The Architectural Design, octubre 1966. p.478.

- CHALK, Warren. Trying to find out is one of my constant doings. En: AD The Architectural Design, enero 1970. pp.15-16.

- DÍAZ MORENO, Cristina; GARCÍA GRINDA, Efrén. Formas del aire 1.0+Arquitectura respirable. En: Obradoiro $n^{\circ} 32$, Revista do Colexio Oficial de Arquitectos de Galicia, Cuaderno 01, 2004. pp.10-40. 
- Global Tools. En: Global Tools, 12 enero 1973. pp.7-8.

- GRUEN, Victor. Two Gruen Shopping Centers. Valley Fair and Bay Fair. En: PA Progressive Architecture, octubre 1968. pp.136-145.

- HAUS RUCKER CO. Le Coeur Jaune. En: AA L'Architecture d'Aujourd'Hui, n¹39, Tendances, septiembre 1968. p.XXXIX.

- HAUS RUCKER CO. Favola. En: Domus, n475, junio 1969. pp.18-21.

- HAUS RUCKER CO. Aria, Aria. En: Domus, n499, junio 1971. pp.44-46.

- HAUS RUCKER CO. Ecoutopia. Grüne Lunge. En: Domus, n537, agosto 1974. p.9.

- HODGKINSON, Peter. Drug-In City. En: AD The Architectural Design, noviembre 1969. p.585.

- HÖLLEIN, Hans. Svodoair. En: AA L'Architecture d'Aujourd'Hui, nº139, Tendances, septiembre 1968. p.1.

- HÖLLEIN, Hans. Alles ist Architektur. En: Bau, Heft 1/2, 1968. pp.2-27.

- HÖLLEIN, Hans. Alles ist Architektur. En: Bau, Heft 2/3 1969. pp.30-31.

- HÖLLEIN, Hans. Austriennale. En: Bau, Heft 4 1969. pp.75-78.

- HÖLLEIN, Hans. Alles ist Architecture. En: AD The Architectural Design, febrero 1970. pp.6063.

- HÖLLEIN, Hans. Pillola Spray. En: IN nº1, enero 1971.

- HUGHES-STANTON, Corin. Closed environment for living space. En: Design, n²41, enero 1969. pp.40-49.

- KERR, Carson. At Home, 2004 A.D. En: Popular Science, Octubre 1954. pp.154-156.

- MIDDLETON, Robin. Living. En: AD The Architectural Design, 2000+, febrero 1967. p.66.

- Mirror Dome. En: AD The Architectural Design, enero 1970. p.2.

- Myra Breckinridge. En: AD The Architectural Design, julio 1970. p.332.

- NATALINI, Adolfo. Imaginary Architecture. En: Domus, n491, octubre 1970. pp.49-53.

- OTERO-PAILOS, Jorge. LS Design:Charles Moore and the Delirious Interior. En: Volume, n²4, Counterculture, 2010.

- OTTO, Frei. Essai d'une vision d'avenir. En: AA L'Architecture d'Aujourd'Hui, nº102, Architectures Fantastiques, junio-julio 1962. pp.89-93.

- PAWLEY, Martin. Architecture Versus the Movies or Form versus Content. En: AD The Architectural Design, junio 1970. pp.288-309.

- PONTI, Gio. /l Gioco del pallone. En: Domus, n427, junio 1965. pp.52-53. 
- PRICE, Cedric. Fun Palace, Camden, London. En: AD The Architectural Design, noviembre 1967. pp. XX.

- PRICE, Cedric. Cedric Price Suplement. En: AD The Architectural Design, octubre 1970. pp.507-522.

- PRICE, Cedric. Inter-Action Centre. En: RIBA Journal, noviembre 1977. pp.458-465.

- Psychedelic Art. En: LIFE, 9 septiembre 1966. pp.60-66.

- RESTANY, Pierre. Breve storia dello stile yéyé. En: Domus, n446, enero 1967. pp.43-40.

- SMITH, C. Ray. Instant Interiors. En: PA Progressive Architecture, junio 1967. pp.176-179.

- SMITH, C. Ray. Instant Exteriors. En: PA Progressive Architecture, marzo 1968. pp.154-155.

- Some New Dodges, or Room to Ponder. En: New York Magazine, 26 enero 1970. pp.58-59.

- S-Space information. En: Domus, n496, marzo 1971. p.55.

- S-Space. En: Casabella, n³56, Autori e Autoria, mayo 1971. p.25.

- Summerland. En: AD The Architectural Design, julio 1968. pp.318-321.

- ST. FLORIAN, Friedrich. Immaginary Architecture. En: AD The Architectural Design, noviembre 1970. p.541.

- SUPERSTUDIO. Lettera da Graz. En: Domus, n481, diciembre 1969. pp.49-55.

- SUPERSTUDIO. Libreria Marzocco, Florence; Boutique Domitilla, Florence; Night Club Mach 2, Florence. En: Domus, n43, abril 1969. pp.25-30.

- TANGE, Kenzo; KAWAZOE, Noburu. Osaka 70. En: AA L'Architecture d'Aujourd'Hui, nº152, noviembre 1968. pp.97-112.

- TRINI, Tommaso. Divertimentifici. En: Domus, n458, enero 1968. pp.13-22.

- WELCH, Paul. The Knowledge Box. En: LIFE, 14 septiembre 1962. pp.109-112.

- WEXLER, Allan. Proposal for Manhattan Skyline. World Trade Center Evening. En: AD The Architectural Design, agosto 1974. p.465. 


\section{Capítulo 7. LA MOVILIDAD COMO OPCIÓN DE FUTURO.}

\section{Libros de referencia}

- AMADO, Antonio. Voiture Minimum. Le Corbusier and the Automobile. The MIT Press. Cambridge, 2011.

- America: una nuova idea per vendere. En: Domus, n²448, marzo 1967. pp.34-35.

- AMBASZ, Emilio. The Taxi Project: Realistic Solutions for Today. The Museum of Modern Art. Nueva York, 1976.

- ANT FARM. Inflatocookbook, n¹, january, Sausalito, 1971.

- BAER, Steve Baer. Dome Cookbook. Lama Foundation. Corrales, 1968.

- BANHAM, Reyner. The Architecture of the Well-tempered Environment. The Architectural Press Ltd. Londres, 1969.

- COOK, Peter (editor). Archigram. Studio Vista. Londres, 1972.

- DAVIES, Colin. The Prefabricated Home. Reaktion Books. Londres, 2005.

- EASTON, Robert; KAHN, Lloyd. Domebook, issue N01. Pacific Domes. Califonia, 1970.

- EASTON, Robert; KAHN, Lloyd. Domebook, issue No2. Pacific Domes. Califonia, 1971.

- EILER, Keith E. Mobilizing America: Robert P. Patterson and the War Effort, 1940-1945. Cornell University Press. Ithaca, 1997.

- Farallones Scrapbook. Momento and Manual of Our Apprenticeship in Making Places and Changing Spaces in Schools at Home and Within Ourselves. Farallones Design, 1971.

- GARTMAN, David. From Autos to Architecture: Fordism and Architectural Aesthetics in the Twentieth Century. Princeton Architectural Press. Nueva York, 2009.

- GEDDES, Norman Bel. Horizons. John Lane. Nueva York, 1932.

- GEDDES, Norman Bel. Magic Motorways. Random House Books. Nueva York, 1940.

- GOWAN, James (editor): Projects. Architectural Association. 1946-71, AA Cahiers series No.1. Architectural Association Press. Londres, 1972.

- HART, John Fraser; RHODES, Michelle J; MORGAN, John T. The Unknown World of the Mobile Home. Johns Hopkins University Press. Baltimore, 2003.

- HUGHES, Jonathan; SADLER, Simon. Non-Plan. Essays on Freedom, Participation and Change in Modern Architecture and Urbanism. Architectural Press. Nueva York, 2000.

- IOWA STATE UNIVERSITY FOR THE SOCIETY FOR COMMERCIAL ARCHEOLOGY (editor). Roadside America: the automobile in design and culture. Universidad de Michigan. Chicago, 1990. 
- ISAACS, Ken. How To Build Your Own Living Structures. Harmony Books. Nueva York, 1974.

- KAHN, Lloyd. Shelter. Shelter Publications.California, 1973.

- KIRBY, Doug; SMITH, Ken; WILKINS, Mike. The New Roadside America: The Modern Traveler's Guide to the Wild and Wonderful World of America's Tourist Attractions. Simon \& Schuster. Nueva York, 1992.

- JELLICOE, G.A. Motopia. A Study in Evolution of Urban Landscape. Frederick A. Praeger. Nueva York, 1961.

- LANDAU, Royston. New Directions in British Architecture. Studio Vista. Londres, 1969.

- LEBRUN, Pierre. Le temps des églises mobiles. L'architecture religieuse des Trente Glorieuses. Gollion. Infolio éditions, collection « Archigraphy. París, 2011.

- LE CORBUSIER. Hacia una arquitectura. Ediciones Apóstrofe. Barcelona, 1977. p.105. Ed. original: Vers une architecture. L'Esprit Nouveau. París, 1923.

- LOEWY, Raymond. Industrial Design. Faber \& Faber. Londres, 1979.

- MALONE, Robert. The Robot Book. Harcourt Brace Jovanovich. Nueva York, 1978.

- MARGOLIUS, Ivan. Automobiles by Architects. Wiley-Academy. Nueva York, 2000.

- MASSEY, Anne. The Independent Group: Modernism and Mass Culture in Britain, 19451959. Manchester University Press, Manchester, 1995.

- NEWMAN, Oscar (editor). CIAM '59 in Otterlo. Stuttgart, 1961.

- NEGROPONTE, Nicholas. Soft Architecture Machines. The MIT Press. Cambridge, 1975.

- NEGROPONTE, Nicholas. The Architecture Machine. The MIT Press. Cambridge, 1970.

- NOYES, Phil. Trailerama. Gibbs Smith. Layton, Utah, 2012.

- PAPANEK, Victor. Design for the Real World. Thames \& Hudson. Londres, 1972.

- PAPANEK, Victor; HENNESSEY, James. Nomadic Furniture. Phanteon Books. Nueva York, 1973.

- PAPANEK, Victor; HENNESSEY, James. Nomadic Furniture 2. Phanteon Books. Nueva York, 1974.

- PAWLEY, Martin. Garbage Housing. The Architectural Press. Londres, 1975.

- POULAIN, Élisabeth. France: L'esprit du camping. Editions Cheminements. París, 2005.

- RISSELADA, Max; VAN DEN HEUVEL, Dirk (editores). Team 10 1953-1981. In Search of A Utopia of the Present. NAI Publishers. Rotterdam, 2005.

- SILK, Gerald. Automobile and Culture. Museum of Contemporary Art. Los Angeles, 1984.

- SZCZELKUN, Stefan A. Survival Scrapbook \#1. Shelter. Shocken Books. Nueva York, 1972. 
- SZCZELKUN, Stefan A. Survival Scrapbook \#2. Food, Shocken Books. Nueva York, 1972.

- VENTURI, Robert; SCOTT-BROWN, Denisse; IZENOUR, Steven. Aprendiendo de Las Vegas. El simbolismo olvidado de la forma arquitectónica. Gustavo Gili. Barcelona, 1978 (1977).

- WALLIS, Allan D. Wheel Estate: The Rise and Decline of Mobile Homes. Johns Hopkins University Press. Baltimore, 1997.

- WILLEIM, Veronique. Maisons Mobiles. Collection Anarchitecture. Editions Alternatives. París, 2004.

- WILLIAMS, Dave; MUNRO, Sthepanie. Survival Scrapbook \#3. Access to Tools, Shocken Books. Nueva York, 1973.

\section{Números de revistas completos}

- AA L'Architecture d'Aujourd'hui, nº131, Tourisme / Loisirs, abril-mayo 1967.

- Bauwelt, n018, 5 mayo 1969.

- TA Techniques et Architecture, n²90, L'Architecture et les Loisirs, diciembre 1972.

- PRICE, Cedric (editor invitado). AD The Architectural Design, What about Learning?, mayo 1968.

- Whole Earth Catalog, Fall 1969, Access to Tools.

- WEBB, Michael (editor invitado). Design Quarterly, n¹21, Robots, Walker Art Center, 1983.

\section{Artículos en libros}

- SCOTT, Felicity D. Fluid Geographies. Politics and Revolution by Design. En: CHU, Hsiaoyun; TRUJILLO, Roberto G. (editores). New Views on R. Buckminster Fuller. Stanford University Press. Stanford, 2009. pp.160-175.

\section{Artículos en revistas}

- ARCHIGRAM. Architecture without Architects. En: World Earth Catalog, spring 1969. p.20.

- At Home in a Round House. En: Popular Mechanics, junio 1946. pp.118-119.

- BANHAM, Reyner. Man, Machine and Motion. En: AR Architectural Review, n¹18, julio 1955. pp.51-53.

- BAYÓN, Mariano. Arquitectura y Movilidad. En: Arquitectura, nº 95, noviembre 1966. pp.3136. 
- BAYÓN, Mariano. PTB. Potteries Thinkbelt. En: Arquitectura, n96, diciembre 1966. pp.5558.

- Bucky Fuller's Hexa-Pent: Dome Home You Can Build. En: Popular Science, junio 1972. pp.80-81.

- CHALK, Warren. Living 1990. Archigram Group. En: AD The Architectural Design, marzo 1967. pp.146-147.

- CHALK, Warren. Touch Not. En: AD The Architectural Design, abril 1971. p. 238.

- Concepts of Educational Mobility. En: AD The Architectural Design, marzo 1973. pp.137-138.

- DOUTHIT, Peter L. Drop City: A Report from the Energy Center. En: Arts Magazine, n 41 , 1967. p.50.

- Drop City. En: AD The Architectural Design, noviembre 1967. p.453.

- Drop City, Colorado. Coupoles géodésiques pour l'habitat hippie. En: AA L'Architecture d'Aujourd'hui, n¹41, Structures, diciembre 1968 - enero 1969. pp.82-84.

- FRANK LLOYD WRIGHT FOUNDATION. Frank Lloyd Wright's Automobiles. En: Quarterly 8, $n^{\circ} 2,1997$.

- FULLER, Buckminster. My new Hexa-Pent Dome Designed for you to live in. En: Popular Science, mayo 1972. pp.128-131.

- GILMORE, C.P. Bucky Fuller's Wonderful Dome. En: Popular Science, diciembre 1961. pp.75-77.

- Kanh Car. En: AD The Architectural Design, abril 1968. p.223.

- Il Metro Quadro. Mini Vehicle. En: Domus, nº 539, octubre 1974. p.41.

- Intervista a Cedric Price. En: Domus, n581, abril 1978. pp.64-65.

- ISAACS, Ken. Build a Vacation Cluster. En: Popular Science, julio 1972. pp.88-91.

- ISAACS, Ken. Guest Room in a Ten-Inch Space. En: Popular Science, septiembre 1970. pp.86-87.

- ISAACS, Ken. A Modern Bowl for Sun-Bathing. En: Popular Science, febrero 1970. pp.112113.

- ISAACS, Ken. Way Out Fun House for Your Vacation Lot. En: Popular Science, julio 1969. pp.131-135.

- ISAACS, Ken. How to Build the Microdorm. En: Popular Science, marzo 1969. pp.138-141.

- ISAACS, Ken. More than a Matrix Idea: A Room of 2x2s. En: Popular Science, abril1968. pp.170-174.

- ISOZAKI, Arata. Festival Plaza. En: JA The Japan Architect, n¹64, junio 1970. pp.XX

- LAPIETRA, Ugo. Ferialità Televisiva. En: Domus, n613, febrero 1981. pp.36-39. 
- La Parole est aux Architectes. En: AA L'Architecture d'Aujourd'hui, Le Centre Georges Pompidou, no 189, febrero 1977. pp.52-53.

- Largest geodesic dome. En: Popular Mechanics, octubre 1966. p.146.

- Le Cupole di Drop City. En: Domus, n458, enero 1968. p.1.

- Living in Circles. En: Popular Science, mayo 1946. pp.74-75.

- LODGE, John E. Plans to Move Homes by Airship. En: Popular Science, septiembre 1929. p.47.

- Metal men get many-metaled building. En: Popular Science, enero 1961. p.113.

- Operations Control Plan. En: JA The Japan Architect, n¹33, agsto 1967. pp.34-40.

- Paper House Review. En: AD The Architectural Design, octubre 1970. pp.449-504.

- PAWLEY, Martin. Garbage Housing. En: AD The Architectural Design, febrero 1971. pp.8694.

- Pine-Cone Dome is made of plywood panels. En: Popular Science, octubre 1957. p.139.

- Plastic Dome for Stadium. En: Popular Mechanics, julio 1956. p.104.

- PRADA POOLE, José Miguel. La Ciudad Instantánea, la Ciudad Cambiante. En: Arquitectura, n¹57, 1972. pp.24-38.

- PRICE, Cedric. PTB. Potteries Thinkbelt. A plan for an advanced educational industry in North Sttafordshire. En: AD The Architectural Design, octubre 1966. pp. 484-498.

- PRICE, Cedric. Fun Palace, Camden, London. En: AD The Architectural Design, noviembre 1967. pp. XX.

- PRICE, Cedric. Non-plan. En: AD The Architectural Design, mayo 1969. pp.269-273.

- PRICE, Cedric. Átomo. En: Cuadernos Summa-Visión, n44, 1970. pp.21-26.

- PRICE, Cedric. Inter-Action Centre. En: RIBA Journal, noviembre 1977. pp.458-465.

- Resurrection City. En: AD The Architectural Design, agosto 1968. p.351.

- RHINE, Charles E. Amazing Sun Dome You Can Build. En: Popular Science, mayo 1966. pp.109-112.

- SMITHSON, Allison y Peter. Mobility. En: AD The Architectural Design, octubre 1958. pp.385-388.

- SMITHSON, Allison y Peter. Caravan, Embryo. Appliance House. En: AD Architectural Design, septiembre 1959. p.385.

- SCHADE, J.R. Health Acces. En: AD The Architectural Design, mayo 1973. pp.271-272.

- TREGO, Charlotte. New Life for Junked Cars. En: Architectural Forum, n¹27, septiembre 1967. pp.74-75. 
- TSCHUMI, Bernard; MONTES, Fernando. Do-It-Yourself City. En: AA L'Architecture d'Aujourd'hui, n¹48, Vers une industrialisation de l'habitat, febrero-marzo 1970. pp.98-105.

- WEXLER, Allan. Mechanical Museum. En: AD The Architectural Design, enero 1972. pp.1112.

- WIEBENSON, John. Planning and Using Resurrection City. En: American Institute of Planners Journal 35, n6, noviembre 1969. pp. 405-411.

- WRIGHT, Frank Lloyd. Broadacre City: A New Community Plan. En: Architectural Record, n०77, 1935. p.244

- WRIGHT, Frank Lloyd. An Autobiography. Pomegranate. San Francisco, 1943, p.411.

- Your Home of the Future. En: Popular Mechanics, octubre 1942. pp.72-77. 
